REVISTA DIGITAL DE CINEMA DOCUMENTÁRIO

REVISTA DIGITAL DE CINE DOCUMENTAL

DIGITAL MAGAZINE ON DOCUMENTARY CINEMA

RÉVUE ÉLECTRONIQUE DE CINÉMA DOCUMENTAIRE

WWW.DOC.UBI.PT

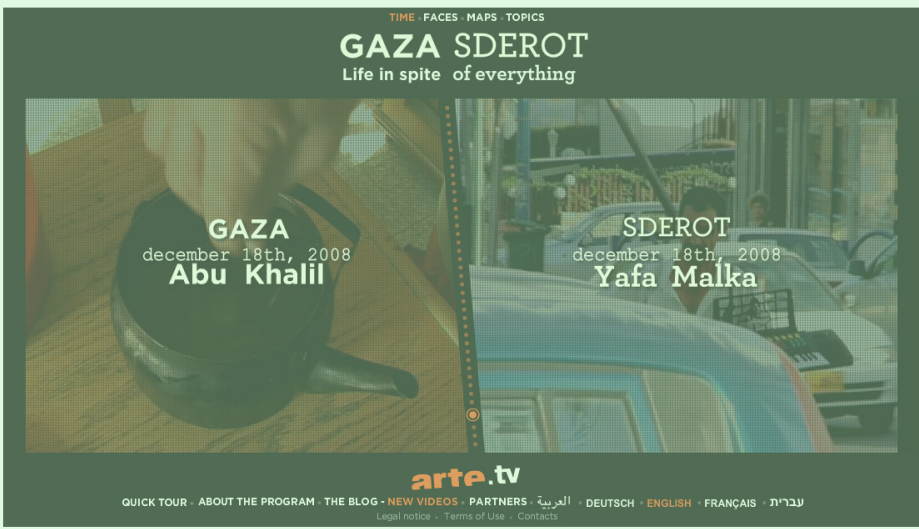

GAZA SDEROT, LIFE IN SPITE OF EVERYTHING (2008) ARTE.TV

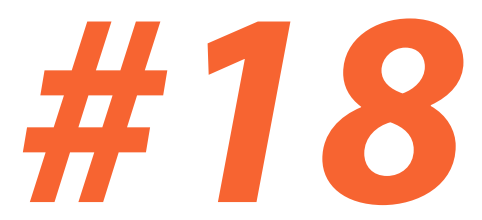

\section{EDITORES}

MARCIUS FREIRE (UNICAMP, Brasil) MANUELA PENAFRIA (UBI, Portugal)

\section{INTERATIVIDADE E DOCUMENTÁRIO}

INTERACTIVIDAD Y DOCUMENTAL

INTERACTIVITY AND DOCUMENTARY

INTERACTIVITÉ ET DOCUMENTAIRE 


\section{CONSELHO EDITORIAL}

Alfonso Palazón (Universidad Rey Juan Carlos, Espanha)

Annie Comolli (École Pratique des Hautes Études, França)

António Fidalgo (Universidade da Beira Interior, Portugal)

António Weinrichter (Universidad Carlos III, Espanha)

Bienvenido León Anguiano (Universidad de Navarra, Espanha)

Casimiro Torreiro (Universidad Carlos III Madrid, Espanha)

Cássio dos Santos Tomaim (Universidade Federal de Santa Maria, Brasil)

Catherine Benamou (Universidade da California-Irvine, EUA)

Claudine de France (Centre National de la Recherche Scientifique - CNRS, França)

Frederico Lopes (Universidade da Beira Interior, Portugal)

Gordon D. Henry (Michigan State University, EUA)

Javier Campo (Universidad Nacional del Centro - UNICEN; Consejo Nacional de Investigaciones Científicas y Técnicas - CONICET, Argentina)

José da Silva Ribeiro (Universidade Aberta, Portugal)

José Filipe Costa (IADE-Instituto de Artes Visuais, Design e Marketing, Portugal)

João Luiz Vieira (Universidade Federal Fluminense, Brasil)

Julio Montero (Universidad Complutense de Madrid, Espanha)

Luís Nogueira (Universidade da Beira Interior, Portugal)

Luiz Antonio Coelho (Pontifícia Universidade Católica do Rio de Janeiro, Brasil)

Margarita Ledo Andión (Universidad de Santiago de Compostela, Espanha)

María Luisa Ortega Gálvez (Universidad Autónoma de Madrid, España)

Michel Marie (Université de la Sorbonne Nouvelle - Paris III , França)

Miguel Serpa Pereira (Pontifícia Universidade Católica do Rio de Janeiro, Brasil)

Patrick Russell LeBeau (Michigan State University, EUA)

Paula Mota Santos (Universidade Fernando Pessoa, Portugal)

Paulo Serra (Universidade da Beira Interior, Portugal)

Philippe Lourdou (Université Paris $X$ - Nanterre, França)

Robert Stam (New York University, EUA)

Rosana de Lima Soares (Universidade de São Paulo, Brasil)

Samuel José Holanda de Paiva (Universidade Federal de São Carlos, Brasil)

Tito Cardoso e Cunha (Universidade da Beira Interior, Portugal)

(C) Doc On-line www.doc.ubi.pt

Revista Digital de Cinema Documentário | Revista Digital de Cine Documental | Digital Magazine on Documentary Cinema | Révue Électronique de Cinéma Documentaire

Universidade da Beira Interior (Portugal), Universidade Estadual de Campinas (Brasil)

Periodicidade semestral > Periodicidad semestral $>$ Semestral periodicity > Périodicité semestrielle

Editores: marcius.freire@gmail.com, manuela.penafria@gmail.com

setembro | setiembre | september | septembre 2015 ISSN: 1646-477X DOI: 10.20287/doc.d18

Membros do Conselho que participaram na presente edição | Miembros del Consejo Editorial que participaron en esta edición | Members of the Editorial Board that participated in this edition | Membres du Conseil Editorial qui ont participé à cette édition: Casimiro Torreiro, Cássio dos Santos Tomaim, Javier Campo, José Filipe Costa, Luís Nogueira, Luiz Antonio Coelho, Miguel Serpa Pereira, Paula Mota Santos, Samuel José Holanda de Paiva, Tito Cardoso e Cunha. Outros avaliadores | Otros evaluadores | Other evaluators | Autres évaluateurs: Paulo Cunha. 


\section{Índice}

\section{EDITORIAL}

\section{Editorial | Editor's note | Éditorial}

Interatividade e documentário

Marcius Freire, Manuela Penafria.......................................................................... 2 -

\section{DOSSIER TEMÁTICO}

\section{Dossier temático | Thematic dossier | Dossier Thématique}

O webdocumentário como um documentário feito de uma narrativa interativa, hipertextual e participativa

Tatiana Levin -5 -

Documentário e tecnologia: duas realidades em desenvolvimento paralelo

Patrícia Nogueira $-33-$

El documental interactivo en la cultura de convergencia y las narrativas transmedia

Maximiliano de la Puente; Lorena Díaz Quiroga $61-$

Documentários com ginga, perspectivas do documentarismo: dos webdocs à tv digital interativa brasileira

Bráulio de Britto Neves $-84-$

Brasil, mostra a sua cara: aproximações ao cenário brasileiro de documentários interativos

André Paz; Julia Salles

Interatividade digital, audiência e webdocumentários

Paulo Eduardo Cajazeira; José Jullian Gomes de Souza $166-$

\section{ARTIGOS}

\section{Artículos | Articles | Articles}

O confinamento de Vanda: uma leitura do dispositivo

Roberta Veiga

Realismos audiovisuais: visibilidades intertextuais em documentários televisivos

Rosana de Lima Soares

Glauber sob um regime de urgência

Érico Araújo Lima 
La primera persona, el amor y la persistencia de las preguntas en El telón de azúcar, de Camila Guzmán Urzúa

Anabella Castro Avelleyra $-272-$

Da exibição dos filmes da Comissão Rondon

Ana Lobato $-300-$

\section{LEITURAS}

Lecturas | Readings | Comptes Rendus

Cinensaios de Agnès Varda: o documentário como escrita para além de si Letizia Osorio Nicoli.

\section{ANÁLISE E CRÍTICA DE FILMES}

Análisis y crítica de películas | Analysis and film review | Analyse et critique de films

Estratégias interativas no webdocumentário Prison Valley

Betina Broch $-329-$

Malvinas: un acercamiento a las imagénes generadas por computadora y las narrativas transmedia

Pablo Francisco Gullino $-346-$

Ley genérica entre mujeres y putos: democracia, Stronato y Guerra Guasu

Rocco Carbone $-359-$

\section{ENTREVISTA}

\section{Entrevista | Interviews | Entretiens}

Filme Janela da alma revisitado - uma conversa com o diretor João Jardim

Dago Schelin $-378-$

Por um cinema infiltrado: entrevista com Adirley Queirós e Maurílio Martins a propósito de Branco sai, preto fica (2014)

Alfredo Suppia; Paula Gomes $-389-$

\section{DISSERTAÇÕES E TESES}

\section{Tesis | Theses | Thèses}

Música em cena: à escuta do documentário brasileiro

Cristiane da Silveira Lima $-415-$ 
Cineastas indígenas, documentário e autoenografia: um estudo do projeto Vídeo nas Aldeias

Juliano José de Araújo. $-417-$

A asserção no cinema documentário musical brasileiro

Cynthia Letícia Schneider ..... $-420-$

Formas de representação no cinema: uma reflexão sobre o uso da mise en scène nos documentários paraibanos

Riccardo Migliore . $-422-$

Islas de la memoria. Construcción del relato histórico y uso de imágenes digitales sobre la Guerra de Malvinas en producciones audiovisuales del periodo 2002-2012

Pablo Francisco Gullino $-424-$

Webdocumentário e as funções para a interação no gênero emergente: análise de Fort McMoney e Bear 71

Fernanda Bernardes $-426-$

A construção biográfica em Santiago

Tais Marcato $-428-$

As primeiras produções do documentarista João Moreira Salles

Caroline Maria Manabe $-430-$

The act of killing, uma autoria partilhada

Diana Rocha Svintiskas

Os documentários de Geraldo Sarno (1974-1987): sertão, poesia e religiosidade Felipe Corrêa Bomfim $-434-$

Documentário e meio ambiente no Brasil: uma proposta de leitura ecologizante Janaína Welle $-436-$

A representação de inclusão social e digital por meio da música em documentários brasileiros

Pamela de Bortoli Machado $-438-$

O som no documentário: a trilha sonora e suas transformações nos principais movimentos e momentos da tradição documentária, dos anos 1920 aos 1960

Renan Paiva Chaves $-440-$

Sokúrov e a montagem em Vida humilde (1997): imagem e representação

Breno Morita Forastieri da Silva $-442-$ 


\section{EDITORIAL}

Editorial | Editor's note | Éditorial 


\title{
INTERATIVIDADE E DOCUMENTÁRIO
}

\author{
Marcius Freire, Manuela Penafria
}

A $18^{\mathrm{a}}$ edição da DOC On-line apresenta um conjunto de artigos bastante reveladores da atual discussão a respeito das tecnologias digitais interativas e a sua relação e interferência com o documentário. Trata-se de uma investigação que discute a respeito dos contornos do seu objeto de estudo, das problemáticas que levanta, da sua própria terminologia e, também, de futuras perspectivas de investigação.

No Dossier temático podem ser lidos: “O webdocumentário como um documentário feito de uma narrativa interativa, hipertextual e participativa", de Tatiana Levin; "Documentário e tecnologia: duas realidades em desenvolvimento paralelo", de Patrícia Nogueira; "El documental interactivo en la cultura de la convergencia y las narrativas transmedia", de Maximiliano de la Puente e Lorena Díaz Quiroga; "Documentários com ginga, perspectivas do documentarismo interativa: dos webdocs à Tv digital interativa brasileira", de Bráulio de Britto Neves; "Brasil, mostra a sua cara: aproximações ao cenário brasileiro de documentários interativos”, de André Paz e Julia Salles e "Interatividade digital, audiência e webdocumentários", de Paulo Eduardo Cajazeira e José Jullian Gomes de Souza.

Na secção Artigos apresentamos: "O confinamento de Vanda: uma leitura do dispositivo", de Roberta Veiga; "Realismos audiovisuais: visibilidades intertextuais em documentários televisivos", de Rosana de Lima Soares; "Glauber Rocha sob um regime de urgência”, de Érico Araújo Lima; "La primera persona, el amor y la persistencia de las preguntas en El telón de azúcar, de Camila Guzmán Urzúa", de Anabella Castro Avelleyra; "Da exibição dos filmes da Comissão Rondon", de Ana Lobato.

Em Leituras, o livro: Cinensaios de Agnès Varda: o documentário como escrita para além de si, de Sarah Yakhni é-nos apresentado por Letizia Osorio Nicoli.

Em Análise e crítica de filmes, são publicados trabalhos de aproximação a diferentes obras cinematográficas: "Estratégias Interativas no 
Webdocumentário: um estudo de caso de Prison Valley”, por Betina Broch; "Malvinas: un acercamiento a las imágenes generadas por computadora y las narrativas transmedia", por Pablo Gullino e "Ley genérica entre mujeres y putos: democracia, stronato, guerra guasu", por Rocco Carbone.

Em Entrevista, uma conversa com João Jardim, diretor de Janela da Alma é-nos trazida por Dago Schelin. Publicamos, também, uma entrevista, por Alfredo Suppia e Paula Gomes ao diretor de Branco sai, preto fica (2014), Adirley Queirós e a Maurílio Martins, responsável pela trilha sonora desse mesmo filme.

Na secção Dissertações e Teses, encontram-se os mais recentes trabalhos científicos de que tivemos conhecimento; as teses de Doutoramento: "Música em cena: à escuta do documentário brasileiro", de Cristiane da Silveira Lima; "Cineastas indígenas, documentário e autoetnografia: um estudo do projeto Vídeo nas Aldeias”, de Juliano José de Araújo; “A asserção no cinema documentário musical brasileiro”, de Cynthia Letícia Schneider e as dissertações de Mestrado: "Formas de representação no cinema: uma reflexão sobre o uso da mise en scène nos documentários paraibanos", de Riccardo Migliore; "Islas de la Memoria. Construcción del relato histórico y uso de imágenes digitales sobre la Guerra de Malvinas en producciones audiovisuales del periodo 2002-2012”, de Pablo Francisco Gullino; "Webdocumentário e as funções para a interação no gênero emergente: Análise de Fort McMoney e Bear 71", de Fernanda Bernardes; "A construção biográfica em Santiago”, de Tais Marcato; “As primeiras produções do documentarista João Moreira Salles”, de Caroline Maria Manabe; "The act of killing, uma autoria partilhada", de Diana Rocha Svintiskas; "Os documentários de Geraldo Sarno (1974-1987): sertão, poesia e religiosidade”, de Felipe Corrêa Bomfim; "Documentário e meio ambiente no Brasil: uma proposta de leitura ecologizante", de Janaína Welle; "A representação de inclusão social e digital por meio da música em documentários brasileiros", de Pamela de Bortoli Machado; "O som no documentário: a trilha sonora e suas transformações nos principais movimentos e momentos da tradição documentária, dos anos 1920 aos 1960", de Renan Paiva Chaves e "Sokúrov e a montagem em Vida Humilde (1997): imagem e representação", de Breno Morita Forastieri da Silva. 


\section{DOSSIER TEMÁTICO}

Dossier temático | Thematic dossier | Dossier Thématique 


\title{
O WEBDOCUMENTÁRIO COMO UM DOCUMENTÁRIO FEITO DE UMA NARRATIVA INTERATIVA, HIPERTEXTUAL E PARTICIPATIVA
}

\author{
Tatiana Levin*
}

Resumo: Tratamos neste artigo do webdocumentário como uma narrativa interativa e hipertextual. Queremos verificar como o engajamento do espectador-usuário em um ambiente digital participativo reconfigura o espaço da produção. Investigamos ainda o tipo de experiência proporcionada em uma narrativa multissequencial.

Palavras-chave: webdocumentário, interatividade, hipertexto, autoria, participação, play.

Resumen: Tratamos en este artículo del webdocumental como una narración interactiva e hipertextual. Queremos comprobar cómo el compromiso del espectador-usuario en un entorno digital participativo reconfigura el espacio de la producción. Además, investigamos el tipo de experiencia proporcionada en una narración multisecuencial.

Palabras clave: webdocumental, interactividad, hipertexto, autoría, participación, play.

Abstract: In this article I discuss the webdocumentary as an interactive and hipertextual narrative. My aim is to observe how the spectator-user engagement in a participatory digital environment reconfigures the space of production. Plus I investigate the kind of experience provided by a multisequencial narrative.

Keywords: webdocumentary, interactivity, hypertext, autorship, participation, play.

Résumé: Dans cet article, le webdocumentaire est abordé comme un récit interactif et hypertextuel. Nous voudrions vérifier comment l'engagement du spectateur-utilisateur dans un environnement numérique participatif reconfigure l'espace de la production. On étudie également le genre d'expérience fournie dans un récit multi-séquentiel.

Mots-clés: webdocumentaire, interactivité, hypertexte, auteur, participation, play.

\footnotetext{
* Doutoranda. Universidade Federal da Bahia - UFBA, Faculdade de Comunicação, Programa de Pós-Graduação em Comunicação e Cultura Contemporâneas. 40110060, Salvador, Brasil. E-mail: tatianalevin@gmail.com
} 


\section{Introdução}

O documentário interativo embora seja um fenômeno recente como produto midiático incorporado ao campo da cultura e entretenimento apresentou avanços na produção de um corpo crítico de textos que buscam entendê-lo. ${ }^{1} \mathrm{O}$ cenário era diferente há menos de cinco anos atrás, quando a reflexão sobre o fenômeno encontrava-se repleta de indefinições e suposições. ${ }^{2}$ Questões que desde um primeiro momento se mostraram importantes tiveram avanços significativos, como o pensar no documentário interativo em termos de ser uma experiência colaborativa, ${ }^{3}$ mas que ainda pode ser espaço para uma visão autoral.

O documentário interativo designa uma mudança estética ao organizar o conteúdo em níveis de interatividade a estabelecer funções para o espectador-usuário ${ }^{4}$ dentro de diferentes possibilidades de participação. Por meio de uma organização hipertextual, a narrativa é apresentada de forma não-linear em seções de informação ligadas entre si. O interator é ativo na decisão da quantidade de material que quer usufruir e em qual

\footnotetext{
${ }^{1}$ Recente pois presente em grandes conglomerados midiáticos em fins da primeira década dos anos 2000. Um dos primeiros webdocumentários a ganhar alguma notoriedade foi Prison Valley, projeto de 2008 do canal ARTE (Disponível em: http://prisonvalley.arte.tv/?lang=en.).

2 Algo que retratei em artigo publicado ainda em 2013 ("Do documentário ao webdoc: questões em jogo num cenário interativo" in Doc On-line: Revista digital de cinema documentário, www.doc.ubi.pt, n. 14).

${ }^{3}$ Colaborativa no sentido de permitir o uso de conteúdo gerado pelo usuário. Como esclarece Sandra Gaudenzi (2014), trata-se de uma participação que vai além de uma interatividade baseada em clicar, selecionar ou escolher em meio a um conteúdo existente, significando portanto um adicionar ou mudar este conteúdo, interferindo assim no projeto.

${ }^{4}$ Defendi o uso da terminologia espectador-usuário em apresentação na SOCINE de 2013. Apesar de achar esta terminologia bastante apropriada na definição daquele que interpreta e navega por um documentário interativo, preservei e adotei termos variados utilizados por outros autores tais como leitor, escritor (Landow) ou interator (Gifreu, Murray), usuário (Gaudenzi, Nash, Gifreu) e prosumer (Gaudenzi). "Prosumer" é uma terminologia em inglês derivada do termo "consumer" e designa especificamente a audiência no contexto de mídias colaborativas, significando ainda "(...) permitir que o conteúdo gerado pelo usuário faça parte do conteúdo do documentário" (Gaudenzi, 2014).
} 
ordem. Sua participação pode dar-se em uma interatividade qualificada como reativa, quando o que se faz é clicar e fazer avançar o conteúdo, ou em um nível mais sofisticado, quando ele adiciona material como comentador ou criador, a ser moderado por vezes por um autor a exercer o papel de curador do material adicionado. É da ordem da autoria a arquitetura do projeto onde os níveis de interação são estabelecidos e é nesta arquitetura que está prevista ou não a possibilidade do espectador-usuário de se tornar um produtor de conteúdo.

Reflexões com base no objeto literatura digital numa configuração de hipertexto trazidas por George Landow no livro Hipertext 3.0 (2006) servem hoje para um entendimento da relação entre autoria e participação no documentário interativo, na ideia da configuração de um leitor muito ativo ou do leitor como escritor. Pensar a origem do hipertexto convoca textos seminais sobre novas mídias de Ted Nelson, responsável pelo termo hipertexto e sua concepção original ainda em 1960, e Vannevar Bush na sua elaboração sobre o memex em 1945, uma máquina que permitiria a associação de textos entre si de uma forma orgânica tal como a mente humana e onde o leitor poderia adicionar documentos nesta rede de informação fazendo anotações quando desejasse. Para Landow (2006: 11) o que é marcante na concepção original de Bush é primeiramente o reconhecimento da "leitura como um processo ativo que envolve escrever" e em segundo lugar a necessidade de um suporte virtual em lugar da estrutura física do livro. Landow cita como referência dois textos de $\mathrm{Bush}^{5}$ onde o autor introduz termos como link e a noção de blocos de textos ligados por links. O autor enfatiza a importância da contribuição de Bush na elaboração de uma nova textualidade em que um texto flexível está aberto às demandas de cada leitor. Nelson e Bush são assim pioneiros na concepção do que seria o hipertexto tal como o conhecemos ao terem percebido seu potencial “(...)

\footnotetext{
${ }^{5}$ As we may think (1945) e Memex revisited (1967).
} 
de permitir que usuários achem, criem, e sigam múltiplas estruturas conceituais num mesmo corpo de informação" (Landow, 2006: 10).

O meio digital por ser naturalmente participativo (Murray, 2003) permitiu que as ideias teóricas dos pioneiros fossem testadas em produtos culturais. Neste artigo queremos examinar as características do webdocumentário como um documentário feito de uma narrativa interativa e hipertextual. Pretendemos ainda averiguar o que ocorre na experiência de acesso a um documentário interativo do ponto de vista do que está previsto na arquitetura do projeto. Entendemos que as diferentes possibilidades de participação do espectador-usuário previstas pelo autor podem reconfigurar o espaço da produção. É importante assim entender essas novas relações. Dito de outro modo, queremos perceber as formas de participação do interator ao navegar por narrativas hipertextuais feitas de diferentes modos de interatividade.

\section{Um documentário não-linear e interativo}

Arnau Gifreu em uma série de textos sob o tema The distinction between linear and interactive documentaries publicados no Research Forum do Mit Open Documentary Lab (2013) fez um esforço de sistematizar as diferenças entre documentários tradicionais (lineares) e documentários interativos (não-lineares). Se há diferenças entre ambos, o documentário interativo segue correspondendo-se com o gênero documental ao ser um meio de representação da realidade histórica trazendo reflexões sobre temas relevantes da cultura humana. Gifreu refere-se à definição de documentário tomando a elaboração de Stella Bruzzi que fala numa “(...) negociação com a realidade, uma mescla da realidade da experiência do cineasta com seus esforços de compreendê-la" (Gifreu, 2012: 261-262). O autor ressalta que Bruzzi encara o realizador como uma figura central, pois sua definição incorpora uma mudança de paradigma sobre o que vem a ser o 
gênero no sentido de ter se deslocado de uma representação da realidade para uma ordenação e então negociação da mesma. Nas palavras de Gifreu, "Bruzzi vê o cineasta como se invadisse um espaço e o marcasse, deixando atrás a ilusão do 'cinema objetivo' que inspirou o cinema direto dos anos sessenta" (Gifreu, 2012: 262, grifo do autor). A subjetividade do realizador é incorporada ao resultado fílmico nessa mescla da sua própria realidade com a tentativa de retratar a realidade histórica em foco. Bruzzi dialoga com uma tradição de estudos do campo do documentário onde a superação do ideal de objetividade é vista como um avanço na compreensão do gênero. Importante observar que se a definição de Bruzzi traz progressos ao situar a representação da realidade no documentário como fruto da subjetividade de um realizador, ela ainda lida com um contexto onde um espectador participante não é uma questão a mexer com o espaço da prática. Mandy Rose (apud Gifreu 2013-2014) reforça essa visão de historicidade baseada na ideia de evolução presente na reflexão teórica de autores ocidentais reconhecidos no campo de estudos sobre documentário. Rose situa o documentário interativo como uma evolução no modo de representar a realidade. A evolução do documentário para ela seguiu até o século XX dentro de uma intenção de gerar significado a partir de um autor modelando uma peça. A forma estava organizada segundo o modelo de início, meio e fim nos documentários lineares. Outras possibilidades surgiram com a lógica interativa componente do documentário interativo, propiciando por exemplo o surgimento de peças mais dialógicas, colaborativas e abertas. Podemos perceber nessa fala de Rose que são outras as questões levantadas para se entender o produto documentário interativo. $\mathrm{O}$ foco sai do texto como peça acabada a ser analisada para incorporar ainda uma negociação, mas entre autor e usuário a modificar este texto. A importância do autor neste caso estaria também ligada ao tipo de experiência proporcionada durante o acesso.

O documentário dentro de um meio interativo faz referência aos 
temas e sujeitos da realidade histórica, porém promove outro tipo de experiência para aquele que passa a ser além de audiência um usuário que tem opções de controle sobre o material. Segundo Gifreu (2012), a mudança dá-se no sentido de transferência de opções de eleição e controle que antes eram propriedades somente do documentarista. Tomando de Bill Nichols o princípio de definir o documentário por meio dos eixos de observação autor, texto e espectador, ele aponta a não-linearidade como uma diferença fundamental entre o documentário tradicional e o interativo. A questão da linearidade sob o ponto de vista da sua manifestação textual colocaria em pontos opostos as duas modalidades de documentário, sendo impossível modificar a ordem do discurso no documentário tradicional quando finalizado para exibição e distribuição. Falar de linearidade para Gifreu diz respeito a se pensar numa rota fixa pré-determinada pelo autor que vai de um ponto inicial até um ponto final. A não-linearidade opera numa lógica diferente, onde se pode ter um ponto inicial estabelecido pelo autor ou escolhido pelo usuário que irá derivar em caminhos e ramificações múltiplos, dependentes da rota escolhida. Trata-se de diferentes narrativas possíveis, um discurso fragmentado em opções variadas, onde há um poder de decisão nas mãos do interator.

O documentário linear demanda apenas um tipo de envolvimento cognitivo da audiência, um envolvimento mental que resulta numa interpretação e reflexão sobre o visto, enquanto que o documentário interativo requer, além da interpretação cognitiva, um tipo de participação física e processo de decisão relacionados que resulta no uso do mouse, movimentar-se por um cenário virtual, ou uso do teclado e escrita, fala, etc. (Gifreu, 2013, parte 1).

O autor finaliza sua reflexão comparativa sobre documentários lineares e interativos ressaltando suas similaridades no uso de convenções de representação textuais como o uso de entrevistas, de sequências 
observacionais, ${ }^{6}$ comentários em voz over ou na forma de textos. E se eles ainda podem ser organizados em torno de um forte apelo narrativo ou em múltiplas histórias categorizadas, há uma diferença fundamental no arranjo temporal dos itens numa nova organização espacial-temporal dos conteúdos não ficcionais agora remediados. ${ }^{7}$ Segundo Mike Robbins (apud Gifreu, 2013-2014), a experiência do documentário interativo é ser uma plataforma que permite o consumo de outras mídias numa única janela. O consumidor deste tipo de produto seria alguém acostumado a lidar com diferentes mídias.

\section{Uma narrativa hipertextual}

Ao discutir o futuro da narrativa no ciberespaço, Janet Murray (2003) lembra da importância da narrativa para a ordenação cognitiva da experiência humana e de como o formato participativo natural do ambiente digital promove um envolvimento diferenciado quando comparado à experiência de se ouvir ou assistir a uma história sem interatividade. Ao definir o formato da narrativa interativa, Murray prefere o termo multissequencial ou multiforme para classificar histórias que se afastam de um formato linear convencional. Sua justificativa é que o termo não-linear é associado erroneamente com a falta de causalidade narrativa. Nas suas palavras, "histórias multissequenciais proporcionam ao interator a habilidade de navegar por um arranjo fixo de eventos de diferentes maneiras, todas elas bem definidas e significativas" (Murray, 2003: 10).

\footnotetext{
${ }^{6}$ Gifreu revisa os modos de representação documentais a partir de Bill Nichols tanto nesse texto quanto em sua tese, sendo o modo observativo um deles. Também revisei os modos de Nichols em artigo publicado na Doc On-Line em 2010, além da minha dissertação de mestrado (2009), a fim de entender questões de representação textual no campo do documentário.

7 "Remediação" é um conceito usado por Gifreu no sentido de Jay David Bolter e Richard Grusin significando “(...) a representação de um meio em outro (...) a remediação é uma característica das novas mídias digitais" (Bolter; Grusin, 2000: 45).
} 
Apesar das raízes do formato multissequencial terem sido plantadas em outros meios, Murray destaca o computador como lugar para uma audiência ativa, participativa, onde o formato do hipertexto tem sido adotado em larga escala. A dinâmica hipertextual permite aos autores experimentar possibilidades de encadeamento lógico dentro de um ambiente interativo e imersivo. O hipertexto funciona enquanto um sistema que permite que diferentes unidades semânticas possam ser ordenadas e reordenadas a partir de links que as conectam. ${ }^{8}$

A revolução trazida pela tecnologia da informação digital que teve início com o computador foi vista por pioneiros como propulsora de uma nova forma de escrita. Landow (2006: 144) explora alguns problemas de uma escrita hipertextual como o lidar com o sentido de desorientação que a experiência de navegação por um espaço digital pode proporcionar quando aquele que navega não sabe em que ponto está na rede ou como chegar a um ponto que sabe ou pensa existir. O autor ressalta que a desorientação embora seja reconhecida como problema pode ser vista também como um prazer estético. Problema ou efeito desejado, a desorientação é enfrentada no planejamento da navegação pelo espaço digital que abriga agora narrativas multissequenciais, onde achar o sentido de orientação engloba mais opções do que o avançar ou retroceder das narrativas lineares. Landow cita ainda a abordagem da experiência de navegação no espaço hipertextual digital por teóricos do hipertexto como o vaguear por uma base de dados.

O hipertexto e a hipermídia convocam para Landow questões de planejamento de sua arquitetura que devem responder a alguns desafios, já que é característica deste tipo de escrita o oferecimento de uma experiência

\footnotetext{
${ }^{8}$ Landow assume os termos hipertexto e hipermídia como similares, visto que para ele o hipertexto já expandia a noção de texto para além do verbal ao classificar a ligação de blocos de textos com outros materiais não verbais (imagens, mapas, diagramas, etc). Hipertexto designa assim um "texto composto de blocos de texto - o que Barthes nomeia uma lexia - e links eletrônicos que os unem” (Landow, 2006:3) e hipermídia expande essa noção ao qualificar também materiais não verbais como parte do sistema.
} 
que implica comportar mudanças de direção através da ligação (links) de blocos de informação. Assim, o autor pergunta (1) o que pode ser feito para ajudar os leitores a obter prazer e um sentido de orientação ao longo da experiência, (2) como eles podem ter seus passos rastreados no seu caminho de leitura, (3) como pode ser desenhada a estrutura dos links de forma que se possa saber onde eles levam e por último, (4) como alguém pode ajudar um leitor que acabou de entrar no projeto a se sentir em casa. Landow resume da seguinte forma os problemas colocados, tratam-se respectivamente de questões de orientação, navegação e informação sobre entrada e saída.

A questão geral aqui é sobre interpretação. Mais especificamente, permitir que visitantes desse novo tipo de texto o leiam prazerosamente, confortavelmente $\mathrm{e}$ eficientemente, quanta interpretação a mais o autor-designer deve adicionar ao sistema como um todo, para ligar caminhos, e os documentos ao fim dos links? (Landow, 2006: 153).

O autor indaga sobre o que é qualidade no hipertexto levantando algumas características do meio que o definem: multilinearidade, multivocalidade em potencial, riqueza conceitual e controle dado ao leitor. O conceito de multivocalidade é tratado por Landow (2006: 56) a partir da noção de Bakhtin sobre romance multivocal, onde múltiplas consciências interagem. No contexto de hipertexto, essa multivocalidade vista como potencialidade do meio é atribuída a uma propriedade dada na "leituraescrita", ou seja, na combinação entre a experiência de interpretação de um bloco de texto específico com a experiência do espectador-usuário que cria sentido através da navegação, considerada a construção de um caminho pessoal na narrativa.

Sobre a narrativa hipertextual, alguns pontos destacados servem para pensarmos o contexto da narrativa no documentário interativo. São eles o 
empoderamento do leitor, as escolhas e possibilidades de intervenção dadas a ele; o uso dos recursos textuais $;{ }^{9}$ a complexidade da estrutura da rede; e os graus de multiplicidade e variação em elementos literários como enredo, caracterização, contextualização e outros. Neste último ponto, o próprio Landow discute o uso da poética aristotélica no contexto do hipertexto como algo a ser tomado como referência para a percepção de uma certa desconstrução, já que a definição de Aristóteles de enredo é baseada no princípio da sequência fixa para falar de início, meio e fim. O trecho da poética citado por Landow embasa sua reflexão:

Um todo agora é aquilo que tem início, meio e fim. Um início é aquilo que não é em si necessariamente depois de nada mais, e que tem algo naturalmente depois dele; um fim é aquilo que naturalmente é depois de algo bem como é necessariamente ou usualmente consequente, e sem nada mais depois dele; e um meio é por natureza depois de uma coisa e também tem outra coisa depois de si. (Aristóteles apud Landow, 2006: 218).

Landow (2006: 218) fala ainda de como um todo segundo Aristóteles deve apresentar "uma certa magnitude definida" para ser belo, além da ordenação das partes constituintes citadas. Assim, o autor estabelece que o hipertexto desafia a sequência fixa, o início e fim definidos, "uma certa magnitude definida" na história e, por fim, a própria concepção de unidade ou de um todo associadas aos outros conceitos. Tomando a poética aristotélica como referência, o autor inicia uma reflexão sobre a própria natureza da conceituação de narrativa dentro de um critério de linearidade, onde a qualidade da multilinearidade do hipertexto requer uma outra visão sobre o papel do leitor.

\footnotetext{
${ }^{9}$ Landow fala em recursos extra-linguísticos textuais já que seu foco está em literatura e portanto no uso do verbal como matéria fundamental. Adotamos aqui o sentido de texto como materiais verbais e não-verbais, especificando-os quando necessário para a reflexão em curso.
} 
Um dos pressupostos do hipertexto é que o linkar prepara o leitor para uma interpretação relacional. Landow posiciona o usuário (espectador, leitor) da narrativa multissequencial como aquele que produz linearidade através da sua leitura, da sua experiência de navegação: “(...) todas as experiências de leitura e escrita em quaisquer meios são num sentido importante lineares, unidirecionais" (Landow, 2006: 152). A linearidade então passa a ser vista como uma habilidade do leitor dada na experiência de interpretação/leitura do material hipertextual no contato com um bloco de textos ou no seguimento de caminhos. Um leitor mais ativo na interpretação do conteúdo ganha novas habilidades a depender do desenho do sistema hipertextual.

Problemas adicionais surgem quando considera-se que o hipertexto envolve um leitor mais ativo, alguém que não apenas seleciona caminhos de leitura mas que também tem a oportunidade (em verdadeiros sistemas leitura-escrita) de ler como alguém que cria um texto; a qualquer momento a pessoa que está lendo pode assumir um papel autoral e também anexar links ou adicionar texto ao texto que está sendo lido. (Landow, 2006: 82).

A reconfiguração do autor dentro de um sistema hipertextual é para Landow uma potencialidade e não uma propriedade automática. No contexto que nos interessa do documentário interativo, a autoria e participação têm sido objeto de reflexão de pesquisadores que tratam especificamente do tema. Um espectador-usuário pode assumir posições variadas a depender do uso da interatividade em níveis e propostas diferenciadas. 


\section{A interatividade aplicada ao documentário, os limites da participação e o exercício da autoria}

As opções de engajamento do espectador através da sua participação na narrativa têm sido exploradas no documentário interativo. Kate Nash no texto Clicking the world: documentary representation and interactivity (2014) explora o conceito de interatividade na sua complexidade pensando como interagir com um documentário é diferente do lidar com outras formas midiáticas no que concerne à experiência proporcionada. O uso da interatividade não apenas distingue o documentário interativo de seus pares televisivos ou cinematográficos, mas promove mudanças no texto em si e em formas de engajamento diversificadas segundo a autora.

Muitas vezes a interatividade é entendida em termos do que a audiência, agora crescentemente descrita como usuários, é capaz de fazer em relação ao conteúdo do documentário. Frequentemente, o significado das ações do usuário é descrito em termos políticos ou epistêmicos: audiências são ativas, empoderadas, profundamente engajadas e o documentário transcendeu suas raízes modernistas finalmente evitando a totalidade e criando espaços nos quais os indivíduos podem falar por si mesmos. (Nash, 2014, grifo do autor).

A autora considera que o ambiente do documentário interativo é um ecossistema dinâmico composto por usuários, realizadores de documentário, assuntos e sistemas tecnológicos, onde a interatividade propicia engajamentos narrativos que derivam em efeitos também diversificados. Dentro deste contexto, algumas das perguntas que Nash quer responder é o que as audiências podem fazer com o conteúdo do documentário, como são endereçadas e posicionadas e o que podem experienciar. Ela distingue para isso as dimensões tecnológica, relacional e experiencial no entendimento da interatividade. Uma quarta dimensão lida com a especificidade do discurso 
do documentário pensando-se a questão da voz, no agenciamento do usuário e no potencial retórico da interação.

Perceber como a tecnologia dá forma a experiência do usuário é o que Nash quer contemplar com a dimensão tecnológica. Dito de outra forma, esta dimensão permite verificar o grau de resposta do sistema tecnológico, sua abertura, as escolhas que ele disponibiliza, e a extensão do controle do usuário sobre o documentário enquanto um sistema. A autora faz referência aqui a Sandra Gaudenzi $(2013)^{10}$ e aponta principalmente o empenho físico requisitado do usuário para fazer o documentário funcionar. Outro destaque na dimensão tecnológica é a presença de affordances ${ }^{11}$ no produto que eventualmente não são utilizadas, quando a audiência é convidada a participar e não adere à proposta mesmo se sentindo capaz.

A dimensão relacional colocada por Nash convoca o entendimento da interatividade como um relacionamento tanto entre máquina e usuário quanto entre usuários que interagem entre si. Aqui interessa analisar como a dimensão tecnológica posiciona o usuário em relação ao documentário no sentido de verificar como ele é endereçado, de que forma é convidado a participar e em que tipo de ambiente comunicacional. Ela cita como características desse ambiente relacional a reciprocidade, a capacidade de resposta, igualdade e participação. Assim interessa avaliar quem fala, a extensão da reciprocidade e como a audiência é posicionada nessa troca.

O documentário interativo estabelece uma posição específica da audiência em relação ao seu conteúdo tendo como premissa a participação do usuário da maneira esperada. Para Nash (2014), "isso pode ser manifestado na forma de instruções específicas ou pode ser implícito, na aposta de familiaridade com metáforas e processos que cercam as

\footnotetext{
$10 \mathrm{Na}$ sua tese de doutorado: The living documentary: from representing reality to cocreating reality in digital interactive documentary (University of London).

${ }^{11}$ Segundo Janet Murray, affordances são as propriedades funcionais que permitem usos particulares para a representação em narrativas interativas (Disponível em: http://inventingthemedium.com/glossary/.
} 
tecnologias comunicacionais digitais". A autora cita os fóruns de discussão presentes nos documentários interativos dentre as formas comunicacionais avaliadas na dimensão relacional. Nash traz como exemplo de análise os mecanismos de discussão como fóruns e chats no webdocumentário Prison Valley, onde os próprios habitantes da comunidade retratada utilizaram o espaço para questionar o ponto de vista dos autores do documentário. Analisando a situação, ela conclui que embora a audiência tenha sido engajada de forma ativa na discussão, o teor das respostas fornecidas pelos realizadores em sua defesa levanta questões de autoridade e enquadramento das contribuições dos espectadores.

Uma outra dimensão considerada pela autora trata de como os participantes experienciam a interação. A gama de quesitos a serem avaliados vai desde o quanto o sistema é percebido como rápido e responsivo ao grau de playfulness ${ }^{12}$ e conectividade com outros interatores. A experiência engloba a percepção de como a audiência entende o convite à participação e os significados apreendidos a partir do seu engajamento.

A dimensão discursiva da interatividade é adicionada por Nash na abordagem do documentário interativo como aquela que diferencia o estudo do documentário do de outras mídias interativas. Essa dimensão visa contemplar a análise da relação entre as ações dos usuários e o discurso do documentário, ou seja, examina até que ponto as ações dos usuários impactam de forma significativa o argumento proposto pelo documentário. Nash cita a fala de Nichols $(1991)^{13}$ sobre o documentário ser um discurso de sobriedade ao endereçar uma realidade compartilhada e fazer afirmações a serem tomadas como verdadeiras. Ainda sobre o autor, ela retoma o conceito de voz como "aquilo que traz o ponto de vista social do texto"

\footnotetext{
${ }^{12}$ Como play quando traduzido para o português qualifica os termos tanto brincar quanto jogar, além de atuar, preferimos assumi-lo na língua inglesa de forma a incorporar ambos significados. Joga-se e brinca-se quando se navega por uma narrativa interativa. Pode-se inclusive atuar como personagem inserido na narrativa. Mesma direção foi tomada em relação a playfulness. Podemos pensar em jogabilidade ou ludicidade.

${ }^{13}$ Representing reality: issues and concepts in documentary
} 
(Nichols apud Nash, 2014) para pensar a relação entre a autoria do documentário e o discurso. ${ }^{14}$ Nash lembra que noções tradicionais de autoria são desafiadas no ambiente interativo onde uma questão central é a interrogação da relação entre os argumentos suportados pelo documentário interativo e a ação da audiência. Para a autora, alguns webdocumentários ao se organizarem em categorias podem promover comparações retóricas. Um exemplo citado é Gaza Sderot com sua interface dividida contendo depoimentos de cidadãos palestinos de um lado e de israelenses do outro. ${ }^{15}$

Importante notar que Nash não propõe uma definição para o conceito de interatividade, mas uma visão multidimensional por meio de aspectos definidores e ferramentas para se indagar seu uso estratégico como recurso de representação da realidade. ${ }^{16}$ Para a autora é preciso pensar no engajamento do usuário no produto posicionando-o em relação ao discurso e planejando sua experiência em curso.

Outro texto que foca na dimensão participativa da interatividade tem autoria de Sandra Gaudenzi. ${ }^{17}$ Em Strategies of participation: the who, what and when of collaborative documentaries (2014) é ressaltada a importância de se planejar níveis de participação do usuário em documentários colaborativos já que nem todos desejam participar na mesma intensidade.

\footnotetext{
${ }^{14}$ Conceito desenvolvido por Nichols no texto A voz do documentário, publicado em 1983.

15 Alexandre Brachet (Upian), produtor de Gaza Sderot, relatou que apesar de ser tecnicamente possível permitir que comentários dos dois lados fossem ouvidos ao mesmo tempo, foi priorizado dar ao usuário a opção de escolher qual lado gostaria de ouvir a cada momento, se o palestino ou o israelense. (Between the Lines, 2013).

16 Murray (2003) já havia utilizado em 1997 uma definição múltipla de interatividade, destacando a dimensão procedimental e participativa do ambiente digital, algo também explorado no glossário de seu blog Inventing the medium: "The digital medium is participatory in allowing an interactor to manipulate, contribute to, and have an effect upon digital content and computer processing. Participation combined with procedurality create interactivity, which means that the designer must script the behavior of the computer and the behavior of the interactor".

17 Participação também se torna um conceito a ser destrinchado quando se fala em documentário interativo e neste sentido ganha outros contornos quando comparado ao uso dado por Murray (conferir nota anterior).
} 
Gaudenzi determina alguns critérios para avaliar níveis de participação, como a lógica de todos serem revisores ${ }^{18}$ da Wikipédia em oposição à edição feita apenas por um autor. Cada opção contém em si fatores a serem avaliados como a manutenção da coerência narrativa por exemplo. Uma lógica de produção que inclua a participação do usuário na adição de conteúdo resulta num documentário feito de uma base de dados crescente, porém sem lhe dar o poder de se envolver na arquitetura do projeto. É a possibilidade de todos contribuirem com o texto imagético ${ }^{19}$, mas sem o poder de agirem como co-autores no sentido de exercerem domínio sobre a edição e permanência de materiais no documentário final. Gaudenzi ressalta que para se construir a arquitetura do projeto é preciso habilidades de programação específicas, mas para ela o cerne da questão é outro: a arquitetura do projeto num documentário interativo é o lugar para a voz autoral, o controle da interface é portanto um novo nível de poder. "Nesse contexto a autoria é menos sobre a expressão de uma intenção particular (Foucault 2008: 53) ou sobre dar poder de interpretação ao leitor (Barthes 1984: 37) e mais sobre orquestrar níveis de agenciamento através do software" (Gaudenzi, 2014).

Permitir a contribuição do usuário em projetos interativos com conteúdo gera essa forma crescente de narrativa onde o problema passa a ser quando interromper o acréscimo de material e como dar uma forma final ao todo. Como ressalta a autora, a estética da forma final desse tipo de produto assemelha-se a um mosaico, onde múltiplas entradas podem ser visualizadas simultaneamente numa única interface. Sua crítica é justamente que há uma perda de detalhamento em meio à apresentação de uma heterogeneidade.

Comparando documentários lineares e interativos, Gaudenzi distingue diferentes modos de produção. Se o linear comporta as fases de pré-produção (pesquisa e ideias), produção (realização técnica, filmagem e

\footnotetext{
18 "Crowd-reviewing" no original.

19 "Crowdsourcing video" no original.
} 
edição) e pós-produção (lançamento e distribuição), o interativo diferenciase por conter durante a fase de produção outros focos de realização técnica (realização da plataforma, com codificação e produção de algum conteúdo ${ }^{20}$ ) e ao ser colaborativo, tenha uma fase posterior destinada à produção de conteúdo do usuário além da fase onde a plataforma digital é lançada com algum conteúdo.

Gaudenzi chama atenção para a importância de se pensar em quem está participando, o que pode ser feito e quando a intervenção é possível a fim de cercear as estratégias de participação em documentários interativos colaborativos. Para ela, decidir quem participa é fundamental para o autor do projeto em termos de quem ele chama para construir uma relação dialógica. O "quem" convoca o envolvimento dos participantes em relação ao assunto enquadrado pelo projeto, o quanto são experts em certo tópico ou companheiros com uma paixão em comum, ou apenas uma multidão de nãoexperts.

Documentários produzidos por muitos ${ }^{21}$ têm que lidar com três grandes desafios: como navegar através de uma grande quantidade de informação (interface), como criar uma narrativa coerente para o usuário final (experiência do usuário) e se e quando parar o acréscimo de conteúdo (ciclo de vida do projeto). (Gaudenzi, 2014).

Segundo Gaudenzi, uma variável no documentário interativo colaborativo é quando os participantes são os sujeitos retratados, quando então eles são diretamente selecionados pelo autor e envolvidos no retrato de si e limitados pelo acordo feito entre as partes durante o processo.

\footnotetext{
${ }^{20}$ Gaudenzi tem como foco no seu artigo os documentários interativos colaborativos e portanto define a produção de parte do conteúdo nessa fase. Documentários interativos que não aceitem a adição de conteúdo de usuários terão a produção de todo o conteúdo em uma única etapa.

${ }^{21} \mathrm{Na}$ nossa tradução o termo utilizado pela autora "crowd-produced" virou "produzido por muitos". Temos no entanto visto a presença corrente de termos como crowd-funding e crowd-sourcing mantidos no original em meios de comunicação em língua portuguesa.
} 
Outro fator destacado pela autora é como enquadrar a participação, sendo exemplos o adicionar conteúdo ao já existente, modificá-lo, interferir no projeto. Gaudenzi enfatiza as relações de poder nessa decisão, lembrando que adicionar conteúdo mudando o tamanho e a forma da base de dados não significa influenciar a arquitetura interativa e a interface do projeto. A autora conclui que, diferentemente dos documentários lineares, onde o que estava em jogo era uma visão particular do mundo, aqui o que importa é estabelecer uma posição no mundo. “'O que o participante pode fazer’ é uma proposta de ação, uma visualização de mudança, dentro de um mundo on-line que tem suas próprias regras e limites - normalmente estabelecidos pelo autor" (Gaudenzi, 2014).

Decisões relacionadas ao "quando" dizem respeito ao selecionar um período de tempo no qual o documentário interativo estará aberto à participação. Gaudenzi situa as fases de pré-produção e produção como aquelas onde a participação ainda é enquadrada sob um forte olhar autoral. Um exemplo é povoar uma interface estabelecida (conteúdo adicionado após lançamento da interface) resultando numa estética de mosaico. Isso muda apenas quando o documentário é construído numa dinâmica de mudança constante, onde o controle do projeto é também compartilhado.

Os mecanismos de participação num documentário interativo têm sido um importante foco de atenção da academia por mexer com uma questão fundamental do documentário, a autoria do seu ponto de vista social. Contudo, nem todos os documentários interativos investem na colaboração. Muitos se organizam em torno de uma base de dados fechada, onde a experiência implica uma interatividade restrita. A experiência no entanto requer ainda uma postura diferenciada do espectador. 


\section{Delimitações da experiência ao se percorrer um documentário interativo: o play e o vaguear}

Quando fala em navegação e especificamente em navegar por uma narrativa hipertextual, Landow (2006: 153) distingue que a navegação pressupõe localizar-se num mundo espacial e o hipertexto pressupõe um mundo experiencial onde algo desejado está sempre à distância de um link. Uma chave interessante de compreensão do documentário interativo é pensar como está enquadrada essa experiência de se transitar por um mundo construído num ambiente digital. Para Willian Uricchio, essa nova forma de contar uma história pode ser vista como herdeira do documentário linear, embora vindo de um espaço diferente daquele da tradicional realização cinematográfica, um espaço entre o documentário e o play (Gifreu, 20132014).

Uricchio apresenta no texto Playing with narrative dois conceitos que buscam dar conta da experiência do usuário enquanto percorre um documentário interativo, o de play e o de vaguear, andar ao acaso. ${ }^{22} \mathrm{O}$ autor cita Caspar Sonnen (diretor do IDFA DocLab) no uso do termo vaguear para explicar a diferença da experiência proporcionada por um documentário tradicionalmente linear e o interativo. Sonnen usa a noção de vaguear fazendo uma analogia com a visita a uma cidade acompanhada por um guia turístico em oposição à opção de se realizar a mesma visita por conta própria andando ao acaso, vagueando. Se a primeira opção corresponde a ter sua atenção direcionada por diferentes pontos previamente selecionados, a segunda opção conduz a um caminho de descobertas próprias onde seguir seu interesse leva à criação de uma história personalizada. São experiências diferentes proporcionadas em cada opção. "Elas oferecem diferentes affordances, atendem diferentes necessidades,

\footnotetext{
22 "Wandering" no original.
} 
requerem diferentes posturas" (Uricchio, 2013). E segundo Uricchio, ambas oferecem engajamento narrativo.

A noção de play é aquela onde o autor se detém mais demoradamente. Uricchio segue o trabalho de Scot Osterweil (diretor criativo do MIT's Education Arcade) que introduz a noção de play fazendo uma distinção entre as experiências de se ouvir um ótimo contador de histórias e de se jogar/brincar (playing). No primeiro caso, a experiência é deixar-se ser guiado pelo contador de histórias que apresenta cuidadosamente uma história amarrada. O play leva a outras experiências que vão de imaginar e co-criar um mundo e suas regras a habitar um personagem ou mesmo compartilhar objetivos com jogadores na mesma situação. A postura solicitada é a de se deixar levar sem se ter certeza do desfecho, sendo importante improvisar habitando personagens e vivendo-se a experiência que segue. Uricchio esclarece que Osterweil elabora essas analogias direcionadas a um objeto de estudo que são os games de computador criados para potencializar o aprendizado, e sendo assim, sua visão de play insere-se dentro de uma situação narrativa onde a história é desconhecida para o jogador que navega seu mundo diegético com suas regras, tendo um objetivo a atingir. A mesma noção aplicada ao estudo do documentário interativo requer outras considerações, embora dentro das possibilidades exploradas exista o jogar/brincar como personagem, situação referida por Osterweil como profundamente narrativa.

No seu interesse por entender o fenômeno do documentário interativo, Uricchio percebe a necessidade de se rediscutir o que é uma narrativa, já que o conceito de narrativa mais aceito na academia é aquele que lida com a narração de eventos ocorridos no passado não contemplando portanto algo em curso, como estar jogando/brincando ou experienciando uma situação ao se adquirir novas vivências. 
No sentido exato, nenhum "contador" de "eventos passados" significa nenhuma narrativa. E ainda nossa experiência enquanto vagueando ou playing pode parecer tão imersiva, instigante, motivada e coerente como qualquer história, e no caso do play, contém explicitamente muito das mesmas características (personagem, ambientação, regras, e um "assim como" mundo ficcional). Este último ponto, é claro, traz sua gama de complicações ao documentário, mas como irei sugerir, isso também oferece importantes formas de repensar o lugar da imaginação no domínio do não-ficcional. (Uricchio, 2013, grifo do autor).

Play trabalhado dessa forma é para Uricchio uma potencialidade a ser desenvolvida no campo do documentário via documentário interativo.

$\mathrm{O}$ autor lembra num breve histórico, que o surgimento dos games em torno de 1960 e de jogos ficcionais interativos em particular, por volta de 1970, mexem com formas narrativas tradicionais. O desenvolvimento sistemático de novas formas de narratividade é um fenômeno recente para ele, como atestam exemplos de filmes interativos em fins de 1980 (MIT's Interactive Cinema Research Group) e de literatura interativa em fins da década de 1990 (Electronic Literature Organization). Uricchio identifica três diferentes estratégias surgidas com o desenvolvimento dos games de computador e a emergência de formas narrativas que promoveram experiências de fruição alternativas nos anos 1980. As três estratégias descritas por Uricchio situam o documentário interativo a partir de diferentes concepções do conceito de narrativa.

A primeira estratégia traz uma relação com a noção corrente de que narrativa é o recontar de eventos passados. A atividade do jogador é redefinida ao se introduzir narratologicamente uma espécie de voz interior que tem a ver com a consciência do jogador ao andar ao acaso, vagueando por aí. Os eventos quando processados cognitivamente seriam algo como experienciados há pouco, portanto tecnicamente passado. Uma variação dessa abordagem toma o problema do "experienciado há pouco" e a natureza indeterminada das conclusões, argumentando que narrativa é o que 
é construído retrospectivamente, depois do processo estar completo, quando lembramos e recontamos nossas experiências.

A segunda estratégia afasta-se de uma teoria voltada para a grande narrativa para lidar com as micro-estruturas da narrativa.

(...) $\mathrm{O}$ processo pelo qual questões são repetidamente colocadas e então respondidas de forma a sustentar o interesse do espectador e fazer avançar a narrativa geral. Em vez de pensar a narrativa como uma estrutura englobadora da experiência total (seja o "começo, meio e fim" de Aristóteles ou Freytag), pode em vez disso ser entendida como os blocos construtores de uma experiência, cada um com seu ciclo de "exposição, transformação e resolução". (Uricchio, 2013, grifo do autor).

Para Uricchio, certas formas de narrativa interativa apenas desagregam essas 'mini-narrativas' uma das outras dando ao espectador a possibilidade de agregá-las segundo seu interesse. "O DNA básico da narrativa - a sequência - permanece intacto, enquanto que o processo maior de junção é aberto à modificação promovida pelo usuário" (Uricchio, 2013).

A terceira estratégia deriva da narratologia cognitivista e define a narrativa como um processo cognitivo que é parte da estrutura psicológica humana. Seria assim um processo usual de ver e organizar a experiência vivida, mais do que uma característica do texto. Um processo defendido por outros autores que pensam na narrativa interativa (Murray, 2003; Landow, 2006). Sobre a narrativa como um processo cognitivo, Uricchio argumenta:

Criada e experienciada on the fly, é situacional e não tem a ver com ter que esperar um recontar post facto ou a agregação de mini-narrativas de forma a constituir uma experiência narrativa. Mas se manifesta na percepção da coerência e ligação entre eventos experienciados. (Uricchio, 2013, grifo meu).

O autor finaliza: 
Documentários interativos vêm de muitas formas diferentes, algumas das suas estruturas textuais aderindo bastante de perto a tradições narrativas estabelecidas; outras, explicitamente tomando a forma de mini-narrativas que o usuário pode mover entre e ligar; e outras ainda oferecendo ricas possibilidades desagregadoras ao participante motivado, que pode conectar os pontos numa experiência narrativa. (Uricchio, 2013).

Para Uricchio, os conceitos de play e de vaguear, andar ao acaso (wandering) servem portanto ao desenvolvimento de formas narrativas interativas. $\mathrm{O}$ autor aponta como razão para uma rápida incorporação dessas novas técnicas por documentaristas uma motivação para o play e o vaguear derivada de um contexto familiar, fruto da realidade histórica. Nas suas palavras, "a familiaridade preexistente do usuário com a realidade proporciona amplo contexto e motivação para que ele explore opções interativas e tendo-as coesas como uma experiência unificada e significativa" (Uricchio, 2013). A ficção exige a criação de um mundo diegético e a adaptação a este mundo antes que os usuários saiam navegando, vagueando de forma a vivenciar uma experiência significativa. Em ambos os casos, a estrutura textual do ambiente é apoiada na natureza da experiência a ser proporcionada ao usuário. Assim como a percepção da narrativa depende do afeto do usuário. Para o autor o play num mundo e o estar em um personagem podem beneficiar o contexto da não-ficção como opção criativa. Explorar olhando por outros olhos é uma estratégia que usa a imaginação como recurso e propicia um engajamento com uma dada agenda.

Uricchio portanto adota a experiência de se vaguear como bastante proveitosa no contexto da não-ficção já que o andar sem rumo a explorar dáse enquadrado pela realidade histórica, algo naturalmente contextualizado e motivante para o autor. 
Uma das grandes potencialidades do documentário interativo é a flexibilidade que ele propicia ao usuário de encontrar seu próprio caminho através de um ambiente construído. (...) no ato de playing (em vez de ouvir a história contada), nós temos a oportunidade de assumir um conjunto de instintos, de inventar uma posição de visionamento e de representá-la, de responder por meio dela, e no processo, aprender. $\mathrm{O}$ documentário interativo de hoje atende o andarilho sem rumo, e com um efeito maravilhoso. Mas tem uma capacidade ainda subutilizada de endereçar o player. (Uricchio, 2013).

\section{Conclusão}

O universo do documentário interativo, especificamente do webdocumentário, tem mostrado resultados no investimento da pesquisa acadêmica, pois requer que questões sejam pensadas unindo estudos de campos diferenciados. Como tentamos demonstrar aqui, é preciso buscar autores que trabalham com cultura digital e voltar os achados para o documentário, pois o documentário em si suscita questões próprias. Encontra-se reflexão importante sobre interatividade, autoria e participação em textos que lidam especificamente com o documentário interativo.

Interatividade é um conceito-chave, autoria, uma questão central e participação a grande potencialidade. Do lugar do autor, cabe a ele pensar na experiência que quer proporcionar, o quanto de controle quer ceder ao espectador-usuário, de que forma vai abrir o projeto para uma participação e até quando. E como a participação estará enquadrada em relação ao discurso do documentário. Do ponto de vista do espectador-usuário, espera-se engajamento físico para fazer acontecer o documentário e adesão às propostas de participação. É importante que o projeto contemple níveis de participação, pois nem todos querem participar da mesma maneira. A inversão de papéis entre autor e espectador é uma das grandes novidades trazidas pela interatividade, mas nem todos projetos vão investir nisso. Há 
que se perceber que no universo dos documentário interativos aquele chamado colaborativo é apenas um tipo.

Pensar a experiência proporcionada pelo documentário interativo a partir dos estudos de games, define um aspecto e abre outros sobre questões de narrativa. Podemos trabalhar com o pressuposto de que o play não exige a busca por um fim, o que conta é a experiência dentro do tempo em que se está jogando/brincando. Dito de outra forma, o play - entendido como brincar/jogar com o tempo - implica numa relação diferenciada de se entrar em contato com o conteúdo de um documentário interativo. Ainda assim, pensamos ser fundamental investigar outros pontos dentro desse espectro de estudo que é o viés narrativo da história. Pensamos ser proveitoso portanto pensar a análise do produto na sua arquitetura hipertextual tomando como norteadores a construção da história (início, meio e fim nas micro-narrativas e no todo e interface como conteúdo), a organização do tempo (da coisa narrada e da narração) e espaço (desenho da navegação, percepção dos mecanismos que orientam o espectador usuário na sua experiência).

Sabe-se desde já que alguns webdocumentários quando organizados como mosaicos podem não ter início, meio e fim, mas investir no enquadramento do assunto através de uma interface contextual e uma pequena introdução do assunto, tendo como grande qualidade a apresentação de múltiplas vozes, ou pontos de vista sociais. Outros irão investir apenas na partida, como diz Landow, sendo a chegada diferente a depender da navegação escolhida, do caminho traçado. Desenhar a história no espaço (interface e navegação) é fundamental para nortear o espectadorusuário que agora pode visualizar o percurso como um mapa a ser percorrido. Entender que o sentido de desorientação pode ser uma experiência estética planejada, justifica-se em algum sentido dentro da experiência do play. O tempo da coisa narrada pode ser uma brincadeira ou jogo no qual vale o tempo que o espectador-usuário quer destinar à experiência. 
Nem todos os webdocumentários vão adotar certas estratégias da mesma forma e embora alguns usem estratégias narrativas tradicionais buscando orientar o espectador-usuário, há ainda um investimento numa experiência personalizada que se dá na variação de tempo destinada ao vaguear pela história. A combinação tempo-espaço traz inevitavelmente a ideia de experiência on the fly, ou seja, do tempo gasto para se navegar pela história. Nesse sentido a noção de play introduzida por Uricchio como o engajar-se fluidamente, estar imerso na narrativa, achar sua própria forma dentro da narrativa, nos parece bastante proveitosa na definição da experiência múltipla que requer a apreciação de um documentário interativo.

\section{Referências bibliográficas}

BETWEEN THE LINES FESTIVAL (2013), Storytelling in the new landscape: the medium and the message. Disponível em: http://vimeo.com/70396815.

BOLTER, J. David; GRUSIN, Richard (2000), Remediation: understanding new media, Cambridge, Mass: MIT Press.

GAUDENZI, Sandra (2014), "Strategies of participation: the who, what and when of collaborative documentaries" in Kate NASH,; Craig HIGH,; Catherine SUMMERHAYES, (eds.), New documentary ecologies: emerging platforms, practices and discourses, UK: Palgrave Macmillan.

GIFREU, Arnau (2013-2014), MIT open documentary lab video profiles, Disponível em: http://opendoclab.mit.edu/category/video-profiles. (2013a), The distinction between linear and interactive documentaries (Partes 1 a 4). MIT open documentary lab research forum. Disponível em: http://opendoclab.mit.edu/category/ research-forum. 
(2013b), El documental interactivo como nuevo género audiovisual: estudio de la aparición del nuevo género, aproximación a su definición y propuesta de taxonomía y de un modelo de análisis a efectos de evaluación, diseño y producción, Barcelona: Tese de doutorado, Universidad Pompeu Fabra, capítulo 5, pp. 258-350.

LANDOW, George P. (2006), Hypertext 3.0: critical theory and new media in an era of globalization, Baltimore: Johns Hopkins, $3^{\text {a }}$ Ed.

MURRAY, Janet H. (2003), Hamlet no holodeck: o futuro da narrativa no ciberespaço, São Paulo: Itaú Cultural; UNESP.

__ Inventing the médium. Disponível em: http://inventingthemedium. com/glossary/.

NASH, Kate, (2014) "Clicking on the world: documentary representation and interactivity" in Kate NASH,; Craig HIGH,; Catherine SUMMERHAYES, (eds.), New documentary ecologies: emerging platforms, practices and discourses, UK: Palgrave Macmillan.

LEVIN, Tatiana (2013), “Do documentário ao webdoc: questões em jogo num cenário interativo" in Doc on-line: revista digital de cinema documentário, Covilhã, PT; Campinas, BR, n. 14, ago, 2013. Semestral. ISSN 1646-477X. Disponível em: http://www.doc.ubi.pt/index14.html.

(2010), “'Eu falo de nós para vocês': subjetividade e performance no documentário os catadores e eu" in Doc on-line: Revista Digital de Cinema Documentário, Covilhã, PT; Campinas, BR, n. 09, dez, 2010. Disponível em http://www.doc.ubi.pt/ index09.html. (2009), A "cinescrita" de Agnés Varda: a subjetividade incorporada ao campo do documentário, Salvador: Dissertação de Mestrado, Universidade Federal da Bahia.

S/ Autor, History of computers and computing, internet, dreamers, Vannevar Bush. Disponível em: http://historycomputer.com/Internet/Dreamers/ Bush. html. 
Tatiana Levin

Upian | IDFA DocLab. Disponível em: http://www.doclab.org/company/ upian/.

URICCHIO, Willian (2013), Playing with narrative in MIT Open Documentary Lab Research Forum. Disponível em: http://opendoclab.mit.edu/category/research-forum.

\section{Webdocumentários}

Gaza Sderot, life in spite of everything (2008). Disponível em: http://gazasderot.arte.tv/.

Highrise: out my window (2010). Disponível em: http://highrise.nfb.ca/. Prison Valley (2008). Disponível em: http://prisonvalley.arte.tv/?lang=en. 


\title{
DOCUMENTÁRIO E TECNOLOGIA: DUAS REALIDADES EM DESENVOLVIMENTO PARALELO
}

\author{
Patrícia Nogueira*
}

Resumo: Os últimos desenvolvimentos tecnológicos evidenciaram que as diferentes abordagens ao "real" no Documentário não são apenas resultado dos movimentos estéticos e sociais, mas também consequência do apparatus cinematográfico. Através da análise de vários documentários, tradicionais e interativos, busca-se compreender de que forma a tecnologia tem alterado o Documentário e o que deve ser preservado como caraterística de autenticidade inalienável.

Palavras-chave: documentário, tecnologia, interatividade, estética, autoria.

Resumen: Los últimos desarrollos tecnológicos han puesto de manifiesto que los diferentes abordajes de lo "real" en el documental no son únicamente el resultado de los movimientos estéticos y sociales, sino también la consecuencia del apparatus

cinematográfico. Mediante el análisis de varios documentales, tradicionales e interactivos, pretendo comprender de qué forma la tecnología ha alterado el documental y qué debe ser preservado como característica de autenticidad inalienable.

Palabras clave: documental, tecnología, interactividad, estética, autoría.

Abstract: The latest technological developments showed that documentary's different approaches to the "real" are not only the result of social and aesthetic movements, but also a consequence of the cinematic apparatus. By the analysis of several classic and interactive documentaries I intend to understand in what way technology has changed the documentary and what should be preserved as an inalienable characteristic of authenticity.

Keywords: documentary, technology, interactivity, aesthetics, authorship.

Résumé: Les derniers développements technologiques montrent que les différentes approches du "réel" dans le documentaire ne proviennent pas seulement des mouvements esthétiques et sociaux, mais sont également la conséquence de l'apparatus cinématographique. A travers l'analyse de divers documentaires, traditionnels et interactifs, je tenterai de comprendre dans quel sens et de quelle manière la technologie a modifié le documentaire et de dégager ce qui doit en être préservé comme caractéristique inaliénable de son authenticité.

Mots-clés: documentaire, technologie, esthétique, auteur.

\footnotetext{
* Doutoranda. Universidade do Texas - Austin International Program, Universidade do Porto Doutoramento em Media Digitais. 4200, Porto, Portugal.

E-mail: patnogueira@gmail.com
}

Submissão do artigo: 10 de junho de 2015. Notificação de aceitação: 20 de agosto de 2015 . 


\section{Introdução}

O Cinema é provavelmente uma das formas de arte mais tecnológicas. A combinação de uma confluência de disciplinas tanto Científicas (química, física, engenharia, ótica) como da área das Humanidades (literatura, pintura, teatro) levou a que inicialmente tenha sido colocado em primeiro plano o apparatus tecnológico, o que Mark Cousins denomina de "sobressalto técnico" (2004: 21). Nos primeiros momentos da história do Cinema foi a tecnologia que despertou um interesse imediato, na medida em que a promoção e a comercialização tinham como objetivo a experiência da máquina (de Lauretis, 1980:1). A máquina foi, de facto, introduzida entre o filme e o espectador. A ponderação do fator tecnológico torna-se por isso central para qualquer consideração sobre Cinema, onde se compreende o Documentário, como fenómeno cultural e histórico.

Além disso, nas origens do Cinema um aspeto central do fascínio pelo médium prende-se com a capacidade do público de reconhecer o mundo que habita. O poder da Fotografia de reproduzir uma espécie de recorte da realidade e congelá-la dentro de um enquadramento aumentou exponencialmente quando evoluímos para uma sucessão de imagens que restauram a sensação de movimento e de vida, ultrapassando o poder da imagem congelada. $\mathrm{O}$ público assistia a um mundo quotidiano aparentemente embalsamado, podendo seguir os acontecimentos e ações que até àquele momento pertenciam ao domínio do passado.

O surgimento do Cinema possibilitou, assim, um arquivo da realidade distinta de qualquer outra forma que o havia precedido e a possibilidade de reconhecimento das situações representadas neste arquivo criou um inegável fascínio sobre o espectador. A sensação de realismo transmitida pelo filme depende fortemente deste ato de reconhecimento que 
está na origem do Cinema e que permanece na tradição documental até à atualidade.

Mas não podemos ignorar os interesses económicos no desenvolvimento de qualquer tecnologia fílmica. Brian Winston (1996), por exemplo, acredita que a inovação e o desenvolvimento tecnológico no domínio do Cinema são impulsionados pelo mercado ou, pelo menos, acontecem em perfeita simbiose com os fatores económicos. Os espectadores têm de desejar o que a tecnologia pode proporcionar ainda antes da sua concretização. De Lauretis (1980) crescenta também que as novas tecnologias não emergem simplesmente, mas que são promovidas pelo mercado, criando necessidades que servem interesses comerciais.

O mesmo se passa com a emergência do multimédia e da realidade virtual:

"Without agreement on what these sytems are expected to do, there can be no mass market. This implies making na unsuspecting public familiar with a new device and persuading it not only of its merit, but of its ease of opperation. In this respect, the introduction of multimédia products into the home is a 'technology driven' push, rather than a 'culturally led' pull." (de Lauretis, 1980: 80-1).

Mas para lá das imposições económicas é possível identificar que os desenvolvimentos tecnológicos proporcionam novas abordagens estéticas e autorais, como são disso exemplo as mais recentes tecnologias digitais emergentes. Definidas as premissas iniciais do cinema, como a criação de uma gramática visual, mais do que alterar significativamente o resultado final, a maioria das inovações tecnológicas na indústria cinematográfica teve como objetivo expandir as práticas de produção (Eidsvik, 1988-9).

Mas no caso do Cinema Documental assistimos a um outro paradigma. Talvez devido aos escassos recursos económicos, o documentário alicerça-se numa tradição de experimentação (Nichols, 2001: 
83), de romper fronteiras ideológicas, estéticas e também tecnológicas, umas vezes apropriando-se das mais recentes invenções, outras vezes provocando essas inovações que depois são transferidas para outros contextos culturais. É esta busca constante pela novidade e pela experimentação que permite ao documentário reinventar-se e manter-se vivo.

Neste sentido, assistimos atualmente, mais uma vez, à reinvenção documentário. As condições de produção cinematográficas, cada vez mais acessíveis a um grande número de autores, a internet de banda larga e as codificações de vídeo que permitem grande qualidade de imagem num ficheiro de informação reduzida levaram novamente o documentário a romper fronteiras. Assistimos à transferência do cinema documental para o meio virtual, a uma fragmentação das narrativas, à construção do filme centrado nas audiências.

No entanto, como diz David Bordwell (2012), um filme já não é um "film", mas um ficheiro encriptado em linguagem binária. Além disso, a internet 2.0 favorece a interação entre produtores, realizadores e audiências, dando origem ao documentário interativo. Esta parece ser uma abordagem apelativa mas simultaneamente apresenta novos desafios ao documentário. A participação das audiências esbate as fronteiras da autoria e a interatividade pode ocultar o ponto de vista do documentário. Os novos contextos documentais de produção e distribuição estão a mudar a abordagem e a estética documental, levando-nos a (equacionar) uma nova fase, que Steven Shaviro (2010) denomina de pós-cinema.

\section{Documentário, da poética à intervenção}

A exploração da realidade vivida pelo cinema inicia-se com um inegável fascínio pelo exótico, desempenhado sobretudo pelo trabalho dos travelogues que se estendiam pelo mundo em busca de imagens do 
desconhecido. A representação do real conheceu uma nova etapa com o nascimento do Documentário. Em Nanook of the North (1922), Robert Flaherty apresenta uma nova representação da realidade, utilizando técnicas do cinema de ficção na construção de um ponto de vista sobre determinado fenómeno do mundo. No entanto, a curiosidade pelo desconhecido em zonas remotas do planeta prolonga-se no tempo e permanece durante o nascimento do Cinema Documental. À semelhança dos primeiros operadores de câmara, também Flaherty alimentava uma visão "romântica", parafraseando Paul Rotha (1983), sobre o conceito de "bom selvagem". Tal como confirmado por Frances Flaherty, companheira do realizador, este "loved primitive people, he loved their simplicity and their dignity, and the way they where free to be themselves" (Ellis e McLane, 2009: 23)

Mas Nanook of the North representa, sem dúvida, o resultado do primeiro esforço significativo de intersubjetividade na realização de documentários, que enfatiza um consenso de partilha entre realizador e sujeitos. Em virtude da capacidade de Flaherty de processar e revelar filme, o realizador podia mostrar sequências filmadas aos Inuit, de modo a obter a opinião dos sujeitos representados antes da montagem (Ellis e McLane, 2009: 13).

Quando a partir de década de 20 os documentaristas procuram novas formas de subjetividade e novas abordagens estéticas de representação do real, a tecnologia disponível permitia pouca flexibilidade. Nesta altura, o Cinema era pouco mais do que uma sequência de imagens fixas: a preto e branco, mudas e muito dispendiosas. As pesadas câmaras de $35 \mathrm{~mm}$ eram difíceis de operar, ruidosas e mantinham os planos presos ao chão através do tripé. Mesmo captando o som separadamente, o ruído da câmara interferia nas condições de gravação e o equipamento de som era ainda mais pesado e complexo do que o de captação de imagem.

Tais restrições não desencorajaram os primeiros realizadores. Pelo contrário, a história mostra-nos que as restrições tecnológicas 
impulsionaram os documentaristas a reinventar-se, com pontos de vista pertinentes e arrojados. A experimentação poética dos anos 20 surge da contaminação com outras expressões artísticas, dando origem a vários filmes das vanguardas modernistas. Sem grande possibilidade de mover a câmara, estes filmes são compostos com imagens quase exclusivamente fixas, nos quais os realizadores da época criaram narrativas eminentemente visuais. Imagens poéticas, misturadas, justapostas e sobrepostas, organizadas por uma montagem rítmica e apelativa, criavam metáforas e envolviam as audiências através das suas figurações emocionais do mundo envolvente. Esta abordagem permite que o filme crie um mundo único, seja através da indução de uma realidade ou exclusivamente através da forma.

O filme Regen (1929) insere-se nesta última abordagem de priorização das qualidades formais do filme sobre a temática. Antes de mais, o documentário centra-se na composição visual e na montagem rítmica, procurando padrões geométricos entre a chuva e os transeuntes, enquanto eles executam uma espécie de coreografia de negociação do espaço pela cidade. A narrativa, apesar de não muito definida, apresenta momentos distintos que lhe imprimem um certo ritmo. O trabalho de Joris Ivens poderse-á comparar a um poema ou a uma pintura em movimento.

Produzido praticamente com meios próprios e rodado durante meses, o documentário causa, no entanto, a sensação de que toda a ação decorre apenas durante uma tarde. Joris Ivens tinha a câmara carregada e pronta a filmar aos primeiros sinais de chuva. Alguns planos do filme foram até captados a partir da cama de Ivens que chegou a confessar "I slept with Anneke and with my camera" (Joris apud Schoots, 2000: 55). Mas já nessa altura o realizador procurava maior flexibilidade e foi na pequena Kinamo, uma câmara profissional de $35 \mathrm{~mm}$, que encontrou a possibilidade de fazer alguns movimentos:

With my camera held in my hand, the marvelous Kinamo of Professor Goldberg, I was, naturally, freed from the rigidity 
of a tripod, and I had given movement to what, normally, would have had to be a succession of fixed shots. Without knowing it, filming flexibly and without stopping, I had achieved a continuity. That day I realized that the camera was an eye and I said to myself, 'If it is a gaze, it ought to be a living one.' (Buckland, 2006: 92-93).

Com o advento do sonoro, à semelhança do que aconteceu nas narrativas de ficção, o cinema documental ganha também uma voz. Bill Nichols considera que a chegada do som ao documentário é uma questão de tecnologia, financiamento, estética e expectativas do público (Nichols, 1995). Mas é também preciso notar que muitos documentários se mantiveram mudos até aos anos 60, altura em que assistimos à introdução do som síncrono.

Consciente da importância do som John Grierson considerava que o microfone, tal como a câmara de filmar, podia superar um simples decalque da realidade. $\mathrm{O}$ fundador do movimento documental acreditava que a dimensão sonora seria capaz de atribuir ao documentário diferentes atmosferas e contribuir para a construção dramática do filme. No entanto, o autor também reconhecia uma falha essencial na precisão semântica do som. Grierson defendia uma estética sonora baseada num conceito de complementaridade entre imagem e som, que reforçava um compromisso com a estrutura dramática da narrativa (Rogers, 2015: 28-29).

A introdução do som no documentário permite uma transição das narrativas poéticas e evocativas para um discurso retórico, cimentado na propaganda de ideias políticas e sociais. Trabalhos como a série documental Why we fight (1952-53) e o filme The Plot that broke the plains (1936) procuram antes de mais manter a continuidade narrativa assente no argumento verbal, através da chamada "Voz de Deus" (Nichols, 2001: 105109). Nesta abordagem, a palavra prevalece sobre a imagem e os planos são muitas vezes meramente ilustrativos das reivindicações retóricas dos 
discursos, ao invés de permitirem que o potencial das sequências compostas por fragmentos imagéticos seja editado para alcançar o expoente máximo da narrativa cinematográfica.

A introdução do som no Documentário confere-lhe maior autenticidade mas simultaneamente desafia o realizador a evitar a dependência da dimensão sonora para marcar o ponto de vista do filme, levando a uma abordagem demasiado óbvia. Uma eventual alternativa baseou-se na substituição da narração off pelas entrevistas como forma de atribuir uma "voz" mais autêntica ao documentário.

O primeiro documentário a integrar o discurso real de cidadãos comuns sobre a sua vida quotidiana foi Housing problems (1935), produzido pelo British Film Institute. Arthur Elton e Edgar Anstey, realizadores do filme, concentraram-se no discurso da classe trabalhadora inglesa e, através de entrevistas com pessoas comuns, permitiram que os sujeitos se apresentassem "more fully and colorfully than was all together possible in silent film" (Elis e McLane, 2009: 69). O facto de os cidadãos expressarem para a câmara as preocupações do quotidiano representou uma inovação no documentário que até aí apenas considerava a voz autoral do documentarista. Igualmente inovador foi a atenção prestada à classe trabalhadora, levando o documentário a aproxima-se de questões e problemáticas sociais.

Estas duas abordagens - entrevistas e preocupações sociais - foram adotadas pelo discurso televisivo e mantêm-se até hoje, tanto no registo jornalístico como documental. No entanto, à medida que as tecnologias de captação de imagem e som evoluíram, o documentário passou a privilegiar narrativas na primeira pessoa e as entrevistas alcançaram uma abordagem mais intimista, num registo de conversas.

Em 1958, Michel Brault e Gilles Groulx realizaram para o National Film Board do Canadá o filme Les raquetteurs (1958), inaugurando uma nova e muito particular abordagem estética. O documentário é composto por 
um ágil trabalho de câmara, em grande parte sonorizado com som síncrono e sem qualquer narração, sem a interferência dos autores na tentativa de recusar a imposição de qualquer tipo de "verdade". Esta abordagem permitia uma maior imersão da audiência, dando aos espectadores a sensação de serem "transportados" para o local e de presenciarem os acontecimentos "tal como sucederam". Estavam, assim, criados os pressupostos do Cinema Direto, mas faltavam os instrumentos tecnológicos que permitiam esta abordagem.

A década de 60 revela-se especialmente desafiante para o Cinema Documental e são os próprios documentaristas que desenvolvem a tecnologia necessária para responder às suas aspirações estéticas, ao invés de apenas se apropriarem das novas ferramentas que iam surgindo. Em 1960, simultaneamente nos EUA (Robert Drew) e na França (Jean Rouch), os documentaristas tentam criar uma câmara leve, portátil, fácil de operar e silenciosa, que permitisse som síncrono. Só assim poderiam representar o mundo envolvente com a sensação de não-interferência que desejavam.

O documentário Primary (1960), produzido por Robert Drew e realizado por Richard Leacok, representou um avanço significativo na abordagem a acontecimentos reais, filmando a campanha das eleições primárias do partido democrático no Estado do Wisconsin com os candidatos Hubert Humphrey e John F. Kennedy (Elis e McLane, 2004: 212). As equipas do filme retratam não apenas os momentos públicos mas também os bastidores da campanha, acompanhando os acontecimentos em tempo real, sem interferência da equipa e sem recurso a entrevistas. O documentário conhece assim uma abordagem observacional (Nichols, 2001: 109-115). Neste registo notabilizou-se um plano sequência ininterrupto, com som síncrono, que acompanha o percurso de Kennedy pelas costas, desde o exterior de um edifício, entrando pela porta, o percurso do corredor e a subida de alguns degraus até ao palco, onde é recebido com aplausos. 
Quase simultaneamente em França, Jean Rouch, com a colaboração do sociólogo Edgar Morin, filmava Cronique d'un Eté (1961), utilizando a nova tecnologia de som síncrono essencialmente para gravar a discussão de ideias com os intervenientes e a captação de entrevistas. Apesar de Rouch, tal como Drew e Leacok, aproveitar a mobilidade das novas câmaras para se movimentar entre as personagens, o objetivo do realizador francês não era causar a impressão da não-interferência. Pelo contrário, Cronique d'un Eté é um filme autorreflexivo, na medida em que inclui no filme o próprio processo de produção e os realizadores aparecem frequentemente nas imagens, na tentativa de consciencializar sistematicamente a audiência para o facto de estar a assistir a um filme, a uma representação do real.

A partir dos anos 70 assistimos à introdução do VHS, que foi evoluindo ao longo da década de 80 , e à democratização da tecnologia. A transição para o vídeo representou um impacto significativo no documentário, tanto em termos de práticas de produção como de abordagem estética (McLane, 2012: 273). O baixo custo das cassetes de vídeo, quando comparadas com o preço da película e dos laboratórios de revelação, permitiu que mais pessoas passassem a produzir documentários e que as horas de imagem captadas aumentassem exponencialmente, apesar da diminuição da qualidade da imagem e do som. A fraca qualidade do vídeo, quando comparado com a película, trouxe acesos debates sobre o valor estético desta tecnologia (Elis e McLane, 2004: 259).

Simultaneamente, no manifesto "For an imperfect Cinema", o realizador cubano Julio Garcia Espinosa interrogava-se:

What happens if the evolution of film technology (there are already signs in evidence) makes it possible that this technology ceases being the privilege of a small few? What happens if the development of video-tape solves the problem of inextricably limited laboratory capacity? (Espinosa, 1979).

A resposta às questões de Espinosa encontra-se nos filmes de autorrepresentação desenvolvidos ao longo dos anos 70 e 80, aquando do 
aparecimento dos movimentos associados às minorias (feministas, LGBT, Afro-Americanos) que encontram no documentário um meio de representação alternativo às conceções das produções cinematográficas mainstream. Filmes com registos confessionais e íntimos, às vezes autobiográficos e narrados na primeira pessoa, resgatam histórias perdidas ou escondidas e exploram as experiências da repressão social. Muitos destes filmes, produzidos por ou com a colaboração de comunidades, apresentam uma experiência partilhada entre realizador e sujeitos.

Também os filmes ativistas, com agendas políticas ou sociais, se desenvolveram graças à democratização das tecnologias emergentes, permitindo que um número crescente de documentários fosse produzido em regiões normalmente sem meios financeiros para a produção cinematográfica, como os países da América Central (Mélane, 2012: 271). No entanto, o desejo de impressionar a audiência com a importância e urgência do tema por vezes negligencia as abordagens formais e artísticas, levando a que muitos dos filmes produzidos nestes contextos não consubstanciem obras de referência para o documentário, ainda que prevaleça o valor social das mesmas.

\section{A revolução digital}

Quando Espinosa previu "the possibility for everyone to make films" (Espinosa, 1979: 24) estava longe de imaginar que os desenvolvimentos tecnológicos iriam permitir que, de facto, qualquer pessoa com uma câmara digital e um computador pessoal conseguisse produzir e distribuir um documentário e, assim, adicionar ao panorama cinematográfico um novo ponto de vista. As câmaras de filmar DSRL - pequenas, acessíveis, fáceis de manusear e com enorme qualidade - permitiram que inúmeros aspirantes a realizadores, até então sem material para a produção cinematográfica, 
produzissem os seus projetos. A distribuição desses documentários também não se revela um problema na era digital, uma vez que muitos festivais de documentário dão visibilidade a realizadores emergentes e simultaneamente as plataformas digitais, como o Youtube e o Vimeo, servem de espaço privilegiado para a promoção e mesmo distribuição dos filmes.

À medida que o acesso a equipamento de produção, distribuição e exibição se democratiza o documentário expande-se e reconfigura-se de formas surpreendentes. No entanto, simultaneamente, a qualidade formal, estética e artística, sem esquecer as questões éticas, são colocadas em causa.

Mas o impacto das novas tecnologias no documentário revela-se através de formas mais amplas e complexas. Aliás "digital media redefines the very identity of cinema" (Manovich, 2006). Paralelamente aos desenvolvimentos tecnológicos que introduziram um novo apparatus cinematográfico, a partir dos anos 60 começou a ensaiar-se uma tendência para a interatividade computacional (Gere, 2008: 68). Com a entrada no novo milénio, a colisão destas duas tendências da atualidade acessibilidade tecnológica e interatividade - representou um impacto significativo nos modos de subjetividade de abordagem ao real e deu origem ao denominado "documentário interativo".

O conceito de documentário interativo encontra-se ainda a ser definido, tendo em conta as inúmeras configurações destes objetos que se situam entre o documental, a interatividade, a tecnologia e diversos elementos multimédia. A própria expressão "documentário interativo", usada originalmente por Whitelaw (2002), não é consensual. Parece-nos ser, no entanto, a que melhor define estes objetos digitais que pretendem uma abordagem criativa do real, com um ponto de vista definido, que utiliza a interatividade como forma de comunicação com o público e que não têm necessariamente de se encontrarem alojados na internet. Exemplo disso é o trabalho Immemoire (1997), do realizador Chris Marker, que concentra num 
CD-ROM diversos segmentos de vídeo que podem ser acedidos aleatoriamente, através de cliques em hiperligações.

Existem definições mais abrangentes para o documentário interativo, como é o caso da entrada no The Johns Hopkins guide to digital media and textuality (2014) escrita por Sandra Gaudenzi. Para a autora, qualquer trabalho que parta de uma intenção de documentar o real e utilize tecnologia interativa pode ser considerado um documentário interativo. Esta definição parece, no entanto, negligenciar que além de documentar a realidade, o documentário tem de imprimir um argumento sobre o mundo, apresentar um ponto de vista autoral, condição que vários teóricos (Bruzzi, 2000; Nichols, 2001) defendem como fundamental para estarmos perante um documentário e não uma mera reprodução da "realidade", como acontece nos trabalhos jornalísticos.

Pelas suas características, os documentários interativos são o que Umberto Eco denominaria de "Obras Abertas" (Eco, 1989), uma forma de arte com características que alteram radicalmente a relação entre autor e espectador, exigindo do público um grau muito maior de colaboração e envolvimento pessoal do que era solicitado nas obras tradicionais. Enquanto no documentário tradicional o espectador tem apenas uma narrativa de fruição, o documentário interativo proporciona ao público vários pontos de acesso e várias possibilidades narrativas.

No documentário interativo o espectador alcança a posição de utilizador, selecionando e apropriando-se dos segmentos que mais lhe interessam, sem que essas escolhas sejam necessariamente as mesmas do realizador. $\mathrm{O}$ número de possibilidades narrativas multiplica-se pelo número de acessos, já que cada experiência é individual e personalizada e a narrativa final só é construída no momento do acesso. Esta perspetiva desafia o princípio da coerência narrativa que sempre constituiu a estrutura das obras cinematográficas. Muitos documentários interativos apresentam estruturas 
de navegação rizomáticas, distribuindo os diversos segmentos de forma nãohierarquizada e descentralizada, o que proporciona ao espectador uma experiência livre. Neste sentido, tal como nota Carey Jewitt, "there is no internal grammar to be broken - there is no essential 'wrong order' because there is no prior reading path.” (2004: 187).

No entanto, é preciso notar, que as opções da audiência estão limitadas pelo tema e possibilidades de conteúdo oferecidas pelo autor do documentário. Apesar de não controlar a ordem pelo qual os conteúdos são visualizados nem a narrativa final o realizador é, ainda assim, quem define o tema, os conteúdos disponíveis e as premissas de interação, quem imprime o tal ponto de vista autoral, que consideramos uma caraterística inalienável no género documental.

Podemos também identificar uma tendência para narrativas mais fragmentadas, compostas por sequências que representam diferentes tempos e espaços. A verdade é que o Cinema, e em particular o documentário, sempre apresentou uma natureza fragmentada, construindo as obras através da junção de elementos discretos que se agregam num "todo", desde o próprio conceito de plano, à constituição de cenas (considerando o tempo e o espaço), alinhadas em sequências que juntas constituem a narrativa. No documentário interativo esta perspetiva pós-estruturalista atinge um outro nível, na medida em que os vários segmentos são apresentados separadamente e cabe ao público encontrar um caminho para os juntar e construir a sua própria narrativa. Este princípio coloca em causa a base ontológica da montagem cinematográfica, já que os elementos discretos têm de ser sequenciados numa ordem lógica de forma a construir um "todo", o que nem sempre se revela fácil considerando que o público desconhece a totalidade dos conteúdos propostos.

A ordem pela qual os segmentos são visualizados também deve ser considerada. A montagem cinematográfica, tal como provou Kuleshov nas suas conhecidas experiências, constituiu parte significativa da interpretação 
da obra. A combinação dos planos cinematográficos, das cenas e sequências e a relação que a audiência estabelece entre estes elementos atribuiu a estas imagens significados distintos de acordo com a ordem apresentada. Tal como o cinema privilegia a narrativa como a forma cultural de expressão da idade moderna, a revolução digital introduz o que Lev Manovich (2001) denomina de database, uma vez que "new media objects do not tell stories; they don't have beginning or end; in fact, they don't have any development, thematically, formally or otherwise which would organize their elements into a sequence" (Manovich 2001: 218).

A relação da obra com as audiências concretiza-se de diferentes formas. Os documentários interativos encontram-se em pleno desenvolvimento e a interação revela-se numa multiplicidade de conexões que exigem diferentes graus de participação e configuram envolvimentos diversos.

Provavelmente a relação comunicacional mais comum nos documentários interativos baseia-se em hiperligações, permitindo à audiência selecionar o conteúdo ao qual pretende aceder e a ordem pela qual os recebe. Um dos exemplos que ilustra o que Sandra Gaudenzi (2013: 4753) denomina de "hypertext mode" é o documentário Out my window (2010), realizado por Katherina Cizek para o National Film Board do Canadá. Trata-se de uma espécie de repositório de segmentos narrativos que permitem ao público conhecer as casas e as vidas de treze famílias em diferentes cidades do Mundo e perceber qual o impacto de viver em prédios de grande altura. As histórias são construídas através da composição de fotografias com uma perspetiva de $360^{\circ}$ e a narração sonora é composta com entrevistas das famílias.

Tal interação proporciona a sensação de navegação que alguns documentários interativos utilizam para criar narrativas paralelas e permitirem ao público traçar um caminho personalizado, na medida em que o espectador seleciona o percurso. No entanto, trata-se de uma obra fechada 
com conteúdos e duração pré-definidos pelo realizador. É o caso de Journey to the End of Coal (2010) que permite ao público encarnar a missão de um jornalista de investigação e empreender uma viagem desde Datong até à região Norte da China, para visitar as minas de carvão e aí conhecer as difíceis condições de trabalho dos mineiros que muitas vezes resultam em acidentes mortais. A estrutura deste documentário interativo consiste no rearranjo dos conteúdos à medida das escolhas do espectador, que vai avançando na narrativa através da seleção de caminhos.

Alguns documentários interativos apresentam uma estrutura mais rizomática, com múltiplas possibilidades narrativas, na intersecção entre o cinema e os videojogos. Aliás, a "gamificação" é outra das tendências do documentário interativo. As obras que se posicionam num registo de “conversational mode" (Gaudenzi, 2013: 39-46) apresentam-se estratificadas em níveis, obrigando o utilizador a cumprir determinados objetivos antes de avançar na narrativa, tal como se verifica numa estrutura de jogo. Através da definição de metas a atingir e da atribuição de "recompensas" o público sente-se encorajado a avançar e a conquistar trunfos que lhe permitem acesso a partes mais restritas do documentário e, consequentemente, proporcionam uma experiência mais envolvente.

Frequentemente, os documentários que apresentam esta abordagem baseiam-se num princípio de Inteligência Artificial e são evolutivos, ou seja as opções tomadas pelo utilizador influenciam a narrativa subsequente, contribuindo assim para uma sensação de possibilidades ilimitadas e tornando a experiência de navegação mais convincente.

Nestas obras o público assume o papel de protagonista do filme, na medida em que a interação com o interface do documentário possibilita que a ação progrida e, nesse momento, acontece a construção da narrativa. Podemos observar esta abordagem de interação no documentário Fort McMoney (2013) que reúne duas mil horas de filmagens de Fort McMurray, no Canadá, nas quais se incluem 55 entrevistas. A obra interativa utiliza 
uma estratégia de jogo que permite à audiência decidir o futuro da cidade virtual e alertar para o desenvolvimento sustentável na exploração da maior reserva de petróleo do mundo.

Outros documentários interativos utilizam como forma de interação a agregação de conteúdos enviados pelo próprio público, numa estratégia claramente participativa. Tal como O’Flynn (2012) nota é possível identificar uma tendência crescente para a interatividade através do uso da web 2.0 e do encorajamento dos recetores a assumirem um papel ativo tanto no financiamento (crowdfunding) como através da contribuição de conteúdos para os documentários. O resultado desta colaboração é a criação de arquivos digitais vivos, evolutivos e em constante atualização. De certa forma podemos enquadrá-los numa manifestação de Inteligência Coletiva, expressão cunhada por Pierre Lévy (1997) para definir uma forma de inteligência distribuída universalmente, constantemente melhorada, coordenada em tempo-real e resultado de uma efetiva mobilização das capacidades humanas.

Um dos exemplos mais conhecidos e bem-sucedidos desta relação com a audiência é o documentário A journal of insomnia (2013), também produzido pelo National Film Board do Canadá. A obra parte de quatro histórias de pessoas que sofrem de problemas de insónias e junta depois as contribuições de participantes que partilham deste mesmo problema, recolhidas através de uma entrevista marcada durante a madrugada, mediante o fuso horário da localização geográfica de cada participante. O documentário conjuga nesta altura mais de duas mil contribuições que também só podem ser acedidas durante a madrugada.

A abordagem dos documentários participativos transforma o espectador em colaborador e até em coautor da obra. Apesar de muitos autores expressarem alguma resistência à partilha da autoria podemos aqui citar Brian Eno (1991) que considera qualquer trabalho interativo incompleto até à intervenção da audiência. Assim, durante o processo, os 
elementos do público transformam-se simultaneamente em performers, autores e membros de uma audiência. Tal particularidade não retira aos autores originais da obra um forte sentido de autoria, na medida em que estes definem as premissas fundamentais de interação e o grau de participação do público. Assistimos sim a uma redefinição da noção de autor num conceito mais abrangente, que engloba o público como elemento fundamental do processo de criação e não apenas como recetor de uma mensagem. Eco (1989) considera as produções que contemplam a participação do público como "Obras em Movimento", possibilitando diversas intervenções pessoais. No entanto, este não é um convite indiscriminado a uma participação amorfa. O convite oferece ao público uma oportunidade devidamente orientada para inserir e manipular conteúdos na obra mas o resultado final permanece como uma obra concebida pelo autor.

Um outro modo de documentário interativo proposto por Sandra Gaudenzi (2013: 62-67) prevê a contribuição de conteúdos por parte das audiências através de elementos de georreferenciação ou dados biométricos referentes a um espaço geográfico específico, potenciando a experiência do lugar. É o caso do trabalho Greenwich Emotion Map (2005-6), de Christian Nold, que Gaudenzi referencia como exemplo de "experiential mode", uma vez que este permite aos utilizadores gravarem emoções e sentimentos num determinado local, para posteriormente o artista criar um "mapa de afetos" da cidade de Greenwich e apresentar como instalação em algumas galerias. Estes trabalhos encontram-se na intersecção entre o documental e as instalações artísticas e, não raramente, assemelham-se a obras de visualização de dados. Gaudenzi considera ainda que existe uma "experiência afetiva" que envolve o público no espaço através de um processo dinâmico e complexo.

Os dispositivos interativos, tais como o GPS, permitem ao público combinar dados de georreferenciação com imagens e sons para criar 
narrativas da experiência humana relacionada com determinado local, permitindo uma consciencialização da experiência do lugar. Nestes casos as tecnologias interativas representam um papel importante como ferramentas criativas de construção de narrativas, permitindo oportunidades colaborativas entre múltiplos utilizadores. A interação e experiências partilhadas contribuem, assim, para reforçar um sentimento de conectividade e de pertença tanto ao lugar como à comunidade participante. Um novo caminho que começa agora a desenhar-se é a fusão do documentário com a realidade virtual. Durante décadas a tecnologia já permitia simular ambientes virtuais, apesar dos conteúdos se limitarem comumente a demonstrações de realismo, sem grandes pretensões narrativas. Mas na edição 2015 do Sundance Film Festival foram apresentados onze projetos pensados para a tecnologia da realidade virtual (Tortum, 2015). Pelo menos três deles integram ambientes 3D gerados por computador, interatividade e um ponto de vista documental. As obras apresentam uma estratégia muito semelhante a videojogos, não só pela componente da interatividade mas principalmente porque a estética da imagem gerada por computador nos remete para um ambiente muito próximo daquele que é reproduzido nos jogos de entretenimento. Isto porque, apesar da animação e do documentário se terem aproximado desde 1918 (elGaudio, 1997), a imagem indexada ao real continua a configurar um forte elo de ligação da audiência a uma certa noção de "verdade".

Ao contrário das imagens captadas pela câmara no cinema tradicional, o documentário de realidade virtual coloca em causa a identidade indexical do cinema, uma vez que utiliza como material bruto imagens construídas: animação e imagens a três dimensões geradas e / ou trabalhadas por computador. O resultado final consiste na combinação de diversos elementos (cortados, sobrepostos, misturados, esticados, recriados) cujo aspeto poderá assemelhar-se de forma irrepreensível à "realidade" mas que nunca foram de facto captados por uma câmara. 
Tal não significa que aqui se negue o carácter documental das obras apresentadas na edição 2015 do Sundance Film Festival. O Project Syria (2014), por exemplo, da autoria de Nonny de la Peña, transporta o espectador para uma rua de Aleppo, na Síria, e após um ataque transfere-o para um campo de refugiados. O documentário apresenta um ponto de vista bem definido, quando pretende sensibilizar o público para a experiência de estar num campo de refugiados, tal como aconteceu a cerca de 3 milhões de sírios. Apesar do projeto ser criado em animação 3D, toda a criação virtual é baseada em acontecimentos, imagens e sons gravados na Síria. De acordo com a autora, a reconstituição destes espaços e a realidade virtual pretendem simular o cenário e evocar na audiência a sensação de estar no local (Peña, 2014). A interatividade limita-se a permitir ao público caminhar nestes cenários e observar os acontecimentos, sem causar qualquer alteração da narrativa.

Pelo contrário, 1979 Revolution (2013), da autoria do iraniano Navid Khonsari, apresenta uma estrutura de jogo, com múltiplas narrativas e cujas escolhas da audiência têm consequências na história (Parkin, 2013). O documentário reflete sobre a revolução que deu origem à criação do Estado Islâmico e foi construído com base na própria experiência do autor, enquanto testemunha ocular dos acontecimentos, e nas fotografias do fotojornalista francês Michel Setboun, que fotografou ambos os lados do conflito. Para Khonsari (Parkin, 2013) a estrutura de videojogo é a que melhor se adapta para acomodar diferentes histórias pessoais e as subtilezas de múltiplas perspetivas, provenientes de diferentes fações da narrativa histórica.

Por último, Assent (2013) lida com as questões da memória e inspirou-se num massacre que ocorreu no rescaldo do golpe militar chileno e ao qual o pai do autor, Oscar Raby, assistiu. O público é levado a colocarse no lugar da testemunha do massacre e, em determinados momentos, ao olhar para objetos ou locais recebe flashes de imagens que reconstroem a 
memória desse momento. Este mecanismo reproduz o stresse pós traumático do pai de Oscar Raby e, de certa forma, questiona os desafios da experiência. Deniz Tortum (2015), investigador assistente do MIT Open Documentary Lab, considera este trabalho extremamente pessoal e inovador na forma como utiliza os ambientes 3D, utiliza a interatividade e explora as “imperfeições” da memória.

Estes últimos trabalhos referenciados demonstram claramente que a indústria do Cinema começa a olhar para a realidade virtual como uma possibilidade de futuro. No entanto, todo o dispositivo criado altera significativamente aquilo que é considerado a "experiência do cinema" e cria novas exigências de distribuição, uma vez que a receção é individualizada e cada espectador necessita de um aparelho de realidade virtual.

As problemáticas ligadas à realidade virtual não se limitam às questões logísticas de distribuição. Nestes filmes corremos o risco que o dispositivo utilizado possa alienar o valor documental da obra. A construção da narrativa assemelha-se em tudo a um jogo de computador, com múltiplas possibilidades de navegação e uma estrutura evolutiva. Além disso, tal como nos jogos, a linguagem visual coloca a audiência no papel do protagonista do filme através do ponto de vista da câmara na primeira pessoa e do recurso a planos subjetivos, o que torna mais difusas as fronteiras entre realidade e ficção. Esta abordagem, ao invés de provocar um sentimento de alteridade como é pretendido pelos realizadores, poderá levar o público a distanciar-se dos acontecimentos reais e a encarar as situações apresentadas como parte de uma construção de puro entretenimento.

Também é fácil perceber que parte substancial do entusiasmo pelas novas narrativas advém da novidade tecnológica e da vontade de experimentar, o que torna difícil por vezes uma visão distanciada e crítica face a estes novos objetos. No entanto, não podemos negar que a realidade virtual exige novas formas de pensar o documental e novas estratégias 
narrativas, que irão intensificar a fusão, que de resto já se tinha iniciado, entre documental e videojogos.

\section{Considerações finais}

Tal como nos restantes média, o advento da internet e a revolução digital desafiam e alteram significativamente as formas de produção tradicional. Para o documentário, o paradigma do digital representa um desafio radicalmente diferente da introdução de outras tecnologias ao longo da história, uma vez que não se trata apenas de mais um passo no desenvolvimento linear da produção cinematográfica, mas do nascimento de uma nova forma de arte, tal como assistimos com o próprio nascimento do cinema. Mas é também verdade que o Documentário sempre se apresentou como uma abordagem criativa e em constante evolução, capaz de abraçar as mais variadas influências e reinventar-se a cada momento, tal como é demonstrado historicamente através dos modos preconizados por Bill Nichols (2001).

Atualmente, os realizadores encontram-se ainda a experimentar e a criar novos modos de abordagem ao real e às novas narrativas. Podemos questionar se os artefactos que surgem agora correspondem a uma evolução dinâmica do cinema documental ou se os novos média irão obrigar a uma rutura com as abordagens existentes para criar um espaço totalmente novo e independente. De acordo com Tom Perlmutter (2014), diretor do National Film Board do Canadá que lançou o programa de produção digital da instituição, o documentário interativo não irá substituir o cinema tradicional. Tal como "photography did not kill art; cinema did not kill theatre; television did not kill cinema. But the new form will grow in strength, maturity and impact" (Perlmutter, 2014). Pelo caminho ficarão muitos documentários que valerão apenas como parte de um processo experimental 
e evolutivo e que dificilmente figurarão na história como obras de referências mas levar-nos-ão a trabalhos mais consistentes.

Apesar do entusiamo que este tipo de filmes tem provocado, tanto junto do público como de alguns documentaristas, a verdade é que os filmes interativos representam uma mudança de paradigma na forma como nos relacionamos com o Documentário. Carolyn Miller chama a atenção para o facto de "users expect to be offered a selection of choices, but by offering them, you give up your ability to tell a linear story or to provide information in a fixed order" (Miller, 2004: 61). Neste sentido o realizador coloca em causa a sua autonomia e transfere para o espectador parte da conceptualização artística. Nos filmes interativos o utilizador ganha a possibilidade de criar uma estrutura discursiva e definir um rumo.

Coloca-se aqui a questão da autoria, uma vez que parte dos documentários interativos são construídos através de uma interação participante, na qual o público cria e partilha conteúdos. Mesmo quando essa participação não se verifica, a própria interação com o objeto fílmico pressupõe que a narrativa é fluida e personalizada para cada espectador, criada no momento de visualização. Esta estrutura não linear é disjuntiva do tempo narrativo de um filme tradicional e transforma a narrativa numa espécie de linha temporal alternativa.

No entanto, as inúmeras possibilidades narrativas e de contribuição do público não significam uma solicitação amorfa para a participação indiscriminada. $\mathrm{O}$ convite oferece ao espectador a oportunidade para uma participação orientada pela conceção autoral do realizador. Por outras palavras, o autor oferece ao público uma obra a ser completada e, mesmo sem ter pleno poder no resultado final, o realizador sabe que a obra continua a refletir o seu ponto de vista sobre o mundo, mesmo que tenha incorporado conteúdos particulares de contribuições externas à obra. Ou, como argumenta Eco em relação às obras em movimento, "The author is the one who proposed a number of possibilities which had already been rationally 
organized, oriented, and endowed with specifications for proper development" (Eco, 1989:19).

De qualquer forma encontramo-nos perante uma realidade nova em que a experiência do cinema se altera radicalmente: deixamos a sala escura, onde fruímos uma experiência pessoal num ambiente coletivo, e passamos para a frente de um ecrã, onde usufruirmos de uma experiência individual num ambiente partilhado.

Nota: trabalho de investigação financiado pela FCT - Fundação para a Ciência e a Tecnologia no âmbito da Bolsa de Doutoramento SFRH/BD/93138/2013

\section{Referências bibliográficas}

BORDWELL, David (2012), Pandora's digital box: films, files, and the future of movies, Madison, Wisconsin: The Irvington Way Institute Press.

BRUZZI, Stela (2000), New documentary: a critical introduction, London: Routledge.

BUCKLAND, Michael (2006), Emanuel Goldberg and his Knowledge Machine: information, invention, and political forces, Califórnia: Libraries Unlimited

COUSINS, Mark (2005), Biografia do filme, Lisboa: Plátano Editora.

DE LAURETIS, Teresa (1980), The cinematic apparatus, Londres: Macmillan. 
ECO, Umberto (1989), The open work, Massachussetts: Harvard University Press.

EIDDSVIK, Charles (1988-9), "Machines of the invisible: changes in film technology in the age of vídeo" in Film Quarterly, 42 (2), ed. Inverno.

ELGAUDIO, Sybil (1997), "If truth be told, can toons tell it? Documentary and Animation" in Film History 9:2, p. 189-199

ELLIS, Jack C. e MCLANE, Betsy A. (2009), A new history of documentary film, Nova Iorque: Continuum.

ENO, Brian (1991), "On writing space" in ARTFORUM, v. 30 n. 6, Nova Iorque, pp. 13-14.

ESPINOSA, Julio G. (1979), "For an imperfect cinema" in Jump Cut: A Review of Contemporary Media, (20), p. 24-26.

GAUDENZI, Sandra (2013), The Living Documentary: from representing reality to co-creating reality in digital interactive documentary. Londres: University of London.

GAUDENZI, Sandra (2014), "Interactive documentary" in The Johns Hopkins Guide to Digital Media, JHU Press, p. 552.

GERE, Charlie (2008), Digital culture, Londres: Reaktion Books.

JEWITT, Carey (2004), "Multimodality and New Communication Technologies" in Philip LeVine e Ron Scollon (Eds.), Discourse and techology: multimodal discourse analysis, Washington D. C.: Georgetown University Press, pp. 184-195.

LÉVY, Pierre (1997), Collective intelligence, Massachussetts: Perseus Books.

MANOVICH, Lev (2001), The language of New Media, Massachussetts: The MIT Press.

MCLANE, Betsy A. (2012), A new history of documentary film, Second Edition, Nova Iorque: Continuum. 
MILLER, Carolyn H. (2004), Digital storytelling: a creator's guide to interactive entertainment, Oxford: Focal Press.

NICHOLS, Bill (2001), Introduction to documentary, Bloomington: Indiana University Press.

O'FLYNN, Siobhan (2012), “Documentary's metamorphic form: Webdoc, interactive, transmedia, participatory and beyond" in Studies in Documentary Film, 6(2), 141-157

ROGERS, Holly (ed.) (2015), Music and sound in documentary film, Nova Iorque: Routledge.

ROTHA, Paul (1983), Robert J. Flaherty: a biography, (ed.) Jay Ruby. Filadélfia: University of Pennsylvania Press.

SCHOOTS, Hans (2000), Living dangerously: a biography of Joris Ivens, Amesterdão: Amesterdam University Press.

SHAVIRO, Steven (2010), "Post-Cinematic affect: on Grace Jones, Boarding Gate and Southland Tales" in Film-Philosophy, 14(1), 1102.

WINSTON, Brian (1996), Technologies of seeing, Londres: BFI.

\section{Filmografia}

1979 Revolution, 2013, Documentário RV. Dir: Navid Khonsari. E.U.A: Ink Stories.

A journal of insomnia, 2013, Documentário Interativo. Dir: Bruno Choiniere, Philippe Lambert, Thibaut Duverneix e Guillaume Braun. Canadá: National Film Board of Canada. Disponível em: http://insomnia.nfb.ca/

Assent, 2013, Documentário RV. Dir: Oscar Raby. Austrália: RMIT University.

Cronique d'un Eté, 1961, Filme. Dir: Jean Rouch. França: Argos Films. 
Fort McMoney, 2013, Documentário Interativo. Dir: David Dufresne.

Canadá: National Film Board of Canada. Disponível em: http://www.fortmcmoney.com/

Greenwich emotion map, 2005-6, Instalação. Dir: Christian Nold. UK.

Housing problems, 1935, Filme. Dir: Edgar Anstey e Arthur Elton. UK:

British Commercial Gas Association

Immemoire, 1997, Documentário Interativo (CD-ROM). Dir: Chris Marker.

França: Centre George Pompidou.

Journey to the end of coal, 2010, Documentário Interativo. Dir: Samuel

Bollendorff e Abel Segretin. França: Honkytonk. Disponível em: http://www.honkytonk.fr/index.php/webdoc/

Les raquetteurs, 1958, Filme. Dir: Michel Brault e Gilles Groulx. Canadá:

National Film Board of Canada

Nanook of the North, 1922, Filme. Dir: Robert Flaherty. E.U.A \ França:

Les Frères Revillon.

Out my window,2010, Documentário Interativo. Dir: Katherina Cizek.

Canadá: National Film Board of Canada. Disponível em: http://outmywindow.nfb.ca/

Primary, 1960, Filme. Dir: Robert Drew. E.U.A.: Drew Associates.

Project Syria, 2014, Documentário RV. Dir: Nonny de la Peña. E.U.A: USC

School of Cinematic Arts.

Regen,1929, Filme. Dir: Joris Ivens. Holanda: Capi-Holland.

The plow that broke the plains, 1936, Filme. Dir: Pare Lorentz. E.U.A.:

Resettlement Administration

Why we fight, 1952-53, Série Documental. E.U.A.: U.S. Government. 
Patrícia Nogueira

\section{Webgrafia}

DE LA PEÑA, Nonny (2014), "Project Syria: an immersive experience". Disponível em: http://www.immersivejournalism.com/projectsyria-premieres-at-the-world-economic-forum/.

MANOVICH, Lev (2006) "What is digital cinema?". Disponível em: http://manovich.net/ind,ex.php/projects/what-is-digital-cinema.

NICHOLS, Bill (1995), "Documentary and the coming of sound". Disponível em: http://filmsound.org/film-sound-history/documen tary.htm.

PARKIN, Simon (2013), "A truly revolutionary video game, in The New Yorker". Disponível em: http://www.newyorker.com/tech/ elements/a-truly-revolutionary-video-game.

PERLMUTTER, Tom (2014), “The interactive documentary: A transformative art form". Disponível em: http://policyoptions.irpp. org/issues/policyflix/perlmutter.

WHITELAW, Mitchell (2002), "Playing games with reality: only fish shall visit and interactive documentary". Disponível em: http://mtchl.net/tag/documentary. 


\title{
EL DOCUMENTAL INTERACTIVO EN LA CULTURA DE CONVERGENCIA Y LAS NARRATIVAS TRANSMEDIA
}

\author{
Maximiliano de la Puente; Lorena Díaz Quiroga *
}

\begin{abstract}
Artigo revisto após publicação, com o objetivo de atender a procedimentos de citação. Revisão ocorrida a 02 de dezembro de 2017.

Artículo revisado después de la publicación con el objetivo de atender a los procedimientos de citación. Revisión ocurrida en 02 de deciembre de 2017.

Revised article after publication with the purpose of attending citation procedures. Revision occurred on December 2nd 2017.

Article révisé après publication afin de se conformer aux procédures de citation. La révision a eu lieu le 02 de novembre 2017.
\end{abstract}

Resumo: Neste trabalho abordamos um dos principais temas da cultura da convergência e narrativas transmídia: o documentário multimídia interativo. Tentaremos definir um objeto complexo, apontar suas principais características e diferenciá-lo do documentário linear tradicional. Teremos em conta as reflexões de vários dos principais especialistas no campo, especialmente as considerações de Arnau Gifreu Castells. Como ele argumenta, encontramos um objeto inserido num ecossistema em constante mutação, caracterizado por um ambiente digital em rápida evolução. A poluição e confusão terminológica é grande e não existe uma única maneira de nos referirmos a esses documentários. Vários termos convivem como "documentário novos meios de comunicação", "biblioteca digital", "WebDocs" ou "webdocumentales", "filmes interativos", explorações interativas", "ensaios digitais", etc. Este artigo é dedicado à descrição e análise das suas características centrais.

Palavras-chave: documentário, interatividade, convergência, transmedia.

Resumen: En este trabajo abordaremos uno de los tópicos principales de la cultura de la convergencia y las narrativas transmedia: el documental multimedia interactivo. Intentaremos definir un objeto complejo, señalaremos sus principales características y lo diferenciaremos del documental lineal tradicional. Tomaremos para ello las reflexiones de varios de los más destacados especialistas en el tema, centrándonos especialmente en las consideraciones de Arnau Gifreu Castells. Como éste sostiene, nos encontramos con un

\footnotetext{
* Maximiliano de la Puente: Doctorando. Universidade de Buenos Aires, Facultad de Ciencias Sociales, Programa de Doctorado en Ciencias Sociales. 2230, Buenos Aires, Argentina. E-mail: maxidelapuente@gmail.com Lorena Díaz Quiroga: Directora de Fotografia, ENERC - Escuela Nacional de Realización y Experimentación Cinematográfica. 1091, Buenos Aires, Argentina.

E-mail: lodikua@gmail.com
}

Submissão do artigo: 31 de maio de 2015. Notificação de aceitação: 20 de agosto de 2015. 
objeto inserto en un ecosistema en transformación constante, caracterizado por un entorno digital en rápida evolución. La contaminación y confusión terminológica es tal, que ni siquiera existe una única manera para referirse a estos documentales. Conviven así expresiones como "documentales de nuevos medios", "documentales digitales", "webdocs" o "webdocumentales", "películas interactivas", "bases de datos narrativas", "exploraciones interactivas", "visitas virtuales", "ensayos digitales", etc. A la descripción y el análisis de sus características centrales, se dedicará este artículo.

Palabras clave: documental, interactividad, convergencia, transmedia.

\begin{abstract}
In this article we approach one of the main topics of the culture of convergence and transmedia narratives: the interactive multimedia documentary. We try to define a complex object, point out their main characteristics and differentiate from the traditional linear documentary. We will take for the reflections of several of the leading specialists in the field, especially focusing on considerations of Arnau Gifreu Castells. As he argues, we find an object insert in a constantly changing ecosystem, characterized by a rapidly evolving digital environment. Pollution and terminological confusion is such that there is not even a single way to refer to these documentaries. Thus, coexists expressions as "new media documentary", "digital library", "webdocs" or "webdocumentales", "interactive movies", "narrative data bases", "interactive explorations", "digital essays", etc. This article describes and analyzes its main features.
\end{abstract}

Keywords: documentary, interactivity, convergence, transmedia.

Résumé: Dans cet article, nous abordons l'un des principaux thèmes de la culture de la convergence et de récits transmédia: le documentaire multimédia interactif. Nous Essayons de définir un objet complexe, souligner leurs principales caractéristiques et de le différencier par rapport au documentaire linéaire traditionnelle. Nous allons considérer les réflexions de plusieurs des plus grands spécialistes dans le domaine, en particulier ceux de Arnau Gifreu Castells. Comme il fait valoir, nous trouvons un objet inséré dans un écosystème en constante évolution, caractérisé par un environnement numérique en constante évolution. La pollution et confusion terminologique est telle qu'il n'y a pas un terme unique pour se référer à ces documentaires. Divers termes coexistent: "documentaire des nouveaux médias", "bibliothèque numérique", "webdocs" ou "webdocumentales», «films interactifs», «bases de données narrative», «explorations interactives", "tour", "essais numériques", etc. Cet article est consacré à la description et l'analyse de ses principales caractéristiques.

Mots-clés: documentaire, interactivité, convergence, transmédia.

\title{
Introducción
}

En este trabajo abordaremos uno de los tópicos principales de la cultura de la convergencia y las narrativas transmedia: el documental multimedia interactivo. Intentaremos definir un objeto sumamente complejo, aún en construcción, y señalaremos sus principales características. Tomaremos para ello las reflexiones de varios de los más destacados especialistas en el tema, centrándonos especialmente en las 
consideraciones de Arnau Gifreu Castells. Como éste sostiene, nos encontramos con un objeto inserto en un ecosistema en transformación constante, caracterizado por un entorno digital en rápida evolución. La contaminación y confusión terminológica es tal, que ni siquiera existe una única manera para referirse a estos documentales. Conviven así expresiones como "documentales de nuevos medios", "documentales digitales", "webdocs" o "webdocumentales", "películas interactivas", "bases de datos narrativas", “exploraciones interactivas", "visitas virtuales", “ensayos digitales", etc.

El desarrollo de un lenguaje hipertextual promueve cambios de magnitud, al alterar los mecanismos tradicionales de interpretación de un mensaje y generar un incremento en las posibilidades de hibridación genérica. Por su propia índole, el hipertexto profundiza en la densidad interpretativa de los mensajes. "La hipertextualidad proporciona un criterio exclusivo de ordenamiento, de acuerdo con las demandas de un marco de categorización específico para los géneros de no ficción interactiva" (Gifreu Castells: 2013). En el marco del hipertexto, el documentalista ya no posee el dominio total sobre el sentido final de su producto. En el documental interactivo puede sustituirse una estructura dramática clásica que se apoya fuertemente en un inicio, un cuerpo central y un final, por nudos temáticos que se utilizan para desarrollar el tema y contextualizar, narrar los antecedentes del caso, incluir información complementaria y documentar el hecho en cuestión. Estos bloques pueden combinarse con núcleos argumentativos o de opinión, a través de enlaces a blogs, redes sociales, etc. El documental interactivo asume la forma de un "metagénero" que contiene formatos, discursos y múltiples experiencias de diversos usuarios.

Desde sus inicios, el género documental se ha constituido en una de las herramientas más eficaces para contar historias de no ficción sobre "la realidad". A lo largo del siglo XX y en lo que va del XXI, el género ha pasado de una búsqueda de representación más o menos "transparente" de lo 
real a desarrollar experiencias que evidencian explícitamente la subjetividad del realizador, en donde la relación con el referente externo a las películas se desdibuja por completo. El documentalista irrumpe, marca, deja huellas en el espacio fílmico/real, realiza un acto performativo que incide sobre este último.

Por su parte, la posibilidad de que los usuarios puedan elegir y adquieran control sobre el propio documental, (un espacio reservado anteriormente en exclusividad para el realizador), se profundiza con el desarrollo de los medios interactivos, los mundos virtuales y los videojuegos. El espectador interactivo puede asumir en algunos casos el rol de cocreación de la propia experiencia documental, aunque por lo general ocupando un rol subsidiario. Por ejemplo, en lugar de editar una película de manera lineal, un documentalista puede crear una base de datos de clips de vídeo y entrevistas, a través de la cual un interactor puede navegar con el uso de una interfaz gráfica de usuario, situación que permite que el usuario profundice en asuntos de su propio interés, generando así una experiencia documental muy personal. Los documentales interactivos se producen con el fin de visualizarse y experimentarse en distintos soportes, ya que más allá de aquellos que se producen para ser vistos a través de una computadora o un dispositivo móvil, muchos otros documentales se han creado también para DVD o consolas de videojuegos. En este escenario, el espectador y/o jugador es también un usuario y un lector.

\section{La representación de la realidad}

Josep Maria Català, en su clase magistral: "Reflujos de lo visible. La Expansión post-fotográfica del documental”, señala que ante la aparición de nuevas formas de expresión visual, como el "Comic book documental" o el "Webdocumental", que se desvinculan del supuesto realismo que impone la fotografía, pero que al mismo tiempo reclaman su pertenencia dentro del 
ámbito del documental, se impone una revisión de las relaciones existentes entre el fenómeno fotográfico y el tratamiento documental. Las nuevas posibilidades que ofrece el genero, tales como el "Webdocumental", el "Comic book documental" o los "Docugames" y las instalaciones interactivas, ocasionan una fuerte expansión del imaginario del documental, debido al surgimiento de nuevos lenguajes y retóricas, que confluyen en el concepto de "documental expandido". Estas nuevas prácticas del documental ponen al servicio del realizador diversificadas herramientas de utilización.

Desde su mismo nacimiento, el documental fue concebido como un tipo de cine que se planteaba "captar objetivamente la realidad". Con la irrupción del giro subjetivo y ensayístico en el género, desde los años noventa del siglo pasado en adelante, junto con la revolución en el espacio de representación que tuvo lugar una década más tarde, el ámbito fotográfico comienza a desvanecerse o al menos, a ponerse seriamente en cuestión. Así, si al giro subjetivo se le agrega

un documental que se acerca al dibujo - un documental dibujado -, el problema es preguntarnos si esto es un documental, si sigue siendo un documental una pieza que no tiene el registro fotográfico como marca esencial, porque el documental basaba su objetividad y capacidad de captar la realidad en que existía un artefacto que se planteaba captar la realidad mecánicamente sin vestigios de subjetividad. (Gifreu Castells: 2013).

Se modifica entonces sustancialmente, hasta el punto de anularse, el vínculo entre la fotografía y la representación en el documental interactivo, puesto que, por ejemplo, la realidad aumentada puede ser utilizada como medio para incrementar significativamente la potencia expresiva, emocional y epistemológica de la fotografía, en la medida en que aquella implica poder superponer datos a la realidad que vemos, con lo cual estamos alterando por completo el concepto de esta última. 
Català sostiene que el cine documental pertenece a lo que denomina como " la era de la verdad", mientras que a esta supuesta "era de la postverdad" en que vivimos, le correspondería el término de "cine de lo real". Paradójicamente o no tanto, en expresiones documentales contemporáneas, como el comic documental o la novela gráfica documental, desaparece el vínculo fotográfico con la realidad, por lo que el carácter de ficcionalización parece aumentar significativamente, de la misma forma en que una película con imagen fotográfica resulta ser muy verosímil por más alejada de la realidad que se encuentre. $\mathrm{Y}$ esto es así porque la forma documental es mucho más amplia que la forma fotográfica. Sin embargo, en el género documental, aún en sus formas contemporáneas, toda propuesta estética, cualquier recorrido formal que se elija, se realiza siempre sobre una determinada concepción de lo real, solo que este compromiso con lo real ha venido adquiriendo maneras novedosas ya desde mediados del siglo XX en adelante. Con la irrupción irreversible de las imágenes digitales, ingresamos en el ámbito de la imaginación. Surge por ejemplo, en el documental dibujado, la posibilidad de un nuevo registro del documental, el del recuerdo como apertura de significaciones, en lugar de como resultado. Pero por más procedimientos ficcionales que ponga en juego el documental interactivo, existe siempre un compromiso testimonial que funciona como anclaje y que lo aleja del género ficcional.

Català toma el comienzo del documental Las playas de Agnes (2008), de la directora francesa Agnès Varda, cuando vemos a la autora en una playa, mientras dispone diferentes espejos y crea composiciones a partir de reciclar diferentes imágenes reflejadas y de reflexionar en torno a los nuevos significados y relaciones que se establecen de su conjunción. De una manera estéticamente similar, Alejandra Almirón utiliza la cámara subjetiva, así como las fotografías personales y el material de archivo en Equipo verde (2003), para armar una imagen caleidoscópica, múltiple y no exenta de contradicciones y zonas oscuras, no sólo de su adolescencia en 
una escuela pública sino también de la dictadura argentina. En esta necesidad de fragmentación contemporánea, en este esfuerzo por romper la unidad de lo que entendemos por realidad, pero al mismo tiempo de recomponer y dar otros múltiples sentidos a las diferentes partes, se desarrollan las formas documentales contemporáneas. Con el advenimiento de las nuevas tecnologías de la información y la comunicación, los responsables de producir los documentales contemporáneos están participando en el proceso de profundizar los cambios que ya vienen teniendo lugar en el campo del documental desde hace décadas. Estos creadores imaginan lo que el documental podría llegar a ser, con atributos relacionados como "no lineal", "multimedia", "interactivo", "híbrido", "plataformas", "convergente", "virtual”, u otros términos o categorías más aún por inventar.

\section{Características principales}

Como ya hemos mencionado, uno de los aspectos centrales de los documentales interactivos, es que en algunos casos pueden otorgarle un gran poder al usuario y el realizador pierde al menos en parte el control de su obra. El resultado final del producto documental puede adoptar una forma muy diferente a la que, en un estadio inicial, el director había plasmado en un guión. En esta situación de autoría compartida el realizador asume un papel más bien asistencial con respecto al usuario/interactor, ya que este último debe aprender unas pautas y mecanismos sin los cuales no podrá avanzar a través de la narración. Cuanto más variados y diversificados sean los desarrollos de los sistemas interactivos, y por ende cuantas más opciones tenga el interactor, mucho mejor.

Los documentales interactivos se encuentran enmarcados dentro de un género interactivo más general, que se podría definir como el de las 
aplicaciones interactivas multimedia de carácter divulgativo y documental. El documental interactivo se vincula con los géneros de no ficción interactiva, y se articula mediante una voluntad de transmisión de conocimiento a partir de la educación informal. Nos referimos a proyectos que muestran una clara intención de divulgación, y en los que existen una forma determinada de interactuar con el sistema, es decir que el usuario debe tomar decisiones para avanzar en el sistema hipertextual. Por educación informal, entendemos un conjunto de procesos permanentes a través de los cuales las personas adquieren y acumulan conocimientos, habilidades, actitudes y modos de discernimiento, a partir de las experiencias diarias y su relación con el entorno.

Cabe señalar que el webdoc o Webdocumental es sólo un subgénero dentro del género mucho más amplio del documental interactivo. En este sentido, hay que diferenciar entre las aplicaciones en línea y aquellas que se encuentran fuera de línea o "offline". Mientras que estas últimas se localizan en soportes físicos, las primeras utilizan un soporte virtual, como la red de redes. Los géneros fuera de línea se asocian generalmente a plataformas pertenecientes a la Web 1.0, a través de soportes cerrados a la aportación del usuario, mientras que las aplicaciones en línea se vinculan a una red con atributos colaborativos y generativos por parte del interactor. En tanto sistema abierto y generativo, Gaudenzi (2009), caracteriza al documental interactivo como un mecanismo "autopoiético" un organismo vivo que se relaciona con su entorno a través de los diferentes modos de interacción.

La interacción que proponen estos documentales puede ser de distintos niveles y expresarse en diversas formas, ya sea corporal, ya sea a través del mouse, como mediante otros dispositivos de interacción (guantes, sensores, microcontroladores, etc.), y que incentiven al usuario/interactor a participar y generar contenidos. Según Berenguer (2004), existen tres tipos de interacción: fuerte, mediana y débil. Gifreu Castells (2013) sostiene que, 
en el caso de los documentales interactivos, la aplicación debe utilizar tecnología digital desde el punto de vista de la interacción mediana o fuerte (debe involucrar al usuario hacia un tipo de respuesta física, en el sentido fuerte del término). El usuario puede interactuar a partir de la interfaz (y sus modalidades de navegación) o a partir de los contenidos y/o los otros usuarios (modalidades de interacción). Así, los espectadores de este nuevo formato incorporan las condiciones de usuario, en la medida en que forman parte de un sistema preestablecido y lo utilizan para sus intereses; de interactor, porque interactúan con la interfaz para avanzar en el desarrollo propuesto; de participante, ya que participan activamente en el desarrollo, eligiendo la línea narrativa que les parezca más adecuada, y de contribuidor, porque contribuyen a la generación del sistema y aportan conocimiento a base de contenidos o impresiones subjetivas.

\section{Sobre la interactividad}

Como ya hemos dicho, en las aplicaciones interactivas la progresión del discurso requiere el procesamiento de las acciones del usuario. La presentación lineal y esquemática de la información es reemplazada para ofrecer una interacción directa del usuario articulado a través del propio medio. Al ser un concepto excesivamente amplio, usado en exceso y en parte mistificado, es necesario acotar su definición. Seguimos aquí a Gifreu Castells cuando piensa la interactividad exclusivamente asociada al vínculo que el espectador mantiene con el contenido del documental, en el nivel de la interfaz hombre-máquina. El mismo nivel en que "todo el contenido digital se puede reordenar, reorganizar y abrir a una interpretación subjetiva" (Stuart Dinmore en Gifreu Castells: 2013). Así, el espectador de documentales interactivos puede intervenir como coeditor, al tener la capacidad de reconstruir el orden y la yuxtaposición de los elementos multimedia. Las modalidades que refieren a la producción, el análisis, la 
distribución y la recepción de los productos audiovisuales varían significativamente, debido a la contraparte no lineal interactiva. Si bien tanto las disciplinas artísticas tradicionales como los antiguos medios de comunicación de masas son interactivos en un sentido amplio, aquí se piensa la interactividad al nivel en que se realiza una selección textual y se excluyen otras, lo que permite un pasaje único para cada usuario a través del sistema hipertextual.

Siguiendo a Xavier Berenguer (2004), se puede pensar en una interacción fuerte, mediana y débil, en función del grado de apertura y de posibilidades de manipulación que ofrezcan. Como él mismo sostiene:

A un nivel bajo, el interactor se limita a escoger entre un menú de opciones. Un nivel algo superior consiste en tener que localizar estas opciones o, más aún, al tener que responder a determinadas pruebas o superar ciertos obstáculos para poder avanzar en la exploración del interactivo. En los niveles altos, el interactor se ve sometido a demandas aún mayores: participar como protagonista del entorno interactivo, contribuir e incluso modificarlo. Se puede hablar, pues, de una interacción débil - así es actualmente la de la mayoría de webs - y de una interacción fuerte, la expresión máxima (participativa, contributiva y comunitaria) se conoce como realidad virtual. Pero no se trata, necesariamente, de maximizar la intensidad de la interacción. En cada género interactivo, y a cada programa en particular, corresponde una interacción más o menos fuerte. La difusión de información, por ejemplo, precisa de un grado débil (sería absurdo, por ejemplo, poner obstáculos para encontrar el significado de una palabra en una enciclopedia). Por su parte, el documental y la no ficción se prestan a una interacción media (idónea para regular el ritmo de asimilación), mientras que la ficción y, en general, la creación libre, permiten la interacción en el sentido más fuerte. (Berenguer: 2004).

Para Berenguer, el diseño de un sistema interactivo consiste en encontrar el grado óptimo con el que la computadora "habla", "piensa" y “escucha", lo cual requiere, para la producción de un sistema de tales características, el desarrollo de habilidades audiovisuales y a la vez informáticas. 


\section{Interacciones e interactores}

Desde esta perspectiva, existen dos tipos de motivaciones completamente distintas en el usuario, al encontrarse frente a un producto interactivo: extrínsecas e intrínsecas. Las motivaciones extrínsecas son ajenas a aquel: una persona que consulta un concepto en Wikipedia o la programación de una cadena de televisión en su sitio web, o videos en YouTube, necesita sólo que se le facilite un acceso rápido y sin obstáculos. Por el contrario, un usuario que decide instalar un CD-ROM, o ingresar a la extensión interactiva de una exposición en la web de un museo o de una serie de televisión, puede tener un interés específico, intrínseco, en el producto interactivo que consulta. Puede llegar a tomar parte en propuestas imprevistas que provoquen y estimulen este interés inicial y que incluso lo vayan llevando a modificar, adaptar o sustituir sus objetivos iniciales.

Marie Laure Ryan (2001), define cuatro formas estratégicas de la interactividad en base a dos pares binarios: interna/externa y de exploración/ontológica. En el modo interno, el usuario se reconoce como un miembro del mundo de ficción, ya sea como avatar o en una perspectiva en primera persona, mientras que en la forma externa se sitúa fuera del mundo virtual. En el modo de exploración, el usuario es capaz de navegar por la base de datos para decidir el camino a seguir, pero no tiene impacto real en el mundo virtual. La forma ontológica sucede cuando los usuarios tienen el poder de cambiar el mundo. (Ryan: 2005). El exterior e interior puede ser visto como una opción decidida por el autor para aumentar el nivel de inmersión del usuario. La inmersión es la sensación de "estar rodeado de una realidad completamente diferente" (Murray: 1997). En un documentaljuego como America 's Army (2002), la sensación de inmersión es muy alta,

y esto hace que el jugador suspenda su incredulidad, y acepte la lógica 
interna de la experiencia, que es, en este caso, disparar a la gente. (Bonino: 2011).

\section{Tipos de narrativas interactivas}

Florent Maurin (2011), por su parte, señala que la interactividad puede ser utilizada como herramienta expresiva con distintos fines y objetivos. Puede transmitir emociones, como el caso del proyecto Bla bla bla 69 (http://blabla.onf.ca/), conectar significado y significante, como en el caso del proyecto La vie en sac70 (http://www.lavieasac.com/), fomentar la exploración, como en el caso del proyecto Sacremontagne71 (http://sacreemontagne.onf.ca/), y desencadenar y provocar estimulación al usuario a partir de la creación de pruebas, como en el caso de Darfur Game72 (http://www.radiodabanga.org/darfurgame/english/game.html).

Establece una tipología de narrativas interactivas que caracterizan a los documentales de esta índole. La narrativa lineal, como ya sabemos, constituye la forma clásica de narrar basada en una sola historia posible. Los acontecimientos se suceden en un orden definido por el narrador. Se trata de un tipo de narrativa sencilla de generar y de usar, de fácil transmisión de emociones al usuario en la que no hay saturación de información. Debido a la poca interacción que produce, cada usuario obtiene la misma experiencia. Ejemplos de este tipo de narración, son los siguientes documentales: Le corps incarcéré (http://www.lemonde.fr/societe/visuel/2009/06/22/le-corpsincarcere_1209087_3224.html), Where is Gary (http://whereisgary.net/) y Bucarest Below Ground (http://www.bombayfc.com/bucharest_uk/).

La narrativa concéntrica es aquella en la que los usuarios tienen acceso a un esquema o mapa general de los diferentes contenidos y secciones, visitándolas en el orden que deseen. Ofrece la posibilidad de ordenar fragmentos heterogéneos que parecen adquirir sentido a través de su unión. Las desventajas que posee es que el punto de vista del autor puede 
debilitarse o desaparecer, y se detecta demasiada saturación de información simultánea: sólo los usuarios más motivados accederán a todas las secciones. Ejemplos son: Vies de jeunes (http://www.lemonde.fr/ societe/visuel/2011/06/10/vie-de-jeunes-a-l-age-ou-tout-oscille_1534639_ 3224.html), The iron curtain diaries (http://www.theironcurtaindiaries.org/) y Behind the veil (http://www.theglobeandmail.com/news/world/behind-theveil/) .

La narrativa "Espina de pescado" o "banda elástica" presenta una historia lineal central y circunvalaciones a subhistorias que vuelven al eje central. Se trata de una combinación equilibrada entre narración e interacción. La gran desventaja que tiene es que justamente parece muy semejante a una historia lineal, lo cual puede provocar que el usuario se aburra o que no tenga interés para consultar las subhistorias. Cada subhistoria puede, a su vez, alejar al espectador del flujo original, haciendo que pierda interés por la historia inicial. Maurin destaca Welcome to Pine Point (http://pinepoint.nfb.ca/\#/pinepoint) y Prison Valley (http://prison valley.arte.tv/?lang=en).

La narrativa ramificada implica que en momentos definidos, el usuario deba tomar decisiones que lo llevarán hacia un nodo determinado de la historia. Constituye una estructura potencialmente muy interactiva con poca saturación de información, debido a que los usuarios siempre se encuentran involucrados en la historia a partir de sus decisiones y siempre quieren saber más. Entre los ejemplos de este tipo de narrativa, se destacan: Journey to the end of coal (http://www.honkytonk.fr/index. php/webdoc/) y en general todos los proyectos creados con el software Klynt.

En la narrativa paralela conviven diferentes ejes, pero nunca uno termina en otro, sino que la historia contempla diferentes nudos y desenlaces, por lo que se basa en una narrativa ramificada. Ofrece una buena interacción, aunque los caminos y los nodos son previamente definidos. 
Destacamos Tanatorama (http://www.thanatorama.com/) y Premiers combats (http://www.premierscombats.com/).

La narrativa enroscada consiste en explicar una historia a partir de diferentes puntos de vista. Debido a su estructura, se salta de nodo a nodo pero no hay que pasar por el eje principal. Debido a que conviven muchas historias dentro de la misma historia o tema, idealmente los usuarios pueden moverse a través de muchas partes de la narrativa simultáneamente. Esto genera una gran saturación de información y un tipo de diseño interactivo complejo, que vuelve necesario seleccionar la información a visualizar, haciendo que el usuario pase por otras historias antes de llegar a lo más importante. Ejemplos de esta narrativa son: Gaza Sderot (http://gazasderot.arte.tv/) e Inside the haiti earthquake (http://www.insidedisaster. com/experience/).

Finalmente, la narrativa dinámica orientada a objetos, está definida por pequeñas historias que incluyen puntos de entrada y salida. Su estructura equivale a minicapítulos de un libro o escenas de una obra, pero menos estrictos en su orden de lectura, ya que no es necesario leerlos todos ni seguir un orden determinado. La concatenación de todas estas historias funciona como una narrativa paralela. Los usuarios no se sienten nunca perdidos, la historia completa sólo es percibida al final. Se trata de una mezcla de roles entre autor y usuario, este último puede llegar al final pero no entenderlo, ya que se ha perdido algún módulo concreto previo. Los ejemplos significativos son Soul Patron (http://www.soul-patron.com/) y Façáde (http://www.interactivestory.net/), aunque este último no sea considerado por Maurin como un documental interactivo propiamente.

\section{Análisis de caso: Prison Valley}

En este apartado retomamos y sintetizamos las reflexiones que desarrolla Roberto Arnau Roselló (2014) sobre este documental interactivo. 
Tal como este último sostiene, Prison Valley nace de la conjunción entre un periodista, David Dufresne, y un fotógrafo, Michel Brault, lo que no hace más que enfatizar el carácter colaborativo de este tipo de realizaciones. El documental aborda la situación de la industria carcelaria en el condado de Fremont, perteneciente al estado de Colorado en Estados Unidos. Las consideraciones de Arnau Roselló sobre la masiva difusión que alcanzó este documental interactivo son contundentes, pues señala que:

El día del estreno en la web la notoriedad es instantánea, la plataforma recibe más de 1.000 .000 visitas. Los días posteriores el número se reduce a 400.000, con millones de videos visionados por los internautas. Además, se cuentan unos 100.000 accesos a través de otras plataformas web colaboradoras, como el periódico Libération o la cadena televisiva Arte (que ya ha aportado, a su vez, 500.000 espectadores más por la difusión del documental de 59 minutos en la tv francesa), a lo que finalmente hay que sumar unas 15000 visitas al mes sostenidas durante el año 2011, hasta principios de 2012. El éxito sin precedentes de una obra de este tipo y su innegable calidad abonan el terreno para que reciba el prestigioso galardón 1er Premio World Press Photo 2011, en la categoría de Interactivo Multimedia, lo que desborda las previsiones iniciales del proyecto y le dota de una proyección internacional al nivel de las producciones cinematográficas de cariz documental más exhibidas de todos los tiempos. (Arnau Roselló: 2014).

Prison Valley es un documental interactivo sumamente interesante puesto que, a la vez que mantiene la narración como el esqueleto estructural central del producto, rompe simultáneamente con la linealidad, a partir de la elaboración de un esquema arborescente o rizomático, en función del tipo de interacción buscada y de los mecanismos empleados para generarla. Con el fin de provocar un interés y una participación decidida del usuario del relato, Prison Valley "cuenta con un amplio abanico de recursos tecnológico-retóricos, una fotografía y un trabajo de diseño de interfase coherente con la articulación discursiva del film (...) Los contrastes generados por el uso del sonido ambiente, el color naranja dominante y los 
claroscuros del interface" (Arnau Roselló: 2014), ubican al espectador en una situación de claustrofobia inmersiva que predomina desde el inicio mismo de la narración. Este documental desarrolla una narración de tipo lineal, en la medida en que su arquitectura hipertextual se apoya "sobre una estructura uniforme que permite retomar la narración documental en cualquier momento en el punto en el que se dejó antes de ejecutar los elementos interactivos. La linealidad de la narración principal contrasta con las líneas de fuga que ofrece el trayecto a partir de enlaces y anclas en las escenas" (Arnau Roselló: 2014). En relación a la puesta en escena, Arnau Roselló afirma que el documental se apoya fuertemente en el género del road-movie, en la medida en que accedemos al recorrido que efectúan los realizadores y sus encuentros con los diversos entrevistados. Prison Valley se conforma como un relato polifónico que desconfía de la supuesta "verdad" que cada uno de los testimonios tiene para transmitir, "pero su validez no se da por sentada sino que supone un punto de partida para ulteriores cuestionamientos de la realidad y la forma en que ésta se (re)presenta" (Arnau Roselló: 2014). El ámbito en el que se desarrolla la acción asume una importancia dramática cardinal.

Los planos en movimiento desde el coche en marcha y el sonido ambiente son una constante, una referencia permanente a una búsqueda incansable y un territorio inhóspito que es un personaje más (quizás el protagonista) y al que la voz over apela repetidamente en busca de respuestas que no acaban de llegar o aún peor, generan más preguntas. (Arnau Roselló: 2014).

A su vez, siguiendo el análisis de este autor, se verifica que la página de inicio (home) no constituye la página central del proyecto, sino que nos ubica frente a una serie de imágenes de perímetros de seguridad vallados, superpuestas con un cuadro de diálogo que nos permite iniciar la interacción con el programa. En esta misma página puede seleccionarse ya el idioma de la voz del narrador y el subtitulado, pudiéndose elegir entre inglés, francés y 
alemán. Es posible también abrir una pestaña de contacto que nos permite mantener correspondencia electrónica con el equipo de producción.

Como sostiene Arnau Roselló, la secuencia introductoria muestra un plano general en movimiento desde dentro de un coche, que nos adentra lentamente en el valle a través de una ruta escarpada y serpenteante en pronunciada pendiente, en medio de en un paisaje semidesértico, a la vez que simultáneamente una voz en off de una mujer "nos revela la procedencia del título del documental" (Arnau Roselló: 2014). La situación de inmersión que se genera en el espectador es intensa y ominosa. Se torna claro sensorialmente que estamos accediendo a un mundo con características siniestras. La cámara subjetiva desde el automóvil se convierte en una suerte de leitmotiv de avance en la progresión del documental, "un motivo recurrente que articula en cierto modo el relato convirtiéndose en otro elemento más que contribuye a la identificación del espectador como protagonista de esta particular investigación" (Arnau Roselló: 2014).

Al llegar al hotel, el documental le demanda al usuario que se registre para poder continuar navegando. “A partir de una lenta panorámica vertical frente al mostrador del motel se nos presenta en pantalla un formulario de registro en una habitación para el que se nos pide un alias y un e-mail de contacto" (Arnau Roselló: 2014). Prison Valley se propone así como un documental netamente inmersivo, en la medida en que el espectador deviene en protagonista de esta narración interactiva. Una interactividad que se encuentra dada también por "la posibilidad de compartir cada pieza en distintas redes sociales como Facebook, Twitter, etc. y en foros específicamente creados para ello" (Arnau Roselló: 2014).

Tal como afirma Arnau Roselló, el ámbito de navegación central del documental interactivo se sitúa de esta forma en la habitación del hotel en el que se hospedan los realizadores durante el rodaje. Desde este lugar, para el que se ha elaborado un espacio sonoro basado en sonidos mecánicos y 
repetitivos, el espectador asume el control del desarrollo narrativo del documental.

En el interior de la habitación, representada por una fotografía de gran formato panorámico desplazable (ya que no podemos ver la habitación completa sin mover nuestro punto de vista) aparecen identificados aquellos elementos interactivos típicos de un motel y de una investigación que despliegan otros contenidos visuales cuya presencia secundaria con respecto al cuerpo central de la aplicación (el documental de 59 minutos) no implica un papel menor en la construcción del sentido. (Arnau Roselló: 2014).

En la habitación del hotel se encuentran dispuestos una gran cantidad

de objetos con los que el usuario puede interactuar. Así, nos topamos con

un teléfono (Recepción) interactivo cuya ejecución despliega automáticamente la fotografía a tamaño casi natural del aparato, un televisor (Infos) interactivo cuya ejecución activa la aparición de un mando a distancia que nos permite cambiar de canal, un ordenador portátil encima de una mesita cuyo click nos lleva directamente a la participación en los foros de la aplicación, un cuaderno de notas (cuaderno) que contiene información hipertextual de los personajes del film, una colección interactiva de indicios y recuerdos (indicios) esparcida por encima de la cama cuyo contenido aumenta a medida que se avanza en el visionado de secuencias, pudiendo llegar a albergar hasta 30 elementos diferentes relativos a personajes o cuestiones centrales de la historia, una ventana sobre el patio (Ventana) que ofrece la vista real desde la ventana de la habitación al patio exterior del motel y, finalmente, una puerta para salir que nos devuelve al punto de la aplicación desde el que hubiésemos accedido a la habitación del hotel. (Arnau Roselló: 2014).

Otro de los objetos centrales en la estructura narrativa del documental lo constituye un mapa, a través del que podemos navegar por los distintos personajes o por las secuencias del documental. De esta forma,

el uso del mapa como factor de localización, ubicación y consecución de un itinerario exploratorio es un elemento que insiste en el motivo principal del documental, la itinerancia, la búsqueda, el movimiento como parte de una estrategia que se enfrenta a la inmovilidad del pensamiento, el rastreo de respuestas 
a las preguntas que el propio espacio genera. (Arnau Roselló: 2014).

En relación a la interactividad, Arnau Roselló identifica en Prison Valley los tres tipos de interacción mencionados anteriormente. La interacción débil se plasma en la selección del idioma en la página de inicio

y en el acceso a determinados lugares de la aplicación que no ofrecen salida ni elementos navegables. La interacción media (interactivo-configurativa) está presenta en buena parte del film, y se manifiesta permanentemente en forma de opción interactiva al final de algunas secuencias (...) que permite o bien ampliar la experiencia con distintos objetos: foros, videos, fotografías, gráficos, etc., o bien continuar el camino, avanzando a la siguiente secuencia del documental. (Arnau Roselló: 2014).

La presencia de la interacción fuerte se manifiesta por ejemplo en secuencias como la diecinueve, de nombre "El miedo",

en la que tras las declaraciones de algunos personajes ya entrevistados en las secuencias anteriores, un par de cuadros de diálogo (...) abren un nuevo espacio de interacción. En él se nos muestra la pantalla partida horizontalmente y se nos ofrece la posibilidad de dar permiso al programa para que acceda a la conexión de nuestra propia webcam para grabar nuestro testimonio: En la parte superior, una línea navegable de videos individuales en los que el resto de personajes responden a la misma pregunta (¿Qué es para ti el miedo?), en la parte inferior otra línea de videos con las opiniones grabadas a través de la webcam de algunos internautas. (Arnau Roselló: 2014).

Finalmente, Arnau Roselló señala un aspecto muy particular de Prison Valley, que consiste en la existencia de una interfase cinemática, específicamente limitada al contenido relativo al cine de la ciudad (El Skyline Theatre), conformándose así como un rasgo metacinematográfico dentro del documental. 
Se trata de la interacción que permite el acceso a uno de los indicios que se sitúan encima de la cama en la habitación del motel, en la que podemos encontrar fotografías tipo Polaroid con un título a través de las que podemos acceder a un contenido adicional. Al penetrar en la correspondiente a 'Canyon City: Hollywood', se nos abre un nuevo espacio interactivo en el que podemos entrar en el cine, entrar en la sala para contemplar carteles de films rodados en la zona décadas atrás o subir a la sala de proyección, organizada en forma de fotografía panorámica navegable tal y como ocurre en el caso de la habitación del hotel. En este caso, el discurso metacinematográfico, que nos permite acercarnos al cine desde el propio cine y con sus herramientas (actualizadas), introduce una reflexión y un espacio de distanciamiento en el que el usuario se interroga sobre las mismas representaciones y su papel como parte del eje autoral de las mismas. (Arnau Roselló: 2014).

\section{A modo de cierre}

Como hemos visto, el campo del documental se encuentra en una instancia de gran apertura a nuevos formatos, técnicas, modalidades de navegación e interactividad, en suma, de enorme experimentación, si bien existen todo tipo de productos, desde aquellos que suponen un tipo de interactividad básica, a algunos otros que implican un desarrollo mucho mayor en este aspecto. La crítica de la realidad y su representación constituyen el centro de las problemáticas de una gran cantidad y calidad de documentales desde hace tiempo, ya sean lineales o interactivos, por lo que el desarrollo de los documentales interactivos supone una profundización y una actualización, posibilitada por las nuevas tecnologías de la información y la comunicación, de lo que ya viene teniendo lugar en el campo del documental subjetivo de autor. 


\section{Referencias bibliográficas}

ARNAU ROSELLÓ, Roberto (2014), "Mutaciones digitales del cine documental. Espacio narrativo e interacción en el webdocumental contemporáneo: Prison valley (Upian/Arte, 2010)". En Fotocinema. Revista Científica de Cine y Fotografía, número 9, pp. 7-34. Disponible en: http://repositori.uji.es/xmlui/handle/ $10234 / 126725$.

BERENGUER, Xavier (2004). A decade of interactive media. Temes de disseny, 21, pp. 30-35. Disponible en: http://www.calgran.net/ articles/decada /index.htm

BONINO, Filippo (2011), Is interactivity in interactive documentaries exploited at its full potential? MA on Interactive Media 2010/2011. London College of Communication. Disponible en: http://www.interactivedocumentary.net/wp-content/2011/09/final_ dissertation_Filippo-Bonino.pdf.

GIFREU CASTELLS, Arnau (2013): El documental interactivo como nuevo género audiovisual. Tesis doctoral UPF. Disponible en www.doc.ubi.pt/14/teses_arnau_castells.pdf.

MAURIN, Florent (2011): Course on i-docs design at the EMI-CFD. Disponible en: http://gamedesignconcepts.wordpress.com/2009/ 07/30/level-10-nonlinear-storytelling/.

MURRAY, Janet (1999): Hamlet en la holocubierta: el futuro de la narrativa en el ciberespacio, Paidós, Barcelona.

NICHOLS, Bill, La representación de la realidad: cuestiones y conceptos sobre el documental, Paidós, Barcelona, 1997. 
RYAN, Marie Laure (2001), Narrative as Virtual Reality: Immersion and Interactivity in Literature and Electronic Media, Johns Hopkins University Press, Baltimore. (2005): "Narrative and the Split Condition of Digital Textuality" en Videogame, Player, Text, Manchester University Press 2005.

\section{Sitios de interés}

Clase magistral a cargo de Josep $\mathrm{M}^{\mathrm{a}}$ Català: Flujos de lo visible: la expansión del documental: https://vimeo.com/33016851

Ma tribu c'est ma vie, documental interactivo: http://matribu.onf.ca/

The Challenge, documental interactivo: http://www.canalplus.fr/c-infosdocumentaires/pid3400-c-le-challenge.html

Becoming Human, documental interactivo:

http://www.becominghuman.org/

Tanatorama, documental interactivo:_http://www.thanatorama.com/

Bla bla bla 69, documental interactivo: http://blabla.onf.ca/

Darfur Game72, documental interactivo:

http://www.radiodabanga.org/darfurgame/english/game.html

The iron curtain diaries, documental interactivo:

http://www.theironcurtaindiaries.org/ 
El documental interactivo....

Black Friday, documental interactivo:

http://www.abc.net.au/blackfriday/home/default.htm

Comunidad de estudios del documental interactivo:

http://i-docs.org/

Prision Valley, documental interactivo: http://prisonvalley.arte.tv/?lang=en

Bear 71, documental interactivo

http://bear71.nfb.ca/\#/bear71

http://iambear71.tumblr.com/archive

Seat, las sombras del progesso, documental interativo www.sombrasdelprogresso.com

Solos, documental interactivo: www.webdocsolos .com/es

Proyecto Walsh, documental interactivo: http://proyectowalsh.com.ar

Sitio de la TVE http://lab.rtve.es/webdoc

Sitio de juegos digitales para el cambio social http://www.gamesforchange.org/ 


\title{
DOCUMENTÁRIOS COM GINGA, PERSPECTIVAS DO DOCUMENTARISMO: DOS WEBDOCS À TV DIGITAL INTERATIVA BRASILEIRA
}

\author{
Bráulio de Britto Neves*
}

\begin{abstract}
Resumo: Com a ampliação do potencial dialógico da nova TV digital interativa brasileira, a articulação de práticas de produção colaborativa de cibertextos transmedia com ampla participação dos públicos e difusão distribuída abre horizontes para a inovação em práticas documentárias. $\mathrm{O}$ desafio para o desenvolvimento da potencialidade comunicativa e poética da TV digital interativa deve ser compreendido como a demanda de desenvolvimento de uma estilística nova, congruente com novos parâmetros éticos das relações realizadas através das imagens documentárias.
\end{abstract}

Palavras-chave: TVdi, i-docs, cibertexto, transmídia, colaboração, participação.

Resumen: Con la expansión del potencial dialógico de la nueva televisión digital interactiva brasileña, la articulación de las prácticas de producción colaborativa de cibertextos transmedia con amplia participación de público y difusión distribuida abre horizontes a la innovación en las prácticas documentales. El reto para el desarrollo del potencial comunicativo y poética de la televisión digital interactiva debe ser entendido como la demanda de desarrollo de una estilística nueva, congruente con los nuevos parámetros éticos de las relaciones realizadas a través de imágenes documentales.

Palabras clave: iDTV, i-docs, cibertexto, transmedia, colaboración, participación.

Abstract: With the ampliation of the dialogic potential of the new brasilien interactive digital television, the articulation of collaborative production practices of transmedia cibertexts with a wide participation of the public and a distributed difusion, horizonts are opened for the inovation in documentary practices. The challenge for the development of communicative and poetic potential of interactive digital TV should be understood as the demand for developing a new stylistic, congruent with new ethical parameters of relations performed through documentary images.

Keywords: IDTV, i-docs, cybertext, transmedia, collaboration, participation.

Résumé: Avec l'expansion du potentiel dialogique de la nouvelle télévision numérique interactive au Brésil, l'articulation des pratiques de production de collaboration cybertexts transmédia avec une large participation du public et leur diffusion, ouvre des horizons pour l'innovation dans les pratiques documentaires. Le défi pour le développement du potentiel communicatif et poétique de la télévision numérique interactive devrait être

* Pontifícia Universidade Católica de Minas Gerais, Departamento de Comunicação e Artes, Grupo de Pesquisa Poéticas audiovisuais: Dispositivo e Temporalidade. CEP 31235 040, Belo Horizonte-MG, Brasil. E-mail: brauliobrittoneves@yahoo.com.br

Pesquisa financiada pelo Programa Nacional de Pós-Doutorado, CAPES, Brasil.

Submissão do artigo: 01 de julho de 2015. Notificação de aceitação: 21 de agosto de 2015. 
compris comme la demande de développement d'un nouveau style, en harmonie avec les nouveaux paramètres éthiques des relations réalisées à travers des images documentaires. Mots-clés: iDTV, i-docs, cybertexte, transmedia, la collaboration, la participation.

Hoje, além de 15 milhões de set-top boxes Ginga, distribuídos para famílias inscritas no bolsa-família, em 2015, já foram vendidos mais de 42 milhões de receptores de TV digital com o sistema - sem contar os aparelhos smartphones capazes de receber o sinal (Novaes e Diniz, 2015).

No entanto, é ainda incipiente o esforço, da parte dos teledifusores e produtores audiovisuais comerciais em explorar os novos recursos interativos. Esta inércia é atribuída, por alguns, à falta de modelos de produção e de negócios para a geração de conteúdo interativo; por outros, ao temor de que um conjunto de novas relações de produção e apreciação de televisão coloquem em risco os modelos de negócios das empresas já estabelecidas - que, como se depreende dos repetidos "socorros" financeiros concedidos pelo Estado nos últimos anos, não ostentam grande segurança quanto à sua lucratividade futura (Tozzeto, 2012; Soares, 2013; Motta, 2009; Dantas, 2009).

Argumentamos, primeiramente, que a introdução da interatividade no audiovisual - na televisão digital e no vídeo on-line - é potencialmente indutora de um novo ciclo de experimentação de novos arranjos participativos e colaborativos. Do ponto de vista normativo, na perspectiva de um processo aberto de democratização da sociedade (Dryzek, 2000) deve-se considerar como medida de sucesso dos novos arranjos de produção a intensidade e a extensão segundo as quais eles efetivam potenciais democráticos, pluralistas e dialógicos, da televisão (Matuck, 1995). No caso do audiovisual não-ficcional, isso se traduziria na emancipação dos três públicos que a comunicação audiovisual documentária coloca em relação: 
os telespectadores (a se transformarem em teleusuários ${ }^{1}$ ); atores sociais (que passam de "informantes nativos" a voluntários); e dos produtores de audiovisual (que se assumem como propositores, ${ }^{2}$ despindo-se de pretensões demiúrgicas).

Segundo, nas circunstâncias atuais de fragmentação patológica da esfera de visibilidade pública política, essa tripla emancipação ganha positividade, em termos ético-comunicativos, ${ }^{3}$ apenas na medida em que se refere à ampliação da capacidade de instaurar espaços de interação de reflexividade discursiva de caráter universalista. Nessa direção, pretendemos mostrar que o uso democrático da interatividade na comunicação audiovisual necessita se desenvolver como uma interpretação da convergência de mídias, que ultrapasse seu entendimento como ardil de apropriação "semanticorporativa" da produtividade dos públicos apreciadores (Jenkins, 2003), na perspectiva crítica de uma produção transmidiática, que supere a antinomia entre informação e narrativa, proposta pela crítica benjaminiana (Benjamin, 2003: “O Narrador...”).

$\mathrm{Na}$ primeira seção, vamos fazer um breve percurso pela produção audiovisual de função referencial - noticiários e documentários observando a crescente tendência à horizontalização das relações entre apreciadores, produtores e atores sociais. Nas quatro subseções, serão caracterizados quatro principais tropos retóricos, que se sucederam historicamente como metáforas da comunicação cinematográfica. Em

\footnotetext{
${ }^{1}$ Segundo Cirne et al. (2009: 102): “... os recursos complementares convertidos em dispositivos interativos, somados à postura pró-ativa dos teleusuários (que agora não são mais telespectadores, mas também usuários), podem suprir uma natureza às vezes superficial de algumas matérias telejornalísticas que têm sua veiculação em função do fator tempo." A observação sobre a diferença entre públicos usuários e consumidores, ref. Benkler (2000).

${ }^{2}$ A nossa principal referência para a concepção de "propositores" provém do trabalho e dos textos de Lygia Clark, artista plástica neoconcretista brasileira, que se tornou famosa por empreender um sistemático esforço de desmaterialização do objeto artístico, explorando poeticamente a base sensorial da percepção corporal e ambiental.

${ }^{3}$ Isto é, referidos à ética da comunicação, tal como elaborada na teoria da Ação Comunicativa, dde Habermas e Apel.
} 
"Sondando a nova ético-estilística: Interatividade, "investigativismo" e colaboração", nossa tarefa será observar quais seriam as mudanças de pressupostos ético-politicos do documentário conforme as diferentes condições de implicitação do apreciador no texto vinculadas às circunstâncias da sua imersão propriamente cinematográfica. Referimo-nos especialmente das possibilidades emersas quando a textualidade audiovisual documentária se torna cibertextual e interativa. A próxima secção, "Ciber-o QUÊ?” é uma exploração livre das implicações ético-estilísticas, para o documentário, das variações de propriedades ergódicas do texto não linear (i. e. , definidoras da topologia textual - para Aarseth, 1994; 1997). A partir delas, avaliam-se também as diferentes condições de comunicação documentária, de acordo com graus dirferentes de interatividade. Na quarta seção, queremos mostrar como é que as complementaridades entre características da interatividade do webdocumentário e dos programas de TV digital, tornam a participação dos públicos algo muito além do mero chamariz, transformando-a no cerne ético-estilístico para novos formatos interativos.

Nas duas últimas seções, faremos um passeio sobre vertentes de investigação poéticas e poético-políticas. Na quinta, sustentamos que a procedimentalização da produção colaborativa propicia a construção de estruturas narrativas distribuídas, de produção colaborativa. Na sexta e última, esboçamos algumas reflexões sobre o sentido de universalidade a ser devolvido às comunicações públicas pelos arranjos audiovisuais interativos. Expressamos nosso juízo sobre o caráter promissor da associação, nos arranjos de enunciação audiovisual, de interatividade com produção colaborativa, como vetor de regeneração da reflexividade universalista do discurso público. 


\section{Tropos da deriva ético-estilística do audiovisual documentário}

Para compreender o contexto da emergência de práticas de produção colaborativa de multidão e sua vinculação à praxes políticas de instauração de espaços de visibilidade contrapública, é preciso reconstruir criticamente a história dos estilos e dos ethoi do cinema documentário. Desde meados dos anos 1960, experimentos artísticos e ativistas com produção audiovisual de função referencial, documentários, cine-reportagens e alguns experimentos de TV já vêm colocando em questão as pretenções "docentes" do jornalismo, das ciências sociais e do cinema documentário, pondo em dúvida a centralidade deles na produção do conhecimento que a sociedade necessita produzir sobre si mesma, para si mesma.

Para tentar dar conta dos dilemas da autorrepresentação cinematográfica da realidade social, as práticas de produção de imagens não ficcionais experimentaram uma deriva histórica na qual emergem vários conjuntos de expedientes discursivos, identificados como "modos documentários" (Nichols 1994) ou "campos éticos" (Ramos, 2005, 2008). Estes conjuntos e valores e protocolos de expressão emergem pela coalescência do desenvolvimentos de máquinas lógicas (Noth, 2002), principalmente as que torna compartilháveis os atos de percepção, (Sobchack, 1992; Neves, 2010 ), com a transformação de convenções de argumentação narrativa e praxes de difusão e de apreciação do audiovisual. Cada conjunto tem vantagens heurísticas e limitações epistemológicas específicas, que se manifestam nos seus procedimentos, estilemas e arranjos de produção típicos. Para que aglomerados retóricos permaneçam coesos, é doecisiva a articulação entre componentes intratextuais, paratextuais e cotextuais. Na produção do sentido de documentário de uma enunciação audiovisual, não basta que os componentes imagéticos do filme sejam indiciais e que os simbólicos sejam hipo-indiciais (p. ex., povoados de 
dêiticos e marcas da embreagem no universo de discurso "realidade histórica"). É preciso que, além de garantir que essas operações sejam reconhecidas enquanto marcas de uma função referencial, tenham sidos realizados procedimentos de indexação institucional (Carroll, 1996), inseridas uma série de marcas de correspondência entre "consígnias intra e extratextuais" (Odin, 1984) que confirmem a eficácia epistêmica do filme. Por isso, propomos identificar esses agregados de expedientes retóricos de conjuntos ético-estilísticos: eles jamais servem apenas a finalidades estéticas, mas também jamais apenas a propósitos político-comunicativos específicos. ${ }^{4}$

É relevante, para interpretar os desdobramentos políticos da sucessão de conjuntos retóricos na comunicação audiovisual documentária observar como representações políticas são enredadas não como argumentos ou narrativas simbólico-verbais, mas também nos atos de compartilhar percepções corporais. A imersão cinematográfica é capaz de sugerir ou induzir ethoi corporais no público, frequentemente desestabilizando corporalidades pré-existentes (David Thomas, 1995, 1996). O cinema permite a reconfiguração corporal de relações intersubjetivas. É desde esse nível pré-reflexivo, inconsciente e corporal, que, através da imersão em enunciações documentárias, é possível realizar experimentos com relações políticas.

No quadro abaixo, essa dimensão da deriva hístórica do documentário é correlacionado às transformações de substratos materiais, circuitos de difusão e condições de apreciação.

\footnotetext{
${ }^{4}$ A nosso juízo, um novo desses conjuntos emerge com o recorrente emprego do audiovisual para a criação de espaços de visibilidade e participação política "ativista", que chamamos de documentário político-prefigurativo (Neves, 2011).
} 


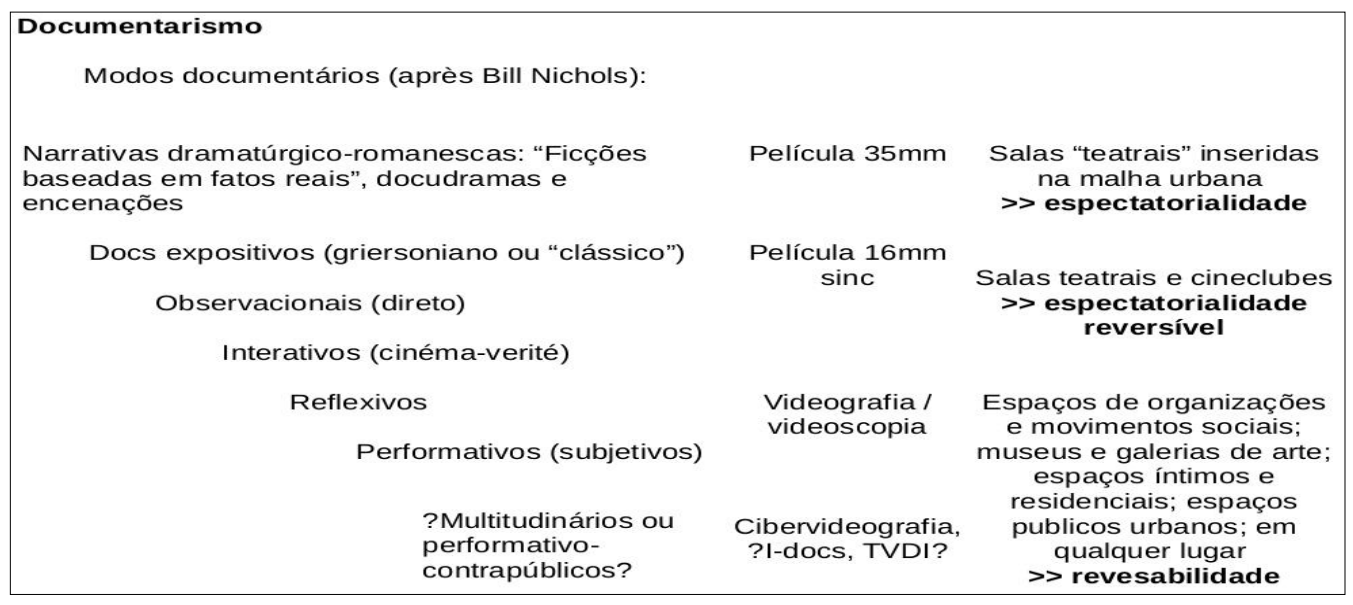

Tal como ocorre com estilos de época que se tornam gêneros literários, os conjuntos ético-estilísticos do documentário se sucederam historicamente, mas seus elementos típicos que eventualmente são reapropriados, em obras idiossincráticas, ou em blends ético-estilísticas comerciais. É instrutivo considerar, por exemplo, o caso do uso da encenação no documentário: hoje, ela é estigmatizada como se fosse uma impureza dramatúrgico-romanesca indevidamente inserida no "documentário propriamente dito" (entendido como os segmentos cuja estilística é próxima do "documentário direto"). Porém, o uso de encenações já constituiu a prática básica de produção no documentário "clássico" (expositivo, griersoniano, de missão didática). E esse expediente permanece, contemporâneamete, sendo reutilizado de modo inovador, para instaurar relações através da enunciação, nos documentários "performativos" (La Commune"; The Corporation ; Essa é a Cara da Democracia; Uncovered: The Whole Truth about the Iraq War); para metadiscursivamente indagar sobre meios e propósitos (Verdades e Mentiras); e/ou para tematizam auto-ironizar os próprios expedientes representacionais (Name Viet, Given Name Nam).

Uma transição, muito privilegiada por boa parte da teoria pósestruturalista do cinema, é identificada como a passagem do "cinema 
clássico" ao "cinema moderno". Trata-se do surgimento do que se convencionou chamar de "cinema direto" ou "cinéma vérité". Coerentes com a mentalidade intelectual pós-Segunda Guerra Mundial, teóricos e cineastas se esforçaram por deslocar a autoconcepção dos produtores do audiovisual documentário, tirando-a da demiurgia didática da encenação de "atualidades criativamente tratadas" (Grierson) para a terapia da observação do ponto de vista de uma "mosca na parede". Nada de conduzir a interpretação do público, cada qual que aprenda o que quiser ou puder, confrontando-se com as evidências cruas dos experimentos documentários. $\mathrm{O}$ cinema direto recomenda à observação desapaixonanda da realidade social.

Esta abordagem, de inspiração existencialista, tem sido tão tantalizante para uma parte da teoria do documentário, que parece ter conduzido a uma certa negligência na demarcação das inflexões éticoestilísticas subsequentes. De outras fontes, próximas da filosofia analítica e do cognitivismo anglófono, provém a maior parte dos estudos sobre as estilísticas reflexiva e performativa. $\mathrm{Na}$ primeira, a pretensão à imparcialidade é obstinadamente colocada em suspeita, através da tematização da agência "detrás da ocular" e dos ardis da interação com os agentes "diante da objetiva". A relação de produção de saber é a parte da realidade a ser escrutinada com maior urgência (Ramos, 2005; Nichols 1994; Renov, 2004). Com o documentário performativo - que atinge o paroxismo no ciberdocumentário performativo ativista - a agência defronte a tela é também sugada para o exame metadiscursivo. Neste caso, o propósito é desenvolver poéticas políticas, ou seja experimentar, usando percepção-enquanto-expressão da comunicação audiovisual, a instauração de relações de produção e interpretação da cinamatográfica (Sobchack, 1982; 1992; Neves, 2010b).

Para compreender os conjuntos ético-estilísticos e suas translações, propomos generalizar a idéia de "métaforas da teoria" do cinema, de Vivian 
Sobchack (1992). A autora propõe que a história da teoria e dos métodos de análise de cinema seguem uma sequência de tropos. Acredito que seja heurístico considera-los também com matrizes retóricas da produção audiovisual.

\section{Primeiro tropo: o quadro}

No primeiro tropo, do quadro ou da pintura, agrupar-se-iam as enunciações audiovisuais que identificamos historicamente como "cinema clássico". É o documentário cinematográfico que emerge a partir do descarte da polissemia, da imersão urbana transitório e de performance improvisada do "cinema das origens" (Burch, 1991; Hansen, 1994; 1997; Costa, 2005; Kluge, 2009). Este arranjo produtivo conduziu o cinema (e o rádio) à sustentabilidade econômica, em moldes industriais. $\mathrm{O}$ sucesso dele seria proveniente da assemblage de um arranjo retórico terso, em que se articularam a estabilização narrativa dramatúrgico-romanesca grifftiana, grandes investimentos de capital, organização de redes de distribuição centralizadas e habitualização da apreciação espectatorial (narcótica, na perspectiva de J.-L. Baudry, [1970]).

A primeira metaformose desse arranjo aparece quando, por iniciativas interessadas na criação de formas de representação politica nãoeleitorais, realizadores quebequenses e franceses começaram a experimentar outros arranjos de produção de documentário, ainda que dentro das condições de difusão massiva e apreciação "clássicas". Isso envolveu, de um lado, uma intensiva inovação técnica nos artefatos de captação de imagens, com a apropriação de câmeras leves usadas em reconhecimento militar e de gravadores magnéticos originalmente desenvolvidos para automação industrial. De outro, houve um esforço de argumentação para sustentar as novas soluções retóricas como respostas estilística condizentes 
com uma nova ética da cidadania no pós-guerra. Discursos omniscientes e heterodiegéticos do documentário clássico não satisfaziam a demanda de meios para expressar as singularidades das experiências "existenciais" de grupos sociais marginalizados - de franco-canadenses independentistas a africanos participantes de rituais de possessão.

\section{Segundo tropo: a janela}

Da "pintura" para a "janela", o ideal estóico de observação imparcial, apelidado como "mosca na parede", jamais foi recebido sem oposição. Desde o início do cinema direto, a imersão homodiegética do observador, enquanto desautorizava pretensões a omnisciência, também torna o observador politicamente responsável pelos eventos que presencia ou mesmo cuja presença precipita. É bastante coerente com o momento histórico no qual a responsabilidade (ou culpabilidade) coletiva pela inação política severamente questionada (Arendt, [1963], 1987; Souki, 1998). O que não é corente é que o enunciador tenha permanecido detentor do privilégio de decidir sozinho quais eram momentos "decisivos" a integrar os filmes. Portanto, persistia a assimetria da relação do operator com quem está defronte às telas e/ou diante das objetivas das câmaras.

Em poucos anos - com grande ajuda do consumo dos gadgets de autoespetacularização - o tropo da janela logo foi sucedido pelo do espelho. Seguindo esta metáfora, teoria e prática do cinema empreendem uma investigação intensiva sobre a subjetividade de quem grava e da performatividade dos atos de gravar vídeos. A "mosca cai na sopa", pelas suspeitas sobre a efetiva eticidade das pretensões de universalidade de representações que não haviam deixado provir de pontos de vista individuais, situados. Por mais que o "cinema direto" estivesse imerso nos acontecimentos, na perspectiva crítica dos novos movimentos sociais, a 
pretensão docente permanece impondo uma perspectiva masculina, hetero- e monoafetivo-normativa, racionalista, eurocêntrica e monoteísta.

A partir do final dos anos 1960, a pressão política pela emancipação dos públicos abriu caminho para um longo período de experimentação de produção colaborativa, no que chamamos de "espectatorialidade reversível". Um marco da emergência dessa relação através do cinema é a película “Classes de Lutte", de Chris Marker. Nela, o cineasta (ou melhor, o coletivo Dziga Vertov, da qual Marker participava), foi constrangido a compartilhar a autoria com o ator social. O coletivo realizou um documentário sobre o movimento grevista dos trabalhadores das indústrias texteis de Besançon e Sochaux ("A bientôt, j'espère", 1967), e, em seguida o exibiu para os operários - prática distintiva do "documentário interativo".

Ao fazê-lo, os cineastas foram acusados pelos operários de explorálos, de aproveitarem-se da sua imagem para benefício próprio, e de não se comprometer com nenhum ganho para o movimento. A resposta do coletivo de Marker foi dar treinamento básico e acesso a equipamentos aos grevistas, resultando em um dos primeiros documentários que hoje chamaríamos de "comunitários".

A introdução do videotape abriu amplas possibilidades para a produção audiovisual experimental independente, como a "Guerrilla Television" estadunidense Paper Tiger Tv. Como algumas outras iniciativas surgidas no contexto da arte experimental, esta depois se tornaria parte da programação da rede "grassroots video" via-satélite Deep-Dish TV. É notável a relevância dada na programação da DDTV aos vídeos metadiscursivos sobre as mediações da televisão, da representação documentária e cinematográfica. O estilo tosco dos programas, coerentemente, visava ao máximo dar saliência aos vestígios dos processos de construção de notícias e documentários; os enviezamentos temáticos são também assumidos, supondo que o apreciador crítico irá "descontar" a parcialidade dos enquadramentos visuais e argumentativos. Quando não 
questionam diretamente os padrões mass-mediáticos, os vídeos servem para experimentar, na imersão cinematográfica, as perspectivas corporalmente inscritas de grupos sociais marginalizados, geralmente vinculados aos chamados "Novos Movimentos Sociais" (NMSs).

Essas experiências viriam a ser reverberadas nas práticas brasileiras de vídeo popular militante, que buscavam o processo de redemocratização e saída da ditadura civil-militar de 1964. Logo depois, no espírito do movimento de rádios livres comunitárias, do midiativismo radical europeu dos anos 1970 e das práticas de produção dos NMSs norte-americanos, tais experiências seriam retomadas em práticas do Vídeo Comunitário. Entre finais dos anos 1970 e meados da década de 1980, floresceu, através da Associação Brasileira de Vídeo Popular, uma vasta produção audiovisual em que colaboram profissionais, entusiastas e leigos, frequentemente pertencentes ao contexto de atores sociais periféricos, rurais, etnicamente minoritários e/ou de baixa renda.

\section{Terceiro tropo: o espelho}

A este ponto, já é possível observar a segunda translação da metáfora central da retórica audiovisual documentária, do tropo "janela" para o "espelho": já não se trata mais de contemplar uma realidade social com um distanciamento estoico que autorizaria capturar "instantes decisivos" de modo privilegiado; o empenho, então, passou a ser dedicado à autoobservação, examinando o resto do mundo atrás de si, como fundo ou cenário projetado com referência à experiência subjetiva.

A disseminação socialmente transversal dos equipamentos e das práticas de videoprodução propiciou que as imagens de um documentarismo não-profissional, "entusiástico" (Lewandowska, 2007) ganhasse cada vez mais espaço nos campos das artes visuais, do telejornal e do documentarismo (Europa em 5 minutos, 1986; Amator, 1979; Amador, 
2011). A incorporação da participação de tomadas de imagens nãoprofissionais no telejornalismo também se ampliou, de modo inexorável, entre os anos 1980 e 1990. A crescente incorporação dessas imagens nos telejornais vem se mostra politicamente decisiva para o deslocamento das representações públicas, por exemplo, dos agentes do aparato repressivo do Estado (Neves, 2000; Neves e Maia, 2008).

Além disso, ampliou-se o espaço de produções participativas experimentais na TV comercial - desde o Jornal de Vanguarda (Rede Bandeirantes, 1988-9), e Perdidos na Noite, (TV Gazeta, 1984-8) até o atual “Esquenta!", do Núcleo Guel Arraes (Rede Globo). Tais produções podem ser interpretadas como "enclaves comunitários" inseridos nas grades de programação da TV de massa. Nelas, como se pode observar no modelar Boca de Lixo $(1993)^{5}$, cria-se um fluxo comunicativo de duas camadas. Em uma, mais interna, ou "comunitária", a produção colaborativa explora a participação direta do público em várias etapas da produção e nas primeiras situações de apreciação (bem ao estilo de Crônica de um Verão, 1961), nos quais os vínculos dos participantes com localidades e grupos sociais específicos são ostentados; em seguida, as imagens desse circuito são apropriadas como produtos para a circulação massiva, agregando os ganhos retóricos da identificação pessoal entre espectadores, produtores e atores sociais.

Ao transformar o circuito comunitário em objeto de fruição estética espectatorial, legitima-se o papel dos produtores especialistas na promoção social de grupos subalternizados - os mesmos que, no resto da programação cinematográfica e telejornalística, permanecem invisibilizados. Nessa

\footnotetext{
${ }^{5}$ A produção de Coutinho cria um primeiro circuito no qual as imagens dos catadores de lixo são exibidas para eles duas vezes: primeiro, viabilizando a abordagem inicial; ao final, ostentando o cumprimento do compromisso ético do documentário progressista; porém, os registros dessa circulação são transpostos para objeto de apreciação estética, no circuito do cinema documentário. É claro que os filmes de Coutinho tem caráter político-prefigurativo, tendo sido produzidos como ferramentas para mobilização de grupos militantes e ativistas.
} 
retórica de duas camadas, há uma espetacularidade reversível - um "espelho duplo".

\section{Quarto tropo: a máscara}

Fora da TV aberta, o uso do audiovisual pelos novos movimentos sociais - de mulheres, gays, negros, aborígenes - fez emergir uma ética para a produção documentária e noticiosa que se manifesta em traços estilísticos peculiares. Espaços de visibilidade corporalmente marcados, buscam afirmar as diferenças físicas, afetivas e cognitivas dos grupos subalternizados, denunciando perceptual e discursivamente o caráter opressivo do padrão "macho, adulto, branco sempre no comando". Retomando uma discussão recorrente nos encontros da $\mathrm{ABVP}^{6}$, o dilema, para os produtores militantes, era então como se passar de uma produção de "vídeo para o povo" a um "vídeo feito com/pelo povo".

A câmera, que já havia saído do tripé para ir para o ombro, agora era passada de mão em mão. As situações de apreciação de imagens documentárias, que já haviam sido deslocadas das salas "teatrais" para os cineclubes e as salas de estar, começaram a ocorrer em muitos outros lugares: experimentais, nas discotecas, galerias e museus; militantes, nas ruas de periferia, salões de associações de bairro, sindicatos, diretórios acadêmicos, ocas e taperas. Reinterpreta-se a reversibilidade da percepção cum expressão audiovisual em experimentos de revesamento actancial: quem age diante da objetiva passa para detrás da ocular; quem estava lá, vai para defronte a tela; e os "ex-espectadores" irão se desolcar para ser

\footnotetext{
${ }^{6}$ A Associação Brasileira de Vídeo Popular é uma organização cívica surgida no final dos anos 1970, que congregava diversos produtores independentes interessados no uso do vídeo para a mobilização coletiva, principalmente ligados ao movimento de redemocratização. Depois, esses mesmos grupos e realizadores individuais deslocaram seu interesse para práticas de etnografia militante, onde o "vídeo comunitário" era empregado como ferramenta de auto-organização. (Alvarenga, 2004) A ABVP era membro de uma das primeiras tentativas de articulação midiativista transnacional, a Coalizão Videazimuth.
} 
gravados por outra objetiva ou para fazer tomadas de imagens de outrem. Nesta circulação entre as posições actanciais do ato da tomada, os sentidos dos documentários são performados pela recursão das enunciações sobre suas relações pressupostas.

Mesmo que, desde meados dos anos 1970, a disseminação de usos extratelevisivos do vídeo já tivesse irreversivelmente pluralizado a audiovisibilidade pública (Hansen, 1994), ainda em meados dos anos 1990, quem quer que abordasse um transeunte com uma camcorder e um microfone, invariavelmente seria tratado como se fosse membro de uma equipe de reportagem da TV comercial massiva. A pluralização (e fragmentação) da visibilidade pública teve que esperar que, em meados dos anos 2000, as estruturas de distribuição de comunicação ganhassem proeminência na definição da topologia da esfera pública mediática. A rigor, as estruturas de comunicação social distribuídas não são novidade: malhas urbanas, correios, sistemas de telefonia, são todos sistemas de comunicação de topologia rizomática (Galloway \& Thacker, 2007). No entanto, a desmassificação dos fluxos de comunicação pela telemática, juntamente com a ampliação exponencial da ocorrência de situações de tomada e de apreciação pela digitalização do cinema, parecem ter conduzido à redefinição das agências do apreciador, do produtor e dos atores sociais envolvidos na expressão audiovisual.

Hoje, temos uma miríade de espaços de visibilidade, cada qual dotado de sua própria eticidade estilística. Em geral, os contatos entre ambientes comunicativos eticamente heterogêneos são marcados pela crueldade (Stoller, 1992) e pela "transculturalidade" (Tomas, 1996). Quando todos dispôem de câmera e detêm uma emissora no bolso, ninguém mais sabe aonde (e quando) vão parar as imagens captadas. Para o bem e para o mal, a produção audiovisual documentária tem mostrado uma forte tendência para superar a metáfora do espelho em favor de outro tropo - o da máscara. 
Neste caso, não se atribui à máscara o significado de disfarce. O anonimato ou camuflagem contra a repressão são propósitos estratégicos efetivos, mas além deles, há uma positividade de pseudonimato do contracampo da imagem-câmera ativista, como marca do pertencimento a uma visibilidade contrapública, performance de instauração de personce coletivas, e manifestação de compromissos com accountabilities não referidas à esfera pública burguesa. Nas situações de protestos de rua, os vídeo-ativistas vêm criando formas ad-hoc de organização, utilizando as câmeras como máscaras coletivas. Ao filmarem-se uns aos outros, os manifestantes-cinegrafistas coíbem a brutalidade policial. Caso contrário, os vídeo-ativistas não são capazes de usar as câmeras como "imperativos categóricos à bateria" e se encontram isolados e se tornam alvos prioritários da brutalidade. Captados uns pelos outros, porém, resistem com corpo autoperceptivo. Tal como outros mascaramentos (capuzes, pseudônimos) o vídeo-ativismo tem propiciado a instauração de agências políticas coletivas que coalescem como representações políticas contrapúblicas. A expressão disso, como vimos, ocrrre desde o nível pré-reflexivo. A exploração performativa da reversibilidade entre expressão e comunicação é indispensável, porque fornece o fundamento perceptual para os experimentos ético-políticos que pretendem contrastar à repressão biopolítica, (Neves, 2010b).

Hackativistas conhecem-se uns aos outros pelos pseudônimos e/ou pelo estilo de suas ações (Samuel, 2004). A metáfora da máscara expressa uma retórica documentária da despersonificação e da coletivização das identidades públicas. Seu propósito é permitir que o cidadão, literal e simbolicamente, imerja em outras pessoas, ou funda-se com outras. Chelsea Manning, Edward Snowden, Aaron Schwartz, Julian Assange, todas as colaboradoras do Wikileaks, só puderam atuar como defensoras da democracia por poderem se passar por funcionárias obedientes, que 
secretamente investiram-se da função de delatoras dos abusos da repressão biopolítica global.

Assim como com o voto secreto, preconizado pelo ocidente como sistema "livre e justo" de eleição de representantes e governantes, atualmente, só no anonimato da máscara, diante e detrás das câmaras, que o cidadão se permite manifestar na rua sem temer perder seu emprego, ser perseguido na rua ou ser expulso de casa. Qualquer um, "câmaramascarado" se investe do olhar da multidão, com o qual pode ousar agir como vigilante do interesse público, acreditar poder abordar quem quiser, conversar ou constrangê-lo(la) a se calar. Sente-se autorizado a entrar em lugares em que não entraria sem uma autorização burocrática prévia. Podese arriscar o próprio corpo individual para transportar o olhar da câmera para pontos de vista inseguros, desde que a câmera-máscara seja também multitudinária.

A situação do cinegrafista "amador" (ou "autodependente", como preferimos, seguindo sugestão de Herzog, 2005), é virtualmente a mesma de qualquer cidadão indignado que use do anonimato, do pseudonimato ou de denominações coletivas para delatar organizações funcionários, políticos, empresas e governos criminosos. O Ho Boulemenos ("cidadão interessado") hoje dispõe de recursos comunicativos para se investir da função de watchdog, contribuindo de modo decisivo para o levantamento investigativo e consolidação de informações dispersas de relevância política. ${ }^{7}$

\footnotetext{
7 Vide, por exemplo, o projeto Free the Files, em que os reais gastos em campanhas eleitorais são apurados por uma multidão de colaboradores (Zamora, 2012).
} 


\section{Sondando a nova ético-estilística: Interatividade, "investigativismo" e colaboração}

As poéticas de mobilização do público para o fornecimento de dados, material audiovisual, narrativas, equipamentos e até dinheiro vêm deixando de ser um traço meramente desejável (para aumentar a variedade de fontes) ou um ardil sedutor (de reforço da identificação entre públicos e produtores audiovisiuais). Para a produção de noticiários e documentários, tornaram-se práticas de pré-produção tão fundamentais que, em alguns casos, ocorre uma inversão: os vídeos de autoria circunscrita servem de ferramentas precursoras para mobilização da produção colaborativa. Começando com um vídeo "viral", desencadeia-se uma campanha em redes sociais convocando o envio de material relevante ou a produção dele por voluntários; termina-se por consolidar esse material em um documentário cibertextual (Aarseth, 1994; 1997).

Este material, mesmo que se preste a ser arrematado como enunciado linear para a circulação televisiva e cinematográfica massivas, permanece como um work-in-progress. Os arranjos de enunciação dos ciberdocumentários - da produção, à apreciação e à crítica - convergem para os arranjos de programas noticiosos interativos, deixando se ser concebidos como produtos acabados, mas como processos de condução de fluxos de informação (ou criadores de enlaces de representação política). Os produtos se convertem em ambientes de interação para agentes autodependentes, constituindo redes que conduzem desde a definição dos argumentos e o design de interface das produções, até o financiamento, a divulgação e a organização de espaços de apreciação coletiva.

Embora esse modelo possa causar alguma insegurança para as definições deontológicas de jornalistas e cineastas, o trabalho do telejornalismo e do documentarismo autoral, longe de se tornar obsoleto, continua altamente especializado. A diferença é que a ênfase do trabalho se 
desloca para a capacidade dos profissionais (e/ou ativistas organizados) de orientar a mobilização, interpretar as argumentações entrelaçadas nos eventos como organização dos fluxos de imagens e relatos, e de criar estruturas de navegação e de observação das implicações éticas do design. $\mathrm{O}$ ofício do comunicador profissional, para isso, precisa superar sua identificação como escultor das narrativas e se redefinir como análogo ao dos arquitetos,urbanistase projetistas de espaços.

Produções audiovisuais abertas e colaborativo-participativas aumentam em número e diversidade. Entre 1999 e 2010, a rede de coletivos Indymedia no Brasil foi catalisada pela circulação de vídeos como A20 Não começou em Seattle, não vai terminar em Québec. Este ciberdocumentário ativista foi exibido à exaustão em centros acadêmicos, associações de bairro, sindicatos e nas ruas, para fins de catálise da organização de coletivos midiativistas.

No mundo, com propósitos semelhantes, foi produzida uma série de ciberdocumentários de Anti-Summits: Showdown in Seattle e This is what Democracy looks like (Big Noise Filmes, Indymedia, 1999), sobre os protestos que levaram a reunião da Organização Mundial do Comércio, em Seattle, ao colapso ${ }^{8}$. Rebel Colours (Indymedia, 2001), exibe a diversidade de táticas dos protestos em Praga. Genoa Red Zone (Indymedia, 2002) detalha a covardia da "ratoeira de Berlusconi”, tornando a violência contra os manifestantes antiglobalização um motivo para a persistência dos ativistas. Miami Model denuncia a militarização e o racismo da repressão nos protestos contra o encontro da ALCA, em 2003. A Kankoon/Km 0, sobre os protestos contra a reunião da OMC em Cancún, ambos produzidos em 2003, vão na mesma toada: partilhar dos riscos e dos sofrimentos corporais dos manifestantes. Além da contrainformação, todos esses vídeos

\footnotetext{
${ }^{8}$ Realizado a partir da contribuição de centenas de vídeo-ativistas, coordenados a partir do primeiro Centro de Mídia Independente, produzindo a contrainformação sobre os protestos de 1999.
} 
visam a imergir corporalmente os apreciadores nas experiências contrapúblicas. Implicitamente, acusam a falta de responsabilidade política dos "espectadores", diante do ativismo pressuposto aos "usuários".

Como mostra Chuck Tryon (2011), a nova retórica da pluralização da autoria e colaboratividade das produções documentárias ultrapassa largamente as redes ciberativistas altermundistas radicais, aparecem em arranjos de enunciação que podem ser mainstream, como Uma verdade inconveniente (2006). Documentários audiovisuais são, em geral, parte de mobilizações ativistas transmidiáticas, que incluem performances em espaços urbanos, websites, uso de plataformas de mobilização (como Avaaz, Article 19, TakePart.com, MoveOn.org) e customizações de sites de redes sociais de grande popularidade. Documentários como A Era da Estupidez (2009) Uncovered: The War on Iraq (2004) foram produzidos com recursos financeiros levantados em house parties, que também serviram para distribuí-los e promovê-los. De maneira semelhante, 99\% Occupy Wall St. Collaborative Film (2013) e The Corporation, criaram sites para a mobilização coletiva. Este último, um libelo contra o abusivo direito das corporações, foi relançado como DVD com mais depoimentos e documentos, voltando a pedir contribuições financeiras dos cidadãos interessados. Esse tipo de documentário pode ser orientado para a mobilização de públicos heterogêneos em torno de uma temática que se quer tornar comum, qualquer que seja ela. Não servem só "às esquerdas". Documentários instauradores de contrapúblicos podem ser manobrados por grupos de pressão reacionários, como em "Expelled: No intelligence allowed"9 (Tryon, 2011).

Esse novo conjunto ético-estilístico, de arranjos de produção apoiados no crowdsourcing, vem se consolidando como alternativa eficaz de produção audiovisual autodependente para a realização de documentários

\footnotetext{
${ }^{9}$ Documentário que defende o criacionismo biológico criando uma rede de promotores do vídeo e apoiadores da causa.
} 
on-line, incluindo documentários interativos. Trata-se de um modelo convidativo também para a produção de noticiários e documentários da televisão digital interativa, por produtores independentes ou por empresas de comunicação de massa. No entanto, no caso destas, costuma haver conflitos de interesse difíceis de superar, entre eles a resistência resultante da cultura profissional de jornalistas e teledifusores, que se apegam ao seu lugar de "heroís modernos" (Sontag, 1981). Documentários “crowdsourceados” não são apenas contrainformação, mas exercícios de uma poética de prefiguração política na qual o caráter performativo do audiovisual busca a instauração de contrapúblicos (Neves, 2010b; 2012).

\section{Ciber-o QUÊ?}

Como já vimos (Neves, 2012), boa parte dos arranjos documentários transmidiáticos acaba expressando, na superfície textual linear, algum tipo de personificação de uma interação de acesso aleatório sobre arquivos. O acesso aleatório, por ser inviável na linearidade dos arranjos massivos de apreciação cinematográfica e televisiva, é projetado, como uma sombra, tal como em um desenho bidimensional se representa a tridimensionalidade de um cubo ou pirâmide.

Para a experiência do cinéfilo e do telespectador, a navegação interativa com as imagens é como uma viagem na quinta dimensão física difícil de imaginar, impossível de experimentar diretamente. Para usuários de sites de videosharing ou para gamers, o caso é outro: o acesso aleatório é a relação esperada com o hipertexto - uma affordance de apreciação da qual ele sentirá falta. Se é provável que os padrões de apreciação estejam em transição entre um conjunto de hábitos e outro, cabe, o quanto antes identificar quais seriam as questões ético-estilísticas mais decisivas, em termos da implicitação do leitor no texto. 
Qual é a dimensão política da implicitação do enunciatário de documentários não-lineares, considerando os efeitos performativos dessa pressuposição? A teoria de Sobchack $^{10}$, pertinente à enunciações cinematográficas lineares e atenta relações, mediadas pelo cinema, entre apreciadores e operadores, com pouco interesse pelos "personagens", parece pouco adaptada para responder tal indagação. Recorreremos à teoria do cibertexto, de Espen Aarseth (1994, 1997), num esforço de sondar os sentidos ético-políticos da imersão cinematográfica nas condições do audiovisual interativo.

Aarseth propõe seis critérios para a caracterização das propriedades topológicas de textos: (a) topologia textual, (b) dinâmica, (c) determinabilidade, (d) transiência, (e) manobrabilidade e (f) funcionalidade de usuário. A partir destes fatores, a teoria "ergódica" do texto identifica, muito sinteticamente, quatro categorias pragmáticas básicas. Entre as ilimitadas combinações desses fatores, encontramos na prática algumas textualidades mais recorrentes:

(a) o texto linear simples;

(b) hipertextos;

(c) cibertextos determinados

(d) cibertextos indeterminados.

Observa-se, nesta lista, um crescendo de participação do enunciatário: começando com a leitura "desobediente" do texto linear, passando para os textos nos quais as escolhas de percurso são livres, mas o conteúdo e estrutura são fixas; destas, aos textos nos quais o intérprete desempenha os papéis no texto (como apreciador de Le Challenge, posto para "jogar" como jornalista investigativo). ${ }^{11} \mathrm{O}$ paroxismo da

\footnotetext{
${ }^{10}$ I. e., sobre a comunicação cinematográfica realizar-se através da imersão do apreciador no "olhar da câmara", na qual percepção e expressão se tornam reversíveis, desprivatizando e desindividualizando a percepção corporal. (Sobchack, 1992).

11 "Le Challange", (Matthieu Belghiti, Arnaud Dressen e Lætitia Moreau, 2009) é um webdoc do Canal Plus e da HonkyTonk Filmes, no qual o usuário "entra na pele" de um
} 
interatividade estaria em expressões nas quais os usuários imergem em um fluxo discursivo imprevisível, participa ao mesmo tempo e em interação com outros usuários fornecendo de segmentos textuais, redesenhando o "mapa" dos percursos navegáveis e as affordances de interação. No momento atual, este extremo só é exemplificado na web ciberativista, único tipo de texto on-line no qual os usuários são convidados (todo o tempo) a fornecer material, a difundir o vídeo, a participar de decisões sobre a estrutura e o uso das plataformas, e a colaborar com a programação (Coleman, 2004; 2012).

Retomemos os fatores elencados por Aarseth, explorando algumas das possibilidades de combinação no documentário audiovisual interativo (online e televisivo):

(a) Considerando as variações topológicas, notaremos que mesmo os textos lineares podem propiciar ou coibir a embreagem do enunciatário no texto. No caso do cinema, isso ocorre na imersão do espectador no filme, seja através das identificações com corpos figurativamente representados, seja na imersão do apreciador na perspectiva dos operadores de tomada de imagens. Como quer que isso aconteça, por mais que os objetos gerados nos atos de apreciação possam mudar ou diferir de um apreciador para outro, os textos, enquanto coisas, continuam idênticos. Não é o que acontece em topologias textuais não lineares: cada apreciação gera concretamente uma variação textual. Em um gradiente, o apreciador e/ou o próprio texto podem: alterar a ordem da expressão de segmentos textuais; mudar as conexões entre eles; acrescentar ou deletar conteúdos; redesenhar a interface de interação; alterar a perceptibilidade dos apreciadores às mudanças de percurso; e assim por diante. No limite, com cibertextos indeterminados, até mesmo a existência do texto está à mercê das decisões do público.

jornalista investigativo o qual, através da navegação nos segmentos audiovisuais, vai compondo uma reportagem sobre os dilemas socioeconômicos da exploração de petróleo no Equador. ( http://www.canalplus.fr/pid3400.html) 
(b) No quesito dinâmica, ou seja, se um texto pode ou não "crescer", isso pode ocorrer com o número de segmentos textuais (dinâmica intertextônica) ou com a extensão desses segmentos (dinâmica intratextônica). É evidente a relevância política para o documentário interativo, porque define o grau de participação do público na modificação de estruturas e conteúdos. Isso se refere à (a) presença das affordances de participação, ou seja, da capacidade cedida aos usuários de acrescentar, retirar ou reestruturar o material, (b) perceptibilidade das affordances, no caso, a transparência das ferramentas de interação para as citadas operações; (c) operabilidade efetiva desses controles para diferentes usuários. ${ }^{12}$

(c) A categoria da determinabilidade serve para caracterizar as relações de "vizinhança" entre segmentos textuais, ou seja, se elas podem ou não variar, se os percursos de navegação são fixos ou mutáveis. As questões ético-políticas da participação do enunciatário são semelhantes às mencionadas acima. A observação empírica sugere que, quanto mais são transformáveis os percursos, mais facilmente uma maior diversidade de usuários irá explorar criativamente a interpretação. Aparentemente, maior dinâmica e indeterminabilidade textuais são traços típicos de textualidades associadas a modelos progressistas de participação democrática (Shaw \& Benkler, 2012). Porém, como citado no caso de Expelled, não há relação necessária; a organização de arranjos de participação com propósitos reacionários é perfeitamente viável - principalmente para mobilizações distribuídas (Gallaway \& Thacker, 2007; Velkhen, 2013).

(d) Quanto ao fator transiência, a questão da sincronia ou dissincronia do fluxo audiovisual é decisiva para a diferenciação entre documentários interativos on-line e noticiários televisivos interativos. Para que os documentários telemáticos sejam apreciados, pelo menos a maioria das

\footnotetext{
12 Sobre as implicações ético-políticas das affordances, ou seja, dos "propiciamentos" de agências definidos pelo design de interação com o texto e entre os sujeitos através dos textos, cf. Bendor et al., 2012; Bardonne, 2010; Magnani \& Bardone, 2008.
} 
sequências e planos deve estar disponível para a apreciação não-linear. No caso dos programas em TVdi - pelo menos considerando a memória local limitada dos set-top boxes definidos pelo padrão brasileiro, e também a velocidade de transferência de dados, apenas uma parte do material pode estar imediatamente disponível para acesso aleatório. É, porém, possível criar arranjos de TV digital interativa (TVdi) em que os teleusuários possam selecionar, através de canais de retorno simples, quais segmentos textuais passaram a ser transmitidos utilizando-se o sistema de carrossel. Mesmo assim, é preciso solucionar uma interface coletiva, que faça com que escolhas individuais do que transmitir sejam agregadas, definindo que novos segmentos serão disponibilizados pela emissora. Por outro lado, é possível criar formas híbridas de webdocumentários interativos-programas de televisão-aplicativos de celular, de forma que o material não disponível no sinal de TV possa ser acessado on-line e eventualmente indexado à informações do usuário (geolocalização, personalização a partir de preferências de uso, idioma, et al.). Uma possibilidade interessante da TVdi é a de desenvolver arranjos para realizar transmissões em "sincronismo defasado", nas quais haveria um lapso de tempo entre a captação das imagens e sua difusão. Neste pequeno atraso, poderiam ser incorporadas informações e imagens complementares para acesso opcional do teleusuário, como uma TV de "realidade aumentada". ${ }^{13} \mathrm{O}$ sincronismo entre a exibição e a apreciação permite um crowdsourcing em tempo real, com o próprio público atuando como "diretor multitudinário de TV". ${ }^{14}$ Dadas as

\footnotetext{
13 Por exemplo: colocando material textual e audiovisual de referência para esclarecer assuntos, obras ou autores citados em um debate; indicando e dando acesso a canais de participação política em notícias que envolvam denúncias; ou realizando e apresentando resultados sondagens de opinião ao longo de programas.

14 Uma das mais surpreendentes experiências audiovisuais documentárias da “automobilização cívica" brasileira de meados de 2013 resultou da articulação entre o uso de serviços de streaming de áudio e vídeo em alta resolução a partir de dispositivos móveis, e o de mensagens instantâneas (como Tweeter, Telegram, Whatsapp). Usando o arranjo, midiativistas de variados graus de amadorismo e profissionalização fizeram uma cobertura das manifestações de 2013 sem qualquer sistema centralizado de coordenação, "subindo"
} 
características do sistema de transmissão de TV digital brasileira, através de soluções narrativas e de interface, notavelmente promissora, é concebível a criação de arranjos de ampla participação dos públicos em transmissões ao vivo de eventos, com imagens de múltiplas fontes (amadoras e profissionais) e com controle feito pelas conversações síncronas dos participantes dos eventos e/ou do público teleusuário. ${ }^{15}$

(e) Aarseth descreve, com sua categoria manobrabilidade, a maneira como o apreciador pode realizar saltos entre segmentos textuais. Em um extremo, está o acesso aleatório pleno - é o caso dos acervos de vídeos indexados por tags e metadados, de bibliotecas e arquivos on-line, como em projetos como o Museu da Pessoa, ou o Internet Archive. Esse tipo de acesso é possível em webdocs interativos, mas aí o trabalho poético sobre a estrutura de percursos de interação emagrece até se limitar ao design de um mecanismo de buscas, que permita cruzamentos de dados ou visualizações de metadados, usando agregações estatísticas ou sistemas de recomendação. Algoritmos de recomendação de proprietários, como os que operam "por trás" dos sites corporativos de videosharing (Youtube, Vimeo, Dailymotion et al.) são quase o extremo oposto do acesso aleatório pleno. Tornam o acesso controlado e controlador, já que todos os comportamentos dos usuários são registrados e acrescentados a agregações estatísticas e perfis aos quais jamais temos acesso. A implementação de navegação de acesso

os vídeos para servidores de streaming enquanto recebiam sugestões e dicas de outros participantes das manifestações através de mensageiros instantâneos.

${ }^{15}$ Hoje, um aparelho com capacidade de produção de imagens full HD, e de upload dessas imagens, custa menos de mil reais (500 dólares ou 300 euros), e permite que qualquer cidadão politicamente interessado e disposto a algum aprendizado técnico - na configuração do serviço de streaming, em geral através do tweetcast - atue como cinegrafista de uma transmissão ao vivo para o público amplo - eventualmente, massivo. Transportando o público usuário para a experiência vicária dos riscos derivados da produção das imagens em situações de indeterminação normativa extrema (como em protestos ou festas de rua), os cinegrafistas-manifestantes reinventaram o telejornalismo de cobertura de eventos, não somente pela corporificação e na incorporação da subjetividade a cada perspectiva de fluxo de imagens, mas pela construção de uma nova experiência multitudinária de "publicalidade". O estatuto público dos acontecimentos passa a ocorrer com a expansão da reflexividade da sua representação audiovisual. 
aleatório pela TVdi tende a exigir grande engenhosidade, porque como já vimos, é preciso carregar o material de um arquivo extenso para o carrossel, e dele para a memória local do teleusuário, a partir de alguma solução de "quem decide" o que transmitir. Soluções de manobrabilidade estilisticamente mais sedutoras, como a inserção de links condicionais ou links escondidos ${ }^{16}$ permitem diversas formas de articulação, poeticamente promissoras. Assim, o acesso à participação em um programa pode ser condicionado ao acesso a determinado material de referência; ou a acumulação de escolhas de determinado tipo pode levar à disponibilização de segmentos audiovisuais variados.

(f) Finalmente, sob a rubrica funcionalidade de usuário descreve-se a capacidade do usuário de explorar um acervo, performar um papel na narrativa, configurar a estrutura de navegação ou o conteúdo do texto e poetizar intervindo de modo criativo no cibertexto. É relativamente fácil implementar tais funcionalidades em webdocumentários, porque o acesso aleatório é geralmente um pressuposto da navegação. Para a TVdi, porém, sua implementação exige um esforço de inovação no arranjo produtivo, sendo necessário desenvolver aplicativos específicos para criar canais de retorno simples e pleno. Sem estes, não seria possível nem a seleção de trechos, nem a remissão de contribuições de material audiovisual, pelo público.

Pode-se observar nos documentários crowdfundeados já existentes uma dissimetria entre um público que tem o privilégio de configurar a estrutura e de desenhar os ambientes de interação e os demais, que, no máximo, acessam a configuração de conteúdos. Do ponto de vista políticodemocrático, práticas de circulação entre membros desses dois estratos de participação seriam recomendáveis; do ponto de vista da sofisticação

\footnotetext{
${ }^{16}$ Os links condicionais aparecem apenas para alguns usuários com características tais e/ou que tenham percorrido outros segmentos textuais; os escondidos são inadvertidamente acionados por comportamentos dos usuários, e são implementáveis tanto em webdocs interativos quanto em programas de TVdi.
} 
poética, não necessariamente. É possível, como em Le Challenge, superpor o papel do explorador e do performer; mas, como nos tweetcasts das manifestações de 2013, ou nos vídeos ciberativistas dos anos 2000, é possível ir bem mais longe: pode-se realmente persuadir os apreciadores a atuar como participantes da enunciação, seja produzindo material, seja criando situações de apreciação. ${ }^{17}$

Os quatro graus de interatividade delineados por Aarseth são convergentes com os modelos de produção propostos por Luís Soares (2013), um dos desenvolvedores do middleware Ginga da TV Digital brasileira. Porém, os dois últimos formatos de programas, delineados por ele, e que teriam o maior grau de interatividade e ampla participação dos teleusuários são justamente aqueles menos confluentes com os interesses de emissoras comerciais e fabricantes de equipamentos.

Soares descreve o penúltimo grau de participação dos usuários sob o título Aplicações utilizando a tela principal conjuntamente e relacionada com o significado do programa de TV, e também sincronizada com esse conteúdo audiovisual. Trata-se de arranjo de produção e uma poética ainda inteiramente inexplorados. Sua concretização demandaria um desenho de produção que incluísse, como elemento fulcral, a participação dos teleusuários. Para isso, é pressuposto que "o produtor do conteúdo principal já o faça sabendo das possíveis não linearidades, e o faça induzindo e estimulando essas não linearidades, fazendo do telespectador parte do seu conteúdo". Trata-se de um modelo no qual a implicitação do enunciatário é diretamente articulada com a imersão audiovisual. Neste caso, ela é posta em uma relação de revesamento concreto, (e não apenas vicário), tornando, persistentemente, o público parte do assunto da programação.

${ }^{17}$ É intrigante que, na literatura sobre TVdi e webdocs interativos, a poética da apreciação coletiva, na qual os percursos interativos não lineares são realizados em grupo, seja tão raramente explorada. Quase sempre pressupõe-se uma apreciação espectatorial, por intérpretes individuais. Uma experiência pioneira nesse sentido é a videoperformance de navegação dialógica por "excertos" de atos de desobediência civil, do A.N.T.I. Cinema / Projeto Mutirão, de Graziella Kunsch. 
O último grau de intensidade na participação do público teleusuário seria encontrado, para Soares, no formato chamado "Narrativas Interativas", que se constituiriam em "narrativas em que o telespectador não só tem a possibilidade de agregar conteúdo adicional ao programa principal, mas também tem a possibilidade de mudar o fluxo desse programa, conforme seu desejo". Aqui, o teleusuário toma decisões de produção (ainda que limitadas àquilo que a pré-produção possa ter preparado). O coinventor do Ginga afirma que se trata de um tipo de produção de custos proibitivos, com os altos riscos de uma produção muito inovadora. No entanto, que seja apenas no caso de permanecermos pressupondo um tipo de produção industrial. Concebendo modelos de produção intensivamente distribuída, efetivamente realizada por um público amplo, os custos seriam minorados e os riscos, também, já que os participantes seriam diretamente interessados na apreciação do material em cuja produção estariam envolvidos de modo decisivo.

\section{Complementaridades entre webdocs e Tvdi}

É espantoso que a maioria das sugestões de formatos de programa para a televisão digital interativa, disponíveis na literatura recente, sejam representações audiovisuais de eventos para os quais não há nenhuma necessidade prática de não linearidade interativa, ou seja, de mudança do curso das ações pela participação do público. Trata-se de práticas sociais de desenvolvimento lineares: eventos esportivos e teledramaturgia folhetinesca. ${ }^{18} \mathrm{~A}$ interatividade se limita à transmissão de imagens de pontos de vista distintos sobre os mesmos acontecimentos, ou à inserção de propagandas comerciais e de outras formas de "realidade aumentada" televisiva. O exemplo recorrente da telenovela de enredo interativo, é, em

${ }^{18} \mathrm{O}$ exemplo mais recorrente dado pela literatura sobre a TV Digital brasileira é o da cobertura de partidas de futebol e de outras competições esportivas. 
última análise, redundante. Como boa parte do público telespectador de novelas sabe ou desconfia, o processo de produção da teledramaturgia atual pressupõe uma atenção voltada aos levantamentos de opinião pública, por grupos focais e surveys, sobre o impacto da evolução das intrigas na audiência. Em certo aspecto, a telenovela brasileira já é, há muito tempo, um gênero audiovisual interativo de massa. Nada disso faz com que os enredos se tornem menos previsíveis e eivados de valores não submetidos à discussão franca. A informação sobre os juízos dos telespectadores não é uma participação dos públicos, e as intrigas seguem uma linearidade de dar inveja a qualquer morfologia do conto maravilhoso. É de se esperar que, por si só, a interatividade da TV Digital não faça do telespectador um teleusuário participante. Há muito o que se pensar a respeito de poéticas de participação na interatividade televisiva.

A mais importante inovação poética que pode ser viabilizada pela TV digital interativa, encontra-se já experimentada pelos documentários transmídia: a construção participativa e interativa de narrativas não lineares. A transmissão aberta da TV reside na otimização da interação dos teleusuários sobre o curso dos acontecimentos teledifundidos, pois permite que seja síncrona ou em tempo diferido, móvel e com possibilidade de transmissão de imagens a partir de aparelhos do público.

A TVdi permite contornar algumas limitações dos i-docs. Primeiro, de cunho técnico: largura de banda e instabilidade dos streamings via web, quebrando a imersão do narratário com imprevisíveis e intermináveis “carregando..." (análogos ciberaudiovisuais dos filmes queimados nas salas de cinema, ou dos "problemas técnicos" das transmissões de TV analógica). Segundo, de caráter topológico-textual: a apreciação via web é individualizada e tendencialmente fragmentadora, pois a experiência não permite ao enunciatário engajar-se em uma apreciação que permita supor uma reflexividade massiva como a da transmissão de TV. Terceiro, limitações retóricas: a interação se limita à navegação em um hipertexto de 
conteúdo e estrutura fixa, pré-determinada pelos produtores profissionais (hipertextual); e raramente, os i-docs permitem uma participação de construção, seja na incorporação (ou exclusão) de segmentos textuais, seja na modificação da estrutura de conexões, seja no interfaceamento (ou seja, cibertextual).

Essa otimização da experiência imersiva é mais provável no caso de a TVdi efetivamente permitir flexibilidade em termos de linguagens de programação de aplicativos, controle da exibição de material semicustomizada pelo teleusuário e recursos de bidirecionalidade. A situação, no Brasil, é ainda bastante indefinida, com padrões abertos sem ferramentas de produção abertas e com poucos laboratórios para testes de transmissão. Provavelmente, a menos que os teledifusores invistam na produção de hardwares e aplicativos que viabilizem a recepção interativa com canais de retorno plenos, a indústria e as emissoras comerciais fazem lobby contra a interatividade. Por exemplo: por lobby das indústrias de eletrônicos, o padrão aprovado para a construção dos set-top boxes, atualmente, não prevê o acesso à conexão wifi. As caixas estão especificadas para dispor de $2 \mathrm{~Gb}$ de memória, mas não para o armazenamento do streaming de imagens, pois o aparelho de recepção não é veloz o bastante para gravar, reproduzir e transmitir imagens de alta definição. Ainda não está claro se serão possíveis expansões de memória nos set-top boxes, mas é possível usar padrão de transmissão de TVdi em computadores e smartphones, criar recursos de hardware e software, tornando a capacidade de armazenamento de imagens para navegação não linear praticamente ilimitada.

Por outro lado, é preciso questionar o pressuposto de que os atos de apreciação são necessariamente individualizados. Usando o sistema de transmissão de dados por carrossel, pode-se conceber, por exemplo, programas de interatividade massiva, ou de interatividade de grupos locais, nos quais os teleusuários navegariam juntos, explorando acervos 
virtualmente ilimitados de imagens. A questão técnica e poética, para formatos interativos massivos, parece ser desenvolver procedimentos de agregação de escolhas individuais por canais de retorno de interatividade simples (textos curtos) que guiem a teledifusão do material.

O modelo de apreciação televisual tampouco precisa se limitar às situações de apreciação domésticas, familiares e privadas. É possível criar arranjos de apreciação coletiva local, com capacidade ampliada de armazenamento e de conexão - ampliando a imersividade e a navegabilidade das imagens. A experiência do vídeo comunitário e ativista mostra que é altamente produtivo, em termos de mobilização coletiva e de experiência estética, criar ocasiões de apreciação coletiva de materiais para a apreciação de programas especialmente desenhados para isso. Que isso possa não ser de interesse direto das corporações privadas de comunicação, não exclui a possibilidade de uso por empresas públicas de comunicação e canais de parlamentos e tribunais, como ferramenta de e-participação política cidadã em debates interativos sobre decisões polêmicas em tramitação em parlamentos, na definição de políticas do executivo, em audiências públicas de parlamentos e tribunais, na criação de minifóruns deliberativos e em consultas populares, como já ocorre nas experiências de orçamento participativo on-line.

É concebível, através do uso das possibilidades de uso do middleware Ginga, que se obtenha:

1. A manutenção de continuidade diegética no fluxo de imagens (ou seja, a largura de banda da TV digital é fixada em aprox. $20 \mathrm{Mb} / \mathrm{s}$, o que evitaria a quebra de imersão do "loading..."), permitindo uma fluência na navegação não linear que é impossível (ou de custo proibitivo) na apreciação interativa doméstica via internet;

2. O aprofundamento da bidirecionalidade dos fluxos comunicativos, experimentando arranjos de revesabilidade nos quais os usuários poderiam circular entre as posições actanciais da representação audiovisual (diante da 
objetiva, detrás da ocular, defronte à tela), através da exploração dos canais de retorno para interatividade simples (para envio de votos, de mensagens de texto e de comandos) e plena (upload de imagens)

3. A conquista de uma reflexividade pública ampla, de massa, para a visibilidade de programação não linear interativa, com implicações políticodemocráticas notáveis, já que é bem plausível que o "precipitado" das conclusões dessas práticas de participação política terá impacto efetivo sobre as escolhas de voto, consumo e na formação de gosto.

Nas histórias das batalhas, as controvérsias sobre quem pode narrar o que e como chegam às vezes a eclipsar os próprios eventos. É, hoje, altamente improvável que algum indivíduo particular venha a ter sucesso ao pretender oferecer testemunhos mais válidos do que o de outros; ou que possa ser julgado incomparavelmente mais hábil na produção de uma síntese dos testemunhos particulares. Por isso, documentarista algum escapa de ser desautorizado em quando manifesta tais pretensões, ainda mais que a perspectivação não mais "necessita" ser necessariamente singular. A proposição de arranjos de interpretações múltiplas, através do uso de artefatos lógico-retóricos, tornou-se uma escolha viável para os comunicadores profissionais e para o próprio público. Do ponto de vista democrático, é recomendável aproveitar todas as condições que permitam que a narrativa dos eventos públicos seja plural e passível de ser perscrutada através do percurso não linear dos públicos. Há um surplus democrático na auto-observação coletiva de interseções entre as perspectivas subjetivas corporalmente inscritas nas tomadas de imagem.

A democratização prometida pela difusão de documentários interativos também se refere ao caráter economicamente redistributivo da produção audiovisual, na medida em que ele for desenvolvido como uma tecnologia aberta (com licenças abertas e/ou libres). Esta escolha política tornaria a produção de i-docs e TV digital interativa (TVdi) um vetor de 
geração de novas oportunidades de negócios de valor agregado, de trabalho de alta produtividade, e geração renda local, para os países latinoamericanos (Soares e Baum, 2012).

Este conjunto de fatores torna o desenvolvimento de produções televisuais interativas acentuadamente propícia para canais públicos, universitários, comunitários, judiciários e legislativos, e pela produção de instituições não organizadas para a obtenção de lucros comerciais (Tozzeto, 2012). O programa Brasil 4D tem sido uma iniciativa pioneira neste sentido, priorizando o acesso a serviços públicos básicos (Barbosa Filho, 2015). Trata-se da oportunidade única (e da tarefa urgente) de inventarmos práticas anteriormente inexistentes de teledifusão audiovisual, não apenas de arranjos produtivos ou de modelos de negócio mas, principalmente, em termos ético-estilísticos. Como veremos, muitas dessas inovações já se encontram dispersas como experimentos de documentários “crowdsourceados”, mídias comunitárias, midiativismo e nos documentários imersivos, interativos e cibertextuais. ${ }^{19}$

\section{Procedimentalização: proposições, jogos de improvisação e poéticas ciberaudiovisuais transmedia}

Nesta seção faremos algumas observações sobre peculiaridades das poéticas da interatividade. Referimo-nos, especialmente, à feliz descoberta da pesquisa sobre métodos de improvisação para o aprendizado de uso de meios de expressão audiovisuais. A notável contribuição do uso de procedimentos de criação, convergindo práticas de aprendizado teatral e de arte contemporânea (Spolin, 2005; Clark, 1997; Neves, 2000), emerge por sua eficácia também como prática de experimentação radiofônica e audiovisual. A transcriação de jogos de improvisação e proposições para a

\footnotetext{
${ }^{19}$ Para uma discussão de fôlego sobre cibertextos, dentro de um quadro mais amplo de topologias textuais, ref. Aarseth, 1994, 1997.
} 
aquisição coletiva, não coercitiva, de habilidades de comunicação e expressão poética, tem resultados que ultrapassam o "domínio da linguagem" ou "gramaticalização para os meios", propiciando inovações poéticas imprevisíveis, no uso do audiovisual. Entre as descobertas do uso de procedimentos de invenção, esteve a decorrente da observação de usos "desviantes" dos protocolos (regras dos jogos), afastando-se de uma utensiliarização do audiovisual como para a função estrita de transmissão de informações. Neste caso, as situações experimentais conduziam a resultados poéticos muito próximos daqueles obtidos através de proposições artísticas e da realização de protocolos de arte conceitual. ${ }^{20}$

Dispensando proximidade geográfica ou empenho de recursos vultosos, há um vasto campo de experimentação na combinação de procedimentos lúdicos de produção com mobilização de públicos para colaboração na produção audiovisual. Trata-se de uma poética que não se limita à dimensão estritamente estética do documentário ou noticiário; mas de um campo emergente para a inovação ético-política, pois conduz ao desenvolvimento de retóricas audiovisuais não ficcionais, de caráter francamente emancipatório. Tais tipos de arranjos e de formatos são inovadores por implicarem mudanças qualitativas na capacidade de pessoas comuns em criar campos de reflexividade pública para seus discursos.

A TV digital interativa permite que a perspectiva cidadã emerja na cena pública sem ser tratada de maneira paternalista e simplificadora pelas mídias massivas, e sem fragmentá-la numa nebulosa de espaços da visibilidade pública heterogêneos - forte tendência dos processos de mobilização coletiva empreendidos através dos sites de redes sociais

\footnotetext{
${ }^{20}$ Um excelente exemplo é o documentário comunitário Sons da Serra, realizado pelo programa Rede Jovem de Cidadania, produzido pela Associação Imagem Comunitária em 2006. Nele, dois adolescentes seguem um protocolo de gravação de sons da Favela da Serra e de reprodução desses mesmos sons para moradores da comunidade. Esses, por sua vez, têm gravado seus depoimentos, relatando impressões e lembranças relacionadas a tais sons. Ao final, indicam novos sons que consideram interessantes para a caracterização da comunidade.
} 
controlados por corporações transnacionais. Uma coisa é um cidadão isolado gostar da árvore centenária de seu bairro, fazer um vídeo e publicar num site de videosharing, outra coisa é ele participar de um programa televisivo colaborativo no qual ele irá descobrir que as histórias das árvores sobreviventes à especulação imobiliária de toda a cidade são muito parecidas. A perspectiva da experiência pessoal de desrespeito ao ser sistematicamente abordado de modo hostil pela polícia na saída da sua comunidade muda completamente quando se participa de um documentário interativo no qual as várias experiências semelhantes são percorridas, propiciando a percepção do caráter escravocrata da repressão social, a descoberta de que todos os jovens pobres da América Latina são perseguidos.

\section{Máscaras para quê? Reflexividade, universalidade e outros dilemas éticos da estilística colaborativo-interativa}

O papel da comunicação social de massa é decisivo para enfrentar o desafio da fragmentação da experiência social correlato à pluralização de espaços de visibilidade pública cada vez mais estanques. A enorme variedade de práticas de produção de sentido coletivo (também criadoras de sentidos de coletivo) através das imagens de função referencial traz indagações de ordem ética. O que caracteriza o uso democrático do audiovisual atual? Como criar alternativas democráticas de apelo universalista, capazes de oferecer soluções para os cruéis problemas de dissonância cognitiva e de isolamento normativo das "comunidades sintéticas" geradas por discursos identitários exclusivistas?

A experiência de uso de modos públicos de endereçamento em noticiários e documentários deixou de ser definida pela referência a uma esfera pública universalista hegemônica. Não se pode contar sequer - como queriam teóricos como Kluge ou Enzensberger - com o horizonte de um 
contrapúblico proletário universal. O enfraquecimento do compromisso universalista dos modos de públicos de endereçamento são correlatos à insegurança generalizada no espaço urbano, à intolerância religiosa, à multiplicação das moedas e mercados, à fragmentação dos discursos político-institucionais. Condições cognitivas "cruéis" e "transculturais" supostamente arcaicas, medievais ou primitivas, estão retornando, como "iconoclashes" (Latour, 2002): a destruição das imagens dos outros, consideradas sacrílegas, origina uma produção feérica de imagens da destruição; a obscenidade dos outros é combatida por atos ainda mais obscenos; a produção de evidências imagéticas pelos outros, questionada por imagens de confiabilidade insondável, frequentemente numa produção institucionalizada de falsificações (Dean, 2008).

A participação dos públicos aqui preconizada só tem sentido democrático na perspectiva de uma "convergência crítica", isto é, numa confluência de retóricas e arranjos de produção que seja benéfica ao projeto inconcluso da democratização das sociedades contemporâneas. Isso é bastante distinto dos ardis corporativos de apropriação do trabalho voluntário, dos grafos sociais, dos hábitos de consumo, das preferências de voto e dos juízos estéticos dos "amadores".

A referência crítica para a convergência das retóricas comunicativas com participação de públicos é a de Walter Benjamin. Citando Tretiakov, escritor russo transmutado para jornalista agitprop soviético, o autor de $O$ Autor como Produtor redefine a ação progressista dos intelectuais, correlacionando a ampla participação na produção jornalística com a “fusão" de retóricas mediáticas com a superação do fetichismo da autoria:

“...o processo de fusão (...) não somente ultrapassa as distinções convencionais entre os gêneros, entre ensaístas e ficcionistas, entre investigadores e vulgarizadores, mas questiona a própria distinção entre autor e leitor. Neste processo, a imprensa é a instância decisiva, e por isso é dela que tem que partir qualquer análise do intelectual como produtor." (Benjamin, 1986 [1934]: 125). 
Para seguir a orientação de forjar conceitos "de modo algum apropriáveis pelo fascismo" e que "podem ser utilizados para a formulação de exigências revolucionárias na política artística” (Benjamin, 1994), a pedra de toque para o viés crítico sobre a convergência de mídias, com decisiva participação dos públicos, é priorizar, no design dos arranjos de produção, de affordances propiciadoras da autoreflexão dos participantes profissionais e voluntários - sobre a dimensão política das relações de produção de bens simbólicos.

Como diz Benjamin, "refletir sobre sua posição no processo produtivo" é o compromisso central do intelectual progressista, tanto em termos estilísticos quanto ético-políticos, que o "transforma de fornecedor do aparelho de produção intelectual em engenheiro que vê sua tarefa na adaptação desse aparelho aos fins da revolução proletária”.

Não é por acaso que há uma forte tendência de documentários realizados através de relações de produção politicamente progressistas usarem licenças de uso libres e abertas para os bens simbólicos. Os protocolos do software livre, do código aberto e da "ética hacker" conduzem as relações de produção e de apropriação social dos bens simbólicos à ultrapassagem da oposição entre informação e narrativa (vide Benjamin, "O Narrador”...). Uma notícia e um documentário livre ou de código aberto deixam de ser mercadorias, pois adquirem uma uberdade participativa e antinarcótica. Tal como as narrativas tradicionais, bens simbólicos livres "guardam seu poder germinativo": não só não são destruídas pelo uso ou ficam irrelevantes depois dos atos de apreciação; elas transformam seus enunciatários em coenunciadores, convidando-os a reutilizar esses bens simbólicos comuns na produção de outros discursos, sob a única condição de que os mesmos direitos de apropriação livre sejam comunicados para todas as derivações futuras.

Muito além de um mero mecanismo jurídico, o licenciamento libre e aberto cria possibilidades para experimentação poético-conceitual, porque 
faz das próprias relações de produção de sentido uma matéria de expressão: os usuários tornam-se coautores do material audiovisual quando, acatando as licenças de uso, concretizam no uso compromissos políticos específicos. Por exemplo: uma licença pode proibir a exibição para fins comerciais, salvo se for para sustentar organizações de defesa de direitos; pode liberar o reúso do material, desde que em obras derivadas de orientação política emancipatória; pode facultar o acesso ao material bruto, desde que os teleusuários remetam suas avaliações e obras derivadas para os produtores originais.

A lógica da circulação social de bens simbólicos libres e abertos propicia a criação através da reciclagem da própria proposição de participação coletiva, traduzindo elementos provenientes de proposições de participação anteriores. Reativam, por isso, condições gerativas combinatórias semelhantes àquelas típicas de narrativas tradicionais. Não é só que o cinema contemporâneo reabre as possibilidades dos cinemas das origens (Kluge, Hansen, Almeida): as relações discursivas possibilitadas pelo audiovisual interativo podem emancipar os públicos da ordem audiovisual imposta pela sua transformação em empreendimento capitalista.

\section{Referências Bibliográficas}

AARSETH, E. J. (1994), "Nonlinearity and Literary Theory” in LANDOW, George P. (Ed.), Hyper/text/theory, Baltimore, Londres: John Hopkins University Press, pp. 51-86.

(1997), Cybertext. Perspectives in ergodic literature, Baltimore, Londres: John Hopkins University Press.

ALVARENGA, Clarisse M. C. (2004), Vídeo e experimentação social: um estudo sobre o vídeo comunitário contemporâneo no Brasil. 
Campinas, SP: Dissertação de Mestrado, Universidade Estadual de Campinas: [s.n.].

ARENDT, Hannah (1999), Eichman em Jerusalém; um relato sobre a banalidade do mal. São Paulo: Companhia das Letras [1963]. (1987) “Collective Responsibility,” in BERNHAUER, James (ed.), Amor Mundi. Dordrecht: M. Nijhoff.

BARBOSA FILHO, André (2015), Interatividade: surge uma nova televisão. Disponível em http://www.ebc.com.br/brasil-4d/2015/04 /interatividade-surge-uma-nova-televisao

BARDONE, Emanuele (2010) "Affordances as abductive anchors" in Studies in Computational Intelligence Volume 314, pp. 135-157. (2011), Seeking Chances - From Biased Rationality to Distributed Cognition. Berlim: Springer.

BAUDRY, Jean-Louis (1983) “Cinema: efeitos ideológicos produzidos pelo aparelho de base" in XAVIER, Ismail (Org.), A experiência do cinema, Rio de Janeiro: Graal, pp. 383-410 [1970].

BAUM, Gabriel; SOARES, Luiz Fernando Gomes (2012), Ginga Middleware and Digital TV in Latin America. Disponível em: http://www.telemidia.puc-rio.br/sites/telemidia.puc-rio.br/files/ baum_2012.pdf

BENDOR, Roy; LYONS, Susanna Haas; ROBINSON, John. What's There Not To 'Like'? The Technical Affordances of Sustainability Deliberations on Facebook. JeDEM 4(1): 67-88, 2012

BENJAMIN, Walter (1994), "A obra de arte na era de sua reprodutibilidade técnica" in Magia e técnica, arte e política: ensaios sobre literatura e história da cultura, São Paulo: Brasiliense, pp. 165-196.

BENKLER, Yochai (2000) From Consumers to Users: Shifting the Deeper Structures of Regulation Toward Sustainable Commons and User Disponível em: http://www.yale.edu/lawweb/jbalkin/telecom/ benklerfromconsumerstousers.pdf 
BURCH, Noel (1991), La Lucarne de l'infini: naissance du langage cinematographique. Paris: Nathan.

CARROLL, Noël, Theorizing the moving image (1996), Cambridge, Melbourne: Cambridge University Press. Cap. 15: "From real to reel: entangled in non fiction film", pp. 224-252.

CLARK. Lygia (1997), Barcelona: Fundació Antoni Tàpies.

COLEMAN, Gabriella (2004), "Indymedia's Independence; From Activist Media to Free Software" in Planetwork Journal, July. Disponível em: http://autonomousuniversity.org/sites/default/files/Biella_Cole man-Indymedia's-Independence.pdf (2012), Coding freedom: the ethics and aesthetics of hacking, Princeton (EEUU) e Woodstock (RU): Princeton University Press.

COSTA, Flávia Cesarino (2005), O primeiro cinema: espetáculo, narração, domesticação. Rio de Janeiro: Azougue Editorial.

DANTAS, Marcelo (2009), “Onde os francos não tem vez: como evoluiu e como evoluiu a TV digital no Brasil" in SQUIRRA, S.; FECHINE, Y. (Orgs.), Televisão digital: desafios para comunicação, Porto Alegre: Sulina, pp. 275-300.

DEAN, Jodi (2008), "Communicative Capitalism: Circulation and the Foreclosure of Politics" in BOLER, Megan (ed.), Digital Media and Democracy: tactics in hard times, Cambridge, Londres: The MIT Press, pp. 101-122.

DINIZ, Rafael; NOVAES, Thiago (2015), “A reinvenção da TV Digital no Brasil" in Carta Capital, Intervozes. Disponível em: http://www.cartacapital.com.br/blogs/intervozes/a-reinvencao-da-tvdigital-no-brasil-4423.html

DRYZEK, John S. (2000), "Discursive Democracy vs. Liberal constitucionalism" in SAWARD, Michael (ed.), Democratic Innovation - Deliberation, Representation and Association, Nova Iorque e Londres: Routledge, ECPR. 
GALLOWAY, Alexander R.; THACKER, Eugene (2007), The exploit, Minneapolis, London: University of Minnesota Press.

HANSEN, Miriam (2007), "Reinventando os Nickelodeons: Considerações sobre Kluge e o primeiro cinema" in ALMEIDA, Jane de (Organizadora), Alexander Kluge: o Quinto Ato, São Paulo: Cosac e Naify, pp.43-66.

(1994), "Early cinema, late cinema" in WILLIAMS, Linda (org.), Viewing Positions, Nova Brunswick, Nova Jérsei: Rutgers University Press.

HERZOG, Werner (2005), “Coração Selvagem. Paulo Camargo e Carlos Augusto Brandão" (texto e entrevista) in Jornal Gazeta do Povo, 31 Jan, Curitiba: Caderno G.

KLUGE, Alexander (2007), “Onze histórias do cinema” in ALMEIDA, Jane de (Org.), Alexander Kluge: o Quinto Ato, São Paulo: Cosac e Naify, pp.79-104.

LATOUR, Bruno; WEIBEL, Peter (2002), Iconoclash, beyond the ImageWars in Science, Religion and Art, ZKM and MIT Press.

LEWANDOWSKA, Marysia. "From Enthusiasm to Creative Commons" in BILLING, Johanna; LIND, Maria; NILSSON, Lars (2007), Taking the matter into common hands: on contemporary art and collaborative practices. Londres: Black Dog Publishing, pp. 47-53.

MAGNANI, Lorenzo; BARDONE, Emanuele (2008), Distributed morality: externalizing ethical knowledge in technological artifacts, Foundations of Science,V 13, I 1.

MATUCK, A. (1995), O potencial dialógico da televisão, São Paulo, Annablume.

MOTA, Regina (2009), "Novos formatos para a TV digital no Brasil" in SQUIRRA, S.; FECHINE, Y. (Orgs.), Televisão digital: desafios para comunicação, Porto Alegre: Sulina, pp. 231-246. 
NEVES, Bráulio de Britto. “Algumas Questões Para O DocumentárioInterface”. Doc On-Line: revista digital de cinema documentario, v. 13, p. 148-170, 2012.

(2010a), “Imagens-câmera, máquinas lógicas e retóricas documentárias" in Semeiosis: semiótica e transdisciplinaridade em revista, v. 1, p. 1-18.

(2010b), "Prefiguração de contrapúblicos em Brad - Uma noite mais nas barricadas" in Revista Galáxia - Revista do Programa de PósGraduação em Comunicação e Semiótica da Puc - SP, vol. 10, n. 20, São Paulo-SP, dez.

_ (2000), Educação mediática: novos espaços, outras autorias, Presença Pedagógica, v. 6, pp. 71-79.

NICHOLS, Bill (1994), Blurred boundaries: questions of meaning in contemporary culture, Indianápolis: Indiana University Press.

ODIN, Roger (1984), "Film documentaire, lecture documentarisante" in Cinémas et Réalités (Travaux XLI), Saint-Étienne: Centre Interdisciplinaire d'Étude et de Recherches sur l'Éxpression Contemporaine, Université de Saint-Étienne.

RAMOS, Fernão Pessoa (2008), Mas afinal... o que é mesmo documentário? São Paulo: Senac/SP. (2005), “A Cicatriz da Tomada: documentário, ética e imagemintensa" in RAMOS, Fernão (org.), Teoria contemporânea do cinema, vol. II. São Paulo: SENAC, pp. 159-228.

RENOV, Michael (2004), The subject of documentary, Minneapolis: University of Minnesota Press.

SAMUEL, Alexandra W. (2004), Hacktivism and the future of political participation. Cambridge: Harvard University, (Tese de Doutorado, 2004). Disponível em: http://www.alexandrasamuel.com/ dissertation/pdfs/Samuel-Hacktivism-entire.pdf 
SHAW, Aaron; BENKLER, Yochai (2012), “A tale of two blogospheres: discursive practices on the Left and Right" in American Behavioral Scientist, 56(4) 459-487.

SOARES, Luiz Fernando Gomes (2013), "Interatividade na TV Digital Aberta Brasileira" in Revista Lumina, UFJF, v. 7, n. 2.

SOBCHACK, Vivian Carol (1982), "Toward inhabited space: The semiotic structure of camera movement in the cinema" in Semiotica, n. 41, vol I/4, pp. 317-335. Amsterdã: Mouton Publishers.

(1992), The address of the eye: a phenomenology of film experience, Princeton: Princeton University Press.

SONTAG, Susan (1981), Ensaios sobre fotografia, Rio de Janeiro: Arbor.

SOUKI, Nádia (1998), Hannah Arendt e a Banalidade do Mal, Belo Horizonte: Editora UFMG.

SPOLIN, Viola (2005), Improvisação para o teatro, São Paulo: Perspectiva.

STOLLER, Paul (1992), "Artaud, Rouch, and The Cinema of Cruelty" in Visual Anthropology Review, vol. 8, Issue 2, pp. 50-57, Set.

TOMAS, David (1996), Transcultural spaces and transcultural beings, Boulder: Wesview Press.

(1995), “Art, Psycastenic Assimilation, and the Cybernetic Automaton" in GRAY, Chris Hables; FIGUEROA-SARRIERA, Heidi J.; MENTOR, Steven (eds.), The Cyborg Handbook, Nova Iorque, Abingdon: Routledge, pp. 255-266.

TOZETTO, Claudia (2012), “TV pública quer liderar criação de conteúdo para Ginga - Para evitar que futuro do sistema para TVs dependa de emissoras comerciais, TV Brasil aposta em serviços públicos”, iG São Paulo, Secção Tecnologia. Disponível em: http://tecnologia.ig. com.br/especial/tv-publica-quer-liderar-criacao-de-conteudo-paraginga/n1597727279334.html 
TRYON, Chuck (2011), "Digital distribution, participatory culture, and the transmedia documentary" in Jump Cut, n. 53, verão. Disponível em: http://www.ejumpcut.org/archive/jc53.2011/index.html

VEHLKEN, Sebastian (2013), "Zootechnologies: Swarming as a Cultural Technique" in Theory, Culture \& Society 0(0) 1-22.

ZAMORA, Amanda (ProPublica, Dec. 12, 2012), Crowdsourcing campaign spending: What we learned from free the files. Disponível em: http://www.propublica.org/article/crowdsourcing-campaignspending-what-we-learned-from-free-the-files

\section{Filmografia}

99\% Occupy Wall St. Collaborative Film, (2013) de Aaron Aites, Audrey

Ewell, Nina Krstic e Lucian Read

À bientôt, j'espère (1968), de Chris Marker/Coletivo Dziga Vertov

A Corporação (The Corporation) (2003) de Mark Achbar, Jennifer Abbott

A era da estupidez (Age of stupid) (2009) de Franny Armstrong, Lizzie

Gillett

Amador (2011), de Néstor Frenkel

Amator (1979), de Krzysztof Kiesowsky

Boca de lixo (1993), de Eduardo Coutinho

Classe de lutte (1969), de Chris Marker/Coletivo Dziga Vertov

Crônica de um Verão (Chronique d'un Été) (1961), de Jean Rouch e Edgar

Morin

Essa é a Cara da Democracia (This is what democracy looks like), de Corrugated Films, Indymedia, 2001

Europa em 5 minutos (1986), de Eder Santos

La Commune (2000), de Peter Watkin. 
Documentários com ginga ...

Sons da Serra, (2006), de Rede Jovem de Cidadania (Associação Imagem Comunitária)

Surname Viet Given Name Nam (1989), de Trinh T. Minh-ha

Uma verdade inconveniente (2006), de Davis Guggentheim

Uncovered: The War on Iraq (2004), de Robert Greenwald

Uncovered: the whole truth about the Iraq War (2003), de Robert Greenwald

Verdades e Mentiras (F for Fake) (1973), de Orson Welles 


\title{
BRASIL, MOSTRA A SUA CARA: APROXIMAÇÕES AO CENÁRIO BRASILEIRO DE DOCUMENTÁRIOS INTERATIVOS
}

\begin{abstract}
André Paz; Julia Salles*
Resumo: Nos últimos anos, surgiu uma ampla e diversa gama de produções internacionais de narrativas interativas não ficcionais, que utilizam mídias digitais e exploram a transversalidade de linguagens e plataformas. Acontecem em um território híbrido, entre reportagem na web, documentário, arte interativa, netart, games, instalação. Têm sido chamadas de webdocumentário, documentário interativo, living documentary. Em parte, essas obras têm sido reconhecidas em festivais internacionais de documentário, como o IDFA, e incorporadas à pesquisa acadêmica em centros de referência internacional, como o MIT Open Documentary Lab. No Brasil, algumas obras surgiram nos últimos anos, mas a produção artística e a pesquisa acadêmica ainda não têm acompanhado esse cenário promissor. Este ensaio apresenta aproximações ao cenário brasileiro contemporâneo de documentários interativos, orientado pela perspectiva de uma estética relacional, que vem sendo desenvolvida pelos autores em um projeto de pesquisa mais amplo sobre o campo.

Palavras-Chaves: documentário interativo, webdocumentário, interatividade.

Resumen: En los últimos años ha surgido una amplia y diversa gama de producciones internacionales de narraciones interactivas no ficcionales que utilizan los medios digitales y exploran la transversalidad de lenguajes y plataformas. Tienen lugar en un territorio híbrido, entre reportaje en la Web, documental, arte interactivo, netart, games e instalación. Se les ha llamado webdocumental, documental interactivo, living documentary. En parte, estas obras han sido reconocidas en festivales internacionales del documental como el IDFA e incorporadas a la investigación académica en centros internacionales de referencia como el MIT Open Documentary Lab. En Brasil, han surgido en los últimos años algunos trabajos, pero la producción artística y la investigación académica aún no han acompañado este escenario prometedor. Este ensayo presenta aproximaciones al escenario brasileño contemporáneo de documentales interactivos, guiado por la perspectiva de una estética relacional que está siendo desarrollada por los autores en un proyecto de investigación más amplio sobre el campo.

Palabras clave: documental interactivo, webdocumental, interactividad.
\end{abstract}

\footnotetext{
* André Paz: Universidade Federal do Estado do Rio de Janeiro - UNIRIO, Pesquisador de Pós Doutorado na Universidade Federal do Rio de Janeiro - UFRJ no Instituto de Letras/Instituto Alberto Luiz Coimbra de Pós-graduação e Pesquisa de Engenharia COPPE, Programa Avançado de Cultura Contemporânea - PACC/Programa de Engenharia de Produção - PEP, 21941-972, Rio de Janeiro, Brasil. E-mail:andredapaz@ gmail.com Julia Salles: Doutoranda. Université du Québec à Montréa - UQÀM, Faculdade de Comunicação, Bolsista do Doutorado pleno da CAPES, Brasil. H3H 2A8, Montréal, Canadá. E-mail: juliacsalles@yahoo.com.br
}

Submissão do artigo: 01 de junho de 2015. Notificação de aceitação: 20 de agosto de 2015. 


\begin{abstract}
In recent years, a series of international productions of interactive nonfictional narratives has developed. They use and explore the transversality of languages and media. These narratives takes place in a hybrid territory between the journalistic webreport, documentary, interactive art, net art, video games, installation. They were called webdocumentary, interactive documentary, living documentary. In part, these works have been recognized in international documentary festivals such as IDFA, and incorporated into academic research by leading research centers such as the MIT Open Documentary Lab. In Brazil, some studies have emerged in recent years, but the artistic production and academic research has not followed this promising scenario. This article presents insights on the Brazilian scene of the interactive documentary, oriented by the perspective of relational aesthetics and developed by the authors in a vast research project.
\end{abstract}

Keywords: interactive documentary, webdocumentary, interactivity.

Résumé: Au cours des dernières années, un nombre important de productions internationales de narrations interactives non-fictionnelles se sont développées. Il s'agit de médias numériques qui utilisent et explorent la transversalité des langages et des supports. Ces narrations se développent dans un territoire hybride, entre le reportage-web, le documentaire, l'art interactif, le netart, les jeux vidéo, l'installation. Elles ont été appelées webdocumentaire, documentaire interactif, living documentary. Ces œuvres ont été reconnues dans des festivals internationaux de documentaire, comme l'IDFA, et incorporées à la recherche universitaire par des centres de recherche de référence, tels que le MIT Open Documentary Lab. Au Brésil, certains travaux ont émergé ces dernières années, mais la production artistique et la recherche universitaire n'ont pas accompagné ce scénario prometteur. Cet article présente un aperçu de la scène brésilienne du documentaire interactif, guidée par la perspective de l'esthétique relationnelle, et développée par les auteurs dans un vaste projet de recherche sur le terrain.

Mots-clés: documentaire interactif, webdocumentaire, interactivité.

Eu quero mapear novos terrenos e não cartografar velhas fronteiras.

Marshall McLuhan

\title{
Cenas e cenários interativos
}

Já há alguns anos, o New York Times criou sua linha de interactive storytelling, ${ }^{l}$ se utilizando dos recursos interativos da web associados a formas de contar histórias que integram textos, vídeos, fotografias, gráficos.

\footnotetext{
${ }^{1}$ Exemplo de sua produção nesse sentido em 2013: http://www.nytimes.com/newsgraphics/2013/12/30/year-in-interactive-storytelling/?smid $=$ tw-nytimes.
} 
O jornal acompanhou assim outras iniciativas francesas e o já premiado Firestorm, do The Guardian. Esses trabalhos são exemplos da crescente gama de produções internacionais de narrativas interativas não ficcionais, que utilizam as novas tecnologias e mídias digitais e exploram a transversalidade de linguagens e plataformas. Essas produções esboçam apenas uma pequena parte de um amplo campo, incipiente e híbrido, que acontece na interseção entre documentário, vídeo digital, arte interativa, netart, games, instalação. As obras dessa campo e suas propostas, processos e ferramentas variam muito entre projetos como Prison Valley, La vie à sac, Le défi des bâtisseurs, Remembrance of things to understand.

Alguns centros internacionais de pesquisa - como o MIT Open Documentary Lab ou Digital Cultures Research Centre - e de realização como o National Film Board (NFB) - têm associado e denominado essa diversidade de obras como webdocumentários, ciberdocumentários, living documentary ou documentários interativos. Por trás de toda essa cena de obras interativas, há cenários propícios para suas realizações. Grande parte das obras foram incorporadas a estudos e festivais de documentário, onde já tiveram algum reconhecimento. Alguns festivais internacionais de cinema de prestígio criaram, inclusive, seus prêmios e mostras de obras interativas, como o Festival de Cannes e o Sundance, que criou um programa chamado de New Frontier Story Lab, a partir do envio da proposta de um documentário interativo chamado 18 days in Egypt. Alguns festivais de documentário também já criaram seus programas para obras interativas, como o Sheffield Doc Fest, na Inglaterra. Talvez o caso mais notório seja de um dos festivais mais reconhecidos de cinema documentário do mundo. O International Film Festival of Documentary (IDFA) de Amsterdã desenvolveu seu IDFA DocLab, que diz em sua apresentação: "The mission of IDFA DocLab is to showcase interactive documentaries and other new 
digital artforms that succesfully push the boundaries of documentary storytelling in the age of the interface."2

O desenvolvimento das narrativas interativas digitais tem sido bastante rápido e se concentrado na França, no Canadá e, mais recentemente, nos EUA e Reino Unido. Em 2010, o canal francês France 2 já era elogiado por sua ousadia ao criar ume série de webdocumentários. Em cinco anos, a situação evoluiu de tal forma que o National Film Board (NFB), no Canadá, principal realizador do mundo, já conta com mais de 40 títulos de projetos interativos, dentre os quais o premiado Highrise, out my Window.

A cena da nova produção de documentários interativos acontece sustentada por redes que apresentam pólos criativos fisicamente determinados em torno de Paris, Montreal/Toronto, Nova Iorque e Bristol/Londres. Esses locais concentram a produção das principais obras e, justamente, os principais centros de pesquisa, os principais canais e fontes de informação e os principais realizadores. Talvez isso aconteça porque, como apresenta um estudo do Observatoire du Documentaire (2013), do Canadá, os documentários interativos requerem novas ferramentas e formas de produção e distribuição, inclusive no processo de financiamento. Situados entre a produção audiovisual, o design e a programação, esses projetos precisam não apenas dos recursos, técnicas e conhecimentos dessas áreas, como de novas ferramentas, processos e habilidades técnicas e estéticas. São precisos novos arranjos produtivos de economia criativa e redes propulsoras de inovação tecnológica e desenvolvimento de experimentações estéticas e de linguagem. Esse quadro destaca a importância da cooperação, o diálogo e as redes entre realizadores, apoiadores, patrocinadores e centros de pesquisa, festivais e canais de informação sobre o tema.

${ }^{2}$ http://www.doclab.org/. 
$\mathrm{Na}$ França, entre os realizadores, encontramos algumas televisões e filmotecas públicas, com destaque para o canal franco-alemão Arte, que aposta fortemente nos documentários para web, às vezes com interseção com a produção para TV. A Arte estabelece convênios e coproduções com outras produtoras multimídias, como a Upian e a Honkytonk Films, que tem se destacado nos festivais e investe no desenvolvimento tecnológico do software Klynt, uma ferramenta de edição interativa dedicada a cineastas, fotógrafos e jornalistas ${ }^{3}$. Em Bristol, na Inglaterra, encontra-se Digital Cultures Research Centre, da University of West England, que realiza o $i$ Docs, o evento mais importante especificamente sobre documentários interativos no mundo. $\mathrm{O}$ evento é coordenado por pesquisadores e realizadores já reconhecidos no campo como Sandra Gaundenzi - uma das teóricas mais citadas em estudos sobre documentários interativos. Em Nova Iorque e arredores, o renomado Tribeca Film Institut (TFI) criou o programa TFI Interactive. E, por sua vez, nos Estados Unidos há o MIT Open Documentary $L A B$ que, entre suas atividades, desenvolveu talvez o maior banco de dados sobre documentários interativos, em parceria com o IDFA: a Docubase.

Talvez o exemplo mais significante, entretanto, seja o Canadá, um dos países pioneiros no desenvolvimento de tecnologias interativas aplicadas aos meios de comunicação, com uma forte tradição de inovação no cinema documentário como um todo. O NFB é reconhecido internacionalmente como um dos principais inovadores na criação de conteúdos audiovisuais interativos para a internet. Projetos como Highrise, Welcome to Pinepoint e Capturing Reality, premiados internacionalmente, são referências importantes para a criação atual. O Doc Toronto criou o docshift, que, entre outras coisas, organiza o Docshift Summit. Em Montreal,

\footnotetext{
${ }^{3}$ Uma série de softwears e plataformas têm sido desenvolvidos nesse sentido: como o Korsakow, por Florian Thalhofer e sua K-films; Klynt, pela Honkytonk; plataformas na web como o já extinto 3WDOC e as novas Conductr e Racontrl.
} 
três universidades (UdeM, UQM, Concordia Univerity) se destacam nas pesquisas sobre arte interativa e documentários e mantém o HexagramCIAM, um centro inter-universitário de artes midiáticas, além da escola L'INIS, que oferece regularmente formações em webdocumentário. Essas instituições de pesquisa e inovação, articuladas em rede com outras similares internacionais e com realizadores como NFB, criam um cenário fértil para a realização de uma série de obras que se destacam no cenário internacional, tanto no sentido de alcance das novas audiência via web, como no sentido de experimentações estéticas.

A produção brasileira de narrativas interativas para a internet e aplicativos não acompanha a cena desses principais pólos internacionais identificados, tanto no volume de produções como na interatividade das propostas. Em um primeiro momento de pesquisa, ainda entre 2010 e 2012 , já havíamos notado uma produção incipiente de narrativas interativas não ficcionais na web. Nesse sentido, se destacava o trabalho da produtora Cross Content, ${ }^{4}$ em São Paulo, liderada por Marcelo Bauer, que realizou trabalhos pioneiros como Filhos do tremor, lançado em 2010. Não havia, inicialmente, uma produção crítica e informativa em português na web. A produtora era responsável pelo único blog identificado que publicava, entre outros conteúdos sobre documentário em geral, informações sobre documentários interativos ${ }^{5}$. Também não havia sido identificado, até o momento, centros ou linhas de pesquisa focadas nas narrativas interativas digitais como objeto de pesquisa explícito, ou publicações acadêmicas. Algumas pesquisas isoladas foram encontradas (Ribas, 2003; Sacrini, 2004; Maia e al., 2009; Renó, 2006). Certamente não havia um terreno fértil que agregasse inovações tecnológicas e experimentações estéticas e de linguagem.

${ }^{4}$ http://www.crosscontent.com.br/. ${ }^{5} \mathrm{http}: / /$ webdocumentario.com.br/. 
Os cenários encontrados sinalizam tanto a insuficiência da produção brasileira, como o potencial que as narrativas interativas já apresentam nos pólos criativos identificados. Além disso, indicam a importância das redes e das inovações tecnológicas e estéticas para as novas produções e seus processos criativos. A partir do reconhecimento desse quadro que demos início a uma projeto de pesquisa-ação ${ }^{6}$ que buscasse um mapeamento crítico das produções brasileiras e das principais referências internacionais. Os cenários esboçados neste item apontam as referências para um estudo do caso brasileiro. O item a seguir explora as linhas gerais da perspectiva teórica orientadora do mapeamento e da pesquisa-ação, que vem sendo desenvolvidos a partir de uma estética relacional própria (Paz e Salles, 2013). Essas orientações e as diretrizes metodológicas da pesquisa, apresentadas no item III, são fundamentais para o recorte apresentado no item IV, que aponta as primeiras aproximações ao cenário brasileiro de documentários interativos.

\section{Uma Estética Relacional}

O campo das narrativas interativas digitais ainda está em formação, de maneira que a própria terminologia não está minimamente estabelecida ${ }^{7}$. Em geral, são designações que associam o suporte da internet ao gênero

\footnotetext{
${ }^{6}$ Como apresentado a seguir, a perspectiva da pesquisa-ação consiste, sumariamente, na articulação entre a pesquisa teórica e uma prática de intervenção. Na pesquisa-ação, os pesquisadores se inserem no fenômeno estudado e assumem papel de co-realizadores da ação estudada.

${ }^{7}$ Há um debate sobre definição do que caracteriza e vem a ser documentário interativo, webdocumentário ou living Documentary (Galloway et al., 2007; Gaundenzi, 2013a, 2013b;Gifreu, 2013). O webdocumentário tem sido visto como um documentário interativo que necessariamente tenha uma plataforma na web como vetor principal de realização da obra/processo. No entanto, os documentários interativos não se restringem ao suporte da internet. Um exemplo é Rider Spoke (2007), do coletivo britânico Blast Theory, um documentário interativo no qual o participante é convidado a fazer um passeio de bicicleta escutando uma gravação e parando em determinados lugares para gravar respostas às perguntas enviadas pelo dispositivo. Não há nenhum objeto a ser visto na internet, a obra existe apenas na experiência de quem sobe numa bicicleta e participa das atividades propostas.
} 
documentário e à interatividade, mas cada vez mais essa associação parece não dar conta da heterogeneidade das obras. O que parece certo é que o estatuto do espectador requer uma nova nomenclatura - como nas artes interativas em geral. Como afirma Louis-Claude Paquin (2006: 15; tradução livre): "Com as interfaces de manipulação direta, os espectadores tornam-se interatores. A interatividade é a relação que une as pessoas ao conteúdo. A interface é o dispositivo que permite o controle e o acesso ao conteúdo". Assim, consideraremos os documentários interativos como os projetos marcados por se constituírem como narrativas interativas não ficcionais que usam diferentes mídias e plataformas. Por enquanto, talvez apenas por estar neste estágio inicial, não há um formato estabelecido, os projetos precisam conceber seus próprios dispositivos em cada caso a partir do uso das diversas ferramentas. Ainda que alguns padrões se repitam, em muitos casos, os dispositivos de interação, as estratégias narrativas e os processos de produção configuram processos criativos singulares. Essa definição mais ampla é que foi a utilizada para o mapeamento do cenário brasileiro.

Alguns trabalhos internacionais já se estabeleceram como referências teóricas para se pensar a diversidade dos documentários interativos (Gifreu, 2013, 2014; Galloway et al., 2007; Gaudenzi, 2013a, 2013b). Gifreu (2013, 2014), por exemplo, faz uma proposta de classificação em função do conteúdo (temática), da experiência interativa e da plataforma que suporta a interface. Nesse sentido (Gifreu, 2013, 2014), destaca cinco categorias temáticas: ecologia e meio ambiente, guerras e conflitos, culturas urbanas, arte e difusão cultural, histórias pessoais. Em relação às plataformas, apresenta todo um conjunto (CD-DVD ROM, Instalação, TV/Cine, Web, Móvil e Multiplataforma), mas destaca o predomínio dos navegadores da web e aponta a televisão interativa como 
uma plataforma promissora ${ }^{8}$. A diversidade das plataformas utilizadas é considerada um fator chave da obra, por isso foi destacada no mapeamento brasileiro.

Outra característica fundamental de cada obra é a natureza da interatividade proposta. Gaudenzi (2013a) define quatro modos de interatividade do interator na obra: experimental, participativo, conversacional e hipertextual. Estes modos implicam o público em diferentes graus de participação. As possibilidades de intervenções criativas na participação do público é decrescente (do experimental ao hipertextual), sendo o modo experimental o que oferece maior margem de manobra ao interator. Há uma relação direta entre essas possibilidades e a imprevisibilidade do resultado: quanto maior a liberdade proporcionada pela interatividade, mais imprevisível será o resultado obtido. No caso da interatividade hipertextual, por exemplo, os caminhos a serem percorridos já estão previamente traçados, o interator pode passar de um ponto a outro mas não interfere no conteúdo da obra. Esses modos de interação não são exclusivos, frequentemente um mesmo documentário utiliza simultaneamente diferentes tipos de interatividade.

Um exemplo dessa coexistência de plataformas e formas de interatividade encontramos em Highrise, talvez a referência mais importante de documentário interativo. Highrise é na realidade um conjunto de documentários interativos sobre a questão das habitações verticais em grandes edifícios, comuns em cidades grandes por todo o mundo. Em Short history of HighRise, o interator pode apenas interagir de forma hipertextual pelos diversos conteúdos e mídias da história do projeto como um todo. O mesmo não acontece em One millionth tower, The thousand tower e Out my window. Em Highrise, Out my window, por exemplo, além de percorrer os

\footnotetext{
${ }^{8}$ Como aponta Gifreu (2014), a maioria dos projetos se concebem com uma lógica de múltiplas plataformas (Crossmedia) e mesclam diferentes gêneros e formatos (transmedia), mas, ainda que essas sejam componentes comuns nos documentário interativos, não são condição suficiente nem necessária para a caracterização de um projeto como documentário interativo.
} 
diferentes ambientes, o interator também pode submeter suas próprias imagens e textos sobre sua experiência em grandes prédios urbanos. Um guia pedagógico também é colocado à disposição do público, principalmente para que educadores possam utilizar o webdocumentário como uma ferramenta para trabalhar questões relacionadas à comunidade local. A obra não existe como um objeto fixo e o interator tem uma participação criativa na mesma.

Os trabalhos de Gaundenzi, Gifreu e outros, apresentam um glossário de referencias teóricas para um mapeamento dos documentários interativos. Inclusive alguns artigos e trabalhos de autores brasileiros ouescritos em português utilizam esses autores como referência (Amorim e Baldi, 2013; Bernardes, 2014; Levin, 2013; Paz e Salles, 2013). A partir dessas referêncais, podemos identificar a variação das propostas e temáticas. A forma de interatividade e experiência do usuário são muito diferentes entre projetos como One millionth tower, Walking the Edit ou Prison Valley. As estruturas narrativas e plataformas utilizadas de Hollow não condizem com as de Le défi des bâtisseurs. O processo de produção e recursos necessários para se fazer Fort McMoney são muitas vezes maiores que produções com software livre como Ceci n'est pas embres. No entanto, como aponta Massumi (2008), a proposta e discussão estética da interatividade precisa ir além da idéia do "You may Interact". A interação instaura um regime de poder que pode ser bastante tirânico. É nesse sentido que este projeto também busca inserir as reflexões em um contexto mais amplo, que não apenas traga as referências já existentes, mas desenvolve contribuições para os debates acadêmicos internacionais sobre as narrativas interativas não ficcionais.

Como já exploramos anteriormente, a interatividade transforma certas práticas de produção e recepção do cinema documentário de tal forma que exige uma reconsideração estética do mesmo. 
É necessário um esforço de redescrição criativa de um novo vocabulário de referências teóricas para interpretar as obras e potencializar suas possibilidades de realização. No sentido de tentar contribuir nesse processo, nos parece fértil buscar desenvolver uma perspectiva relacional, análoga à forma como Bourriaud (2009) compreende a arte contemporânea em geral, com seu caráter processual e comportamental, em função de noções interativas, convivenciais e relacionais. (Paz e Salles, 2013).

As reflexões nesse sentido precisam incorporar as contribuições teóricas do campo da criação artística e da tradição do documentário, em um contexto mais amplo das relações humanas, que fazemos a partir de autores como Vilém Flusser (2002a, 2002b, 2003, 2007, 2008). Nesse sentido, este ensaio faz parte de uma linha de investigação que reflete sobre a possibilidade de uma estética relacional para narrativas interativas focada nas formas de interações, encontros, relações e poéticas dos diferentes processos criativos. Como aponta Bourriaud (2009: 12), diante da padronização e previsibilidade das relações humanas, inseridas nas dinâmicas de espetacularização, mercantilização e profissionalização da vida cotidiana, as experimentações criativas podem fornecer possibilidades férteis para se criar novas formas de relação no mundo. E as obras não são mais vistas como um objeto pronto e acabado, mas como uma duração a ser experimentada, aberta para uma discussão ilimitada, que tem como tema central o estar-juntos, o encontro e a elaboração coletiva do sentido (2009: 21).

Nesse sentido, as contribuições de Vilém Flusser podem ser referências bastante úteis para se pensar os documentários interativos como uma forma específica de pensamento imagético, ${ }^{9}$ inserido em um novo

\footnotetext{
9 Para Flusser (2002/2007/2008), no universo da imagem técnica, o exercício crítico do pensamento não se restringe à escrita textual. As novas formas de pensamento precisam buscar configurações singulares de suas práticas que alternam recursos textuais e imagéticos de linguagem. O próprio Flusser desenvolveu a sua forma particular de pensamento imagético, afinal via os tradicionais textos filosóficos como algo decadente.
} 
regime de poder marcado pelos programas, aparelhos, funcionários, ferramentas e usuários. As contribuições flusserianas são elaborados desde uma perspectiva técnica que destaca a materialidade da comunicação. O que está em questão na obra de Flusser é a relação entre o homem e suas ferramentas, sobretudo aquelas que dizem respeito aos processos de comunicação a partir da disseminação das imagens técnicas. É nesse contexto onde surgem os documentários de dispositivo, ao conceberem e experimentarem diferentes formas de interações entre os elementos de realização do documentário como um processo criativo (Paz e Klinger, 2011). O que importa aqui é que esses documentários não narram uma história ou representam uma realidade pré existente às filmagens, eles produzem as realidades das quais falam a partir das interações eventuais da equipe com os participantes.

Os documentários interativos podem ser vistos como novas formas de documentários de dispositivo (Paz e Salles, 2013). A diferença fundamental é que a interação não acontece apenas nas filmagens, mas na própria recepção da obra enquanto processo. A recepção da obra é incorporada ao processo criativo através das diferentes formas de interatividade. Assim, o documentário interativo instaura um processo criativo coletivo, onde o espectador se transforma em interator e participa da criação mediada pelas interfaces das plataformas. As reflexões que se estabelecem vão no sentido de pensar de que forma os documentários interativos estabelecem seus processos criativos coletivos e interativos. Que relações de poder marcam suas interatividades? Que tipo de experiências e afetos disseminam? Obviamente, esses questionamentos requerem um trabalho de pesquisa muito mais extenso do que propõe este ensaio. O

Por um lado, o pensamento imagético traz a importância da experiência estética. Por outro, requer práticas de realização e recepção que se diferenciam bastante da escrita e leitura individual, solitária e silenciosa dos textos abstratos modernos. 
importante aqui é sinalizar um leque de questões que atravessa a realização da proposta de mapeamento a partir de uma estética relacional.

O exemplo de Highrise, mais uma vez, ilustra o quanto tais questões poderão estar presentes nesse novo campo. Highrise se tornou um departamento no National Film Board, um projeto guarda-chuva de produções interativas relacionadas com a temática de moradias em grande edifícios, como instalações, aplicativos para dispositivos móveis, filmes. O objetivo é explorar como o documentário interativo pode participar e ativar a inovação social mais do que apenas representá-la ou documentá-la. Em sintonia com a estética relacional apontada, o dispositivo interativo vislumbra que novas relações sejam criadas não apenas entre os interatores e a obra, mas também entre os interatores e seu meio social. ${ }^{10}$

Highrise ilustra como um documentário interativo pode ser visto como uma arte relacional (Bourriaud, 2009), que toma como horizonte teórico a esfera das relações humanas e seu contexto social e não a afirmação de um espaço simbólico autônomo. Vislumbra pequenas modificações, novas formas de relação no mundo a partir de seu processo criativo rizomático, múltiplo, indeterminado. Tenta mobilizar um esforço crítico que coloca em questão a vida em arranha-céus através de um engajamento criativo que imagina mudanças concretas, para o qual não há qualquer garantia e muita indeterminação. Highrise, One millionth tower foi desenvolvido com moradores do subúrbio de Toronto ao longo de anos. O projeto tem sua origem na relação desenvolvida com os moradores e em suas experiências de habitação. A diretora Katerina Cizek associou então os moradores a urbanistas, arquitetos, designers e programadores de

\footnotetext{
10 No próprio site encontramos a proposta do projeto: Over the years, Highrise will generate many projects, including mixed media, interactive documentaries, mobile productions, live presentations, installations and films. Collectively, the projects will both shape and realize the Highrise vision: to see how the documentary process can drive and participate in social innovation rather than just to document it; and to help re-invent what it means to be an urban species in the 21 st century.
} 
informática, para criar uma plataforma web ilustrando projetos de novas formas de habitação.

Assim, nos termos de Flusser, Highrise parece ser uma nova forma de pensamento imagético e nômade que se direciona como prática de experiências diferenciadas daquelas programadas por aparelhos. Tenta mobilizar um esforço crítico que coloca em questão a vida em arranha-céus através de um engajamento criativo que imagina mudanças concretas. Uma proposta como a de Highrise requer pelo menos uma estrutura e um processo produtivo complexo e custoso que está muito além da realidade brasileira. No cenário brasileiro, conforme apresentamos a seguir, não encontramos nenhuma obra com essa dimensão e alcance. Mesmo nos pólos criativos internacionais, projetos dessa dimensão representam apenas uma pequena parcela dos projetos de documentário interativo existentes. No entanto, no contexto da estética relacional apresentada, Highrise é a principal referência para se pensar as potencialidades e questionamentos por trás das correlações entre as possibilidades produtivas e as propostas éticas e estéticas das narrativas interativas.

\section{Uma bricolagem metodológica}

A metodologia da pesquisa do cenário brasileiro se justifica quando compreendida dentro do quadro de um projeto de pesquisa mais amplo, que compõe diversas abordagens metodológicas - uma prática definida nos campos das artes e da comunicação como uma bricolagem metodológica (Paquin, 2015). Esta composição nos permite articular diferentes metodologias para responder aos aspectos diversos das questões centrais de pesquisa e embasar ações, como apresentado a seguir. Nesse sentido, incorporamos princípios e orientações da perspectiva da pesquisa-ação e da cartografia, assim como técnicas de metodologia de estudo de caso. O estudo de caso nos permite definir o enquadramento do fenômeno 
observado, determinando, juntamente com a base teórica e conceitual da estética relacional, o recorte de observação dos dados, ou seja, o contorno do cenário brasileiro. Por outro lado, a cartografia, aliada aos princípios das metodologias de pesquisa-ação, orienta a observação participativa, a descrição dos projetos de narrativas interativas não ficcionais brasileiras e a concepção do projeto de intervenção.

A pesquisa-ação consiste, sumariamente, na articulação entre a pesquisa teórica e uma prática de intervenção. Para Desroche (apud Thiollent, 2006), grande parte das pesquisas sociais foram e ainda são elaboradas com o pressuposto de que o pesquisador se encontra fora do fenômeno que ele toma como objeto, onde sua ação está direcionada para a representação teórica daquele fenômeno. Na pesquisa-ação, os pesquisadores se inserem no fenômeno estudado e assumem esse lugar, como co-realizadores da ação estudada. A pesquisa-ação encontra eco na cartografia (Passos et al., 2009, 2014), que propõe o monitoramento e registro das transformações em um território presente, suas conexões e redes e a implicação do pesquisador nessa rede. Busca uma intervenção e sua validação acontece justamente em função dos efeitos e desdobramentos das ações. Importa se a pesquisa tem ou não potência para transformação da realidade. Por outro lado, faz parte da cartografia se afetar com o território, com o campo de pesquisa. Busca-se afetar e ser afetado, construir saberes de forma coletiva. Não é um método para se aplicado (Passos et al, 2009, 2014). Assim, entre pesquisa-ação e cartografia, a pesquisa buscar influenciar e ser influenciada pela realização de um projeto, onde autores e objetos de pesquisa se misturam.

As ações do projeto de pesquisa formam a plataforma digital Bug404, ${ }^{11}$ que busca incentivar o diálogo crítico e produtivo e fomenta a formação de parcerias e de uma rede sobre narrativas interativas não

\footnotetext{
${ }^{11}$ BUG404 é um website com mídias sociais através das quais se divulga e articula um rede sobre narrativas interativas no Brasil. www.bug404.net
} 
ficcionais. Como primeiras ações, procuramos realizar e divulgar um mapeamento das principais produções internacionais e das obras e realizadores nacionais. Esse mapeamento é voltado para a replicação criativa dos procedimentos interativos, estratégias narrativas, recursos técnicos. A pesquisa do projeto em geral se propõe como uma espécie de reflexão sobre os processos criativos, que articula as condicionantes produtivas (atores, procedimentos, técnicas, recursos, softwares e linguagens) às características estéticas da obra e suas implicações éticas, a partir da estética relacional esboçada anteriormente. É dentro desse quadro que se estrutura a pesquisa sobre o cenário brasileiro. O Bug404 tenta colaborar para a superação dos obstáculos ao desenvolvimento das narrativas interativas não ficcionais no Brasil identificados nos estudos de caso.

O estudo de caso é uma abordagem que visa observar o objeto de estudo em sua complexidade, através da consideração das interações com o meio no qual ele se insere. No caso desta pesquisa, o contexto do objeto de estudo é um aspecto central, pois um de nossos principais objetivos é justamente compreender o cenário atual brasileiro no campo do documentário interativo. A metodologia de estudo de caso nos permite então observar o fenômeno do desenvolvimento das narrativas interativas sem retirá-las de seu contexto, para em seguida compor uma imagem mais ampla do cenário nacional deste tipo de criação. Esta abordagem também nos permite evitar determinismos tecnológicos, pois ela propõe: “(...) une compréhension profonde des phénomènes, des processus les composant et des personnes y prenant part" (Gagnon, 2011: 2).

A primeira etapa de nossa abordagem foi a identificação dos casos, ou seja, identificar o maior numero possível de narrativas interativas não ficcionais realizadas no Brasil. Em razão da ausência de redes específicas de informação, da escassez de pesquisas acadêmicas sobre esta temática e do dinamismo destas mídias (muitas obras existem por apenas um ano, 
tornando-se inacessíveis posteriormente), acreditamos que esse levantamento inicial não abarque a totalidade dos casos, mas seja uma amostra suficiente para o desenvolvimento da pesquisa. As obras foram encontradas principalmente a partir de buscas e das citações nas diversas formas de publicação na internet. A maioria das obras possui um site especifico.

Este levantamento mais amplo foi feito com um recorte desenvolvido a partir dos trabalhos de Gifreu (2013), Bole e Mal (2014) e Gaudenzi (2013a), que identificaram as tendências internacionais da produção de narrativas interativas não ficcionais. Este recorte foi adequado e complementado pelas orientações das reflexões sobre uma estética relacional. Nesse sentido, selecionamos grupos de variáveis para uma primeira observação do cenário brasileiro atual de produção dos documentários interativos, através do estudo inicial das obras. Os grupos de variáveis são os seguintes:

- Suporte: meio de exibição da obra (internet, aplicativo, DVD).

- Metodologia de criação: o desenvolvimento da interatividade foi feito por um programador ou por software?

- Campo de atividade dos realizadores: áreas de origem e atuação dos autores e realizadores (jornalismo, artes plásticas, web designer).

- Experiência do interator: a forma de interatividade (hipertextual, participativa, geolocalizada) e de experiência (informativa, estética) propostas ao interator.

A partir deste primeiro trabalho mais amplo de levantamento, as principais tendências das narrativas interativas não ficcionais brasileiras foram identificadas. Passamos então para a segunda etapa do estudo de caso, onde um número menor de obras foi selecionado para ser observado com mais detalhes. Para cada uma das tendências encontradas dentro dos quatro grupos de variáveis, uma obra foi selecionada como exemplo-tipo. O critério para a seleção destas obras foi a disponibilidade de material sobre a 
criação. Assim, foram selecionadas as obras sobre as quais encontramos inicialmente uma quantidade maior de informações a respeito do processo criativo, das intenções dos autores e da metodologia de criação. O estudo de caso mais detalhado nos ofereceu uma compreensão um pouco mais clara dos principais problemas encontrados na realização de documentários interativos no Brasil, que funcionam como barreiras ao seu desenvolvimento.

\section{Cenário Brasil}

Nas publicações brasileiras recentes, o termo webdocumentário (ou web documentário) aparece pela primeira vez, precocemente, em 2002, no trabalho de conclusão do curso (TCC) de jornalismo na UFBA, Maracangalha.com, um web documentário sobre uma vila do recôncavo baiano, apresentado por Beatriz Ribas. A estudante realizou um webdocumentário e produziu um texto teórico sobre sua produção e sobre este campo emergente. Como a própria já apresentava: “A elaboração de um produto para a Web, que explora características do suporte digital como interatividade, hipertextualidade, multimídia, e memória, para a documentação jornalística da experiência passada, presente e futura de uma comunidade demonstrou a necessidade de definir melhor o conceito emergente de web documentário" (Ribas, 2003:1). Este webdocumentário está atualmente fora do ar (offline), destino muito comum entre os diversos webdocumentários identificados que foram realizados como TCC. Apesar dessas primeiras referências serem contemporâneas ao surgimento do formato do webdocumentário no contexto internacional, o cenário brasileiro não acompanhou o ritmo de produção e de pesquisa dos pólos criativos. Nesse sentido, já afirmavam Sangiovanni e Rocha (2007: 28): 
A falta de uma tradição no desenvolvimento de webdocumentários, causada pela recente aparição do gênero no cenário comunicacional, impõe, logo a princípio, uma limitação no número de trabalhos acadêmicos e teóricos em torno da discussão do formato e suas potencialidades. Limitados numericamente sim, mas não inexistentes.

Desde o trabalho de Ribas, encontramos na literatura científica brasileira algumas tentativas de definir o campo do webdocumentário (Sacrini, 2004; Reno, 2006, 2013; Sangiovanni e Rocha, 2007; Maia et al., 2009; Amorim e Baldi, 2013; Levin, 2013; Pereira e Moraes, 2013; Spinelli, 2013; Rodrigues, 2013; Vissotto, 2015). Nesse sentido, aliás, cabe ressaltar a iniciativa do periódico Doc On-Line ao lançar um número em 2013 com um dossiê sobre webdocumentário, contando com diversos artigos em língua portuguesa ${ }^{12}$. Apesar de escassa, entretanto, a produção bibliográfica foi um importante caminho para levantarmos as obras realizadas no Brasil e identificar o que já era esperado: a produção brasileira de obras em termos numéricos e na complexidade da interatividade proposta não acompanhava a cena dos pólos criativos.

Fizemos um levantamento de cinquenta e cinco obras que identificamos como narrativas interativas não ficcionais digitais, mesmo que elas não se auto-definissem como tal. Os critérios para a seleção das obras observadas seguem os princípios metodológicos do estudo de caso. Dessas obras, uma grande parte são websites ou instalações que contam histórias factuais apresentadas por vídeos curtos, textos e ilustrações, marcadas sobretudo pelo que Gaundenzi chamou de modo de interatividade hipertextual. Apenas alguns casos possibilitam uma interatividade mais participativa, que permita, por exemplo, o envio de conteúdos pelos interatores. É muito comum as obras estarem envolvidas com alguma questão social (chamadas de issue driven) e terem um propósito que se

\footnotetext{
${ }^{12} \mathrm{http}: / /$ www.doc.ubi.pt/index14.html.
} 
aproxima de uma postura ativista. Mas apesar destas primeiras considerações mais gerais, vale ressaltar que nosso foco neste trabalho é apontar as primeiras considerações sobre, como indicado na metodologia, as seguintes variáveis: suporte, metodologia de criação, o campo de atividades dos realizadores e a experiência do interator.

O primeiro aspecto que chama atenção na cena de documentários interativos brasileiros é o suporte de exibição das obras. Neste grupo de variáveis, quatro tipos de suporte foram identificados: website, aplicativo, instalação e DVD interativo. Um único exemplo de narrativa interativa não ficcional foi encontrado em DVD, que é o caso do projeto de Lucas Bambozzi, O Tempo não recuperado (2003). O suporte observado com mais frequência foi, destacadamente, o website, principalmente na forma de webdocumentários. Filhos do tremor, lançado em 2010, foi o primeiro realizado por uma produtora, a Cross Content. Do mesmo grupo, Rio de Janeiro - Autorretrato é um dos webdocumentários realizados que se destaca nesse início no campo tanto da pesquisa quanto da produção do webdocumentário brasileiro. Realizado por Marcelo Bauer, em 2011, esta obra permite ao interator, através de uma interatividade hipertextual, acessar vídeos e fotos de fotógrafos moradores do complexo da Maré, no Rio de Janeiro.

O webdocumentário é uma das principais tendências no campo das narrativas interativas não ficcionais não apenas no Brasil. Em geral, o termo webdocumentário se refere às narrativas interativas que usam como suporte apenas um website. Nesse sentido, além de Rio de Janeiro - Autorretrato, as produtoras Cross Content e DocTela, em São Paulo, se destacaram inicialmente por trabalhos como Filhos do tremor, Se eu demorar alguns meses e Webdoc Graffiti. Mas nem todos documentários interativos se limitam ao website, nem mesmo possuem, necessariamente, um website, seja como parte da obra ou como material de divulgação. Muitos se utilizam dos aplicativos para smartphones e/ou tablets. É para esses trabalhos que o 
termo documentário interativo passa a ser mais usado, embora essas obras se afastem da estética e daquilo que, tradicionalmente, se associa ao termo documentário.

O aplicativo é um dispositivo ainda pouco utilizado no meio das narrativas não ficcionais brasileiras. Apenas sete trabalhos utilizaram esse suporte. A MobContent, ${ }^{13}$ no Rio de Janeiro, se destaca com a realização do Polissonorum e o projeto em andamento Rio Antigo. O desenvolvimento de um aplicativo necessita um trabalho e habilidade de programação ainda menos difundida entre programadores e designers (principalmente se comparados com o de um website). E os gerenciadores de conteúdo para website, que dispensam o programador para a realização de websites, ainda não têm correspondentes a altura quando se trata de aplicativo móvel. O aplicativo torna-se assim uma opção de suporte com um custo superior aos outros, um fator que influencia bastante a produção brasileira em função de ainda não existir um mercado estabelecido voltado para as narrativas interativas. A grande maioria dos projetos foram auto-financiados, apenas alguns conseguiram recursos por editais.

Um exemplo promissor de narrativa não ficcional brasileira que utiliza o aplicativo é o projeto Som dos sinos (2015), de Márcia Mansur e Marina Thomé. Como se define: “Através da plataforma multimídia com navegação interativa, documentário de longa metragem, intervenção pública e aplicativo para dispositivos móveis, o Som dos Sinos estabelece canais de acesso ao imaginário ao mesmo tempo em que revela identidades culturais desta região do estado de Minas Gerais.” (Som dos sinos, Sobre, 2015 [site web]: sem pagina). Este projeto transmídia se desenvolve também em aplicativo, utiliza a geolocalização (GPS) do telefone celular e oferece "Um áudio-guia a céu aberto, que promove outros sentidos à experiência da visitação e laços afetivos através de uma cartografia de memórias,

\footnotetext{
${ }^{13}$ Www.mobcontent.com.br.
} 
ressignificando os sons dos sinos que, muitas vezes, já não se escutam mais do cotidiano local." (Som dos Sinos, Aplicativo, 2015 [site web]: sem página). A plataforma do webdocumentário está prestes a ser lançada, mas o projeto já aparenta ser o exemplo mais elaborado de documentário interativo brasileiro, no sentido da multiplicidade de ferramentas, plataformas e ações. O projeto conta ainda com mapeamento sonoro, envio de vídeo-cartas e intervenções itinerantes: "uma noite em cada uma das 9 cidades, com projeções de imagens e amplificação de paisagens sonoras, sobre trilha composta a partir dos sons dos sinos, entrevistas e outras sonoridades locais, em apresentações com conteúdo exclusivo de cada cidade." (Som dos Sinos, Itinerâncias, 2015 [site web]: sem página).

Além dos DVD, websites e aplicativos, consideramos algumas instalações com tecnologias digitais como trabalhos de narrativas interativas não ficcionais. Essa forma de exibição é utilizada principalmente na interseção dos campos das artes plásticas e das narrativas digitais. Artistas como Lucas Bambozzi, Fernando Velazquez e Giselle Beiguelman vêm criando instalações como os dispositivos exibidos no MASP (Museu de Arte de São Paulo), em 2011, na exposição 6 bilhões de outros (realizados por Lucas Bambozzi e Kika Nicolela, como parte do projeto 7 milliards d'autres, de Yann Arthus-Bertrand), para que o público explore de forma interativa histórias de imigrantes em São Paulo. A experiência dessas instalações é bastante diferente da experiência na internet, principalmente em relação ao espaço e à coletividade. Por exemplo, para visitar uma instalação, o interator deve se dirigir ao local onde se encontra o dispositivo de narrativa, com isso, a questão do espaço físico onde se encontra o interator ganha uma relevância que não existe na internet. Dessa mesma forma, a experiência de uma instalação se faz, na maioria das vezes, em público, e não em um espaço individualizado.

Vale ressaltar que desde a década de 1960 artistas brasileiros começaram a incorporar computadores e algoritmos às suas obras 
interativas. Como nota Priscila Arantes: “Já em 1969, Waldemar Cordeiro, um dos pioneiros, juntamente com o artista cinético Abraham Palatnik, na área de arte e tecnologia no Brasil, desenvolve As derivadas de uma imagem, em parceria com o Professor Giorgio Moscati, inaugurando as experimentações em computer art no país." (Arantes, 2005:55). A obra Your life, our movie (2008), realizada por Fernando Velazquez, é um exemplo recente interessante da apresentação de narrativas interativas na forma de instalações. Neste trabalho, a narrativa é construída a partir de palavras selecionadas pelo interator, que são em seguida processadas por um software (desenvolvido pela colaboração do artista com um programador), e servem como tags para a busca de imagens na rede social Flickr. Três imagens são exibidas lado a lado em sequência, compondo assim um tríptico de vídeos, criados a partir da associação entre interator, software e redes sociais. Paula Braga coloca alguns questionamentos levantados pela obra de Velazquez, principalmente sobre essa tríplice autoria da obra: “Quem é o autor da obra? O artista? O programador? Os três participadores iniciais? O coletivo que criou o repositório de imagens na Internet? A santíssima trindade desdobra-se em uma multiplicidade incontável nessa net art.” (Paula Braga, in: Fernando Velazquez, 2012 [site web]: sem página).

O segundo grupo de variáveis observadas do cenário brasileiro diz respeito à metodologia de criação. Neste momento da pesquisa, o aspecto que avaliamos desta variável se reduz à forma do desenvolvimento da interatividade: se esta foi desenvolvida por um programador ou se o realizador utilizou um software de desenvolvimento de narrativas interativas (Klynt, Korsakow, Conductr, Racontr, entre outros). A observação desta variável é importante pois a utilização de softwares permite que realizadores sem experiência em programação possam criar narrativas interativas com mais autonomia, sem dependerem da colaboração de um programador, o que reduz muito o custo de realização. A falta de familiaridade com os softwares, ferramentas tecnológicas que facilitam e diminuem os custos do 
desenvolvimento de narrativas interativas, é um freio ao crescimento do campo, como concluem Maia et al., em pesquisa de 2009 sobre o papel do webdocumentário no letramento digital: "No Brasil, grande parte da população se vê excluída dessas novas formas de comunicação e encontra dificuldade quando se depara com a situação de ter que utilizar computadores para realizar alguma atividade. Embora a questão econômica possa ser vista como responsável por esta exclusão, ela não pode ser considerada o único fator que a determina." O conceito de letramento digital é então uma forma de incluir novas camadas da população ao processo de desenvolvimento e experiência das narrativas interativas. Maia et al. também ressaltam o importante papel pedagógico do letramento digital: "Consideramos, no entanto, o letramento digital como um lugar a ser introduzido/explorado como forma de auxiliar a inclusão digital e como aprendizado que deve ser estimulado, sobretudo no ambiente educacional para a formação do estudante." (Maia et al, 2009: 2).

Os dados obtidos no mapeamento indicam que uma porcentagem pequena (14\%) das narrativas interativas não ficcionais brasileiras utilizou softwares especializados. Foram encontrados quatro tipos de softwares de narrativas interativas entre as produções brasileiras: Korsakow, Klynt, Managana, ThingLink. O software Korsakow, inicialmente gratuito e opensource, foi criado pelos artistas/pesquisadores Florian Thalhofer e Matt Soar. O software, que tem versão em português, foi utilizado, por exemplo, na criação do webdocumentário brasileiro Se eu demorar uns meses (2014), de Giovanni Francischelli e Lívia Perez. Na apresentação do webdocumentário há uma referência direta ao software Korsakow: "Se eu demorar uns meses é um K-Filme, ou seja, um filme desenvolvido em Korsakow. Tendo como fundamentos a interatividade e a não linearidade, K-filmes são uma superação da limitação técnica de filmes anteriores a era do computador". 
Pelo Laboratório de Desenvolvimento Social (LTDS) da COPPE, o projeto Roteiro dos Fortes, dirigido por André Paz, utilizou o Klynt para fazer um webdocumentário sobre as diferentes relações das fortificações no Rio de Janeiro com as comunidades de seus entornos, chamado Nós dos Fortes. Diferente do Korsakow, o Klynt é um software pago, mas com mais recursos gráficos. Esses softwares têm sido ferramentas bastante úteis na realização de oficinas de webdocumentário. No 26 Festival Internacional de Curtas de São Paulo, em agosto de 2015, André Paz e Julia Salles realizaram, por exemplo, uma oficina de webdocumentário fruto da parceria do BUG404 com a Associação Cultural Kinoforum, que utilizou o Klynt e possibilitou que, em cinco dias de oficina, fosse realizado um webdocumentário chamado Pedalei até aqui?, sobre cicloativismo na cidade de São Paulo. Essas atividades só puderam ser realizadas em função de um software que dispensa a atuação de um programador profissional.

No terceiro grupo de variáveis, foi observada uma grande diversidade no campo de atividade dos realizadores de narrativas interativas não ficcionais. Esta diversidade pode ser um fator que dificulte a organização de redes de informação, assim como de curso regulares, no campo das narrativas interativas não ficcionais. Ela demonstra uma forte tendência das narrativas interativas a serem interdisciplinares, trabalhando com elementos do audiovisual, do grafismo, da informática e outros campos, dependendo do projeto.

Uma das principais áreas de desenvolvimento das narrativas interativas não ficcionais é o jornalismo. Como observou Sandra Gaudenzi em entrevista ao documentário interativo Caixa-Preta (Paz e Salles, [entrevista em vídeo] 2015: sem página), o consumo de jornais se faz cada vez mais no formato digital, os jornalistas estão precisando se adaptar a este novo suporte que utiliza diferentes mídias e não apenas textos e ilustrações. Nós já havíamos notado acima que esta tendência também se verifica no cenário internacional, onde jornais e televisões como The Guardian, Le 
Monde, TV5, Arte e Radio Canada, vêm produzindo um grande numero de webdocumentários. No Brasil, a produção interativa jornalística se aproxima mais da infografia do que das narrativas interativas, como nos exemplos Líquido e Incerto e A Batalha de Belo Monte, ambos da Folha de S. Paulo. No entanto, algumas produções para a internet se destacam no campo das narrativas interativas do jornalismo brasileiro, como A História de Mim e Filhos da dor, publicados em 2014 e 2015 respectivamente, pelo Jornal do Comércio.

Muitos estudantes de jornalismo têm escolhido recentemente o formato do webdocumentário para apresentar seus trabalhos de conclusão de curso (TCC). É o caso, por exemplo de Até breve, Haiti! (UnB), Transgressões (PUC-PR), Um novo olhar - abuso sexual infantil e pedofilia (PUC-SP). Estudantes de disciplinas ligadas à área de informática também produziram TCC na forma de webdocumentários, como no caso de For Game, de alunos do Curso Sistemas e Mídias Digitais, da Universidade Federal do Ceará.

Alguns realizadores de narrativas interativas não ficcionais vêm da prática do documentário audiovisual. É o caso por exemplo de Giovanni Francischelli, diretor de Webdoc Graffitti e Se eu demorar uns meses, e sócio fundador da produtora Doctela, uma das poucas produtoras brasileiras a constituir uma seção especializada em webdocumentários. Campos de atuação mais ligados à tecnologia também foram observados entre os realizadores de narrativas interativas, principalmente nas áreas ligadas à web e às TIC (tecnologias de informação e comunicação). A produtora MobContent é um exemplo de pioneirismo no desenvolvimento de narrativas interativas com forte apelo tecnológico. Como é colocado em seu site: “A natureza dos projetos desenvolvidos por nós tem, em seu DNA, a exploração de novas tecnologias como Realidade Aumentada, Captura de Movimentos e Robótica. Com o uso dessas ferramentas o aspecto narrativo é potencializado.” (Mob Content, Sobre, 2014 [site web]: sem página) . 
Enfim, gostaríamos de mencionar outros dois campos de atuação observados entre realizadores de narrativas interativas não ficcionais brasileiras: a pesquisa acadêmica e as artes plásticas. Este último já foi abordado no contexto das instalações interativas. Quanto à pesquisa acadêmica, além dos trabalhos de estudantes (TCC), o webdocumentário Nós dos Fortes, realizado pelo LTDS (Laboratório de Tecnologia e Desenvolvimento Social da Coppe/UFRJ), aponta para o potencial já demonstrado da interseção do webdocumentário com projetos de pesquisa e extensão nos cenários internacionais dos pólos criativos destacados, sobretudo no Canadá. O LTDS trabalha há mais de vinte anos com projetos de pesquisa-ação e, nos últimos anos, tem incorporado as narrativas interativas como ferramenta. É este o caso do projeto Ilha Grande: cada praia, uma ilha; cada ilha, uma história, que conta através de um webdocumentário histórias da Ilha Grande, no litoral sul do estado do Rio de Janeiro. Esse webdocumentário é também um Guia de Turismo Comunitário, que visa empoderar as iniciativas de turismo de base comunitária na ilha, como pousadas, restaurantes, campings ou mesmo residências de nativos que hospedam turistas em casa.

O último grupo de variáveis observa a experiência do interator. Considerando a postura da estética relacional da qual parte esta pesquisa, o modo de interatividade e o tipo de experiência estética propostos pelo realizador são aspectos que determinam as características da própria obra, pois esta se constrói na relação com o público. Assim, o trabalho de Gaudenzi (2013a) sobre os modos de interatividade mencionado acima e a estética relacional de Bourriaud (2009) nos oferecem alguns parâmetros para avaliarmos os dados do cenário brasileiro. Nós constatamos que a experiência de interatividade proposta pelas narrativas estudadas é principalmente a hipertextualidade. Outras formas de interatividade ainda são pouco exploradas no cenário brasileiro. O campo das narrativas jornalísticas contribui em grande medida ao desenvolvimento deste tipo de 
experiência interativa. No entanto, algumas exceções podem ser destacadas. O modo de interatividade experiencial (geolocalizado) é utilizado no aplicativo Som dos Sinos. O modo participativo, por sua vez, pode ser encontrado no trabalho de André Deak, Mapas afetivos. Neste webdocumentário, o interator pode enviar depoimentos em vídeo sobre sua relação com lugares da cidade de São Paulo. O projeto, realizado pela Liquid Media Laab, se define com "uma narrativa transmídia que conta histórias de pessoas a partir dos lugares." (Mapas afetivos, 2014 [site web]: sem página).

Essas primeiras aproximações ao cenário brasileiro de narrativas interativas não ficcionais e digitais evidenciam que ainda não se estabeleceram redes sólidas de realizadores e críticos do campo do documentário interativo. A incipiente produção de obras, conteúdo critico e pesquisa acadêmica no campo das narrativas interativas brasileiras ainda não encontrou respaldo em centros de estudo, festivais, instituições de produção e redes de informação (online e offline). Faz-se necessário não só um trabalho de comunicação entre os principais atores deste campo (realizadores, pesquisadores, críticos e público), como de divulgação das referências internacionais, tanto no sentido das obras, processos produtivos, procedimentos e estratégias, como das discussões e propostas estéticas. Trata-se de construir um terreno fértil que agregue inovações tecnológicas e experimentações estéticas e de linguagem, o que requer a cooperação entre realizadores e centros de pesquisa, base de dados, festivais e canais de informação a respeito desse campo incipiente e promissor. Essa necessidade é ainda mais aguda neste momento inicial, onde cada projeto precisa conceber a especificidade de seus dispositivos de interação, pois ainda não há um gênero ou processo produtivo estabelecido, que possa simplesmente ser replicado. 


\section{Referências bibliográficas}

AMORIM, Pedro e BALDI, Vania (2013), "Ética e estética da representação no Web-documentário" in Cultura midiatica 6(11). Disponível em: http://www.ies.ufpb.br/ojs/index.php/cm/article/view/17546/10066.

ARANTES, Priscila (2005), “Arte e mídia no Brasil: perspectivas da estética digital" in ARS, 3(6), pp. 53-65.

BERNARDES, Fernanda (2014), “Webdocumentário e interação: compreendendo o papel do usuário em Fort McMoney" in Anais de 10 Interprograma de mestrados, São Paulo, Faculdade Casper Libero.

BOLE, Nicolas e MAL Cédric (2014), Le webdoc existe-t-il?, Paris: Le Blog Documentaire éditions.

BOURRIAUD, Nicolas (2009), Estética relacional, São Paulo: Martins Fontes.

CLARK,Tracy Boyer Clark (2011), Behind the scenes of NFB's One millionth tower. Disponível em:

http://innovativeinteractivity.com/2011/11/22/behind-the-scenesof-nfbs-one-millionth-tower/.

DESROCHE, Henri (2006), "Pesquisa-ação: dos projetos de autores aos projetos de atores e vice-versa" in THIOLLENT, Michel (org.). Pesquisa-ação e projeto cooperativo na perspectiva de Henri Desroche. São Carlos: EdUFSCar, pp. 33-68.

FLUSSER, Vilém (2002a), Filosofia da Caixa Preta: ensaios para uma futura filosofia da fotografia, Rio de Janeiro: Relume Dumará. (2002b), Writings, Minneapolis, MN: University of Minnesota Press. 
(2003), The Freedom of the Migrant: objections to nationalism, Urbana and Chicago: University of Illinois Press. (2007), O Mundo codificado: para uma filosofia do design e da comunicação, São Paulo: Cosac Naif.

(2008), O universo das imagens técnicas: elogio da superficialidade, São Paulo: Annablume.

GAGNON, Yves-C. (2011), L'étude de cas comme méthode de recherche, Québec: Presses de l'Université du Québec.

GALlOWAY, Dayna; MCALPINE, Kenneth B. e HARRIS, Paul. (2007), "From Michael Moore to JFK Reloaded: Towards a working model of interactive documentary" in Journal of Media Practice, 8(3), pp. 325-339.

GAUNDENZI, Sandra (2013a), The Living Documentary: from representing reality to co-creating reality in digital interactive documentary. Tese de Doutorado, Goldsmiths College, University of London. (2013b), "The interactive documentary as a living documentary" in Revista Doc On-line, n. 14, pp. 9-31. Disponível em: http://www.doc.ubi.pt/.

GIFREU, Arnau C. (2014), "El Documental interactivo en la estrategia de la multidifusión digital: evaluación del estado del arte en relación con la temática, las plataformas y la experiencia del usuario" in Revista TELOS (Cuadernos de Comunicación e Innovación), pp.1-11. (2013), El Documental Interactivo: evolución, caracterización y perspectivas de desarrollo. Barcelona: UOCPress.

(2010a), The interactive multimedia documentary: a proposed analysis model. Tese de Doutorado, Department of Communication, Pompeu Fabra University. 
(2010b), El Documental Interactivo: una propuesta de modelo de análisys. Proposta paraTese de Doutorado, Department of Communication, Pompeu Fabra University.

LEVIN, Tatiana (2013), “Do Documentário ao Webdoc - questões em jogo num cenário interativo" in Revista Doc On-line, n. 14, pp. 71-92. Disponível em: http://www.doc.ubi.pt/.

MAIA, Ravena Sena; FREIRE, Fernanda M. P. e HILDEBRAND, Hermes R. (2009), "Letramento Digital em Foco: Design de Interação na Construção de um Web-documentário", in Anais de XIV Congresso de Ciências da Comunicação na Região Sudeste, Rio de Janeiro, Intercom - Sociedade Brasileira de Estudos Interdisciplinares da Comunicação.

MASSUMI, Brian (2008), "The Thinking-feeling of What Happens: a semblance of a conversation", Inflexions 1.1 "How is researchcreation?”, Université de Montréal, Montréal. Disponível em: www.inflexions.org

OBSERVATOIRE DU DOCUMENTAIRE (2013), Documentary and New Digital Platforms: an ecosystem in transition, A Documentary Network's Study, Montréal.

PASSOS, E.; KASTRUP, V.; ESCÓSSIA, L. (org.) (2009). Pistas do método da cartografia: pesquisa-intervenção e produção de subjetividade. Porto Alegre: Sulina.

PASSOS, E; KASTRUP, V.; TEDESCO, S. (org.) (2014), Pistas do método da cartografia 2: a experiência da pesquisa e o plano comum, Porto Alegre: Sulina

PAQUIN, Louis-Claude (2006), Comprendre les médias interactifs, Québec: Isabelle Quentin Éditeur. (2015), Méthodologie de la recherche création. Disponível em http://lcpaquin.com/methoRC/. 
PAZ, André F. e KLINGER, Diana (2011), "Refracción fragmentada. Personajes, vivencias y dispositivos en las realidades de los documentales contemporáneos en Brasil" in Revista Inti. University of Conneticut, n. 60.

PAZ, André F. e SALLES, Julia (2015), Entrevista com Sandra Gaudenzi, Caixa-Preta [entrevista em vídeo]. Disponível em: http://bug404.net/caixa-preta/.

(2013), "Dispositivo, acaso e criatividade: por uma estética relacional do webdocumentário" in Revista Doc On-line, n. 14, Agosto de 2013, pp 33-69.

Disponível em: http://www.doc.ubi.pt/.

PEREIRA, Luiz P. F. e MORAES, Isabela C. R. (2013), "Cinema Documentário, novos meios e formas: sobre os deslocamentos provocados pelo webdocumentário Out of My Window”. Revista Doc On-line, n. 14, Agosto de 2013. Disponível em: http://www.doc.ubi.pt/.

RENÓ, Denis (2013), "Diversidade de modelos narrativos para Documentários transmídia" in Revista Doc On-line, n. 14, Agosto de 2013. Disponível em: http://www.doc.ubi.pt/. (2006), “Ciberdocumentarismo: tópicos para uma nova produção audiovisual” in Ciências e Cognição, 7, pp.128-134.

RIBAS, Beatriz (2003), "Contribuições para uma definição do conceito de Web Documentário" in MACHADO, Elias; PALACIOS, Marcos, Modelos de Jornalismo Digital, Salvador: Calandra. Disponível em: http://docplayer.com.br/4491679-Contribuicoes-para-umadefinicao-do-conceito-de-web-documentario.html

RODRIGUES, Pedro F. V. A. (2013), Processos narrativos e autoria em documentário interativo, Dissertação de Mestrado, Departamento de Comunicação e Arte, Universidade de Aveiro. 
SACRINI, Marcelo (2004), "Perspectivas do gênero documentário pela apropriação de elementos de linguagem da TV Digital Interativa", in BOCC-Biblioteca on-line de Ciências da Comunicação. Disponível em: http://www.bocc.ubi.pt/pag/sacrini-marcelo-docdigital-interativo.pdf

SANGIOVANNI, Ricardo F. e ROCHA, Vitor B. (2007), Bolívia: mídia, política e sociedade: Roteiro para um web-documentário, Monografia de conclusão de curso Comunicação Social, com habilitação em Jornalismo, Faculdade de Comunicação, Salvador: Universidade Federal da Bahia.

SPINELLI, Egle M. (2013), "Webdocumentário: implicações dos recursos tecnológicos digitais na composição estrutural e narrativa do formato" in Revista Comunicação Midiática, 8(2), pp. 169-183.

VISSOTTO, Izabel (2015), "Memória e interface no web documentário Le Défi Des Bâtisseur: o irrompimento do presente expandido" in Tematica, 11(1), pp. 99-111.

\section{Referências de projetos}

\section{Cenário mundial:}

18 days in Egypt

http://18daysinegypt.com/

Capturing Reality

http://films.nfb.ca/capturing-reality/

Ceci n'est pas embres

www.embres.ca

Do not track

https://donottrack-doc.com/en/ 
Firestorm

http://www.theguardian.com/world/interactive/2013/may/26/firestor m-bushfire-dunalley-holmes-family

Fort McMoney

WWW.fortmcmoney.com

Highrise

http://highrise.nfb.ca/shorthistory/

Hollow

www.hollowdocumentary.com

La Vie à Sac

http://www.lavieasac.com/

Le défi des bâtisseurs

www. cathedrale.arte.tv

Offshore

www.offshore-interactive.com

One millionth tower

http://highrise.nfb.ca/onemillionthtower/

Out my window

http://interactive.nfb.ca/\#/outmywindow

Prison Valley

www.prisonvalley.arte.tv

Remembrance of Things to Understand

www. webdoc.chrismarker.ca

Short history of HighRise

http://highrise.nfb.ca/tag/a-short-history-of-the-highrise/

Walking the edit

www.walking-the-edit.net

Welcome to Pinepoint

http://pinepoint.nfb.ca/\#/pinepoint 


\section{Cenário brasileiro:}

\section{6 bilhões de outros}

http://www.lucasbambozzi.net/projetosprojects/6-bilhoes-de-outros

\section{A Batalha de Belo Monte}

http://arte.folha.uol.com.br/especiais/2013/12/16/belo-monte/

A história de mim

http://especiais.jconline.ne10.uol.com.br/ahistoriademim/

Até breve, Haiti!

http://www.atebrevehaiti.com/\#capitulo1

Fernando Velazquez

http://www.blogart.com/BIO

Filhos da dor

http://especiais.jconline.ne10.uol.com.br/filhos-da-dor/

Filhos do tremor

http://www.webdocumentario.com.br/haiti/index.html

\section{For Game}

http://www2.virtual.ufc.br/forgame/

Ilha Grande: cada praia, uma ilha; cada ilha, uma estória

www.ilhagrande.website

Liquido e incerto

http://arte.folha.uol.com.br/ambiente/2014/09/15/crise-da-agua/

Mapas afetivos

http://www.mapasafetivos.com.br/

Nós dos Fortes

http://nosdoforte.net/

Pedalei até aqui?

www.bug404.net/pedalei 
Brasil, mostra a sua cara ...

Polissonorum

http://www.polissonorum.com/

Rio de Janeiro - Autorretrato

http://www.riodejaneiroautorretrato.com.br

Se eu demorar uns meses

http://doctela.com.br/se-eu-demorar-uns-meses/

Som dos sinos

http://www.somdossinos.com.br/\#!documentariointerativo/

O tempo não recuperado

http://www.lucasbambozzi.net/projetosprojects/o-tempo-nao-

recuperado

Transgressões

http://www.transgressoes.com.br/

Um novo olhar - Abuso Sexual Infantil e Pedofilia

http://www.webdocnovoolhar.com.br/cgi-sys/suspendedpage.cgi

Your life, our movie

http://www.blogart.com/Your-life-our-movie

Webdoc Graffiti

http://www.webdocgraffiti.com.br/videos 


\title{
INTERATIVIDADE DIGITAL, AUDIÊNCIA E WEBDOCUMENTÁRIOS
}

\author{
Paulo Eduardo Cajazeira; José Jullian Gomes de Souza*
}

Resumo: O presente texto pertence a uma investigação em que busca-se a compreensão da interatividade e da audiência, tendo como ponto de partida o desenvolvimento de novos produtos audiovisuais jornalísticos. Os webdocumentários procuram em sua estrutura uma nova tendência mais participativa, e sendo assim, analisar e compreender este conteúdo na Web possibilita adentrar neste novo cenário advindo com a convergência digital das mídias.

Palavras-chave: Interatividade; webséries documentais; INFOtenimento; audiovisual; convergência

Resumen: Este texto pertenece a una investigación que pretende entender la interactividad y la audiencia, tomando como punto de partida el desarrollo de nuevos productos audiovisuales periodísticos. Los webdocumentales buscan en su estructura una nueva tendencia más participativa, y, por ello, analizar y comprender este contenido en la Web permite adentrarse en este nuevo escenario surgido con la convergencia digital de los medios.

Palabras clave: interactividad, webseries documentales, INFOtenimiento, audiovisual, convergencia.

Abstract: This text is part of an investigation that seeks to understand the interactivity and the audience, taking as a starting point the development of new journalistic audiovisual products. The webdocumentaies seek in its structure a more participatory trend. If so, to analyze and understand this content on the Web enables us to enter in a new scenario that has been arising with digital media convergence.

Keywords: interactivity, documentary webseries, INFOtainment, audiovisual convergence.

Résumé: Ce texte appartient à une enquête qui cherche à comprendre l'interactivité et le public, en prenant comme point de départ le développement de nouveaux produits audiovisuels journalistiques. Les webdocumentários cherchent dans sa structure une nouvelle tendance plus participative, et s'il en va ainsi, analyser et comprendre ce

\footnotetext{
* Paulo Eduardo Cajazeira: Doutor em Comunicação e Semiótica (PUC-SP), Pós-doutor em Ciências da Comunicação - UBI/Portugal. Professor do Curso de Jornalismo do Instituto Interdisciplinar de Sociedade, Cultura e Arte da Universidade Federal do Cariri, Brasil. Grupo de Pesquisa: Centro de Estudos e Pesquisa em Jornalismo (UFCA, CNPq, Brasil). 63048-080, Juazeiro do Norte, Brasil. E-mail: paulo.cajazeira@ufca.edu.br

José Jullian Gomes de Souza: José Jullian Gomes de Souza: Graduando em Jornalismo, Curso de Jornalismo do Instituto Interdisciplinar de Sociedade, Cultura e Arte da Universidade Federal do Cariri, Brasil; Grupo de Pesquisa:Centro de Estudos e Pesquisa em Jornalismo (CEPEJor, UFCA, CNPq). 63048-080, Juazeiro do Norte, Brasil.

E-mail: jullianjose64@gmail.com
}

Submissão do artigo: 30 de maio de 2015. Notificação de aceitação: 03 de setembro de 2015. 
contenu sur le Web permettrait de pénétrer ce nouveau scénario résultant de la convergence des médias numériques.

Mots-clés: interactivité, websérie documentaire, INFOdivertissement, la convergence de l'audiovisuel.

\section{Introdução}

Com o desenvolvimento das novas tecnologias da informação e da comunicação, novos formatos audiovisuais surgem como um modelo de apropriação e forma de permear toda a superfície dessas produções, em paralelo com os novos meios de comunicação. O advento da Internet, no campo da informação e entretenimento, possibilitou diversas inovações tecnológicas, que propiciaram a criação e o desenvolvimento de um novo seguimento no campo audiovisual: os webdocumentários ou webséries documentais. A fórmula conhecida de narratividade do documentário mais a junção das ferramentas da Web permitiram a hibridação entre o tradicional e contemporâneo, e assim, tornou-se possível visualizarmos a produção de um conteúdo audiovisual que ultrapassou as barreiras do cinema, da televisão e adentrou à Internet com características específicas: a narrativa hipertextual, multimídia e a interatividade permanente com o usuário.

A interatividade e a interação são conceitos importantes e que vem sendo muito explorados e discutidos por teóricos ao longo dos anos, nos estudos em comunicação. Na Era Digital essa relação é indispensável para que possamos compreender como se relacionam com a audiência. Alex Primo (2007: 19) na obra “A interação mediada por computador" traz um panorama sobre essa relação de interatividade e interação que está sendo difusa no meio digital, pois "o desenvolvimento dos meios de comunicação veio oferecer novos formatos de ação e novos tipos de relacionamento sociais". 
A interatividade, em conjunto com o hipertexto, a multimídia e a instantaneidade na convergência digital transformam não apenas a produção audiovisual disponibilizada na Internet, mas na própria apropriação dos novos conteúdos por usuários ou web- espectadores, como define Guto Aeraphe (2013: 11). Esses webespectadores assistem a uma crescente modificação nos formatos audiovisuais, com a expansão da Web. A pesquisadora Raquel RitterLonghi (2014: 70) explica que os formatos noticiosos no Ciberjornalismo estão em renovação constante, o que desafia classificações tradicionais estabelecidas. Isso nos possibilita a denominar ou classificar essa nova produção como uma websérie documental, com características próprias e impactadas pelo elemento da interatividade, que se situa na reflexão atual da Internet e dos meios de comunicação em convergência.

O webdocumentário, nas palavras de Oliver Crou (2010: 18), é um documentário cuja concepção e realização são feitas para a Web e por ela difundida. O modo de narração dos webdocumentários é concebido de maneira que o leitor/espectador navegue pela interface de forma totalmente delinearizada. É ele quem conceberá de maneira única seu percurso no webdocumentário. São esses percursos que denominamos de hipertextualidade que visamos delinear nessas novas produções e que trataremos aqui como webséries documentais. Desconstruir as peças para que possamos entendê-la isolada e conjuntamente, a fim de perceber como as webséries documentais são apropriadas pelo jornalismo e se utilizam dessa narrativa hipertextual, multimídia e interativa como meio de alavancar a sua audiência e atingir novos públicos nesse novo cenário midiático.

Inicialmente com um caráter de entretenimento, as webséries buscavam estabelecer não apenas uma nova linguagem, mas outra relação de produção, consumo, circulação e interação com o espectador que se encontra no ambiente virtual, e que não se encaixa no padrão de receptor passivo que recebe o conteúdo sem algum questionamento, como as mídias 
tradicionais o percebem. Contendo características próprias de funcionalidade, como narrativa, formato, duração de episódio e ambiente de circulação, as webséries provocam uma reflexão sobre o futuro que o audiovisual percorrerá nos próximos anos, principalmente no campo das ciências da comunicação e em sua abertura nos novos formatos jornalísticos.

O processo de interação entre o conteúdo das webséries e os espectadores, surge com a proposta de narrativa transmídia, com a centralização da figura do computador mediando a interação entre o universo digital e os usuários desse novo meio de comunicação. Produtores e espectadores passam a ter um funcionamento diferenciado, uma vez que o receptor - considerado por muito tempo como passivo - passou a intervir e a reivindicar uma maior participação e interação como destaca Henry Jenkins (2009: 32) já que a circulação do conteúdo na Web, hoje, depende fortemente de uma participação ativa. Esse paradigma da convergência, que modifica a percepção dos formatos jornalísticos, da interação com os novos meios e, principalmente, do papel que o espectador possui na mídia atual, tem sido utilizado pelo jornalismo como uma das tendências em produzir novos conteúdos mais dinâmicos e interativos para esse público.

As webséries tinham em sua criação inicial um viés fortemente de entretenimento, e com a apropriação jornalística passam por uma (re) configuração com a convergência e que se desenvolve o webdocumentário (ou websérie documental, como pretendo denominar). Há uma discussão no campo acadêmico sobre a conceituação e denominação desses novos formatos oriundos com à Internet, e que devido a "variedade de estilos e formatos desses projetos não facilita a tentativa de conceituar o que é um webdocumentário" (Bauer, 2011: 91).

Não apenas os conceitos acima remodelam a produção desse novo conteúdo audiovisual elaborado especificamente para a Web, mas também a relação entre informação (jornalismo) e diversão (entretenimento) que estes 
produtos possuem. Sob o conceito de INFOtenimento e interatividade, as webséries documentais perpassam a atual fase dos documentários, e nos coloca em uma posição defronte as inovações audiovisuais no campo da comunicação que buscaremos compreender nesse cenário emergente de múltiplos produtos digitais e na sua relação estabelecida com o espectador na análise exploratória e de conteúdo, tendo como base o aspecto da audiência.

\section{Revisitando os aspectos teóricos do estudo}

Alejandro Rost (2014: 52) discute a interatividade como sendo um dos conceitos chaves para o jornalismo em época de convergência das mídias. O autor compreende a interatividade para além do jornalismo online, mas como algo que está presente no cotidiano dos jornalistas e da sociedade do século XXI:“A interatividade é um conceito ponte entre o meio e os leitores/utilizadores, porque permite abordar esse espaço de relação entre ambas as partes e analisar as diferentes instâncias de seleção, intervenção e participação nos conteúdos do meio" (Jost, 2014: 53). Essa proposta de interatividade vem acompanhada, principalmente, por outros três conceitos: a hipertextualidade, instantaneidade e a multimedialidade.

Na coletânea de textos organizada pelo pesquisador João Canavilhas (2014: 1-2) com a colaboração de diversos autores sobre determinadas características do webjornalismo, três foram discutidas e problematizadas por João Canavilhas (a hipertextualidade), Paul Bradshaw (a instantaneidade) e Ramón Salaverría (a multimedialidade). Esses conceitos nos ajudam a compreender o universo complexo desses novos fenômenos audiovisuais das webséries documentais. Por hipertextualidade, Canavilhas (2014: 3) explica as novas arquiteturas noticiosas da Web, a partir de três fatores: os históricos, técnicos e econômicos. A hipertextualidade possui papel central no processo de interatividade entre o conteúdo jornalístico e o 
espectador que se encontra na Internet. $\mathrm{O}$ webjornalismo fundamenta-se na utilização do hipertexto criando uma nova narrativa não sequencial e permitindo que o webespectador crie sua própria narrativa, a partir das possibilidades de navegação.

A instantaneidade é outro fator que vem sendo difundido na rede e impactando no modo das produções audiovisuais jornalísticas para a Web. As webséries documentais possuem em sua estrutura esse caráter instantâneo, que é explicado por Paul Bradsahw (2014: 111) como relativo a velocidade intrínseca ao jornalismo digital e que denomina como imediaticidade da informação. E que carrega consigo as questões relacionadas a chegada da nova mídia e dos novos suportes. A propagação e $\mathrm{o}$ alcance que possuem modificam o consumo e a redistribuição do produto audiovisual na era da Internet. A instantaneidade funciona como um processo inerente da digitalização que o pesquisador Marcos José Pereira (2011: 58) descreve como sendo a partir da informatização dos sistemas e que a comunicação perpassa essas novas formas de trabalho, e passa a funcionar com uma maior rapidez na transmissão de informação.

A informatização do sistema foi um processo fundamental para que o computador se tornasse definitivamente uma ferramenta de interação trabalhando com as várias mídias integradas e os recursos, como imagens, sons, vídeos e filmes interagindo dinamicamente, como explica Pereira (2011: 59). Essa interação nos leva diretamente ao conceito de sistema multimídia, entendido pelo autor como a possibilidade de manipulação dessas mídias no ambiente digital, propiciado pelo computador.

O pesquisador Ramón Salaverría (2014: 25) trata da multimídia analisando-a em um contexto histórico e como a sua evolução processa-se na contemporaneidade. Essa combinação de sons, textos e imagens explicada por Pereira (2011: 59) é compreendida por Salaverría (2014: 29) como uma definição que não dá conta da complexidade do conceito de 
multimídia, pois seria um reducionismo das possibilidades inerente a esse novo sistema.

A multimídia encontra-se ancorada, em nossa sociedade, principalmente com a revolução da Era da Convergência e da Web 2.0. A Internet entra em despontamento nas últimas décadas do século XXI, num cenário predominantemente marcado pelo fenômeno televisivo. A Web, como é denominada pela maioria dos usuários e pesquisadores, perpassa diversos estágios e (re) configuração de suas funções, criações, desenvolvimentos e potencialidades desse novo meio de comunicação que transpassa fronteiras, e que foi denominada de Web 2.0. Aglomerando as multiplataformas, as possibilidades permitidas a partir de cada um dos meios de comunicação tradicional e unificando-as em um único meio difusor, o digital, a Web 2.0 integra um sistema em conjunto com a cultura da convergência.

Com o advento da difusão da Internet e da Web 2.0 em larga escala na sociedade contemporânea, novos conceitos, nomenclaturas e modos de organização, no universo da comunicação, são fundamentados para que seja possível abarcar uma infinidade de transformações e movimentos em torno da cultura digital. Problematizando as questões pertinentes aos novos conteúdos, as empresas de comunicação, na relação entre produtores e consumidores e formatos midiáticos é um dos problemas pesquisado por Henry Jenkins (2009: 30) que traz em seu livro "Cultura da Convergência" um panorama atual sobre o status dos meios de comunicação tradicionais em diálogo com a revolução advinda do meio de comunicação digital e os novos consumidores.

"Bem-vindo à cultura da convergência, onde as velhas e as novas mídias colidem, onde mídia corporativa e mídia alternativa se cruzam, onde o poder do produtor de mídia e o poder do consumidor interagem de maneiras imprevisíveis" (Jenkins, 2009: 29). Assim, somos apresentados ao mundo convergente que o autor descreve em sua obra e que define como: 
Um fluxo de conteúdos através de múltiplas plataformas de mídia, à cooperação entre múltiplos mercados midiáticos e ao comportamento migratório dos públicos dos meios de comunicação, que vão a quase qualquer parte em busca das experiências de entretenimento que desejam (Jenkins, 2009: 29).

Não sendo um conceito tão recente, a convergência foi discutida por Ithiel de Sola Pool, um dos profetas dos meios de comunicação, e em seu livro "Technologies of freedom" (1983). O autor foi um dos primeiros a delinear o conceito de convergência. Mas foi a partir da discussão permeada por Henry Jenkins, que o conceito tomou as suas devidas proporções e problematizações que se encontram no cenário atual do jornalismo, entretenimento e produções audiovisuais no ciberespaço.

Com o surgimento dos novos meios de comunicação criou-se uma expectativa sobre o fim dos antigos meios. Porém, o que se observa é uma integração entre esses diferentes meios midiáticos, em que de um lado temos a manutenção dos antigos meios, e de outro, as novas possibilidades de produção e circulação de conteúdos fragmentados e dispersos na Internet baseado na interatividade. Na era da convergência:

As fusões multimídia e as concentrações de empresas na produção de cultura correspondem, no consumo cultural, à integração de rádio, televisão, música, notícias, livros, revistas e Internet. As fusões multimídia e as concentrações de empresas na produção de cultura correspondem, no consumo cultural, à integração de rádio, televisão, música, notícias, livros, revistas e Internet. (Canclini, 2008: 33).

Essa interação e integração entre as velhas e novas mídias estão modificando não somente o olhar das grandes empresas de comunicação e da produção de conteúdo para a plataforma digital, mas, principalmente, o olhar do espectador/usuário que adquire um novo status com a introdução dessas tecnologias e da convergência das mídias. O espectador passa, neste 
atual momento, a compor um dos elementos indispensáveis para o entendimento mercadológico e participativo da comunicação. A inserção do espectador com uma lógica mais participativa é um dos principais fatores que alteraram a sociedade tecnológica contemporânea. Mas é importante esclarecer é que os meios de comunicação não estão sendo substituídos, mas suas funções estão se transformando, uma vez que:

A convergência das mídias é mais do que apenas uma mudança tecnológica. A convergência altera a relação entre tecnologias existentes, indústrias, mercados, gêneros e públicos. A convergência altera a lógica pela qual a indústria midiática opera e pela qual os consumidores processam a notícia e o entretenimento. (Jenkins, 2009: 43).

A convergência é vista como um processo, um impacto profundo no modo como a sociedade consome e como as empresas produzem os conteúdos para os meios de comunicação. Ela pode ocorrer de várias maneiras, mas a principal como explica Jenkins (2009: 45) é na tomada de controle das mídias pelos consumidores. A ideia de controle pelos consumidores decorre da apropriação que estes atores têm de uma conscientização do seu papel nessa reconfiguração das mídias. O sentimento de coletividade, expresso na ideia de Pierre Lévy (2014: 29) da inteligência coletiva, em que o saber fragmentado entre os participantes de uma comunidade é compartilhado e distribuído entre os seus membros, como uma forma de fazer emergir essa cultura mais participativa visualizada por Jenkins, afinal, “a expressão cultura participativa contrasta com noções mais antigas sobre a passividade dos espectadores dos meios de comunicação" (Jenkins, 2009: 30).

$\mathrm{Na}$ cultura da convergência, a interatividade é uma palavra-chave para que seja possível compreender os novos paradigmas que a sociedade digital tem sido constantemente transformada. As produções em audiovisual encontram-se em um momento de renovação com a difusão das ferramentas 
de produção, edição e participação do espectador/usuário. Se a televisão adaptou o audiovisual para o seu suporte advindo do modelo cinematográfico, na era da Internet, essas produções são desafiadas a incorporaram-se em meio a uma infinidade de variações de formatos.

A narrativa consolidada pelo cinema e pela televisão busca adaptarse para as telas da Web, sob as novas diretrizes ditadas pela convergência e pela cultura participativa numa época marcada pelo hibridismo. Essa nova audiovisualidade que está imergindo é, segundo a pesquisadora Miriam Rossini (2009: 14), uma hibridação entre o cinema e a televisão que não se dá, agora, com o tempo atual, mas foi uma construção ao longo do tempo. Uma construção que passou por uma série de processos e permeou a mídia digital com sua forte hipertextualidade em uma narrativa transmídia. E, sendo assim, o estudo dessa apropriação se faz necessário para que seja possível a compreensão da nova produção audiovisual jornalística (a websérie documental) na perspectiva dos conceitos acima e agregando-se a ele o conceito de INFOtenimento nesse produto audiovisual digital.

Essa audiovisualidade tem sido percebida pelas corporações jornalísticas e utilizadas para atrair novos públicos e novos formatos noticiosos, com a interrelação entre informação e entretenimento explicada por Dejavite (2006: 71) como INFOtenimento: um jornalismo que ao mesmo tempo traz uma prestação de serviço e propicia aos leitores informação com entretenimento. O INFOtenimento é o espaço destinado às matérias que visam informar e divertir como, por exemplo, os assuntos sobre estilo de vida, as fofocas e as notícias de interesse humano - os quais atraem, sim, o público. Mas na sua aplicação as webséries, o conceito de INFOtenimento colabora para que a proposta de uma narrativa hipertextual e interativa se torne o ponto de discussão entre o jornalismo e o entretenimento na era da convergência.

O termo INFOtenimento surgiu na década de 1980, quando acadêmicos da área da comunicação, passam a refletir sobre a prestação de 
serviço e ao mesmo tempo que oferece divertimento ao consumidor. Deuze (2001: 12) explica que o conceito de INFOtenimento no jornalismo está dividido em duas categorias: [1] no aumento de elementos de entretenimento em gêneros de notícias informativas e [2] na elevação e no estabelecimento de gêneros de INFOtenimento existentes atualmente. É nesse segundo ponto que trazemos a problematização das webséries documentais: a sua relação entre informação e entretenimento a partir dessa linguagem hipertextual e transmidiática. E que buscaremos compreender como essa classificação se encontra na contemporaneidade dialogando com a websérie documental e o seu conteúdo.

A audiência, em termos gerais é a medição da satisfação do público em relação, por exemplo, a um programa de TV, um filme, um jogo ou a algo que se relaciona com o hábito de consumo, principalmente midiático. O pesquisador Daniel Dayan (2006: 45) explica que a audiência se encontra em uma posição complexa, pois o caráter da audiência reside no que resta do público após o seu estabelecimento. Em linhas gerais é possível afirmar que o público representa um meio, e esse meio poderá determinar o nível de audiência que determinado produto terá ou não, como ocorre no caso das webséries, em que o público virtual será o balizamento para a sua medição.

A relação entre o público e audiência é uma relação instável e passiva de movimentações a todo o instante. Com essas novas transformações que acompanhamos e com o crescente aumento das mídias e suas ferramentas de alcance, a audiência enfrenta modificações em sua estrutura. A pesquisadora Carla Pollake da Silva (2006: 12) ao estudar sobre audiência e recepção visa compreender como a passagem do consumidor passivo para ativo implica, diretamente, no modelo de audiência. A autora explica que já com as primeiras manifestações de mobilização das multidões no início do século XX, com a utilização da propaganda, os estudos de audiência começam a ser formados na sociedade. 
A audiência não se caracteriza por essa personificação e nem por uma obrigação de ser sociável e estável. A sua atuação responde a uma solicitação. Tal qual o público, a audiência se instala em uma realidade imaginada (Cajazeira, 2014: 21). O pesquisador e professor Paulo Eduardo Cajazeira retrata com a fala acima que a audiência tende a ser uma realidade imaginada, pois ela tem um caráter simbólico na relação entre produtores e consumidores, e na era da convergência essa relação perpassa novos desafios de medição.

A audiência com o advento das tecnologias, das redes sociais digitais e da maior interatividade entre produtores e consumidores de conteúdos não está baseada mais apenas em números de ibope. Outros formatos e formas são considerados para a compreensão dessa nova audiência como, por exemplo, o número de visualizações, os inúmeros comentários deixados nas páginas, a número de compartilhamento, curtidas e etc. A reconfiguração da audiência perpassa os próprios moldes de produção, circulação e difusão do conteúdo da era digital.

Uma descentralização da audiência começa a ser percebida pelas empresas de comunicação com a chegada do aparato digital. E com isso requer que novos processos sejam analisados, aferidos e compreendidos diante essa nova sociedade que busca uma maior participação em conjunto com a produção noticiosa.

\section{Metodologia}

Para analisar e compreender como o fenômeno das webséries documentais se encontra no campo digital, um estudo de caso a partir da pesquisa exploratória e da análise de conteúdo nos permite um maior detalhamento das acepções e conceitos pré-estabelecidos no conteúdo das webséries documentais. A relação de interatividade e a participação do espectador a partir de uma navegação interativa, e que permeia 
possibilidades e experiências diferenciadas é sentida na webséries "A short historyofthehighrise" (2013). A websérie documental elaborada pelo NYTimes.com sob a proposta de interação a partir dos toques, pois visa dialogar diretamente com as novas possibilidades advindas com o avanço da tecnologia, principalmente para o campo jornalístico.

A pesquisa exploratória permite uma aproximação mais intimista entre o pesquisador e o tema pesquisado, visto que o tema ainda é pouco explorado e conhecido, como no caso das webséries documentais em que poucas pesquisas existem sobre o assunto, principalmente no Brasil. Nesse sentido, a problemática não se apresenta com aspectos que permitam uma visualização dos procedimentos, e se faz necessário que o pesquisador inicie um processo de sondagem, de varredura para o aprimoramento das ideias, e, posteriormente, da construção de suas hipóteses.

Em consonância com a análise de conteúdo de Laurence Bardin (1977: 29) que "é uma proposta em reação à análise subjetiva de textos, e envolve uma necessidade de sistematização impostas pelo próprio desenvolvimento do processo" (Temer, 2014: 36). Compreendemos esse tipo de análise para a medição do tipo de conteúdo com finalidades descritivas, sistemáticas e quantitativas e que se adaptou para uma metodologia de análise das tecnologias digitais. A análise de conteúdo possui duas funções: 1) função heurística: a análise de conteúdo enriquece a tentativa exploratória, aumenta a propensão à descoberta. É a análise de conteúdo <para ver o que dá>; e uma 2) função de <administração da prova>: hipóteses sob a forma de questões ou de afirmações provisórias servindo de diretrizes, apelarão para o método de análise sistemática para serem verificadas no sentido de uma confirmação ou de informação.

$\mathrm{Na}$ análise de conteúdo não existe o "pronto", mas uma base norteadora. "O conteúdo é marcado por uma grande disparidade de formas e

${ }^{1}$ A short history oh the Highrise - websérie documental produzida pelo NYTimes.com. Disponível em: http://www.nytimes.com/projects/2013/high-rise/. 
adaptável a um campo de aplicação vasto a comunicação" (Bardin, 1977: 31). Ela pode ser aplicada a uma descrição do conteúdo das mensagens, já que a palavra é o conteúdo a ser analisado em sua metodologia. Uma análise detalhada e rigorosa que aplicada ao conteúdo interativo das webséries documentais, nos possibilitará a compreensão da ascensão desse modelo de produção e da emergência desse novo espectador que está na rede, na Web: o webespectador.

O usuário adere à participação dos formatos audiovisuais que se encontram nesse novo espaço midiático e participa dessa nova discussão que permite um retorno mais rápido sobre essa produção digital e interativa. A participação no ambiente digital é de extrema importância para que possamos compreender como o diálogo está sendo estabelecido entre o conteúdo e o espectador, e como esse participa do processo interativo possibilitado pelas webséries documentais, uma vez que as tecnologias estão avançando e que estamos inseridos nessa conjuntura. Sendo assim, em conjunto com a metodologia exploratória, utilizaremos a método qualitativo no estudo de caso, um tipo que se refere a esse tipo de metodologia mais específica da análise de conteúdo.

“A pesquisa qualitativa não se preocupa com representatividade numérica, mas sim como o aprofundamento da compreensão de um grupo social" (Gerhard; Silveira, 2009: 31). Esse grupo social, aplicado a nossa pesquisa se encontra no grupo pertencente à rede social digital. $\mathrm{Na}$ busca por compreender, explicar e descrever esse tipo de análise, o estudo de caso por ser caráter singular, particular permite-nos desenvolver um maior aprofundamento em nosso objeto de estudo, como por exemplo: a interpretação em contexto, a retratação de uma realidade de forma mais completa e a variedade de informações. A partir da sistematização qualitativa das mensagens encontradas no conteúdo das websérie documental A short history of the Highrise (Uma breve história do Highrise), é que será possível a percepção do impacto que esse audiovisual 
na Era da Internet vem modificando e transformando não apenas o modo do fazer jornalístico, mas também, no aumento do índice de audiência que as webséries visam obter com esse novo público.

\section{Resultados}

A websérie documental A short history of the Highrise é dividida em quatro partes em que explica como o processo de verticalização foi sendo construído ao longo da história. A partir de imagens fotográficas que constroem a narrativa, a websérie foi elaborada em duas versões: uma para a visualização comum, como todo conteúdo audiovisual sem grandes novidades, e outra, para estimular a interatividade a partir da visualização do mesmo conteúdo em tablets. O recurso utilizado para a interatividade encontra-se na perspectiva de obtenção de informações extras, detalhes e no próprio percurso que o espectador fará ao assistir o conteúdo.

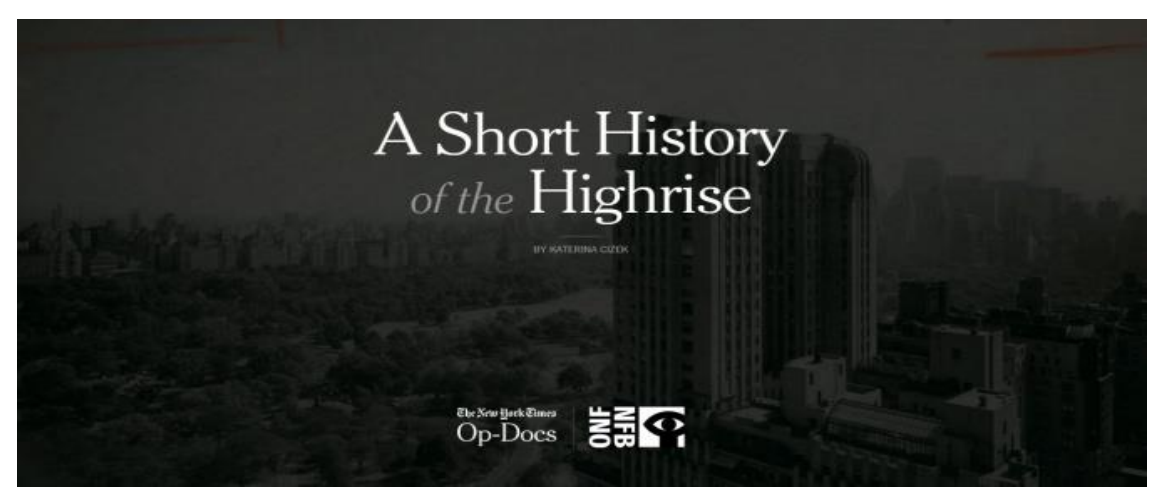

Figura 1: Abertura da websérie documental A short history of the Highrise 


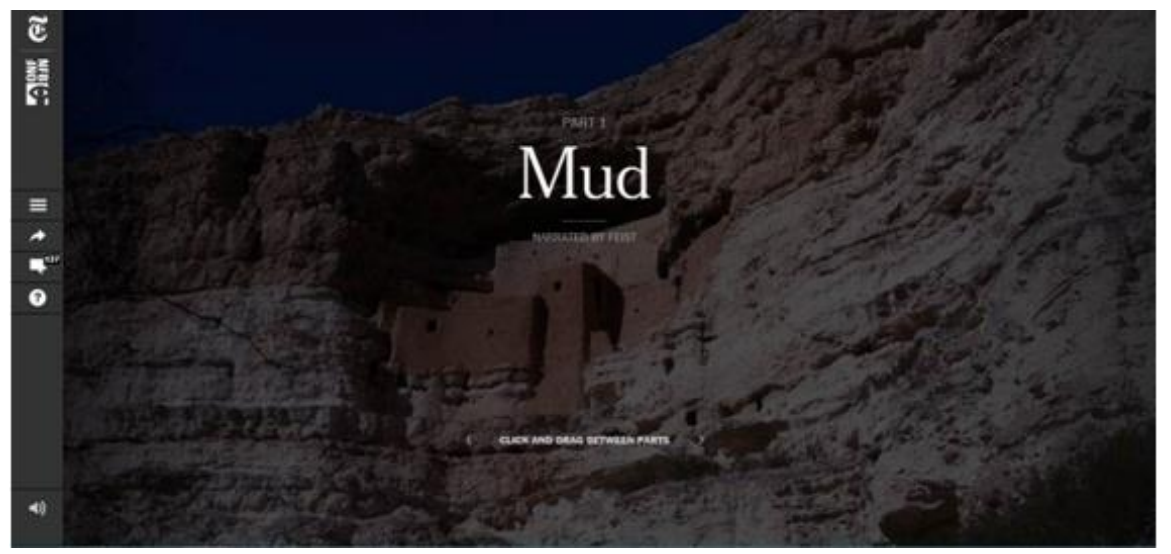

Figura 2: Parte 1 da websérie documental A short history of the Highrise

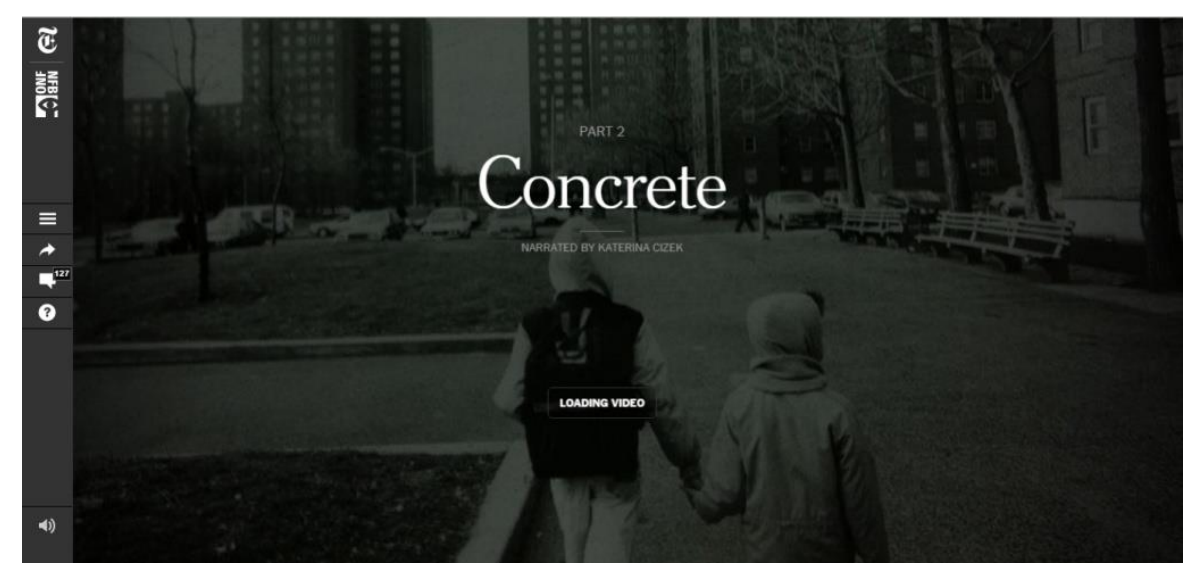

Figura 3: Parte 2 da websérie documental A short history of the Highrise

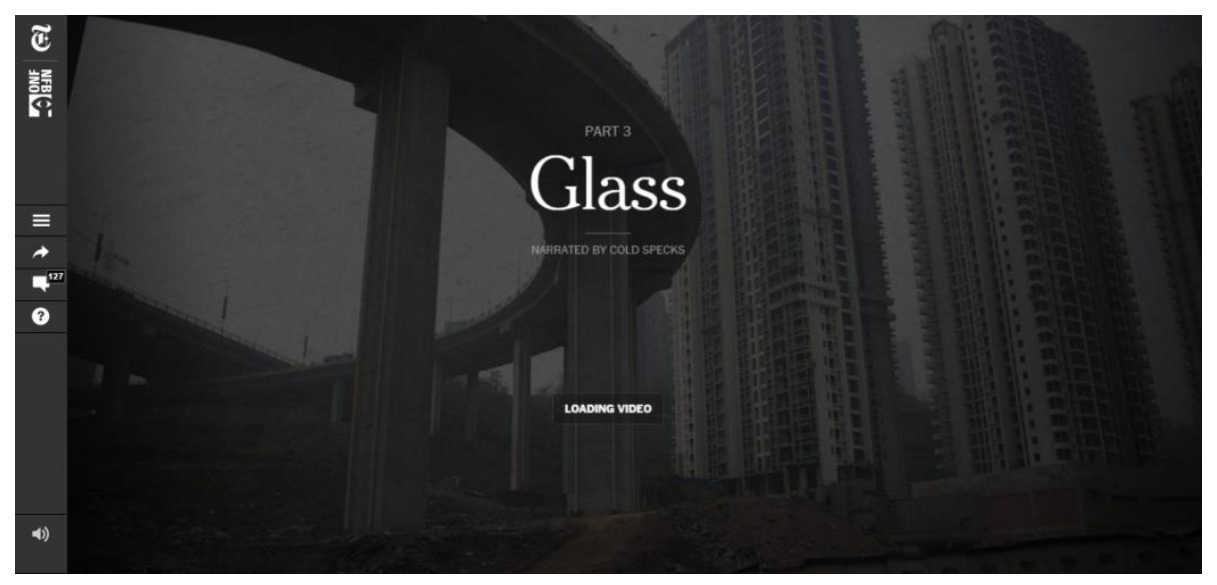

Figura 4: Parte 3 da websérie documental A short history of the Highrise 


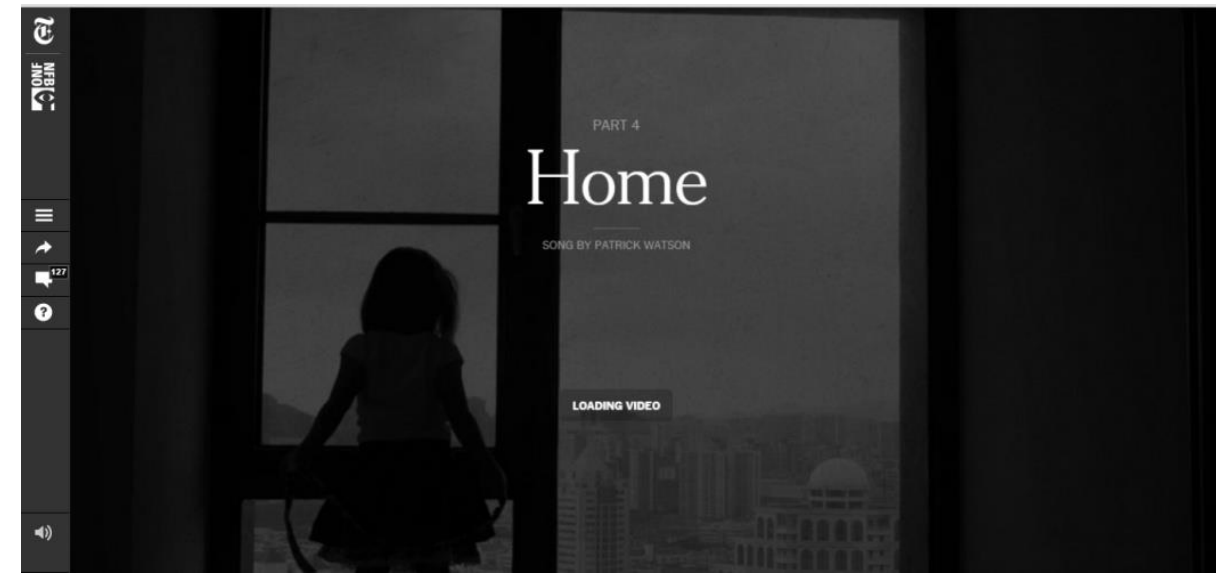

Figura 5: Parte 4 da websérie documental A short history of the Highrise

Uma experiência diferenciada pode ser analisada ao assistir o conteúdo através da plataforma digital pelo tablet. A narrativa construída com informações no verso das fotos, informações extras sobre determinada construção, época e local, nos permite identificar que a mensagem encontrada, no percurso feito pelo webespectador, a partir do conteúdo nem sempre será a mesma para cada indivíduo, e a compreensão desse conteúdo nos possibilita enxergar como a estrutura dessa nova produção digital funciona: "a análise de conteúdo tenta compreender os jogadores ou o ambiente do jogo num momento determinado, com o contributo das partes observáveis" (Bardin, 1977: 43). Essa compreensão proposta por Laurence Bardin determina como a aplicação da análise de conteúdo situa-se no estudo de caso dessas webséries específicas. 


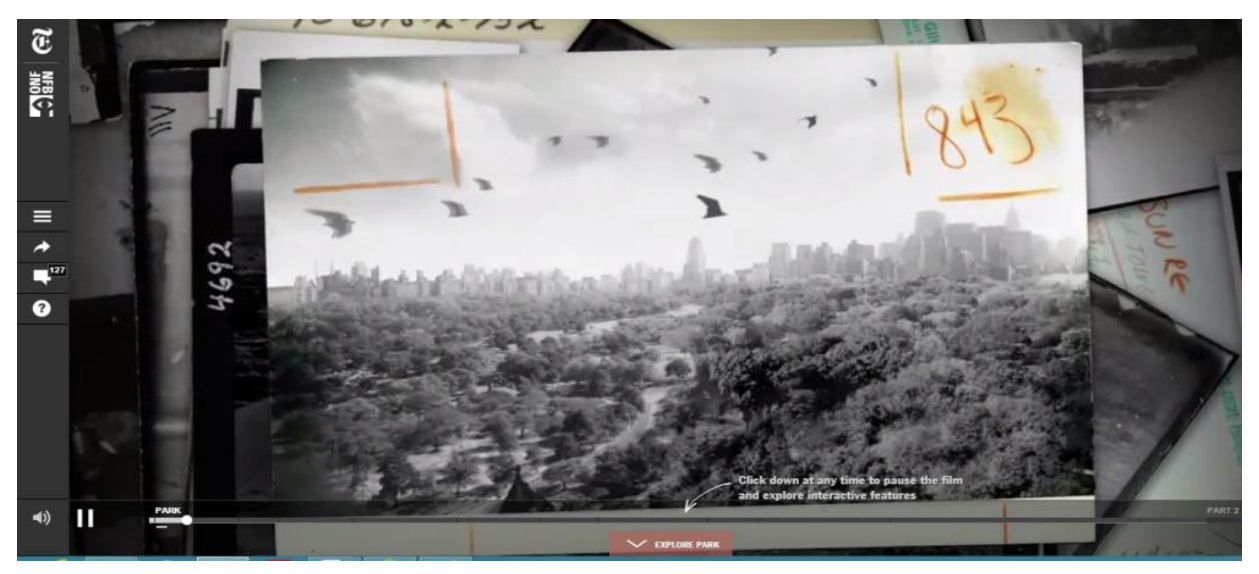

Figura 6: Trecho da parte 2 da websérie documental A short history of the Highrise

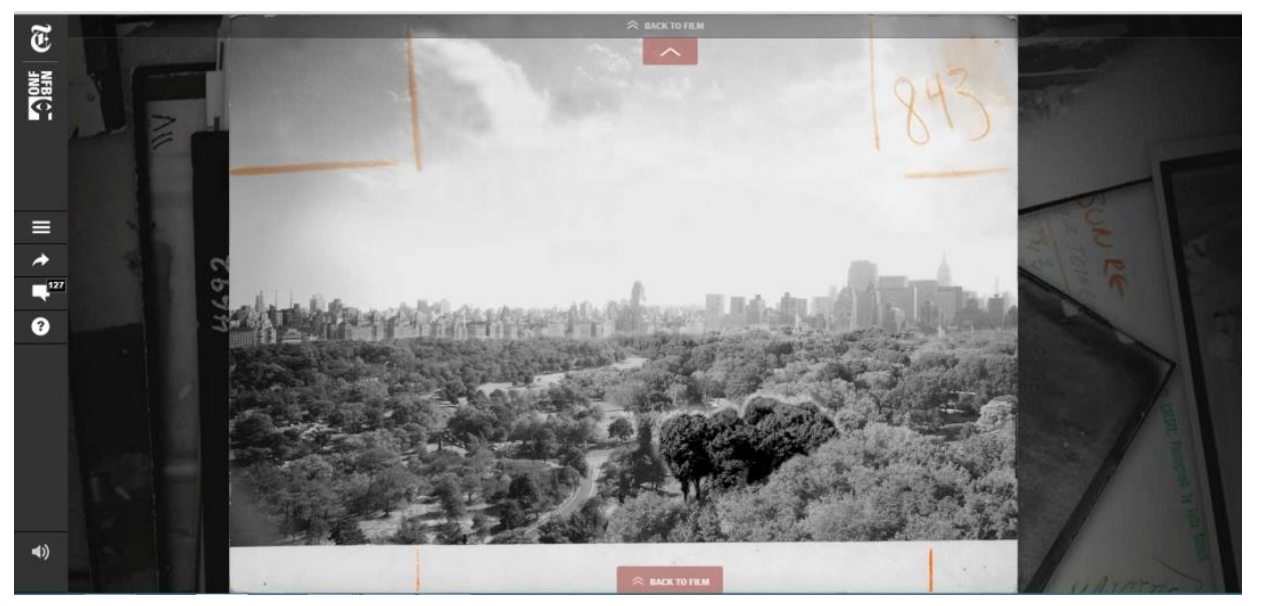

Figura 7: Trecho da parte 2 da websérie documental A short history of the Highrise em que explora a interatividade 


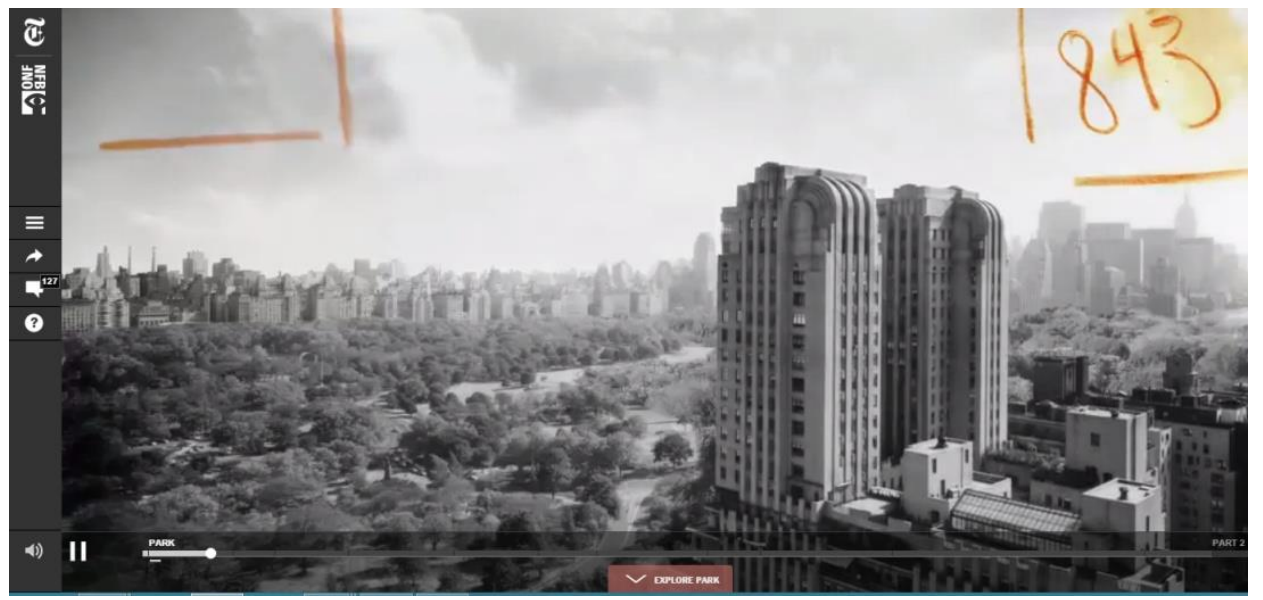

Figura 8: Trecho da parte 2 da websérie documental A short history of the Highrise em que explora a interatividade e as informações extras

A interatividade é um dos fatores mais importantes nesse processo de produção da websérie escolhida. Em conjunto com o conceito de tactilidade explorado por Marcos Palacios e Rodrigo Cunha (2012: 668) como mais uma das características do webjornalismo e que "antes ligada apenas a recursos de acessibilidade para deficientes visuais, tornou-se elemento essencial na comunicação em dispositivos móveis com tela sensível ai toque". Essa nova característica que permeia a produção dos conteúdos audiovisuais altera até então a relação prévia que se tinha estabelecido. Os dispositivos móveis propiciam novas experiências de contato.

Nas figuras acima (6, 7 e 8) podemos identificar como a interação permeia a produção desse conteúdo e sua relação com o webespectador. Os retângulos em vermelho com as indicações de setas representam os caminhos para as informações extras sobre a fotografia que aparece. Esses fluxos a mais (re) configuram o trajeto pré-estabelecido e proporcionam leituras e experiências diferentes para cada webespectador. Leituras que já são pré-definidas pelos produtores dos conteúdos dentre as " $\mathrm{x}$ " formas que 
são possíveis de acompanhar a visualização desta websérie. A interatividade neste sentido dá uma sensação de liberdade, mas que pode ser encarada como uma espécie de falsidade em sua estrutura, pois está, ao contrário, ainda no controle e na manipulação. A interatividade se encontra na possibilidade de acompanhar este conteúdo na hora em que o espectador desejar, pausando quantas vezes desejar e retrocedendo para visualizar algum detalhe ou se ater a uma informação com mais precisão.

Na significação da análise desse conteúdo não são as palavras, na forma escrita, que estão em jogo, mas as palavras em forma de visualidade. É a visualidade dessa narrativa interativa que perpassa entre um conteúdo noticioso e jornalístico, e outro, de diversão e de entretenimento. Esse infotenimento com características de interatividade, intrínseco ao conteúdo digital, confere a websérie documental como um dos produtos multimídias que adquirem cada vez mais espaço no cotidiano da sociedade. A relativa temporalidade de produção, circulação e distribuição, a fragmentação do conteúdo sem uma relação direta com as outras partes e a possibilidade de "manipulação" são itens que merecem total atenção das webséries. Esse conjunto de características corrobora para um aprofundamento das questões pertinentes a interatividade.

A websérie documental A short history of the Highrise tem em seu conteúdo uma proposta que permeia o jornalismo e o entretenimento. A crescente percepção desse recurso aplicado as empresas de comunicação tem sido conferido, nos últimos tempos, como uma tentativa de abarcar uma nova audiência para outro público além do já existente. Esse formato de audiovisual tem sido apropriado pelo webjornalismo, principalmente após a discussão sobre convergência das mídias e pelo desenvolvimento tecnológico das ferramentas disponibilizadas na Web. Essa mudança de movimentação das mídias e dos conteúdos é um dos interesses de aplicação da análise de conteúdo, e nas webséries não reside apenas na descrição dos conteúdos, mas no que eles podem trazer depois de serem tratados. 


\section{Considerações finais}

A escolha por tratar especificamente da websérie documental "A short history of the Highrise" deu-se, primeiramente, pelo objeto de estudo que visa a compreender o conteúdo de uma websérie documental. Em segundo, a partir do período de observação, durante 2 semanas entre os dias 3 a 17 de maio de 2015, porque nos foi possível constatar que pela utilização da narrativa fragmentada, hipertextual, interativa e multimídia poderíamos compreender as hipóteses que previamente estabelecemos como, por exemplo, a relação de participação que se altera a partir desse conteúdo interativo com o espectador.

O aumento significativo das produções, em larga escala, das webséries documentais perpassa a mídia digital e a relação multimidiática, que essa produção é modificada e alterada com esse tipo de conteúdo especializado para a Web, estabelecendo a participação do público diretamente no sentido da narrativa da websérie. Sendo considerado um item indispensável na construção da narrativa das webséries documentais, a interatividade surge como uma espécie de entretenimento, que busca atrair esse novo público (público que não mais apenas busca receber um conteúdo, mas que busca manipulá-lo, interagir com eles das mais variadas formas possíveis, ainda que não seja com uma total liberdade), e nas possibilidades de navegabilidade, como é demonstrada no estudo de caso escolhido acima, e que modifica a medição da audiência tradicional.

A navegabilidade está relacionada com as formas que cada indivíduo pode controlar sua forma de assistir, por exemplo. O conteúdo aqui pode ser acessado tanto pelo PC (Computador Pessoal), notebook, como pelos dispositivos móveis. A experiência de controle sobre pausar, retroceder ou avançar não está mais diante do poderio do produtor, mas dos próprios 
consumidores que decidem o que vão assistir, quando, como, onde vão acompanhar esse novo audiovisual.

A observação, a partir desse estudo de caso, nos demonstra que as webséries documentais estão se adaptando a nova realidade midiática. O amplo cenário da mídia digital ultrapassou as fronteiras que distanciavam produtores e consumidores, obra e espectador, e foi além dos tradicionais processos interativos que as mídias tradicionais disponibilizam em suas plataformas. A TV é um bom exemplo para que possamos compreender o processo de interatividade que até então se tinha estabelecido na sociedade. Era, e de certo modo permanece, um processo hierárquico em que os grandes conglomerados de comunicação detinham todos os poderes centralizados e propunham aos seus espectadores que participassem, mas sob as suas condições. Os produtos audiovisuais na Internet, ainda mantêm certo parâmetro com esses antigos meios, mas o avanço tecnológico possibilita que o "controle remoto" pausar, retroceder e avançar esteja nas mãos dos espectadores, e com isso a interação aconteça a partir da relação que cada indivíduo constrói com o objeto.

Esse processo que se apresenta junto a convergência midiática digital é fundamental para que uma participação e desenvolvimento de conteúdos participativos se encontrem cada vez mais permeados na vida social e cotidiana na contemporaneidade. Os documentários que passaram as fronteiras do cinema e da televisão e chegam ao espaço digital com uma proposta interativa, deixam visível a forte tendência que adentra o campo jornalístico no século XXI, com o desenvolvimento de novas ferramentas. Não é uma questão apenas tecnológica, de suportes e plataformas por onde permeiam os conteúdos. A relação de produção tem sido transformada com a realidade midiática que presenciamos. Os conteúdos são produzidos e pensados para as múltiplas telas, e não apenas para determinado suporte. É um caminho que vem sendo percorrido e que já encontramos, por exemplo, no audiovisual produzido pro empresas como a Netflix. Conteúdos 
audiovisuais para a Internet que estão sujeitos a se adaptarem para as mais diversas telas (TV, computador, smartphone e tablet).

É um caminho ainda sendo percorrido e adaptado, compreendido por ambos os lados (produtores e consumidores), e que necessita de uma maior exploração enquanto pesquisa para perceber os avanços e as transformações que esses conteúdos carregam consigo. Uma vez que a narrativa vai sendo alterada de acordo com o fluxo de navegação individual, e que não pode ser mais determinado ou pré-estabelecido pelo produtor. Essa relação narrativa concentra-se apenas no conteúdo e no seu espectador/usuário. Desconstruindo ou não a narrativa, seguindo ou modificando as passagens que busca assistir e criando novas formas de enredo para o conteúdo que está sendo manipulado.

\section{Referências bibliográficas}

AERAPHE, Guto (2013), Webséries: criação e desenvolvimento, Rio de Janeiro: Ed. Ciência Moderna Ltda.

BARDIN, Laurence (1977), Análise de conteúdo, Tradução de Luís Antero Neto e Augusto Pinheiro, São Paulo - Ed. Editora 70.

BAUER, Marcelo (2011), Os webdocumentários e as novas possibilidades da narrativa documental, Cross Content, Brasil.

BRADSHAW, Paul (2014), "Instantaneidade: efeitos da rede, jornalistas móbile, consumidores ligados e o impacto no consumo, produção e distribuição" in CANAVILHAS, João (Org.), Webjornalismo: 7 características que marcam a diferença, Covilhã, Portugal: UBI/ LabCom.IFP, Livros LabCom.

CAJAZEIRA, Paulo Eduardo (2014), A audiência convergida do telejornal nas Redes Sociais. Tese de Pós-doutorado, Laboratório de 
Comunicação Online do Programa de PósGraduação em Ciências da Comunicação (Universidade da Beira Interior/LabCom.IFP/ Portugal) sob a supervisão do Professor António Fidalgo.

CANAVILHAS, João (2014), "Hipertextualidade: Novas arquiteturas noticiosas" in CANAVILHAS, João (Org.), Webjornalismo: 7 características que marcam a diferença, Covilhã, Portugal: UBI/ LabCom.IFP, Livros LabCom.

CANCLINI, Néstor García (2008), Leitores, espectadores e internautas, Tradução Ana Goldberger, São Paulo: Iluminuras.

CROU, Oliver (2010), Qu'est-ce que le webdocumentaire?, WEBDOCU.fr. CUNHA, Ricardo; PALACIOS, Marcos (2012), A tactilidade em dispositivos móveis: primeiras reflexões e ensaios de tipologia. Contemporânea - Comunicação e Cultura - vol. 10, n. 03, pp. 668685. Salvador, Brasil - UFBA.

DAYAN, D. (2006), Televisão, o quase público. Lisboa: Livros Horizonte.

DEJAVITE, Fábia Angélica (2006), Infotenimento: informação mais entretenimento no jornalismo, São Paulo: Ed. Paulinas.

GERHARDT, Tatiana Engel; SILVEIRA, Denise Tolfo (2009), Métodos de pesquisa, Universidade Aberta do Brasil - UAB/UFRGS e pelo Curso de Graduação Tecnológica - Porto Alegre: Editora UFRGS.

JENKINS, Henry (2009), Cultura da convergência, Tradução Susana Alexandria, $2^{a}$ Ed., São Paulo: Aleph.

LÉVY, Pierre (2014), A inteligência coletiva: por uma antropologia do ciberespaço, Tradução Paulo Rouanet, $9^{a}$ Ed., São Paulo: Edições Loyola.

PEREIRA, Marcos José (2011), Sistemas multimídia in DURÃO, Paulo Carlos Pires da Costa; MANDARINO, Denis Garcia (Org.), Novas interfaces em comunicação e audiovisual: mudanças no pensamento cotidiano, São Paulo: Lexia. 
PRIMO, Alex, (2007), Interação mediada por computador: comunicação, cibercultura, cognição, Porto Alegre: Sulina.

RITTER, Raquel Longhi (2014), O audiovisual como gênero expressivo e sua reconfiguração no jornalismo online, Revista Estudos da comunicação, nº 16, p. 69-88, junho.

ROSSINI, Miriam de Souza (2009), Traduções audiovisuais: múltiplos contatos entre cinema e tevê. In: ROSSINI, Miriam de Souza; SILVA, Alexandre Rocha da (Org.), Do audiovisual às audiovisualidades - convergência e dispersão nas mídias, Porto Alegre, RS: Asterisco.

ROST, Alejandro (2014), "Interatividade: definições, estudos e tendências" in CANAVILHAS, João (Org.), Webjornalismo: 7 características que marcam a diferença, Covilhã, Portugal: UBI/ LabCom.IFP, Livros LabCom.

SALAVERRÍA, Ramón (2014), "Multimedialidade: Informar para 5 sentidos", in CANAVILHAS, João (Org.), Webjornalismo: 7 características que marcam a diferença, Covilhã, Portugal: UBI/ LabCom.IFP, Livros LabCom.

SILVA, Carla Pollake (2006), Estudos de Audiência e Recepção: mais do que números do Ibope - aspectos históricos, Sociedade Brasileira de Estudos Interdisciplinares da Comunicação XXIX Congresso Brasileiro de Ciências da Comunicação, UnB, 6 a 9 de setembro, pp. 1-17.

TEMER, Ana Carolina Rocha Pêssoa (2014), Desconstruindo o telejornal: um método para ver além da mélange informativa. In. COUTINHO, Iluska; MELlO, Edna; PORCELlO, Flávio; VIZEU, Alfredo (Org.) Telejornalismo em questão, Coleção Jornalismo Audiovisual, V. 3. Florianópolis, Insular. 


\section{ARTIGOS}

Artículos | Articles | Articles 


\title{
O CONFINAMENTO DE VANDA: UMA LEITURA DO DISPOSITIVO
}

\begin{abstract}
Roberta Veiga *
Resumo: Através da análise do filme No quarto da Vanda e do debate com J.L Comolli, busca-se pensar o método de filmagem, o controle formal, e a violência operada nos corpos dos personagens e do espectador, como constituintes de um campo de forças: o dispositivo cinematográfico. Ao conjugar uma dimensão estética e outra política, sugere-se pela análise do dispositivo que o confinamento é um vetor de sensações e de produção de espectatorialidade.

Palavras-chave: dispositivo, confinamento, Pedro Costa.

Resumen: A través del análisis de la película En la habitación de Vanda y del debate con J.L Comolli, se busca pensar el método de filmación, el control formal y la violencia causada en los cuerpos de los personajes y del espectador como constituyentes de un campo de fuerzas: el dispositivo cinematográfico. Al conjugar una dimensión estética y otra política, se sugiere por el análisis del dispositivo que el confinamiento es un vector de sensaciones y de producción de espectatorialidad.

Palabras-clave: dispositivo, confinamiento, Pedro Costa.
\end{abstract}

Abstract: My analysis of Vanda's room and the debate with J. L. Comolli are the support to discuss the filming method, the formal control, and the violence inflicted upon the bodies of characters and spectators, understood as a power field: the cinematic device. By combining aesthetic and political dimensions, the analysis of this device suggests that confinement acts as a vector of sensations and the production of spectatorship.

Keywords: device, confinement, Pedro Costa.

Résumé Par l'analyse du film Dans la chambre de Vanda et du débat avec J.-L. Comolli, on cherche à penser la méthode de tournage, le contrôle formel et la violence opérée sur les corps des personnages et du spectateur, en tant que constituants d'un champ de force : le dispositif cinématographique. En combinant une dimension esthétique et une politique, on suggère par l'analyse du dispositif que le confinement est un vecteur de sensations et de production de spectatorialité.

Mots-clés: dispositif, confinement, Pedro Costa.

\footnotetext{
* Universidade Federal de Minas Gerais, Departamento de Comunicação Social, Programa de Pós-Gradução em Comunicação. 31270-901, Belo Horizonte, Brasil.

E-mail: roveigadevolta@gmail.com
}

Submissão do artigo: 01 de julho de 2015. Notificação de aceitação: 20 de agosto de 2015 . 
No quarto da Vanda (2000) é o segundo filme da trilogia ${ }^{1}$ do diretor português Pedro Costa, que coloca em cena os precários modos de vida dos moradores das Fontainhas. O filme é "uma crônica da demolição do bairro" (Costa, 2007b), na qual os habitantes, em sua maioria imigrantes caboverdianos, são retratados em suas práticas diárias. A vida de Vanda Duarte é insistentemente acompanhada pelo olhar de Costa: no quarto, na cama, ela repete rotineiramente os gestos de preparar a heroína e consumi-la. Os outros personagens também são toxicômanos e vivem nos miseráveis espaços da vizinhança. Como esses espaços estão sendo destruídos ${ }^{2,}$ os habitantes desalojados passam de um lugar a outro, ocupando os barracos abandonados que restam.

Ao se aproximar de Vanda e dos moradores de Fontainhas, Pedro Costa vai perseguir, rigorosamente, o que há de concreto num espaço reduzido e degradado. O resultado é um filme seco, confinante, e completamente avesso ao melodrama. Pensando nos três lados que constituem a experiência cinematográfica - o modo de realização, a obra em si, e o lugar do espectador - a questão que pode caracterizar o dispositivo do filme conjuga o método de filmagem - que passa pelo enfrentamento daquela realidade e dos sujeitos filmados -, as opções expressivas do diretor e a espectatorialidade instituída a partir daí. De que maneira o método de filmagem pode ser definido ao mesmo tempo pela abertura para o cotidiano dos moradores de um bairro em ruínas, gesto documental, e pelo controle formal e narrativo sobre a plasticidade, a temporalidade e a violência próprias daquele mundo, gesto ficcional?

\footnotetext{
${ }^{1}$ O primeiro filme da trilogia é Ossos (1997) e o último Juventude em Marcha (2006). Fontainhas é um bairro muito pobre localizado na periferia de Lisboa que abrigava um grande número de imigrantes cabo-verdianos e que na época dos filmes foi sendo desapropriado em função do desenvolvimento urbano e comercial.

${ }^{2}$ Essa prática de demolição das localidades de bairros periféricos em Portugal se deveu a medidas governamentais de expansão de vias de acesso e construção de pontos comerciais.
} 
Se No quarto de Vanda pode ser tomado como um dispositivo, ele está muito distante das caracterizações comuns de tal mecanismo com uma armadilha para o real ${ }^{3}$. Não há imposição de uma estrutura de normas fixas que criariam para o filme uma realidade a partir da qual os sujeitos envolvidos seriam constrangidos a determinadas ações. Há antes, a escolha de uma circunscrição de possibilidades, por um espaço único: o bairro de Fontainhas. A invenção do método só passa por um controle protocolar se esse é entendido não como prescrição, mas como o domínio do diretor sobre os modos de ver.

Seria ingênuo achar que Pedro Costa apenas sofre a ação das forças que vêm do real (como é ingênuo que tal premissa definiria qualquer documentário) que não há preparação de atores, ensaios e exigências por parte do diretor, quais sejam: normas que o permitam concretizar um trabalho dentro de suas crenças. Assim como não se pode acreditar que tais exigências imperaram a despeito dos sentimentos e processos das pessoas dali. Existem regras visíveis, e também uma escuta, uma disposição em acolher o ritmo daquelas vidas. Há um encontro de forças: escolhas éticas e estéticas do diretor e afectos presentes no funcionamento concreto de um mundo. O dispositivo significa muito mais esse campo conflituoso de forças pelo qual passam formas de controle do que um artifício de invenção do próprio filme. Por outro lado, o dispositivo não se isenta de um artifício explícito no rigor dos enquadramentos e da duração nas ações e pequenos gestos dos personagens que vão conformando a estética do confinamento.

No quarto da Vanda faz o espectador caminhar fora da linha que separa ficção e documentário. Jean Louis Comolli identifica bem o fenômeno que vemos operar no filme: “... esclareço que, pra mim, essas

\footnotetext{
3 "Para Cezar Migliorin (2005), em Rua de mão dupla, o dispositivo é análogo a uma armadilha, a um artifício que o diretor constrói para disparar um movimento que não existia antes como um dado, ou fato, no mundo. O que se produz com esse estratagema é um acontecimento inesperado que o artista não domina. $\mathrm{O}$ diretor constrói a armadilha sob a qual ele tem o controle, e ao mesmo tempo o mecanismo instaurado produz o acontecimento, o descontrole." (Veiga, 2008: 94).
} 
duas dimensões estão sempre conjugadas no cinema, pois 'as ficções' sempre têm uma versão documentária — os corpos filmados dos atores, por exemplo - e os documentários não cessam de contar histórias e constituir personagens." (Comolli, 2004b:159). No entanto, na visão de Comolli, o documentário possui a especificidade da inscrição verdadeira, alcançada através do registro dos corpos e da máquina num aqui e agora, que o torna capaz de escapar à lógica espetacular e atingir uma zona onde as experiências singulares e a alteridade sobrevivem. "Longe de 'toda-ficção de tudo', o cinema documentário tem, portanto, a chance de se ocupar das fissuras do real, daquilo que resiste, daquilo que resta, a escória, o resíduo, o excluído, a parte maldita" (Comolli, 2001a:101).

Pedro Costa também acredita no cinema engajado nos sentimentos e distante das maquiagens que constituem as imagens comerciais da publicidade e da moda (como ele mesmo já afirmou em entrevistas). Apesar de se dizer contrário à separação entre documentário e ficção, o diretor alega, que em No quarto de Vanda, nem para ele, nem para os personagens, tratava-se de documentário, mas um filme muito próximo da ficção, intensamente construído e controlado não só por ele, mas por todos que participaram. Ou seja, se para Costa, "um filme é sempre um documentário de sua própria realização" (Costa, 2007a:134), é porque ele é pensado como um gesto recíproco: de intervir num mundo e ser contaminado por ele. Trata-se de um método de construção da mediação entre uma vida diferente, que se impõe como um material bruto, e um cineasta, que se deixa também conduzir por ela, sem abrir mão de seu desejo, de algo de seu domínio. Em No quarto da Vanda, para que a vida surgisse em sua repetição e precariedade, o corpo do diretor se inscreveu ali, criando um jogo contingente e delicado de relações na esfera do real. É esse mecanismo instituído pela contingência de uma situação determinada em um espaço, e submetido a uma pressão do real, que damos o nome aqui de dispositivo e que conjuga, em sua gênese, ficção e documentário. 
Em No quarto da Vanda, os afectos surgem na fricção das próprias vidas e não numa realidade autônoma criada como um roteiro ou como um modo de ativação do real ${ }^{4}$. As pessoas filmadas aparecem como atores das mise en scènes próprias a seu campo social, com seus hábitos e apropriações locais. Quando isso se faz no filme é porque o diretor resguardou a diferença que funda sua relação com aquelas pessoas. Instaura-se um espaço compartilhado que, para Jacques Rancière (1996), diz respeito, ao mesmo tempo, à comunidade e à separação que está na base da política. A política se define pela partilha do sensível que se refere tanto ao que é comum, quanto ao que é diferente, determinando as inclusões e exclusões nos lugares. Trata-se de uma repartição de espaços, tempos e tipos de atividade que indicam como o comum se institui e como cada indivíduo ou grupo toma parte nessa divisão. Ao contrário do consenso, há um conflito de base estética que fundamenta a política: os modos como o sensível é disputado, ganham visibilidade e são percebidos, ditos e vistos num dado tempo. ${ }^{5}$

Já que o cinema é igualitário, filma a todos igualmente, porém como igualmente únicos e distintos, ele se funda justamente nessa tensão entre consenso e dissenso. A partilha do sensível é um substrato da política que

\footnotetext{
4 "Acreditamos que a utilização de dispositivos em produções audiovisuais recentes está ligada a um desejo de referencialidade no real contido nestas obras. Se tudo é cena, se tudo está dado para ser filmado, se 'o fundo da imagem já e sempre uma imagem'(Serge Daney) a criação de dispositivos se propõe a filmar o que ainda não existe, e só existirá quando o dispositivo entrar em ação. O dispositivo é uma ativação do real.”(Migliorin, 2005)

${ }^{5}$ Para Rancière, a base do desentendimento na política está na diferença dos registros dos falantes, suas inserções particulares na língua, nos usos e atribuições dos sentidos em função de suas formas de vida. Por isso, ele é insuperável, pois, antes de qualquer confronto de valores e interesses, há um conflito que parece ser ignorado - quando se apela à igualdade dos seres falantes, quando o mundo comum dos falantes deixa de ser entendido como vários mundos que estão em constante tensão. "A afirmação de um mundo comum efetua-se assim numa encenação paradoxal que coloca juntas a comunidade e a nãocomunidade." (1996:66) Se a estética é "o que coloca em comunicação regimes separados de expressão" (1996:66), não podemos falar de uma estetização do político nas modernas sociedades, pois a estética é seu princípio. Podemos falar de uma autonomização da estética: "A estética assim autonomizada é em primeiro lugar a emancipação das formas de representação, em segundo lugar a constituição de um novo tipo de comunidade do sensível que funciona sob o modo da presunção, do 'como se' que inclui aqueles que não estão incluídos, ao fazer ver um modo de existência do sensível subtraído à repartição das partes e das parcelas" (Rancière, 1996:68).
} 
não se dá a ver de imediato nas práticas sociais, mas precisa ser desvelada. Ao assumir seu caráter de representação, o cinema produz esse desvelamento, ou seja, marca as diferenças através do ato coletivo de ver. Mas se o cinema já é de saída político, essa dimensão é diluída, quando o desentendimento que funda a partilha dá lugar à anulação da diferença, à imposição do consenso. Por outro lado, quando o poder de filmar não se sobrepõe ao outro filmado, mas esse outro pode tomar a cena para nela inscrever seu tempo e o gesto do diretor é de, a todo custo, dar a ver essa singularidade; a partilha estética é política.

\section{Plasticidade: entre a sombra e a luz}

Em No quarto da Vanda, a crueza dos acontecimentos, a ausência de enredo, a ligação não-teleológica entre as sequências, a duração da exposição dos corpos, aproximam o filme do mito da revelação de uma realidade sem mediações. Essa sensibilidade não é dada, mas alcançada pelo diretor, justamente porque ele mantém nas escolhas formais de seu trabalho um controle evidente. Tal controle se mantém através de uma certa distância no ato de filmar: a manutenção das mesmas posições em relação aos corpos; o rigor dos enquadramentos secos e repetitivos; a fixidez da câmara; e, principalmente, a insistência nesses procedimentos.

Apesar de No quarto da Vanda não ter estrutura narrativa tradicional, o espectador é conduzido por uma história porosa e complexa, feita de acontecimentos, ações, memórias e vivências de Fontainhas. Um aspecto sutil, mas determinante da montagem, é a forma como o diretor interpõe os dois ambientes principais onde essas vidas são encenadas, e os situa no espaço maior do bairro que está sendo demolido. São dois barracões vizinhos, cenografias que ao longo do filme se alternam, se diferem e, ao mesmo tempo, se espelham e confluem. Uma oscilação de visibilidades com contrastes e reflexos sutis que gera duas ambiências. 
Ao contrário de uma montagem que opera por saltos rápidos, a interpolação ocorre entre extensas durações permitindo que cada ambiente seja experimentado na força de sua experiência temporal. Há um fluxo de tempo contínuo, muito mais próximo da maneira como experimentamos o tempo, estruturado e estruturante das atividades ordinárias do cotidiano: dos momentos de ócio, silêncios e ações menos pragmáticas.

Num espaço está Vanda Duarte e sua família: a mãe, a irmã Zita e uma criança cega. Assistimos ao cotidiano de Vanda pontuado sistematicamente pelo consumo da heroína. No quarto, ela e Zita preparam a droga, fumam e conversam. Amigos da vizinhança aparecem e compartilham a droga. Na casa da família empilham-se caixas de legumes e frutas que Vanda vende no bairro, junto com outros objetos e móveis, e com a tevê, sempre ligada. Num barracão vizinho vivem Pango, Nando e Russo, que também passam os dias consumindo heroína. O barracão vai ser demolido. Lentamente, preparam a mudança enquanto ouvem, cada vez mais alto, o barulho das máquinas e dos estrondos dos blocos de concreto jogados ao chão. O espaço dos rapazes é menor, mais vazio e pouco iluminado. Há pequenos pontos de claridade - uma vela, uma brasa de cigarro, um raio de sol que se esgueira pela janela. Não vemos bem o rosto deles. Pango é negro e Nando usa um gorro e um boné por cima, que tapa seus olhos. A câmara está próxima deles e quase sempre mantém a mesma distância. Trata-se de uma encenação tímida que parece ocupar parcela menor do filme.

Na primeira sequencia nesse ambiente, Pango está tomando banho de bacia, a cena é escura e uma pequena fresta de luz ressalta a fumaça que sobe da água quente enevoando o quadro e dificultando ainda mais a visão. Vemos apenas seus contornos. Os rapazes aparecem constantemente assim: silhuetas, vultos, sombras nas paredes. São silenciosos, falam baixo, cadenciado e lentamente. As conversas são cifradas pelas gírias próprias ao 
universo das drogas. "As bombas é que estão todas maradas. Toma lá este bico, vê lá se atinas com este bico", diz um deles.

A ambiência é carregada e a atmosfera misteriosa e impenetrável em função da imobilidade da câmara e dos movimentos lentos dos personagens, da pouca luz, da indefinição dos rostos e corpos, das conversas pausadas e cifradas. Há um peso real maior ainda: os rapazes usam heroína injetável e conversam sobre as dificuldades com a agulha, as veias, os hematomas, o ar que fica na seringa e impede que o sangue entre nela. Quase como zumbis, em atos pausados, se mostram e não se mostram. Surge daí a estranheza de uma experiência de vida precária que toca à morte.

É nesse paralelo, que a vida de Vanda se torna bem menos sombria e ocupa no filme um lugar central. Seu quarto, onde ela executa o ritual de se drogar, é mais iluminado. Apesar de a câmara permanecer imóvel, ela está sempre aberta e quase nunca se aproxima, enquadrando, na maioria das vezes, todos os personagens presentes. Vanda e Zita são expressivas. $\mathrm{Na}$ primeira cena vemos os rostos com clareza, elas falam mais alto, riem e conversam sobre várias coisas enquanto fumam, ainda que as drogas ou a miséria sejam a toada dos diálogos. Há uma família ali. A mãe cozinha, Zita costura, Vanda vende verduras, a criança canta. O telefone toca e a tevê transmite uma novela brasileira, um show de Barbara Streisand. Há elementos reconhecíveis que tornam aquele universo mais penetrável e menos distante. Vanda possui carisma e senso de humor, sua fala é sincera e segura, demonstra carinho, principalmente pela mãe. Verbaliza suas revoltas, com o país, o sistema prisional (sua irmã está presa), o pai. Quando a amiga lhe diz que foi presa, ela repete muitas vezes: "Por caldos knorr, onde é que já se viu? Levarem uma pessoa presa por caldos knorr?"

A afetividade de Vanda se estende aos amigos e vizinhos. Quando, numa conversa com Pedro, o vizinho reclama de falta de ar, ela oferece remédios e insiste maternalmente que ele os tome. Quando a casa de Pango é destruída, Vanda lhe dá abrigo e é a ela quem Russo pede para tomar conta 
de seu passarinho Mandarim. Vanda tem um papel importante para sua família e para a comunidade. Tem uma força e uma segurança visíveis, aconselha, cuida e acolhe. Ainda assim, o peso de sua história é constante, ela se droga repetidas vezes. Repetido é o gesto que insiste em sugar o pouco da vida que ali se encontra.

Os dois ambientes são mostrados em longos planos imóveis. Aos poucos, num movimento de contraste e de reflexo ${ }^{6}$, a alternância lenta vai tecendo uma profunda ligação entre os personagens e suas vidas: a proximidade dos atos e rituais que envolvem as drogas, o barulho ensurdecedor, as vidas que transitam por ali. Logo na primeira cena, Vanda pergunta a Zita se Pango já arranjou outro "cubículo". Vanda e Pango se conhecem desde a infância e compartilham o vício, a destruição das Fontainhas, e uma história de sobrevivência naquela situação de constante miséria. Próximo ao fim do filme, Pango está desabrigado, sua casa foi demolida. Um close de Vanda por trás de um véu branco cobre todo o quadro e, em seguida, um close de Pango com seu rosto negro em um ambiente escuro. Do sutil contraste entre claro e escuro, aquelas vidas parecem mais próximas.

Pango: Que eu sempre que entro aqui, penso como se estivesse em minha casa. Por isso é que eu vim te pedir um abrigo, um teto.

Vanda: E sabes que o tens. Não tens porque não queres. Comida nunca te faltou.

Pango: Claro. Comida nem um lugar para me encostar. Vanda: Mas é a vida que a gente quer é essa, vida da droga. (...)

Pango: Hoje em dia é assim. Com a vida que tens também já sabes. O que me aconteceu a mim... Aconteceu-me a mim, a ti, a outros. E a muitos mais."

(Diálogo retirado do filme)

${ }^{6}$ Refletido; indireto; devido à reflexão; efeito de luz refletida; influência indireta; reprodução; imitação; diz-se de movimento que se produz no organismo por uma excitação qualquer vinda do exterior, sem intervenção da vontade.(Houaiss, Dicionário eletrônico, versã $1.0,2001$ ) 


\section{Temporalidade: duração e enquadramento}

Em No quarto da Vanda, há longos momentos de silêncio e de puro ruído: o som da rua, das máquinas que demolem o bairro, dos muros que caem, de pessoas falando ou gritando, da tevê. Em ambos os ambientes, as conversas parecem fragmentadas, partes de assuntos que não dominamos, falas que se referem a alguém que não sabemos quem é, pedaços de vidas, cacos de histórias, e são ainda mais ininteligíveis em função do dialeto e da dicção própria àquele gueto. Muitas vezes não vemos todos personagens que participam do diálogo, de modo que quem fala pode estar fora de quadro enquanto vemos aquele que escuta. As palavras se inscrevem em uma duração e desenham a continuidade, as conexões, mesmo fracas, entre pessoas, histórias, acontecimentos e memórias. Elas carregam a fragilidade e a precariedade daquelas vidas. Em muitos momentos, remetem às ações e acontecimentos imediatos. Podem ser relativas ao ambiente - calor, frio, barulho que dá nos nervos; ao corpo — dores, ressaca, cabelo sujo; às drogas, como, por exemplo, "achastes a veia", "deixa lá dar o bafo" ou "não me dês o caldo fora!"; ou aos afazeres domésticos banais; arrumar ali, deixar aquilo, sentar, levantar. Essas falas inscrevem os personagens num aqui e agora, num tempo vivido. Parece não haver textos previamente elaborados, como se a interação emergisse das situações. Os atos de fala trazem a linguagem para o cotidiano, para a vida ordinária daqueles sujeitos. Ecarnada naqueles corpos, a linguagem reencontra a experiência.

A vida só me tem dado desprezos. Morar em casas fantasmas que outras pessoas deixaram. Estive em casas... Nem uma bruxa queria lá morar! Mas também estive em casas que valiam a pena. Eram casas que... Todas as minhas casas, que eu ocupei, eram casas clandestinas. Foram casas que as pessoas abandonaram, mas... Se estivesse lá uma pessoa de bem... Eles até não mandavam abaixo. E olha, foi assim... 
Casa atrás de casa. Já paguei mais pelas coisas que não fiz... Que pelas coisas que fiz. (Fala de Pango)

Em meio às conversas corriqueiras referentes ao que há de mais concreto, imediato ali, surgem lembranças e histórias de família, de amigos, de sofrimentos, que inserem as vidas num contexto mais amplo de exclusões sociais e misérias humanas. Ditos com naturalidade, no mesmo tom das interações banais, colhidos nas vozes e ritmos das experiências cotidianas, os relatos das misérias são desprovidos de carga dramática ou extraordinária. "Ela (Vanda) é filmada quase todo o tempo em planos fixos, bem abertos, por uma câmera que nunca se aproxima muito, não detalha, não fatia, não decupa - portanto, nada é feito para dramatizar, nem mesmo para significar ou contar" (Comolli, 2001:151).

A longa e sufocante duração nos planos fixos, fechados e repetidos, reforça o confinamento dos pequenos espaços e a quase imobilidade dos corpos. Como diria Comolli (2001a:100), parece que o filme é "atravessado, furado pelo mundo", um mundo claustrofóbico onde as mesmas atividades, os mesmos gestos, resistem ao barulho e à destruição que ilham os espaços, ao mesmo tempo em que compõe com eles uma melodia macabra. Contrárias à piedade e à compaixão, as lentes do diretor fazem da lida com a pobreza, a destruição, do corpo ou do espaço, e a solidão, uma forma de vida.

Pedro Costa permite que os corpos durem nos planos, valoriza cada enquadramento pelo qual a matéria se molda ao olhar, pelo qual cada figura humana é, ao mesmo tempo, constrangida e liberada de suas cargas, deformações e asperezas. Ele abre mão de seu poder de cortar, de impor o tempo da aceleração e do olhar administrado àquele mundo filmado, para que a cena seja tomada pelos sujeitos e a auto mise-en-scène surja. Contra o tempo do espetáculo, Costa alcança o tempo lento das figuras humanas, ali 
onde elas parecem tocar a morte - corpos esquálidos, olhos fundos, gestos repetitivos e titubeantes, falas descontínuas.

Para Comolli, a descontinuidade é o gesto de morte no cinema, pois é justamente o que o aparato técnico recalca a fim de que a reprodução do contínuo da vida se dê a ver. No filme, a descontinuidade não é imposta, mas surge da porosidade e complexidade da vida que dura na cena. Se há fragmentação nas falas, ela nada tem a ver com a ditadura dos cortes dos regimes de visibilidade da tevê, dos videoclipes, dos filmes de ação. É a duração da exposição dos corpos em suas interações e ações banais que fazem com que elas apareçam cadenciadas, repetitivas, gaguejadas. A descontinuidade surge na liberdade que o corpo filmado alcança quando apanhado na continuidade das ações, vozes e movimentos, quando o corte não vem como força de fora que violenta e desrespeita seu ritmo em prol da vontade de poder do diretor. A descontinuidade aí não é recalcada pelo aparato. O diretor filma o "trabalho de morte", na destruição pelas drogas, na repetição dos atos, no enclausuramento dos corpos.

Como não há movimento de câmara, o filme oferece a possibilidade de entrarmos nas imagens, escolhermos o que queremos reter, e de trabalharmos nossa relação com elas. Num mundo onde não temos tempo, onde somos expostos a imagens incessantes que concorrem pela nossa atenção, No quarto da Vanda revive o confinamento nos cubículos e no recorte dos quadros fixos, pressiona o olhar para reduzir o campo de visão, permitindo que a experiência da alteridade nos alcance na duração do ver. Os enquadramentos confinam, parecem adensar a carga daquelas vidas ali. Sem recurso ao melodrama, sem acesso direto ao sofrimento das pessoas, o que se sente é um acúmulo de tempo a cada enquadramento: um tempo cíclico do vício da droga (drogar-se para dormir, drogar-se para suportar a ressaca ao se levantar), um tempo repetido dos movimentos para consumir a droga, e um tempo parado, quase imóvel, dos pequenos espaços - a cama de Vanda, o pequeno barracão de Pango. 
Ao sair para as ruas, a sensação do olhar pressionado, do tempo adensado, não é aliviada. Nos estreitos becos, há sequências de planos fixos de pessoas que estão por ali em meio à destruição do bairro, espaço que outrora fora habitado: os olhos delas se dirigem enviesados para a câmara, não sabemos o que elas fazem ou para onde vão. Os planos são como fotografias e os personagens fotografados como estátuas vivas. São vidas que permanecem presas àquele lugar, àquela situação, àquela experiência.

Além da precariedade dos ambientes e dos espaços reduzidos, há redução do que se vê, busca por uma exiguidade do olhar, uma insistência em pôr em cena, repetir, durar nessa precariedade: as pálidas paredes, a cama de Vanda, o cubículo quase sem móveis de Pango, os mesmos gestos e sons. ${ }^{7}$ Nada é profuso e o filme se reduz a poucos elementos, a nenhuma explicação. É da pobreza que de fato surge a experiência. ${ }^{8}$

\section{Violência e emparedamento: o paradoxo vida e morte}

Do ponto de vista de Comolli, durar na cena é uma possibilidade para o espectador encontrar "o outro como imprevisto", a figura humana em suas asperezas e excessos, no que vai da forma ao disforme. Ao durar nas cenas em que corpos padecem, o filme atinge uma experiência do tempo e do espaço que se faz sentir no corpo, que surge no tempo circular do consumo da droga e no tempo duradouro da clausura.

\footnotetext{
7 "Nesse quadro bastante realista, bastante limitado, poucos meios, pouco dinheiro, não quero fazer coisas que transbordem para outros lados. Nesse quadro um pouco realista, eu acho, o que é difícil é ter essa concentração do real, um aspecto de uma realidade ou vários aspectos de tal maneira concentrados como os Straub, que tinham um sentido coeso, verdadeiro nos filmes deles. No meu caso ainda é difícil, realidade complexa, vasta, contraditória, dispersa. A não dispersão num filme me custa muitíssimo, com tempo vou colocando ordem nessa dispersão que eu acho que é um problema contemporâneo, essa dispersão das razões, dos porquês que se fez o filme. A razão se esvai. Há uma espécie de ponto de partida para o filme, depois dilui-se na própria dispersão, salada russa... Um cineasta como Godard sempre viveu nesse dilema: como pôr ordem na salada e mostrar a salada." (Costa, 2007b)

${ }^{8}$ Fazemos aqui uma ligação com a idéia da pobreza da experiência em Benjamin, que diz respeito à incapacidade do sujeito de ter experiência e não à pobreza material.
} 
Para viver a liberdade que lhe é dada na cena, o espectador passa pelo sacrifício de tentar se projetar num corpo que pesa e num tempo que não escorre. Sua liberdade de habitar o filme é constrangida visto que a continuidade nos planos refaz os mesmos atos. Exposto durante horas a uma vida enclausurada, pressionado a olhar os mesmos corpos em seu trabalho de morte, a olhar a intimidade do outro na sujeira, na doença, na putrefação, o espectador é levado a uma experiência de alteridade muito mais sensorial que intelectiva, seu corpo resiste ao peso daquela vida e padece também por isso.

Quanto mais as cenas duram e se repetem, mais se questiona sobre a possibilidade de continuidade daquela forma de vida, a possibilidade de sua existência. Essa possibilidade não é mais um lugar ficcional, a "missão redentora" do cinema expressa na travessia do personagem (Comolli, 2007:152). É a ilusão que se desfaz, ilusão muito maior do que o domínio da representação num filme, do que o fracasso do visível ante o "trabalho de morte" (Comolli, 2007: 152). É a ilusão da própria vida. Ao tocar em algo muito cru e real, a experiência ultrapassa os limites do engodo cinematográfico, das fronteiras entre real e ficcional, pois é experiência corpórea, sufocante, duradoura. A vida está ali de fato tocando a morte. Entre as paredes do cinema, o espectador sofre o emparedamento junto com os personagens, e não pode julgá-los.

Como diz Pedro Costa (2007a: 131), a ficção é sempre uma porta que queremos abrir, e no cinema de hoje, de Hollywood, a porta que se abre é a promessa da projeção de que o espectador se sentirá bem. O espectador quer ver a si mesmo na tela. O peso e o desafio de No quarto da Vanda está em fechar a porta para que o espectador veja a imagem, a imagem que diz “é", e nada mais. A pressão é para se ver realmente, e para isso é preciso que o espectador se mantenha à margem do filme. É preciso saber apenas ver, sem querer que o filme seja sua própria projeção. 
Comolli afirma que em No quarto da Vanda, o espectador está num falso lugar "nem 'bom' nem 'mau', deslocado, fora dos eixos, inútil talvez" (2007: 154). Na teoria do autor, o lugar da crise na espectatorialidade é esse em que os fenômenos de identificação e projeção — que se dão em função de transformações na narrativa e de ganhos e perdas que sofrem os personagens ao longo da história — não são possíveis. No quarto da Vanda contraria a "representação clássica" (Comolli, 2007: 151) pois não permite ao espectador jogar o mesmo jogo que os atores-personagens. Estamos fora desse sistema de representação, já que o filme institui-se como um "documento sobre provas vividas pelos corpos filmados durante sua gravação" (Comolli, 2007: 151). Aquele que vê é barrado e está ante uma obra que não o convida a participar da cena e a compartilhar algo dos personagens. Para o autor, essa obliteração é intensificada no filme, pois nada é dito, contado ou montado, há apenas um "quarto mortuário" onde Vanda se droga repetidamente. Nas palavras do autor, o que se passa nesse espaço "não é da ordem do olhar, manifesta ao contrário toda a impotência do olhar, o fracasso do visível diante do tempo que passa e a morte que trabalha" (Comolli, 2007: 151).

Sem espetáculo, o espectador não é aquele que vê Vanda se destruir, mas quem vê algo que se "oferece sem se dar a ver" (Comolli, 2007:151). Ou seja, o gesto lento da morte é o que se oferece e ao mesmo tempo não pode ser visto. $\mathrm{O}$ trabalho de morte está na repetição incessante do gesto de consumir a droga, na demolição do bairro, no enclausuramento de Vanda no quarto e na duração nas mesmas cenas. Formas de constrangimento a que os moradores de Fontainhas estão submetidos. Características que definem a cena constante do filme: o dispositivo de Costa. Para Comolli, esse trabalho ressalta a condição maquínica do cinema, o cinema como máquina de registro, de contagem do tempo. Sua versão descontínua, analítica, de fragmentar e repetir o movimento. Se a prisão está em toda parte e o constrangimento do tempo e espaço não se abre para que a personagem se 
ofereça à significação ou ao testemunho, para o autor, é impossível ao espectador projetar ali qualquer tipo de sentimento. Ele está "perturbado" pela cena que insiste em se repetir, e que não abre espaço para salvar aquela que se destrói. Vanda não tem desejo de se livrar das drogas. Prevalece a indiferença da personagem em relação a sua destruição e a indiferença da câmara de Costa àquele ato terrível.

Nada resta ao espectador diante da recusa da evolução, do progresso, da terapia, do salvamento. Para Comolli, por ser demasiadamente humana, Vanda é inútil para aquele que vê, sem finalidade ou uso. Tal indiferença, a princípio sempre falsa no cinema — pois filmar seria, de saída, conferir uma interpretação a algo, uma fabricação — para o autor é alcançada em No quarto da Vanda, uma vez que o ritual da droga desafia a narrativa e o drama, o cinema enfim. Por isso, o autor associa a câmara de Costa à câmara de vigilância que nada deseja e que é insensível ao sofrimento do outro. Eis o gesto de morte.

Diante de nós (que não podemos fazer nada, a não ser assistir sem esperança de assistência, como o próprio cineasta tendo renunciado à toda 'intervenção' portadora de sentido porque seria demasiadamente plena de sentido), o quarto se esvaía da presença de Vanda que é como um desafio mudo e cego a toda presença, no sentido forte dessa palavra no cinema. (Comolli, 2007: 152).

O lugar do espectador seria então falso, não-lugar onde nada pode ser partilhado. Se Vanda não muda, não há espaço para o espectador, ele não se encontra ali, por isso sobra, “é espectador em demasia" (Comolli, 2007: 152). A partilha possível através da perda, por exemplo, torna-se impossível, pois Vanda de fato vive a condição que a leva a morte. Mas ao mesmo tempo, Comolli confere ao espectador um lugar "entre" o ser e o não-ser, entre a vida e a morte. Concordamos que o espectador do espetáculo é frustrado e barrado em seu desejo de participar da cena. Não há espaço para 
o imaginário quando a clausura não é só aprisionamento no espaço, mas no ritmo da vida, no gesto que se repete, na indiferença de um corpo que se oferece a câmara. Porém, se seguirmos o raciocínio do autor de que Vanda é a recusa da transformação, a indiferença nela mesma, na qual conta apenas o trabalho de morte, trabalho maquínico do cinema, há de fato uma impossibilidade de jogo ou da partilha. Mas na medida em que aquilo que barra o espectador é de uma força tal que não há jogo, como é possível falar num lugar "entre" o jogo e o não-jogo? Se o lugar "entre" é um entre dois, onde está nesse par antinômico, o primeiro: o jogo?

Talvez Comolli esteja assumindo o jogo como um a priori do cinema, aquilo que é esperado pelo espectador no momento em que ele entra na sessão, o que constitui sua condição de espectador. Então estar entre o jogo e o não-jogo não é algo que o cinema e não o filme em si oferece. Por outro lado, se o filme não reinstitui o jogo, se não há participação na cena, e nenhum sentimento se constrói, há cinema? O que engajaria o espectador para persistir vendo? Se Comolli admite que o espectador está entre o sentido e o não sentido, entre o ser e o não-ser, perguntamo-nos onde está o sentido, o ser, se o autor na verdade ressalta apenas a morte, o não-ser, a recusa do filme em engajar o espectador. Se não há partilha de sentido, o cinema está fora do homem, perdeu-se como experiência.

Sabemos que não é esse o lugar para onde Comolli quer conduizir seu argumento. Ele afirma que a partilha é impossível, mas afirma também que ela existe na medida em que Vanda é quem nos partilha e nos dilacera. Então há afectos, somos afetados pelo filme. Encontramos aí a possibilidade desse espaço "entre" que pressupõe de imediato que o filme ao mesmo tempo concede e recusa algo ao espectador. Pensamos no outro lado que não é sombra, noite, mas luz, dia. Pensamos a "vanidade" de Vanda como forma de vida. Para Agambem (2000b), nenhuma vida pode ser separada de sua potência, a vida nua não pode ser isolada, ela "é" o viver, a imanência, sempre aberta a formas de resistência e fluxo. 
Ao contrário do que diz Comolli, esse lugar "entre" do espectador não poderia ser falso. Os termos falso e verdadeiro, bom e ruim, não parecem se adequar aí. Um lugar que dificulta um julgamento não é falso por oscilar entre possíveis. Talvez a melhor pergunta seja: o que se passa não é da ordem do ver (como o ver do espetáculo)? A despeito de participar ou não da cena, é possível ao espectador apenas olhar? É possível uma relação com o ver que passe pelo olhar sem julgamento, sem identificação plena? Ver não é consumir aquelas vidas, mas ser conduzido pela imanência do viver (vive-se), deixar-se atravessar pelos afectos. Se é possível estar num "entre", lugar legítimo para o espectador, é porque os embates entre a narrativa e o repetir-se, entre o drama e a não-significação, precisam ser melhor equacionados. Por mais fragmentada que seja, há narrativa no filme, seja por aquilo que os personagens dizem sobre suas condições de existência, seja pela montagem que permite a construção de uma história, ainda que frágil e precária. Essa história se faz nas relações entre Vanda e Pango, Vanda e a mãe, Vanda e Zita; Zita no hospital, Vanda na comunidade, Pango e sua relação com a droga. O bairro está sendo demolido, Vanda vende verduras, a mãe cozinha, Pango prepara sua mudança. Por isso é possível jogo.

Para Comollli, Vanda expressa a recusa de sentimentos, quando talvez seja preciso perceber nos intervalos entre os momentos em que ela se droga, aqueles em que partilha sua vida com os outros, representando um elo na comunidade. Assim, os personagens expressam sentimentos por ela que produzem afeto no espectador. A opção pelo ritual de drogar-se é manifestação ordinária ali, inscreve-se como forma de vida no filme. A indiferença não dá conta de todo o filme, ela é atravessada por elos frágeis que compõem as histórias, que permitem, inclusive, que se fale de "trabalho de morte" e não da morte como fim. É porque há vida numa experiêncialimite de estar próxima da morte que o espectador se situa nesse "entre", que é um lugar difícil, oscilante, exigindo do espectador outra relação com o 
ver. Se o espectador sobra, se o que se lhe oferece é pouco, é justamente porque seu lugar não é o do controle, mas o do deixar-se olhar e ser levado.

Estar entre vida e morte, luz e sombra, é possível porque o trabalho lento da morte se impõe como obliterarão do ver, ao mesmo tempo em que a luz pouca que se esgueira nas frestas dos cubículos afirma uma existência, mais ainda: afirma uma experiência. Na esteira de Agamben (2005: 25), Vanda talvez queira se desvencilhar de toda experiência ao drogar-se. Porém, uma vez que tal experiência a aproxima da morte, limite da experiência, é ali que o olhar se fixa e se adere. Ali mesmo, a impotência do espectador aponta para um outro lugar do cinema que não é o da transformação, das perdas e ganhos dos personagens, mas do devir. Vanda e seus vizinhos nos tocam, tanto como afetividade, o comum da vida partilhável no simples fato de viver, quanto nos afectos, essa força da qual não podemos falar, não sabemos julgar.

Para Comolli, Vanda esvazia o espaço do quarto. A repetição do ato de drogar-se torna-se um gesto maquínico. Mas o desejo pela droga está impregnado no espaço. O quarto guarda os vestígios da experiência-limite: o cobertor engordurado e puído em que Vanda escarra, limpa o nariz, deixa cair o pó da droga; a fumaça constante, as paredes descascadas, o saco de isqueiros, as pessoas que entram e saem, que convivem ali com ela. Parece que o paradoxo vida e morte coloca o espectador nesse entre, como esse caminho lento que se oferece a ver mas que oblitera a visão. Comolli afirma que o espectador é solicitado a confrontar o outro filmado. Ora, não seria essa solicitação uma forma de engajamento na vida, no sentido do ser? Como dizer que Vanda é sem uso para o espectador, como esperar uma assistência, ali onde só há inutilidade? Talvez o lugar vazio e falso do espectador seja o da presença de um cinema que não é mais assistencialista e dramático, bom ou mau, mas que implica o espectador num campo de forças bem mais complexo do que aquele no qual a identificação é a entrada. O quarto só é uma clausura porque está preenchido de vida, seja ela 
qual for. Se, como diz Comolli, "pertencemos a Vanda" (2007: 153) é porque também somos emparedados ao longo do filme.

A clausura ao extremo leva à consciência de um poder biopolítico que controla a todos, e do qual eu, espectador, de alguma maneira também sou vítima. Não "estou fora do lugar do espectador" (Comolli, 2007: 152), estou fora do lugar do espectador do espetáculo que consome vorazmente imagens e vê seu desejo satisfeito nas telas; fora do espectador dos programas de reality shows que crê controlar a vida dos outros porque os vigia, que goza com a intimidade do outro, que quer ver mais aquelas vidas assépticas. Assim como nada muda, meu lugar de espectador também é o mesmo, não muda, e manter-se nele é o aprendizado do ver, do saber ver para além de mim, o outro. Por isso, não sou "espectador em demasia" (Comolli, 2007:152), mas, parafraseando Godard, ${ }^{9}$ sou justo um espectador de uma vida qualquer.

No filme, o dispositivo que confina personagens, diretor e espectador não é uma invenção estratégica ou uma escolha, mas um encontro e um embate com o confinamento. É como se a imagem estivesse sempre aquém de uma vida por demais confinada, que os meios audiovisuais não podem inventar, nem simular. Se, como diria Comolli (2001a), algo do real resta ali, ele já é pura clausura, na repetição dos pequenos atos diários que se impõem como mandamentos e constrange a vida em seus cubículos.

A própria precariedade já é o constrangimento maior que impõe uma vida enclausurada, emparedada, já que o que mais vemos são as paredes, cinzas, beges, descascadas, sem cores, imagens ou figuras, com poucas janelas, que não se abrem para um horizonte, mas para outros espaços menores, para pedaços de muros (entulhos e detritos), onde há apenas poucos feixes de luz e a sombra se sobrepõe. A situação social mais ampla a

9 "Godard tem uma bela fórmula: não uma imagem justa, justo uma imagem. (...) 'justo ideias' é próprio do devir-presente, é a gagueira nas ideias; isso só pode se exprimir na forma de questões, que de preferência fazem calar as respostas. Ou mostrar algo simples, que quebra todas as demonstrações." (Deleuze, 1992:53). 
que os personagens estão sujeitos, a realidade crua da exclusão, está em toda parte, não roteirizada, não explicada, mas sentida pelo real que a imagem ao mesmo tempo não dá a ver de todo, mas aponta sem cessar por tons, ambiências, atos e ritmos claustrofóbicos.

Na Antiguidade e na Idade Média, as pessoas eram emparedadas, condenadas a viver, resistindo até a morte, nos escuros de pequenos vãos entre paredes. Conta-se que na Roma Antiga as vestais, moças virgens que perdiam a pureza, eram confinadas a cubículos onde morriam de fome ou asfixia. Trata-se do homo sacer, ${ }^{10}$ a vida que não pode ser sacrificada, mas que se pode matar. Nos campos de concentração, judeus eram entulhados em espaços escuros e reduzidos, mortos nas câmaras de gás: vida nua que podia ser eliminada. De um lado, a soberania inquestionável, de outro o poder da biopolítica. Ali, no quarto da Vanda, a vida está no próprio emparedamento, não há saídas, ela pode existir só ali, é uma vida quasemorte. Enquanto há paredes que não foram demolidas, circunscrevendo pequenos espaços, ainda vemos Vanda, Pango e seus vizinhos em seus modos de vida.

Essa experiência-limite do emparedamento está em Vanda completamente determinada pela droga, pois o que vemos na clausura é sua relação diária com as drogas: sua tosse compulsiva, os repetidos escarros, sua voz rouca, pilhas de isqueiros testados e acesos, catálogos de telefone, abertos e folheados para que o pó da droga seja raspado e usado, uma, duas, muitas vezes. Se a vida é uma quase-morte, ao mesmo tempo resiste à morte. Se o ato que se vê, incessantemente, é o de se drogar, Vanda sobrevive é na droga. Paradoxo vida-morte. Aquilo que a exclui dos códigos da normalidade é o que a inclui numa forma de vida qualquer, uma bios que nasce na clausura.

\footnotetext{
${ }^{10}$ Conferir Agamben, 2002.
} 
No dispositivo de Pedro Costa, a droga não é linha de fuga que permite Vanda e outros moradores alcançarem um fora dali. Ao contrário, a droga constitui aquele confinamento, assegura a existência. Nós, espectadores, não vemos as "viagens" de Vanda após consumir a droga, não estamos com ela em outro lugar ao qual a droga a levaria, nem a outra sensação, de prazer, liberdade ou êxtase; ao contrário sempre estamos ali, no quarto, na cama, nas repetidas vezes que o consumo se dá. Vemos acontecimentos concretos, atos corporais, a presença física da personagem - que tem os olhos amarelados envoltos por uma órbita vermelha, o rosto pálido e molhado de suor. Ela escarra na cama e dobra a colcha encardida e ensebada por cima do líquido que expeliu. Ela se cobre e cantarola seu frio: "estou com frio, frio, frio...". Outro dia, acorda, tosse, escarra, vomita, soa o nariz na colcha, e novamente se droga pra aplacar a ressaca constante, num ciclo que se repete. Em meio a poucos e curtos diálogos, passa grande parte do tempo na cama, cumprindo os movimentos repetitivos que a levarão a se drogar.

Nada muda com a droga, ao contrário, ela é parte da rotina de Vanda, pontuando-a com sua presença sempre reiterada. Mais ainda: a droga torna Vanda mais presente e carnal, próxima da morte, mas viva a nossos olhos, pois é o ritual que ela cumpre várias vezes ao dia, os movimentos mínimos que executa, o que pontuam sua presença na imagem. Acompanhar a vida de Vanda é esperar por esses momentos como parte de sua subjetividade.

Se o dispositivo se instaura no paradoxo vida e morte, é justamente porque a força de evidência do visível não pode ser apagada, nela está a vida de Vanda resistindo ali, no interior da prisão. A duração dos planos, a valorização dos enquadramentos, a exiguidade, a fixidez da câmera, enfim o confinamento que dá a ver a violência, o ruído, a sombra, o trabalho de morte, também acolhe a resistência, a palavra, a luz, uma vida. É a dupla face da biopolítica de que nos fala Foucault (1998): o poder que incide sobre a vida rouba sua potencialidade e a conforma, cria resistência, ou seja, 
outras formas de subjetivação. Assim como o cinema não consegue constranger por completo os corpos e a vida, por mais que a reduza e a modele, o poder também, para Foucault, vai, ao controlar, sempre criar o contra-poder, brechas por onde se esgueira o descontrole e o impensável. É de dentro do dispositivo que dá a ver o mundo em sua dimensão mais claustrofóbica que uma forma de vida qualquer se insinua.

\section{Referências bibliográficas}

AGAMBEN, Giorgio (2005), Infância e história. Destruição da experiência e origem da história, Belo Horizonte: Editora UFMG. (2002) Homo Sacer. O poder soberano e a vida nua I, Belo Horizonte: Editora UFMG.

COMOLLI, Jean-Louis (1975), "Técnica e ideologia" in Revista de cinema. n.1. agosto/setembro, Porto: A regra do jogo edições. (Textos traduzidos dos Cahiers du Cinéma n. 229, 230, e 321). (2001a), "Sob o risco do real" in Catálogo forumdoc.bh.2001, (5 festival do Filme Documentário e Etnográfico), Belo Horizonte. (2001b), "Cinema contra espetáculo" in Catálogo forumdoc.bh.2001, ( $5^{\mathrm{a}}$ festival do Filme Documentário e Etnográfico), Belo Horizonte. (2004a) Voir et Pouvoir. L'innocence perdue: cinema, télévision, fiction, documentaire. Paris: Éditions Verdier. (2004b) "Não pensar o outro, mas pensar que o outro me pensa" in Revista Devires - Cinema e Humanidades. Belo Horizonte: Universidade Federal de Minas Gerais. Faculdade de Filosfia e Ciências Humanas (Fafich), v. 2., n.1. (2007) "O anti-espectador" in Catálogo forumdoc.bh.2007, (11 festival do Filme Documentário e Etnográfico), Belo Horizonte. 
O confinamento de Vanda ...

COSTA, Pedro (2007a), "Uma porta fechada que nos deixa a pensar" in Catálogo forumdoc.bh.2007, (11 ${ }^{\mathrm{a}}$ festival do Filme Documentário e Etnográfico), Belo Horizonte.

(2007b), Entrevista em áudio concedida a Daniel Ribão. Produção Procurarte - associação cultural e social e Filmes de Quintal.(encarte) in Catálogo forumdoc.bh.2007 (11 a Festival do Filme Documentário e Etnográfico), Belo Horizonte.

DELEUZE, Gilles (1992), Conversações, Rio de Janeiro: Ed 34.

FOUCAULT, Michel (1998), História da sexualidade I: a vontade de saber, Rio de Janeiro: Edições Graal.

MIGLIORIN, Cezar (2005), O dispositivo como estratégia narrativa. Disponível em: http://www.estacio.br/graduacao/cinema/ digitagrama/numero3 /cmigliorin.asp

RANCIÈRE, Jacques (1996), O desentendimento. Política e filosofia, São Paulo: Ed 34.

VEIGA, Roberta (2008), A estética do confinamento: o dispositivo no cinema contemporâneo, Tese de doutorado, PPGCOM, FAFICHUFMG. 


\title{
REALISMOS AUDIOVISUAIS: VISIBILIDADES INTERTEXTUAIS EM DOCUMENTÁRIOS TELEVISIVOS
}

\author{
Rosana de Lima Soares *
}

Resumo: $\mathrm{O}$ artigo tem como objetivo o estudo de discursos das mídias de caráter realista a fim de estabelecer uma análise contrastiva entre eles. Buscaremos demonstrar que o estabelecimento das fronteiras entre fato e relato se faz no tensionamento dessas posições, alargando os limites entre "referencialidade" e "ficcionalidade" em narrativas audiovisuais, contribuindo para a reflexão sobre o estatuto da imagem na atualidade. Fatos e relatos colocam-se, assim, como estratégias complementares na organização desses discursos, embaralhando as fronteiras entre realidade e fabulação. Por meio da análise do documentário televisivo "Make Bradford British", exibido pelo canal inglês Channel Four, exploramos a questão dos novos realismos presentes nos discursos das mídias a partir da observação dos modos de construção da representação de diferentes sujeitos nas mídias.

Palavras-chave: Documentário. Televisão. Políticas da representação. Reality TV. Estigmas sociais.

Resumen: Este artículo tiene como objetivo estudiar los discursos de los medios de carácter realista con el fin de establecer un análisis contrastivo entre ellos. Intentaremos demostrar que el establecimiento de las fronteras entre hecho y relato se hace en el tensionamiento de esas posiciones, ampliando los límites entre "referencialidad" y "ficcionalidad" en las narraciones audiovisuales y contribuyendo a la reflexión sobre el estatuto de la imagen en la actualidad. Hechos y relatos se presentan, así, como estrategias complementarias en la organización de estos discursos, enmarañando las fronteras entre realidad y fabulación. A través del análisis documental televisivo Make Bradford British, exhibido por el canal inglés Channel Four, exploramos la cuestión de los nuevos realismos presentes en los discursos de los medios a partir de la observación de los modos de construcción de la representación de diferentes sujetos en los medios de comunicación.

Palabras clave: documental, televisión, políticas de representación, reality $t v$, estigmas sociales.

Abstract: This research aims to study media discourses which convey a realistic approach in order to perform a contrastive analysis between them, pointing out proximities and differences. As one of my research hypothesis I intend to demonstrate that the limits between fact and reality occur at the very tensioning of their assumed grounds. New realisms are established in audiovisual narratives broadening the boundaries between "referentiality" and "fictionality", thus contributing to the debate on the contemporary statute of images. Through the analysis of the British television documentary "Make Bradford British" (Channel Four), I intend to report on the issue of new realisms identified

\footnotetext{
${ }^{*}$ Universidad de São Paulo, ECA - Escola de Comunicação e Artes, Programa de Pósgraduação em Meios e Processos Audiovisuais. 05508-020, São Paulo, Brasil. Email: rosanasoares@gmail.com
}

Submissão do artigo: 28 de junho de 2015. Notificação de aceitação: 20 de agosto de 2015. 
on media discourses today recurring to a historical perspective on the modes of addressing the concrete world. stigmas.

Key words: documentary, television, politics of representation, reality tv, social

Résumé: Cet article vise à étudier les discours du caractère réaliste des médias afin d'établir une analyse contrastée entre eux. Nous cherchons à démontrer que l'établissement de la frontière entre le fait et sa relation se fait jour dans la mise en tension de ces pôles, repoussant les limites entre «référentialité» et «fictionnel» dans les récits audiovisuels, et contribue à la réflexion sur le statut de l'image aujourd'hui. Faits et histoires sontse trouvent ainsi disposés, comme des stratégies complémentaires dans l'organisation de ces discours, brouillant les lignes entre réalité et fabulation. Grâce à l'analyse du documentaire de télévision "Make Bradford British" (Rendre Bradford britannique), diffusé sur Channel Four, nous explorons la question du nouveau réalisme du discours des médias, à partir de l'observation dans ceux-ci des modes de construction et de représentation des différents sujets.

Mots-clés: documentaires, la télévision, la représentation politique, Télé-réalité, stigmates sociaux.

$\mathrm{O}$ artigo tem como objetivo o estudo de discursos das mídias de caráter realista a fim de estabelecer uma análise contrastiva entre eles. Buscaremos demonstrar que o estabelecimento das fronteiras entre fato e relato se faz no tensionamento dessas posições, alargando os limites entre "referencialidade" e "ficcionalidade" em narrativas audiovisuais, contribuindo para a reflexão sobre o estatuto da imagem na atualidade. Fatos e relatos colocam-se, assim, como estratégias complementares na organização desses discursos, embaralhando as fronteiras entre realidade e fabulação. Por meio da observação de documentários e reportagens, exploramos a questão dos novos realismos presentes nos discursos das mídias a partir de uma perspectiva histórica sobre as formas de endereçamento do mundo concreto, passando pelas injunções das imagens técnicas frente a uma cultura audiovisual cada vez mais marcada por processos que visam produzir determinados efeitos de realidade, oscilando entre o retorno do real e o elogio da ficção. 
Tomamos a expressão "novos realismos" a partir da definição de Jaguaribe, que aponta no cinema iraniano, no manifesto do grupo escandinavo Dogma, no cinema engajado britânico, nos documentários contemporâneos, em filmes latino-americanos sobre conflitos urbanos, entre outros exemplos, os "novos registros do realismo" como um fenômeno global - presentes não apenas no cinema, mas também na literatura, na fotografia e nas mídias - que contribui para os modos de percepção da realidade: "No Brasil, os novos realismos despontam dentro de gêneros como o romance policial e a narrativa da violência marginal, ou em retratos do cotidiano que esmiúçam, com maior ou menor pendor psicológico ou naturalista, os impasses de vidas anônimas" (Jaguaribe, 2007:11).

Sabemos ser este um tema abrangente e, desse modo, iremos nos deter em exemplos recentes voltados à construção da representação de diferentes sujeitos nas mídias. Buscamos identificar, nas imagens, as maneiras pelas quais se estabelecem os espaços de visibilidade/invisibilidade em relação a grupos minoritários estigmatizados no cenário social. Nas oscilações entre reforço ou transposição de estigmas, tais narrativas audiovisuais empreendem, em relação ao "outro" para o qual se voltam, processos de assujeitamento ou, ao contrário, de protagonismo. Nesse confronto de representações, para além de visões hegemônicas, uma pergunta norteia a proposta: se as realidades são discursivamente construídas, como propor modos de representação do "outro" da forma mais ativa (e altiva) possível?

Ao apontar que, recentemente, as contradições sociais têm sido tematizadas, na produção teórica e audiovisual contemporânea, por meio das relações entre estética e política, Figueiredo nos alerta: "Se, no passado, ao fazer referência ao abismo entre as elites e o povo, falava-se dos que tinham ou não tinham voz, hoje, fala-se, cada vez mais, dos que possuem ou não possuem visibilidade" (Figueiredo, 2012: 11). Mais do que a proliferação de imagens ou o excesso de exposição, "é a imagem mais do que a palavra, o 
espectador, mais do que o ouvinte ou o leitor, que servem de ponto de partida quando se trata de refletir sobre a necessidade de alterar a distribuição de papéis e competências hierarquicamente estabelecidos" (Figueiredo, 2012: 11), fato que nos coloca frente às especificidades da cultura audiovisual contemporânea, sobre a qual iremos refletir em alguns de seus aspectos.

Desse modo, a estética realista e a hiper-realidade; a retórica testemunhal e a ênfase em visualidades precárias; as políticas de partilha do sensível e os novos regimes de visibilidade, entre outros, são elementos fundamentais para problematizarmos o estatuto das imagens hoje. A dimensão da cultura, e os processos de sua legitimação por meio dos discursos circulantes, possibilita que pensemos a produção audiovisual como sintoma de uma época pautada pelo desajuste, pelo transbordamento e pelo conflito, aspectos que se fazem presentes, portanto, em tal produção.

Ao nos indagarmos sobre as maneiras pelas quais a autenticação da realidade se impõe nas narrativas da televisão e do cinema, indagamo-nos, também, sobre as possibilidades de delinear os contornos de um realismo crítico e político, oscilando entre uma forma documental de expressividade e o melodrama ficcional narrativo. Para além da construção de efeitos de realidade, em que ocorre o mascaramento dos processos de ficcionalização nela implicados, vemos nas narrativas audiovisuais uma espécie de retorno pregnante do real (na forma de choque, paixão ou horror) ${ }^{1}$ contrapondo-se ao elogio disperso da ficção (na encenação reiterada do mundo vivido). ${ }^{2}$

\footnotetext{
${ }^{1}$ A exemplo do que apontam diversos teóricos, as narrativas audiovisuais contemporâneas se constituem por meio de inúmeros hibridismos e, mais do que isso, a partir de uma reiteração da possibilidade de representação fiel (ou verdadeira) da realidade. A expressão "choque do real", cunhada por Beatriz Jaguaribe em livro homônimo, é por ela definida como sendo "a utilização de estéticas realistas visando suscitar um efeito de espanto catártico no leitor ou espectador" (Jaguaribe, 2007: 100). Para a autora, o impacto do "choque" não vem de seu caráter extraordinário, mas de sua intensificação. Ainda nesse sentido, a "paixão pelo real" (em expressão de Badiou, 2002), ou o "retorno do real" (nas palavras de Foster, 1999), fazem-se presentes em diversos discursos das mídias, de modo especial na televisão e no cinema, sinalizando a presença marcante de elementos de
} 
Se, a partir da psicanálise, o Real é aquilo que insiste, mas não resiste à simbolização, é no registro do imaginário que podemos investigar as atuais políticas de construção da representação frente às posições de totalização ou inadequação, adesão ou fricção, transparência ou opacidade, presentes nas narrativas audiovisuais, pensadas não como categorias estanques, mas como formas genéricas: "Contra a ficção que pretende existir por si mesma, como reflexo do real, é proposto o discurso que fala sobre suas próprias condições de existência e, portanto, afirma-se como reflexo do trabalho de produção e de suas funções sociais e materiais" (Xavier, 1984: 134). Assim como a opacidade permite que seja desvelado o dispositivo, ao negar a transparência do discurso audiovisual provoca o tensionamento dessas posições, apontando para outros modos de dar a ver o visível.

Ao voltarmo-nos para os modos de construção da realidade em narrativas audiovisuais assumimos, portanto, que processos de ficcionalização se fazem presentes para o engendramento da referencialidade pretendida em tais discursos, tanto no caso de produções de caráter factual, como naquelas propriamente ficcionais. Nas palavras de Jaguaribe, "o paradoxo do realismo consiste em inventar ficções que parecem realidades" (Jaguaribe, 2007: 16). Mais do que isso, desde a modernidade compreende-se que as realidades são socialmente fabricadas, ou seja, "que os imaginários culturais são parte da realidade e que nosso

realismo/naturalismo ou delineando o "deserto do real" e seu potencial catártico (como afirma Zizek, 2002).

${ }^{2}$ Nesse sentido, lembramos a obra de Wolfgang Iser, especialmente no que diz respeito ao princípio da representação, em que o realismo seria, também ele, fictício ou imaginário pois estes se apresentam como "disposições antropológicas" com poder libertário em relação às normas culturais estabelecidas (Iser, 2013). A obra de Umberto Eco, especialmente ao tratar dos conceitos de autor e leitor modelos (ou implícitos), aproxima-se de Iser em sua dimensão da recepção como um modo ativo de participação (Eco, 1994). Além desses autores, Peter Gay, aponta os modos diversos de endereçamento da realidade em obras de ficção, notadamente naquelas de cunho predominantemente realista (Gay, 2010). 
acesso ao real e à realidade somente se processa por meio de representações, narrativas e imagens" (Jaguaribe, 2007: 16).

Interessa-nos, assim, explorar as tensões advindas dessa relação e seus modos de inscrição nos discursos das mídias, produzindo efeitos de sentido que vão da ilusão da objetividade ao testemunho da verdade em tais narrativas (cf. Soares; Freire, 2013). É importante destacar que, na passagem do fato ao relato, um processo de narrativização se inscreve nos discursos referenciais, no qual determinadas formas narrativas contribuem para produzir efeitos de sentido que corroboram seus pressupostos, ou seja: "Só podemos conhecer o real comparando-o ou equiparando-o ao imaginável" (White, 1994: 115).

Do ponto de vista metodológico, buscamos abordar os novos realismos por meio da temática dos estigmas sociais presentes em narrativas audiovisuais. Ao falarmos de mídias e estigmas partimos de alguns postulados. $\mathrm{O}$ primeiro diz respeito à dinâmica dos processos de identificação; o segundo diz respeito aos discursos referenciais a partir da assunção de seu estatuto enquanto construção na linguagem, lembrando o caráter arqueológico dessa criação; o terceiro diz respeito à definição de discurso sob três aspectos: a) a linguagem é constituinte do humano; b) o mundo vivido é instaurado pela linguagem; c) o discurso é um laço social que se desenvolve na linguagem. Nas diferentes posições ocupadas pelos sujeitos no tecido social; nos embates entre cada um e todos os outros; nas demarcações entre estigmas, estereótipos e preconceitos; nos modos de estabelecimento dos espaços de visibilidade e invisibilidade social; e nas disputas por formas hegemônicas de construção da representação nos discursos circulantes, identificamos um terreno fértil para a problematização de tal questão. Se o retorno do real surge como resposta ao elogio da ficção, novos realismos parecem também apontar para novos modos de ficcionalização. 
A produção televisual recente, notadamente documentários, grandes reportagens e reality shows (estes últimos considerados não enquanto programas isolados, mas como um gênero televisivo que se espraia por diversos outros gêneros) constitui a amostragem ampliada da proposta. Nesse sentido, destacamos as produções integrantes daquilo que se convencionou chamar de "reality tv" (ou "factual tv", incluindo documentários jornalísticos), do qual fazem parte não apenas reality shows, mas também documentários, séries, seriados, reportagens, programas de auditório ou de variedades, enfim, uma imensa gama de gêneros e formatos que confluem para este que seria, a partir de nossas observações, o modo privilegiado presente na televisão atual (cf. Machado; Vélez, 2009; Kavka, 2012).

A partir da observação da programação televisiva e da aderência aos reality shows - tanto do lado da produção, como da recepção -, notamos que, ao contrário do que acontecia anteriormente, as formas de inscrição da realidade na televisão tem se pautado por novos realismos. Nesse sentido, a realidade é encenada através de diferentes formas narrativas oriundas da ficção. A reality tv torna-se a narrativa televisiva predominante, para além dos reality shows, como se os gêneros televisivos se endereçassem de algum modo a ela. Essa demarcação é tomada como uma espécie de marca distintiva (ou até mesmo uma vocação da produção televisiva), apontando sua inserção na produção audiovisual recente.

Ao observarmos os programas televisivos, tomamos como ponto de partida formas narrativas impuras, que privilegiam a referencialidade mas englobam estratégias de ficcionalização. Para alcançar nosso intuito, estabelecemos nesse momento diálogos com a produção inglesa, buscando demonstrar como as questões dos hibridismos e dos novos realismos se apresentam em diferentes culturas, enfatizando os conceitos articuladores das análises. Desse modo, buscamos tratar não apenas de um dos grandes eixos no estudo das imagens hoje, mas também iluminar, ainda que de modo 
tangencial, a dinâmica da produção audiovisual, em que as especificidades nos modos de produção, circulação e recepção tornam singulares seus diferentes discursos, dentre os quais destacamos a televisão.

Em termos conceituais, finalmente, observamos os espaços da presença/ausência de atores sociais não hegemônicos, bem como os pontos de redundâncias e ressonâncias dos estigmas sociais nos discursos das mídias; as formações discursivas como espaços de intertextualidade e heterogeneidade, comumente referidas nos debates sobre convergências midiáticas e hibridismos narrativos; as novas posicionalidades do sujeito em meio à proliferação de imagens e, consequentemente, as transformações no imaginário social; as políticas de representação ou as atuais formas de "partilha do sensível” (cf. Rancière, 2005), especialmente aquelas relacionadas a figuras de alteridade, estabelecendo as tensões entre as narrativas do mesmo e do outro nelas apresentadas (Prado, 2008).

Em relação à amostragem, interessam-nos os "contratos comunicacionais" (ou "pactos de leitura") frente aos novos "regimes de visibilidade" em que os discursos referenciais ${ }^{3}$ deslizam para narrativas híbridas presentes nas mídias por meio de novos realismos: "Para nós que discutimos os regimes de visibilidade dos media, construídos em torno dos contratos de comunicação voltados a modalizar formas de ser e de fazer o corpo e com o corpo, sustentando-se em valores simbólicos ligados ao mundo do consumo, tais formas de ver e de ser olhados pelos objetos culturais é preciosa" (Prado, 2012: 181). Desse modo, reportagens e documentários não são considerados de maneira estanque, ressaltando as interfaces entre referencialidade e ficcionalidade presentes na televisão e no cinema.

\footnotetext{
${ }^{3}$ Discursos voltados à experiência da realidade, em que elementos históricos são tomados de forma supostamente objetiva para compor os relatos sobre os fatos, ao contrário do que é suposto nos discursos ficcionais, em que modos de fabulação são prioritariamente acionados na composição de suas narrativas (ver Barthes, 1988).
} 
Assumindo, portanto, o hiato desde sempre incontornável entre linguagem e referente, e embasados pelos debates sobre convergências midiáticas e hibridismos discursivos, vislumbramos um conjunto de imagens que oscila entre as fronteiras movediças das narrativas impuras, mescladas por meio do trânsito entre elementos estéticos e tecnológicos. A crítica ao conceito de representação e sua desconstrução, como apontamos no início do artigo, é um importante eixo teórico-metodológico para as análises, problematizando tensionando narrativas de caráter referencial a partir dos modos de "dar a ver" as figuras de alteridade nelas presentes e as políticas de representação nelas ensaiados. Entendemos "política" na acepção dada por Rancière a este conceito: "A atividade política é a que desloca um corpo do lugar que lhe era designado ou muda a destinação de um lugar; ela faz ver o que não cabia ser visto, faz ouvir como discurso o que só era ouvido como barulho", alterando, assim, os regimes de visibilidade (Rancière, 1996: 42).

Dentro desse cenário, a questão dos modos de construção da representação - especialmente de sujeitos tradicionalmente deles excluídos - pode ser elaborada a partir de alguns apontamentos, em que os discursos (ou seus vestígios) articulam-se, inicialmente, a partir da aproximação a um outro diverso e distante. Vemos surgir nessas narrativas um outro não representável e que, ao longo delas, oscila entre ausência e presença, invisibilidade e visibilidade. Em termos de posições discursivas, podemos afirmar que o outro, qualquer que seja ele, pontua desdobramentos que vão dos não ditos à inclusão consentida para, finalmente, assumir lugar de protagonismo, apontando para momentos de afirmação e identificação. Nas palavras de Geertz, ao tratar das relações entre aqueles que podem propor modos de representar o outro e aqueles neles representados, "o fim do colonialismo alterou radicalmente a natureza das relações sociais entre os que perguntam e observam e os que são perguntados e observados" (cf. Geertz, 2005: 172), problematizando os relatos produzidos sobre os outros, 
próximos ou distantes, e acentuando o caráter conflituoso desse encontro com a alteridade.

Pensemos na proposição de Hall a respeito de identidades desalojadas de tempos, lugares e tradições específicos, identidades que parecem "flutuar livremente" (Hall, 2000: 75) no contexto de uma vida social globalizada em seus estilos, com participação ativa dos sistemas de comunicação interligados e das imagens da mídia. Desse modo, podemos afirmar que o "outro" opera de modo relacional com o "mesmo"; incomoda justamente quando se torna mais semelhante a este. A questão dos estigmas sociais, por exemplo, aponta para esse aspecto: diferentemente dos preconceitos, eles dizem respeito ao outro que se torna próximo quando, ao contrário, deveria permanecer "em seu lugar", não encontrando, por isso, espaço nos discursos circulantes. De acordo com Charaudeau, "o discurso circulante é uma soma empírica de enunciados com visada definicional sobre o que são os seres, as ações, os acontecimentos, suas características, seus comportamentos e os julgamentos a eles ligados" (Charaudeau, 2006: 118).

As polêmicas passagens que envolvem as formações discursivas não surgem, portanto, do exterior, mas presumem a partilha do mesmo campo discursivo e das normas a ele associadas. Se o discurso constrói, em um mesmo movimento, sua identidade e sua relação com outros discursos, verdade e ficção se entrelaçam em tramas complexas, possibilitando caminhos nos quais tecer as narrativas audiovisuais.

\section{Representações da (in)visibilidade em narrativas audiovisuais}

A produção televisiva inglesa é amplamente reconhecida por meio da rede de televisão inglesa BBC - British Broadcasting Corporation -, uma emissora pública do Reino Unido fundada em 1922. Regulamentada pelo Estado, produz um grande e variado volume de programas, por meio de 
diversas estações de rádio e canais de televisão, atuando tanto em nível nacional como internacional. Tradicionalmente tida como produtora de programas de qualidade, tanto no rádio como na televisão, a BBC tem atuado na criação e renovação de gêneros audiovisuais, contribuindo para o estabelecimento de modos inovadores de fazer televisão, tanto em termos narrativos como estéticos. De formato único, combinando um modelo de gestão pública e estatal, nos últimos anos a emissora tem passado por crescentes transformações, especialmente após a entrada, no mercado britânico, de emissoras privadas, entre elas o Channel Four Television Corporation, criado em 1982 por um ato do Parlamento Britânico. Em termos de audiência, a rede é a quarta maior emissora de televisão do Reino Unido, atrás apenas da ITV (uma emissora comercial), da BBC One e da BBC Two. A exemplo de outras emissoras britânicas, por ser uma empresa de serviço público o Channel Four deve exibir conteúdo diversificado e de qualidade, ainda que não receba, como a BBC, financiamento público.

Notemos, curiosamente, que ao contrário do que ocorre em canais brasileiros a categoria reality shows não é encontrada separadamente nos sites da $\mathrm{BBC}^{4}$ ou do Channel Four ${ }^{5}$ (entre as seções, temos "drama", “comédia", "entretenimento" e "factual"), sinalizando uma importante questão, qual seja: a de que em um dos países mais destacados na produção televisiva, tal formato está espraiado em vários outros, confirmando uma das hipóteses. Da vasta produção televisiva inglesa iremos nos deter, portanto, na programação factual, termo utilizado no site das emissoras citadas ou, de modo mais abrangente, na chamada reality $t v$, destacando sua originalidade: ao percebermos o alcance da "telerrealidade" para além de seu formato mais direto (os reality shows) podemos afirmar que, longe de se caracterizar como um gênero específico, a reality tv surge, no atual

\footnotetext{
${ }^{4}$ Disponível em: www.bbc.com.

${ }^{5}$ Disponível em: www.channel4.com.
} 
momento, como o próprio modo de operação da televisão, notadamente na Inglaterra. ${ }^{6}$

A fim de demonstrar essa premissa e as linhas principais de sua observação, iremos tecer algumas considerações sobre o programa "Make Bradford British", ${ }^{7}$ documentário televisivo ${ }^{8}$ que mescla elementos de grandes reportagens, programas de entrevistas e reality shows. Lembramos, nesse momento, a importância que os gêneros factuais possuem tradicionalmente na televisão britânica, apontando para uma realidade bastante específica e instigante: a grande produção de documentários televisivos sem pensá-los de modo reducionista, colocando-os lado a lado com séries, seriados, reportagens, telejornais e realities. A pregnância das formas narrativas definidoras da reality tv é preponderante, contando com bastante aceitação não apenas por parte da audiência, mas também de produtores e realizadores. Desse modo, a maior ênfase na produção de teledramaturgia por meio de séries, seriados e novelas, além de reality shows propriamente ditos, é uma característica que perpassa a programação inglesa, confirmando também a tendência na produção de documentários e reportagens com estratégias ficcionais em suas narrativas.

Nesse ponto, uma importante característica da produção televisiva britânica se sobressai: o hibridismo de gêneros se faz de diversos modos, tanto em termos estilísticos, como tecnológicos. As fronteiras entre sensacionalismo, entretenimento, documentário e informação não estão claramente demarcadas, pois o que observamos é a presença crescente de

\footnotetext{
${ }^{6}$ Uma vasta bibliografia sobre o tema tem sido produzida por estudiosos de televisão, dentre eles destacamos: Holmes, S. \& Jermyn, D. (eds.) (2004). Understanding reality television. New York: Routledge; Murray, S. \& Ouellette, L. (eds.). (2004). Reality TV: remaking television culture. New York: New York University Press; Hill, A. (2005). Reality TV: audiences and popular factual television. New York: Routledge; Ouellette, L. (ed.) (2014). A companion to reality tv. Oxford: John Wiley \& Sons.

${ }^{7}$ Informações detalhadas em: www.channel4.com/programmes/make-bradford-british.

${ }^{8}$ Adotamos a terminologia utilizada pelo diretor, condizente com a visada inglesa, ainda que, nos estudos de televisão no Brasil, o programa provavelmente seria chamado de "série televisiva".
} 
programas que utilizam, em diferentes graus, esses elementos. Talvez a combinação de aspectos factuais e ficcionais seja justamente aquela que propicia a estruturação de um padrão de programação baseado no que estamos chamando de reality $t v$. No caso do Reino Unido, a diversidade étnica e cultural coloca em primeiro plano problemas relacionados ao multiculturalismo, imigração, xenofobia e segregação racial, temática na qual se insere o documentário televisivo "Make Bradford British", desenvolvido para o Channel Four em $2012^{9}$ e dirigido por Heenan Bhatti, ${ }^{10}$ realizador que produziu filmes, séries e documentários (como diretor e roteirista), além de atuar, anteriormente, como repórter para jornais e telejornais.

O programa contou com a participação de oito personagens, que foram agrupados em duplas compostas por pessoas com formações culturais bastante distintas para que cada um pudesse viver a vida do outro no cotidiano, dividindo com ele o mesmo espaço. Diferenças étnicas, raciais, geracionais, educacionais, profissionais, regionais, de gêneros, religiosas, culturais, políticas e econômicas foram ressaltadas para que os participantes pudessem pensar sobre as vantagens e desvantagens de se viver mais próximos ou distantes de pessoas radicalmente distintas deles mesmos, enfrentando os conflitos decorrentes desse convívio. Na maior parte, os

\footnotetext{
${ }^{9} \mathrm{O}$ documentário televisivo, composto de duas temporadas, foi realizado em quatro meses e produzido em um ano, contando com aproximadamente cem horas de gravação por episódio e sete semanas de edição. Cada episódio custou por volta de 150 mil libras, valor elevado mesmo se comparado àqueles relativos a um capítulo de uma telenovela da Rede Globo, e pouco frequente, no caso brasileiro, em outros formatos televisivos dramatúrgicos ou informativos. Bradford foi escolhida por ser uma das cidades consideradas mais segregadas no Reino Unido. Em 2014, uma outra temporada, chamada Make Leicester British, foi produzida nos mesmos moldes e com a mesma equipe, reunindo quatro participantes ingleses e quatro imigrantes de países diversos (três de países europeus e um da Somália) para tratar questões relativas à imigração e identidade, tema recorrente no debate sobre países europeus. Ver: http://www.channel4.com/programmes/make-leicesterbritish.

${ }^{10}$ Em nossa pesquisa de pós-doutorado, tivemos a oportunidade de acompanhar uma palestra e realizar uma entrevista com o diretor, além de assistir ao making of e a alguns episódios do programa, na Birmingham City University (Inglaterra), em 28 de novembro de 2013.
} 
embates foram travados em torno de questões raciais e étnicas, justamente em um programa que busca tematizar o multiculturalismo presente na sociedade britânica. Preconceito racial contra de brancos para negros, entre mulheres cristãs ou muçulmanas, entre brancos e muçulmanos, e mesmo divergências religiosas entre muçulmanos foram algumas das situações retratadas nos episódios a partir de duplas de personagens.

É assim que Rashid (37 anos, ex-jogador de rúgbi e pertencente à comunidade árabe), Maura (66 anos, juíza aposentada e moradora de um dos bairros mais ricos da cidade), Mohammad (41 anos, motorista de táxi de origem árabe), Jens (71 anos, policial aposentado e morador de uma região predominantemente formada por moradores brancos), Audrey (48 anos, mãe de três filhos e gerente de um pub), Sabbiyah (22 anos, muçulmana de origem paquistanesa nascida na Inglaterra e formada em filosofia e política), Damon (24 anos, metalúrgico e morador de um bairro em que 90\% dos moradores são brancos), Desmond (47 anos, trabalhador em serviço de limpeza e um dos poucos negros a morar em um bairro branco) se encontram e iniciam seu convívio com situações diversas das suas. Alguns dos momentos que demonstram as dificuldades dessa experiência se deram, justamente quando Rashid insistentemente paralisava sua participação no programa para suas orações cinco vezes ao dia, ou no desconforto de Sabbiyah ao trabalhar no pub gerenciado por Audrey.

Em sua entrevista, Bhatti afirmou que define seus trabalhos a partir de uma inquietação: quais são as histórias que valem a pena ser contadas e qual a melhor forma de fazer isso? Cada história, segundo ele, é singular e deve ser destacada dentre outras, seja em formato cinematográfico ou televisivo. No caso da televisão, o menor tempo de produção pode determinar alguns dos resultados, mas os assuntos voltados a atualidades, seja em forma de notícias ou reportagens, encontram mais espaço nessa mídia. Tradicionalmente, os documentários televisivos têm se dedicado a temas culturais, enfatizando a importância em narrar histórias de diferentes 
atores sociais e buscando a melhor maneira de contar essas histórias por meio de personagens fortes. Um aspecto importante foi ressaltado pelo diretor ao afirmar que há diferentes maneiras de se filmar uma história, inclusive em termos de escolhas narrativas e de gêneros, mas que atualmente é possível realizar narrativas hibridizadas e que misturem, inclusive, entretenimento e informação visando apresentar ao público a maior variedade possível de temas históricos, culturais, sociais e políticos.

Buscando agregar um grupo de pessoas que pudesse representar, de modo abrangente, aspectos multiculturais presentes em diversas regiões do Reino Unido - reproduzindo uma espécie de microcosmos com indivíduos variados - e que, ao mesmo tempo, fosse capaz de compreender as diferentes comunidades constituintes da sociedade britânica e da cidade retratada, o programa visava construir seus personagens da maneira mais aprofundada possível. Para definir os oito participantes, partiu-se de candidatos que não haviam passado em um exame de cidadania aplicado pela imigração britânica. A seleção se mostrou bastante complexa por ser, na opinião da equipe de produção, a chave definidora do programa, já que este deveria falar sobre sujeitos diversos e a posição que cada um deles ocupa na sociedade britânica. Encontrar boas histórias em comunidades de diferentes origens étnicas e culturais seria possível, segundo Bhatti, apenas se os produtores conseguissem criar bons personagens a partir dos participantes escolhidos, capazes de ao mesmo tempo entreter, cativar e desafiar a audiência.

De modo semelhante a alguns documentaristas brasileiros, entre eles Eduardo Coutinho, a passagem do indivíduo concreto ao personagem - e a naturalidade com que atores não-profissionais poderiam interpretar papéis que representassem a eles mesmos - foi um dos desafios apontados pelo diretor: "A respeito da relação entre pessoa e personagem ocorre algo interessante. Se a filmo durante uma hora, ficam na edição final cinco ou sete minutos. Faço dela um concentrado daquilo que eu acho que é o melhor 
que ela possa ter" (Coutinho, 2014: 175). Além disso, a questão da edição foi colocada com um dos pontos fundamentais da produção, já que tanto a narrativa como os personagens, de acordo com Bhatti, foram construídos no momento da montagem. Muitas vezes um personagem pode parecer excelente no momento da filmagem e, ao chegar o momento da edição das imagens, sua presença se dilui em detrimento de outro.

Nesse ponto é interessante apontar um aspecto inusitado ao pensarmos as produções televisivas britânicas e brasileiras: enquanto no Reino Unido o modelo de produção televisiva parece acompanhar aquele da produção documental (inclusive com a forte presença de documentários televisivos), no Brasil ocorre algo oposto, afastando a televisão da estética documental. No caso brasileiro, tradicionalmente a televisão (incluindo séries, reportagens ou novelas, com pequena presença de documentários) tem utilizado procedimentos de produção bastante distintos daqueles utilizados nos documentários, fato que podemos observar ao nos debruçarmos sobre entrevistas, depoimentos e relatos de realizadores, diretores e roteiristas. De modo análogo, a própria definição de "documentário" parece ser mais ampla no Reino Unido, podendo contemplar vários formatos neste gênero, incluindo educacionais, reflexivos, científicos, tradicionais, ficcionais, jornalísticos e até mesmo, como mostrado, produções seriadas.

Isso aponta para uma questão fundamental: para além da distinção entre jornalismo e cinema, ou entre reportagens e documentários, tratandoos como gêneros ou formatos separados, interessa-nos ressaltar seus pontos de contato, suas zonas de aproximação e seus espaços limítrofes, justamente pensados em produções hibridizadas em termos de discursos audiovisuais e seus efeitos de sentido (cf. Nichols, 1991; Winston, 2005). É importante sublinhar, nesse sentido, a preocupação da produção do documentário televisivo no que diz respeito à relação dos gêneros integrantes da chamada "telerrealidade" com a realidade concreta - e lembramos uma vez mais que 
o diretor, em momento algum, define seu documentário como reality show, mas concebe-o simplesmente como um documentário.

Assim como nos documentários que visam a construção do outro de modo relacional e reversível, subvertendo as posições hierarquizadas entre realizador e entrevistado, o programa analisado não se preocupa com o maior ou menor grau de verdade nele presente, mas com a construção dos personagens feita por meio da filmagem e da montagem. Mais do que se perguntar sobre se as situações criadas são artificiais ou verídicas, ou se aconteceram de fato da maneira como são mostradas, o documentário ressalta justamente seu aspecto narrativo e a fabulação implicada em sua fatura, qual seja, a de que tanto os personagens como a história emergem do processo de interação entre cada um deles e o próprio realizador, mediados pelos dispositivos estéticos, políticos, éticos e tecnológicos presentes em qualquer produção audiovisual.

A exemplo de outros realities televisivos, esse documentário - e notamos uma distinção importante em relação à televisão brasileira, já que, como dissemos, o programa não foi simplesmente classificado como uma serie, tampouco como um reality show -, ao contrário de apresentar desafios de transformação, talentos ou competição, propôs a convivência entre diferentes sujeitos em um mesmo espaço físico, caracterizando-se como uma espécie de "experimento" ou, de modo mais extenso, possibilitando uma aproximação à questão dos conflitos e intolerâncias decorrentes do convívio entre todos ${ }^{11}$. Indagado sobre a existência ou não de uma hipótese prévia à realização do programa, Bhatti afirmou não partir de uma tese que

\footnotetext{
11 Ainda que o programa tenha buscado tratar da questão multicultural como um modo de integração e não de separatismo, alguns setores da sociedade protestaram contra sua veemência em termos de crítica social. A pergunta colocada pelo diretor na apresentação do programa parece guiar sua narrativa: "How do we, despite class, cultural and religious differences, find a way to live together? What makes us all British today?". Por meio dos personagens e de seus conflitos, vemos possíveis respostas a essa questão, inserindo a televisão como agente no debate público sobre questões sociais. O mesmo ocorreu na temporada filmada em Leicester. Para mais informações, ver: www.channel4.com/programmes/make-bradford-british/articles.
} 
devesse ser comprovada mas, ao contrário, possuir apenas uma premissa. Tomando como base o multiculturalismo formador da atual sociedade britânica e problematizando o senso comum de que, para ser seu cidadão, um estrangeiro deve ser capaz de passar em um teste que prove o quão britânico ele é, o documentário televisivo partiu de duas perguntas: o que faz de alguém um britânico? O que é comum a todos os britânicos? As questões se referem a um tema especifico mas dizem respeito a aspectos mais gerais sobre como tratar temáticas densas e socialmente relevantes de modo reflexivo e, ao mesmo tempo, atraente.

Nesse sentido, destacamos tanto na produção ficcional inglesa como naquela factual o esforço por produzir programas inovadores, sejam séries, reportagens ou documentários, estes últimos uma das marcas de tal produção. Para além da percepção de que o formato reality tv diz respeito a "pessoas reais fazendo coisas reais em lugares reais", da pré-produção até a pós-produção, incluindo filmagem, edição e finalização, o documentário televisivo "Make Bradford British" buscou agregar elementos ficcionais e jornalísticos em sua realização. Para o diretor, a separação entre reality shows e documentários televisivos, bem como aquela entre sensacionalismo e humanização, ou entre fabulação e jornalismo, não pode ser facilmente estabelecida, já que todos esses gêneros tornam-se cada vez mais hibridizados e visam, ainda que de maneiras distintas, contar histórias por meio da criação de personagens em interação. Na perspectiva do diretor, seriam eles os que estabelecem demarcações entre os gêneros, já que se tornam mais autênticos à medida que são criados pelos próprios sujeitos, e não a partir de imposições do realizador, a exemplo do que vemos em documentários que deslizam entre uma ou outra posição autoral: aquela mais exterior, voltada para a construção dos personagens, ou aquela mais subjetiva, realizada a partir deles.

De certo modo, um dos aspectos mais relevantes foi a percepção de que mais do que separar uma produção televisiva ficcional de uma factual, 
podemos identificar elementos constituintes da ficcionalidade ou da factualidade de um programa em diferentes graus. Mais do que isso, cabe ao espectador decifrar, em sua "leitura", a ênfase em um ou outro desses elementos, como propõe Odin ao tratar da "leitura ficcionalizante" e da "leitura documentarizante" de obras audiovisuais (Odin, 2012: 14). No caso de "Make Bradford British", há uma clara tendência de aproximação à linguagem dos documentários no modo de articulação narrativa, como se pudéssemos reconhecer a aglutinação de elementos não evidentes em documentários tradicionais mas presentes em novos documentários, propondo um possível formato de reality documentary, ou mesmo uma espécie de documentário seriado.

Se pensarmos na relação entre reportagens e documentários, a partir da observação da produção inglesa veremos que ocorre a emergência de um novo formato em termos de produção de filmes e séries, enquanto o jornalismo ainda se mantém 'fechado em modelos mais convencionais. De certo modo, tal descoberta vai ao encontro das hipóteses iniciais, e também de conclusões obtidas em pesquisas anteriores, no que diz respeito aos estigmas sociais em termos de seu reforço ou transformação. Em relação a essa questão, ainda que haja um grande volume de produções televisivas que não colocam essa preocupação em primeiro plano, confirmamos uma tendência já observada no caso da televisão brasileira: a forte presença de temas polêmicos, geralmente de cunho social, chamando ao posicionamento e ao engajamento não apenas de produtores, mas também da audiência.

Em "Make Bradford British", a questão dos estigmas se coloca em evidência, a começar pelo elemento aglutinador do documentário: a temática do multiculturalismo, da imigração e das formas de convívio. Como dissemos, os episódios mostram os participantes convivendo nas casas uns dos outros e divididos em duplas formadas por sujeitos que, a 
princípio, possuem diferenças inconciliáveis entre $\mathrm{si}^{12}$. É assim que vemos um típico garoto inglês de origem operária ser inserido na família de um muçulmano; a mulher muçulmana colocada no cotidiano de uma negra inglesa que trabalha em um bar; a senhora idosa convivendo com uma jovem, e assim por diante.

Seja em termos étnicos, religiosos, geracionais, as diferenças entre cada um - e os modos de lidar com elas - colocam-se como definidoras do documentário. Ou seja, uma vez mais, a questão do convívio e do conflito entre cada um e todos (o outro próximo e o outro distante) aparece como preponderante e configura, assim, uma aproximação aos estigmas sociais. No caso do programa, isso ocorre de modo transgressor, já que aprender a lidar com as diferenças, por meio da subversão da pergunta sobre se há algo que possa definir a "britanicidade" de um cidadão do Reino Unido, é justamente seu objetivo. País de longa história no que diz respeito à presença de imigrantes - sejam eles de origem negra, árabe ou indiana, de ex-colônias ou outros lugares, entre eles o Brasil -, a premência dessa questão salta aos olhos quando nos deparamos com os desafios encenados no documentário televisivo, que deriva seu aspecto realista não apenas na definição de um formato, mas na problemática tratada.

Em termos dos personagens, uma vez mais confirmamos o modo como o documentário desmobiliza lugares comuns: ao revezar entre realizador e audiência o espaço de construção narrativa, movimento esse contemplado na produção de reality shows, os personagens não são simplesmente encaixados na história - como muitas vezes acontece no

\footnotetext{
${ }^{12}$ É interessante observar que o diretor brasileiro Cao Guimarães, no filme Rua de mão dupla (2002), utiliza um dispositivo semelhante como estratégia para a realização de um documentário, colocando em contato pessoas que antes não se conheciam e formando duplas que, transformadas em personagens, deveriam trocar de casa durante 24 horas. Munidos de câmeras de vídeo e com liberdade para filmar o que quisessem, cada participante tentou elaborar uma "imagem mental" do outro morador, sendo posteriormente entrevistados pelo diretor para relatar suas impressões sobre como teriam imaginado esse "outro" desconhecido e delas distinto.

Disponível em: http://www.caoguimaraes.com/obra/rua-de-mao-dupla/.
} 
jornalismo - mas colaboram com sua narração, determinando e sendo determinados por ela. É nesse ponto que a mistura entre realidade e ficção pode ser apontada, pois o aspecto de fabulação advindo dessa escolha - ao mesmo tempo estética e politica - corrobora a aposta factual do formato documental do programa, e é dessa síntese que vemos delinear-se o gênero da "telerrealidade", percebida como um lugar próprio da linguagem televisiva contemporânea que coloca em operação a triangulação entre autor, leitor e texto (nos termos de Eco, 1994; Iser, 2013), ou entre realizador, público e programa.

Uma espécie de factual entertainment, como colocado pelo diretor, faz-se presente nesses formatos híbridos, propondo novos modos de produzir, assistir e refletir sobre a televisão. Bhatti aponta que o documentário, especialmente o televisivo, não se encontra tão distante dos formatos de entretenimento como desejaríamos e, desse modo, programas televisivos como "Make Bradford British" podem tratar de temas relevantes e densos por meio de uma abordagem mais lúdica e emocional e, ainda assim, problematizar estigmas sociais relacionados a questões de identidade, alteridade e representação social. Não se trata, portanto, de simplesmente classificar diferentes programas mas, ao contrário disso, reconhecer um conjunto deles que possa integrar esse lugar híbrido que desliza entre formas documentais diversas, sejam elas referenciais, convencionais ou popularescas. É desse modo que a realidade passa a ser intertextualmente encenada, por meio de documentários, reportagens, séries e reality shows, complexificando os novos realismos presentes na televisão e no cinema.

Finalmente, um último aspecto merece ser apontado no estabelecimento da relação entre documentários, reportagens e realities. De acordo com Bhatti e em consonância com análises anteriormente realizadas (cf. Soares; Limberto, 2014), percebemos nas várias possibilidades factuais da programação televisiva a importância da relação entre realizador e entrevistado. Se baseada na reciprocidade, nos termos em que o filósofo 
Buber (2001) utiliza este conceito, é um pacto de confiança - e de fidúcia que se estabelece entre ambos. É dessa maneira que a relação aparentemente dual entre realizador e entrevistado se torna uma relação triádica entre realizador, entrevistado e personagem e, posteriormente, destes com o espectador.

Nesse ponto as diferenças entre a produção audiovisual brasileira e a britânica se colocam como prementes, justamente devido às características singulares de cada uma e à forte presença, no caso da produção inglesa, de formatos híbridos em termos narrativos e estéticos, e de documentários televisivos (gênero ainda pouco presente na televisão brasileira, que ainda se pauta, como notamos, por divisões mais rígidas de formatos). Além da hibridização em termos de gêneros televisivos, na produção inglesa isso se reflete no modo de demarcação dos estigmas, que se tornam mais diluídos e, portanto, potencialmente mais transformadores, levando a uma baixa frequência de redundâncias e aumentando as ressonâncias de suas imagens, mesmo que polêmicas.

Os estigmas sociais presentes nas formas audiovisuais, as politicas de representação e os regimes de visibilidade a eles relacionados se fazem na tensão entre esses sujeitos, empíricos e discursivos, colocados em cena e em tela. Mais do que reproduzir imagens de minorias ou de grupos sociais, trata-se da apresentação de diferentes culturas, construindo novas realidades. Ainda que os limites da representação sejam dados pela impossibilidade de tudo representar ou pela irredutibilidade de um outro desde sempre não-representável, quando tratamos de estigmas podemos notar certos deslocamentos nos intervalos entre ausência/presença, invisibilidade/visibilidade. Nos interstícios entre os ditos, inclusão e protagonismo deslizam possibilidades de dar a ver o outro e a ele responder, demarcando distintos posicionamentos discursivos e, consequentemente, outros modos de representação da alteridade. 
É interessante confirmar que, em relação aos estigmas, podemos acompanhar alguns temas recorrentes - como se uma dinâmica regular (repetição e diferença) acompanhasse tais tematizações. Entre eles, questões agrárias e/ou urbanas, questões de gênero, assuntos relativos ao movimento negro ou questões raciais, o mundo árabe (incluindo supostas ações terroristas a ele associadas), o tráfico de drogas e, sobretudo nas mídias audiovisuais, questões relacionadas à violência, imigração, pobreza e exclusão social, retratando em suas imagens sujeitos em situação de risco ou vulnerabilidade. Em termos de tendências, retomamos a observação de que um tema específico tem se sobressaído nas pesquisas em comunicação apoiado, sobretudo, pelos estudos culturais ou pós-coloniais e pela psicanálise: as complexas relações envolvendo a dinâmica social do convívio entre cada um e os outros, e os conflitos daí decorrentes, inseparáveis da própria sociedade em que estão inseridos. As chamadas figuras de alteridade, como dissemos, presentes nos discursos midiáticos sinalizam, de maneira privilegiada, pontos de confluência e de demarcação dos estigmas sociais.

É sempre em relação a um outro, diferente de nós (e supostamente inferiorizado na dinâmica social), que os estigmas se articulam e apontam suas especificidades, respondendo a uma questão que acompanha, insistentemente, a produção audiovisual: como, afinal, dar a ver o "outro" e estabelecer políticas para representá-lo? Se tomarmos os processos comunicacionais como uma permanente negociação, entendemos que as mídias podem ser vistas como lugares de reconhecimento e trânsito simbólico, como zonas de fronteira e passagem nas quais as reapropriações se fazem nas bordas dos contratos discursivos estabelecidos, transformando os modos de construção da representação, especialmente quando tratamos dos espaços de visibilidade e invisibilidade nelas articulados. 


\section{Referências bibliográficas}

BADIOU, A. (2002), Pequeno manual de inestética, São Paulo: Estação Liberdade.

BARTHES, R. (1998), “O efeito de real” in O rumor da língua, São Paulo: Brasiliense.

BUBER, M. (2001), Eu e tu, São Paulo: Centauro.

CHARAUdeaU, P. (2006), Discurso das mídias, São Paulo: Contexto.

COUTINHO, E.; XAVIER, I.; FURTADO, J. (2014), “O sujeito (extra) ordinário" in MOURÃO, M. D. \& LABAKI, A. (orgs.), O cinema do real, São Paulo: Cosac Naify.

ECO, U. (1994), Seis passeios pelos bosques da ficção, São Paulo: Companhia das Letras.

FIGUEIREDO, V. L. F. (2012), “A partilha do espaço urbano e a questão do outro próximo: repercussões no discurso teórico e na ficção cinematográfica" in Revista Galáxia, São Paulo, n. 24.

FOSTER, H. (1999), The return of the real, Cambridge: MIT.

GAY, P. (2010), Represálias selvagens. Realidade e ficção na literatura de Charles Dickens, Gustave Flaubert e Thomas Mann, São Paulo: Companhia das Letras.

GEERTZ, C. (2005), Obras e vidas. O antropólogo como autor, $2^{\mathrm{a}}$ Ed., Rio de Janeiro: UFRJ.

HALL, S. (2000), Identidade cultural na pós-modernidade, Rio de Janeiro: DP\&A.

ISER, W. (2013), O fictício e o imaginário: perspectivas de uma antropologia literária, $2^{\mathrm{a}}$ Ed., Rio de Janeiro: Eduerj.

KAVKA. M. (2012), Reality TV - Television genres, Edinburgh: Edinburgh University Press.

MACHADO, A. \& VÉLEZ, M. L. (2009), "Persistência da reality $t v "$ in Revista Significação, São Paulo, n. 32. 
NICHOLS, B. (1991), Representing reality, Bloomington/Indianapolis: Indiana University Press.

ODIN, R. (2012), "Filme documentário, leitura documentarizante" in Revista Significação, São Paulo, Ano 39, n. 37.

PRADO, J. L. A. (ed.) (2008), A invenção do Mesmo e do Outro na mídia semanal, DVD, São Paulo: PUC-SP/CNPq. (2012), "Política da imagem na era da convocação" in Revista Significação, São Paulo, Ano 39, n. 37.

RANCIÈRE, J. (1996), O desentendimento: política e filosofia, São Paulo: Editora 34. (2005), A partilha do sensível, São Paulo: Editora 34.

SOARES, R. L. \& LIMBERTO, A. L. (2014), “Tramas do outro nas telas do discurso: circulação audiovisual e consumo cultural" in PragMatizes - Revista Latino-Americana de Estudos em Cultura, Rio de Janeiro, Ano 4, n. 6.

SOARES, R. L. \& FREIRE, M. (2013), "História e narrativas audiovisuais: de fato e de ficção" in Revista Comunicação, Mídia e Consumo, São Paulo, V. 10, n. 28.

WINSTON, B. (2005), “A maldição do 'jornalístico' na era digital” in MOURÃO, M. D. \& LABAKI, A. (orgs.), O cinema do real, São Paulo: Cosac Naify.

WHITE, H. (1994), Trópicos do discurso, São Paulo: Edusp.

XAVIER, I. (1984), O discurso cinematográfico, Rio de Janeiro: Paz e Terra.

ZIZEK, S. (2002), Bem-vindo ao deserto do real, São Paulo: Boitempo. 


\title{
GLAUBER SOB UM REGIME DE URGÊNCIA
}

\author{
Érico Araújo Lima*
}

Resumo: Neste artigo, tento colocar em relevo dois filmes de Glauber Rocha, $D i$ Cavalcanti (1977) e Claro (1975), a partir de um enfoque no que poderia ser considerada uma modulação no pensamento do realizador, rumo a uma anti-razão. Apostando em novos caminhos para uma arte política, haveria nessas pesquisas - e também no texto sobre a estética do sonho - uma inflexão para a irrupção de novas formas de experiência, no que seria possível propor como um regime de urgência da imagem, em que a linguagem é liberada para outras modalidades de contágio com o real.

Palavras-chave: Glauber Rocha, urgência, sonho, delírio.

Resumen: En este artículo tratamos de poner de relieve dos películas de Glauber Rocha, Di Cavalcanti (1977) y Claro (1975), a partir de un enfoque en lo que podría considerarse una modulación en el pensamiento del director, rumbo hacia un anti-razón. Apostando por nuevos caminos hacia un arte político, habría en esas investigaciones $-\mathrm{y}$ también en el texto sobre la estética del sueño- una inflexión hacia la irrupción de nuevas formas de experiencia, en lo que sería posible proponer como un régimen de urgencia de la imagen, donde el lenguaje se libera hacia otras modalidades de contagio con lo real.

Palabras clave: Glauber Rocha, urgencia, sueño, delirio.

Abstract: In this article I try to put in evidence two films of Glauber Rocha, $D i$ Cavalcanti (1977) and Claro (1975), from an emphasis on what could be considered a modulation in the mind of the director, towards an anti- reason. Betting on new researches for a political art, we could find in those films - and in the text on the aesthetics of dream a shift to the emergence of new forms of experience. It would be possible to propose this problem as a regime of urgency of the image, where the language is released to other forms of relation with the real.

Keywords: Glauber Rocha, urgency, dream, delirium.

Résumé: Dans cet article, nous essayons de mettre en évidence deux films de Glauber Rocha, Di Cavalcanti (1977) et Claro (1975), à partir d'une focalisation sur ce qui pourrait être considéré comme une modulation dans l'esprit du réalisateur, vers une antiraison. Dans une recherche sur de nouvelles propositions pour un art politique, il s'agit dans ces films - et dans le texte sur l'esthétique du rêve - d'un changement de pensée, où l'émergence de nouvelles formes d'expérience se pose comme question fondamentale. Il serait possible de proposer les procédures filmiques comme un régime d'urgence de l'image, où le langage est libéré pour rencontrer d'autres formes de rapport avec le réel.

Mots-clés: Glauber Rocha, urgence, rêve, délire.

* Doutorando. Universidade Federal Fluminense, Programa de Pós-graduação em Comunicação, LEE-Laboratório de Estudos e Experimentações em Audiovisual da Universidade Federal do Ceará. 60455-769, Fortaleza, Brasil. E-mail: ericooal@gmail.com

Submissão do artigo: 31 de maio de 2015. Notificação de aceitação: 20 de agosto de 2015. 


\section{Gestos de impulso}

"Di Cavalcanti foi feito num impulso. Acordei de manhã, sete e meia, li que o Di Cavalcanti tinha morrido, nove horas fui filmar" (Rocha, 2006: 332), retoma Glauber Rocha a respeito do curta que realizou em 1977 logo que soube da morte do amigo e pintor Di Cavalcanti. Há aí um gesto de arrancar imagens e sons do mundo, produzir cinema num movimento tomado por forças imprevistas e por uma abertura ao descontrole. Falar em um regime de urgência nessas imagens implica, desde já, um mergulho em experiência de tensão com modalidades de planejamento e regra. A imagem é ela mesma um processo de experimentação. É no limite que Glauber filma e monta o curta. No limiar das possibilidades de efetivar uma filmagem de um velório e de um sepultamento, vai com a câmera em close-up no rosto do pintor que morreu. " $1,2,3,4,5,6,7,8,9,10,11,12$. Corta! Agora dá um close na cara dele!", diz o realizador, na faixa sonora incluída após as filmagens, quase numa descrição do processo. Estamos no entremeio de uma experiência estética porosa, aberta às trocas, intempestiva. O que se dá nesse meio, nessa zona de indiscernibilidade que passa a ser delineada? É de qual ordem esse encontro tão urgente? Glauber desencadeia um processo que faz a mistura entre olhares, sensibilidades e temporalidades. "Ninguém assistirá ao enterro da tua última quimera. Somente a Ingratidão - esta pantera - foi a tua companheira inseparável": os versos de Augusto dos Anjos são entoados por Glauber e seriam ainda um título para o filme.

Todo o caos promovido em Di Cavalcanti tem a ver com pesquisas estéticas em que o aleatório, o simultâneo e o descontrole seriam condutores da fabricação fílmica. Nessa experiência, a questão é deixar-se tomar por forças capazes de arrastar para algo novo. Trata-se de fazer o movimento e desencadear transformações. Nos encontros promovidos pela imagem, é possível gerar torções e resistir aos enquadramentos dos corpos, que podem se libertar em percursos de relação com o outro. A experiência estética nessa 
região perde uma direção clara e faz fissura com uma organicidade e com uma linha dominante e ordenadora da percepção. No turbilhão, o que se tem é alteração de si, dos sentidos, uma incapacidade de síntese, de organização de significados. Uma polifonia barroca prolonga as intensidades e multiplica as vozes, que aqui já não remetem a uma verticalidade capaz de reunir o conjunto, mas estão a todo o momento em choques e rodopios, em trajetos disjuntivos.

Filmar como quem não sabe filmar. Filmar sem o cálculo ordenador da experiência, abrir-se às bifurcações de possíveis que o próprio processo pode desencadear. A imagem não tem clareza, os corpos não estão com lugar marcado e direcionamento claro. Com $D i$, o realizador acrescenta possibilidades para a produção de olhares. Prolifera mesmo os possíveis para fazer cinema, numa estética com gritos, misturas, impurezas, desordenamento. É toda uma ocupação de espaço marcada pela errância: era assim já nas filmagens de Câncer (Glauber Rocha, 1968-1972), em 1968, quando ia para as ruas do Rio de Janeiro sem planejamento do que fazer, sem roteiro, apenas com a proposta de deixar ações acontecerem em frente a uma câmera ligada, em planos-sequência; era assim na experiência do exílio, com Claro (Glauber Rocha, 1975), perambulador das ruas de Roma, dando orientações sobre os enquadramentos no ato de filmagem, com posteriores sobreimpressões de camadas, fusões na imagem, simultaneidades de blocos sensíveis reunidos na montagem.

Essas experiências de urgência são operações de risco, poderia ser dito. Um cinema que se dá na tensão com o mundo, que parte para o encontro numa tentativa de escapar ao controle dos programas, no que trago as discussões desenvolvidas por Comolli (2008). Se a roteirização da vida se espalha, é preciso buscar outros métodos para fazer com que os filmes aconteçam. A proposição de Comolli marca uma defesa de uma postura do documentário frente ao caráter consensual dos roteiros. A experimentação do risco faz surgir cenas, que se constituem de forma aberta e em meio a um 
imponderável. Fugir ao controle de uma previsibilidade, sair de zonas de segurança, desarranjar, borrar. "Os filmes documentários não são apenas 'abertos para o mundo': eles são atravessados, furados, transportados pelo mundo" (Comolli, 2008: 170). Deixar-se furar pelo mundo seria uma postura política que se constitui como um modo de agir na polis, em gesto indisciplinado. Furar: há na proposta de Comolli uma radicalidade que diz respeito mesmo a uma maneira de se dispor ao encontro. Pois não basta a postura da abertura. É preciso uma atitude mais drástica que se opera na escritura mesma do filme, um movimento de deixar que o mundo faça a fissura no filme, crie buracos e fendas. Quando furo, exponho algo ao indecidível, invento caminhos e permito que sejam traçadas bifurcações. A figura conceitual da fissura tem grande importância aqui, como modo de resistência potente para pensar a experiência estética do cinema. "Longe da 'ficção totalizante do todo', o cinema documentário tem, portanto, a chance de se ocupar apenas das fissuras do real, daquilo que resiste, daquilo que resta, a escória, o resíduo, o excluído, a parte maldita" (Comolli, 2008: 172). $\mathrm{O}$ que resiste faz fugir, inventa outras perspectivas para apreender o mundo, para recortar o espaço e o tempo, para constituir mise-en-scènes. A parte maldita é tensionadora de formas majoritárias de organizar a experiência. Ela é o que foi colocado fora de uma partilha do sensível e vem introduzir, então, uma cena litigiosa, expondo um erro de contagem (Rancière, 1996). Ela é o que resiste apesar de tudo (Didi-Huberman, 2012a). Mas como lidar com essa parte maldita? Quais procedimentos estão envolvidos na tensão gerada pelo pequeno, pelo resíduo? Seria uma simples questão de incluir aquele que está fora?

Glauber sofre um grande impacto ao saber da morte do amigo Di Cavalcanti. Ele filma porque é fundamental fazer essa homenagem nesse momento, estar ali no velório com a câmera. Nesse processo singular, em que um filme se faz desencadeado pelo aqui e agora de uma notícia trágica, a tensão com uma forma prévia de imagem é instituinte do movimento, e o 
filme se faz como um resíduo que não procura legitimidade, porque guarda na potência mesma de um pequeno gesto a dimensão política capaz de instaurar um desacordo sensível no mundo. É uma tensão com a relação canônica que se prescreve para as sensibilidades diante da morte e é uma perturbação fundamental no próprio cinema. Em uma das sequências que penetra o fluxo das imagens do filme, Glauber e os amigos da equipe estão com vários livros e revistas que têm reproduções das pinturas do pintor homenageado. Eles parecem, muitas vezes, fazer quase um vídeo caseiro, reunidos ali para erguer publicações, folhear páginas, abrir um livro para mostrar um pouco mais de uma imagem que está em alguma parte dali. Não existe uma composição de quadro rigorosa, a câmera faz parte daquela reunião de pessoas numa casa, seres que estão juntos, sobretudo, pelo desejo de fazer um filme que possa festejar a vida de Di Cavalcanti. De repente, surge um espelho, em torno do qual todos parecem fazer pequenas brincadeiras, experimentar o que resulta de um encontro com essa superfície. E tudo isso se passa em meio à fala desordenada de Glauber, que conta os próprios encontros com $\mathrm{Di}$ ou que passa a descrever o que se passou no velório, sempre numa corrente de devires completamente embaralhados e livres de uma dominante de organização. Uma marchinha de carnaval de Lamartine Babo cria o tom de samba para essas imagens. A operação delas é diferente daquelas que surgem logo no início do filme, a câmera dentro de um carro que percorre as ruas rumo ao Museu de Arte Moderna, local do velório, ou quando se está filmando o próprio corpo morto no centro do salão. Mas é justo um procedimento de leveza que vem se articular ao espaço mais solene, um tom que vai contaminando o filme todo, porque o que também é urgente é a celebração, mais do que o lamento.

Seria possível dizer que estamos, nessa experiência, diante de imagens urgentes, imagens que queimam (Didi-Huberman, 2004, 2008, 2012b). Dentre outras maneiras, elas queimam "com seu movimento intempestivo, incapaz de parar no caminho (como se diz 'queimar as 
etapas'), capaz de sempre bifurcar-se, de ir bruscamente a outra parte (como quando se diz 'arder de inquietude')" (Didi-Huberman, 2008: 52). Ao tocarem o real, as imagens incendeiam, desencadeiam modos inquietantes para o ver, lançam outras perspectivas de temporalidades, maneiras outras de ter com o mundo. Elas não se adequam a uma lógica formatada do sensível, tomam espaço com um movimento que não pode ser parado, na constante sístole e diástole e no jogo de tensores de uma experiência cindida. Elas não são uma organização clara e bem ordenada do sensível, mas um rodopio, uma maneira de se espalhar e de confrontar o turbilhão. O cinema que queima pode teimar em ser enquadrado num modelo e também evitar ser ele mesmo um indicador autoritário de posturas de corpos dos seres filmados, sejam os corpos de homens ordinários, sejam mesmo as paisagens como corpos - a cidade, talvez, como um ser, em processos de individuação. Diante do mundo em movimento, a cena desencadeada pelo cinema se situa em região produtora, zona de constantes variações e heterogeneidades. Diante do corpo de Di Cavalcanti e da vida a ser festejada, cabe produzir uma imagem que é pura inquietude e agitação, queimando sucessões, ultrapassando limites, fazendo saltos. Retomando as discussões de Comolli, vale lembrar que "o movimento do mundo não se interrompe para que o documentarista possa lapidar seu sistema de escrita" (Comolli, 2008: 177). A tentativa de pôr em ordem vai, então, estar em perpétua tensão com as variabilidades sensíveis em jogo na própria vida, intermitente e instável. A decisão de dar o close no rosto do morto é intempestiva, no ato, em meio a todo um mundo que não para de se revolver e mesmo em meio ao incômodo da família que chega a demonstrar a inquietude com as filmagens, como chega a indicar Glauber na voz off.

Filmar sob o risco seria partir para um processo de imponderabilidades, para caminhos tortuosos. Daí a impossibilidade do roteiro, como defende Comolli, e a necessidade mesma do documentário. "Filmar os homens reais no mundo real significa estar às voltas com a 
desordem das vidas, com o indecidível dos acontecimentos do mundo, com aquilo que do real se obstina em enganar as previsões" (Comolli, 2008: 176). Existem lacunas, intervalos. Uma postura política é situar-se na indiscernibilidade que esse espaço intervalar abre, como potência para a invenção de cenas e de novas possibilidades para ocupar o mundo. "Sentir aquilo que, no mundo, ainda nos ultrapassa. As narrativas ainda não escritas, as ficções ainda não esgotadas" (Comolli, 2008: 177). Apesar de tudo, há algo ainda. Caminhos a serem explorados, posturas de corpos a serem inventadas, experiências a serem fruídas. Nas brechas que se abrem, podem estar contidas as potências para as roturas; na dimensão do inacabado, o desejo de sentir outras relações entre próximo e distante, entre luzes e sombras, entre vida e morte; num impulso com pontas de negativo, o desejo de filmar apesar de tudo, de partir para o encontro e fazer com que as imagens e os sons aconteçam. O filme e as filmagens, na resistência ao controle, tornam-se acontecimentos. A precariedade da escritura que desponta em Di Cavalcanti é uma condição de invenção de novos espaçostempos.

Eis porque os dispositivos do documentário são antes de tudo precários, instáveis, frágeis. Eles são úteis apenas para permitir a exploração do que ainda não é de todo conhecido. Os roteiros de ficção são, frequentemente (cada vez mais), fóbicos: eles temem aquilo que lhes provoca fissuras, que os corta, os subverte. Eles afastam o acidental, o aleatório. Alimentados pelo controle, eles se fecham sobre si mesmos. Retroação. O não-controle do documentário surge como condição de invenção. Dela irradia a potência real deste mundo. (Comolli, 2008: 177).

O que é preciso fazer para que haja um filme? Existem condições de possibilidade? O impulso da realização em Di Cavalcanti traz que implicações para as maneiras de fazer e pensar cinema? O gesto fílmico do curta de Glauber implica, num primeiro momento, desejo. É a partir daí que são reunidos amigos, para celebrar a vida do pintor Di Cavalcanti, também 
ele amigo do realizador. É como produção desejante que a equipe parte para as ruas e arrisca fazer imagens no velório e no enterro do artista. Risco no contato com o mundo, risco na criação de uma relação. Já um outro sentido para a ardência da imagem: "A imagem queima com o desejo que a anima, com a intencionalidade que a estrutura, com a enunciação, inclusive com a urgência que manifesta (como quando se diz 'ardo de desejo' ou 'ardo de impaciência')". (Didi-Huberman, 2008: 51). O trabalho de homenagem ganha contornos de uma experiência que perturba a ordem da cerimônia configurada para o ato de despedir-se dos mortos. A chave do transe, tão cara ao pensamento cinematográfico de Glauber, vai aqui operar mesmo uma ideia de transformação e de delírio, na elaboração de um ritual descentrado, marcado por desequilíbrios e pelo caos. E o transe vai ter conexão com a ideia mesma de trânsito, de operar passagens, de arrastar o corpo, a vida, as imagens e os sons num movimento. $\mathrm{O}$ corpo velado e sepultado de Di Cavalcanti é profanado porque precisa ser misturado, para que já não estejamos na dimensão sagrada, do que foi separado (Agamben, 2007). No contágio com o mundo, é fabricado o filme, que é tomado pelo efeito transformador do outro, que se aventura no lugar do intervalo, do meio, região repleta de perigos. A obra funda para si as próprias condições de possibilidade, a partir da postura de enfrentamento com o que se apresenta como dado e como separado. Traz para si a experiência do limiar, de uma polifônica associação de imagens e sons, formas em desarranjo, em quebras, em livre corrida pelo mundo.

Também sem passar por longo período de preparação, Claro é rodado durante 15 dias em Roma, numa abordagem ensaística que mistura blocos de deriva nas ruas e cenas de interior em que se esboçam situações ficcionais. Como destaca Mateus Araújo Silva (2012), todo o filme fica pronto em cerca de dois meses e meio, após um processo sem roteiro prévio, com amigos, câmera na mão e som direto. Aqui há um mergulho delirante em relação com a própria cidade, com questões tão caras a Glauber, em 
crítica ao capitalismo. As imagens têm nelas mesmas uma processualidade, uma escritura marcada por planos que não estão previamente estabelecidos, por tensões com os que passam e estranham Juliet Berto em movimentos errantes pelas ruas, por uma câmera que vai expondo a própria busca nos caminhos que experimenta. "A incursão de Glauber e Juliet é uma aventura em terreno desconhecido, atravessada pela instabilidade de um gesto desmedido e insólito" (Silva, 2012: 262). Trata-se, muitas vezes, de um filme de viagem, uma obra atenta às implicações do fazer filme para a vida, uma experiência que pode ter muito a ver com incursões de Glauber pelo Super8, como no trabalho que chamou de Letícia e Mossa no Marrocos (1971), ${ }^{1}$ feito com as amigas Letícia Maria Moreira de Souza e Flora Bildner (Mossa), em viagem a Marrakech, depois de rodar Cabeças Cortadas, na Espanha. Glauber no exílio em busca da vida.

Esses gestos de Di Cavalcanti e de Claro guardam uma estreita proximidade ainda com outro filme de Glauber, Câncer, realizado em 1968 e montado em 1972. Era também de uma urgência e de uma vibração desejante que se tratava essa outra obra. Arriscaria aqui dizer que há mesmo um prolongamento das tensões desencadeadas pelos filmes, cada um com uma pesquisa própria, mas todos profundamente marcados por um mergulho intempestivo no mundo, sem estabelecimentos prévios de direções, sem hierarquias na organização da experiência, sem uma territorialidade ordenadora de caminhos. ${ }^{2}$ No caso do trabalho de 1968, Glauber estava prestes a filmar O Dragão da Maldade contra o Santo Guerreiro (1969), mas por problemas burocráticos, as latas de negativo foram presas na alfândega, e a espera deixava o realizador ansioso. Ele queria fazer um

\footnotetext{
${ }^{1}$ Trata-se de um filme ao qual, infelizmente, não tive acesso e que cito aqui brevemente, apenas a partir do que pude ler a respeito dele, nas compilações das filmografias do realizador, como a que está disponível no site do Tempo Glauber: www.tempoglauber.com.br. Sabe-se que Glauber teve algumas experiências em Super8 no exílio, inclusive com a própria Juliet Berto, o que pode indicar novas modalidades de pesquisa, uma experimentação de mais caminhos.
} 
filme, partir para as ruas, experimentar possibilidades. Chamou amigos que já estariam no Dragão e realizou filmagens em quatro dias, sem roteiro, sem dizer previamente aos atores uma história, apenas dando situações de violência que deveriam ser improvisadas diante da câmera em planosequência, até terminar o tempo de cada chassis de uma Éclair $16 \mathrm{~mm}$. Os rolos de negativo preto-e-branco utilizados eram antigos, já em fase de deterioração, que estavam na Mapa Filmes, produtora do amigo de Glauber, Zelito Viana. Eram negativos não utilizados, restos, sobras. E o filme se deu em meio ao aleatório e ao acaso, em desnorteio e desordem dos sentidos. Deixado de lado por quatro anos, porque Glauber não via grande importância no que havia feito (Rocha, 2004: 180), só é montado em 1972, quando os trânsitos e as dobragens da vida e do tempo já tinham remodelado a experiência do diretor e mesmo as imagens e os sons produzidos. A obra cruza temporalidades e toma o espaço num espírito de aventura e de invenção de outros lugares, outras partilhas, outras pulsações da imagem na tensão com o mundo. "O Câncer, filme meu, de $16 \mathrm{~mm}$, como todas as coisas que faço, estão ligadas a mim. O que acontece é que cada um tem sua forma. Em pintura, às vezes se decide fazer um mural, outras um quadro pequeno. Isso não quer dizer que o mural seja por isso mais importante" (Rocha, 2004: 179). Invenção também de outras variabilidades para a experiência, uma escolha pelo pequeno, pelo que pode resistir numa inquietude. Fazer filmes em devir-menor como maneira de tomar uma posição no mundo, não para colocar uma verdade absoluta quanto a formas válidas de fazer cinema, mas para situar-se no entre e tornar aberto o processo. Um modo de situar-se na dimensão de um movimento constituinte, mais do que no constituído. Tomar posição como um gesto de aproximação e distanciamento, em que reserva e desejo estão em jogo (Didi-Huberman, 2009). Tomar posição como algo distinto de tomar partido, na medida em que essa segunda abordagem é menos dialética e tensionadora de si mesma, aproxima-se muito mais da univocidade que da 
multiplicidade. Diria, então, numa aposta com Glauber, que vale pensar o cinema como campo aberto, em que não há um só caminho.

O Câncer era filme que não tinha sentido fazer em cor ou em $35 \mathrm{~mm}$. Não é filme comercial, não o fiz para ser exibido em circuito. É obra com que me diverti com meus amigos. Decidi fazer um filme em $16 \mathrm{~mm}$, chamei meus atores, meus amigos, e lhes disse: "Vamos fazer um filme". Fiz e não me custou nada, o material está aí, mas não está pronto e não sei quando vou prepará-lo. Fiz o filme também para demonstrar que em cinema não há um só caminho. [...] Naquela época alguns diziam: "O caminho do cinema é o filme a cor, de grande espetáculo", e outros: "O caminho do cinema é o filme de $16 \mathrm{~mm}$, underground". O caminho do cinema são todos os caminhos. Em vez de fazer uma superprodução em cores fiz um filme em $16 \mathrm{~mm}$, com equipamento reduzido, para demonstrar que alguém pode fazer tudo, que não existem preconceitos... Minha guerra é contra isto: a intolerância, os preconceitos, a demagogia. (Rocha, 2004: 180).

Sair, então, de oposições binárias. Os desafios estéticos e políticos do cinema são mais complexos do que uma perspectiva dicotômica poderia supor. Preferência, então, por esse uso do plural: caminhos - e diria também: resistências. Bifurcações, então. As invenções que cada filme possibilita dizem respeito às urgências movimentadas nas imagens pelos desejos. Trata-se de afirmar uma maneira de estar no mundo, que se afirma na produção de imagens e na necessidade de fazer cinema. Didi-Huberman (2012a), a todo o momento colocando o problema de um apesar de tudo, situa as fissuras que quatro fotografias arrancadas de Auschwitz fazem na história. Ele toma essas imagens para pensar resistências e sobrevivências que se dão em um campo de concentração, na tensão mesma com as câmeras de morte. Em meio à falta de esperanças: ainda assim, uma imagem. Em jogo de sombra e luz, de tensão com as formas, ela mesma é um gesto que diz da própria situação do fotógrafo, do momento de registro, do risco. 
Esta imagem, formalmente, não tem fôlego: pura 'enunciação', puro gesto, puro ato fotográfico sem fito (logo, sem orientação, sem alto nem baixo), ela permite-nos aceder à condição de urgência na qual quatro fragmentos foram arrancados ao inferno de Auschwitz. Ora, esta urgência também faz parte da história. (Didi-Huberman, 2012a: 58).

Essa figura conceitual de um apesar de tudo pode nos movimentar também com a urgência das imagens dos filmes de Glauber - é também o próprio Didi-Huberman que empreende essa operação teórica com uma série de outros trabalhos, em diferentes textos, guardadas sempre as singularidades de cada caso.

\section{Sonho e delírio}

Como extrair do caos a produção de outros espaços e tempos? Como enfrentar o caos? Uma experiência sensível caótica em Glauber tem relação direta com aquilo que ele propunha em Eztetyka do sonho, texto lançado em 1971. É um escrito instigador de uma nova postura sensível diante de um problema fundamental que inquieta o realizador, a articulação entre arte e revolução. As saídas que são apontadas a partir daí têm algo de bastante emblemático para uma tomada de posição, que se dá por uma abordagem da própria vida que não passe por uma lógica racional. É possível ler esse texto, acompanhando-o bem de perto, e daí discutir as implicações políticas do que Glauber chama de uma anti-razão. Convocar aqui os escritos de Glauber não implica uma tentativa de transpor o que se diz no âmbito textual para aquilo que se realiza no campo das formas fílmicas. Mas esse manifesto em especial do realizador é entendido aqui como emblemático de uma dobragem nas pesquisas de Glauber, um texto que também sofre desvios quando se passa à fabricação dos filmes, mas que parece ressoar, com variações concertantes, pelas obras que se seguem. A tensão que Glauber opera com o que chama de uma racionalidade burguesa pode ser 
vista mesmo como uma aposta teórica, não sistematizada como categorias, mas lançada como provocação a novas maneiras de traçar a linha entre o cinema e a política. Existe um desejo bastante forte de instigar uma arte revolucionária, preocupação que se situa em debates do período, mas também se carrega de uma abordagem singular em relação aos caminhos que se discutiam, já que não se trata mais nem de uma razão de esquerda nem de uma razão de direita. "Os sistemas culturais atuantes, de direita e de esquerda, estão presos a uma razão conservadora" (Rocha, 2004: 249). A operação que se abre leva o embate para o campo do pensamento, para instaurar um abalo nas matrizes que ordenam e encadeiam a percepção do mundo. Glauber quer produzir um cinema que desencadeie outras sensações, uma arte que não apele à formação de um todo intelectual mobilizador de ações, mas que possa encarar efetivamente um movimento caótico em direção à tensão com um mundo supostamente dado.

No embate feito com a racionalidade e a ordenação esquemática, cabe colocar mundos fora do lugar. Produção de caos e de desordem. Não se pretende explicar a pobreza, os processos de exclusão ou a situação social do Terceiro Mundo. E ao mesmo tempo há uma preocupação urgente de Glauber com tudo isso. Mas parece que as pesquisas dele ao longo dos anos, e as experiências de filmes como Deus e o Diabo na Terra do Sol, Terra em Transe e O Dragão da Maldade contra o Santo Guerreiro, carregaram para outra aproximação dos problemas que o inquietam.

A "Estética da fome" era a medida da minha compreensão racional da pobreza em 1965. Hoje recuso falar em qualquer estética. A plena vivência não pode se sujeitar a conceitos filosóficos. Arte revolucionária deve ser uma mágica capaz de enfeitiçar o homem a tal ponto que ele não mais suporte viver nesta realidade absurda. (Rocha, 2004: 251).

Existe aí uma decisiva indicação de outra aposta de agora em diante. As investidas são moduladas e já não têm a mesma orientação que vinha do 
outro manifesto fundamental do realizador, a Eztetyka da fome (1965). Era muito importante nesse primeiro texto o apelo a uma consciência e a definição de uma estética da violência, que fosse capaz de mobilizar para novas posturas a partir do choque. Não que Glauber abandone os procedimentos de que lançava mão ao longo da cinematografia dele, mas o que parece importante aqui é perceber como se processa uma passagem. $\mathrm{O}$ que se vê, tanto expresso nessa variação evidenciada nos dois textos quanto na matéria dos filmes, é uma inflexão: passar de uma compreensão racional a uma plena vivência é experimentar com a imagem a possibilidade de derivações, de errâncias, de enfeitiçamentos. São mesmo outras palavras que Glauber passa a convocar, a mágica, o místico, a possessão, o feitiço. Ele tenta agora outras conexões com o mundo, e aqui essas novas chaves podem ser entendidas em seu apelo direto ao corpo, a uma percepção que envolve com intensidade o sensível. É quase como se ele se aproximasse das preocupações de Benjamin (1994) com a perda da experiência e se remetesse a uma magia como dimensão possível para a revolução. "A revolução é uma mágica porque é o imprevisto dentro da razão dominadora" (Rocha, 2004: 250).

O homem já não suporta mais. E se ele chega a esse ponto, não é por uma via construída de modo dedutivo e sistemático. Também não é porque a ele se explicam dinâmicas de contradição social ou porque as estatísticas das Ciências Sociais informam e indicam interpretações sobre a pobreza, tomando aqui uma provocação feita por Glauber (2004: 248). Mas é por experimentar no corpo as forças que o apartam do mundo. "As vanguardas do pensamento não podem mais se dar ao sucesso inútil de responder à

\footnotetext{
${ }^{3}$ Não irei me deter aqui na discussão benjaminiana a respeito da experiência, mas cabe mencionar que, em textos como "Experiência e pobreza", Benjamin fala que as ações da experiência estão em baixa, sobretudo após o atravessamento da Primeira Guerra Mundial. Ao mesmo tempo, ele também detecta novas possibilidades que podem se abrir em meio à pobreza de experiência: os homens "aspiram a um mundo em que possam ostentar tão pura e tão claramente sua pobreza externa e interna, que algo de decente possa resultar disso" (Benjamin, 1994: 118).
} 
razão opressiva com a razão revolucionária. A revolução é a anti-razão que comunica as tensões e rebeliões do mais irracional de todos os fenômenos que é a pobreza. Nenhuma estatística pode informar a dimensão da pobreza" (Rocha, 2004: 250). Glauber faz aqui uma torção em paradigmas de leitura mais marcados pelo marxismo, ainda que sempre envolvido, ao seu modo bastante singular, nesse campo de pensamento. A revolução precisa ser entendida como anti-razão, essa é uma das questões centrais na estética do sonho. E nessa condição, ela não se articula a partir da oposição entre sistemas racionais, porque eles teriam como fundo uma mesma estrutura, incapaz de intervir no mundo. "Na medida em que a desrazão planeja as revoluções a razão planeja a repressão" (Rocha, 2004: 250). Uma racionalidade é, nesse sentido, repressora em sua base mesma, e não cabe invocar qualquer outro modelo como alternativa. A arte revolucionária defendida por Glauber, enquanto mobilizada pelo sonho, é uma arte de desconexões, descontinuidades, digressões, descentramentos. É um mergulho no caos, não para nele permanecer, mas para daí extrair movimento. A invenção se dá como liberação de formas esquadrinhadoras do pensamento e da produção de imagens.

A revolução, como possessão do homem que lança sua vida rumo a uma ideia, é o mais alto astral do misticismo. As revoluções fracassam quando esta possessão não é total, quando o homem rebelde não se libera completamente da razão repressiva, quando os signos da luta não se produzem a um nível de emoção estimulante e reveladora, quando, ainda acionado pela razão burguesa, método e ideologia se confundem a tal ponto que paralisam as transações da luta. (Rocha, 2004: 250).

As transações da luta precisam estar em movimento, que é parado quando existe uma ordem de dominação racional. No processo de combate em desrazão, há um coeficiente de destituição do instituído, ou da colonização, como é possível ler de forma recorrente nas discussões de 
Glauber e também ver nos filmes dele. O que essas palavras nomeiam, o burguês, o colonizador, o imperialismo - evidentemente, com as cargas próprias que têm, em termos de matrizes - é, sobretudo, uma instância de poder que submete tudo a um estado de fato, que faz da vida um conjunto de restrição de desejos e de possibilidades. E o que a desrazão vem contrariar é justo esse Poder transcendente, para colocar novas saídas, indicar linhas de fuga, caminhos ainda não explorados, sabores ainda não experimentados. A razão é policial, a desrazão é uma política. Uma estética do sonho existe como eterno movimento de investida no desequilíbrio, no heterogêneo e no alto índice de perturbação dos consensos. "O sonho é o único direito que não se pode proibir" (Rocha, 2004: 251). Essa é a saída que Glauber parece encontrar nesse momento das pesquisas dele, essa é uma fresta de possível que ele vislumbra, o lugar que ainda não foi capturado. Sonhar é elaborar novos mundos. No cinema de Glauber, não se trata de uma saída da luta, de fuga para não se pôr em combate, mas justo de linha de fuga desencadeada a partir da tensão com os fatos majoritários. É nesse ponto que se pode experimentar a invenção.

\section{Limiares}

Delirar, delirar: um delírio, dentro de uma perspectiva crítica à racionalidade burguesa, não é alienação do mundo, mas uma modalidade de se conectar com ele, operando desenraizamentos e fazendo fissuras. É uma maneira de apostar em outros paradigmas de pensamento, em outras cosmologias. Trata-se de distorcer um espaço, de confundir as palavras e se colocar em zonas de mistério. Delirar no limiar, desgarrar-se dos territórios e atingir estados de esgarçamento. A sequência de abertura de Claro já reúne todo um clima insólito e um conjunto de experimentações imagéticas e sonoras que escapam ao encaixe do entendimento e do inteligível. Seguimos Glauber e Juliet Berto em ações performáticas em meio às ruínas 
de Roma, com percursos desconexos e marcados por forte carga de alucinação. $\mathrm{O}$ filme instaura uma experiência de desequilíbrios no espaço turístico, na centralidade carregada de peso histórico. Delirar torna-se uma política de perturbação de centros e de estabilidades.

Logo no primeiro plano do filme, Juliet Berto está diante de um muro pintado com um rosto. Ela é vista de perfil, enquanto são ouvidos cantos. Repentinamente, uma mão vem por trás da atriz e, com um lenço vermelho colocado na boca dela, a puxa para fora do quadro. Um corte introduz uma tela branca por alguns segundos, à qual se segue um plano completamente aberto que mostra a imensidão das ruínas de Roma e a pequena figura de Berto, ajoelhada, inicialmente bem distante. A mulher dá início a movimentos performáticos pelo espaço, sem finalidade, numa temporalidade aberta, numa disponibilidade em fazer travessias. Os cantos permanecem, vozes que gritam, sonoridades que remetem a um tom ritualístico. É Glauber falando uma língua indígena, fora de quadro. Aos poucos, o plano se fecha mais e se aproxima da atriz que abre os braços, caminha, leva as mãos à cabeça. Ela começa a responder a Glauber, retornando com as mesmas palavras, entrando na mesma língua. Há aqui uma interação direta entre quem está no campo e quem está no antecampo, tanto com a mediação mais direta das palavras, quanto a partir de gestos e olhares de Berto. Ela prossegue o percurso, fazendo um trajeto da esquerda para a direita e depois se dirigindo ao fundo, partindo em maior velocidade, até começar uma corrida, rumo a se perder de vista. Alguns turistas, muitos deles com câmeras fotográficas, olham sorrindo para o acontecimento desencadeado, alguns chegam mesmo a acenar. Após a corrida de Berto, a câmera se desvia um instante dela, se desloca para a esquerda, filma mais do espaço e do céu, até retomar para a direita e tentar localizar mais uma vez a atriz, que agora volta do fundo, gritando novamente para o antecampo. Passa-se a uma movimentação cada vez mais dispersa, de ir e vir, de se perder constantemente pelo espaço e de mapear a paisagem. 
Esse procedimento lançado logo de entrada no filme é prolongado nas cenas seguintes, que vão acompanhar ainda o percurso de Berto. Também se trata do percurso da própria obra em errância. Em um momento, ela rola pelo chão, diante do Coliseu, enquanto Glauber salta por cima do corpo dela em movimento. Mais uma vez, os passantes olham, ora com uma curiosidade e um sorriso, ora com certo assombro. O corpo esgotado de Berto precisa ser erguido por Glauber, mas ela logo se levanta e começa a mostrar os dedos em tom provocativo, segue o caminhar, distanciando-se da câmera, enquanto uma mulher que estava sentada olha com espanto para a câmera, se ergue e passa apressada, cruzando o campo visual. Intervenções no som fazem os áudios de diferentes sequências se interpenetrarem, misturando o som direto com o prolongamento de vozes ouvidas momentos antes ou ainda com uma música que começa a tocar. Berto passa também a enunciar algumas frases em francês: "Ouço a voz de fantasmas", diz repetidas vezes. "Eu mato, eu mato, eu mato". Ela estala os dedos e aponta para a câmera com um gesto que imita a posse de uma arma. "Vemos nosso reflexo, através da realidade, através dos sonhos", diz em dois planos distintos, cortados e unidos para completar a frase que sai fragmentada. "A destruição da civilização ocidental”, segue ela, estendendo os braços. Em meio a esses planos dos gestos e das ocupações de Berto em Roma, surgem imagens que mostram separadamente algumas estátuas nas ruas, monumentos de uma civilização, de períodos clássicos, de um império construído há muitos anos. A câmera delirante, o percurso imagético que vira balbucio, reinvenção de linguagem, encontra a história, toda a carga de uma civilização construída ao longo dos tempos, em meio a inúmeros processos de estabelecimentos de partes, em distribuições litigiosas do sensível, para retomar termos de Rancière (1996).

Nesse embate com Roma, a poética de Glauber vira o movimento do estrangeiro que busca produzir uma outra espessura de tempo, que desarticula o monumento erigido para contar a História de grandes 
empreendimentos e se empenha em abrir frestas, pequenas formas delirantes de devir. Essa tensão, que começa a se constituir primeiramente como imagem, passa também a se evidenciar no discurso em off que o realizador enuncia, na medida em que surgem estátuas, praças e mais extensões da grandiosidade de um império. Glauber fala de Otávio Augusto, o imperador romano que empreendeu expansões de poderes, estabeleceu dominações e uma soberania romana sobre outros povos. "A conquista imperialista de Roma sobre o Terceiro Mundo", define Glauber. Com um plano aberto, ele filma de cima a estátua de Otávio Augusto montado em um cavalo, no centro de uma praça, tendo em volta outras estátuas e uma amplitude de espaço. "A sede do imperialismo, fixada aqui embaixo das patas desse cavalo monstruoso. Essa imagem é a última imagem do Ocidente, la ultima immagine del Occidente”. A fala de Glauber começa a misturar as línguas, uma penetrando a outra. Ele chega a conversar com Berto em outro instante, falando um italiano mergulhado pelo português, ouvindo as respostas da companheira em francês e replicando também com variações de francês e italiano. Passa-se, então, a torções com uma forma estável de filmar e de falar.

Propondo o conceito de imagem-exílio nesse filme de Glauber, Hudson Moura (2005) já desenvolveu uma análise detida no aspecto das línguas que proliferam em Claro, a partir de uma ênfase na situação de exilado do realizador em Roma. Glauber opera conexões com todo um mundo de referências. Da discussão de Moura, é interessante reter as implicações entre dois movimentos gerais do filme, a superposição de línguas e a de imagens. Existe um aspecto cultural nesse entrecruzamento de idiomas, mas parece aqui importante também pensar como isso reverbera de modo bastante emblemático na experiência estética do filme. Não estamos, simplesmente, diante da constatação de uma diversidade cultural, de um cinema mundial ou globalizado, tão recorrente em casos recentes de produção industrial. $\mathrm{O}$ exílio aqui é efetivamente imagético, 
desestabilização de nacionalidades, justo enquanto operação na plasticidade e na sonoridade. Moura (2005) destaca as metamorfoses dos espaços, as misturas dos procedimentos de ficção e documentário, os cortes na palavra. Ainda segundo o autor, não se trata de construir uma história sobre o exílio, mas de colocar o exílio em potência, tornar sua força pulsante e em transe, na ordem de um insuportável (2005: 98-100). A política é formulada mais como uma força do que como um discurso (2005: 102). Essa força torna-se sensível nas transgressões operadas por Glauber no âmbito das formas cinematográficas, na abertura que faz em uma sequência como a discutida aqui, com Berto rolando pelo chão diante do Coliseu, ou na ida a um bairro periférico de Roma, onde empreende sobreposições de imagens e um encontro com corpos singulares. Retomando Moura (2005), trata-se de levar para as imagens a hesitação expressa na fala, a partir do contágio entre as línguas.

O procedimento que consiste em cortar a palavra e torná-la hesitante se traduz em imagens. Há, ao longo de todo o filme, sequências interrompidas, inacabadas, cenas sem som, sons ouvidos a partir de uma cena precedente e que retornam, barulhos que tornam inaudíveis as palavras e as reenviam ao segundo plano, superposições de imagens e de cortes das cenas. (Moura, 2005: 96). ${ }^{4}$

Fazer a imagem delirar. Ela atinge níveis de suspensão, ela traça desvios. Berto guia o filme para a perda de uma conexão segura com o mundo, para estados de embriaguez. Um movimento delirante é de um lado o do corpo que se libertou para rolar ou para ir e vir, sem ordenações prévias, sem uma funcionalidade. E de outro, é o da câmera, completamente mergulhada no processo e tornada uma viajante em exílio. O filme não é

\footnotetext{
${ }^{4}$ Tradução minha do original em francês: « Le procédé qui consiste à couper la parole et à la rendre hésitante se traduit en images. Il y a, tout au long du film, des séquences interrompues, inachevées, des scènes sans son, des sons entendus lors d'une scène précédente et qui reviennent, des bruits qui rendent inaudibles des paroles en les renvoyant au second plan, des superpositions d'images et des coupures de scènes ».
} 
uma narrativa pessoal que se conta sobre a experiência de estar fora do próprio país, ele já surge em meio a esse lugar de correlação de mundos. Não se torna uma expressão da subjetividade do realizador em uma suposta nostalgia da pátria. Aqui há muito mais uma tomada de posição diante do capitalismo mundial e da História contada a partir de uma perspectiva vertical em detrimento das potências dos povos submetidos às dominações dos colonizadores. E as relações instauradas nas imagens de Claro estão estreitamente conectadas às dobragens já empreendidas por Glauber em outros dois filmes também de exílio, Cabeças cortadas (Cabezas Cortadas, 1970), filmado na Espanha, e O leão de sete cabeças (Der leone have sept cabeças, 1970), rodado no Congo africano. São também obras fundamentais de enfrentamento e de passagem para uma estética do sonho, já marcadas por uma postura de delírio. A posição de exílio em Glauber faz com que ele se empenhe num trabalho de pesquisa em que as singularidades de cada lugar são pensadas em conexão com as lutas e os processos de subordinação na conjuntura do capitalismo. E isso se dá como trabalho de imagens, como operação de escritura fílmica.

Didi-Huberman (2009), ao tratar de algumas pesquisas de Brecht, o Diário de Trabalho e o $A B C$ da Guerra, enfatiza o quanto a posição de exílio do artista no período em que se dedicava a essas obras é tornada um trabalho de escritura e de pensamento apesar de tudo (Didi-Huberman, 2009: 13). A condição da escrita desterritorializada, sempre à beira de uma próxima partida, numa insegurança constante quanto ao porvir, suscitava uma poesia não só na guerra, quanto uma poesia de guerra, diz ainda DidiHuberman (2009: 13). "Poesia abundante, de outros lugares, exploratória e prismática: longe de se redobrar sobre a elegia, longe de sacrificar a qualquer nostalgia que seja, o escritor multiplica aqui as escolhas formais e os pontos de vista" (Didi-Huberman, 2009: 14). Evidentemente, as situações de exílio de Glauber e de Brecht não são as mesmas, nem o são as matérias artísticas que tomam para si. Mas vale reter aqui essa discussão que Didi- 
Huberman leva adiante, na medida em que ele detecta no exílio a possibilidade de um trabalho, que se modula na forma, reinventa gestos, desmonta e remonta. É criada uma dimensão de desordem para tomar posição, para engajar-se no mundo, em apostas quanto a novas condições de criação e de vida.

Delirando, Glauber experimenta uma dimensão de mistério na linguagem, uma maneira de fazer o cinema estranhar o próprio cinema. No caminhar sem referência segura, a imagem pode ser produzida de forma cambaleante, o corpo pode vacilar na cena, a fala pode se desorganizar em palavras que se tornam puras vibrações. O delírio se investe de uma postura de resistência à expropriação da linguagem pelo capitalismo, à destinação de lugares, ao constrangimento de outros mundos possíveis. Em um momento, Juliet Berto fala a respeito de um esgotamento das palavras. Ela está sozinha no plano, com um chapéu, o quadro recortando seu rosto ao lado da estátua de um leão.

Não há mais palavras a dizer, pois a linguagem não é mais a linguagem, e a diferença entre o ato e a palavra caiu em algo de unilateral, onde toda a cor, onde todos os sons, onde todas as formas se agruparam num caos "cosmono-demonical", onde eu esqueço o que chamávamos de lucidez, pois gera, gera, como algo cristalino e novo, como novos sons, onde os perfumes, que poderiam começar... Não, não é ele.

A própria fala é dita em estado de alteração, ela vai se desfazendo aos poucos, chegando a um liame. O filme parece explicitar uma questão cara ao próprio movimento que tenta instaurar. A linguagem não é mais a linguagem. As palavras tornam-se inoperantes, já não cabe proferi-las. $\mathrm{O}$ que se constata é um abismo, ato e palavra em defasagem. E o que isso implica para a cena fílmica? Como a obra se situa nesse lugar em que todas as formas se agrupam num caos "cosmono-demonical"? Há nas sequências ficcionais de Claro um impulso maior para a marcação de emblemas, para o recurso a personagens que proferem discursos mais circunscritos ao campo 
das insatisfações de Glauber com situações sociais do mundo. Mas é preciso ainda se colocar de forma mais detida diante dessa ficção singular que é operada no filme, a penetrar o real, que também insiste e pulsa por todo o corpo da obra. Porque é também uma ficção delirante, que mesmo expressando, em alguma medida, uma discursividade pontuada por teses, cria um movimento de tal modo imprevisto que já não se podem controlar os modos de as imagens resvalarem no campo da experiência e virarem linhas que escapam ao próprio curso do filme.

Há um plano aberto e vários personagens circulando livremente pela cena, no espaço de um jardim, em torno de uma mesa que contém pedaços de carne. É uma sequência profundamente marcada por movimentos performáticos e também gestos teatrais. Mais uma vez, é Berto quem conduz a encenação, enunciando o discurso. À sua volta, todos parecem completamente independentes de qualquer fala, desligados, de um modo mais evidente, daquilo que é dito. Dois homens circulam em torno da mesa, conversando com gestos largos. Outros dois e uma mulher rodopiam livremente, dançam, também fazem o movimento circulatório em torno do centro da cena, mas segunda uma linha desmesurada e desregrada. O plano se fecha progressivamente: mais cerrado, ele faz com que os personagens estejam por mais tempo fora de quadro, criando na imagem um acúmulo de gestos, de pedaços de movimentos, que muitas vezes apenas reverberam indiretamente no campo do visível, não chegando a ocupar efetivamente o quadro. Aos poucos, a câmera se movimenta para baixo e mostra em mais detalhes o que está sobre a mesa do centro, algo como a carne crua de animais, como se estivéssemos também num ritual de sacrifício e de oferenda. Um corte leva a um novo plano longo, também de movimentação intensa e de desconexão entre os corpos. Agora os personagens que apenas circulavam também falam, mas as palavras não são encadeadas, elas são, sobretudo, soltas, e raramente formam frases completas. A mulher aparece com os seios expostos, dos quais um homem se aproxima com a boca. Os 
pedaços de carne são erguidos. Quando Berto surge novamente, ela coordena a encenação, oferece um punhal a um dos homens para que mate o outro. O fim da sequência coincide com a morte desse personagem, um plano fechado sobre seu rosto.

E o que fala Berto nesses momentos? Ela se remete aos próprios personagens em cena, que já estiveram em sequências anteriores, mas agora são quase que apresentados por essa mediadora da cena. Ela fala ainda de algo já lançado por imagens anteriores, a decadência da civilização ocidental, o desmoronamento de Roma, a exploração do homem pelo homem. "O povo nascerá dessa cidade onde tudo o que existe é disposto em cartões-postais. Uma cidade de cartões-postais, que rodopia e se movimenta em meio a turistas loucos por um passado doente. Doente por um capitalismo que está explodindo, degenerando, totalmente perdido". Ela cita Ho-Chi-Mihn e repete a ideia do vermelho, de um sangue vermelho. De algum modo, esse discurso se situa em zona bastante estratégica no conjunto do filme, após uma série de sequências que são, de certa maneira, explicadas aqui, e antes de outras que também repercutem esse anseio de que um povo nasça dessa cidade - se pensarmos, principalmente, na ida à borgata, em uma outra sequência fundamental de Claro.

Mas o didático e o explicativo são também borrados. Se é possível identificar um esquema geral que torna cada personagem um emblema em determinado jogo de sentido: o capitalista, o colonizador, os burgueses, a prostituta (como também era a marca em $O$ Leão de Sete Cabeças, por exemplo), há uma dramaturgia que vem se elaborar como outra política do espaço da cena. Essa outra inscrição cênica coexiste, em tensão, com a lógica explicadora, e torna potente na ficção a mesma carga de deambulação delirante que marcava os percursos de Berto pelas ruas de Roma, quando o filme abria-se, de forma mais explícita, a um regime documental. As palavras entoadas enquanto os personagens circulam entram naquele abismo que era justamente identificado por Berto entre ato e palavra, e daí a crise 
que o filme põe em movimento é uma irremediável cisão experimentada no jogo ficcional em que a metáfora tenta se desenhar. Enquanto o regime da significância tenta surgir, uma força de presença sempre a coloca para dançar. Se existe uma ordem burguesa a ser desmontada, uma história única de Roma a ser tensionada, a força maior do filme para levar esses processos adiante está nesses corpos que jogam sem finalidade pelo espaço, tanto nos momentos da ficção quanto do documentário. É quando uma possibilidade de vida se abre no acontecimento da cena, quando a dramaturgia traz para a sensação o enfrentamento que tenta expor no âmbito do discurso, a respeito da necessidade de superar o capitalismo. $\mathrm{O}$ corpo precisa não suportar mais esse regime sensível. A vida precisa se fazer na cena como irrupção de outros desejos, que surgem de uma delirante rarefação do dizível, do visível e do audível, para resistir aos processos de captura e de ofuscamento por parte dos poderes.

Benjamin (1994) fala de um espaço da imagem que surge na política, o que pode ser aqui uma figura bastante potente para situar melhor essa tensão exposta nesse cinema de Glauber. "É na política que a metáfora e a imagem se diferenciam da forma mais rigorosa e mais irreconciliável. Organizar o pessimismo significa simplesmente extrair a metáfora moral da esfera da política, e descobrir no espaço da ação política o espaço completo da imagem" (Benjamin, 1994: 34). É, então, nesse processo, que as imagens não param de se fazer. E não param porque existe uma política de insistência que não organiza a metáfora nem a moral, mas um espaço completo de imagem. Organizar o pessimismo é a possibilidade de aposta numa política da imagem. E Benjamin ainda completará mais adiante essas transformações para o que chama de um espaço da imagem, indicando que ele se modifica em "algo de mais concreto ainda: espaço do corpo" (Benjamin, 1994: 35). Espaço do corpo e espaço completo da imagem são experimentações de tensões revolucionárias, que se dão materialmente. Elas precisam de um espaço efetivamente - e de um tempo também, poderia ser 
acrescentado. O que Benjamin recusa é o caráter contemplativo da experiência. Poderia dizer que é também uma tensão com a abordagem no âmbito do puro intelecto, de onde vem essa demanda do corpo, e de um corpo que possa se desdobrar em corpo coletivo para gerar contágio por meio de uma physis. Delirar pode ser uma maneira material de fabricar outros espaços de imagem e de corpo.

Nessa linha, os esforços do surrealismo, se seguirmos com a leitura de Benjamin (1994), já estabeleciam como questão central uma política poética implicada numa maneira de delirar relacionada à embriaguez. "Mobilizar para a revolução as energias da embriaguez" (1994: 32). Benjamin fala de uma iluminação profana, ligada tanto ao uso de drogas, o haxixe, o ópio, quanto à própria experiência desencadeada pela arte, pelo pensamento, pela deambulação na cidade. Era nesse âmbito que ele se esforçava em situar os trabalhos dos surrealistas. "O homem que lê, que pensa, que espera, que se dedica à flânerie, pertence, do mesmo modo que o fumador de ópio, o sonhador e o ébrio, à galeria dos iluminados. E são iluminados mais profanos”. (Benjamin, 1994: 33). Novamente, aqui existe uma relação com forças cósmicas, que impliquem o homem num movimento revolucionário, ligado ao caos e a uma desordem produtiva de novos mundos. Em Rua de mão única, ele chega a apontar também para essas potências da embriaguez. "É embriaguez, decerto, a experiência na qual nos asseguramos unicamente do mais próximo e do mais distante, e nunca de um sem o outro. Isso quer dizer, porém, que somente na comunidade o homem pode comunicar em embriaguez com o cosmos" (Benjamin, 1987: 64). Benjamin acrescenta aí outro elemento para pensar a integração que se pode alcançar com o cosmos. É que além da embriaguez, ele fala também de uma comunidade. A experiência cósmica é da ordem de um comum, e podemos traçar conexões variadas com o mundo, na alteração e no trânsito possibilitados pela embriaguez. Talvez, assim, o povo nascerá de uma Roma doente, como invocado por Berto, não tanto por uma 
chamada intelectual, mas por certa medida de delírio, por um trânsito que promove comunicações com o cosmos. Uma outra chave aqui para pensar o problema do comum pode ser arriscada: a comunidade agora fundada pela experiência do desnorteio e da implicação do corpo no universo. Não uma contemplação do cosmos, mas uma integração cósmica que instala um interstício para o em-comum. Não uma racionalidade dedutiva, mas uma liberação de sonhos. "Eu acredito que a obra de arte é um produto da loucura, no sentido em que fala o Fernando Pessoa, que fala o Erasmo, quer dizer, a loucura como a lucidez, a libertação do inconsciente" (Rocha, 2006: 333). Glauber estava preocupado com a dimensão produtiva desse inconsciente, liberado para gerar, maquinar, desencadear espaços de imagem, espaços de corpo. ${ }^{5}$

O delírio pode ser pensado como um processo que arrasta as palavras de um extremo a outro do universo, como diria Deleuze (2011: 9). Esses movimentos de arrastar são bastante concretos aqui, uma maneira de pensar as palavras, enunciadas num filme ou escritas num livro - Deleuze trata especialmente da literatura, nessa discussão trazida aqui. Mas é também uma possibilidade de operar com as imagens, também carregadas entre extremos, deslocadas de forma intensa. Trata-se de traçar desvios na língua, operar devires variados. Delirar é minorar uma língua maior. "Dirse-ia que a língua é tomada por um delírio que a faz precisamente sair de seus próprios sulcos" (Deleuze, 2011: 16). É preciso pôr em evidência no delírio a criação de uma saúde, uma possibilidade de vida, de invenção de um povo, indica Deleuze.

A literatura é delírio, mas o delírio não diz respeito a paimãe: não há delírio que não passe pelos povos, pelas raças e tribos, e que não ocupe a história universal. Todo delírio é histórico-mundial, "deslocamento de raças e de continentes".

\footnotetext{
${ }^{5} \mathrm{Na}$ fortuna crítica a respeito de Glauber Rocha, existe um estudo bastante central que se situa no campo das relações entre cinema e psicanálise, desenvolvido por Raquel Gerber. Ver: GERBER, Raquel. O mito da civilização atlântica. Glauber Rocha, Cinema, Política e a Estética do Inconsciente. Petrópolis: Editora Vozes, 1982.
} 
A literatura é delírio e, a esse título, seu destino se decide entre dois polos do delírio. O delírio é uma doença, a doença por excelência a cada vez que erige uma raça pretensamente pura e dominante. Mas ele é a medida da saúde quando invoca essa raça bastarda oprimida que não para de agitar-se sob as dominações, de resistir a tudo o que esmaga e aprisiona e de, como processo, abrir um sulco para si na literatura. (Deleuze, 2011: 15).

O capitalismo doente, desmontado nas imagens delirantes de Claro, precisa ser posto em crise por essa outra espécie de delírio, medida de saúde, que pode fazer sulcos na linguagem, num cinema estruturado, para desencadear devires variados que apontam para a vida, para o desejo de viver de modos inéditos, libertos das dominâncias e do passado doente. Como já observou André Brasil (2008), ao discutir o delírio e o transe em Aboio (Marília Rocha, 2005) e Andarilho (Cao Guimarães, 2006), as imagens deliram na contramão do delírio do capitalismo, que se esforça em dissociar experiência e linguagem. "Cao Guimarães nos mostra a linguagem em sua forma pura, que é, paradoxalmente, sua extrema impureza: a substância heterogênea dos sons, do balbucio, do grito, do gesto, da performance, do esforço, a substância do silêncio", diz Brasil a respeito de Andarilho. Em Aboio, como tentei pontuar também em Claro, existe uma tensão entre a explicação e o transe. E a força do filme, seguindo com Brasil, está menos nos momentos didáticos que na impotência, "naquilo que ele não consegue explicar nem controlar" (Brasil, 2008). A linguagem dos vaqueiros se transforma em música e parte diretamente da experiência cotidiana. Trata-se, nos dois filmes, de "um delírio que é a própria realidade, o delírio da experiência, seu lastro" (Brasil, 2008). Existem novas possibilidades de a linguagem se conectar com a experiência e de o delírio efetivamente ter conexão com uma vida, com a movimentação do viver. Nos filmes de Cao Guimarães e de Marília Rocha, a imagem pode guardar seu mistério e escapar aos clichês e aos estereótipos. "A linguagem, neste caso, 
está colada ao corpo, aos gestos, à paisagem, à experiência sensível. Longe da abstração das gramáticas e dos manuais técnicos, ela delira, canta, entra em transe, fundindo, em um só corpo, os gestos, as palavras, a natureza, os mitos" (Brasil, 2008).

Se em Claro, as imagens têm essa potência de delirar, elas partem para caminhos desconhecidos, misteriosos. Caminhos de um cinema que ainda não está dado, que se inventa como feitiçaria dos sentidos, como transe e passagem. Berto não enuncia apenas discursos, ela rola no chão, canta e detecta, de forma bastante emblemática, os impasses da palavra. Fazer a linguagem delirar não é um objetivo, mas um caminho de tensões abertas, em que as incertezas proliferam. $\mathrm{O}$ delírio como processo que fende o cinema, faz nele sulcos. Delirar nos limiares da imagem e instaurar aí um espaço de corpo. Talvez sejam essas algumas modulações, nesse regime de urgência e de delírio, que esses filmes de Glauber nos colocam para pensar o cinema e a política da imagem. Ao optar pelo enfoque, sobretudo, em Claro e Di Cavalcanti, a tentativa aqui é perceber uma curva, algo como uma inflexão na cinematografia glauberiana, que não deixa de estar absolutamente conectada com o mundo e com o real, mas se investe de outros paradigmas para o pensamento, especialmente mais enfeitiçados e mágicos, como o próprio realizador apontava na sua estética do sonho. Se assim podem ser fabricados filmes documentários em profícua tensão com o real, é porque as formas da imagem não cessam de se contaminar pela experiência do encontro entre corpo e mundo. A linguagem delira justo porque o real nelas insiste e pulsa.

\section{Referências bibliográficas}

ARAÚJO SILVA, Mateus (2012), "Glauber Rocha e os Straub: diálogo de exilados" in E. Gougain, F. Taddei, P. Mourão e M. Araújo Silva 
(Orgs.), Straub-Huillet, São Paulo: Centro Cultural Banco do Brasil, 2012, pp. 243-263.

BENJAMIN, Walter (1994), Obras Escolhidas I. Magia e técnica, arte e política: ensaios sobre literatura e história da cultura, $7^{\mathrm{a}}$ Ed., São Paulo: Brasiliense.

(1987), Obras Escolhidas II. Rua de mão única, São Paulo: Brasiliense.

BRASIL, André (2008), "Quando as palavras cantam, as imagens deliram" in Revista Cinética. Disponível em: http://www.revistacinetica.com.br/aboioandarilho.htm

COMOLLI, Jean-Louis (2008), Ver e poder - a inocência perdida: cinema, televisão, ficção, documentário, Editora UFMG.

DELEUZE, Gilles (2011), Crítica e Clínica, 2a Ed, São Paulo: Ed. 34.

DIDI-HUBERMAN, Georges (2012a), Imagens apesar de tudo, Lisboa: KKYM.

(2008), "La emoción no dice “yo". Diez fragmentos sobre la libertad estética" in JAAR, Alfredo, La política de las Imágenes, Santiago de Chile: ediciones metales pesados.

(2012b), "Quando as imagens tocam o real” in Pós: Belo Horizonte, v. 2 , n. 4 , pp. $204-219$.

(2009), Quand les images prennent position. L'oeil de l'histoire, 1, Paris: Les Éditions de Minuit.

MOURA, Hudson (2005), Glauber Rocha et L'image-exil dans Claro, Cinémas (Montréal), Montréal, v. 15, p. 81-103.

RANCIÈRE, Jacques (1996), O desentendimento, São Paulo: Ed.34.

ROCHA, Glauber (2004), Revolução do cinema novo, São Paulo: Cosac Naify. 
Glauber sob um regime de urgência

\section{Filmografia}

Aboio (2005), de Marília Rocha.

Andarilho (2006), de Cao Guimarães.

Cabeças cortadas (1970), de Glauber Rocha.

Câncer (1968-1972), de Glauber Rocha.

Claro (1975), de Glauber Rocha.

Deus e o Diabo na Terra do Sol (1964), de Glauber Rocha.

Di Cavalcanti (1977), de Glauber Rocha.

Letícia e Mossa no Marrocos (1971), de Glauber Rocha.

O Dragão da Maldade contra o Santo Guerreiro (1969), de Glauber Rocha.

O leão de sete cabeças (1970), de Glauber Rocha.

Paloma, Paloma (1972), de Glauber Rocha.

Terra em Transe (1967), de Glauber Rocha. 


\title{
LA PRIMERA PERSONA, EL AMOR Y LA PERSISTENCIA DE LAS PREGUNTAS EN EL TELÓN DE AZÚCAR, de CAMila GuZMán Urzúa
}

\begin{abstract}
Anabella Castro Avelleyra *
Resumo: Entendendo a experiência dos anos noventa como uma pulsão que promove a busca de novas perspectivas sobre a atualidade (Dipaola, 2012), o artigo reflete sobre o lugar do autobiográfico e o performativo, o subjetivo e o individual na construção e desconstrução da Revolução e da sociedade cubana desde o Período Especial no documentário El telón de azúcar (2005), de Camila Guzman Urzúa.

Palavras-chave: cinema cubano, Período Especial, documentário performativo.

Resumen: Comprendiendo a la experiencia de los años noventa como una pulsión que promueve la búsqueda de nuevas miradas sobre la actualidad (Dipaola, 2012), el artículo intenta reflexionar sobre el lugar de lo autobiográfico y lo performativo, lo subjetivo y lo individual en la construcción y deconstrucción de la Revolución y la sociedad cubana a partir del Período Especial en el documental El telón de azúcar (2005), de Camila Guzmán Urzúa.

Palabras clave: cine cubano, Período Especial, documental performativo.

Abstract: Understanding the experience of the nineties as a drive that promotes the search for new perspectives on today (Dipaola, 2012), the article reflects on the place of the autobiographical and the performative, the subjective and the individual in the construction and deconstruction of the Revolution and Cuban society since the Special Period in the documentary El telón de azúcar (2005), by Camila Guzman Urzúa.

Keywords: Cuban cinema, Special Period, performative documentary.

Résumé: Pour comprendre l'expérience des années quatre-vingt dix comme stimulation qui favorise la recherche de nouvelles perspectives aujourd'hui (Dipaola, 2012), l'article se penche sur la place de l'autobiographique et du performatif, du subjectif et et de l'individu dans la construction et la déconstruction de la Révolution et de la société cubaine de la Période spéciale dans le documentaire El telón de azúcar (2005), de Camila Guzman Urzúa.
\end{abstract}

Mots-clés: cinéma cubain, Période Spéciale, documentaire performatif.

\footnotetext{
* Doutoranda. Universidad de Buenos Aires, Faculdad de Filosofía y Letras, Instituto de História del Arte Argentino y Latinoamericano. 1181, Buenos Aires, Argentina.

E-mail: anabella.castro.a@gmail.com
}

Submissão do artigo: 26 de junho de 2015. Notificação de aceitação: 07 de setembro de 2015. 
Así que los noventa con algo de los ochenta, el rebote tal vez, es lo que nos constituye. Romina Paula, Agosto.

\section{Introducción}

Camila Guzmán Urzúa, la directora del documental El telón de azúcar (2005), nació en Chile en 1971. El golpe de Estado contra el gobierno de Salvador Allende hizo que su familia (su padre es el cineasta Patricio Guzmán, director de La batalla de Chile) se exiliara en Cuba. Así, Camila llegó a La Habana a los dos años de edad y pasó allí su infancia y adolescencia. Luego de finalizados sus estudios, viajó a Europa para pasar tiempo con su padre, quien había abandonado el país poco después de su arribo. Años más tarde, a mediados de la década del 2000, Camila regresó a Cuba a realizar un documental que podría calificarse como autobiográfico ${ }^{1}$, en el que vuelve sobre los recuerdos y los espacios de sus primeros años interrogándolos desde una actualidad fuertemente marcada por los estragos del Período Especial.

En ese contrapunto entre el ayer y el hoy, entre la próspera Cuba de los ochenta y el país desolado por el Período Especial, y también entre la infancia y la adultez se desarrolla El telón de azúcar, una indagación política y social, pero sobre todo personal. Es desde allí - desde lo propio, lo íntimo, el yo- que se construye - y deconstruye - un entramado amplio que propone más preguntas sinceras que respuestas definitivas en torno a la Revolución y la sociedad cubana.

La propuesta del trabajo es realizar una lectura del filme a partir de las reflexiones de Esteban Dipaola (2012) en su libro Todo el resto. Estética

1 Subjetivo, performativo, en primera persona, ensayístico, son otras posibles clasificaciones. 
y pulsión de los años '90, traspolando su análisis de la cultura argentina a la cubana. También intentaremos pensar el régimen de verdad que propone el documental a partir de las ideas desarrolladas por Alain Badiou (2012) en Elogio del amor. Nos proponemos explicar por qué consideramos que el film se encuadra dentro de los documentales autobiográficos, tomando como guías los pensamientos de Esteban Dipaola (2012), Ana Amado (2009) y Pablo Piedras (2009). Eric Selbin (2012) también nos permitirá arribar a estas conclusiones a partir del concepto de storyteller.

\section{Los noventa en Cuba y su proyección en el cine reciente}

En su relato, Camila parte de la premisa de que los ochenta fueron "años dorados". Su voz estipula al comienzo del film: "pertenecimos a la generación de cubanos nacidos y criados en los años dorados de la Revolución”. Realiza aquí una triple inscripción: 1) ella, aunque nacida en Chile y actualmente residente europea, se considera cubana y se inscribe como tal en el relato; 2) hay un yo que opera como narrador; ${ }^{2}$ y finalmente, 3) establece a los ochenta como los años dorados de la Revolución, afirmación que podría cuestionarse desde la Historia "dura", dado que ya en esa década el campo socialista europeo se encontraba en crisis (Perestroika, Glasnost) y eso tenía una repercusión negativa sobre Cuba. Habiendo establecido que la directora se inscribe como un yo a cargo de quien estará la narración, resulta posible comprender el concepto de "años dorados" más allá de lo político-económico-social, o sea, centrándonos no tanto en la

\footnotetext{
${ }^{2}$ Si bien la frase citada refiere a un "nosotros", anteriormente, en las palabras iniciales del film, Camila se inscribe claramente como el "yo" narrador. Luego de mostrarnos imágenes de pioneros en la escuela Camila relata: Así crecí yo. Usé ese mismo uniforme y también dije que sería como el Che. Eso fue hace más de veinte años y recuerdo que Cuba era como un paraíso. Un lugar sin preocupaciones, sin angustia, sin violencia. Aquí el dinero no tenía valor, lo material no tenía importancia y no existía ni el desempleo ni la religión. En esta isla calurosa la solidaridad reinaba en todas partes. Todos nos sentíamos iguales y en las calles no había ni publicidad ni apuro. (Aparece aquí el insert de una foto de Camila en 1977, en la que se lee "Recuerdo de pre escolar"). Recuerdo que fui muy feliz.
} 
Historia sino en la historia, comprendida esa catalogación así entonces desde la visión subjetiva de la niñez $z^{3}$. Más allá de esto, es innegable que la economía cubana en la década del ochenta era aún lo suficientemente próspera como para garantizar la satisfacción de las necesidades de todos sus ciudadanos. Redundan en este sentido en el film las declaraciones en torno a la abundancia de comida y la desestimación del dinero, que no era considerado como algo esencial o ni siquiera necesario. Esta bienaventuranza se debía en gran medida a los estrechos vínculos del país con la Unión Soviética, con quien mantenía casi todas sus relaciones de intercambio comercial, planteadas en un sentido altamente beneficioso para Cuba. La caída del muro de Berlín en 1989 y posteriormente la disolución de la Unión Soviética, en 1991, conllevaron al ingreso del país en lo que se denominó el Período Especial en Tiempos de Paz. La crisis económica subsiguiente alcanzó una magnitud desconocida en Cuba desde el triunfo de la Revolución ${ }^{4}$. El gobierno tomó entonces una serie de medidas económicas y políticas que buscaban ajustar la economía a la nueva realidad. Esta reforma se proponía la reinserción de Cuba en el mercado capitalista mundial, el mejoramiento del consumo y el aseguramiento de las necesidades básicas de la población, garantizando a su vez la supervivencia de las conquistas revolucionarias y el modelo político socialista (Álvarez Arce, 2006). Las nuevas medidas económicas incluyeron el fomento del turismo, la libre circulación de monedas extranjeras y el ingreso de capitales foráneos en algunas áreas de la economía como, por ejemplo, la producción

\footnotetext{
${ }^{3}$ En palabras de Rainer María Rilke, "La única patria que tiene el hombre es su infancia". Es inevitable tener esto en consideración a la hora de analizar El telón de azúcar.

${ }^{4}$ En su libro Raúl Castro, estratega de la defensa revolucionaria de Cuba, Hal Klepak (2010) enumera las siguientes cifras: una retracción de la economía de entre el 35 y el $50 \%$ entre 1989 y 1993; una profunda disminución de las exportaciones, debido a que la Unión Soviética absorbía el 63\% de la producción de azúcar, el 73\% del níquel, el 95\% de los cítricos y el $100 \%$ de los componentes eléctricos; una importante disminución de las importaciones, ya que la URSS era proveedora, en el campo de productos importados, del $63 \%$ de los alimentos, el $80 \%$ de maquinarias y equipos y el $74 \%$ de bienes manufacturados. Así, señala Klepak, Cuba perdió el $80 \%$ de su poder de compra en el exterior (p. 107).
} 
cinematográfica. Esto se debió a que la inversión estatal se vio reducida en múltiples sectores, de los cuales el cine no fue ajeno. El dinero asignado a la producción cinematográfica se redujo de modo brusco, mermando significativamente el número de films producidos por año y convirtiendo al régimen de coproducción con otros países en la única alternativa para la realización de películas. De este modo, el cine cubano comenzó a establecer fuertes vínculos transnacionales con otras cinematografías. A partir del 2000, el ingreso en la era digital favoreció un incremento en el número de films realizados y una significativa diversificación de la producción cinematográfica, que dejó de ser dependiente del Instituto Cubano del Arte e Industria Cinematográficos (ICAIC). En este tipo de producciones se enmarca El telón de azúcar, realizada de modo independiente al Instituto, con la financiación de diversas instituciones de distintas nacionalidades. ${ }^{5}$

Llegados a este punto, cabe pensar en las reflexiones de Ulrich Beck (2006) en torno a la individualización para comprender los cambios a los que se vio expuesta (de modo brusco) la sociedad cubana. El autor habla de “un tipo de 'cambio de forma' o de 'cambio categorial' en la relación entre individuo y sociedad" (2006: 209), al que refiere como un nuevo modo de sociabilización. Beck habla de una triple individualización:

disolución de las precedentes formas sociales históricas y de los vínculos en el sentido de dependencias en la subsistencia y dominio tradicionales ("dimensión de liberación"); pérdida de seguridades tradicionales en relación al saber hacer, creencias y normas orientativas ("dimensión de desencanto"), y un nuevo tipo de cohesión social ("dimensión de control o de integración”). (ídem: 210).

\footnotetext{
5 Los títulos del film nombran a las siguientes empresas productoras e instituciones auspiciantes: Luz Films (Francia), Paraíso Production Diffusion (Francia), Televisión Española, Groupe de Recherches et Essais Cinématographiques París (G.R.E.C.), Escuela Internacional de Cine y Televisión de San Antonio de los Baños (Cuba), Cine en Construcción Toulouse Donastía, San Sebastián.
} 
Esto parece ser lo ocurrido en Cuba con posterioridad al inicio de la crisis del Período Especial y, en tal sentido, se hace presente en El telón de azúcar. La primera dimensión señalada por Beck se aprecia en los cambios que se producen en los individuos en torno a su posibilidad de dependencia del Estado, ya sea en cuanto a sus garantías laborales (con el ingreso de la divisa en el sistema económico cubano los salarios estatales en moneda nacional no alcanzan para la supervivencia), como al resto de las garantías sociales (merma en los productos entregados a partir de la libreta de abastecimiento, por ejemplo). En el primer caso, de acuerdo a lo que señala una de las entrevistadas en el documental, la dependencia parecería simplemente correrse de lugar, ya que asegura que si no fuera por las remesas que le envía su hermano desde el exterior, no podría vivir de su salario. Respecto a lo segundo, una niña muestra su libreta, en la que muchos troqueles permanecen intactos ya que, señala su madre, ninguno de esos artículos aún se entregaron, tras lo cual recuerda todo lo que les era facilitado profusamente con anterioridad. La segunda dimensión se expresa en los cambios acaecidos en la sociedad y su vinculación con diversas áreas, una de las cuales es la profesional. La posición que otorgaba la posesión de un título, el desempeño de un oficio o profesión, se ve rearticulada en función de las nuevas lógicas de funcionamiento económico, en las que, como manifiesta uno de los entrevistados en el documental, se aspira a ser botones de un hotel por la posibilidad de ingresos en divisas que ello implica, mayores a los que se obtendrían desempeñando una profesión tradicional. El mismo entrevistado sostiene que esa falta de deseo por estudiar y desarrollarse en una profesión por parte de los jóvenes está dada por aquello en lo que los trabajos en Cuba han devenido: hacer una labor mecánica, sin mucho empeño, en la que no se entrega todo ya que la energía debe ponerse en alguna otra labor que permita "resolver", hacerse de la divisa necesaria para subsistir. La tercera dimensión deriva de las dos anteriores (como puede apreciarse, las tres están íntimamente 
interrelacionadas) y tiene que ver con una reestructuración de la cohesión social, que adquiere nuevas y cambiantes características. Una de las ex compañeras de escuela de Camila comienza su relato sosteniendo, ¿Qué cambió? Todo. La gente. La sociedad. La forma de uno poder obtener el dinero para vivir. No sé... todo cambió. Después de que comenzó el Período Especial todo cambió. Todo es diferente. Fue salir de la felicidad para entrar en la infelicidad. Fue difícil. El nuevo tipo de cohesión social, lejana y ya casi ajena a la de comienzos de la Revolución, contempla y justifica actitudes individualistas y no solidarias, como los pequeños robos efectuados por quienes trabajan en fábricas o bodegas, vistos como "necesarios" para la propia subsistencia.

\section{La fuga, la deriva, los traslados}

En su libro Todo el resto. Estética y pulsión de los años '90, Esteban Dipaola (2012) analiza el lugar que ocupa la década del noventa en la producción cultural posterior. A pesar de que su análisis se centra en Argentina, las reflexiones son en gran medida extrapolables a lo sucedido en Cuba. Dipaola plantea que "algo nos pasó en los noventa y no deja de pasarnos" (2012: 7, cursivas en el original). Esa reflexión, aplicada por el autor a los años de neoliberalismo salvaje, puede comprenderse también pensando en los años del Período Especial en Cuba y la crisis, no sólo económica sino de valores, que conllevó. “¿Se fueron los noventa?”, se pregunta. Y responde, "(s)i los noventa remiten a una temporalidad es porque dejaron marcas" (ídem: 10). Sin dudas, los noventa en Cuba no se fueron en el sentido de que dejaron marcas profundas en la sociedad, aún apreciables. Estas marcas son fundantes de la narración en el film de Camila. Los noventa articulan el relato de la década anterior, ideal e idealizada, y de la posterior, acuciante y controvertida. La caída del muro de Berlín, la disolución de la Unión Soviética y la inevitable crisis bautizada 
como Período Especial son las marcas lacerantes que propician la reflexión sobre el pasado proyectándolo hacia el presente. Dipaola plantea la posibilidad de "pensar los noventa bajo la figura de la temporalidad y, con ellos, pensar los años en fuga". Agrega que esa noción de fuga "ha sido una constante en la literatura y la cinematografía naciente por aquellos años. Las películas de lo que se conoció como Nuevo Cine Argentino, recurrían permanentemente a la estética de una experiencia de la fuga, de la deriva, de los traslados" (ídem: 13,14). La fuga aparece también en el cine cubano producido a partir de los noventa de múltiples formas. Por un lado, la fuga como opción primordial: fugarse al exterior, emigrar, ya sea a través de la búsqueda del otorgamiento de una visa, por el matrimonio con un extranjero, o huyendo de modo ilegal. Como sucede con un elevado porcentaje de los films realizados con posterioridad al ingreso en el Período Espacial, la temática de la emigración atraviesa El telón de azúcar. Cada una de las voces que contribuye a la construcción del relato está matizada por la emigración: la de un hermano o hermana, la de los padres, la de amigos o incluso la propia. La deriva también, personajes que deambulan por la ciudad, sin rumbo aparente, cooptados por la incertidumbre característica de esos tiempos. En El telón de azúcar, específicamente, la manifestación política parece haberse convertido de marcha firme y convencida en simple deriva, deambular. Los traslados aparecen como doble problemática, por un lado vinculados a la fuga y a la deriva, pero también como alegato de la crisis del transporte aparece el traslado como deseo problemático. La fuga, la deriva y el traslado también pueden apreciarse en las inquietudes estéticas y formales que manifiestan los films del período. Los sentidos y las identidades se interpretan y construyen como en constitución permanente; ya no se trata de sentidos e identidades fijas, estáticas, fosilizadas, cerradas, sino fluidas, inasibles, que escapan, en movimiento constante. Creemos que es posible establecer un cierto paralelismo, a la vez, entre el Nuevo Cine Argentino y el cine producido a 
partir del Período Especial en Cuba no sólo por estas constantes apreciables en ambas cinematografías y por la incidencia de los contextos políticos, económicos y sociales, sino también a partir de otro factor propiciador del surgimiento de estos nuevos cines. Si en el nacimiento del Nuevo Cine Argentino tuvo que ver el capital profesional surgido de la Fundación Universidad del Cine (FUC), lo mismo puede pensarse en la renovación del cine cubano a partir de las primeras generaciones de egresados de la Escuela Internacional de Cine y Televisión (EICTV) de San Antonio de los Baños y de la Facultad de Arte de los Medios de Comunicación Audiovisual (FAMCA) del Instituto Superior de Arte (ISA) y la renovación que esos nuevos realizadores inyectaron en el panorama del cine hasta entonces reinante, producido en el marco de formación del ICAIC. ${ }^{6}$ En este sentido, Joel del Río (2011) también señala en su artículo "Fermentos genéricos en el cine joven del siglo XXI" la importancia de cuatro eventos en el desarrollo del cine cubano de la última década y media: el Festival Internacional del Nuevo Cine Latinoamericano, el Festival Internacional Santiago Álvarez in Memoriam, el Festival Internacional de Cine Pobre y la Muestra Joven organizada por el ICAIC. Hace hincapié sobre todo en esta última y destaca, a partir de ella, una reanimación en el cine documental, que al momento se encontraba estancado al interior del Instituto. Entre los principales problemas que evidenciaba el documental institucional señala “el exceso de apología y exégesis, la confusión de los realizadores respecto al reportaje televisivo de ocasión, la violación del punto de vista y de los

\footnotetext{
${ }^{6}$ En una primera etapa de desarrollo de la cinematografía cubana aún no existían en el país escuelas de cine, por lo cual la formación se daba de modo "artesanal" al interior del Instituto. Los fundadores habían realizado su formación en el exterior (Tomás Gutiérrez Alea y Julio García Espinosa habían pasado por el Centro Sperimentale di Cinematografía, en Italia) y, en el quehacer cotidiano, bajo su ala se iba formando el relevo. Los jóvenes interesados en participar de la realización cinematográfica se acercaban al ICAIC y comenzaban trabajando como asistentes de producción. Luego pasaban a producción, asistencias de dirección, dirección de sus propios documentales, en un camino que, eventualmente, alrededor de los cuarenta años de edad, los "graduaba" como directores de largometrajes de ficción.
} 
principios dramatúrgicos elementales, exceso de didactismo y de convenciones, y el uso pedestre y poco creativo del archivo o de la entrevista" (2011: 405, 406). Frente a esto, los nuevos documentalistas aparecen como comprometidos en la reflexión sobre aspectos problemáticos de la realidad social, generando una polémica en torno a esos temas que propicie la concientización y el debate social. El autor señala la importancia en estos films de la dimensión emotiva, que no va en detrimento del rigor y la profundidad, algo apreciable en El telón de azúcar. En torno a estos documentales Del Río también sostiene valores aplicables a la película de Camila Guzmán Urzúa, entre los que destaca "problematizar el entorno, complejizar la existencia, plantar un espejo revelador ante lo que es poco conocido y terminar revelando circunstancias muchas veces dolorosas, discutibles, ásperas, invariablemente situadas más allá de la mera propaganda o de la divulgación concebida para apaciguar la digestión de los conformistas" (ídem: 406).

En esta línea se distinguen una serie de documentales contemporáneos al de Guzmán Urzúa, que se le emparentan por distintas cuestiones tanto formales como temáticas. Habana abierta, dirigido por Arturo Sotto y Jorge Perugorría en 2003, registra el retorno del grupo musical homónimo tras su triunfo en España. Algunos de los integrantes de la banda dan su testimonio también en El telón de azúcar, donde aparece el registro de esa presentación en vivo que marcó su triunfal bautismo en los escenarios cubanos. La canción que Camila elige hacernos escuchar es, no casualmente, "Divino guion", cuya lírica reza "La vida es un divino guión (...) / Quedó bonito pero se destiñe / Ya no es lo mismo que cuando éramos fiñes / Pioneros por el comunismo / Ilusión de cosmonautas / Todas las ratas se van tras la flauta / José Martí fijó la pauta / El elefante tiene cuatro patas / Y una memoria que te aplasta / Yo no me fui, yo me alejé un poquito / Desde más lejos se oye más bonito". En lo que respecta a lo formal, el recurso a la primera persona así como la reflexión sobre la repercusión del 
pasado en el presente puede apreciarse en documentales como Las colmenas (Alejandro Ramírez Anderson, 2007) y The Illusion (Susana Barriga, 2009). El primero trabaja sobre la experiencia personal del director en un proyecto a través del cual un grupo de hijos de guerrilleros guatemaltecos fueron protegidos del contexto que los rodeaba siendo llevados a Cuba, donde crecieron. Aunque el formato del documental es el clásico de entrevistas, al comienzo el director se dirige a cámara inscribiéndose como yo narrador al señalar que él formó parte del proyecto y que la historia que se narrará es, también, su historia. En un tono más intimista y experimental, la película de Susana Barriga registra la búsqueda y el (des)encuentro con un padre autoexiliado y paranoico.

Esteban Dipaola vuelve sobre el concepto de fuga analizando la obra teatral de Mariano Pensotti El pasado es un animal grotesco. Sostiene que se trata del retrato de

una generación que tuvo que vivir la experiencia de heredar un pasado que no le corresponde ni pertenece y afrontar una proyección en donde nada parece indicar qué se hallará sobre el camino en ese tránsito hacia adelante. Apenas un relato de los noventa, entonces, se presenta justamente en esa condición: fugar de lo que no se quiere hacia lo que no se sabe. (Dipaola, 2012: 36).

Los cambios a los que se ve enfrentada la generación de Camila (pero más aún, como señala uno de los entrevistados, los cambios más profundos a los que se ven enfrentadas las generaciones criadas en el Período Especial, a quienes verdaderamente el pasado ya parece no corresponder ni pertenecerles en absoluto) genera una fuga desde algo que no se quiere (esa realidad actual) hacia lo que no se sabe (el futuro incierto, el exterior desconocido). La emigración, como hemos señalado, se retrata en el film de múltiples formas. El recuerdo de una ex compañera que ya no está y que sólo puede hacerse presente a través de un video que la hermana muestra a 
Camila, donde se ve a su pequeña hija contando a cámara del uno al diez, primero en inglés y recién después en castellano. O los padres milicianos y alfabetizadores de un joven que eligió quedarse, aunque ellos se fueron, desilusionados por el resultado de todo, tenían otra idea de lo que iba a ser su vida con la Revolución, y con el Período Especial ellos pensaron que todo lo que habían hecho por esto no había servido para nada, como sostiene el hijo. O el compañero que regresa de visita y ve todo con una mirada externa. Y esa suerte de epílogo final, en el que junto con él Camila también ya una emigrada que regresa de visita- nombra a todos los amigos que se fueron. Es una lista larga, interminable, que se oye en off mientras la cámara muestra un parque con juegos infantiles vacíos, abandonados. Es la puesta en escena de esa larga y dolorosa fuga "de lo que no se quiere hacia lo que no se sabe", que parece haber comprendido a toda una generación.

\section{El despojo, el desamparo}

Dipaola propone como conceptos característicos de la década del noventa en Argentina al despojo y al desamparo y elije a la cinematografía de Raúl Perrone para dar cuenta de cómo esto aparece de modo concreto,

las calles del conurbano bonaerense están ahora (des)pobladas por edificios abandonados a medio construir, fábricas cerradas, negocios oscuros y de persianas semibajas; y entre todo ello, hacen su aparición jóvenes desinteresados por los valores y las prácticas de antaño: no buscan trabajo o escapan a las posibles maneras de conseguirlo, y en cualquier caso siempre se trata de trabajos precarios y sin proyección, yacen tirados en plazas fumando o tomando cerveza, miran televisión, deambulan, etc. (Dipaola, 2012: 19).

En El telón de azúcar lo que nos es mostrado es el contrapunto entre los edificios en pleno funcionamiento en la década del ochenta (a través de 
inserts de fotografías) y su estado de derruimiento actual. En una escena, Camila y dos de sus amigas recuerdan el campamento de pioneros Tarará. La puesta en escena de ese recuerdo supone la contraposición entre el ayer y el hoy: mientras vemos imágenes de un espacio completamente abandonado, que a partir de algunas desgastadas pintadas en la pared podemos inferir que estaba dedicado a la infancia, en off escuchamos las voces de las jóvenes narrando historias felices de su época de esplendor. Vemos la Cuba que fue y se nos insta a imaginar el país que podría haber sido, para finalmente mostrarnos el país que es, éste en el que se convirtió realmente. Mientras las imágenes del actual estado de Tarará continúan, la voz de Camila relata

Hoy, las ruinas de nuestros recuerdos cohabitan con los nuevos empresarios extranjeros y con algunas víctimas de Chernobyl que llegan todavía a recibir tratamiento médico. Ya nada es lo que era, siento que mi país de infancia ha desaparecido. Sólo quedan las consignas y las viejas estructuras de aquel sueño que entonces tenía sentido y que yo me creí.

En la primera parte de esta reflexión (y en el contrapunto con las imágenes que la acompañan) se pone de manifiesto la realidad contradictoria de la contemporaneidad cubana. Las ruinas de la prosperidad revolucionaria, los emprendimientos turísticos financiados con capitales foráneos y el sostenimiento de baluartes característicos de la Revolución, como la solidaridad, el internacionalismo y la medicina "de punta" cohabitan en esa nueva sociedad a la que aún no le cabe otra etiqueta que la de quien atraviesa un "Período Especial". En el discurso de los entrevistados (todos compañeros de escuela de Camila, amigos de la infancia) se pone de manifiesto el cambio en la escala de valores de la juventud. Uno de ellos, quien actualmente reside en el exterior, sostiene, comparando a su generación con la actual: 
es una realidad que te forma con seguridad en ti mismo, con capacidad sobre todo. Y tú lo notas. Cuando tú te sientes que tú compites, ese nivel de competencia te lo da tu educación anterior, tu realidad anterior que fue aquí. Eso fue una suerte realmente, sobre todo para nuestra generación, la que viene no sé. Nosotros éramos los forjadores del futuro, no jodas, eso te da tremenda responsabilidad y tremenda confianza también. Y yo me lo sigo creyendo, aunque esté donde esté.

Escuchamos entonces la voz de Camila en off, que le pregunta cuál cree que es la diferencia con la juventud de hoy. El entrevistado prosigue:

pienso que si estudiar no vale nada porque al final lo que quieres es ser portero de un hotel o trabajar en una tienda o algo de eso, entonces al estudiar no valer nada, no estudias, y al no estudiar, no tienes referentes, y al no tener referentes ni leer ni oír buena música ni ver buen cine, pues nada, te quedas parado en la esquina del club esperando al extranjero de tu vida. Ya el plan cambió. El plan es qué vas a hacer cuando salgas de aquí.

Sostiene Dipaola que surge entonces la "sensación de que no hay nada o no hay mucho para hacer", abundando en la cinematografía de esos años imágenes que daban cuenta de "la abulia, la apatía, un imaginario del cansancio y del desgaste, cierta soledad y desolación" (ídem: 20). En la cinematografía cubana del período, así como en el film que nos compete, esto también es apreciable aunque, a su vez, hay siempre una pulsión vital que hace que los personajes nunca se detengan del todo, nunca acaben de darse por vencidos, siempre intenten "inventar", "resolver", para seguir adelante. En el caso de los entrevistados en El telón de azúcar parece haber algo de su formación en esos idílicos -e idealizados- años ochenta que les da una fortaleza -que por momentos parecería ser más bien nostálgica- para continuar. Al mismo tiempo, hay un cierto desamparo vivenciado por una generación que nació en la década del setenta, en el éxtasis de una lucha revolucionaria que atravesaba toda Latinoamérica (se puede ver en el documental, por ejemplo, en el retorno sobre la figura de Salvador Allende 
en Chile), y a la que los cambios políticos producidos con posterioridad y reafirmados sobre todo en la década del noventa la vuelve, de algún modo, huérfana. Se genera así una situación peculiar que el film construye como una contradicción entre teoría y práctica. Las imágenes actuales de los niños y los adolescentes, con las enseñanzas escolares y los himnos que recuperan las históricas y míticas figuras de Camilo Cienfuegos, Ernesto Che Guevera, Conrado Benítez y José Martí, así como las consignas revolucionarias que Guzmán Urzúa nos muestra a partir de carteles en las calles, chocan con las declaraciones de los entrevistados que dan cuenta de la profunda crisis económica y de valores, que conlleva la naturalización de pequeños robos para subsistir. En los jóvenes que asisten a las marchas, toman clases de “preparación militar" con armas de cartón o realizan trabajo voluntario ("obligatorio", acota en un momento Camila, intensificando la contradicción), parecen perpetuarse prácticas propias de la generación que presta su testimonio en el film, pero que se realizan ahora sin un sentido real, sin saber por qué. Así, la teoría revolucionaria y la práctica del “inventar" coexisten en una contradicción velada, no siempre manifiesta. Ponerla de manifiesto parece ser parte de la propuesta de Guzmán Urzúa en el film. De este modo, una escena muestra imágenes del Museo de la Revolución: las figuras hechas en cera de Camilo y el Che, el rígido traje de un cosmonauta cubano, encerrado en un cubo de cristal. La Revolución parece encontrarse estática, detenida, pieza de museo. A través de un corte la directora procede a mostrarnos luego, como contrapunto, el Malecón, el mar agitado, vital, que rompe contra esa pared de piedra que intenta contenerlo y no lo consigue, ya que él estalla y se vierte sobre la ciudad. 


\section{... y no deja de pasarnos}

La experiencia de los noventa, de acuerdo a Esteban Dipaola, se convierte en una pulsión que promueve de modo permanente la búsqueda de una nueva mirada.

Si es posible argumentar que los noventa es algo que nos pasó y no deja de pasarnos, se debe (...) a esa pulsión que nos indica siempre la necesidad y búsqueda de una nueva mirada, porque justamente lo que aparece allí es que la mirada sobre los noventa no es ya nunca una mirada sobre el pasado, sino sobre nuestra actualidad, sobre nuestra forma de intervenir hoy en la experiencia de nuestras vidas y en sus resignificaciones. (Dipaola, 2012: 22).

Algo de esto se aprecia en las miradas que sobre los noventa realiza el cine cubano. La mirada de Camila en El telón de azúcar es sobre la actualidad y "la forma de intervenir hoy en la experiencia de nuestras vidas". Aquellos años se resignifican, resignificando a su vez el presente del relato. Más que mirar hacia atrás, la búsqueda de Camila consiste en una reflexión sobre la actualidad.

Continúa planteando Dipaola al respecto que "(s)e trata de una insistencia, una pulsión que arrastra experiencias para componer momentos del presente que no pueden prescindir de esa especie de lazo íntimo con la memoria y los vestigios de esa década del noventa" (ídem: 39). El telón de azúcar es, sobre todo, una indagación sobre el presente, que vuelve sobre los noventa porque eso es lo que "nos pasó y no deja de pasarnos", eso que nos insta a buscar una nueva mirada que nos permita comprender nuestra actualidad. Por eso, creería, ya no estamos ante el reinado del documental expositivo, la Historia, la sentencia, la afirmación unívoca, "la" Verdad, sino que se produjo el ingreso en el documental autobiográfico, la historia, la interrogación, las preguntas que se ramifican e, intentaremos proponer a 
continuación, un procedimiento de verdad a partir del amor, una verdad del Dos.

\section{Camila y Cuba: el amor y la verdad}

Alain Badiou (2012) sostiene en Elogio del amor que éste es

un "procedimiento de verdad" (...), una experiencia en la que se construye cierto tipo de verdad. Esta verdad es sencillamente la verdad del Dos. La verdad de la diferencia como tal. Pienso que el amor (...) que acepte justamente esta experiencia del mundo desde el punto de vista de la diferencia produce a su manera una verdad nueva acerca de la diferencia. (Badiou, 2012: 43).

Partiendo de estas reflexiones cabe pensar si acaso no es amor lo que se da entre Camila Guzmán Urzúa y Cuba, y si en esa experiencia no se construye un cierto tipo de verdad, que tiene que ver con la diferencia. Una doble diferencia, podríamos pensar. Por un lado, la diferencia entre Camila y Cuba, pero también la diferencia entre esa Cuba en la que Camila creció y ésta a la que regresa. Dos Camilas y dos Cubas. La verdad del dos y de la diferencia como tal. Podemos pensar así en dos momentos del amor, dos momentos de la verdad y dos momentos de la diferencia en su primera llegada a Cuba y en el retorno.

Sostiene también Alain Badiou que "el amor comienza por el carácter absolutamente contingente y azaroso del encuentro. (...) Pero el azar debe, en un momento, fijarse. Debe, justamente, comenzar una duración" (ídem: 45). Aquí, siguiendo la lógica que hemos implementado, podríamos pensar en el azar del comienzo de este amor, lo azaroso por lo cual Camila llega a Cuba a los dos años de edad. Y cómo luego ese azar se fija y comienza una duración que incluso la lleva a volver para interrogar ese amor, esa relación, esa diferencia, esa verdad. Patricio, el padre de 
Camila, abandona Cuba al poco tiempo de su llegada, pero ella se queda con su madre, fijando el azar, comenzando la duración de este amor.

Continúa Badiou sus reflexiones sosteniendo que "de lo que fue un azar voy a sacar otra cosa. Voy a sacar de él una duración, una obstinación, un compromiso, una fidelidad" (ídem: 47). Leo “obstinación” y pienso inmediatamente en la película del padre de Camila, Chile, la memoria obstinada (Patricio Guzmán, 1997), ese retorno sobre La batalla de Chile años después, esa vuelta atrás sobre la memoria y me pregunto si no hay allí un mecanismo similar al de El telón de azúcar, una obstinación en la memoria y, al mismo tiempo, su actualización. Un compromiso y una fidelidad con el amor. Un ejercicio de producción de verdad permanente.

Concluye Badiou diciendo:

Hay puntos, pruebas, tentaciones, nuevas apariciones y, cada vez, es necesario volver a interpretar la "escena del Dos", encontrar los términos de una nueva declaración. Declarado al inicio, el amor también debe ser "re-declarado". Es por esto que el amor es también el origen de las crisis existenciales violentas. Como todo procedimiento de verdad. Desde este punto de vista, además, es chocante la vecindad que existe entre el amor y la política. (ídem: 53).

Podríamos pensar en la partida de Camila, en el derrotero del Período Especial y sus coletazos como esos "puntos, pruebas, tentaciones" y "nuevas apariciones" de las que habla Badiou. El retorno de Camila y su ejercicio al realizar el documental es síntoma de esa necesidad de "volver a interpretar la escena del Dos”. Hay aquí una re-declaración del amor, una crisis existencial violenta y, por supuesto, una vecindad entre el amor y la política.

Nos parece válido pensar, a partir de estas reflexiones, en que hay una cierta calidad particular de verdad en la propuesta de Camila Guzmán Urzúa, el tipo de verdad que surge del amor, de la escena del Dos y de sus permanentes reinterpretaciones. 


\section{Camila, la cuentacuentos}

Eric Selbin (2012) plantea en El poder del relato. Revolución, rebelión, resistencia que los pueblos cuentan historias, y que son éstas las que los definen como pueblos. "Creamos, entendemos y dirigimos el mundo a través de las historias que contamos" (p. 17). Agrega posteriormente que "quiénes somos, qué somos, es inseparable de las historias que contamos. Lo cual, finalmente, equivale a decir que las historias son todo, y que todo, de una forma u otra, es una historia" (ídem: 17). Se puede comprender así un cambio en las historias que el pueblo cubano narra. Si hasta el Período Especial se contaba un determinado tipo de historias (podemos pensar, por ejemplo, en un cine de características más bien épicas, en un cine histórico), y a partir de aquel momento empiezan a contarse historias de otro tipo, tiene que ver también con una reestructuración del quién y qué somos. Hay una retroalimentación entre este cuestionamiento, los procesos de (re)constitución identitaria ${ }^{7}$ y las historias que se cuentan.

En el tipo de historias narradas a partir del Período Especial, a diferencia de lo ocurrido con anterioridad, las preguntas que se realizan adquieren una importancia superior a las respuestas dadas. Esto, el privilegio de las preguntas en el cine reciente por sobre el hincapié en las respuestas que existía en el cine anterior, es algo que se aprecia al comparar los filmes de los setenta con los de los noventa y las décadas posteriores. Si el cine político de los setenta encontraba su mecanismo en la afirmación de sentencias definitivas, el cine reciente, y sobre todo el de características

\footnotetext{
${ }^{7}$ La hipótesis de trabajo de mi tesis de posgrado en curso parte de la premisa de una reconfiguración identitaria a partir del ingreso en el Período Especial. Se considera que ésta es producto de diversos factores, uno de los cuales sería el intento desde la oficialidad de crear una cubanidad más amplia e inclusiva en el afán de contrarrestar los posibles efectos negativos que la crisis pudiera tener en la gobernabilidad y lo social. Esto conduce a la visibilización e inclusión de sectores anteriormente discriminados, como los religiosos y los emigrados. Esto, sumado al compulsivo ingreso en regímenes de coproducción, se manifiesta a su vez en la construcción cinematográfica de la identidad, que se empieza a considerar como más porosa, híbrida y móvil.
} 
autobiográficas, centra su lógica en la presentación de preguntas. Y son estas las que adquieren verdadera relevancia por sobre cualquier tipo de respuesta (siempre parcial, fragmentada) que pudiera encontrarse. A algo de esto parece referirse Selbin cuando señala que "las respuestas, con sus distintas calidades y sus diversos grados de satisfacción, parecen ir y venir; lo que sobrevive son las preguntas" (ídem: 17).

De acuerdo a Selbin,

"Historia" es el término comúnmente utilizado para rotular a nuestro depósito de conocimiento; y en otras épocas estaba constituida por las tradiciones populares, los relatos y los cuentos. La Historia, tradicionalmente, narraba historias que eran una combinación de realidad y ficción. Esto, en la euforia de la Ilustración y particularmente a los ojos del racionalismo del siglo XIX, fue súbitamente considerado un horror. Mucho esfuerzo fue puesto en la idea de que los historiadores eran artesanos (...) que lidiaban únicamente con "hechos". Mientras que los narradores eran libres de inventar lo que quisieran, los historiadores debían ceñirse a la Verdad, una convicción orientada a obtener el estatuto de "ciencia" que ha dominado a las sociales hasta el día de hoy. (ídem: 18, 19).

Una nota del traductor señala que el término utilizado en el original de Selbin es storyteller, al que el traductor prefiere expresar como "narrador", por las posibles implicaciones desmerecedoras que la traducción “cuentacuentos" pudiera conllevar. Me parece interesante la posibilidad de pensar a Camila como una cuentacuentos, no sólo por la libertad de inventar con la que narra, sino por la frescura de un relato que no intenta ceñirse a la Verdad y, así y todo, da cuenta de una verdad concreta, tal como expusimos anteriormente.

\section{El documentalismo del yo}

Consideramos que El telón de azúcar es, por sus características, un documental autobiográfico. En este sentido, Esteban Dipaola sostiene que 
la autobiografía no se constituye como documentación de la época, sino como interpretación y síntoma de ella. Es decir, no es ese registro autobiográfico algo exterior respecto a lo narrado o al relato, sino que se configura y disemina en sus trayectorias internas. Lo biográfico se expresa como una experiencia y, como tal, se muestra en el despliegue temporal con todas sus vicisitudes y dislocaciones -incluso con sus propias ficciones- y no como racconto lineal de una historia. (Dipaola, 2012: 27).

Como ya hemos expresado, creemos que el filme de Camila Guzmán Urzúa constituye una interpretación de la época, una mirada y, en función de las reflexiones acerca de la proyección de los noventa en el cine reciente, también un síntoma de esa época. El film no se propone como documento, sino como indagación personal e interpretación de la historia reciente de un país y su proyección en el presente. Así, la narración de Camila va y viene, entre épocas y espacios, voces que se multiplican y que también se quiebran o no pueden escucharse, entre los niños del hoy, que aprenden y repiten lecciones y prácticas de antaño y los jóvenes adultos que vuelven sobre esos niños que una vez fueron y que fundan a esos seres que hoy afrontan y confrontan un presente ríspido y desolador.

Pablo Piedras (2009) retoma las reflexiones de Antonio Weinrichter en torno al modo performativo del documental, sosteniendo que, en éste, "hay un trastorno observable de la experiencia del director - de su cuerpo, de sus disposiciones psicológicas y de sus actitudes-, que desvía nuestra atención de la cualidad referencial del documental". El propósito de tal desvío es, de acuerdo al autor, "subrayar los aspectos subjetivos de un discurso clásicamente objetivo" y aumentar el énfasis en "las dimensiones afectivas de la experiencia para el cineasta" (párr. 5). Estaríamos con El telón de azúcar ante un documental de este tipo. Lo subjetivo y lo afectivo son las marcas más fuertes del filme. Es la experiencia de Camila y sus 
modos de hacerse presente en la película lo que nos interpela, por sobre cualquier tipo de cualidad referencial. Sus vivencias personales y las de sus seres más cercanos (aquellos que formaron parte, justamente, de sus años constitutivos) son las que el documental nos presenta. Las fotografías, los dibujos y los testimonios que se hilvanan sobre la base del recuerdo, ponen de relieve de modo permanente lo subjetivo, afectivo y autorreferencial sobre lo que se construye el relato.

Continuando con la cita de las reflexiones de Weinrichter, Piedras sostiene que, en el documental performativo, se pone en primer término el hecho de la comunicación, sacando el foco de atención de la discusión objetividad/veracidad característica del documental tradicional. De este modo "los enunciados performativos no serían verificables, a diferencia de los enunciados descriptivos" (párr. 5). La subjetividad se impone. "El director literalmente 'actúa', siendo una primera persona que se materializa en la escena, ya sea interviniendo con su propio cuerpo o a través de un narrador omnipresente" (párr. 5). Camila se inscribe en el documental de ambos modos. Con su propio cuerpo, a través de fotos de su infancia y a partir del mecanismo de filmar su reflejo en un espejo mientras realiza preguntas a su madre en su casa. Y a través de su voz como narradora omnipresente y realizando preguntas en off.

El formato de un documental como El telón de azúcar es además de autobiográfico y performativo, ensayístico. En este sentido, Paola Lagos Lobbé (2011) sostiene que “(e)l ensayo -por definición- más que aportarnos respuestas, nos formula preguntas; a través de la reflexión, nos interpela como espectadores convocándonos a someter al mundo a la prueba de la duda, a tomar distancia y a adoptar un punto de vista en la formulación de las ideas" (párr. 17). Algo de esto, que sin dudas forma parte de la propuesta del film, se materializa incluso en una reflexión en off que realiza la propia cineasta. En el registro de una marcha (de las muchas que se realizan ahora, según ella misma sostiene, y a las que las personas acuden por obligación o 
por inercia, por contraposición a las menos numerosas y más significativas de otros tiempos, a las que se asistía por convicción) Camila se pregunta si anteriormente no se cuestionaba al sistema por el confort que el mismo propiciaba y si el resquebrajamiento de ese bienestar no es el que tal vez permita la toma de distancia y adopción de un nuevo punto de vista. Agrega finalmente, sólo ahora me doy cuenta que si no seguí chocando con el sistema, fue porque me fui y me quedé con un recuerdo idílico de algo que quizás nunca fue. Lagos Lobbé plantea la existencia, en estos filmes, de una

voz en off que matiza, cuestiona, da cuenta de los estados de ánimo del autor y sus disquisiciones vitales, voz que no posee certezas y que, por lo tanto, difiere consustancialmente del comentario ilustrado, omnisciente, anónimo, de las autoritarias voces en off del documental expositivo, que certifican y autentifican pretendidas verdades universales y conocimientos absolutos. (párr. 17).

La voz de Camila, como acabamos de confirmar, retorna en múltiples ocasiones a lo largo del metraje, sin verdades absolutas sino plena de cuestionamientos y subjetividad, mucho más cargada de su historia que de la Historia.

Pablo Piedras considera que la profusión del uso de la primera persona en los documentales latinoamericanos en los años 2000 tiene que ver con "la imposibilidad del documental clásico de dar cuenta de una verdad histórica sobre los hechos traumáticos de la historia reciente" (párr. 13). Los documentales que mejor repercusión han tenido en el registro de las vicisitudes propias del Período Especial han sido filmes que escaparon a las pautas más clásicas del género ${ }^{8}$. El telón de azúcar es uno de ellos. Piedras continúa:

\footnotetext{
${ }^{8}$ El documental de mayor repercusión de las últimas décadas fue Suite Habana (Fernando Pérez, 2003). Proponiendo un lenguaje sumamente particular, que toma muchos elementos propios del cine de ficción, el film registra con extrema sensibilidad a unos personajes y a una ciudad atravesados por el Período Especial. Sobre el mismo se puede consultar un
} 
Resignificando la lectura del pasado a través de la propia subjetividad de los realizadores, el documental subjetivo encuentra verdades parciales, tentativas y provisorias, pero profundamente encarnadas y operativas para la construcción de una memoria cercana que transite de lo individual a lo colectivo, invirtiendo de esta forma la parábola del cine político militante de la década de los setenta. (párr. 13).

Este es el movimiento que realiza el documental de Guzmán Urzúa: sus verdades no son absolutas sino parciales, no son definitivas sino provisorias, pero sí profundamente encarnadas en una subjetividad. Una construcción desde lo individual que se extiende hacia lo colectivo. Ese cuestionamiento que Camila se hace respecto a sí misma, cuando escuchamos su voz en off sobre las imágenes de la marcha convocada con motivo del natalicio de José Martí, repercute hacia lo colectivo, se expande convirtiéndose en un cuestionamiento general.

En este sentido, y en comparación con la documentalística tradicional, Piedras plantea que la incorporación de la subjetividad y la primera persona en el documental "promueve la aparición de nuevos pactos comunicativos entre la obra y el espectador, a la vez que genera un giro epistemológico que se vislumbra en la ruptura de los sistemas explicativos tradiciones por medio de los cuales el documental clásico explicaba y daba cuenta de diversos fenómenos históricos, políticos y sociales" (párr. 28). De este modo, tanto Pablo Piedras como Ana Amado plantean una distinción entre los documentales de los años 2000 y los de la década del setenta. Se construye en los primeros un nuevo régimen de verdad, que en lugar de centrarse en afirmaciones políticas contundentes, como sucedía en los setenta, expone un discurso afectivo. Frente a las características colectivas y sociales del cine documental de los setenta, en el cine reciente se trabaja,

artículo de autoría propia titulado "Suite Habana, los sonidos del silencio" y publicado en el número 12 de la revista Cine Documental (http://revista.cinedocumental.com.ar/suitehabana-los-sonidos-del-silencio/). 
como hemos expresado, desde la individualidad. Ana Amado señala un pasaje representacional del relato épico al trágico.

Coincide en estas apreciaciones Esteban Dipaola al señalar que el estudio de los noventa no puede centrarse en el archivo o el documento.

Ese recurso de análisis usual en la sociología y afines para la comprensión de la década del setenta por ejemplo, pierde su eficacia para un pensamiento de los años noventa, porque, como venimos sosteniendo, no se trata de la potencialidad de exponer un relato sobre esa década, sino de entender a la propia década como un dispositivo que inaugura múltiples potenciales relatos y que los dispersa a todos abriendo sus constantes e indeterminados cruces y desviaciones. Entonces, los años noventa no se insertan en la lógica del archivo y el documento, sino en la pulsión narrativa de nuestras trayectorias actuales en tiempo presente. (Dipaola, 2012: 36, $37)$.

Los materiales de archivo y los documentos en El telón de azúcar son personales y subjetivos. En este sentido nos referimos a los dibujos y las fotografías escolares y familiares, pero también incluso al único fragmento de película que podría considerarse más clásicamente como "archivo documental" y que, de todos modos, la narración inscribe como sumamente íntimo. Se trata de un fragmento de Primer año (1972), documental de Patricio Guzmán, padre de Camila, sobre cuya imagen la voz en off de la cineasta inscribe el trazo de lo único y personal: mientras su padre registraba las imágenes de Fidel Castro y Salvador Allende en Chile su madre presenciaba el desfile y ella también, desde su panza, justo un mes antes de nacer. Hay en Guzmán Urzúa esa pulsión narrativa que busca sobre todo indagar sobre la actualidad comprendiéndola como un tiempo en el que otras temporalidades indefectiblemente se proyectan. 


\section{Palabras finales}

Los noventa en Cuba implican un quiebre drástico en el entramado social. La profunda crisis económica que debió enfrentar el país a partir del derrumbe de la Unión Soviética quedó grabada a fuego en la sociedad. Creemos que parte de lo que se produjo se puede explicar a partir de lo que Ulrich Beck (2006) llama individualización y que implica una disolución de formas sociales históricas, una pérdida de seguridades tradicionales y un nuevo tipo de cohesión social. Estos aspectos son apreciables a su vez en la producción cultural posterior al período, en el cine y, en particular, en el documental que se tomó como caso en el presente trabajo, El telón de azúcar (Camila Guzmán Urzúa, 2005). A su vez, resultan apreciables en esta producción y en la cinematografía cubana a nivel más amplio algunos conceptos que Esteban Dipaola (2012) pone en juego para caracterizar a diversas manifestaciones culturales argentinas del período: la fuga, la deriva, los traslados, el despojo, el desamparo y la idea de que no hay nada o mucho para hacer. Pero los noventa, al margen de ser retratados de este modo en la producción que los procede, aparecen de modo latente también desde otro lugar. Como plantea el autor, los noventa también y sobre todo se manifiestan como una pulsión que impulsa la necesidad y la búsqueda de una nueva mirada que no es necesariamente ni tan sólo una mirada sobre el pasado, sino más bien una mirada sobre la actualidad. Consideramos que esa pulsión es la que lleva a Guzmán Urzúa a realizar El telón de azúcar.

A partir de esa pulsión, el documental plantea también un nuevo régimen de verdad. A diferencia del documental tradicional, que ponía el foco sobre la objetividad, la veracidad, lo verificable, la certeza y el hincapié en la Historia, en el documental de características autobiográficas, performativas, ensayísticas, en primera persona, el foco pasa al hecho de la comunicación, la subjetividad, el cuestionamiento, lo individual, lo propio, el hincapié en las historias. Son estos aspectos los que constituyen un nuevo 
tipo de verdad que ya no es la Verdad sino una verdad. En este sentido, nos atrevimos a esbozar la posibilidad de pensar el régimen de verdad en $E l$ telón de azúcar en términos de Alain Badiou (2012), considerando al amor como procedimiento de verdad que se pone en juego en el film.

Lo fuertemente traumático de la historia reciente, como sostiene Pablo Piedras (2009), puede pensarse como lo que hace que la posibilidad primordial de encararlo sea desde la subjetividad de la primera persona. A su vez, coincidiendo con lo propuesto por Dipaola, creemos que los noventa son eso que nos pasó y no deja de pasarnos y, de ese modo, son constitutivos de nuestros esfuerzos de explicación del presente, por lo cual el archivo y el documento no son ya suficientes para comprender esa década conflictiva y fundante. Sobre todo porque lo que esa década provoca en nosotros es la necesidad y la pulsión de generar nuevas miradas que, desde allí, nos permitan comprendernos ahora y, desde este ahora, nos ayuden a comprender cómo eso que nos pasó se actualiza en cada uno de nuestros actos creativos.

\section{Referencias bibliográficas}

ÁLVAREZ ARCE, Mauricio (2006), La transformación del discurso oficial y la representación del Modelo político cubano en la década de los noventas, Seminario de tesis, México: Flacso.

AMADO, Ana (2009), La imagen justa. Cine argentino y política (19802007), Buenos Aires: Colihue.

BADIOU, Alain y TRUONG, Nicolas (2012), "Verdad del amor" en Elogio del amor, Buenos Aires: Paidós.

BECK, Ulrich (2006), “Individualización, institucionalización y estandarización de las condiciones de vida u de los modelos 
biográficos", en La sociedad del riesgo. Hacia una nueva modernidad, Barcelona: Ediciones Paidós Ibérica.

DEL RÍO, Joel (2011), “Fermentos genéricos en el cine joven del siglo XXI", en Notario, Luis Alberto y Paddington, Bruce, Explorando el cine caribeño, La Habana, Ediciones ICAIC, pp. 382-417.

DIPAOLA, Esteban (2012), Todo el resto. Estética y pulsión de los años '90, Buenos Aires: Pánico el pánico.

KLEPAK, Hal (2010), Raúl Castro, estratega de la defensa revolucionaria de Cuba, Buenos Aires: Capital Intelectual.

LAGOS LABBÉ, Paola (2011), "Ecografías del "Yo": documental autobiográfico y estrategias de (auto)representación de la subjetividad", en Comunicación y medios n. 24, Instituto de la Comunicación e Imagen, Universidad de Chile.

PIEDRAS, Pablo (2009), "El problema de la primera persona en el cine documental contemporáneo. Modos de representar lo autobiográfico en ciertos documentales latinoamericanos", ponencia presentada en las V Jornadas de Jóvenes Investigadores del Instituto Gino Germani, Buenos Aires, Facultad de Ciencias Sociales de la Universidad de Buenos Aires.

SELBIN, Eric (2012), "Un prolegómeno, una apología y una obertura”, en El poder del relato. Revolución, rebelión, resistencia, Buenos Aires: Interzona Editora. 


\title{
DA EXIBIÇÃO DOS FILMES DA COMISSÃo RONDON
}

\begin{abstract}
Ana Lobato*
Resumo: Este trabalho trata da exibição dos filmes realizados pela Comissão Rondon, dirigidos por Luiz Thomaz Reis, entre 1912 e 1938, enfocando o circuito em que os filmes foram exibidos - tanto aquele constituído por salas comerciais quanto o que diz respeito aos eventos de caráter político-científico -, o público alcançado, destacando-se ainda as estratégias mobilizadas visando à otimização desse processo. Thomaz Reis.

Palavras-chave: documentário, exibição, filmes da Comissão Rondon, Luiz

Resumen: Este trabajo trata de la proyección de los filmes realizados por la Comisión Rondon, dirigidos por Luiz Thomas Reis, entre 1912 y 1938, enfocando el circuito en el que tales películas fueron exhibidas -tanto el constituido por salas comerciales como el relativo a actos de carácter político-científico- y el público alcanzado. Se destacan, además, las estrategias movilizadas con vistas a la optimización de ese proceso. Thomaz Reis.

Palabras clave: documental, exhibición, filmes de la Comisión Rondon, Luiz
\end{abstract}

Abstract: This paper deals with the exhibition of films made by the Rondon Comission, directed by Luiz Thomaz Reis, between 1912 and 1938, focusing on the circuit in which the films were shown - consisting both on commercial exhibitions, in the theaters, as well as at political and scientific events - , the audience reached, and the mobilized strategies aiming to optimize this process.

Keywords: documentary, exhibition, Comissão Rondon's films, Luiz Thomaz Reis.

Résumé: Ce travail porte sur la projection des films produits par la Commission Rondon, réalisés par Luiz Thomaz Reis, entre 1912 et 1938, mettant l'accent sur le circuit où les films ont été présentés - aussi bien le circuit de salles commerciales que celui concernant les événements à caractère politique et scientifique -, sur le public atteint et sur les stratégies déployées visant l'optimisation de ce processus. Thomaz Reis.

Mots-clés: documentaire, projection, films de la Comission de Rondon, Luiz

* Universidade Federal do Pará - UFPA, Instituto de Ciências da Arte - ICA, Curso de Cinema e Audiovisual. 66075-110, Belém, Brasil. Email: analobatoazevedo@gmail.com

Submissão do artigo: 29 de maio de 2015. Notificação de aceitação: 20 de agosto de 2015 . 
Da exibição dos filmes...

\section{Filmes para serem vistos}

A historiografia clássica não dirigiu sua atenção para a exibição dos filmes no Brasil, o que levou Jean-Claude Bernardet a atribuir a inexistência de uma história da exibição, a uma "profissão de fé ideológica", que privilegiou a produção em detrimento da exibição, momento que inclusive é erigido como marco do "nascimento" do cinema brasileiro, por diversos autores que trataram dos primeiros tempos (Bernardet, 1995: 26). Em várias outras cinematografias a situação é distinta, destacando-se o caso clássico da França, no qual o evento tido como fundador do próprio cinema é uma "sessão pública, paga e com êxito" realizada em Paris, no Grand Café, em 28 de dezembro de 1895. (Bernardet, 1995: 25).

Este trabalho tem como foco justamente essa etapa final da trajetória das produções fílmicas, que tem sido deixada à sombra nas pesquisas relativas à história do cinema brasileiro, concentrando-se na exibição e no contato com o público dos filmes produzidos pela Comissão Rondon (CR), como ficaram conhecidas diversas comissões e órgãos chefiados por Cândido Mariano da Silva Rondon nas primeiras décadas do século XX. ${ }^{1}$ Seu objetivo é traçar um panorama da chegada desses filmes ao circuito exibidor, destacando-se aqueles que chegaram às telas dos cinemas, com que intensidade isso se deu, qual o número de espectadores alcançados, tratando ainda dos diferentes momentos desse processo e das estratégias utilizadas com vistas à difusão dos filmes.

Há referências a dezessete filmes produzidos pela $\mathrm{CR}$, realizados entre 1912 e 1938, os quais foram em sua quase totalidade dirigidos pelo Major Luiz Thomaz Reis, ${ }^{2}$ chefe da Seção de Fotografia e Cinematografia

\footnotetext{
${ }^{1} \mathrm{O}$ próprio Rondon faz menção a essa denominação em relatório encaminhado ao DASP, datado de 1943, referindo-se a “...várias repartições denominadas vulgarmente 'ComissõesRondon' " (Lasmar, 2008: 33). Para maiores informações a respeito da Comissão Rondon remeto a LASMAR, 2008 e LOBATO, 2011.

2 Os sertões de Mato Grosso (1912-1913); Expedição Roosevelt-Rondon (1913-1914); Mato Grosso em revista (1916); Rituais e festas Bororo (1916); Indústria da borracha em
} 
da $\mathrm{CR}^{3}$. Cinco desses filmes foram lançados comercialmente - Os sertões de Mato Grosso, Expedição Roosevelt, De Santa Cruz, Operações de guerra e Ao redor do Brasil -, e alguns deles também exibidos em programações de caráter político-científico.

Isso significa que aproximadamente $30 \%$ dessa produção chegou às salas comerciais. Embora a exibição dos filmes realizados pela $\mathrm{CR}$ tenha se dado de forma desigual, é importante ressaltar que tal empreitada foi bastante eficiente no que diz respeito à colocação de determinados títulos no circuito exibidor, gerando resultados altamente positivos, como se verá a seguir. Houve um significativo investimento na difusão de certos filmes, o que acarretou numa série de ações, assumidas, principalmente, pelo Major Reis, que se coloca à frente não só da realização dos filmes - envolvido com direção, fotografia e montagem - como articula iniciativas visando sua difusão. Dessa atividade, o Major Reis presta contas a seus superiores através de relatórios, ${ }^{4}$ nos quais menciona as cidades em que os filmes foram exibidos, rendas obtidas nas projeções, percentuais que consegue negociar com os empresários, relatórios esses que se constituíram em fontes fundamentais para a elaboração deste trabalho. ${ }^{5}$

Pode-se perceber tanto nos relatórios de Thomaz Reis, quanto em outros documentos e publicações da CR, em especial aquelas assinadas por Amilcar Armando Botelho de Magalhães, que assume em 1915 a chefia do Escritório Central, o firme propósito não só de realizar uma extensa

Mato Grosso e no Amazonas (1917); Wilderness/De Santa Cruz (1918); Inspeção ao Nordeste (1922); Ronuro, selvas do Xingu (1924); Operações de guerra (1924-1925); Parimã, fronteiras do Brasil (1927); Viagem ao Roraimã (1927); No rio Içana (1928); Mato Grosso e Paraná: fronteiras com o Paraguai e Argentina (1930-1931); Posto Alves de Barros (1930); Ao redor do Brasil (1932); Os Carajás (1932); Inspetoria Especial de Fronteiras (1938). Dentre esses filmes, apenas No rio Içana foi dirigido por José Louro.

${ }^{3}$ A grafia original é Seção de Photographia e Cinematographia. Utilizarei neste texto a grafia adotada nos dias de hoje, visando à fluência do mesmo. Entretanto, em casos de citação, os textos serão transcritos em sua grafia original.

${ }^{4}$ Os filmes a respeito dos quais há informações mais detalhadas nos relatórios de Thomaz Reis são Os sertões de Mato Grosso e Wilderness.

5 Os relatórios apresentados pelo Major Thomaz Reis a seu chefe imediato, Amilcar Armando Botelho de Magalhães, fazem parte do acervo do Museu do Índio. 
cobertura fotográfica e cinematográfica das ações da instituição, como também de exibir os filmes produzidos.

A CR, na pessoa de seu dirigente Cândido Mariano da Silva Rondon, atribuía enorme valor à produção imagética, a qual se destinava a finalidades diversas, como servir de fonte para pesquisas científicas e divulgar o trabalho que realizava, prestando contas à sociedade de suas atividades, contribuindo assim para o seu fortalecimento. Além disso, tais registros imagéticos permitiriam que a população fosse transportada aos locais mais longínquos e inóspitos do interior brasileiro, conhecendo suas diferentes regiões e os povos que nela habitavam. Quando Botelho de Magalhães (Magalhães, 1930: 373) destaca a possibilidade de levar as pessoas a conhecerem o "sertão" sem que precisassem se expor aos incômodos a que estariam sujeitas ao para lá se deslocarem fisicamente, aponta, indiscutivelmente, para o encontro dos filmes com o público. Em consonância com tais objetivos, a CR investe tanto na produção dos filmes quanto em sua exibição.

\section{$O$ vigor dos primeiros anos}

A primeira produção cinematográfica realizada pela $\mathrm{CR}$ convida o espectador a embarcar para Os sertões de Mato Grosso. Nesse filme inaugural a $\mathrm{CR}$ realiza plenamente os fins pretendidos, é ele que percorre o circuito mais extenso, sendo exibido em todas as regiões do Brasil, atingindo um público significativo.

Entre outubro de 1915 e março 1916, o filme circulou pelos estados do Rio de Janeiro, São Paulo e Minas Gerais. No Rio de Janeiro, chegou às telas de cinco cidades e da capital, atingindo nesta última um público de 20.000 espectadores. Na então capital da República, destacam-se as exibições de caráter político-científico realizadas em evento promovido pela Sociedade de Geografia do Rio de Janeiro no Teatro Fênix, nos dias 5, 7 e 
9/10/1915, após conferência de Rondon. Ainda no mês de outubro, o filme chegou a duas importantes salas de cinema cariocas, ${ }^{6}$ ficando em cartaz durante oito dias, no período de 18 a 27/10/1915.

No estado de São Paulo, Os sertões foi exibido comercialmente em quarenta e três cidades, entre as quais a capital, tendo sido visto, nesta última, por 15.360 pessoas, através de sessões realizadas em nove cinemas ${ }^{7}$, por um período de onze dias, entre 8/11/1915 e 12/2/1916 (Bernardet, 1979). Em Minas Gerais, chegou a três cidades, entre as quais não estava incluída, naquele momento, a capital. Nesse circuito, percorrido pelo próprio Thomaz Reis, o filme atingiu um público de 65.788 espectadores. ${ }^{8}$

Finda essa primeira etapa, o inspetor Frederico Ortiz do Rego Barros entra em cena, encarregando-se de levar Os sertões a outras cidades dos estados do Rio de Janeiro, São Paulo e Minas Gerais, bem como ao Norte do Brasil, começando pelo Estado do Amazonas, em agosto de 1916, de onde segue para o Pará. Em março de 1917, Rego Barros cuida da exibição do filme nos estados da região Sul - Paraná, Santa Catarina e Rio Grande do Sul. No relatório em que dá conta desse percurso, há ainda menção à sua exibição nos estados da Bahia, Alagoas, Pernambuco, Paraíba, Rio Grande do Norte, Ceará, Maranhão. Nos estados das regiões Sul, Norte e Nordeste, as exibições concentraram-se nas capitais.

Por ocasião de algumas sessões de $O$ sertões, caso das realizadas no Teatro Fênix, foi também incluído, como parte da programação, o filme Expedição Roosevelt, fruto da expedição científica liderada pelo expresidente norte-americano Theodore Roosevelt, entre dezembro de 1913 e

\footnotetext{
${ }^{6}$ Cinemas Palais e Pathé.

${ }^{7}$ Cinemas Íris, Pathé, Coliseu, Colombo, Guarani, Teatro Brasil, São Paulo, Rio Branco, Celso Garcia.

${ }^{8} \mathrm{O}$ relatório de Thomaz Reis, encaminhado ao Chefe do Escritório Central da CLTEMGA, que trata das atividades realizadas de outubro de 1915 a março de 1916, fornece dados detalhados a respeito desse primeiro circuito, informando as cidades em que o filme foi exibido, número de espectadores, bem como renda arrecada em cada uma delas (Reis, 1916).
} 
janeiro de 1914, guiada por Rondon e que percorreu o interior do Mato Grosso. Tal expedição foi acompanhada, durante parte de seu trajeto, por Thomaz Reis, que em determinado momento, insatisfeito com as condições de filmagem, dela se desligou, referindo-se ao resultado como "incompleto [...] devido à pressa da viagem" (Magalhães, 1930: 375). A precariedade do filme, apontada pelo próprio realizador, certamente não contribuiu para que Expedição Roosevelt tivesse uma carreira tão profícua como Os sertões. De todo modo, além das projeções mencionadas acima, foi exibido em duas salas da cidade de São Paulo, em Manaus, bem como em alguns outras cidades, juntamente com Os sertões, sendo difícil, entretanto, precisar quando isso efetivamente aconteceu, pois muitas vezes as matérias publicadas nos jornais são ambíguas, falando-se ora em filmes, ora apenas no filme Os sertões.

Ao longo dos anos 1915, 1916 e 1917 a CR cuida com afinco da exibição de Os sertões. O filme atinge um público expressivo e pelo que se pode deduzir da prestação de contas apresentada por Thomaz Reis nos relatórios em que trata desse assunto ${ }^{9}$, gerou uma renda significativa, revertida em prol das populações indígenas, dos flagelados da seca, sendo ainda utilizada para cobrir custos de produção e amortizar adiantamentos. Embora tais fatores indiquem terem sido expressivos os rendimentos gerados pelo filme, não é possível avaliar seu real significado, considerando tratar-se de moeda distinta da atualmente em circulação, e de outro contexto econômico ${ }^{10}$. Thomaz Reis fornece-nos um parâmetro nesse sentido,

\footnotetext{
9 Thomaz Reis trata do circuito de exibição de Os sertões nos relatórios relativos às atividades executas no período de outubro de 1915 a março de 1916 (Reis, 1916) e de outubro de 1916 a março 1917 (Reis, 2008). Menciona também as exibições dos filmes Expedição Roosevelt e Mato Grosso em revista.

10 Para auferir a real expressão dos valores arrecadados com a exibição do filme, seria necessário ir muito além da conversão da moeda em circulação no momento, para reais, buscando-se ainda referências relativas a custos de equipamentos, película, gastos de produção à época, procurando equivalências com os dias de hoje, tarefa que não será contemplada neste trabalho.
} 
mencionando que a exibição dos filmes ${ }^{11}$ nos teatros brasileiros gerou uma renda de dez mil dólares. (Reis, 2011: 267).

\section{Estratégias de difusão}

O divórcio entre produção e exibição, que levaria os filmes brasileiros a enfrentarem profundas dificuldades para chegar às telas dos cinemas, provocando o fim da Bela Época (1907 a 1911), considerada por alguns autores a fase áurea do cinema brasileiro $^{12}$, não impediu que $O s$ sertões de Mato Grosso fizesse uma carreira de sucesso Brasil afora. O que teria possibilitado esse estado de coisas?

Acredito que grande parte do sucesso de Os sertões, no que concerne à sua trajetória no circuito comercial de exibição, bem como de outros filmes da CR, se deve, em grande medida, às estratégias desenvolvidas com esse fim, que, devem ser creditadas, sobretudo, à pessoa de Thomaz Reis. Profissional múltiplo, extremamente habilidoso em diversas áreas da produção audiovisual, é também um homem de produção, que se envolve com questões relativas à circulação dos filmes, o que faz com tenacidade e criatividade, tirando partido das articulações possibilitadas pela instituição a qual está vinculado, o Exército.

Assim, é o próprio Thomaz Reis quem percorre o circuito inicial em que Os sertões foi exibido, composto por diversas cidades de São Paulo, Rio de Janeiro e Minas Gerais; para isso se dirigia ao local em que pretendia

\footnotetext{
${ }^{11} \mathrm{O}$ uso do plural significa que Reis se refere a Os sertões e Expedição Roosevelt, embora, como já apontei, as exibições deste último tenham sido bem mais limitadas.

${ }^{12}$ A caracterização desse período do cinema brasileiro como Bela Época, com produção intensa e a chegada dos filmes ao circuito exibidor, foi proposta por Vicente de Paula Araújo em seu livro A Bela Época do cinema brasileiro, São Paulo: Editora Perspectiva, 1976. Paulo Emilio Salles Gomes adere a essa visão em sua periodização do cinema brasileiro, proposta no "Panorama do Cinema Brasileiro: 1986/1966", publicado em Cinema: trajetória no subdesenvolvimento, Rio de Janeiro: Paz e Terra: Embrafilme, 1980. Tal compreensão a respeito desses primeiros anos do cinema brasileiro é questionada por Jean-Claude Bernardet, bem como a periodização proposta por Paulo Emílio (Bernardet, 1995: 34-48).
} 
exibir o filme, onde procurava potenciais exibidores e negociava os termos que regeriam a transação. A inexistência da figura do distribuidor possibilitava que a $\mathrm{CR}$, enquanto produtora, auferisse um percentual mais elevado do valor arrecado, dividido entre este e o exibidor, e que se situava entre $40 \%$ e $60 \%$ da renda líquida do filme ${ }^{13}$. Além disso, evitava-se a falta de controle sobre o número de espectadores e os rendimentos alcançados, bem como o desaparecimento de cópias, histórias que abundam nos primeiros anos do cinema brasileiro.

Com relação à forma como transcorriam as exibições, Thomaz Reis se encarregava de revisar as cópias, podendo realizar pequenos reparos caso necessário. A partir de certo momento, passa a contar com um assistente, que se responsabilizava pela revisão da película, garantindo assim sua integridade e a qualidade das sessões. É importante mencionar que Thomaz Reis se deslocava de uma cidade para outra, fazendo longos percursos, de modo que a cópia (é provável que viajasse com mais de uma) era intensamente utilizada, necessitando de frequentes revisões, e de uma manipulação adequada a fim de evitar maiores desgastes.

As longas viagens de Reis tinham objetivos diversos, de modo a otimizar suas ações. A caminho de uma filmagem, fazia escalas, desvios com o intuito de realizar outras atividades, procedimento esse que era rotineiro, podendo-se mapear em seus relatórios muitas situações desse tipo. No período em que se dedicava às filmagens entre os índios Bororo, que resultaram no filme Rituais e festas Bororo, cuidava também da promoção e lançamento de Os sertões no estado de Mato Grosso. Quando da exibição desse primeiro filme da CR nas cidades de Corumbá e Cuiabá, roda Mato Grosso em revista, filme realizado como uma espécie de satisfação à

\footnotetext{
${ }^{13}$ No relatório relativo ao período de outubro de 1915 a março de 1916 Thomaz Reis menciona que a renda no circuito tratado variou de $40 \%$ a 60\% (Reis, 1916). Com relação à exibição do filme em Corumbá, se detém em suas negociações com o empresário Sr. Fontanillas, que resultaram na obtenção de um percentual de 60\%, ficando sob responsabilidade da CR os custos com a música (Reis, 2008: 213).
} 
população do estado de Mato Grosso, a fim de compensar certo mal-estar face ao universo abordado em Os sertões, e mostrar à população do Rio de Janeiro que no estado havia algo além da "vida natural e selvagem". Apesar da promessa de Reis de que o filme seria levado ao Rio de Janeiro e São Paulo, suas exibições se restringiram às cidades de Corumbá e Cuiabá, onde as filmagens foram realizadas.

Ainda com o intuito de otimizar os recursos de que dispunha, Thomaz Reis recorre à estrutura da instituição a qual está vinculado, o Exército, que muitas vezes lhe fornece hospedagem durante suas viagens, em outras, se encarrega, através de seu pessoal, da execução de números musicais durante as projeções ${ }^{14}$.

Essa forma de atuação certamente contribuiu para o amplo lançamento de Os sertões, já que os recursos da instituição, sempre reduzidos, eram aproveitados ao máximo, gerando resultados diversos, num mesmo período, em decorrência da realização de atividades paralelas.

\section{A investida no mercado norte-americano}

O trabalho realizado nesses primeiros anos da Seção de Fotografia e Cinematografia da CR aponta para a existência de uma ótima infraestrutura para que o mesmo fosse realizado, com equipamentos de qualidade, bem como verba para custear deslocamentos e outras necessidades. É importante salientar, entretanto, que Botelho de Magalhães, em relatório sobre o trabalho da Seção do ano de 1916, encaminhado a Rondon em fevereiro de 1918, já pedia sua extinção "por falta de numerário". Acredito que tal solicitação revele que, apesar de bem aparelhada em seus primórdios, a Seção de Fotografia e Cinematografia esteve sob constante ameaça,

\footnotetext{
14 A propósito da exibição de Os sertões de Mato Grosso em Cuiabá, Thomaz Reis menciona que as "musicas [foram] oferecidas pelo Batalhão Policial e pelo QuartelGeneral” (Reis, 2008: 227).
} 
havendo setores no interior da CR que não apoiavam suas atividades, alvo de frequentes pressões, aplacadas pela intervenção de Botelho de Magalhães e o apoio de Rondon.

Apesar desse quadro, parte da renda de Os sertões foi revertida para as populações indígenas bem como para os flagelados da seca, sendo apenas um percentual da mesma utilizado para amortizar alguns gastos de produção e custear ações visando à exibição do filme, não permitindo que aquele serviço se capitalizasse, continuando a depender inteiramente de verba proveniente da $\mathrm{CR}$ e dos diferentes ministérios ao qual esteve vinculada. É provável que o montante arrecadado não fosse suficiente para a manutenção dos equipamentos de filmagem, do laboratório para revelação dos filmes e feitura de cópias, bem como para a aquisição sistemática de película e de outros materiais, embora pudesse minimizar essa situação de dependência. Acredito que a maneira como foram utilizados os rendimentos do filme, escapando a uma lógica de viés predominantemente econômico, possa ser atribuída a razões políticas, visando chamar atenção para a importância do trabalho realizado pela Seção e fortalecê-lo aos olhos do público e do aparelho de Estado.

O fato é que em 1919 a carência já anunciada chega a um ponto crítico, exposto por Thomaz Reis em seu memorando de 1919, encaminhado a Rondon, em que aborda a venda dos equipamentos, incluindo "material de campo e oficinas", por questões de economia, restando apenas uma câmera alemã frágil e que se encontrava inutilizada.

Nesse contexto é que se dá a viagem de Reis a Nova York, em 1918, abordada em relatório bem escrito, minucioso e espirituoso, através do qual se pode tomar conhecimento das ambições da CR e, especificamente, de Thomaz Reis, de distribuir internacionalmente os filmes produzidos pela instituição, bem como do aprendizado ao qual se debruça de forma aplicada, a fim de entender os meandros da distribuição e exibição de filmes nos Estados Unidos. Nesse relatório, Reis menciona que o objetivo da viagem 
era "exibir o filme da nossa Comissão", como também "angariar donativos para o serviço de pacificação dos nossos silvícolas" (Reis, 2011: 255, grifos meus). Embora Reis fale em donativos, o que se pode depreender de suas ações durante a viagem é a tentativa de negociar os filmes da CR no mercado norte-americano e em outros mercados internacionais, com o objetivo de gerar recursos através da exploração dos mesmos.

Voltando ao trecho do relatório de Thomaz Reis destacado acima, observa-se a menção à exibição de um filme, em outros momentos, entretanto, encontra-se referência à exibição de filmes da CR, ou ainda do filme Os sertões, o que ocorre no ofício que encaminha o relatório em questão ao chefe do Escritório Central da CR, Botelho de Magalhães. Já no relatório propriamente dito, Reis se refere a um programa em seis partes intitulado Wilderness: "1 ${ }^{\mathrm{a}}$ parte - RJ e SP; $2^{\mathrm{a}}$ parte - Expedição Roosevelt; $3^{\mathrm{a}}$ parte - índios Pareci, jogo de bola etc.; $5^{\mathrm{a}}$ e $6^{\mathrm{a}}$ parte - Índios Coroado" (Reis, 2011: 278). ${ }^{15}$

Afinal, que filme estaria sendo levado aos Estados Unidos? Trata-se de um filme ou de alguns filmes da Comissão Rondon? Tal oscilação não se constitui, certamente, em simples erro, considerando-se o esmero com que eram escritos os relatórios de Thomaz Reis. A compreensão dessa situação, do que está por trás dessa aparente confusão, nos remete à genealogia do filme Wilderness, seu processo criativo e trajetória, lançando luz ao conhecimento do tipo de cinema realizado por Thomaz Reis, e de sua atuação a fim de conquistar o mercado norte-americano.

Acredito que uma pista importante, nesse sentido, seja a categoria "programa", encontrada em vários relatórios de Thomaz Reis. Neles, "programa" não diz respeito a uma programação composta por vários

${ }^{15}$ Como se pode observar, Thomaz Reis não menciona o conteúdo da $4^{\mathrm{a}}$ parte. Denise Lasmar também se refere ao fato de Wildernes ser composto por seis partes, as quais, entretanto, apresentam algumas diferenças, sendo elas: "o ritual Bororo, caçada à onça no Pantanal, vistas do 'salto Iguassú', Rio de Janeiro e SP, Expedição Roosevelt e jogo de bola dos índios Pareci” (Lasmar, 2088: 105) 
filmes, mas a um produto específico, que normalmente designaríamos hoje como um filme. No caso das realizações de Thomaz Reis, entretanto, tais filmes ou "programas" não têm um caráter fechado, podendo ser remontados, rearticulados em função dos contextos de exibição. É isso que se pode deduzir da forma como é tratada a produção que Reis pretende exibir nos Estados Unidos. Tal possibilidade de remontagem é favorecida pelo tipo de trabalho desenvolvido por Thomaz Reis, que, como bem chama atenção Samuel Paiva, em texto sobre o filme Ao redor do Brasil, apresenta certa unidade, decorrente de uma "reiteração temática e formal" (Paiva, 2006: 231). É como se toda sua produção se resumisse a um só filme, sobre uma longa viagem pelo interior do Brasil (Lobato, 2011: 178).

O programa Wilderness é efetivamente (re)montado em Nova York; Reis viajara preparado para isso, já que levava consigo uma caixa de filmes contendo positivos e negativos. Ao planejar a viagem, filma cenas que seriam incorporadas ao "programa" a ser exibido em Nova York, como as relativas ao Rio de Janeiro e São Paulo, que não foram incluídas nos outros filmes da CR. Tais cenas tampouco seriam incluídas na versão do filme exibida no Brasil, intitulada De Santa Cruz, de acordo com sua descrição nos anúncios publicados nos jornais da cidade de São Paulo (Bernardet, 1979). As alterações feitas no filme que levava consigo, ou talvez seja mais apropriado falar na (re)montagem do material que vinha filmando ao longo de alguns anos, visavam adequá-lo à exibição nos Estados Unidos e aos futuros negócios com as empresas de exibição e distribuição do país, buscando satisfazer as exigências daquele mercado e o gosto do público norte-americano.

Chegando a Nova York, Thomaz Reis procura o ex-presidente americano Theodore Roosevelt, em nome de Rondon, a quem pede ajuda para exibição do filme da CR na cidade. Reis sugere a Roosevelt a realização de uma "função solene", para a qual seriam convidados “elementos oficiais" e a imprensa, com objetivo de atrair empresários das 
casas de exibição (Reis, 2011: 267). O programa Wilderness é exibido no Carnegie Hall, de Nova York, com casa lotada (2.800 lugares), após conferência do ex-presidente Roosevelt, em 15/5/1918, sob os auspícios da Sociedade Americana de Geografia. Thomaz Reis aproveita a magnitude dessa sessão, convidando representantes das "companhias principais de filmes", tendo comparecido à mesma "os chefes da Metro, Paramount, National, Interocean, Fox, Educational Goldwin, World" (Reis, 2011: 278).

Esse grandioso e bem sucedido evento foi preparado de forma cuidadosa, Thomaz Reis se dedicou a estudar o mercado cinematográfico norte-americano, com preocupações que iam desde o gosto do público, até questões ligadas ao circuito distribuidor e exibidor, investigando quais as empresas confiáveis e adequadas ao tipo de cinema realizado pela CR. Para isso, faz sessões prévias, a partir das quais percebe que algumas adaptações deveriam ser feitas no filme que estava (re)construindo. Assim, faz cortes em função da censura, com eliminação de cenas em que os índios estão nus e as tomadas são próximas; elabora intertítulos em inglês, com a contribuição da jornalista Lilian Elliot, que possuía um livro escrito sobre o Brasil e havia viajado pela América do Sul. Os títulos relativos à parte dos índios Pareci e Nhambiquara foram traduzidos do livro do Coronel Roosevelt, "a fim de dar interesse quanto ao ponto de vista americano" (Reis, 2011: 271).

Com relação ao gosto do público, merecem destaque os perspicazes e irônicos comentários de Reis, cuja percepção decorreu de contatos feitos por ele com o objetivo de conseguir a publicação, naquele país, do livro de Conferências de Rondon. Com a palavra Thomaz Reis:

Deveria ter um certo número de fotografias nítidas, sobre animais ferozes, índios, etc., e que quanto possível alguma cousa sensacional, por exemplo, o Coronel Rondon lutando com um tigre ou um colossal sucuri dominando um chefe Coroado em presença da tribo espavorida atirando-lhe 
flechas, depois tudo isto arrastado pelo Salto Belo e precipitado na queda onde deveria aparecer algum americano forte como George Walsh e salvar tudo, exclamando "Liberty", foi o que eu imaginei pudesse ser o estilo mais apreciado ali. (Reis, 2011: 259).

Ainda com o intuito de garantir a realização de um evento de alto nível, e exibir um filme capaz de agradar o público em geral e, em particular os representantes das salas de exibição e empresas de distribuição, Thomaz Reis cria condições para produzir os materiais necessários e não subsidiados pela Sociedade Americana de Geografia, que se responsabilizara pelos custos com o Carnegie Hall. Administrando a reduzida verba de que dispunha, Thomaz Reis se encarrega da impressão dos programas para a sessão, bem como de contratar a orquestra para a execução dos números musicais, recorrendo a músicos pertencentes aos regimentos militares, que se dispuseram a trabalhar por um preço mais em conta do que o praticado por músicos profissionais. Reis se encarrega da escolha das músicas a serem tocadas, definindo o momento em que deveriam ser executadas, e para que isso acontecesse de forma precisa, desenvolve um método de sinalização para os músicos, fazendo as vezes de maestro.

Apesar do sucesso da exibição de Wilderness no Carnegie Hall, a imprensa nova-iorquina manteve total silêncio a respeito do filme, não colaborando com sua divulgação e circulação na cidade, onde o filme ainda permaneceu em cartaz, no Teatro Strand, por oito dias. De acordo com Reis, afluiu um público bastante expressivo a tais sessões no Strand, importante cinema da Broadway, embora o verão já estivesse iniciando, o que afastava a população nova-iorquina das salas de cinema.

Depois de muitas idas e vindas, de possibilidades frustradas por razões variadas, entre as quais a falta de idoneidade de uma companhia com a qual estava prestes a fechar negócio, Reis assina um contrato para distribuição da produção cinematográfica da $\mathrm{CR}$ no mercado internacional 
com a empresa Interocean, o que, entretanto, não dá resultados positivos, tendo sido rescindido após dois anos (Bernardet, 1979). A viagem de Reis aos Estados Unidos, muito bem sucedida de certo ponto de vista, com a exibição de Wilderness numa das mais importantes casas de espetáculo de Nova York, o Carnegie Hall, bem como numa sala de cinema de primeira linha, o Strand, não foi capaz de produzir os resultados econômicos esperados.

Depois da experiência nova-iorquina, o filme circularia apenas no Brasil: na cidade de São Paulo onde foi exibido em doze cinemas da capital $^{16}$, bem como em Santos e Campinas, entre agosto e setembro de 1920, tendo atingido um público de 20.677 espectadores (Bernardet, 1979). Chegou também às telas de nove cinemas da cidade do Rio de Janeiro, ${ }^{17}$ durante vinte dias, no período de 11/10/1920 a 8/11/1920.

\section{Nos anos seguintes}

Apesar das dificuldades econômicas e técnicas enfrentadas pela Seção de Fotografia e Cinematografia da CR no final de 1919, Thomaz Reis propõe a feitura de um filme para os festejos do Centenário da Independência em 1922, lembrando que para isso seria necessário adquirir novo equipamento. O projeto, extremamente ambicioso, no qual pretendia abordar o Brasil do ponto de vista de sua fauna, flora, geologia, bem como os usos e costumes de suas populações indígenas, a ser feito em duas partes, não se concretiza (Reis, 1919). Cerca de dez anos depois, Thomaz Reis realiza Ao redor do Brasil, filme que dialoga com esse projeto não executado, e parece ter sido o filme possível, construído a partir de trechos de diversos outros trabalhos por ele realizados. Esse será o último filme da

${ }^{16}$ Cinemas Avenida, Central, Pathé, Colombo, São Paulo, São Pedro, Royal, Rio Branco, Coliseu C. Elíseos, América, Brasil e Espéria.

${ }^{17}$ Cinemas Pathé, Atlântico, Centenario, Cine Theatro America, Modelo, Ideal, Meyer, Smart e Velo. 
CR a chegar ao circuito comercial, com projeções em sete salas da cidade de São Paulo ${ }^{18}$, no período de janeiro a março de 1933 , durante vinte e nove dias.

No período que se situa entre a circulação dos filmes De Santa Cruz e Ao redor do Brasil, apenas dois outros filmes produzidos pela $\mathrm{CR}$ foram exibidos em situações públicas: Ronuro, selvas do Xingu, por ocasião do Congresso de Geografia realizado em Vitória em 1926, e Operações de guerra, no Cinema Parisiense, no Rio de Janeiro, em agosto de 1926.

A não circulação de diversos filmes produzidos pela $\mathrm{CR}$, ou sua exibição em situações bem pontuais, pode ser atribuída a um conjunto de fatores, entre os quais a precariedade da Seção de Fotografia e Cinematografia da $\mathrm{CR}$, em diversos momentos de sua trajetória, como o final da década de 1920. Podem, ainda, ter concorrido para isso as características dessas produções, já que algumas delas tratam de situações muito específicas e com possibilidades mais restritas de diálogo com um público diversificado. Deve-se levar em conta, também, a forma como muitas filmagens aconteceram, gerando não apenas limitações do ponto de vista técnico, quanto no que concerne à construção da narrativa fílmica, sem que o cineasta tivesse condições e tempo necessários para a elaboração de sua obra, o que é apontado por Thomaz Reis a propósito da situação em que se deram as filmagens que redundaram em Ronuro, selvas do Xingu:

Certas viagens, a marchas forçadas, em que não se perde tempo, num "toca-toca" para a frente, são um verdadeiro martyrio para o artista, que não tem oportunidade de repousar o sentimento, para melhor coordenar os elementos de seu trabalho. Não sou amigo das viagens de urgencia, quando ha um objetivo de arte a obter. (Magalhães, 1930: 376).

\footnotetext{
${ }^{18}$ Cinemas Odeón, São Bento, Santa Cecília, Mafalda, Braz Politeama, Capitólio e Central.
} 
Nem sempre foi possível harmonizar o trabalho da CR com as demandas da produção artística, e, como observa Botelho de Magalhães, em determinadas circunstâncias o serviço cinematográfico acabou secundarizado (Magalhães, 1930: 376). Em diversas ocasiões, por razões distintas, Reis se ressentiu com as limitações impostas a suas possibilidades criativas, e consequentemente à realização de outros filmes com a qualidade artística desejada, e potencial para chegar a um público mais amplo. Apesar da compreensão dos membros da $\mathrm{CR}$ e, em particular, de Botelho de Magalhães e Rondon quanto à importância do trabalho cinematográfico de Thomaz Reis, não havia como superar inteiramente as demandas da instituição, suas prioridades e ritmos.

\section{Da divulgação dos filmes}

Os filmes realizados pela CR e lançados comercialmente foram intensamente divulgados, seja através de anúncios publicados em jornais de grande circulação, como através de matérias, frequentes, sobretudo nos jornais de cidades do interior dos estados de São Paulo, Rio de Janeiro, Minas Gerias e Mato Grosso, por ocasião da exibição de Os sertões, bem como nos jornais das capitais dos outros estados nos quais o filme circulou $^{19}$. Thomaz Reis tem um papel central nesse trabalho de divulgação, embora, em várias ocasiões sua posição de diretor não seja explicitada, sendo-lhe atribuída, por exemplo, a função de "hábil operador" (Commercio de Jahu, Jahu, 29/10/1916), ou de ser a pessoa encarregada de levar o filme ao local em que seria projetado (Tribuna, Corumbá, 17/6/1916). De todo modo, sua presença na redação dos jornais é constantemente mencionada, municiando os jornalistas com informações sobre o filme, contando

\footnotetext{
19 Há cópias de matérias publicadas em jornais de diversas cidades brasileiras em que o filme foi exibido em pasta relativa a esse diretor, no acervo da Cinemateca Brasileira de São Paulo.
} 
histórias e aventuras vividas durante as filmagens, capazes de despertar o interesse do espectador. Tais notícias, em certos casos, começam a ser veiculadas algum tempo antes da realização das projeções e até mesmo do seu agendamento. Em várias cidades são promovidas sessões dirigidas especialmente à imprensa, e por vezes também às autoridades locais.

Tanto nas matérias tratadas acima, quanto nos anúncios publicados nos principais jornais das cidades do Rio de Janeiro e São Paulo, relativos à exibição dos filmes Os sertões de Mato Grosso, De Santa Cruz e Ao redor do Brasil, ressalta-se, logo de início, o fato de o filme abordar o "importante" e "eficaz" trabalho da Comissão Rondon. Em geral destaca-se a figura de Rondon, a estrela dos filmes, tratado sempre de forma elogiosa, como um profissional "abnegado", "valoroso", um "ilustre patrício". Um episódio ocorrido no momento em que Os sertões estava em cartaz ilustra bem o prestígio de Rondon e, consequentemente, seu potencial para atrair espectadores para os filmes. Trata-se de debate travado na Comissão de Finanças do Senado, a respeito da concessão de um crédito suplementar à CR, ocasião em que o Sr. Guanabara defende tal concessão, enumerando os feitos de Rondon, qualificando-o como "um patriota, um benemérito e um abnegado". ${ }^{20}$

Por diversas vezes, através dos textos jornalísticos, faz-se uma espécie de chamamento à "população culta", apela-se a seu "patriotismo" e "humanismo", e à sua capacidade de valorizar o "trabalho admirável de cattechese do imortal Rondon, Roosevelt do Sul, gloria do Brasil". ${ }^{21}$ Vai nesse mesmo sentido a menção ao fato de a renda dos filmes ser revertida para o fortalecimento do trabalho do Serviço de Proteção aos Índios (SPI), com a pacificação dos grupos indígenas, bem como para os flagelados da seca. Assistir aos filmes da CR se torna, assim, uma missão cívica, uma forma de contribuir para a solução de algumas questões sociais que afligem

20 "No Senado", Correio da Manhã, Rio de Janeiro, 31/10/1915, p. 2.

21 "Radium Parque", Tribuna do Norte, Pindamonhangaba, 30/03/1916. 
a sociedade brasileira de então. Tais argumentos ganham mais força, num momento em que se trava intenso debate a respeito do tratamento que deveria ser dispensado às populações indígenas, com quem as frentes de expansão, e em particular a CR, vinham se defrontando, ganhando terreno a posição assumida por Rondon em prol de um contato pacífico, recusando taxativamente o recurso à violência, a fim de levar a "civilização" às populações indígenas, incorporando-as à sociedade nacional.

Outro aspecto destacado na divulgação dos filmes é o fato de abordarem as riquezas do interior brasileiro, suas belezas, sua fauna exuberante, formada por animais de grande porte, que exigem especial destreza para serem enfrentados. Nos diversos anúncios que tratam da exibição de De Santa Cruz no Rio de Janeiro, tal aspecto é sempre referido logo após menção à Comissão Rondon e a Rondon, conforme trecho que se segue:

Conjunto cinematográfico relactando aspectos inéditos da patriotica campanha da Comissão Rondon. (...) Cinco partes em que se acompanha o Apostolato Rondon através do pantanal e a floresta, em que se verá a caçada da onça, a caça do jacaré pelos Indios, em que as selvas brasileiras se desdobram magnificentes, em que rios e cascatas são entrevistos pela Civilização, em que pela primeira vez foram cinematografados os rituais das Tribus Borôros. Tradições dos silviculas. A beleza do nosso imenso solo. ${ }^{22}$

Ainda que o cinema de Thomaz Reis se distancie do filão que se dedicou a flagrar as belezas naturais brasileiras, a exuberância de sua fauna e flora, suas magníficas cachoeiras, identificado por Paulo Emílio Salles Gomes como "berço esplêndido" (Gomes, 1986: 328), tais situações permanecem presentes em seus filmes, ele também aponta sua câmera para os aspectos grandiosos e espetaculares do interior do país, dedicando-se, por exemplo, a filmar as Cataratas do Iguaçu, investindo na filmagem da caçada

\footnotetext{
${ }^{22}$ Anúncio publicado no Correio da Manhã, Rio de Janeiro, 09/10/1920, p. 12.
} 
da onça e seu embate com o homem, situação difícil de ser registrada e à qual se dedicou com perseverança ${ }^{23}$. Entretanto, tais situações certamente não se constituem no cerne do cinema de Thomaz Reis, cujo objetivo é abordar o trabalho desenvolvido pela $\mathrm{CR}$, as populações com as quais a mesma entra em contato, em particular os grupos indígenas, como também a fauna e flora do interior do país, sua geografia, o que serviria de fonte para pesquisas científicas. O próprio Paulo Emílio distingue o trabalho de Thomaz Reis do tipo de produção que qualifica como "berço esplêndido" (Gomes, 1986: 328); vai nessa mesma direção a compreensão de Carlos Roberto de Souza quando diz que "decididamente não seriam esses os aspectos que Reis gostaria de ver revelados em seu trabalho" (Souza, 1981: 8). Embora tais aspectos estejam presentes, a ênfase dada aos mesmos soa excessiva, e acredito que possa ser compreendida como uma estratégia de divulgação, capaz de potencializar o diálogo dos filmes com o público, que vinha sendo alimentado com fartas doses de "berço esplêndido", e estimulado a demandar esse tipo de produção.

No trecho do anúncio transcrito acima, enfatiza-se, ainda, a abordagem de grupos indígenas, de seus costumes, possibilitando o contato do espectador com populações que lhe eram desconhecidas. Se tal fato, por um lado, funcionava como um atrativo, por outro, a forma de vida desses grupos, e mais especificamente sua nudez, é apontada como uma limitação à visão do filme por certos segmentos da população, como as senhoritas. Esse assunto é tratado em várias matérias, havendo aquelas que aconselham as senhoritas a se retirarem da sessão após a $5^{\mathrm{a}}$ parte, constando nesse ponto do filme uma advertência acerca do conteúdo do trecho final: "Previne-se as Exmas Familias de que na Sexta parte a seguir foram cinematografados os índios Nhambiquaras completamente nús, tal qual vivem no sertão." (Lasmar, 2008: 208). O debate sobre esse assunto é intenso, havendo

${ }^{23}$ Em um de seus relatórios se detém nas filmagens das "Cataractas do Iguassú", bem como da "caçada da onça" (Reis, 2008: 17-40). 
também aqueles que não veem problema na veiculação de tais imagens, já que "esta circunstancia do nú não implica de modo algum uma offensa moral". ${ }^{24}$

O cinema de Thomaz Reis tanto se detém na missão "civilizadora" da $\mathrm{CR}$ e as consequentes mudanças advindas desse processo, representada, por exemplo, pela doação de roupas a um grupo de índios em Ao redor do Brasil, quanto busca sua força ao flagrar os índios Bororo da forma como viviam antes do contato com o colonizador, com o intuito de transmitir ao espectador uma "perfeita e nítida impressão da Era da Descoberta do Brasil, na época de Cabral", como diz o trecho final do anúncio que vem sendo discutido. Thomaz Reis tinha consciência do quão impactantes podiam ser os costumes dos índios Bororo, bem como da importância de tais registros para estudos científicos, empenhando-se em registrar sua cultura em seu estado mais "puro" possível, evitando, as mudanças introduzidas pelo homem branco. Movimento pendular: doa-se roupas, em um momento, e em outro, pede-se aos índios que se dispam, apenas temporariamente ${ }^{25}$. Embora tais filmagens tenham acontecido em 1916, de acordo com os termos do anúncio e os valores que o sustentam, as tradições culturais registradas, em verdade, diriam respeito a um tempo pretérito, à época de Cabral, de modo que os índios Bororo e os demais povos indígenas precisariam passar por transformações, a fim de adequar seu passo, entrando em sintonia com os novos tempos.

24 “Os sertões de Matto Grosso", Gazeta de Taubaté, Taubaté, 19/2/1916.

${ }^{25}$ Sabe-se, através de relato do próprio Thomaz Reis, que o mesmo solicitou aos índios Bororo que não usassem as roupas introduzidas pelos brancos, durante as várias etapas do ritual funerário que estava filmando (Reis, 2008). 
Da exibição dos filmes...

\section{Referências bibliográficas}

BERNARDET, Jean-Claude (1979), Filmografia do Cinema Brasileiro 1900-1935: jornal O Estado de São Paulo, São Paulo: Secretaria de Cultura, Comissão de Cinema.

BERNARDET, Jean-Claude (1995), Historiografia Clássica do Cinema Brasileiro, São Paulo: Annablume.

GOMES, Paulo Emílio Salles (1986), “A experiência social dos filmes documentais no cinema mudo brasileiro (1898-1930)" in Carlos Augusto Calil e Maria Teresa Machado (eds.), Paulo Emílio: um intelectual na linha de frente, São Paulo/Rio de Janeiro: Brasiliense/Embrafilme, pp. 323-330.

LASMAR, Denise Portugal (2008), O Acervo Imagético da Comissão Rondon, Rio de Janeiro: Museu do Índio.

LOBATO, Ana (2011). "Viajando pelas fronteiras do Brasil" in Samuel Paiva e Sheila Schvarzman (eds.), Viagem ao cinema silencioso do Brasil, Rio de Janeiro: Beco do Azougue, pp. 174-191.

MAGALHÃES, Amilcar Armando Botelho (1930), Pelos sertões do Brasil, Porto Alegre: Liv. Globo.

REIS, Luiz Thomaz (2008), "Relatório apresentado pelo $2^{\circ}$ Tenente Luiz Thomas Reis ao Capitão Dr. Amilcar Botelho de Magalhães, chefe do Escriptorio Central, relativo ao período de outubro de 1916 a março de 1917" in Denise Portugal Lasmar, O acervo imagético da Comissão Rondon, Rio de Janeiro: Museu do Índio - FUNAI, pp. 210-255.

REIS, Luiz Thomaz (2011), "Relatório apresentado pelo Sr. $1^{\circ}$ Tenente Luiz Thomaz Reis da sua excursão aos Estados Unidos da América do Norte - 1918", in Samuel Paiva e Sheila Schvarzman, (eds.), Viagem ao cinema silencioso do Brasil, Rio de Janeiro: Beco do Azougue, pp. 252-287. 
RODRIGUES, João Carlos (1982), Major Luiz Thomaz Reis: o cinegrafista de Rondon, Rio de Janeiro: Departamento de Documentação e Divulgação da Embrafilme.

SOUZA, Carlos Roberto (1981). Apresentação. São Paulo: Cinemateca Brasileira, datilografado.

PAIVA, Samuel (2006), "Ao Redor do Brasil: cinema como apropriação", in Rubens Machado Jr. et al. (eds.), Estudos de Cinema Socine, VII, São Paulo: Annablume; Socine, pp. 225-231.

\section{Fontes arquivísticas}

REIS, Luiz Thomaz (1916), Supplemento $n^{o}$ 5, Relatório apresentado ao Capitão Amilcar Armando Botelho de Magalhães, Chefe do Escriptorio Central, dos trabalhos executados de outubro de 1915 a março de 1916, Rio de Janeiro: Comissão de Linhas Telegraphicas Estrategicas do Matto-Grosso ao Amazonas.

REIS, Luiz Thomaz (1919), Memorandum de Luiz Thomas Reis ao General Cândido Mariano da Silva Rondon, Rio de Janeiro: Comissão de Linhas Telegraphicas Estrategicas do Matto-Grosso ao Amazonas. 


\section{LEITURAS}

Lecturas | Readings | Comptes Rendus 


\title{
Cinensaios de Agnès VARda: O documentário Como ESCRITA PARA ALÉM DE SI
}

\author{
Letizia Osorio Nicoli*
}

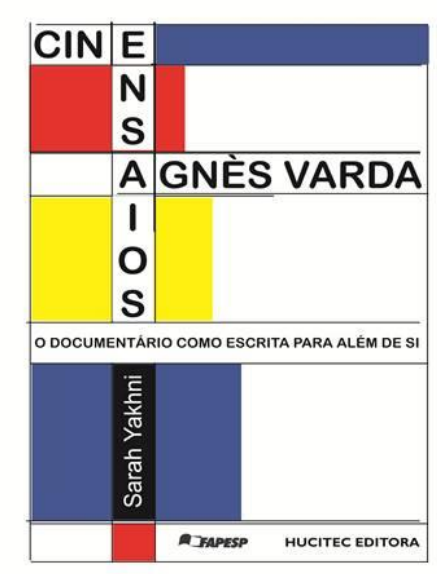

Sarah Yakhni, Cinensaios de Agnès Varda: o documentário como escrita para além de si, Campinas, HUCITEC/FAPESP, 2014. ISBN: 858404003X

A Editora Hucitec, muito oportunamente, lançou, no final de 2014, o livro Cinensaios de Agnès Varda: o documentário como escrita para além de si, de Sarah Yakhni, publicação esta resultante da tese de doutorado defendida pela autora junto ao Programa de Pós-graduação em Multimeios da Unicamp. O livro se dedica à análise da obra de Agnès Varda, cineasta bastante reconhecida e de carreira longeva. A pesquisa de Yakhni, no entanto, traz uma abordagem particular da filmografia da cineasta, centrando-se nos documentários realizados pela diretora entre 1958 e 2004, sob a perspectiva do filme-ensaio. Com isso, a obra de Sarah Yakhni se inscreve em uma tendência de interessantes e contundentes trabalhos que

* Doutoranda. Universidade Estadual de Campinas - UNICAMP, Instituto de Artes, Programa de Pós-Graduação em Multimeios. 13083-854, Campinas, Brasil.

E-mail: letizianicoli@gmail.com 
vêm se dedicando ao ensaio no cinema. Ainda que o conceito não seja novo, chama a atenção que tantos pesquisadores estejam atualmente se voltando para o tema, seja através da análise de filmes mais antigos, seja daqueles tantos que experimentam o formato ensaístico na atualidade.

Em seu livro, Sarah Yakhni não se detém em conceitos e referenciais teóricos para construir uma estrutura rígida que encarcere a obra de Varda. Nos primeiros capítulos, dedicados a apresentar o corpus, o referencial teórico e a metodologia, são introduzidas as principais referências no que diz respeito ao ensaio, iniciando-se pela necessária menção a Michel de Montaigne, salientando a construção do texto do autor como uma reflexão para si mesmo. A obra de Theodor Adorno aporta contribuições para as reflexões sobre a forma do ensaio. No que diz respeito ao cinema, a autora faz questão de referenciar autores brasileiros que se dedicam a pensar o formato ensaístico, como Jean-Claude Bernardet, Arlindo Machado, Consuelo Lins e Francisco Elinaldo Teixeira.

Ao invés de partir das considerações já levantadas por esses autores, no entanto, o ponto de partida de Yakhni é claramente a força de seu corpus. A autora não se limita a enquadrar os filmes numa tessitura de conceitos, e desenvolve as análises de maneira bastante original, trazendo aspectos únicos de cada um dos filmes e do processo de criação de Varda. Ao apresentar sua metodologia, no segundo capítulo, a autora deixa claro o destaque dos filmes como condutores da pesquisa, percebendo cada um deles como "processo criativo autônomo que irá, ele mesmo, informar e fazer vir à tona parâmetros que dialoguem de perto com seu modus operandi” (p. 25). Essas considerações levaram-na a trabalhar com análises individuais, construindo a partir dessas um todo coeso, unidas por uma rede de relações entre elas, bem como com a cineasta e seus processos criativos. Vale ressaltar aqui a força que tais análises adquirem quando Yakhni se debruça sobre os procedimentos de realização de Varda. Desde o princípio, a pesquisadora - ela própria realizadora - revela uma grande sensibilidade 
no tratamento que dispensa à cineasta Varda: ao apresentar a trajetória da diretora, Yakhni relata sua contemporaneidade com a Nouvelle Vague, sua participação nos debates acerca da política dos autores, e seu relacionamento com cineastas como Alain Resnais e Chris Marker. Em seu texto, porém, Yakhni foge da armadilha historicista de considerá-la apenas como parte das divisões e discussões políticas e estéticas do período, dando ênfase às declarações da própria Varda sobre sua formação como cineasta. Após os três primeiros capítulos introdutórios, a obra está organizada a partir das análises fílmicas dos filmes que compõem o corpus: L'opéramouffe (1958); Daguerréotypes (1974-75); Salut les cubains (1963); Ulysse (1982); Ydessa, les ours et etc...(2004); Oncle Yanco (1967); Les glaneurs et la glaneuse (2000); Deux ans après (2002). A cada capítulo, Yakhni desvenda processos de composição dos filmes de Varda que a pesquisadora aproxima da escrita ensaística. Entre os diversos elementos abordados, sobressaem-se idéias como o de "filme-diário" ou "caderno de notas", que reiteram o conceito de ensaio de Montaigne. Já nesse primeiro capítulo (dedicado ao filme mais antigo do corpus), delineia-se um estilo ensaístico de Varda que valoriza a subjetividade do olhar, uma relação familiar com o espaço e a construção da poética na justaposição das imagens. Como Yakhni bem o percebe, a força da construção narrativa não jaz apenas na força independente de cada plano, mas na construção de uma ação que não se dá no eixo-dramático, e sim "num encadeamento de estados emocionais" (p. 59).

Mais adiante, no capítulo dedicado à trilogia Cinevardaphotos (com documentários que têm como dispositivos não apenas fotografias, mas a experiência da cineasta como fotógrafa profissional), Yakhni demonstra como esta constrói narrativas a partir de memórias e divagações acerca de registros imagéticos feitos por ela mesma, no passado. Ao passo que L'opéra-mouffe e Daguerréotypes são cadernos de notas de um presente afetivo e cotidiano, os documentários de Cinevardaphotos são viagens a um 
passado registrado em imagens estáticas. Yakhni ressalta o efeito de distanciamento produzido pela inserção das fotografias nos filmes a partir da obra de Raymond Bellour (1997).

Por último, um capítulo dá conta dos filmes mais recentes que Yakhni apropriadamente caracteriza como "cinema de encontro". Cabe aqui mencionar que a dissertação de mestrado da pesquisadora, intitulada $O E u e$ o Outro no filme documentário: uma possibilidade de encontro dedicava-se a esmiuçar as relações entre documentarista e documentado na construção do filme. Essa experiência anterior se reflete na propriedade com que Yakhni desenvolve o conceito de "cinema de encontro" no livro. A subjetividade, o afeto, o acaso, a performance e o caráter de work in progress na obra de Agnès Varda são percebidos e caracterizados com a sensibilidade de quem já elaborou diversas considerações sobre o tema, tomando como base sua própria experiência como realizadora.

O reconhecimento e o valor do Outro nos documentários de Varda configuram o ponto chave da argumentação de Yakhni. É a partir dessa estrutura do trabalho da cineasta que a pesquisadora defende os filmes como uma escrita "para além de si". Ao contrário do que diz Montaigne sobre o texto ensaístico, a presença do Outro como um sujeito pleno nos documentários do corpus permitiria, para Yakhni, uma fala compartilhada. Com tais considerações, a leitura do livro chega ao seu final como uma experiência rica e sensível, configurando uma contribuição original para as discussões que se desenvolvem atualmente acerca do ensaio no cinema. 


\section{ANÁLISE E CRÍTICA DE FILMES}

Análisis y crítica de películas | Analysis and film review | Analyse et critique de films 


\title{
ESTRATÉGIAS INTERATIVAS NO WEBDOCUMENTÁRIO PRISON VALLEY
}

\author{
Betina Broch *
}

Prison Valley (2010, França e Estados Unidos)

Direção: David Dufresne e Philippe Brault

Produção: Alexandre Brachet

Co-produção: ARTE France 4

\section{Introdução}

A produção e o consumo de conteúdos audiovisuais na web tem crescido devido à expansão da internet. Com a ampliação do acesso à banda larga e a evolução dos dispositivos móveis, novas formas de comunicação estão sendo exploradas e muitas delas se utilizam da interatividade. A própria interação entre homem e máquina está mudando, uma vez que o usuário de conteúdo na web tem mais autonomia em relação ao que consumir, como e quanto quer consumir. Com o desenvolvimento das tecnologias mobile, as pessoas têm os conteúdos à distância de um toque. Assim como os produtos são alterados, sua forma de consumo também. Dentro desse conjunto de produtos que são desenvolvidos para a internet insere-se o webdocumentário, um tipo de material audiovisual pensado e desenvolvido exclusivamente para plataformas online. A interatividade foi adicionada ao universo do filme documentário, acarretando muitas vezes uma quebra da linearidade da sua narrativa e transformando o telespectador em usuário participativo.

\footnotetext{
* Bacharel. Universidade Luterana do Brasil - ULBRA. Curso de Comunicação Social com Habilitação em Jornalismo. 92425-900, Canoas, Brasil. E-mail: betina.broch@ulbra.edu.br
} 
A criação do documentário interativo exige uma plataforma online, animações, ambientes virtuais, entre outros recursos próprios à internet. $\mathrm{O}$ produto se constrói com a participação do usuário, possibilitando que ele deixe a sua opinião, decida qual caminho seguir e quais micronarrativas consumir e, por fim, possibilita outros pontos de vista e conclusões, de acordo com as informações fornecidas e aquelas que foram consumidas pelo usuário, entre conteúdo principal, micronarrativas acessórias e conteúdo extra.

O presente trabalho tem como objetivo analisar o webdocumentário francês Prison Valley, ${ }^{1}$ lançado em 2010, um projeto multimídia que envolve o webdocumentário, um documentário linear, um aplicativo para dispositivos móveis, um livro e uma exposição fotográfica. A análise busca identificar de que forma a narrativa é afetada pela interatividade proposta. O trabalho é desenvolvido a partir de uma análise descritiva, de acordo com a experiência de usuária da própria pesquisadora/autora do artigo, indicando como os fatos são apresentados, quais opções de interatividade são propostas e de que forma a narrativa principal é consumida.

\section{A interatividade no webdocumentário segundo Gaudenzi e Nash}

Gaudenzi (2012) define quatro modos de interatividade a saber: o conversacional, hipertexto, participativo e o experiencial. Um webdocumentário pode utilizar mais de um desses modos. O modo conversacional se refere a webdocs que recriam mundos em $3 \mathrm{D}$, em que a interação do usuário com a plataforma é semelhante a uma conversa. Nesse modo se encaixam os chamados docu-games, nos quais a interação entre ambos os lados parece ser real, apesar de ser pré-programada. O usuário troca com a obra, ou seja, não apenas assiste, mas também contribui,

\footnotetext{
${ }^{1}$ Disponível em: http://prisonvalley.arte.tv.
} 
deixando suas "respostas" no ambiente virtual. No modo hipertextual, ele pode escolher como percorrer a narrativa. Julia Salles (2014), que utiliza as categorias propostas por Gaudenzi (2012), explica que esse modo retira a linearidade da narrativa, e desta forma, mesmo que o usuário não intervenha na construção do conteúdo, ele participa da composição da forma do documentário (Salles, 2014, on-line). O modo participativo permite que o usuário participe da obra, ou seja, produza material e intervenha nela. Por fim, o modo experimental traz para o usuário uma experiência de espaço físico, com a utilização do GPS; é quase como se o usuário realmente estivesse andando por certo lugar, ouvindo os sons e vendo as pessoas, ao invés de estar sentado em frente ao computador navegando.

Assim como Gaudenzi, Nash também cria uma tipologia e divide o webdoc em três categorias: narrativo, categórico e colaborativo. O webdoc narrativo se detém sobre a narrativa principal, ou seja, terá uma narrativa central, que será guiada por alguém, ou pelo próprio cineasta. O webdoc categórico possui diversas micronarrativas, que formam uma estrutura narrativa, mas não apresentam uma narrativa entre as sequências. E, por fim, o webdoc colaborativo, que demanda que os usuários contribuam com o projeto, mesmo que no final ele se torne um webdoc narrativo ou categórico.

Uma das característica do documentário interativo é a quebra da linearidade da narrativa. A premissa de um webdoc é uma narrativa nãolinear, a qual abriga diversas micronarrativas que ajudam a complementar a história principal e a melhorar o entendimento do usuário. Essa quebra da linearidade aumenta a imersão do espectador e o transforma em um usuário, já que a partir da interatividade, ele deve tomar decisões e, literalmente, se mover clicando no mouse ou utilizando o teclado. Pensando nessa maior autonomia do usuário, Nash (2012) questiona a coerência com que a narrativa é transmitida, já que em webdocs o usuário ocupa um espaço no qual pode gerar conteúdo e alterar o ambiente. Ainda assim, a interatividade 
proposta será em sua maioria limitada, ou seja, por mais que o usuário seja incentivado a escolher caminhos ou interagir com o ambiente virtual, ele sempre passará por pontos chaves da narrativa, pré-determinados pelo diretor e limitados pela plataforma.

\section{Uma análise de Prison Valley}

Prison Valley é um webdocumentário francês que apresenta a história de Canon City, em Colorado, nos Estados Unidos, região onde estão localizadas 13 prisões. O trabalho foi dirigido pelos jornalistas David Dufresne e Philippe Brault, produzido pela empresa francesa Upian e distribuído pela Arte.tv em 2010. Os realizadores dirigem o usuário por uma viagem pela indústria das prisões, visitando as cidades que as abrigam, as pessoas que moram lá, mostrando as instalações dos presídios, conversando com presidiários, policiais, parentes de presos e a população local.

Ao acessar a plataforma de Prison Valley, nos deparamos com um filme de abertura. Logo após o capítulo inicial acabar, o usuário é convidado a se cadastrar na plataforma, para poder seguir adiante. Esse cadastro pode ser feito pela criação de um login ou pela conta do Facebook (figura 1). 

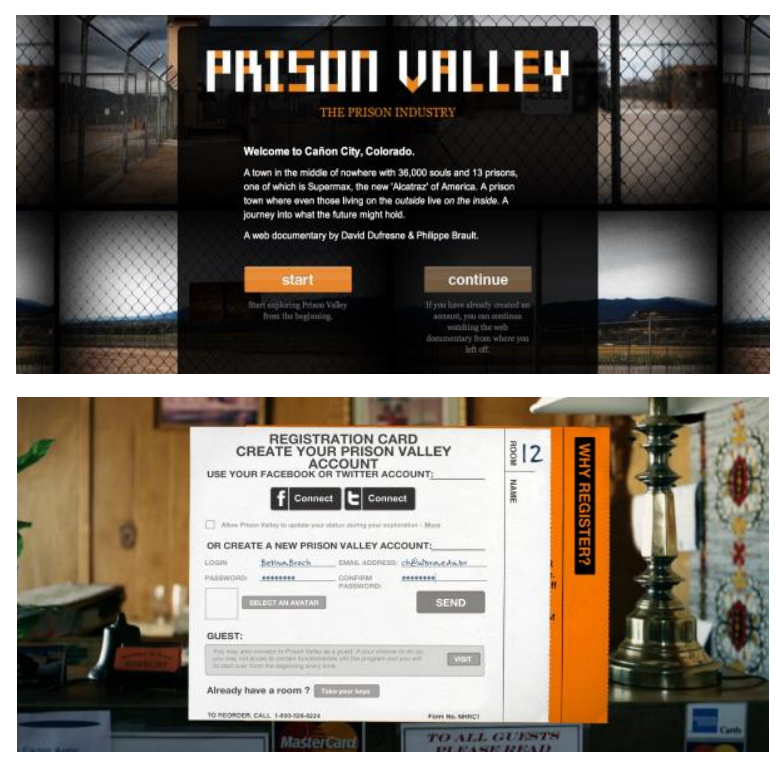

Figura 1: Área para cadastro na plataforma (Impressão de tela Prison Valley)

A narrativa é apresentada em forma de capítulos, e a cada capítulo o usuário conhece novos personagens e um novo ambiente. Prison Valley pode ser caracterizado como um filme on the road, pois os capítulos são sempre ligados por trechos na estrada, ou seja, sempre que uma etapa do filme acaba, ele volta para a estrada, onde há uma sucessão de imagens que ajudam a completar o entendimento (figura 2) e levam o usuário até o próximo ponto. Assim, os produtores acharam um meio de costurar a narrativa principal. Conforme Nash, que menciona Prison Valley em seu estudo sobre o webdocumentário, durante esse trajeto em que é narrada a história principal, são fornecidas algumas informações:

É interessante notar que alguns webdocs (Prison Valley, por exemplo) mantêm uma sequência de abertura muito cinematográfica para cumprir esta função. A ordenação temporal de elementos no cinema e de documentários televisivos faz conexões e investe em eventos com significado dramático. Embora a estrutura do cinema e do documentário televisivo seja determinada antes da recepção, no caso do webdoc o utilizador desempenha um papel no arranjo dos elementos do documentais. (Nash, 2012: 203). 

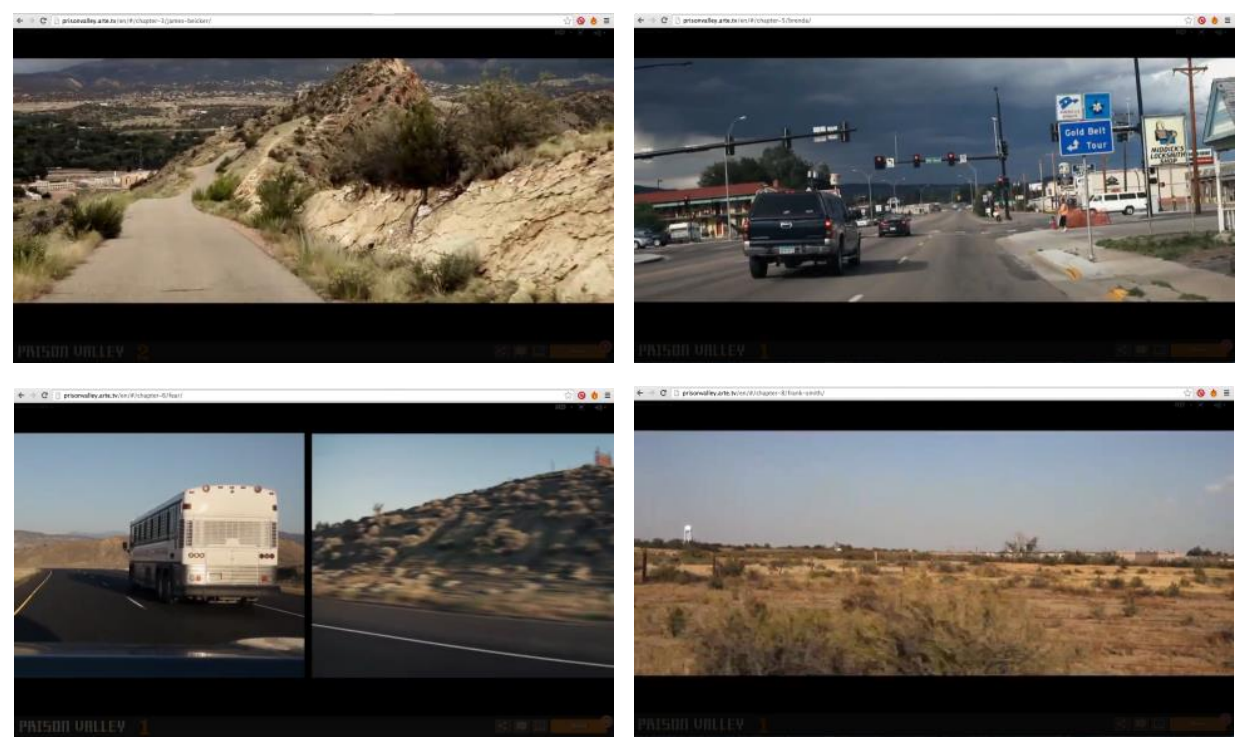

Figura 2: Cenas da estrada que ligam capítulos (Impressão de tela Prison Valley)

Jost comenta que, ao olhar de um telespectador, nada diferencia um webdocumentário de um documentário clássico, mas se o telespectador virar um usuário, a experiência muda: “(...) se entro no jogo, ele me permite escapar da estrada principal e saber um pouco mais sobre tal ou tal aspecto e de construir meu próprio itinerário em função de meus interesses pessoais." (Jost, 2011: 99).

Durante cada capítulo, são oferecidos ao usuário alguns bônus (que aparecem em forma de número no canto inferior direito da tela) e mais informações sobre determinado personagem ou local, e o usuário pode escolher entre receber aquele conteúdo extra ou não (figura 3). 


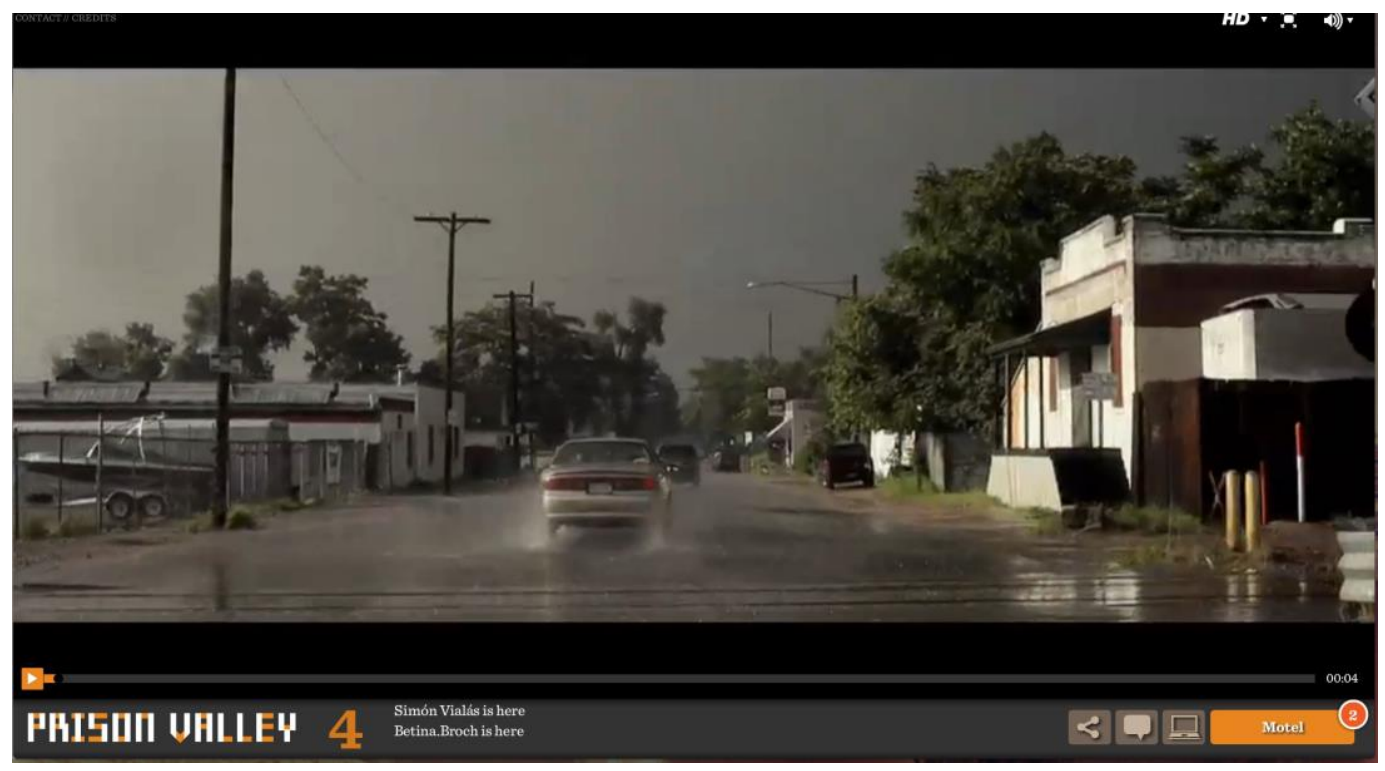

Figura 3: Opções de bônus na aba do Motel (Impressão de tela Prison Valley)

Ao final de cada capítulo também são oferecidas informações extras de forma interativa, por meio de gráficos, imagens, links, textos, estatísticas, entre outros. Um exemplo deste conteúdo são os slideshow fotográficos oferecidos aos usuários ao final de algumas etapas da narrativa principal (figura 4). 

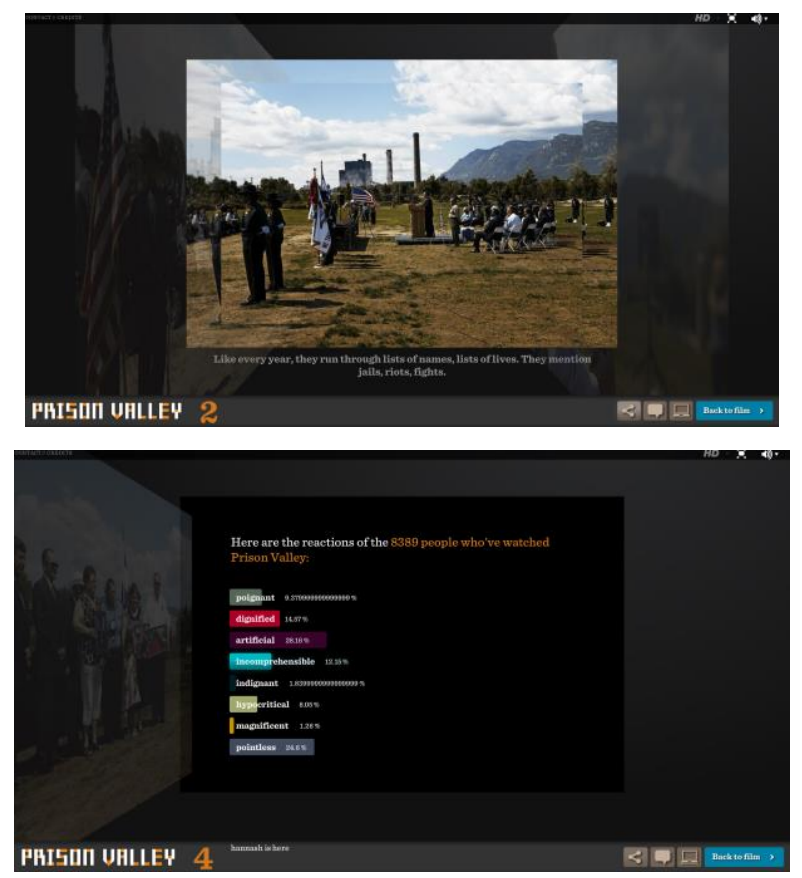

Figura 4: Material extra e enquete. (Impressão de tela Prison Valley)

O usuário tem a opção de conferir as fotos ou não. O slideshow traz uma micronarrativa sobre algum assunto mencionado previamente, como algum evento que tenha acontecido na cidade visitada, a história mais aprofundada de algum personagem, etc. Esses slides apresentam sempre imagens estáticas e em cada foto há legendas descritivas. Ao final do slideshow, o usuário deve responder uma enquete, clicando sobre a palavra que mais descreve o seu sentimento após conferir as fotos. Depois de escolher uma das opções, é exibido um gráfico com as porcentagens das palavras votadas por outros usuários.

Os produtores do webdoc tomaram cuidado na hora de oferecer recursos interativos, mesclando vídeo, imagem estática, texto e gráficos, dessa forma nunca esgotando um único recurso. Esse cuidado torna o produto mais leve e de fácil recepção por parte do usuário, evitando que a cada novo conteúdo extra o usuário tivesse que assistir a mais um vídeo (o que poderia cansá-lo, causando a perda do valor de imersão da experiência interativa. 
Prison Valley pode ser enquadrado dentro das categorias definidas por Nash (2012) como narrativo, pois existe uma narrativa principal que guia a história e apresenta micronarrativas que a complementam. Apesar de o usuário poder colaborar no webdoc comentando em fóruns, Nash explica que a categoria de colaborativo se aplica a webdocs que dependem que o usuário interaja para que a obra "funcione". Desta forma, Prison Valley não se enquadraria na categoria colaborativa de Nash (2012), já que a colaboração proposta é voluntária e não obrigatória.

Nash (2012) destaca que Prison Valley incorpora diversos recursos interativos para comunidades de interesse. Nesses recursos o usuário é convidado a "reagir", como num videogame, em que o usuário é inserido em um desafio ou nova etapa, e para desbloquear o segundo capítulo é necessário vencer o primeiro. Esse modo de interatividade proposto é o hipermídia, como descreve Gaudenzi (2012), pois a todo momento o usuário é convidado a escolher caminhos, decidir o que assistir ou o que acessar, criando sua própria "versão" do webdoc.

A plataforma permite ao usuário transitar entre o filme e o "Motel" (figura 4), um ambiente virtual onde se encontram os bônus e oportunidades de interação com personagens já apresentados. O modo experimental de interatividade descrito por Gaudenzi (2012) pode ser verificado nessa parte do webdoc, já que o usuário é inserido no ambiente virtual em primeira pessoa. Ele pode transitar e interagir com o quarto de motel, como se estivesse de pé naquele espaço. Este motel é o lugar onde os produtores se hospedaram durante o período de realização das gravações para o documentário, e ali tiveram a ideia de fotografar o quarto para fazer a animação que compõe o bônus, além de gravar os sons ambientes. 


\section{Betina Broch}
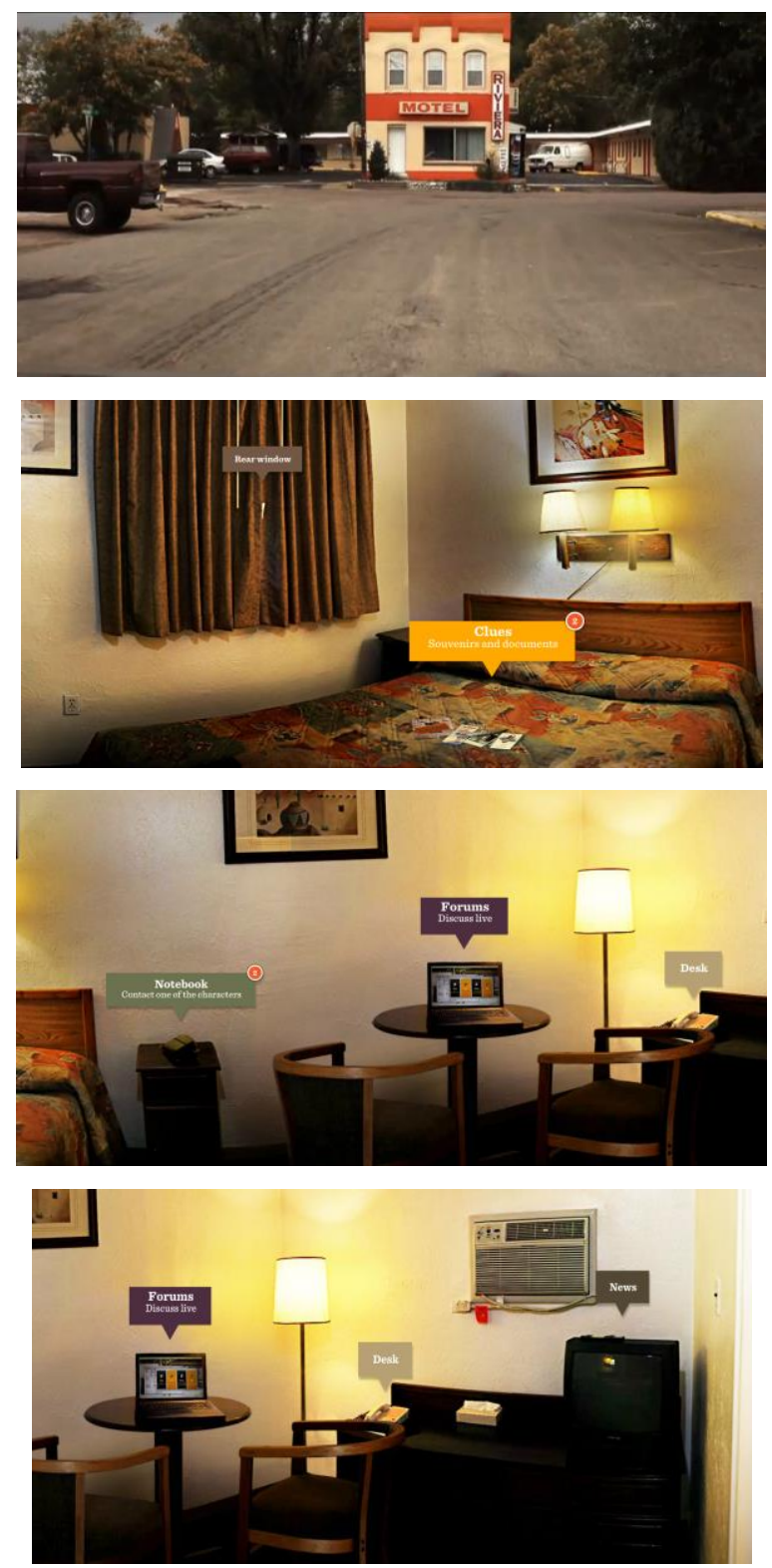

Figura 4: Ambiente animado Motel (Impressão de tela Prison Valley)

O usuário desfruta do prazer de comandar as ações nesse ambiente, além de desvendar e descobrir novas informações armazenadas por ele, como se estivesse em um jogo de videogame, procurando por pistas e objetos que revertam-se em pontos. Jost (2011), ao se referir a Prison Valley, afirma que para prender um telespectador em um conteúdo informativo, é necessário permitir que ele brinque: 
Porque escolher voltar ao motel clicando sobre um botão na base da tela é primeiro retornar ao prazer de tocar em seu teclado e comandar (os botões são os comandos). Então, o webdocumentário: prazer de ver, de aprender ou prazer de jogar? O quarto do motel de onde partem os percursos e todas as excursões se apresenta bem como um videogame onde a gente entra na história por cliques sucessivos. (Jost, 2011: 99).

Dentro desse ambiente virtual, o usuário pode acessar as pistas. Novos recortes de jornal, fotos e informações extras sobre os locais já visitados aparecem à medida que são citados no filme. Há também o Notebook, a agenda dos jornalistas onde estão os contatos de todos personagens que já apareceram no filme, entrevistas especiais e curiosidades. É possível acessar o computador presente no quarto, onde o usuário pode interagir em fóruns sobre alguns tópicos abordados durante o filme, além de abrir novos fóruns para debate com outros usuários. Nessa parte do jogo, apresenta-se a interatividade participativa proposta por Gaudenzi (2012), onde o usuário produz conteúdo para a obra. Dentro da plataforma em que se desenvolve Prison Valley, o usuário é livre para abrir novos fóruns, propor novas discussões, fazer perguntas aos criadores do documentário e aos demais usuários e criar debates que acrescentem no entendimento da obra. Quando novos usuários acessarem essa etapa do webdoc, o material produzido pelos antigos usuários vai ser uma parte da própria obra. Por fim, o usuário pode atender ligações no telefone, as quais sugerem visitar algum lugar e conferir a programação da televisão. 


\section{Betina Broch}
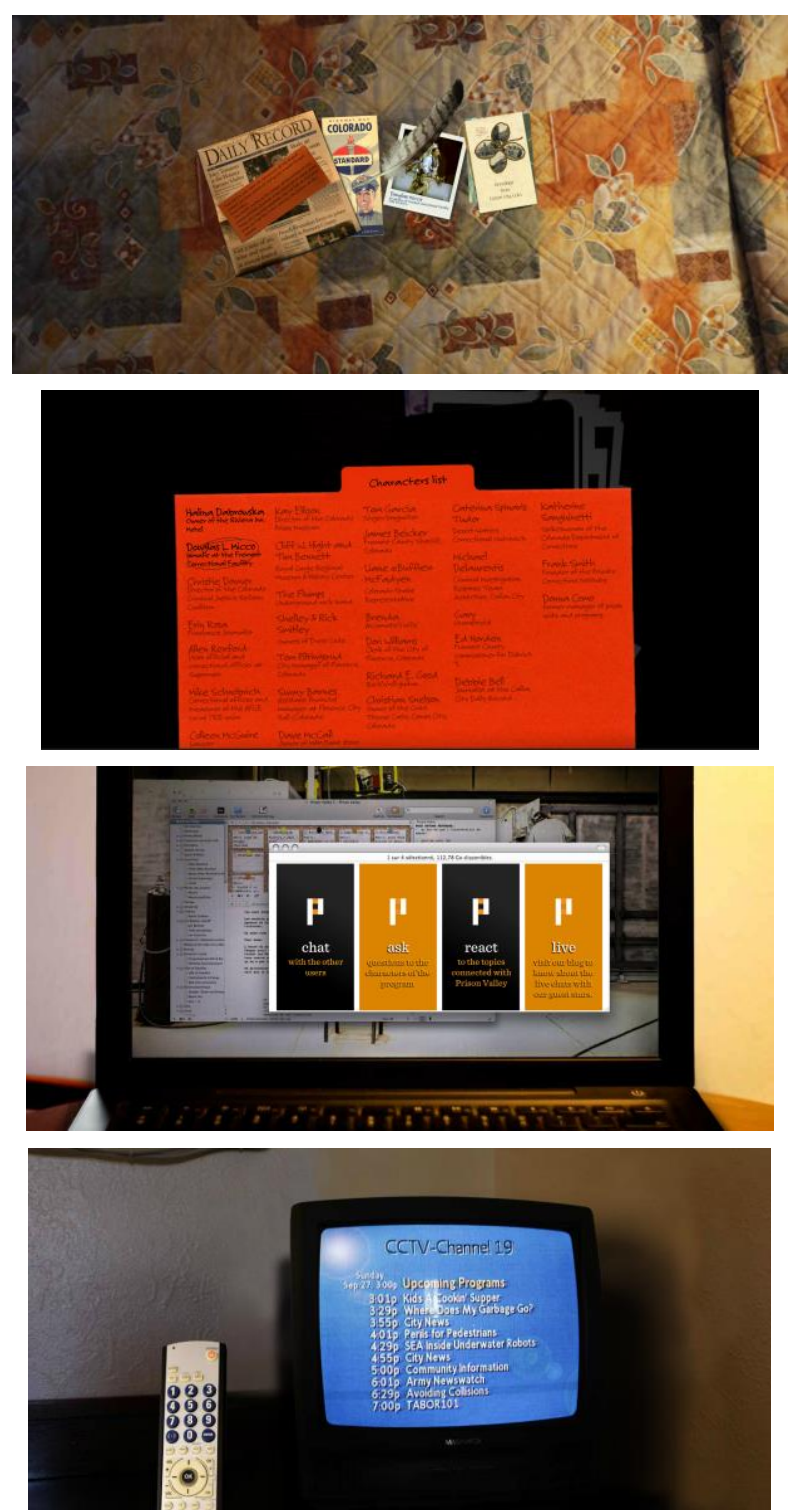

Figura 5: Interações no Motel (Impressão de tela Prison Valley)

Prison Valley também apresenta o modo de interatividade conversacional, proposto por Gaudenzi (2012). O usuário conversa com a obra, ele acessa o ambiente virtual e um leque de opções é oferecido, como entrevistas para acessar. Quando o usuário clica em um comando, a plataforma responde aquele comando, o qual é pré-programado, caracterizando assim uma conversa. 
Há três botões na barra inferior de menu da plataforma do Prison Valley. O botão caracterizado por um computador leva o usuário a um menu com quatro opções: Temas, Discussões, Personagens e Busca. O primeiro deles, Temas, abre um painel com diversos assuntos abordados durante a narrativa, e cada um leva o usuário a um leque de discussões. Dentro dessas discussões o usuário é convidado a reagir, deixando sua opinião, e ainda a apontar suas dúvidas, muitas vezes respondidas por outros usuário, ou mesmo pelo produtor David Dufresne (figura 6).

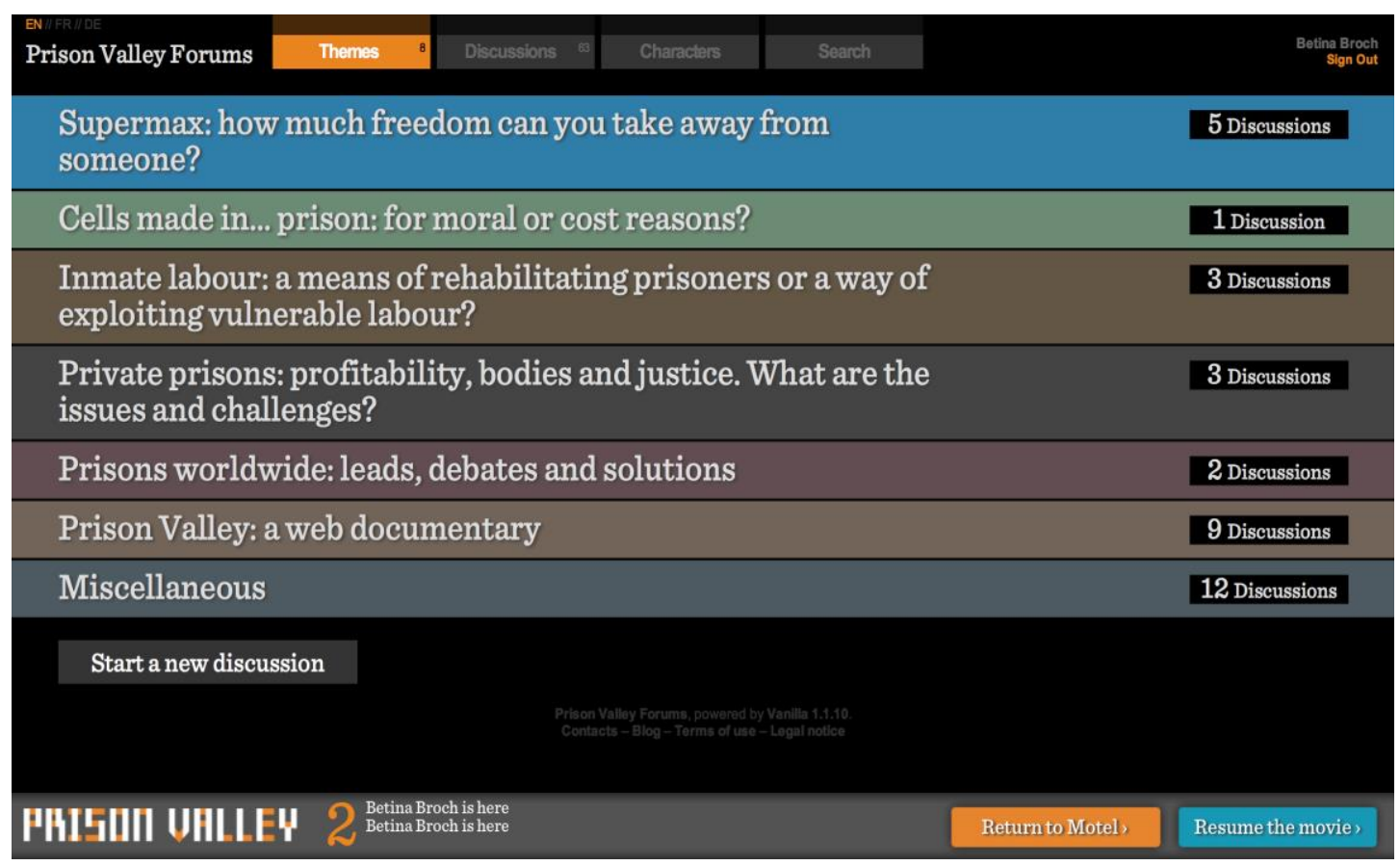

Figura 6: Temas e Discussões na plataforma. (Impressão de tela Prison Valley)

Se o usuário acessar a opção de Personagens, uma janela com os personagens da obra irá aparecer. Sempre que acessado um dos perfis, o usuário é levado a um texto sobre o personagem, o qual explica seu engajamento na história, além de apontar links relativos ao seu trabalho ou vida pessoal, (figura 7). Ainda dentro de cada perfil, os usuários têm a possibilidade que deixar mensagens para os personagens. 
$\checkmark$

Christie Donner, Criminal Justice Reform Coalition

6 Comments

Christie Donner, director of the Colorado Criminal Justice Reform Coalition

Denver (Colorado) - She arranged to meet us at the HQ of her charity. An unholy mess of an office with letters, brochures, statistics and documents everywhere. The building she works in is one of the few social centers of this size in the US. Food bank, legal aid, all kinds of other assistance; this place, the Denver Inner City Parish, gives a face to the misery size of a gym. Christie Donner kept laughing. And her face told the rest of the story, all the years spent fighting against what slavery in this country. We have a long legacy of making a profit out of people in chains."

Links

- Website: Colorado Criminal Justice Reform Coalition

- Blog: thinkoutsidethecage2.blogspot.com

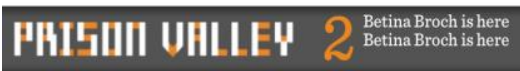
that exists just a few blocks from the center of Denver. It was late in the day. We did the interview in the blue room, one the she calls "mass imprisonment". This is what she had to say about the prison valley: "There's a reason why our prisons are so far away: 'out of sight, out of mind'. It hearkens back to this notion of banishment in other times. It hearkens back to

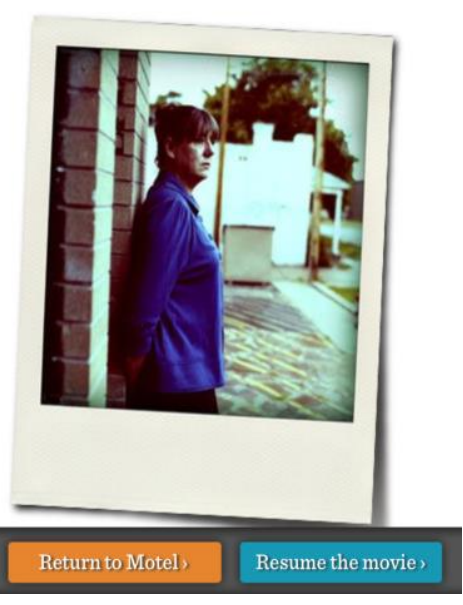

Figura 7: Perfil de personagens. (Impressão de tela Prison Valley)

A plataforma ainda conta com um chat entre todos os usuários online. Sempre que um usuário acessa a plataforma, um aviso aparece para todos que estão nela, informando que uma nova pessoa entrou no site. $\mathrm{O}$ chat fica aberto durante todo o tempo em que o usuário estiver na plataforma, qualquer pessoa online pode conversar por esse dispositivo, tirando dúvidas, fazendo questionamentos ou simplesmente conhecendo os outros usuários. Entre as opções de interação disponíveis na plataforma, está a possibilidade de o usuário compartilhar, em sua conta pessoal do Facebook, que está assistindo ao webdoc. Outro recurso utilizado pelos criadores é o de mandar e-mails para os usuários afastados, os quais ainda não passaram por todas as partes da obra, convidando-os para continuarem assistindo, mantendo desta forma uma relação com as pessoas cadastradas.

Esses recursos alteram a percepção do webdoc de usuário para usuário, já que, ao assistir Prison Valley, ele não estará somente fazendo 
uma troca com a obra, mas sim, com outros usuários online, além da troca com os usuários mais antigos, os quais irão influenciar na percepção da obra do novo visitante, uma vez que suas próprias impressões já estarão gravadas na obra.

\section{Considerações finais}

Mesmo com todo conteúdo extra oferecido durante Prison Valley, o usuário é obrigado a passar por todas as etapas da narrativa principal para chegar ao fim da obra, incentivando assim que ele consuma toda a narrativa principal e abrindo oportunidades para que se engaje mais no universo retratado. Prison Valley conta com um documentário televisivo linear com cerca de 59 minutos de duração, exibido em sessões "convencionais" em festivais de cinema. A narrativa principal é apresentada nos dois modelos, porém os extras oferecidos durante o webdocumentário proporcionam ao usuário criar diversos roteiros diferente com as micronarrativas, dependendo das suas escolhas durante o caminho. Mesmo que ele sempre tenha que voltar para a estrada para avançar na narrativa principal, essa mesma estrada é utilizada para guiar o telespectador no documentário televisivo, explicando para qual lugar ele está sendo levado.

Sabendo que a principal característica do webdocumentário é a interatividade, nota-se que oss recursos oferecido em Prison Valley complementam a obra e abrem a oportunidade para os usuários mais interessados conhecerem melhor o universo apresentado na narrativa principal, explorarem personagens e lugares. Em sua plataforma, o webdoc apresentado tem o cuidado de nunca desviar o usuário da linha de raciocínio. Ele terá a possibilidade que consumir uma informação extra, mas sempre será jogado de volta à linha narrativa principal. Estas informações podem ser descartadas sem interferir na obra, caso o usuário não tenha interesse em consumi-las. 
Toda a plataforma onde o Prison Valley é hospedado é cuidadosamente animada e programada para uma fácil navegação, cercando o usuário para que ele não se perca dentro dela, e sim consuma o conteúdo oferecido. Mesmo que as micronarrativas quebrem a linearidade da obra, toda a utilização é pré-programada, sempre dando três opções para o usuário: continuar assistindo o filme (narrativa principal), consumir a micronarrativa ou voltar ao Motel e conferir os novos Bônus debloqueados. A plataforma também leva o usuário ao grau quatro de interatividade, no qual ele pode produzir conteúdo para a obra. Assim, o usuário irá consumir o conteúdo da narrativa principal e micronarrativas de forma cronológica (determinada pelos produtores).

Outra característica a ser ressaltada é que Prison Valley pode ser acessado a qualquer momento, quantas vezes o usuário quiser. Sempre que ele voltar a plataforma, será direcionado ao local que visitou por último. Mesmo que o usuário já tenha explorado toda a plataforma, se ele voltar depois de alguns meses, irá encontrar novas informações e poderá se relacionar com o webdocumentário de uma forma diferente da primeira vez, deixando de consumir algumas micronarrativas ou consumindo algumas que tinha deixado de lado em sua experiência anterior. Usuários que criam fóruns de discussões ou respondem a fóruns podem sempre retornar à plataforma para ver os novos comentários e pontos de vista adicionados por visitantes mais recente. Desta forma, podemos concluir que um documentário interativo não pode ser tratado como um objeto finalizado ou uma obra fixa a ser exibida, pois ele está em transformação permanente (Salles 2014), devido aos usuários que já contribuíram para com a obra e interferiram no seu conteúdo, podendo também ser caracterizada como uma obra em constante construção. 


\section{Referências bibliográficas}

ASTON, Judith e GAUDENZI, Sandra (2012), “Interactive documentary: setting the field". Disponível em: http://www.tandfonline.com/doi/pdf/10.1386/sdf.6.2.125_1.

JOST, François (2011), "Novos comportamentos para antigas mídias ou antigos comportamentos para novas mídias?" in Revista Matrizes, São Paulo, ano 4, jan-jun, n. 2. Disponível em: http://www.matrizes.usp.br/index.php/matrizes/article/view/68.

NASH, Kate. "Modes of interactivity: analysing the webdoc" in Media, Culture \& Societ, v. 34, n. 2. Sage Journals, pp. 195 -210. 2012. Disponível em: http://mcs.sagepub.com/content/34/2/195.full.pdf.

SALLES, Julia (2014), “Agenciamento e indeterminação: conceitos para um estudo do documentário interactivo". Disponível em: http://www.socine.org.br/rebeca/pdf/DOSSIE_3_Julia\%20Salles_fin al.pdf. 


\title{
MALVINAS: UN ACERCAMIENTO A LAS IMAGÉNES GENERADAS POR COMPUTADORA Y LAS NARRATIVAS TRANSMEDIA
}

\author{
Pablo Francisco Gullino*
}

\section{Introducción}

Desde los primeros años del siglo XXI la consolidación de los medios de comunicación electrónicos produjo un descentramiento con respecto a la primacía de la cultura escrita como factor de transmisión y conservación de la memoria, cobrando fuerte impulso la reflexión y consideración de otras modalidades de construcción. La utilización de diferentes lenguajes y medios potencian las formas de comunicación que promueven cambios cualitativos que complejizan los fenómenos comunicativos en su conjunto. Dentro de este proceso la digitalización de los medios y sistemas de comunicación junto con el desarrollo de las telecomunicaciones introduce un nuevo horizonte sobre el que se proyectan las prácticas comunicativas contemporáneas. En esta coyuntura las técnicas de animación y los cruces transmediáticos (Internet, videojuegos) renacen, tanto en el cine como en la televisión donde las reconstrucciones de ciudades de civilizaciones del pasado, animaciones que recrean batallas históricas o el mundo de los dinosaurios colman de imágenes las pantallas. Los documentales pedagógicos y científicos impulsan esta tendencia (Aprea, 2010). Simultáneamente algunos documentales buscan el

\footnotetext{
* Magister en Diseño Comunicacional - Universidad de Buenos Aires. Licenciado en Comunicación - Universidad Nacional de General Sarmiento. 1665, José C. Paz, Argentina. E-mail: pablogullino@gmail.com
} 
intercambio con las audiencias más allá del momento de la transmisión televisiva al generar otros productos relacionados, en los sitios webs del canal con material exclusivo (videojuegos, textos, audios, etc). Para pensar estos productos nos parece pertinente el concepto de "Post producción" de Nicolás Bourriaud. El término pertenece al mundo de la televisión, el cine y el video; y "designa el conjunto de procesos efectuados sobre un material grabado: el montaje, la inclusión de otras fuentes visuales o sonoras, el subtitulado, las voces en off, los efectos especiales" (Bourriaud, 2009: p. 11). La intervención humana se hace evidente en alteraciones, en la yuxtaposición y combinación de diferentes tipos de imágenes: dibujos realizados a mano inanimados, imágenes generadas por computadora, dramatizaciones, etcétera. En la actualidad, se cuenta con una gran cantidad de técnicas, de efectos de 'iluminación y texturas de superficie. En los programas utilizados en arquitectura es muy común este tipo de tecnología para el procesamiento de la información y su interpretación. Por su parte, los avances en la informática y en la representación de imágenes a partir de simuladores de vuelo han sido utilizados para capacitar a pilotos civiles y militares. Pero también ha tenido un desarrollo comercial en la industria de los videojuegos. Entre estos podemos nombrar al IL-2 Sturmovik, 2001 de Maddox Games, Rise of Flight: The First Great Air War, 2009 de Microsoft, o el clásico Flight Simulator, de Microsoft. Este último fue creado en 1979 y ha sido utilizado incluso con fines profesionales y militares en la capacitación temprana de aspirantes a pilotos. Casi todos los simuladores de vuelo de ámbito militar están ambientados en conflictos aéreos históricos, con aviones realmente existentes. También existen los programas basados en aviones o helicópteros que, aunque reales, pueden ser pilotados en conflictos ficticios (por ejemplo: Falcon 4.0 o Lock On: Modern Air Combat). Además, la afición a los simuladores de vuelo ha hecho que muchos usuarios lleguen a ser diseñadores de aeronaves para estos sistemas. Estas modificaciones del simulador (mods) añaden gran 
valor a la simulación y permiten expandir significativamente la experiencia del vuelo con nuevas situaciones y contenidos. Un caso que podemos citar es el del popular juego Counter Strike tiene un desarrollo sobre Malvinas. En ocasión del $30^{\circ}$ aniversario de la Guerra de Malvinas, la empresa argentina Dattatec creó un espacio en su sitio web en donde los internautas podían dejar mensajes a los soldados que murieron en combate y descargar este desarrollo para el Counter Strike que permite jugar a recuperar las islas, pero en el año 2013. "El CEO de la empresa, Guillermo Tornatore, luego viajó a las Islas y enterró en un pendrive todos esos comentarios en el cementerio Darwin". ${ }^{1}$ Otro ejemplo es el MAJR (Malvinas Argentinas Juego de Recuperación) que desarrolladores argentinos difunden por internet de manera gratuita para usar en PC.

En este sentido, una línea interesante de investigación surge para nosotros a partir de preguntarnos cómo funciona la televisión en relación a proyectos de internet y a las propuestas participativas que el mismo programa genera. Frente a otros momentos históricos nuestra sociedad redefine polémicamente el campo de lo recordable: cambian las perspectivas de selección y conservación y, a su vez, éstas transforman a los objetos convocados. La sociedad modifica sus pedidos al pasado y se redefinen los criterios de validación y jerarquización que definen a lo recordable. Así es que nos encontramos frente a un intento transmediático (que se vehiculiza a través de la televisión, de Internet, de un videojuego y un libro) de proponer una relectura de la Guerra. En este sentido, retomamos el concepto de narrativa transmedia de Carlos Scolari como aquel "tipo de relato en el que la historia se despliega a través de múltiples medios y plataformas de comunicación y en el cual una parte de los consumidores asume un rol activo en ese proceso de expansión" (Scolari, 2013a: 52).

\footnotetext{
1 "Un nuevo mapa del juego Counter Strike permite recuperar las Islas Malvinas" Disponible en: http://www.infobae.com/2013/03/26/702792-un-nuevo-mapa-del-juegocounter-strike-permite-recuperar-las-islas-malvinas
} 


\section{Jet Thunder llega a la televisión}

Jet Thunder: Falklands/Malvinas es un proyecto de videojuego desarrollado por un grupo de entusiastas de la aviación militar. El juego ofrece al jugador la experiencia de participar en la Guerra de Malvinas a partir de un combate aéreo. Los desarrolladores manejaron diferentes fechas estimadas de lanzamiento que, muy a su pesar, nunca lograron concretarse. Como antecedente de este conflicto en particular sólo se cuenta con dos juegos que contaron con apoyo de empresas para llevar a cabo el proyecto y enfocados en los combates aéreos. El primero en ver la luz tempranamente fue Harrier Attack, en 1983 por Durell Software para computadoras Commodore 64. El segundo lanzamiento comercial del juego Dogfight 80 Years Of Aerial Warfare de la empresa MicroProse en 1993.

Jet Thunder es un simulador de vuelo y la guerra de Malvinas ofrece un marco especial. Fue el primer conflicto "moderno", esto es, con la utilización de sistemas de armas avanzados por ambas partes: aeronaves Super Etendard equipadas con misiles Exocet por la Argentina; aviones de despegue y aterrizaje vertical Sea Harrier de Gran Bretaña, entre otros. Se podrá optar por ser parte de alguno de los dos ejércitos enfrentados. Del lado de la Armada Argentina y la Fuerza Aérea Argentina, los aviones disponibles son el Dassault Mirage III, A-4 Skyhawk y para los británicos el jugador puede optar entre pilotear un Harrier o un Aero Vulcan. Debido a que estuvo siendo desarrollado de forma independiente por Thunder Works Studios, sin la participación y apoyo de los productores internacionales, no hubo una fecha precisa para el lanzamiento. Las novedades sobre el desarrollo del producto están en el sitio oficial y en su fanpage de Facebook ${ }^{2}$ Juan Turturro es uno de los integrantes de este proyecto. Al mismo tiempo,

\footnotetext{
${ }^{2}$ Estos son los sitios donde el director César Turturro junto a otros realizadores intentan darle vida al juego sobre Malvinas http://www.thunder-works.com/spanish/noticias.htm https://www.facebook.com/JetThunder?fref=nf
} 
forma parte del estudio Creavisión. A partir de allí el joven creativo utilizó las imágenes generadas para el simulador de vuelo del videojuego en el film 1982; Estuvimos ahí del año 2004 y luego en 1982. La guerra desde el aire. A estas dos obras nos referiremos brevemente a continuación.

\section{Estuvimos ahí - La ficción realista}

El afiche promocional y el tráiler difundido por internet tiene como eslogan la siguiente frase: “Ayer hubo una guerra. Hoy hay héroes”. Es decir, ya desde uno de sus elementos paratextuales más importantes sabemos que el foco de la narración no estará en la guerra en sí como un suceso histórico cerrado, sino como una temática actual centrada en las acciones de dichos héroes. Es un film de bajo presupuesto y de difusión solo por la web o en eventos pequeños en escuelas y salas de cine de la ciudad de Bahía Blanca que relata la historia de dos grupos de militares. Por un lado esta Carlos, un soldado del ejército argentino con 19 años y pocos meses de instrucción militar que aguarda junto a José y Pedro en su trinchera la llegada del enemigo. Por otro lado, un grupo de seis pilotos deben ejecutar una de las misiones más importantes de la aviación argentina; la Operación Invencible. Es decir, atacar y hundir el portaaviones "Invincible", una de las naves más protegidas por las fuerzas armadas británicas. Jean-Marie Schaeffer dice que "un modelo ficcional siempre es de facto una modelización del universo real" (Schaeffer, 2002: 112). Y esta condición se presenta en el film de Turturro al enlazar el destino de sus personajes de ficción al de una misión militar y un enfrentamiento entre las fuerzas terrestres en particular que acontecieron en el mundo histórico.

En los títulos de inicio, el film nos ubica el contexto en el que se da la batalla a partir del 2 de abril de 1982. La iniciativa militar argentina es descripta como un "restablecimiento de la soberanía" después de un periodo de 150 años de “usurpación británica". Entonces, al mismo tiempo que el 
director deja explicita su posición sobre la soberanía argentina en el archipiélago evita analizar las complejas y particulares condiciones políticas que llevaron a la guerra a ambas naciones y sus consecuencias. Decide centrarse en la narración de las acciones militares de los argentinos que efectivamente combatieron y su resistencia frente al invasor europeo. Toda la acción del film va orientada a la aparición de las escenas con imágenes generadas por computadora (CGI). ${ }^{3}$ No son otros que los modelados de las aeronaves pensados en principio para el videojuego Jet Thunder. Vemos desde el comienzo los preparativos de los pilotos y la espera de los soldados en la trinchera a la llegada del invasor. Cuando las escenas de lucha tienen lugar, son las CGI las que dan sentido a la historia de heroísmo en combate. Las escenas de acción hacen uso en muchos casos del sonido de tipo acusmático (Bordwell et al., 1995), crean en efecto un misterio sobre el aspecto de su fuente. También hay en los films de acción, no sólo dentro de los bélicos que ciertos personajes con aura maléfica, importante o impresionante, sean introducidos por el sonido antes de aparecer en cuadro. Esto es lo que podemos observar con los ingleses. Los invasores trastornan la calma aparente de la noche en Monte Longdon y luego lo vuelven a hacer sobre el final del film, cuando un francotirador asesina a Pedro.

Por momentos, son evidentes sus intenciones de alejarse de discursos audiovisuales previos. El grupo de Carlos refugiado en la trinchera a la espera de la llegada de los ingleses, que ya han desembarcado decide tomarse una fotografía. Esta toma de un documento visual adquiere colores sepia, a diferencia del resto de la escena que es a color. La ficción es la imagen en movimiento; la vida de los soldados en las islas, las acciones que los convierten en héroes nacionales. El tono de las imágenes durante la mayor parte del film posee cierto difuminado, otorga una especie de marco

\footnotetext{
${ }^{3}$ Utilizamos este término entre varios posibles, por ejemplo, 3D Computer Animation o Image Synthesis and Computer Animation. El término elegido refiere específicamente al uso del ordenador y al uso de software específico para la creación e imágenes.
} 
de ensoñación. La utilización de actores no profesionales y los tonos saturados con los que el director elije trabajar las escenas de la vida en los pozos de zorro nos recuerdan a los rasgos y el estilo de las secuencias de los documentales televisivos, aquellos registros ficticios (imágenes no documentales) pero imprescindibles para contar la historia. Las escenas previas al enfrentamiento, en las trincheras, son de un ritmo digno de lo real, ya que transmiten a partir de recursos como la monotonía y los silencios.

Sobre las características de los personajes, nos parece importante rescatar los aportes de la historiadora norteamericana Jeanine Basinger (citada en Revuelta Rojo, 2008: 30) sobre los films de guerra donde se suele presentar el siguiente esquema de personajes característicos:

a) El Héroe: todo filme bélico cuenta con uno o varios personajes que destacan del resto por su heroísmo. Suele encarnarse en un oficial competente y heroico. Muchas veces es un militar de carrera que guía al grupo de conscriptos en el campo de batalla. Para este film, el héroe está en la piel del piloto sobreviviente del ataque

b) Grupo de soldados de distinta procedencia: Los soldados pertenecen también a distintos grupos socioeconómicos y etnias. Por ejemplo, el estudiante universitario (el soldado Webster de Hermanos de Sangre (Spielberg, 2001) un granjero, un afroamericano, etc. Esto encontramos en 1982: Estuvimos Ahí. Los diálogos en las trincheras son de soberanía del territorio, de orígenes arraigados con fuerza ("Mis abuelos eran aborígenes. También tuvieron que pelear para defender su tierra. Como nosotros, ahora."). También se le otorga un importante rol a la religión y a la simbología cristiana. En una escena muy emotiva uno de los soldados le regala al momento de morir a su compañero un rosario. $\mathrm{Y}$ le dice: "La fe me ayuda mucho. Tenés que rezar. Aunque no creas mucho o te parezca una boludez". Ese objeto, el rosario, está al comienzo del film cuando el soldado en tiempo presente recuerda los sucesos de la guerra y vuelve a aparecer al final. Con el soldado que recuerda de regreso a las Islas. En el Cementerio 
de Darwin lo vemos dejar sobre una de las tumbas el rosario. En este sentido, Jean- Marie Schaeffer (2002) afirma que la identificación del estatus (ficción versus documental) de una película casi nunca plantea problemas, debido a que la separación entre el nivel de la inmersión y el de las creencias es fundamental. Sin embargo, los casos mixtos son preponderantes. Esta película maneja estos dos niveles y a partir de ello genera un tipo de relato complejo con una retórica de simulación documental. Un movimiento pendular constante entre personajes ficcionales envueltos en fechas y ubicaciones históricas.

1982: Estuvimos ahí también recupera algo de ese Hollywood que construye épicas sobre reveses militares. A partir de la derrota en la guerra, se cuenta una historia de valor y coraje comienza con una placa en fondo negro y letras blancas que nos advierte sobre la ficcionalidad de los hechos y personajes presentados a continuación. Pero, al mismo tiempo, a continuación de esa información inicial le siguen unas placas informativas sobre la Guerra de Malvinas que hacen referencias a lugares, nombres propios (personas, barcos, aviones) existentes. Sobre el cierre de este texto introductorio, se nos notifica que la historia que se va a contar transcurre en Goose Green (Pradera del Ganso), el 27 de mayo de 1982. Es decir, una batalla real. Es aquí donde comienza la construcción del verosímil que propone el director. Al igual que otros films de tipo bélico televisivos y cinematográficos se introduce al espectador en la temática general mediante un cúmulo de índices didascálicos, según la clasificación canónica de Casetti y Di Chio (1991). ${ }^{4}$ A continuación, vemos a uno de nuestros personajes sentados en un café. Los subtítulos nos ubican de manera temporal y geográfica: "Bahía blanca, Argentina. Época actual”. Es este

\footnotetext{
4 "Estos códigos regulan la materia de la expresión que va a constituir, junto con la imagen gráfica en movimiento, el componente visual del cine: hablamos de indicios gráficos, es decir, de todos los géneros de escritura que están presentes en un film. Para poner un poco de orden, podemos subdividir los indicios gráficos en: didascálicos, subtítulos, títulos y textos". (Casetti, Di Chio, 1991: 96).
} 
personaje quien empieza a recordar la Guerra. Ahí es donde el espectador se da cuenta que está frente a un veterano de Malvinas. Mediante imágenes que actúan a manera de recuerdos, de rememoración del protagonista. Incluso con sus limitaciones, 1982: Estuvimos Ahí intenta construir credibilidad a partir de la utilización del idioma como índice de lo real; el personaje inglés solo habla su lengua nativa y el film hace uso de subtítulos para traducir sus escasísimas líneas. Otro momento que contribuye a la construcción de la estructura del film son las secuencias a color, similares a los rasgos y el estilo relacionados con la dramatización de los documentales.

\section{Malvinas, la guerra desde el aire - imágenes nunca vistas}

1982. Malvinas, la guerra desde el aire, de César Turturro, transmitido durante el año 2009 por la señal de televisión History Channel. Este documental propone trabajar sobre un aspecto supuestamente inédito en las narraciones audiovisuales sobre Malvinas: el papel exitoso que cumplió la Fuerza Aérea Argentina a lo largo del conflicto. El recurso visual fundamental para sus realizadores es la presentación de "imágenes únicas" generadas por computadora. Estas imágenes "realistas y exactas" 5 recrean los combates aéreos y el hundimiento de flotas británicas. En 1982GDA varias secuencias se repiten para explicar hechos diferentes. ${ }^{6} \mathrm{Al}$ correr el velo de la artificialidad de la construcción mediática, el director puede tomarse esta licencia y repetir una escena hasta, incluso, cuatro veces. El autor del documental exhibe con el registro de algunos testimonios los

\footnotetext{
${ }^{5}$ La gacetilla de prensa del documental promete: "Imágenes únicas que recrean los momentos históricos que hasta el día de hoy no han sido vistas por nadie más que los protagonistas de cada uno de los combates. A través de reconstrucciones en animaciones CGI, realistas y exactas, bajo el detallado relato de los propios pilotos, se desarrolla este programa de la última batalla de la guerra fría y el bautismo de fuego para la Fuerza Aérea Argentina." Disponible en: http://www.0291.com.ar/articulo/4783/URI

${ }^{6}$ El ataque al Sheffield y 1 Atlantic Conveyor tiene las mismas animaciones, pese a ser hechos de días diferentes.
} 
aviones reales, dando cuenta de la similitud entre el objeto real y la representación construida con un programa de diseño. ${ }^{7}$ Aquí se dan algunas críticas a mandos superiores sobre el armamento con el que se contaba. Los aviones de la Armada no estaban preparados para este tipo de operaciones. Ahora el héroe, en términos de Jeanine Basinger, está encarnado en la Fuerza Aérea Argentina. Por sus técnicos quienes trabajan contra reloj para poner a punto el material bélico. En este caso, no hay un relato sobre las condiciones climáticas adversas ni denuncias sobre el trato que recibían los conscriptos como sí sucede en otros relatos audiovisuales argentinos del periodo. Y este es un quiebre fundamental con los documentales argentinos que abordaban la Guerra de Malvinas hasta los comienzos del siglo XXI. Aquí el oponente es, claramente, el ejército británico. Pero también las limitaciones del material bélico, inferior al usado por los ingleses. De hecho, el relato gira alrededor de este concepto. Pese a la inferioridad numérica y tecnológica, la Fuerza Aérea logró resistir y atacar incluso hasta en momentos posteriores a la capitulación argentina.

Sobre los testimonios, es llamativa la nominación de los entrevistados. A diferencia de piezas documentales precedentes al periodo analizado, no se habla de ellos como veteranos de guerra o ex combatientes. Se los llama "pilotos". Son ellos mismos quienes describen detallada y minuciosamente los riesgos de volar a menos de diez metros del mar y a una velocidad de mil kilómetros por hora, los bombardeos, los enfrentamientos aire-aire y las dramáticas recargas de combustible en medio del océano. Este relato vivencial se articula a partir de la experiencia directa de sus protagonistas. Es esta intención del director está fuertemente marcada.

\footnotetext{
7 "Fue una vorágine porque empezamos a contactar a los pilotos, armar el guión, y trabajar las animaciones porque los tiempos de 3D son enormes, lo que se ve en diez segundos puede llevar un trabajo de dos meses, es un trabajo muy puntilloso, porque hay que generar todo: la luz, el agua, las condiciones climáticas. En enero ya estábamos grabando las notas en Buenos Aires con los pilotos, e hicimos filmaciones acá en Espora". Entrevista al director del documental, César Turturro.

Disponible en: http://www.ecodias.com.ar/art/1982-malvinas-la-guerra-desde-el-aire
} 
Todos los entrevistados son integrantes de la Fuerza Aérea que combatieron en 1982.

Al acotar el acontecimiento de la guerra a los combates librados por la Fuerza Aérea, parece acercarse a las costas de cierto planteo de la historia contrafactual. Sobre los últimos 5 minutos del documental, momento de conclusiones, uno de los entrevistados afirma que: "Si uno hace números, la guerra económica la ganó la Fuerza Aérea Argentina. Porque los A4 eran aviones viejos que nadie calculó que iban a dañar a una flota tan profesional y moderna". Al mismo tiempo, el relator asegura que: "El conflicto deja a los británicos con su flota desmantelada. Y no es posible proseguir con las batallas navales". Las dificultades de los pilotos en el uso de sus aviones en combate son detalladas por los testimonios de sus protagonistas. Sin embargo, no se explican las causas de las ausencias de asientos eyectores, combustible y otros elementos vitales para el combate aéreo y que perjudicaron - al punto de producir varias bajas- a los argentinos.

\section{A modo de cierre}

En los dos films analizados las CGI nos ubican frente a una base de la estructura del discurso y la estética diferente a la los años posteriores al final inmediato del conflicto. Las narraciones de Malvinas se anclan en el testimonio de batallas específicas y la experiencia de quienes efectivamente participaron de los combates. Las CGI ilustran las imágenes de estas escenas de acción bélica y en muchos casos son el argumento fundamental para promover su visualización, la posibilidad de ver imágenes "nuevas". La animación construye referentes visuales a hechos y personajes del pasado reciente, con una dimensión simbólica que el registro de base fotográfica no podría aportar. Las CGI se anotan en este juego desde la cultura visual mediática contemporánea para recuperar las posibilidades que ofrece la tecnología y la imaginación de los realizadores para producir piezas 
audiovisuales que implican nuevas formas de contar el pasado. A futuro, nos interesa explorar como es que se expanden estas narrativas audiovisuales de las que nos notifica Carlos Scolari (Scolari, 2013b), pero en relación a la historia y la memoria. En las distintas formas de dar sentido a la experiencia de lo vivido y de incorporar imágenes de combates aeronavales producto del desarrollo de las tecnologías informáticas.

\section{Referências bibliográficas}

APREA, Gustavo (2010), "La construcción del conocimiento en los documentales: entre la indicialidad y la digitalización” en Gabriel Yoel y Alejandra Figliola (Coord.) Bordes y texturas. Reflexiones sobre el número y la imagen, Buenos Aires: Imago Mundi., pp. 153162

APREA, Gustavo (comp.) (2012), Filmar la memoria. Los documentales audiovisuales y la re - construcción del pasado, Los Polvorines: Imago Mundi - UNGS.

BORDWELL, David; THOMPSON, Kristin (1995), El arte cinematográfico: una introducción. Barcelona: Paidós.

BOURRIAUD, Nicolas (2009), Postproducción: la cultura como escenario. Modos en que el arte reprograma el mundo contemporáneo. Buenos Aires: Adriana Hidalgo.

CASETTI, Francesco, DI CHIO, Federico (1991), Cómo analizar un film, Barcelona: Paidós.

FIGLIOLA Alejandra (2010), "Notas al pie para Image Future" en Gabriel Yoel y Alejandra Figliola (Coord) Bordes y texturas. Reflexiones sobre el número y la imagen, Buenos Aires: Imago Mundi., pp. $197-$ 202 
REVUELTA ROJO, Elisa (2008), "Evolución del cine de ficción sobre la

II Guerra Mundial: el caso del Desembarco de Normandía" en Revista de la SEECI, n. 16. Julio. Año XI.

Disponible en:

http://www.seeci.net/revista/index.php/seeci/article/view/175.

SCHAEFFER, Jean-Marie (2002), Por qué la ficción Madrid: Lengua de Trapo.

SCOLARI, Carlos (2013a), Narrativas transmedia: cuando todos los medios cuentan, Barcelona: Deusto.

SCOLARI, Carlos A. (ed.) (2013b), Homo Videoludens 2.0. De Pacman a la gamification, Barcelona: Universitat de Barcelona.

\section{Filmografía}

1982, Estuvimos ahí (Argentina, 2004), de César Turturro y Fernando Acuña

1982 Malvinas La guerra desde el aire (Argentina, 2009), de César Turturro (Escritor: Jorge Luis Sucksdorf) 


\section{LEY GENÉRICA ENTRE MUJERES Y PUTOS: DEMOCRACIA, STRONATO Y GUERRA GUASU}

\section{Rocco Carbone *}

108/ Cuchillo de palo (España, 2010, 93 min.)

Director y Guión: Renate Costa (Paraguai)

Director de fotografia: Carlos Vásquez

Com: Renate Costa, Miguel Auad Petunia, Manuel Cuenca

Montagen: Núria Esquerra, Carlos García

Música: Berta Rojas

Productores: Jordi Ambròs, Marta Andreu, Susana Benito, Ruth Casanovas

\section{Telón. O: de las bienvenidas y los accesos}

Varias dimensiones. Paraguay es la primera. Y sobre este trabajo él formula un estado de interrogación. Lo interroga a partir de un emergente integrado por un complejo dispositivo cultural-militante, una película: 108/ Cuchillo de palo (2010) de Renate Costa. Modo de la memoria porque, desde la historia familiar, filma/reflexiona (a partir de un número que en Paraguay tiene su historia) sobre los modos homosexuales de hacer sexo en relación con la sexualidad "normal" dominante-autoritaria en la década de 1980, cuando el país aún estaba asediado por un orden político autoritario: el Stronato (1954-1989). Y al desarrollar los contenidos de la memoria de 108/ Cuchillo de palo, el trabajo descubre la existencia de una ley genérica en estado de disponibilidad a la cual el Stronato le hace producir sentido

* Universidad Nacional de General Sarmiento, Consejo Nacional de Investigaciones Científicas y Técnicas - CONICET. C1033AAJ, Buenos Aires, Argentina.

E-mail: rcarbone@ungs.edu.ar 
pero que estrictamente no le pertenece. Apenas amplía sus márgenes que, postulamos aquí, fueron articulados por lo menos 150 años antes: posguerra Guasu (1865-1870). Cuando Paraguay estaba ocupado por los ejércitos de Argentina, Brasil y Uruguay.

Estas dimensiones que entraman un diálogo permanente entre lo cultural-militante y la historia política son formuladas desde el hoy.Y que por la obviedad misma de la formulación requieren una línea de explicación: el hoy es una contemporaneidad democrática latinoamericana que nos reclama acerca de temas sensibles como los derechos humanos y las políticas de derechos humanos. Tiempos democráticos y reclamo de derechos - genéricos, concretamente - que como tales pretenden impactaren la ampliación de los marcos de ciudadanía.

\section{En casa de herrero}

En esa sub-región de América Latina que conocemos como Cono Sur suele repetirse y escucharsea menudo el refrán, "en casa de herrero, cuchillo de palo", que más o menos alude a toda persona que, siendo especialista en algún rubro, usa ese saber-hacer en cualquier lugar menos en su casa. Ésa es la parte del título menos difícil de explicar del largometraje documental (producido en España) por la cineasta paraguaya Renate Costa Perdomo y estrenado en febrero de 2010 en la Berlinale: 108/ Cuchillo de palo. La parte más compleja, y por eso mismo la que más entusiasmo provoca, sin que esta frase tenga nada de refranero, es ese numerito aparentemente inocuo: 108, que no implica ningún tipo de numerología. Ese número, precisamente, desborda lo cinematográfico-documental de Costa y lo pone en paralelo con esa porción de la historia política paraguaya que se inicia en 1954 y que "termina" en 1989. O sea, con el Stronato: régimen político-autoritario-heteropatriarcal articulado alrededor de la figura del general Alfredo Stroessner Matiauda. 
Ese numerito aparentemente inocuo hace de la película de Costa un vehículo de memoria que representa el pasado y lo incorpora fáctica y subjetivamente en el presente. Es consabido que dentro de los márgenes de la historia política paraguaya (como de los otros países del Cono Sur) la memoria fue y es dramatizada por las tensiones (irresueltas) entre recuerdo y olvido, latencia y muerte, revelación y ocultamiento, prueba y negación, sustracción y restitución. Precisamente a causa de las violentaciones (violencias más violaciones) a los derechos humanos. 108 es y tiene el sentido de un testimonio que rebate la ficción genérica pretendidamente universal del sujeto absoluto; ése que no se hurta al canon de la heterosexualidad normativa. Entonces, ese número remite a un tema de los derechos humanos, a un tema de género, pero sobre todo a uno de la democracia. ¿Por qué?

En democracia podemos recuperar esa gramática de los cuerpos articulada alrededor de las violentaciones sexuales y otros delitos de violencia de género. En democracia podemos reexplorar (reapropriar/recitar) en sus capas superpuestas la existencia de una memoria activa y disconforme. En democracia podemos recuperar sin temor las señales de vida que grafican el trauma: los hilos rojos, aún clandestinos, de ciertas memorias críticas que se rebelaron contra el determinismo ideológico de un pasado guiado por racionalizaciones finales. Las que en el Cono Sur llamamos "dictaduras".

\section{Dispositivo cul-mit}

Antes de explicitar una lectura posible del documental de Costa para ponerlo en paralelo con la historia política paraguaya, me parece relevante señalar que no se trata de un producto cultural que funciona esquizofrénicamente respecto de la realidad político-cultural que le es 
contemporánea. No se trata de un dispositivo cultural aislado de su contexto, dado que en Paraguay desde hace unos (pocos) años la cuestiónde lxs108 viene siendo abordada desde la literatura - con una novela de Armando Almada Roche,108 y un quemado. ¿Quién mató a Bernardo Aranda? (2012), un cuento de Bernardo Neri Farina, "El rock and roll de Bernardo" (2010), una dramaturgia de Agustín Núñez, 108 y un quemado (2003/2010) -, una investigación militante colectiva - ErwingAugstenSzokol y otrxs, 108/Ciento ocho (2013) - y también reivindicada por parte de grupos militantes LGTBI. Pienso en la Asociación 108 con sus múltiples acciones: la fundación de La Mansión 108 en Asunción, "un proyecto queer alternativo" (https://www.airbnb.mx/rooms/2196875), la publicación de un panfleto que ya va por su segunda edición 108/Ciento ocho (Augsten Szokol y otrxs), el blog 108 memorias (http://108memorias.com/la-historia/) o la impresión de remeras coloridas que llevan en la parte anterior el número como declaración de principios. También hay que recordar a Somos Gay (http://somosgay.org/quienes-somos), una "asociación solidaria, comprometida con la innovación de estrategias efectivas contra la homofobia". Por el lado lésbico-feminista, Aireana (http://www.aireana.org.py), espacio político cultural "de información, de encuentro (para diálogos, charlas y debates) y de servicio a mujeres lesbianas". Y Lesvos, una nueva organización de mujeres lesbianas nacida en 2013 (https://www.facebook.com/LESVOSorg/info).

108/Cuchillo de palo integra este complejo dispositivo culturalmilitante. No referir ese entramado adelgazaría el amplio debate del cual el documental de Costa participa desde las peculiaridades de su propia historia familiar - entroncada con la historia política de su país - y las del cine en tanto séptimo arte. Debate que nexa múltiples dimensiones: derechos humanos, memoria, espacios de discusión que generan relatos y acciones a propósito de la memoria y el olvido, que impulsan reflexiones que entraman justicia, memoria e historia política con el arte en un contexto pos-represión, 
de resistencia y de denuncia de la violencia, maltrato y tortura contra la homosexualidad, tanto hoy en día como durante el Stronato: un régimen político autoritario y heteropatriarcal que a lo largo de su existencia desató múltiples razzias sobre subjetividades que síse hurtaban al canon de la heterosexualidad normativa. Heterosexualidad masculina articulada alrededor del cuerpo del hombre, postulado como único sexo con existencia ontológica.

Sobre una de esas persecuciones reflexiona Renate, en un mano a mano entre ella, casi siempre detrás de cámara - como si fuera un símbolo de la memoria inquieta, indócil, escondida, que no puede parar de recordar y saber en presente sobre el pasado - y su padre - como si fuera símbolo del olvido, de lo dicho a medias, de lo negado, oculto o manoseado en el presente sobre el pasado; su padre que, como su abuelo, era (es) herrero. 108/Cuchillo de palo relata la historia de una familia o, en última instancia de dos hermanos: el viejo de Renate y su tío Rodolfo, "el cuchillo de palo", ya que contrariamente a sus hermanos y a su padre no quería ser herrero. Sino bailarín. En el Paraguay de la década de 1980. Precisión: si bien es cierto que la tensión fundamental de la película está repartida entre Renate y su padre, el documental articula otras voces/miradas que sirven para reconstruir la historia de Rodolfo. La película pone en foco a otrxs personajes, integrantes de la cultura LGTBI, que conocieron a Rodolfo de manera más o menos mediada y sus recuerdos contrabalancean la "versión familiar" paterna que Renate pretende rearticular con honor a la verdad o a otra verdad, que es la que ella pretende filmar.

Bailarín: una subjetividad reconocida visualmente como hombre, en un régimen político ya en tiempo de descuento (se narran hechos pertenecientes a la década de 1980) que se ocupó de perseguir con atención de cirujano todolo diversamente deseante en distintos ordenes del ser: ideológico, político, militante, insurgente, genérico... El Stronato, como los demás autoritarismos militares latinoamericanos, se ocupó de acotar, vigilar, 
castigar, desaparecer la circulación de signos militantes, disidentes, diversamente deseantes por medio de "medidas inmunitarias" que conocemos. La sumatoria de todos los polos victimados describían (describen) lo diversamente deseante respecto de ese Orden que opera(ba) porque sigue operando en el Paraguay de hoy - como molde disciplinario de una verdad menos revelada que obligatoria.

Rodolfo Costa: fue encontrado muerto en su domicilio, desnudo y tirado en el piso. En ese mismo momento, una Renate aúnal borde de la infancia pregunta cómo ha muerto su tío. Le replican:“de tristeza”. Un tío que ella recordaba alegre, jovial. El recuerdo de ese hecho sombrío subjetivo, familiar y en la sincronía, lo vamos a ver, colectivo - es lo que la insta a filmar muchos años después el presente para recuperar un pasado traumado y trémulo en la recuperación de su recuerdo. Filmar con vistas aformular nexos constructivos y productivos entre pasado y presente para hacer estallar el "tiempo-ahora" (Benjamin, 1989) que se ve retenido y comprimido en las partículas históricas silenciadas por las memorias oficiales.

\section{Contextuales. O: la Patria de los ortos}

Rodolfo Costa: 108. Su muerte, más precisamente, su asesinato, en la década de 1980 reactualiza(ba) el asesinato del primer 108: Bernardo Aranda, cuya muertedio inicio a la cuestión 108. Dicho esto, es el momento de explicitar qué quiere decir ese número en el ámbito del documental de Renate y en el contexto de la historia político-cultural paraguaya. Concretamente, se vincula con la primera razzia pública (ampliamente documentada por la prensa de la época y seguida por el conjunto de la sociedad) que el Stronato perpetró sobre la comunidad homosexual asuncena en 1959 y que implicó la represión de sexualidades disidentes (no obedientes a la normahetero). Una represión acontecida en setiembre de ese 
año pero que a lo largo de la experiencia stronista volvió a repetirse en otras ocasiones (con variaciones mínimas y otros sujetos, desde ya) y que creó significaciones que siguen haciendo sentido en pleno siglo XXI dentro de los márgenes de un orden pretendidamente democrático. De hecho, atendiendo a una investigación de archivo de Francisco Alcaraz Sosa, "Memoria histórica del caso 108 durante el régimen represivo del stronato", puedo hacer constar lo que sigue. Antes de 1959 y del caso de los 108, en Paraguay ya se había asociado la homosexualidad a un número: el 13. El diario La Tribuna en 1931 se ocupa de denunciar el hacinamiento de los presos en la cárcel y haciendo referencia al número de una celda, la 13, escribe: "fatídica celda donde se hospedan más de 15 recluidos, la mayor parte de ellos aficionados al vicio contra natura" (año 6, no. 2425, 7 de abril de 1931: 1). Luego de 1959, la razzia que se desató con motivo del asesinato de Aranda, volvió a repetirse con el caso de Enrique Mai, Tito Ainer, Mario Luis Palmieri y Rodolfo Costa, quien nos ocupa aquí.

Todos estos hechosmerecen ser interrogados - y en esto reside uno de los aciertos de 108/Cuchillo de palo - porque fuera del dispositivo cultural-militante que explicité anteriormente el trauma que implica la cuestión 108 aún no es motivo de reflexión ni por parte de las ciencias humanas ni de las sociales.

En 1959, Bernardo Aranda, locutor radial, fue encontrado calcinado en Radio Comuneros, su lugar de trabajo. A partir de ese asesinato, el Stronato desató una razzia y apresó a 108 presuntos homosexuales con vistas a "esclarecer" el motivo de esa muerte, cuyos móviles fueron presentados como pasionales por el poder y por el dispositivo prensa ( $E l$ País, El Independiente, Nande). A partir de ese momento se acuñó el sintagma "ciento ocho" como sinónimo despectivo para designar a todx homosexual. 
Interrogar la primera razzia o el asesinato de Rodolfo Costa en realidad busca interrogar los modos homosexuales de hacer sexo en relación con la sexualidad "normal" dominante-autoritaria impuesta por el Stronato (en este contexto de discusión, si bien esa imposición es anterior y “tan vieja como el mundo"). Modos nexados con un orden político, un orden sexogenérico, y uno anatómico de los cuerpos. También con la estabilidad de esos órdenes. En cuanto al orden: una primera base axiomática del discurso del poder autoritario-totalitario-heteropatriarcal consiste precisamente en la absolutización de un Orden como principio clasificatorio con un impacto en los discursos como en las identidades. La cuestión 108, y concretamente la de Rodolfo Costa, indica una situación de desborde respecto del sujeto monológico de la autoridad genérica propia de las tradiciones oficiales que consagraba el autoritarismo de la cultura militar. Y "ciento ocho" es una cifra que apenas tiene relevancia matemática porque su peso específico es de índole política, tal como sugerí hace unos minutos. Más concretamente, de índole sexopolítica. Y filmar sexopolíticamente, como lo hace Costa, nos permite formular una serie de reflexiones sexopolíticas de ese régimen que llamamos Stronato. Porque el sexo, el género y la sexualidad - a partir de 1959 y el asesinato de Aranda, que en la década de 1980 se reactualiza con el asesinato de Rodolfo Costa - impactaron en la actividad política y viceversa.

Mirando el documental es posible postular una relación directamente proporcional entre la lógica represiva de la patologización de la homosexualidad y el grado de opresión del régimen. En este sentido, 108 significa la activación de un mecanismo sexopolítico de orden disciplinario. Y 108 es uno de los tantos polos victimados por el Stronato que integraban una cultura contestataria cuyo objetivo general y generalizable era torcer el 
alfabeto de Tembelo. ${ }^{1}$ Polo victimado, subjetividad social traumada integrada por Rodolfo Costa y precisamente por eso su caso es menos ejemplar que colectivo - que aprendió sobre/con su propio cuerpo, un cuerpo colectivo - traumáticamente - a disputarle sentidos al habla oficial, con un sordo reclamo por más derechos y más ciudadanía, impugnando el formato reglamentario de una significación única: hombre/mujer/ heterosexual. Habla oficial con su correspondiente cultura oficial, que hablaba la lengua de la razón autoritaria. Lengua que en su propio léxico acuñó un sustantivo para designar la desviación sexual, la "degeneración" genérica, la amoralidad. Sustantivo - cuando no lengua en su totalidad - que sigue teniendo vigencia hoy en día y aparece por las calles paraguayas bajo forma de graffiti pretendidamente antifascistas.

108/Cuchillo de palo (de)muestra cómo el sistema sexo/género entró a formar parte de los cálculos del poder de manera declaradamente pública. Y cómo los 108 fueron (y son porque la racionalidad stronista es todo menos un recuerdo en Paraguay) transformados por esos cálculos, en centros moleculares de dominación heterosocial. Con el caso Costa, con las razzias del Stronato sobre la comunidad homosexual, ese orden político le agregó un apéndice a la misoginia propia de cualquier sistema heteropatriarcal: el desborde sobre la homofobia que, al fin y al cabo, ¿qué es sino una misoginia extendida?

La homofobia efectivamente es - en el sentido de que puede entenderse como - una misoginia extendida. O, dicho de otro modo, ampliando los márgenes de esta interrogación sobre la historia y la construcción de género en Paraguay, la persecución sobre el cuerpo de la homosexualidad es activable porque el orden político paraguayo entre 1954 y 1989 tenía una ley genérica en estado de disponibilidad, cuyo marco podía

\footnotetext{
${ }^{1}$ Apodo de Stroessner, basado en la palabra guaraní tembé que significa "labio", con el que se ridiculizaba su enorme papada; y tembolo, cuyo significado es persona ridícula, despreciable.
} 
ser, tal como efectivamente fue, ampliado. Una ley genérica que en 1959 casi cumplía un siglo. Una ley que por lo menos venía circulando vertiginosamente en Paraguay desde los primeros añosde la posguerra guasu. Luego de insinuar esto se precisa aquí una aparente digresión.

\section{Larga duración. O: la Patria es de los otros}

La historia política del Paraguay es un entramado tupido de hombres contrabandeados como héroes. En este sentido, resulta sintomático el Panteón Nacional de los Héroes que está en plena Asunción y enfatiza la importancia de las figuras masculinas en la historia de la patria, que es la historia patria, la patria - patría -, terreno de la historia: terreno hecho historia. Héroes: antes de Solano López y después de Bernardino Caballero, haciendo pie en Stroessner, para llegar a Cartes.A contrapelo de ese entramado, y en este contexto propongo un ejercicio de imaginación, a 150 años de una de lasmayores conflagraciones bélicas de la historia americana. Me refiero a la Guerra contra la Triple Alianza o Guerra Guasu (18651870). Que imagine la situación de Paraguay desde un punto de vista genérico sobre el fin de esa guerra y en la inmediata posguerra porque es cuando se acuña o - mejor: se refuerza - una ley de género, recuperada luego de algún modo por el orden autoritario stronista para hacerle producir sentido y perseguir el cuerpo de la homosexualidad ya sobre la mitad del siglo XX.

La patria soñada por Solano López era una patría: heterosexual, heteropatriarcal, cuya ecuación fundante es masculinidad, machismo, erección. Una verdadera patría que en Paraguay, por su historia postguerra guasu hubiera podido ser una matría. Matría opuesta a la patría: la patria oficial programada por López, ésa que descansaba sobre la guerra y la posibilidad de victoria. Y esa matría, esa Matria (Patria) que hubiera podido ser, no fue. Por qué en un país de mujeres, que habían participado en la 
guerra y que luego reconstruyeron el nuevo Paraguay, el poder siguió estando en mano de los hombres. ¿Por qué lo que venía siendo una patria no se transformó en una matria? Vuelvo a insistir sobre la razón de esta pregunta: son mujeres las subjetividades que reconstruyeron el Paraguay. O que construyeron el nuevo Paraguay.

Cuando la guerra se dio por fin por concluida con la muerte del presidente López, la población paraguaya estaba reducida a menos de 200.000 personas, lo que significó una pérdida de aproximadamente el $60 \%$ de la población existente antes del conflicto. Además, había un exceso muy marcado de población femenina con respecto a la masculina, por lo que el Paraguay fue llamado "el país de las mujeres". (Potthast, 2001: 86).

Sobre el filo de 1870 Paraguay es una nación destruida. Paraguay: país de mujeres pero no de las mujeres (distinción sutil pero decisiva). Frente a esto, la pregunta: ¿por qué en un país de mujeres, que habían participado en la guerra y que luego se encargarán de reconstruir (parir) el nuevo Paraguay, el poder siguió en mano de los hombres? ¿Por qué el Estado siguió siendo un dispositivo heteropatriarcal y masculino? ¿Por qué lo que venía siendo una patria no supo transformarse en matria? Ya que la guerra es lo que hace cambiar de sitio las cosas, reales o simbólicas que sean. Valga un punto nomás: con la guerra, la vida misma sufre una aceleración enfática que la acerca a la muerte; en el mejor de los casos. Porque en el peor la hace adherir a ella: la muerte deglute la vida transformándola en su contrario, que es ella misma.

Precisión. Matria no debe ser entendida como sinónimo de matriarcado, pues un matriarcado como mera inversión de un patriarcado sigue siendo heterosexual y opresor, con un signo inverso. Una matria, desde hoy, como construcción política, podríamos imaginarla como un orden regido por la paridad sexo-genérica. 
Posguerra Guasu la condición femenina siguió articulando una posición subalterna respecto del hombre pese a una situación novedosa: la población masculina había sido raleada sensiblemente por el conflicto bélico. Se obtura una potencialidad y la soberanía del poder, la potestas sigue siendo del paterfamilias, del dueño de casa, del señor del lugar. Esas mujeres, en situación de mayoría, son extranjeras en su propio país. Y una reflexión sobre esas mujeres implica, entre otras cosas, delimitaciones precisas entre ámbitos. Entre lo familiar y lo no familiar, entre lo extranjero y lo que extranjero no es, entre lo ciudadano y lo no ciudadano, entre lo privado y lo público, entre el derecho privado y el derecho público. Y quién puede ejercer/ocupar esas posiciones dentro del orden social. Interrogarse sobre la condición de extranjería de esas mujeres es interrogar una frontera entre lo público y lo no público, entre el acceso al poder y su negación, entre el espacio político y el lugar propio, individual o familiar, entre lo secreto y lo fenoménico. Esas mujeres se sustrajeron a la fenomenalidad pública, política, estatal. Esa frontera atraviesa una turbulencia genérico-política desestructurada con la guerra y que a partir de ese drama vuelve a reestructurarse de manera aún más potente. Las mujeres paraguayas de posguerra oponen una reacción (auto)privativa respecto del poder y por ende respecto del país (en términos de construcción política). Eso implica no fundar una matria. La ley de reconstrucción de Paraguay por parte de las mujeres sobrevivientes es paradójica: pone en colusión reconstrucción y poder.

La ecuación ahí es mujer = extranjera: como si fuera una recién llegada a Paraguay. Claro: recién llegada al Paraguay de posguerra. Ocupando un lugar-propio destruido y con el deber de reconstruirlo, pero despojada del derecho de poder/al poder: poder reivindicar poder en sí y para sí. En los márgenes de la sociedad civil y del Estado. El poder de la mujer se relega una vez más a la familia y a sus actividades complementarias: la educación, la escuela. Estamos frente a una aporía que 
emana de un conflicto: en el Paraguay posguerra Guasu hay mujeres con el poder de poder y al mismo tiempo despojadas de esa potencia. Estamos frente a una tragedia del destino: a un momento sin momento: a una posibilidad imposible. Esas mujeres sobrevivientes sitúan el poder masculino por encima del propio. Y sobre ese poder el Stronato construye sentido y poder cuando se arroga el derecho de perseguir al cuerpo colectivo de la homosexualidad. Paraguay posguerra guasues necesidad y deseo: masculinos. Un país destruido y reconstruido por mujeres. Mujeres empoderadas: con un aumento en su sensación de poder. Y sólo de sensación hablo, ya que Paraguay retoma muy rápidamente la inflexión heteropatriarcal como organizadora de la patria. Programación que no resulta extraña: la carencia otorga valor.El poder masculino, el poder del heteropatriarcado, es dictado por esas mujeres como una ley por encima de todas las demás. Y por el revés, esas mismas mujeres postulan su poder como abstracto, utópico, ilusorio. Como un poder que puede transformarse, como de hecho se transforma, en su contrario. Esas mujeres se implican en la reconstrucción y se (auto)excluyen del poder, se disocian de él en un momento histórico irrepetible, excepcional, en el que hubieran podido articular reconstrucción y poder. Postulan una ley genérica. Del deber pero no del derecho: un llamado que (auto)obliga sin exigir. Y de esa ley son responsables y víctimas, paradójicamente. Ley que de alguna manera es recogida por la Constitución de la República del Paraguay de 1870. Esa Magna Carta estuvo inspirada -principalmente- en el pensamiento liberal de la Declaración de Virginia de 1776 y en la Constitución Argentina de 1853. Con sus 118 artículos, esa norma era una formulación en contra del sistema político vigente desde 1811 y tenía un corte democrático-liberal. A partir de ese momento Paraguay es declarado república y como tal se adopta una forma de gobierno democrática representativa y el Estado se organiza en tres poderes. Se Reconoce el principio de la soberanía popular con la organización del gobierno, de acuerdo al sistema de separación de poderes 
del Estado. Por primera vez, en la historia cívica del Paraguay aparece la figura jurídica del ciudadano con derechos y deberes. Instituye también la incorporación de las libertades civiles y - en el caso de los varones mayores de edad - el sufragio. Pero no el sufragio universal. De hecho, ni mujeres ni indígenas tenían derecho al voto. En este sentido, podemos decir que esas mujeres postularon una ley genérica, de la cual fueron a la vez responsables y víctimas, recogida por la Constitución, que las pueso fuera de la ley (anomos). Posguerra Guasu, la mujer es el extranjero, el xenos, simplemente el otro absoluto, absolutamente excluido del ejercicio del poder. El poder, a partir dela posguerra, se declina en el hombre y por extensión en el sistema heteropatriarcal sin reciprocidad alguna hacia las mujeres. Sistema heteropatriarcal que puede hacer de ellas lo que se le antoje y que pude ser resumido en una palabra: rentabilidad.

Declinar esa posibilidad, de imaginar y por lo tanto construir una matria - no tanto antiheteropatriarcal como desviada de lo heteropatriarcal, las posibilidades parecen infinitas - es marcar un destino genérico para Paraguay. Que no queda relegado al post 1870 sino que impacta en las construcciones de la masculinidad y la feminidad, y en las combinaciones posibles entre esos dos paradigmas: hoy como en 1959. Esa ley genérica fija un destino: anulando el derecho de las mujeres a empoderarse (porque se declina en favor de los hombres), se lo anula también para su descendencia. Esa ley genérica de posguerra impacta así, de manera directa, en el futuro. En la posguerra se crea una dinámica, un ethos. Se condena esa patria, resultado de un momento excepcional en la historia la "tragedia" de una tierra (casi) sin hombres - a la normada existencia heteropatriarcal. Se configura una realidad de mujeres abnegadas, trabajadoras, pero sobre todo expropiadas. Del fruto de su labor por sus hijos, padres, maridos, hermanos. Madres de varones que se insertarán sin dificultades en la retahíla de abusos de género - sobre el cuerpo de la homosexualidadtambién -, de mujeres silentes, gauchitas, programadas para 
soportar penas. "Pena" que es a la vez tristeza, castigo y trabajo. ¿Hay una forma más generosa y terrible del don?

Posguerra guasu nace el Paraguay actual, un país en el cual la mujer habita en extranjería constante. En términos de poder, las mujeres paraguayas, a su pesar, se hacen cargo - en el doble sentido de que cargan con y son deudoras - del legado de Mme. Lynch (la concubina irlandesa de Solano López). Extranjeras en su país, no tanto despojadas de poder como del derecho a tenerlo. Invisibilizadas, sistemáticamente. Disminuidas. En definitiva, aún, una mayoría minorizada. Y a partir de 1959 es posible decir que esa ley genérica impacta también sobre el cuerpo de la homosexualidad. En adelante, el sistema sexo/género entra a formar parte de los cálculos del poder, del cálculo del gobierno. Y "los" 108 son transformados, por esos mismos cálculos, en centros moleculares (elementales: lo contrario de globales) de la dominación heterosocial. Además, como sugería, a la misoginia propia de un sistema heteropatriarcal se le agrega un apéndice: se desborda sobre la homofobia, que al fin y al cabo,puede entenderse como una misoginia extendida. Tanto el cuerpo femenino como el cuerpo homosexual son producto de la historia política y no simplemente de la historia natural. Misoginia y homofobia nos demuestran cómo la estructura heteropatriarcal es castradora tanto del cuerpo de la mujer como del delhomosexual (en términos simbólicos, desde ya, pero también, muy a menudo, reales: pensemos en otras geografías y en otras tradiciones como la clitoridectomía). Para el heteropatriarcado el cuerpo homosexual resulta homologable con el cuerpo de la mujer y por eso ambos pueden ser sujetos discriminados, sujetos de represión, dependencia, subalternidad. Porque en definitiva son contenidos en el mal llamado "sexo débil", respecto del único "sexo fuerte" que tiene existencia ontológica: el masculino.

\section{Marronage. O: de las salidas}


De este recorrido un tanto frenético, descienden por lo menos dos cosas. Que el cine, y dentro de ese arte 108/Cuchillo de palo, tiene el poder de crear imágenes y convertirse en un contra-laboratorio virtual de producción de realidad. Contra-laboratorio que crea las condiciones para "nuevos" recuerdos - mejor: recuerdos renovados - en nuestro presente. Y dos: que el documental de Renate Costa, junto con las obras que mencioné anteriormente en "Dispositivo cutural-militante", desde el ámbito artísticocultural, se constituyen en acciones complementarias de aquéllas de los grupos LGTBI políticamente organizados. Ese macro-conjunto de acciones/intervenciones recuperan una palabra que integra el léxico stronista y que remite a una práctica represiva - cuya ley genérica tiene sus raíces histórico-políticas posguerra guasu - pero sobre todo, se la reapropian (invertida) respecto de su uso primigenio.

En definitiva, todas esas acciones resemantizan la palabra 108 y nos devuelven en el presente un pasado revectorizado a partir del orgullo LGTBI. Y al recuperar esa palabra, recuperan también experiencias y memorias que hoy, en tiempos democráticos, si bien frágiles, reclaman derechos. Que como talespretenden impactaren la ampliación de los marcos de ciudadanía. Para un Paraguay con derechos para todos y todas y todxs. Esa re-apropiación, que tematiza 108/Cuchillo de palo, nos dona la garantía de que con la conmemoración (en tanto justicia) puede fortalecerse la democracia (en tanto verdad). Una democracia que a 150 de la Guerra Guasu no puede olvidar las peculiaridades genéricas que tiene Paraguay dentro de los entramados regionales y sobre las que impactaron las acciones de ejércitos de ocupación. 


\section{Referencias bibliográficas}

ALCARAZ SOSA, Francisco (s/data), "Memoria histórica del caso 108 durante el régimen represivo del stronato", mimeo.

ALMADA ROCHE, Armando (2010), 108 y un quemado. ¿Quién mató a Bernardo Aranda? Arandura, Asunción.

AUGSTENSZOKOL, Erwing y otrxs (2013), 108 / Ciento ocho, Arandura, Asunción.

BENJAMIN, Walter (1989), Discursos interrumpidos I. Filosofía del arte y de la historia, Taurus, Madrid.

CARBONE, Rocco (2014), Putos de fuga. Stronato, sexopolitica, trauma, memoria, Servilibro, Asunción.

DERRIDA, Jacques; DUFOURMANTELLE (1997), Anne, De l'hospitalité, Calman-Lévy, Paris.

JELIN, Elizabeth (2002), Los trabajos de la memoria, Siglo XXI, Buenos Aires.

NERI FARINA, Bernardo (2010), El siglo perdido, Servilibro, Asunción.

NUÑEZ, Agustín (2010), 108 y un quemado, Arandura, Asunción.

PRECIADO, Beatriz (2014), Testo yonqui, Paidós, Buenos Aires.

POTTHAST, Bárbara (2001), "Residentas, destinadas y otras heroínas: el nacionalismo paraguayo y el rol de las mujeres en la Guerra de la Triple Alianza". En: Potthast y Scarzanela, Eugenia (compiladoras), Las mujeres y las naciones. Problemas de inclusión y exclusión, Iberoamericana, Frankfurt/Madrid, pp. 77-92.

RICHARD, Nelly (2013), Fracturas de la memoria. Arte y pensamiento crítico, Siglo XXI, Buenos Aires.

SONDERÉGUER, María (compiladora) (2012), Género y poder. Violencias 
de género en contextos de represión política y conflictos armados, Universidad Nacional de Quilmes, Bernal.

\section{Filmografía}

108/Cuchillo de palo (2010), de Renate Costa. 


\section{ENTREVISTA}

Entrevista | Interviews | Entretiens 


\section{FILME JANELA DA ALMA REVISITADO - UMA CONVERSA COM O DIRETOR JOÃO JARDIM}

\section{Dago Schelin *}

Há dois anos comecei meu doutorado na Philipps-Universitat Marburg aqui na Alemanha. Minha área é cinema, o tema mais específico é a visualidade. Há muitos filmes que tratam direta ou indiretamente de visão (e cegueira). Enquanto vou afunilando e delimitando o meu problema, deixo alguns filmes de lado e elejo outros para continuarem no corpus. Janela da Alma (2001), de João Jardim e Walter Carvalho é a cereja nesse bolo de filmes e está se tornando o principal para discutir dialéticas da visão. Há algum tempo eu queria conversar com João Jardim para tirar umas dúvidas, para trocar ideias e por simples curiosidade. Pensei que seria muito difícil conseguir um tempo com alguém que já esteve nomeado para um Oscar e ganhou prêmios na Berlinale e em Sundance. ${ }^{l}$ Mas para a minha grata surpresa João Jardim se dispôs de pronto a dar entrevista. Da entrevista deixei de fora somente os comentários iniciais de um fã lisonjeado. O texto abaixo tem a sensação de uma conversa pois foi exatamente isso.

\footnotetext{
* Doutorando. Philipps University Marburg, Institute for Media Studies (Institut für Medienwissenschaft), Programa de Doutoramento em Media Studies. 35039 Marburg, Alemanha. E-mail: dagols@gmail.com

${ }^{1}$ Lixo Extraordinário (2011), dirigido por Lucy Walker, João Jardim e Karen Harley, ganhou o prêmio do público para o melhor documentário internacional no Festival de Sundance 2010, prêmios da Anistia Internacional e do público na mostra Panorama do Festival de Berlim 2010, indicado ao Oscar 2011 para o prêmio de melhor documentário.
} 
Entrevista realizada a 10 de agosto de 2015 via skype.

\section{Legenda:}

$\ldots \rightarrow$ micropausa ou interrupção ou alongamento vocálico.

$($...) $\rightarrow$ demonstração de corte em trechos não relevantes.

$(($ palavra $)) \rightarrow$ comentários da transcrição ou onomatopeias.

Dago Schelin: Mostrei Janela da Alma para um grupo de doutorandos e professores aqui em Marburg. Creio que seja porque o brasileiro tem um estereótipo tão forte que quem é de fora não espera, por exemplo, um filme que nem Janela da Alma vir de um brasileiro.

João Jardim: Totalmente. Inclusive quando o filme foi lançado aí, na verdade na França, eu senti que há uma resistência... eu lembro que teve um pouco esse preconceito. Eu li as críticas que saíram. Tinha um lado assim: "Mas por que um brasileiro fazer um filme sobre o pensamento, com tanta coisa mais interessante para ele falar do Brasil?" Era como se aquilo fosse um assunto que cabia mais a um europeu do que a um brasileiro. É como um francês fazer um filme sobre samba. E você, antes de ver se o filme é bom ou ruim,

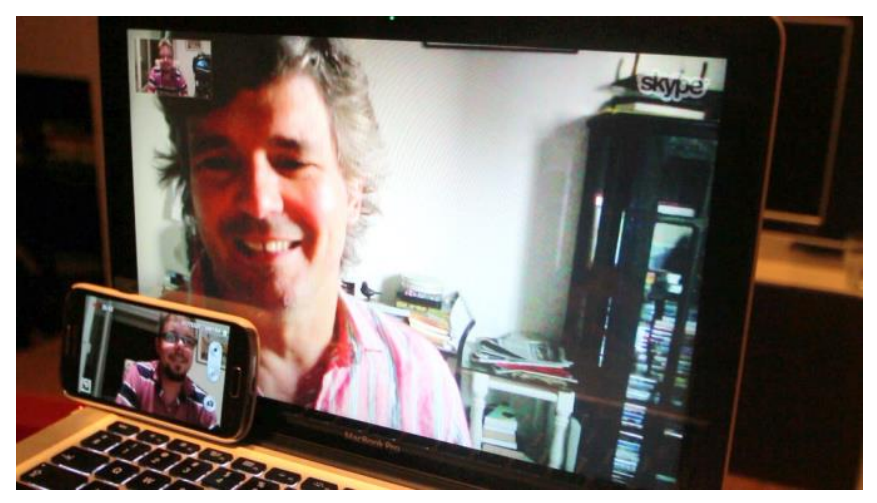
já vai dizer, "esse cara não tem autoridade para fazer um filme sobre isso". Em um primeiro momento eu até fiquei um pouco chateado, mas depois eu entendi que era natural, porque realmente tem uma estranheza mesmo. 
DS: De qualquer maneira, o pessoal pra quem eu mostrei aqui gostou muito do Janela da Alma. Fizeram-me várias perguntas que não pude responder. Uma pergunta sobre a ideia inicial: qual foi a primeira faísca que levou você a querer fazer um filme sobre esse tema?

JJ: Eu sempre fui muito míope, agora eu operei os olhos. Eu tive catarata e operei os olhos, mas eu era bastante míope, e aí eu comecei a ideia do filme, no caso, porque eu queria investigar como o fato de eu ser míope tinha influenciado a minha vida. Isso foi o primeiro momento (...) da minha insegurança, porque eu me sentia mais inseguro por causa disso. Isso foi uma primeira faísca. Depois essa ideia inicial até parece meio boba mas sem ela você não teria elaborado o todo. Mas eu me lembro bem que eu estava fazendo um trabalho nos Estados Unidos, eu morava no Brasil, mas eu fazia efeitos especiais comerciais em Nova Iorque. Eu me lembro que fui passar alguns dias lá fazendo esse comercial e saía com os olhos muito cansados de ficar vendo. Aí, pegava um táxi e tinha que andar várias ruas, tipo, setenta ruas entre o estúdio de pós-produção e o hotel. E eu tirava os óculos. E aí, aquela paisagem que é o que está no filme, aquela paisagem da cidade toda desfocada, (...) como ficava mais bonito o fora de foco do que o em foco, como a cidade ganhava toda uma magia da maneira, teoricamente, incorreta. Então, juntando essas duas questões, a minha questão da minha miopia, de como aquilo tinha afetado a minha personalidade e a ideia de que ver “errado", às vezes, pode ser ver melhor, essas duas ideias foram um ponto de partida do filme. Aí, eu comecei a pesquisar, conversar com pessoas, fui vendo que a questão do ver ou não ver, do ponto de vista pessoal, era muito mais interessante do que só as questões que eu estava levantando ali.

DS: No e-mail você me falou que pesquisou sobre o assunto visão. Como é que é isso para você?

JJ: Você começa a conversar com as pessoas. Eu chamei pessoas para trabalhar comigo em uma ideia, uma pesquisadora basicamente. Aí, você 
começa a conversar com pessoas de várias áreas da filosofia, da psicologia, da antropologia, da medicina, para tentar entender como é que funciona a visão em todos os sentidos. Os filósofos sempre falaram do ver. Você tem isso na medicina, você tem na arte, também. Só que eu notei que desse jeito não daria um filme, que era uma coisa muito técnica. Aquilo foi muito bom porque foi fazendo com que eu fosse cada vez procurando mais a subjetividade do tema, porque eu acho que o cinema passa muito por isso, pela questão subjetiva. $\mathrm{O}$ tema era muito subjetivo, por experiência própria e pelo que eu podia ler. A imagem é sempre muito mais aquilo que ela está te dizendo sem mostrar, que a essência da subjetividade é aquilo que está sendo dito e percebido sem estar sendo visto. Isso é a essência até do cinema e de todas as artes. Enfim, a arte funciona em um quadro, ele é emocionante justamente por causa disso, que não está no rabisco, o conjunto de tudo aquilo toca a gente de uma forma inexplicável, por isso aquilo funciona como arte. Foi a procura desse entendimento, do que é que significa isso (...) foi porque o filme todo foi feito. Eu fui pegando pessoas que podiam falar sobre isso. Quanto mais eu ia nessa direção, mais eu via que precisavam ser pessoas mais importantes, do ponto de vista do pensamento delas, (...) misturá-las com outras, vamos dizer assim, e aí, a gente fez cinquenta entrevistas para usar dezenove no filme.

DS: Isso é um dado bem interessante de vocês terem cinquenta entrevistas gravadas, mas na edição final entrarem só dezenove. É isso?

JJ: Isso. Exatamente.

DS: Quais são os critérios para descartar ou deixar uma entrevista, para você?

JJ: A palavra não seria exatamente "critério". Quando você vai para a ilha de edição, você já está construindo um filme. Você tem que obedecer a uma dramaturgia interna dele. Você não está mais fazendo um livro. Você está 
construindo um filme que tem que ter início, meio e fim, que tem que ter uma emoção. Cinema é uma coisa muito mais sensorial do que só informação, do que só reflexão. Essa é a diferença entre um filme ser chato ou não ser chato, que é aquilo que o filme está fazendo você pensar, ou está te provocando ali, para onde ele está te levando, para onde ele está levando a sua mente, que essa é a interatividade que existe, que é a real interatividade, que é aquilo que o filme está fazendo você pensar e sentir. A edição é uma parte disso porque quando você junta uma coisa na outra você já provoca um outro sentimento, que é a essência do cinema. Você bota uma imagem de um prato de comida e uma imagem de uma pessoa olhando (...) você assimila "ah, o cara está com fome." Essa mecânica é a força que move aquele processo. A única força é essa, é como que a junção de pensamentos que aquilo está provocando. Uma coisa quase química mesmo: juntar 'A' com 'B' vira 'C', não vira 'A+B'. Se você não cria esse sentimento, não cria o ser, você faz um filme que é ruim. Você tem 'A' mais 'B' mais 'C' mais 'D', mas o que torna interessante o Janela da Alma e os bons filmes, é que porque você junta uma ideia na outra, surge uma outra coisa. O que torna muitos filmes muito óbvios e muito comerciais é que eles são muito fáceis. Eles só vão até ali, enfim, levando você para um caminho que você já conhece.

DS: Eu acho que essa é uma característica que pelo menos os cinéfilos e os estudiosos de cinema gostam bastante em Janela da Alma, porque ele não é óbvio, justamente como você falou, é bem subjetivo. Para mim, pessoalmente, não tem um personagem que eu não goste de ouvir nesse filme. O começo com o Hermeto Pascoal, aliás, essa é uma pergunta que eu queria fazer: tem uma pessoa que fala com ele no início para ele olhar mais para a lente, para ele poder tirar o foco...

JJ: É o Walter Carvalho. 
DS: É o Walter Carvalho? Como é que foi essa interação com o Walter Carvalho antes de apertar o rec?

JJ: Esse foi o meu primeiro filme e eu, na verdade, me sentia pouco preparado para fazer um filme sozinho. Uma temática tão visual e tão... Eu achava que eu tinha que ter junto uma pessoa que tivesse mais vivência naquele tema. O Walter foi ótimo porque ele é um codiretor e ele deixou espaço para eu trabalhar, colocar no filme aquilo que eu acreditava que era o caminho e ao mesmo tempo me aconselhava "não, talvez isso não" e sugeria coisas, mas sempre de maneira muito generosa e nunca se apegando com nada. Ele sabia que o trabalho mais importante ali era que o filme estava nascendo de mim, foi indo até o final. Eu fiz a montagem toda sozinho. O Walter foi generoso o suficiente de entender isso. Mas eu diria que o filme não seria o que é sem ele, parceiro, generoso, indicando caminhos, dizendo o que poderia ser, o que não poderia ser, um ponto de saber. Algumas vezes aquilo não era seguido e aí, quando não era seguido, também estava tudo bem. A própria ideia do Hermeto Pascoal foi dele. Uma pessoa que foi uma (...) parceria maravilhosa, sabe, muito boa.

DS: O filme começa logo depois de umas imagens de um fogo, daí começa essa sequência com Hermeto Pascoal. Dá para perceber que tinha gente por trás, que tinha toda a preparação acontecendo de ajustar foco e preparar o entrevistado. Já estava valendo aquele momento?

JJ: Na verdade, a gente sabe que o filme está valendo o tempo todo, o filme vale o tempo todo. A gente está o tempo todo muito atento a tudo. O melhor que às vezes você pode conseguir de uma pessoa é justamente na hora que ela acha que não está valendo. Então, esse sentimento é proposital, para relaxar. O tempo todo você está muito ligado naquilo procurando o inusitado. 
DS: Qual que é o nível de preparação e o de "vamos ver o que é que vai acontecer" para você?

JJ: Tem que ter muita preparação. Você tem que chegar para conversar com essas pessoas muito bem preparado. Você tem pouco tempo com as pessoas. Elas têm mais o que fazer do que te dar entrevista. Mas, ao mesmo tempo, também tem que dar um espaço ali para coisas acontecerem. Você tem que fazer as duas coisas, você tem que estar muito preparado, mas estar muito atento. Se ela indicar um caminho melhor do que pelo qual você se preparou, você joga a sua preparação no lixo e segue. Eu acho que isso é fundamental em um trabalho de um documentarista: se prepara sabendo que pode jogar tudo fora, sabendo que pode vir uma outra coisa totalmente diferente. A gente tinha uma lista de assuntos que queria abordar e a gente ia conversando com as pessoas sobre aquelas coisas, e aí, a gente ia elencando um número de cada pessoa, o que é que cada pessoa podia falar sobre aqueles diferentes temas. Por isso alguns dos temas que o filme aborda não pediriam uma pessoa famosa para falar e então variava. Outras pessoas que até tinham uma reflexão. Mas apesar de terem uma história interessante para contar, não comunicavam aquela história de uma maneira cativante, interessante, e aí acabava que perdia força quando o filme ia para elas. Aí, elas foram sendo expulsas do filme, (...) pelo próprio filme, não por mim. Por isso é que foram feitas entrevistas, a gente elencou vários temas (...) só que aí, dava um desnível muito grande entre quem se expressava com clareza e emoção e quem se expressava com pouca clareza e pouca emoção. Essa é uma característica das pessoas. Não à toa elas são figuras representativas, têm uma representatividade no mundo de hoje, porque elas expressam suas ideias de maneira muito interessante. A câmera gosta disso, o filme gosta disso. Essas pessoas têm uma reflexão também. A Agnès Varda, a princípio, a gente não pensou em entrevistar. Mas a produtora pensou nela para alguma ponta, e aí, mandou uma mensagem para ela, lá na 
França, se ela teria alguma coisa para falar sobre esses temas, se em algum momento ela viu as coisas de maneira diferente, que a gente estava fazendo um filme sobre a visão e tal. E ela, na mesma hora, respondeu "sim, é um tema que me interessa, porque quando meu marido estava doente eu tive uma experiência...". Assim, ela falou de um filme que ela tinha feito, e aí, a gente "pô, imagina", na mesma hora, "vamos". O que ela estava dizendo ali, o que ela tinha para falar, não tinha nada a ver com o que a gente estava imaginando para o filme, mas você percebe que a pessoa reflete e pensa sobre aquele tema. Isso é mais importante do que o que eu estou imaginando. Não à toa foi maravilhosa a entrevista dela.

DS: Alguns dos entrevistados são cegos. Como é que é para você fazer um filme, que é uma arte audiovisual, com pessoas cegas e sobre cegueira? Essa questão passou pela sua cabeça?

JJ: Não, isso nunca foi uma questão porque a gente estava justamente entrevistando pessoas cegas que tinham uma visão de mundo interessante, e a gente percebeu muito rapidamente que o filme era sobre o discurso mais do que sobre a imagem. Mais importante do que aquilo que você vê é como você pensa sobre aquilo que você vê.

DS: Agora que Janela da Alma já está na adolescência, desde o lançamento em 2001, como é que você vê esse filme agora? Também agora que você já fez vários outros longas e ainda mais depois do sucesso de Lixo Extraordinário, enfim, você já tem uma bagagem.

JJ: Eu tenho muitas saudades do filme. O primeiro filme é uma coisa muito mágica porque a gente se dá a liberdade de descobrir como é que faz. Você não tem resposta nenhuma, só perguntas, então, isso te dá muita liberdade. Eu tenho muitas saudades. Depois que você faz o primeiro vem a convivência com o meio do documentário, com as pessoas que fazem documentário, os parceiros, os outros diretores, você já é muito influenciado 
pelo meio, pelo pensamento, e aquilo de alguma maneira te tira um pouco. Não é que tira, mas aquilo de alguma maneira acaba virando uma parede e você acaba tendo que andar dentro de algum trilho. Antes você não tinha trilho nenhum. Você ia, você tinha a liberdade de ir para onde você queria. A liberdade própria mesmo sua. Agora você já se sente mais na obrigação de otimizar o recurso, otimizar o tempo. Tem a questão do tempo também, que naquela época eu tinha todo o tempo do mundo. Então, eu olho para ele com muitas saudades daquele momento em que para mim era legítimo fazer qualquer ousadia. Hoje em dia, aqueles parâmetros nos quais você tenta se colocar são, com certeza, danosos. Mas é inevitável porque na verdade é o seu conhecimento. Não tem como você fingir que não tem aquele conhecimento. Mas aquele conhecimento que é também aquilo que te coloca em uma trilha pode te levar ainda mais longe. Você pode refletir melhor sobre as coisas e produzir obras até mais contundentes. Aquilo também é uma coisa que te cerceia. Então, como equilibrar isso? Eu acho que o Janela da Alma é fruto muito disso, de uma pessoa ou de duas pessoas, ou de muitas pessoas, que estavam ali tateando com muita liberdade um tema que é muito relevante. E aí, eu sinto falta dessa liberdade, enfim, mas não tem muito jeito. ((acha graça))

DS: Sobre as imagens de close-up, de pele humana, você pode falar um pouco disso?

JJ: A Agnès Varda falou disso e eu acho que tem uma relação com uma coisa que todo mundo que você vê, o tempo todo, mas você vê muito pouco como ela é imperfeita. A pele humana é muito imperfeita. O nosso olho é feito, como José Saramago fala, para perceber a pele humana de uma maneira. Ele consegue ver o detalhe o suficiente para você ver a pele humana de uma maneira bonita, por isso até que a pessoa quando fica velha, é menos interessante, ((acha graça)) porque ela começa a ter defeitos demais na pele. Então, eu acho que essa questão da capacidade que a gente tem de 
ver está justamente ligada intrinsicamente à nossa capacidade de perceber a quantidade de defeitos que têm na pele humana. Eu acho que é uma coisa muito forte, quando se vai perto da pele e você vê do que ela é feita. É disso que o filme tenta falar, como é que a gente não vê, e ao mesmo tempo está vendo tudo o que tem que ver.

DS: João, você teria mais alguma coisa para falar sobre Janela da Alma?

JJ: Eu acho o Janela da Alma um mergulho muito sincero, (...) dentro de um processo de criação. Por isso é que ele resultou de uma maneira tão interessante, porque ele é um mergulho muito profundo dentro de um assunto muito relevante. Quando as pessoas percebiam o quanto eu estava envolvido e mergulhado naquilo, elas entendiam, elas intuíam que o que elas dissessem para mim de relevante sobre aquele tema seria bem usado. Que aquilo para mim era muito relevante. E aí, houve essa troca. Elas doaram para mim, de maneira muito generosa, a vivência delas, o conhecimento delas sobre aquele tema. Eu fiquei ali na ilha de edição meses... e meses... e meses. Foram muitos meses de edição, tentando fazer, honrar, da melhor maneira possível, aquilo que tinha sido dito para mim, e eu acho que a gente fez um trabalho bom. Até gostaria que o filme fosse um pouco mais longo. Hoje em dia eu queria que ele tivesse uns - sei lá - cinco, oito minutos a mais, que (...) coisas incríveis que as pessoas falaram, que na hora eu acabei não usando. Mas, é um filme que trouxe muita satisfação, muito prazer e até hoje eu tenho muitas saudades dele, da época de fazê-lo. Uma saudade boa, não uma saudade nostálgica, mas uma coisa assim "nossa... como aquilo foi vivo". Mas, também (...) com certeza, foi um processo muito sofrido, porque eu não sabia direito o que eu estava fazendo, então, era muita persistência, insistência até fazer alguma coisa surgir.

DS: Dá para ver no filme. Dá para notar essas coisas boas. 
Dago Schelin

Daqui em diante ainda foram mais uns dois minutos de conversa para se despedir. Enquanto transcrevo esta entrevista, fico sabendo que faleceu Oliver Sacks, um dos entrevistados por João Jardim em Janela da Alma. No filme, Sacks fala sobre o olho da mente e chama este olhar de imaginação. Desde o lançamento do filme também já faleceu José Saramago em 2010. Dentre outras falas, Saramago comenta que "se Romeo tivesse os olhos de um falcão provavelmente não se apaixonaria por Julieta.”

Agora pretendo assistir Janela da Alma novamente para ver se vejo o filme com novos olhos, olhos imbuídos das lentes elucidativas do próprio cineasta. 


\title{
POR UM CINEMA INFILTRADO: ENTREVISTA COM ADIRLEY Queirós E MAURÍlio MARTins A PROPÓSITO DE BRANCO SAI, PRETO FICA (2014)
}

\author{
Alfredo Suppia; Paula Gomes*
}

Branco sai, preto fica (2014), de Adirley Queirós, mescla documentário e ficção científica para discutir a cidadania e os direitos civis sob a alça de mira do estado. Vencedor do Festival de Brasília de 2014, este longa-metragem recorre ao artifício da viagem no tempo para tratar de um fato real ocorrido em meados dos anos 1980, quando policiais invadiram o Quarentão, baile de black music organizado na cidade de Ceilândia, na periferia da capital federal, e agrediram violentamente os jovens negros que se encontravam no local. O título do filme remete à ordem de um dos policiais agressores, o qual teria ordenado que apenas os brancos deixassem o recinto do baile.

O filme de Queirós é ambientado num futuro próximo indeterminado em que a segregação centro-periferia persiste e se intensifica. As populações periféricas são excluídas da capital, notícias de rádio e comunicados sugerem um estado policial racista e o trânsito de pessoas no plano piloto de Brasília só é permitido mediante apresentação de um passaporte.

Branco sai, preto fica se estrutura em torno do seguinte eixo: um viajante do tempo, Dimas Cravalanças (Dilmar Durães), chega a Ceilândia num futuro próximo, mas indeterminado, onde vivem dois personagens

\footnotetext{
* Alfredo Suppia: Universidade Estadual de Campinas - UNICAMP, Depto. de Cinema, Pós-graduação em Multimeios. 13083-854, Campinas, Brasil. E-mail: alsuppia@gmail.com Paula Gomes: Doutoranda. Universidade Estadual de Campinas - UNICAMP, Depto. de Cinema, Pós-graduação em Multimeios. 13083-854, Campinas, Brasil.

E-mail: paulagomesrtv@gmail.com
} 
"reais": o radialista Marquim, interpretado por Marquim do Tropa, e o mecânico de próteses Sartana, interpretado por Shockito. Esses dois personagens, que na verdade se confundem com os atores, sobreviveram à noite de violência policial no Quarentão, trazendo em seus corpos a marca da agressão. Marquim ficou paraplégico após levar, indefeso, um tiro da polícia. Sartana/Shockito perdeu uma perna depois de ser pisoteado pela cavalaria policial. Os depoimentos de Marquim do Tropa e Shockito são costurados a cenas ficcionais em que ambos conduzem um plano de vingança. Nesse futuro alternativo de Ceilândia, os sobreviventes Marquim e Sartana pretendem explodir Brasília com uma "bomba sonora", um artefato apocalíptico que inclui variedades da música popular de periferia.

A máquina do tempo que transporta Dimas Cravalanças é uma espécie de contêiner improvisado e, assim como em La Jettée (1962), de Chris Marker, ou Je t'aime, Je t'aime (1968), de Alain Resnais, pouca ou nenhuma explicação sobre tecnologia sofisticada é necessária para justificar a viagem no tempo. No caso do filme brasileiro, ao invés da cura de uma epidemia ou de um caso de amor perdido, o viajante do tempo precisa reunir provas da responsabilidade do estado brasileiro sobre o incidente no Quarentão de Ceilândia, o qual resultou na morte e mutilação de civis. No futuro mais distante, o Brasil se encontra no banco dos réus por crimes cometidos contra sua população negra e pobre.

Gostaríamos de salientar dois aspectos particularmente originais em Branco sai, preto fica: o fato de este filme ser a um só tempo uma curiosa experiência de circuit bending e um digno representante sul-americano do que se convencionou chamar de borderlands science fiction. Circuit bending porque se trata de um filme híbrido de documentário e ficção científica, feito com verba concedida a partir de um edital público destinado à realização de filmes documentários - conforme depoimento de Queirós aos autores desta resenha, e em entrevistas como a concedida a Claudio Reis, Maurício Campos Mena e Raquel Imanishi (2013). Essa “torção” de 
um edital originalmente voltado à realização de documentários, resultando num filme misto de documentário e ficção científica com razoável sucesso de público e crítica, parece ratificar eventuais afinidades operativas já apontadas por Suppia (2009: 13-22), fenômeno ainda mais explícito no caso dos mockumentaries (pseudo-documentários). Diegeticamente, Branco sai, preto fica recorre a toda sorte de circuit bending narrativo, cenográfico e da mise-en-scène no sentido de provocar o "estranhamento cognitivo" em paisagens e circunstâncias aparentemente familiares e corriqueiras - refirome ao estranhamento cognitivo nos termos de Darko Suvin, em seu livro Metamorphoses of Science Fiction, originalmente publicado em 1979.

Como um amálgama de documentário e ficção científica, Branco sai, preto fica é também um filme limítrofe, híbrido em termos de gênero e regime de representação - e também diegeticamente sua fábula se situa num território de fronteira, aquele que separa Brasília, a capital federal, do município de Ceilândia, endereço da classe subalterna ou classe trabalhadora. Narrativa fronteiriça entendida aqui como borderlands science fiction nos termos de Lysa Rivera (2012), Branco sai, preto fica soma-se a filmes latino-americanos anteriores de ficção científica cujas fábulas também se situam em zonas de fronteira, casos de La sonámbula (1998), de Fernando Spiner, ou Sleep Dealer (2008), de Alex Rivera, entre outros.

Enquanto trans-border fantasy, no sentido de fábulas que especulam sobre o trânsito de personagens entre zonas interditas ou interditadas - a exemplo do já citado Sleep Dealer, ou ainda da própria série brasileira 3\%, concebida por Pedro Aguilera e dirigida por Daina Giannecchini, Dani Libardi e Jotagá Crema (www.youtube.com/watch?v=R_rvS7nX7pM), Branco sai, preto fica reinsere o multiculturalismo brasileiro na pauta não apenas do cinema, mas da ficção científica nacional (por mais tênue que sua interface com o gênero possa vir a ser). E com uma particularidade em relação a demais fábulas de fronteira: as geografias acidentadas e zonas de interdição não se restringem aos cenários ou paisagens por onde transitam 
os personagens; elas se inscrevem em seus próprios corpos, na mutilação que os limita e interdita. "Índices" que intensificam o apelo documentário da ficção científica de Adirley Queirós, os corpos mutilados em Branco sai, preto fica são eles próprios "cartografias" da violência ou "mapas" da interdição, "geografias" alteradas pelo uso da força do estado. Esses corpos submetem-se a um duplo regime (o da ficção e o do documentário), à medida em que, por um lado, são legalmente impedidos de cruzar as fronteiras de Ceilândia e, por outro, não mais conseguem realizar as coreografias que costumavam apresentar no baile do Quarentão, devido às óbvias dificuldades de locomoção resultantes do confronto com os policiais. Se a movimentação da periferia para o centro é limitada ou proibida, agora até a dança, o movimento expressivo em seu próprio ambiente, é finalmente confiscado aos excluídos.

Na fábula de Adirley Queirós, a barreira geopolítica que exclui a periferia de Brasília do Plano Piloto deixa sua marca no corpo dos oprimidos: é mais difícil e trabalhoso locomover-se com a necessidade de próteses ou cadeira de rodas. O corpo, em Branco sai, preto fica, é uma geografia tão violentada quanto a do Planalto Central, ou de outros centros urbanos brasileiros. E as cenas de deslocamento de Marquim e Sartana, por mais "estranhadas" pela mise-en-scène que elas possam parecer (o elevador adaptado na casa de Marquim, a oficina de próteses onde trabalha Sartana), são também um retrato fiel de uma realidade nossa contemporânea muito bem conhecida, porém sempre ocultada, interdita, ou referida de passagem: o fato de que o Brasil pune fisicamente seus excluídos, todos os dias, com acidentes de trabalho e/ou acidentes de percurso (no trajeto para o trabalho ou no trajeto para o lazer). Os corpos em Branco sai, preto fica remetem ao extra-filme da infra-estrutura de transporte público no Brasil, dos planos urbanísticos, das ruas e calçadas que bem conhecemos. Por que tão poucos deficientes físicos circulam pelas ruas brasileiras em comparação com 
países desenvolvidos? Porque, no Brasil, a rua (o espaço público) ainda não é lugar de deficiente físico.

E, diferentemente das bem conhecidas "narrativas de superação", Branco sai, preto fica não contemporiza. Os corpos mutilados não terminam por recuperar a dança, por criar novas coreografias com o recurso a cadeiras de rodas ou próteses. Sua expressão é contida. O desfecho é mesmo a explosão do centro irradiador da opressão - explosão esboçada em desenhos, vingança interditada ao cinema brasileiro.

Por fim, gostaríamos de lançar ao debate a hipótese de que tais transborder fantasies, ou borderlands science fiction films (filmes de ficção científica de fronteira), têm oferecido, ao longo dos últimos anos, uma moldura narrativa e uma "paleta de cores" bastante úteis à representação, à problematização e até mesmo ao ensaio sobre temas da agenda contemporânea, notadamente o recrudescimento dos nacionalismos, a xenofobia, o acirramento do estado policial, os rearranjos em termos de fluxos migratórios nacionais/internacionais e a convivência multiétnica ou multicultural. Também faz parte desta hipótese a suspeita de que, com sua ficção especulativa ambientada em geografias limítrofes ou transicionais, os filmes de ficção científica de fronteira têm recorrido com frequência, direta ou indiretamente, a preceitos marxistas revisitados em sua problematização do futuro próximo.

A seguir oferecemos a íntegra de uma entrevista gravada com Adirley Queirós e Maurílio Martins em 12 de junho de 2015, em Brasília, no âmbito do projeto de pesquisa "O pensamento cinematográfico independente brasileiro: história, formas, questões e cartografias", conduzido no Programa de Pós-graduação em Multimeios, da Universidade Estadual de Campinas (UNICAMP), e financiado por linha de fomento Demanda Universal CNPq (CHAMADA UNIVERSAL- MCTI/CNPq N ${ }^{\circ}$ 14/2014). 
Maurílio Martins trabalha na produtora Filmes de Plástico (www.filmesdeplastico.com.br/). Bacharel em Audiovisual pelo Centro Universitário UNA, é produtor, roteirista e diretor. Editor da Revista Lateral (www.revistalateral.com.br), é sócio-fundador da Filmes de Plástico. Dirigiu os filmes Pisciana, 23, calibre .380 (DV, 2006), Descriação (anotações para um anti-filme) (DV, 2008), Pêlos de cachorro (HDV, 2010), Contagem (35mm, 2010) e Estado de sítio (HD, 2011).

Adirley Queirós é diretor e roteirista do filme Rap: $O$ canto da Ceilândia (2005), vencedor do Festival de Cinema de Brasília de 2005 nas categorias júri popular e júri oficial e de outros 13 prêmios no Brasil. Diretor, roteirista e produtor executivo dos filmes Dias de greve (2009) e Fora-de-Campo (digital, documentário, 2009), vencedor do DocTV no Distrito Federal. Dirigiu também os filmes A Cidade é uma só? (2013), vencedor do Festival de Tiradentes-MG, e Branco sai, preto fica (2014), vencedor do Festival de Brasília.

$\mathrm{Na}$ seguinte entrevista, Adirley e Maurílio falam de cinema independente, métodos de trabalho, políticas públicas de fomento, o papel das produtoras e distribuidoras, mercado audiovisual e cinema de ficção científica no Brasil.

ALFREDO SUPPIA: Eu queria saber de vocês, que já têm uma história em termos de cooperativa de cinema, de realização independente, se ainda podemos falar de um cinema independente brasileiro. Se isso ainda faz sentido, se todo mundo é independente, ou se ninguém é independente. Como vocês se colocam nesse cenário? Qual é a relação de vocês com as políticas de fomento, qual o seu grau de dependência dos editais? Qual o método de trabalho de vocês?

ADIRLEY QUEIRÓS: Eu acho que essa história de independente brasileiro tem várias coisas. Tem a questão financeira, obviamente, que é 
determinante sim; e eu acho que tem uma questão de temas, tem uma questão estética, tem uma questão política e econômica. Eu acho que existe o cinema brasileiro independente, mas cada vez menos, porque a política do edital no Brasil é muito presente, e isso é muito bom. Então um certo cinema brasileiro, que durante cinco ou dez anos trabalhou com independência econômica, já não trabalha mais, porque mesmo tendo pouco dinheiro, tem algum dinheiro. O Branco sai preto fica tinha dinheiro de edital. Dinheiro pouco, se pensar que a gente tinha liquido 250 mil reais. E a gente trabalhou durante um ano pagando todo mundo. A gente tinha cinco pessoas recebendo por mês pra estar no filme, fora atores, cenários, etc. Então era muito pouco dinheiro para aquele filme, tinha que inventar muita coisa pra que aquilo acontecesse. Mas eu acho que é independente sim no modelo de produção. É um modelo de produção que se impõe sobre o filme.

Mesmo os filmes no Brasil que são feitos com pouco dinheiro às vezes, ou sem nenhum dinheiro, têm uma dependência política muito forte, eles têm uma coisa de concessão política, então eles não transformam aquela forma do filme em algo que poderia trazer um viés político. Não é só a questão econômica, é a questão de como essa forma do filme se relaciona com o modo de produção. Porque todo filme é modo de produção. Se você tem um real ou mil reais você vai ter que adaptar seu filme ao modo de produção. Se você quer construir uma nave espacial e só tem mil reais, você tem que adaptar aquilo lá a isso. Então eu acho que a forma do filme tem uma independência em relação ao modelo de produção. As pessoas saem da universidade com um exemplo muito rígido de modo de produção, de que pra fazer um filme tem que ter ordem do dia, tem que ter equipe grande, tem que ter dez pessoas etc., e o primeiro filme deles nunca vai ter isso, não se consegue dinheiro pra isso. Então você adapta o modelo de produção, você cria um modelo de produção, e aí eu acho que nasce o cinema independente. Desde Sganzerla, desde Carlão, desde Tonacci, desde Glauber em seu 
primeiro filme, como eles lidavam com esse modelo de produção que gere o filme.

Então existe sim o cinema independente brasileiro, principalmente a Filmes de Plástico do Maurílio, por exemplo, existe o cinema independente na Paraíba que é muito forte, e o nosso cinema de certa forma é independente. Mas eu acho que não é necessariamente porque o filme tem o lugar de algumas temáticas que ele já é automaticamente independente. Tem temática, por exemplo, que supostamente está fora de um padrão de filmes consagrados, mas o filme já tem uma dependência de forma de produção. Então não é porque tem pouco dinheiro que é independente, ele pode ter pouco dinheiro às vezes, mas pode ter toda uma estrutura de modelo de produção que é dependente. Imagine assim, o cara está no quarto filme dele, e ele tem 100 mil pra fazer o filme, aí ele cria um modelo de produção que significa trinta pessoas no set, grua, um monte de coisa, aí ele fala "o meu cinema é independente". Não é independente. É até uma apropriação de mão-de-obra porque, através de uma legitimidade que ele tem, está impondo às pessoas que elas trabalhem de graça para o seu filme. $\mathrm{O}$ modelo que ele está impondo é o modelo de produção grande. Serve pra ele, e pode ser um grande filme, mas não foge do modelo clássico, e é tão perverso quanto, inclusive porque, se ele está no quarto filme dele, e ele quer fazer um filme assim, é direito dele, mas ele tem que captar recurso, a obrigação dele é empregar pessoas. Então tem muitas nuances para o que seria o cinema independente, seja da forma, seja política, seja econômica, e tem o modo de produção mesmo.

MAURÍLIO MARTINS: Essa emulação eu acho que é até um aspecto fundamental, essa emulação de um modo de produção. Por exemplo, o inverso acontece, mas há também um cinema atrelado aos editais. E voltando à sua pergunta, de como é sobreviver sem esses editais, é praticamente impossível. Nós tivemos ciclos irregulares de indústria, nós 
nunca tivemos uma indústria nacional, só tentativas, que eram emuladas também. Até as tentativas aqui não se pareciam com sistema americano, que é de onde eles copiavam. E aí esse cinema que resta hoje, ele está baseado em edital, mas até dentro destes editais há uma gradação muito grande. Por exemplo, o Adirley filma o Branco sai preto fica com um edital pra documentário que dá a ele líquido 240 mil reais. Esse filme novo que nós vamos dirigir agora, tem o mesmo valor. O André Novais faz o Ela volta na quinta [produzido pela Filmes de Plástico, lançado em 2014] com 100 mil reais de um edital de curta-metragem e se adapta a isso. E aí eu acredito que eu posso chamar de cinema independente, e chamaria dentro dos conceitos que o Adirley fala, porque ele vai lá, coloca uma equipe mínima, e consegue estabelecer um filme com uma narrativa do modo que ele queria, mas dentro de uma possibilidade real, que eram 5, 6 pessoas dentro de um set, um filme enxuto, que não tem nada a ver com esse modelo engessado, grande, com equipes saturadas.

Mas dentro até desse sistema de editais você tem esses níveis. Tem desde cara adaptando filme a um recurso mínimo, como tem filmes de 1 milhão, e que chamam de independente. Não sei qual é a lógica, mas chamam. Até mesmo o conceito da ANCINE das Produtoras Independentes Qualificadas, para todas as produtoras. Então acho que o conceito é complicado porque, por exemplo, se a gente vai falar do cinema do pessoal do sul, o pessoal do trash, como o Petter Baiestorf, é uma turma que faz um cinema independente no sentido de ajuntamento de amigos, e que sobrevivia com venda de DVDs. Você tem que restringir isso até a pessoa que tem uma estrutura um pouco maior, pois todos se autodenominam independentes. A grande questão é (e aí eu concordo plenamente com o Adirley) o modo de produção, é como isso é feito, de que forma esse filme é feito, de que forma que há a apropriação do sistema pra esses filmes. 
AQ: Isso joga com várias questões. A questão dos editais por exemplo, o que é o edital no Brasil, e como existe hoje uma política no país de falar de uma certa indústria [do cinema], que é esquizofrênica. Indústria de que no Brasil? Não existe indústria no Brasil. O edital é uma luta histórica de pessoas do cinema independente. Se pegar o cinema independente brasileiro desde o Cinema Marginal paulista, ou até anteriormente, eles lutaram para que houvesse uma lei de incentivo que pudesse ajudar minimamente. Eu acho que tem esse lugar também do edital que tem que ter cuidado, porque o cinema independente jovem, não o mais antigo, outra geração, um pouco mais jovem que a gente, tem um discurso de que "o dinheiro não é importante". Mas aí tem uma questão de classe, porque o lugar de classe fala assim: "o dinheiro é ruim para o cinema". Não, o dinheiro não é ruim pra o cinema, tem dinheiro de monte, quem trabalha tem dinheiro, o problema não é isso não.

As grandes empresas começaram a sacar isso, elas sabem que existe uma demanda política no Brasil, é obvio. No governo Lula e no governo Dilma o audiovisual faz parte da pauta política brasileira, porque eles têm uma questão principal que é a de incentivar as TVs públicas, e incentivar que produções nacionais aconteçam. As grandes empresas sacaram isso e começaram a se apropriar dos editais, a terceirizar os editais, e é a coisa mais absurda do mundo. Por exemplo, tem a DF Cine, tem a SP Filme, tem a RioFilme, que são o maior caô (sic) do mundo, a maior malandragem do mundo. Eles chegam pra vocês e falam "vocês agora são artistas, pronto, vocês são artistas; e vocês vão ganhar 100 mil reais. Nós somos o mercado, e nós vamos ganhar 3 milhões". Então eu quero ser o mercado, não quero ser artista. Artista é o c******, porque vou ganhar 100 mil, e você vai ganhar 3 milhões. Então é esse lugar que eles colocam que é muito absurdo, e eu acho que a gente, talvez nesse discurso nosso de cinema independente, que é cinema independente mesmo, de (sic) correria, a gente perde um pouco da noção política, pois existe uma malandragem por trás disso, existe 
uma perversidade por trás disso. Esses caras que historicamente ganham dinheiro, eles vão buscar ganhar dinheiro em cima da nossa luta histórica e política. Então é só isso que eu fico preocupado quando fala "lançamos DVD" e "a gente faz sem dinheiro". Sim, fazemos, até os 25 anos a gente faz, com 30 vai ficando mais difícil, com 35 a gente precisa comer...

Eu estou falando de coisa pouca, você imagina, se você ganha em uma cidade igual Brasília, 3 mil reais por mês, é um dinheiro pouco pra viver... Isso é independente, fazer cinema assim é loucura. Nos meus filmes, em todos eles, no tempo de trabalho a pessoa não ganha menos de $3 \mathrm{mil}$, nem o ator nem a equipe técnica. Eu estabeleço no edital um valor com o qual eles possam minimamente viver.

MM: É porque você se adequa. Uma coisa que eu acho que vale a pena levantar são essas questões, até mesmo para que não se cultive o rótulo de que quem quer fazer cinema independente não precisa de dinheiro, ou que está abrindo mão de dinheiro. Eu não estou abrindo mão de dinheiro nenhum e acho que o Adirley também não está. Pelo contrário, quero brigar. Uma das coisas que acho interessantíssima é que no edital do Fundo Setorial, o PRODECINE 3, tinha lá pra produção de filmes com "baixo orçamento", mas dentro da estrutura já consolidada, que são filmes de até 1,5 milhão, 2 milhões se eu não me engano. Igual o B.O., a mesma lógica que a do B.O. Mas o PRODECINE tinha uma coisa que era interessantíssima que era não exigir o comprometimento com distribuidoras, porque eles partiram da ideia de que quem fosse fazer aquilo podia ser capaz de gerenciar aquele dinheiro e não atrelar o projeto a uma distribuidora. E aí houve reclamações. Eu ouvi produtoras e produtores consagrados falando assim: "que absurdo, como vão entregar essa grana toda a uma pessoa, e ela não tem sequer uma distribuidora por trás". Mas o pensamento da distribuidora está muito atrelado a: "se existe um cinema independente, então é dependente de uma distribuidora". Só que quem garante que seu 
filme vai ser distribuído? E quem garante que aquela distribuidora valida o seu caráter, que você realmente vai levar aquele projeto até o fim? É a distribuidora que vai garantir isso? Ou seja, é a dependência de algo externo que vai garantir isso? Eu sei que a discussão é muito mais profunda, mas me preocupa, porque é quase como um atestado que diz assim: "vocês não são capazes, nós somos".

AQ: Difícil é gerenciar 100 reais. 2 milhões é mais fácil. [risos]

MM: Exato. "Ah, a Filmes de Plástico e a 5 Da Noite fazem filmes independentes, vocês gerenciam 500, 600 mil e fiquem satisfeitos com isso, e nós continuamos a movimentar". Então é difícil, a pecha do independente é linda no sentido de ser independente politicamente, ser independente de um certo sistema, mas deixar esse estigma ficar colado neste sentido econômico, no de que "Ah, vocês fazem um cinema barato, que bom, continuem aí”, eu acho isso muito perverso, porque aí sim é a luta de classes que continua dentro do cinema, e continua igual aqui fora. E eu, por mim vou brigar contra isso a vida inteira, e vou brigar sim pra que existam editais B.O. de 1,5 milhão, 2 milhões para produtoras como a nossa, porque nós somos capazes de movimentar esse dinheiro sim e continuar sendo independentes de uma série de coisas. E eu não quero estar atrelado a uma distribuidora que não vai sequer me garantir que meu filme vai ser distribuído.

AQ: Se fala muito "edital é isso, edital é aquilo", mas não tem outro modo de ser mais público, de ser mais democrático. Qual o modo mais democrático que ainda existe sem ser o edital? É uma perversidade, é difícil, a gente sabe que tem muita coisa subjetiva, mas é engraçado que ninguém questiona, ou questiona só agora. Ninguém questionava a relação que existia de quem entrava na universidade, por exemplo, quem eram os alunos que 
estavam na universidade. Então ninguém discutia o mérito da universidade, mas em relação ao mérito do edital, se discute. Tem muita coisa envolvida porque eu acho que nesse momento há muita gente envolvida. É isso. O dia que acabar essa grana, ninguém fala mais sobre isso.

O cinema independente então gira em torno de duas questões, desde a questão política, da promoção do edital, até a questão de forma mesmo, porque não adianta nada dizer que é independente e reproduzir tanto valores estéticos como ideológicos de formas perversas. Tem cinema independente de massa, feito com pouca gente, mas o filme tem uma vontade enorme de ser novela (nada contra), ou de ser filme americano (nada contra também), mas eu não vejo onde está a independência nisso. Às vezes parece muito mais que é uma coisa de classe mesmo, um grupo de garotos que quer fazer filme (que é massa), pois eles têm dinheiro, então eles podem fazer. Um cara fala assim: "eu fiz um filme com 50 reais". Mentira! A câmera veio de algum lugar, o carro veio de algum lugar, isso já é valor agregado, que é de classe, pronto. Isso ai é perverso em relação às pessoas que não têm aquilo, e que querem fazer. Essas pessoas vão ter que produzir uma câmera, produzir um carro, produzir uma comida.

MM: É o discurso do filme gratuito. "Fiz o filme de graça". Você não fez de graça porque as pessoas que trabalharam nele não receberam. Não existe isso de filme de graça.

AS: Achei ótimo o depoimento de vocês porque vocês tocaram em um ponto essencial, que é essa questão de como o independente hoje tem um lado perverso também. Há duas faces dessa moeda: se por um lado o cinema independente favorece uma renovação em termos de estética, de forma, sangue novo que entra, novas gerações, etc., por outro lado ele acaba sendo prontamente cooptado pelo sistema, no sentido de manter o mercado meio que reservado para alguns peixões. 
AQ: Grande parte dos nossos amigos estão discursando e defendendo a universalidade de privilégios. Não há como você olhar politicamente para um certo grupo e não ter consequências. É obvio que vai ter consequências. Não existe você pregar um discurso independente e ao mesmo tempo se alinhar com algumas questões.

MM: O problema são esses conceitos também (por isso que eu falei que a discussão é muito além), porque são conceitos que a gente se apropria do sistema americano, o conceito de independente, que são filmes feitos fora dos sindicatos.

AS: Fora dos estúdios também...

MM: Fora dos estúdios... Hoje até menos fora do sindicato, porque no início eram os filmes da TROMA, que eram filmes feitos completamente fora dos sindicatos, então eles tinham que fazer tudo independente mesmo, porque a distribuição, a produção, não eram atrelados a nada. Hoje em dia eu vejo filmes americanos de 50 milhões que são chamados independentes. Um filme independente americano custa 50 milhões de dólares! Então até estes conceitos se embaralham e a gente se apropria disso igual a vários outros conceitos que fomos cooptando ao longo do tempo. E eles se embaralham, ainda mais no Brasil, onde nós temos essa coisa esquizofrênica: dizemos que nunca existiu indústria, mas existiram tentativas como a Cinédia, e outras; os editais vão e vêm; uma época tem muito dinheiro, depois some.

AQ: A questão da garantia eu também acho muito complicada. Se você procura uma vanguarda é o Estado, não é o mercado, mercado não promove vanguarda. O Estado tem direito de ser vanguarda na educação, na saúde, em todos os lugares. Faz parte da Constituição Brasileira, está no artigo 
quinto. Então a obrigação do Estado é ser vanguarda. Nos editais de 10 filmes, se 2 forem bons está ótimo. É risco mesmo. É um risco que o Estado tem que correr porque tem muito dinheiro na parada. O Estado banca cinema, banca obra, banca pista, banca tudo. Toda a movimentação econômica brasileira é do Estado. Então se coloca que o cinema tem que ter essa obrigação de dar certo. O que me incomoda é que parece que o dinheiro do Estado tem que ter uma garantia. Garantia de quê? De que o filme vai dar certo? Impossível. Se houvesse garantia os filmes americanos todos davam certo. Porque os caras trabalham com pesquisa, então garantia não tem de nada. Mas essa premissa da burocracia, de que o cara vai usar o dinheiro pra fazer o filme, isso eu concordo plenamente. Tem que ser feito isso. Isso é o mínimo.

AS: É a garantia sobre o que foi proposto. Não que ele vai ter sucesso ou não, isso é imprevisível.

AQ: Eu acho que tem que administrar o dinheiro bem e aplicar o dinheiro no filme. Isso é obrigação sua. Agora, fora isso, não tem garantia de nada. Ainda acho que o dinheiro do Estado é um dinheiro que é pra ser de risco. Porque é através destes riscos que você cria uma possibilidade de linguagem. Fora isso, não existe. Como você vai criar risco em novela? É engraçado que as minisséries da Globo estão antenadas nessas vanguardas, tanto a européia como a brasileira, e pegam algumas dessas formas de vanguarda e aplicam na minissérie. Pra eles é um risco de público, mas serve como rótulo para passar lá fora. Então eles se apropriam da linguagem do cinema independente, dão uma (sic) gourmetizada nela (de uma forma mediana), e aí eles conseguem que a minissérie vire exportação, conseguem via Itamaraty que vire exportação. E então eles conseguem pontuação para edital. Como esses caras são malandros assim?! Então tem um negócio 
envolvido ai e é hora de discutir como que a gente se encaixa nesse negócio também.

AS: Vou fazer uma provocação ligada a isso: durante muito tempo teve essa discussão na história do cinema brasileiro, que entre os cineastas brasileiros vigorou durante muito tempo o pensamento de que o filme está pronto quando está feita a primeira cópia. O que vocês pensam disso? Vocês querem que os filmes de vocês sejam vistos? Vocês acham que o filme se completa quando vocês conseguem a primeira cópia, ou na verdade que ele se completa quando faz o público? É interessante porque, no caso de Branco sai preto fica, não teve Itamaraty na jogada, não teve nada disso. E é um filme que está sendo muito discutido. Como vocês vêem isso? Vocês acham que ainda vale essa coisa de "faço filmes pra mim ou pra satisfazer minha predileção estética", ou não?

AQ: A Sílvia [Cruz] da Vitrine [Filmes] disse que o Branco sai preto fica é o blockbuster do cinema independente porque fez 20 mil pessoas. Eu pensava que ia fazer 2 mil, aí a Joana [Pimenta, fotógrafa portuguesa que mora em Nova York] disse que ia fazer 20. Eu falei "nunca que vai fazer 20. Não existe fazer 20 mil porque a distribuição é muito difícil, não tem dinheiro pra aplicação". Eu faço filmes para as pessoas verem. A minha ideia de fazer filmes é que as pessoas assistam a esses filmes. Mas assistir em festival não faz parte da contabilidade de público, e qualquer filme nosso que entra em festival, só no Brasil ele consegue 15 mil pessoas, se passar em 10 ou 15 festivais maiores. Também não se contabiliza público de escola pública e os nossos filmes passam em todas as escolas públicas, eles pegam os filmes e passam. Sem nenhum recurso de retorno pra gente.

MM: Tem a internet também. 
AQ: Na minha cabeça filme tem que ser exibido. Mas a gente não tem que ficar refém dessa loucura de fazer filmes "para” o público. Quem é o público? Público de festival é meu público? Eu não sei. Público de festival é de classe média alta, então quem assiste aos meus filmes é de classe média alta. Eu acho que o público é um termo fascista: quando dizem "O seu filme não atingiu o público, foi vaiado", eu não sei se isso é bom ou é ruim. É tão legítimo um cara se levantar por não querer ver um filme de festival como é legítimo o cara querer manter uma linguagem do seu filme em um festival. É pra isso que ele é feito. Então eu acho que não é nesse sentido não de "é porque tem público que deu certo", esse raciocínio não funciona.

MM: O cinema é a arte que se difere de todas as outras porque é coletiva (quase sempre), e é por isso mesmo que até o público que rejeita faz parte dessa ideia quando você faz o filme. Porque muitas vezes os filmes são rejeitados hoje, e daqui a 20 anos são redescobertos, retomados, pesquisados, eles caem de novo na internet, e as pessoas acabam redescobrindo o filme.

Além de ser uma pergunta extremamente difícil de ser respondida, acho que no fundo é o processo todo, é óbvio que eu quero que meus filmes sejam vistos. Mas não quer dizer que eu vá brigar e lutar por esse público de um milhão. Talvez um dia eu me contente com isso. Óbvio que eu quero que o filme seja visto, mas até esse público que vê o filme, ele é completamente distinto, você não tem o menor controle sobre isso. É esse público elitizado, de certos festivais. Mas por exemplo, eu fui ao interior do Ceará com meu filme agora, em uma cidade que não tem cinema há 30 anos, e eram pessoas locais mesmo, e aí chegou um rapaz perto de mim que era agricultor, e veio conversar sobre o filme. Ele ficou uma hora conversando comigo sobre cinema, e era um rapaz agricultor que por algum motivo tem interesse em cinema e literatura. Eu nunca imaginei atingir esse tipo de público e de repente você está ali conversando, pois seu filme 
dialoga com aquela pessoa! Então tem isso também. Eu quero que o filme seja visto, agora, como ele vai ser visto, de que forma vai ser visto, é cada filme, cada processo, cada coisa. Eu tenho certeza de que o Adirley deve ter ficado feliz, você fica feliz com isso, com esse público de festivais, com esse retorno. Agora dizer: "eu vou fazer esse filme pra público X”, isso eu acho complicado.

AQ: Eu acho que o festival devia pagar pra gente, e colocar como bilheteria. Parece que os filmes...

MM: Inexistem!

AQ: São um empecilho, um problema, porque não fazem público. Não existe isso! Todo mundo faz público! Todo filme tem um lugar em que as pessoas vão gostar ou odiar um filme assim. Isso também é um lugar perigoso politicamente falando, quando dizem "o filme teve público ou não teve público”. No Brasil existem modelos públicos, que são uma média, mas existem. Não é garantia mas existe um lugar que dá mais possibilidade. Qualquer daqueles atores chatos da globo...

MM: Comédia...

AQ: Comédia racista e homofóbica principalmente, uma câmera horrível e bem iluminada, e atores ( $\mathrm{sic}$ ) coxinhas, pronto. Isso ai é o modelo que a classe média quer ver. Então esse lugar vai ter um certo público. Agora, a gente fazer filme de edital que vai atender esse modelo, pra que isso? Pra que um edital serviria pra reproduzir o que a novela faz? Não que a novela seja boa ou ruim, só estou querendo dizer que a novela é dinheiro de mercado, não é o filme de edital que tem que fazer isso. Tem caras no Brasil que ganham um edital de 3 milhões, pra que esse dinheiro pra eles? Esses 
caras fazem filmes de 30 milhões! 3 milhões teria que vir pra produtora que não consegue captar isso. O dinheiro do Estado é pra promover a atuação de quem não pode atuar no mercado. Se você quer fazer um filme com mais de 3 milhões, você que vá ao mercado e capte isso, é um direito seu.

AS: Branco sai preto fica é um filme de ficção científica brasileiro? Sim ou não, e se é, por que? O que a ficção científica tem a ver com você ou com vocês?

AQ: Eu acho que é um filme de ficção científica sim. Mas não é que é uma ficção científica, é um filme que teve na sua origem uma tentativa de dialogar com esse lugar. Se ele é ou não, é aquilo que a gente falou anteriormente, o modo de produção impõe outras questões. O meu sonho era fazer um Blade Runner [Ridley Scott, 1982]. Queria fazer um Blade Runner. Então o nosso imaginário é Blade Runner, Mad Max [George Miller, 1979], meu exemplo era As crônicas marcianas [The martian chronicles (1950) de Ray Bradbury]. Era sempre essa coisa de girar num tom de um certo lugar de ficção científica, então a gente sai para o filme pensando: esse filme é um filme de ficção científica. Pra mim é um filme assim. Então toda a questão de arte e fotografia e som é um lugar onde dialoga com a ficção científica, um lugar de distopia, de futuro, de distopia social, de uma cidade sitiada, de sons estranhos, de passagem de tempo, tudo isso pra mim é ficção clássica científica.

Obviamente que ele é feito dentro de um edital de documentário, então o imaginário, a fabulação, a ideia coletiva, a impossibilidade, tudo isso está envolvido no filme, mas na minha cabeça ele é um filme de ficção científica sim. Eu acho que existe no Brasil essa possibilidade sim de fazer. Até a Joana [Pimenta] estava brincando hoje porque eu vou fazer um filme agora que começa com uma nave caindo, e alguém falou assim: "a nave na verdade ela não pousa assim (movimento de mãos no sentido vertical), ela 
pousa assim (movimento diagonal)". Ela não pousa na vertical, ela pousa na diagonal. Mas onde está escrito isso? Você já viu uma nave pousar? Quem estabeleceu esse modelo de pouso de nave assim? Se é ficção, se é do espaço, se ele tem outra matéria, se tem outra dinâmica, se ele pode obedecer outras questões físicas, então ele pode fazer outras coisas. Por isso eu acho que a ficção científica tem esse lugar em que você manipula a ordem real da física. Porque tem a ordem da física, a matéria da física, a gravidade, etc. Mas se ele vem de outro lugar, ele por ter uma dinâmica de matemática diferente.

De novo, a ficção científica enquanto forma seria muito interessante para questionar esse lugar ideologicamente imposto de que ela é ficção. O paradigma do corpo, por exemplo... Eu assisti ao Mad Max agora [Mad Max: fury road (2015), de George Miller], e achei incrível, fiquei extasiado com o filme. E é só um filme de atmosfera. O que é o roteiro dele? Ela vai, esqueceu, volta! $\mathrm{F}^{* * * * * * *}$ o roteiro, mas tem uma atmosfera incrível que é a atmosfera do tempo de cinema, a questão dos planos, como ele lida com a questão do incesto, tem várias coisas envolvidas ali no filme, que são muito potentes, do imaginário da ficção. Então eu acho que a nossa ficção pode lidar com esse imaginário também, com essa potência.

Porque se liga à ficção científica a ideia do orçamento alto. Se pensar em ficção científica no meu filme, é muito mais som que imagem. A gente tem muito mais potencialidade de trabalhar sons do que imagem. Só que daí vai pra distribuição... A gente faz um filme que lida com todo um espectro de som, trabalha, e na primeira exibição do filme os caras colocam o filme no mono, uma exibição horrível, que ninguém ouve $\mathrm{p}^{* * * *}$ nenhuma, então lá se foi todo o trabalho do cara. Então tem muito essa coisa de como que a gente vai lidando com essas possibilidades estéticas. Se a gente não pode fazer uma nave espacial potente na sua forma somente de imagens e luzes, a gente pode brincar, a gente pode estabelecer o jogo do filme, e brincar com o som por exemplo. A ficção clássica também era isso, de ter o extra- 
cotidiano, e não o cotidiano. A ficção [científica] na verdade é o extracotidiano, não é o cotidiano. O cotidiano está lá. Mesmo o Branco Saí Preto Fica tem muito um lugar cotidiano, mas é o extra-cotidiano que traz a ficção científica.

AS: Eu acho que algo que o Branco sai preto fica faz (e por isso eu acho que é uma ficção científica brasileira muito potente, representativa) é usar imagens do cotidiano, mas o filme estranha essas imagens. Está tudo estranhado ali de maneira que, por exemplo, aquele depósito de próteses, que obviamente existe, mas do jeito que ele está constituído ali, a atmosfera que é criada automaticamente estranha aquele lugar!

MM: Mas a periferia já é uma ficção científica para a classe média branca brasileira! Ela já é uma ficção científica! Mostrar a periferia no cinema já é algo que provoca.

AQ: Mas o problema é esse mesmo, eu acho que é esse o problema. A Filmes de Plástico é uma exceção maravilhosa, talvez a melhor. Eu acho a Filmes de Plástico a melhor produtora brasileira. Se alguém seria modelo de mercado é a Filmes de Plástico, porque tem uma tentativa de lidar com o popular, tem uma pegada muito forte com o aluno de escola pública... imagina, se você consegue que o aluno de escola pública goste do teu filme, se eu sou do governo eu falo assim: "Pronto! Isso pra mim é cinema popular. Eu posso investir nesse filme que ele pode ser uma nova televisão brasileira, um novo cinema brasileiro".

Mas enfim, o modelo que a periferia tem de cinema é o modelo de classe média, que é a novela. Então ela nega aquilo que ela tem de mais forte, que é aquele lugar de estranhamento. Aquele lugar de estranhamento sim, pode ser um agente de ficção. A forma como ele caminha, a forma como ele chega no ferro velho, a forma que ele tem um carro... 
MM: O gradeamento que você sempre comenta... [Maurílio se refere às grades na arquitetura]

AQ: Mad Max fez isso na verdade...

MM: É isso. E por isso eu acho o filme maravilhoso!

AQ: Esse Mad Max novo roubou minha ideia inclusive, vamos processar ele [risos]. Os caras são mecânicos. Na origem são mecânicos, nesse filme nosso que a gente está fazendo agora a ideia original era essa, eram mecânicos que faziam um monte de carro velho virar uma nave científica. Então os caras são espertos. São espertos pra c******. Essa é a questão. A gente coloca um lugar de vanguarda que é caretíssimo. A nossa vanguarda é o que? Onde está a nossa sensibilidade de vanguarda? A gente fica falando sobre opressão, que o cinema americano é opressor, mas o cinema de Cannes é tão opressor quanto, porque ele estabeleceu um modelo de bom gosto, um modelo de sensibilidade, um modelo de sensibilidade em relação ao espaço, que é lindo, mas é um modelo de sensibilidade europeu. É massa, é tão lindo quanto lá, mas será que pra gente esse é o modelo de sensibilidade? Será que esse "tosco", que eles chamam de tosco nosso não é a nossa potência sensível? Talvez o tosco seja a nossa potência sensível. Talvez aquilo que é mais forte da gente, que é o que eles chamam de tosco, é aquilo que a gente se envolve enquanto cinema. Porque cinema nada mais é do que corpo e atmosfera. Cinema é corpo e atmosfera! Você constrói a montagem, a mise-en-scène de tal forma que chega o momento em que você tem afinidade com o cara, você gosta daquele cara, um cara que fala pouco, que às vezes tem dificuldade de se expressar, que fala errado, que fala rápido... Talvez aquele lugar seja o lugar mais sensível que existe. Então eu acho que a ficção brasileira tem esse problema. Mesmo em relação à 
periferia, tirando exceções, ele tem como modelo o modelo clássico de televisão brasileira.

MM: São os modelos mesmo, são os modelos que são errados. A grande questão é essa. Por exemplo, o filme novo do André Novais, o curta que estava em Cannes agora, tem a coisa do realismo fantástico [Maurílio se refere a André Novais Oliveira, seu colega na Filmes de Plástico, e ao filme Quintal]. A sinopse é "um dia comum na vida de um casal de periferia", que é um dia comum na vida dos pais dele, com esse toque do Murilo Rubião, do realismo fantástico, chegando na ficção científica. E eu vejo que o estranhamento das pessoas não é só pelo que acontece de sobrenatural, é também por ser um casal de negros idosos na periferia! Porque isso também não é colocado no cinema, e por isso eu falo que esse estranhamento é o que mais me encanta no Branco sai preto fica. O gradeamento da Ceilândia, que é algo único, essa arquitetura da Ceilândia, as casas todas frontais, todas na beira da rua, todas com grades... Nada pode ser mais distópico que isso! Nada pode ser mais atemporal, essa coisa maluca, esse tipo de arquitetura... E o Adirley explora isso, isso é explorado no filme, mas isso faz parte da cidade. Está colocada ali como algo que você encara mesmo como futuro, mas aquilo é agora. Se você andar na Ceilândia você vai ver as casas daquele jeito. Mas ele só tem esse olhar porque ele mora lá e não é um olhar forasteiro, não é um olhar estrangeiro. Então eu provoco isso: qual é a fórmula, qual é o padrão, o que a gente está querendo copiar? A gente quer copiar o padrão americano ou a gente pode fazer a nossa própria ficção científica? E esse filme novo [Maurílio se refere ao filme que ele e Adirley estão realizando no momento], ele parte muito disso, parte do que temos, e do que somos.

AQ: Eu acho que a ficção [científica] tem a coisa também do absurdo, assim, a ficção é o absurdo. Eu estou fazendo um filme [Mato Seco em 
chamas] também que vai ser com a Joana [Pimenta], estamos fazendo juntos, que é um filme que parte de uma ideia real, e entra numa ideia absurda, que também é ficção científica. Ele vai entrar numa ideia de que vai nascer petróleo na Ceilândia, o petróleo é nosso. Então partindo deste discurso clássico que move a direita e a esquerda brasileira, que derruba o governo, que está quase derrubando a Dilma (infelizmente, o que seria um golpe perverso e reacionário), derrubou tudo... Se o petróleo fosse mesmo nosso, se nós então furássemos um buraco nessa porra e nascesse petróleo na cidade, o que é um absurdo, e nos começássemos a ressignificar a ideia de transformar o petróleo, de manipular o petróleo como fonte de energia e econômica, isso viraria ficção científica. A ideia do absurdo traria isso. Isso eu acho muito massa, a ficção tem esse lugar também. Ela, mesmo sendo distópica, traz uma utopia de linguagem, isso que eu acho muito bonito! Mesmo um conteúdo distópico, que pode gerar um filme melancólico, um filme que a gente se perca na narrativa, pode trazer essa utopia de que é possível sim, através de narrativa, construir um lugar político. Porque essa narrativa é política! Na medida em que você se apropria e diz assim "eu posso fazer essa narrativa", então você pode fazer cinema, pode fazer literatura, pode fazer música, pode transformar imaginários. Então a ficção tem esse poder muito $\mathrm{f}^{* * *}$ de transformar imaginários. A ficção científica é muito comunicativa, todo mundo se encanta assistindo, o público jovem se encanta vendo isso, remete a aventura, a um corpo que tem mil anos, a um corpo que pode tudo, o próprio ato de fazer o filme, aquela narrativa do filme, ele se faz com um corpo que pode transmitir coisas. Então eu acho muito legal a ficção enquanto absurdo, porque a ficção enquanto modelo de produção clássica tem absurdos normais... Todo personagem de ficção científica é luz, tudo é luz é, sapiência... No nosso filme, por exemplo, a gente quer que o cara seja um peso, um cara que come muita carne, um cara que fala um monte de merda, ele é passado. O futuro é o Brasil, por mais complicado que seja, por mais estranho que seja, por mais pesado que seja, 
o futuro é o Brasil. Não é um cara que vem de 60 [Adirley se refere à década de 1960]. O cara que vem de 60 tá $\mathrm{f} * * * * * .60$ deve ser ruim aqui e em todo lugar do mundo. É por ai.

MM O deslocamento é nele [no personagem em questão].

\section{Referências bibliográficas}

REIS, Claudio; MENA; Mauricio Campos; IMANISHI, Raquel (2013), Entrevista com Adirley Queirós, Negativo, Brasília: Cineclube Beijoca/Universidade de Brasília, v. 1 n. 1, jul/set, pp. 16-69.

RIVERA, Lysa (2012), "Future Histories and Cyborg Labor: Reading Borderlands Science Fiction after NAFTA”. Science Fiction Studies. Vol. 39, No. 3 (November), pp. 415-436. Disponível em: http://www.depauw.edu/sfs/pioneers/rivera118.html.

SUPPIA, Alfredo (2009), "Afinidades operativas entre cinema documentário e cinema de ficção científica", Cadernos da Pósgraduação Multimeios, Edição Especial Cinema e Fotografia, Vol. 10, pp. 13-22).

SUVIN, Darko (1979), Metamorphoses of Science Fiction: On the poetics and history of a literary genre, New Haven: Yale University Press. 


\title{
DISSERTAÇÕES E TESES
}

\author{
Tesis | Theses | Thèses
}




\section{MÚSICA EM CENA: À ESCUTA DO DOCUMENTÁRIO BRASILEIRO}

\section{Cristiane da Silveira Lima}

Tese de Doutorado.

E-mail: crislima1@gmail.com

Designação do Programa de Estudos: Programa de Pós-graduação em Comunicação Social.

Instituição: Universidade Federal de Minas Gerais.

Resumo:

Em um contexto em que a música surge como objeto de interesse renovado tanto do cinema documentário brasileiro quanto das pesquisas em Cinema e em Comunicação, buscamos responder à seguinte indagação: de quais maneiras os filmes documentários brasileiros inscrevem a música (articulada aos outros sons e também às imagens) em sua escritura, de modo a engajar a escuta do espectador? A partir da análise de um conjunto variado de filmes que têm a música em cena, empreendemos um duplo movimento: primeiramente, observamos como a música se articula aos diferentes componentes sonoros (a voz, o ruído e o silêncio) e visuais da escritura fílmica; segundo, apontamos como tais articulações solicitam o trabalho complexo e dividido da escuta espectatorial. As análises assinalam novos aspectos acerca da problemática do som e da escuta no cinema, 
evidenciando múltiplas formas do documentário estabelecer uma afinidade - plástica, processual ou formal - com o fenômeno musical.

Palavras-chave: Cinema documentário brasileiro, música, som, escuta, espectador.

Ano: 2015.

Orientador: César Geraldo Guimarães. 


\title{
CINEASTAS INDÍGENAS, DOCUMENTÁRIO E AUTOENOGRAFIA: UM ESTUDO DO PROJETO VÍDEO NAS ALDEIAS
}

\author{
Juliano José de Araújo
}

Tese de Doutorado.

E-mail: araujojuliano@gmail.com

Designação do Programa de Estudos: Programa de Pós-Graduação em Multimeios.

Instituição: Universidade Estadual de Campinas - UNICAMP.

\section{Resumo:}

Criado em 1986 pelo indigenista e documentarista Vincent Carelli, o projeto Vídeo nas Aldeias (VNA) objetiva fortalecer as identidades, patrimônios culturais e territoriais dos povos indígenas através dos recursos audiovisuais. O VNA atua como uma escola de cinema para os povos indígenas brasileiros por meio de oficinas de formação em audiovisual realizadas nas aldeias e na sede do projeto, em Olinda, no estado de Pernambuco. Desempenha também um papel fundamental como entidade responsável pela captação de recursos, produção e distribuição dos documentários. Nesse contexto, esta pesquisa analisa 28 documentários da série “Cineastas indígenas" realizados entre 1999 e 2011 no âmbito do projeto VNA. Trata-se de seis curtas-metragens e 22 médias-metragens de cineastas indígenas das etnias Ashaninka, Huni Kui, Kisedje, Kuikuiro, 
Mbya-Guarani, Panará e Xavante. Essa produção audiovisual de não-ficção é considerada como uma prática de autoetnografia no documentário, à medida que ao conceder a câmera para os indígenas lhes é permitido o que dizer, quando, onde e como filmar, a partir de uma perspectiva interna, na qual eles apresentam suas aldeias, seu cotidiano, sua história, suas festas e rituais, como também os problemas sociais que enfrentam. Nesse sentido, a tese propõe a categoria de documentário autoetnográfico para o corpus analisado, tendo como questões norteadoras: Quais são os procedimentos de criação, métodos de trabalho e condições de realização dos documentários autoetnográficos do projeto VNA? E as posturas éticas, opções estéticas e técnicas neles presentes? Qual a importância desses filmes para as comunidades indígenas que deles participam? Com que finalidade eles são realizados? A partir da análise fílmica, em uma perspectiva textual e contextual, isto é, estabelecendo um diálogo entre elementos internos (imagem, som etc.) e externos dos documentários (entrevistas com realizadores indígenas, equipe do VNA, sujeitos filmados, conceitos das teorias do cinema antropológico e documentário etc.), apresenta-se o estudo do corpus enfatizando, respectivamente, as dimensões ética, estética e política da produção audiovisual de não-ficção do projeto VNA. Considerase essas três dimensões do discurso fílmico como fundamentais para se compreender melhor a categoria de documentário autoetnográfico que, para além de um conceito dos estudos pós-coloniais, acredita-se constituir em uma tomada de posição e reflexão do campo do cinema diante dos filmes dos realizadores indígenas. A análise dos documentários autoetnográficos do projeto VNA revela: um processo de realização cinematográfica (preparação, filmagem e montagem) no qual a autoria é compartilhada, sendo a ética um elemento presente em todas as etapas; o emprego e a modulação de diferentes gestos estéticos com uma forte influência dos cinemas direto/verdade, mas também questões que emergem com força na produção audiovisual de não-ficção contemporânea, como a encenação e o 
uso das imagens de arquivo; o papel político desempenhado pelos documentários, tendo em vista que se direcionam aos espectadores nãoindígenas, seus enunciatários, para discutir a relação entre história oficial versus história não-oficial, a identidade e cultura indígenas, ou ainda para denunciar, reivindicar e lhes dar visibilidade.

Palavras-chave: cineastas indígenas, documentário autoetnográfico, ética, estética, política, Vídeo nas Aldeias.

Ano: 2015.

Orientador: Marcius Freire. 


\section{A ASSERÇÃo NO CINEMA DOCUMENTÁRIO MUSICAL BRASILEIRO}

\section{Cynthia Letícia Schneider}

Tese de doutorado.

E-mail: cyls72@uol.com.br

Designação do Programa de Estudos: Programa de Pós-Graduação em Multimeios.

Instituição: Universidade Estadual de Campinas - UNICAMP.

\section{Resumo:}

O objetivo geral desta tese é o estudo dos documentários musicais brasileiros de longa-metragem com duração superior a 70 minutos. A seleção de filmes intenta responder ao seguinte problema de pesquisa: como organizar em categorias conceituais os documentários musicais brasileiros de forma a contribuir para a compreensão de uma possível ordem cinematográfica que perpassa os filmes do subgênero, mas que ao mesmo tempo reconhece as especificidades de cada um? Os principais objetivos específicos da pesquisa são: a) compreender a asserção no documentário musical brasileiro; b) aplicar individualmente a cada filme do corpus da pesquisa um modelo analítico para determinação de sua asserção; c) nominar categorias que permitam o arranjo dos filmes de acordo com a 
asserção; d) responder ao problema da pesquisa de forma que as categorias criadas possam organizar os filmes ao mesmo tempo em que reconheçam suas especificidades assertivas; e) contribuir para o conhecimento e a pesquisa em cinema documentário e as características de subgênero. A hipótese é de que os documentários de um subgênero nao podem ser meramente organizados por sua proximidade temática ou por sua plástica formal e que o conceito de asserção pode ser norteador para a compreensão do documentário musical.

Palavras-chave: documentário musical; documentário musical brasileiro; asserção no documentário.

Ano: 2015.

Orientador: Fernão Pessoa Ramos. 


\title{
FORMAS DE REPRESENTAÇÃO NO CINEMA: UMA REFLEXÃO SOBRE O USO DA MISE EN SCÈNE NOS DOCUMENTÁRIOS PARAIBANOS
}

\author{
Riccardo Migliore \\ Dissertação de Mestrado. \\ E-mail: tanofb@gmail.com \\ Designação do Programa de Estudos: Programa de Pós-Graduação em \\ Comunicação e Culturas Midiáticas. \\ Instituição: Universidade Federal da Paraíba.
}

Resumo:

Nesta dissertação abordamos a utilização da mise en scène no âmbito do documentário paraibano desde o primeiro ciclo de cinema deste Estado (década de 1960), até à década de 2000, através da análise fílmica de cinco documentários, sendo eles: Aruanda (Linduarte de Noronha, 1960), A pedra da riqueza (Vladimir Carvalho, 1975), Imagens do declínio, ou Beba Coca Babe Cola (Bertrand Lira, Toquato Joel, 1981), Passadouro (Torquato Joel, 1999) e Oferenda (Ana Bárbara Ramos, 2009). Para suprirmos às carências e ambiguidades que permeiam as categorias aqui utilizadas, isto é, documentário, mise en scène e representação fílmica, fomos impelidos pelas circunstâncias a começarmos por uma busca conceitual plural e 
interdisciplinar, procurando auxílio nos campos da teoria do cinema e naquela do documentário, na teoria sociológica e antropológica, naquela da comunicação social e ainda, na semiótica da imagem cinematográfica. Foi a partir destes aprofundamentos que abordamos o objeto aqui representado pelos filmes paraibanos, procurando dialogar tanto com autores da teoria do cinema, como também, com cineastas que, ao debruçar-se sobre a sétima arte, introduziram e discutiram conceitos que também podemos considerar complementares àqueles retratados neste trabalho acadêmico. Enxergamos, pois, a mise en scène como uma articulação multi-conceitual e uma práxis fílmica igualmente complexa e heterogênea, ao implicar questões técnicas, estéticas e ideológico-morais. Nesta conjuntura, o grau de controle por parte do realizador, em termos de encenação, é reduzido a respeito do cinema ficcional, devido à auto-mise en scène dos atores sociais, isto é, a autorepresentação por parte dos personagens dos filmes não-ficcionais.

Palavras-chave: cinema, documentário, estética, mise en scène, filmes paraibanos.

Ano: 2015.

Orientador: Bertrand de Souza Lira. 


\section{ISLAS DE LA MEMORIA. CONSTRUCCIÓN DEL RELATO HISTÓRICO Y USO DE IMÁGENES DIGITALES SOBRE LA GUERRA DE MALVINAS EN PRODUCCIONES AUDIOVISUALES DEL PERIODO 2002-2012}

\section{Pablo Francisco Gullino}

Dissertação de Mestrado.

E-mail: pablogullino@gmail.com

Programa de Estudios: Maestría en Diseño Comunicacional.

Institución: Universidad de Buenos Aires, Facultad de Arquitectura, Diseño y Urbanismo.

Resumen:

En mi Tesis de Maestría, planteo un estudio sobre las modalidades de construcción del relato audiovisual a partir de un corpus seleccionado de documentales realizadas durante el periodo 2002 - 2012. Seleccionamos catorce piezas en total: siete argentinas, siete británicas. En todas ellas se repite la reconstrucción de escenarios y de batallas terrestres, aéreas y marítimas por medio de la tecnología informática.

La elección de dicho período me permite dar cuenta de diversos procesos de transformación del documentalismo iniciados hacia fines de la década 1990 y que se prolongan en el siglo XXI a partir del caso de la guerra de 1982. A lo largo de estos años podemos notar la consolidación del documental, en diversos modos de circulación a través de las pantallas del 
cine, la televisión con sus canales temáticos y los sitios de internet. De acuerdo al concepto de prueba documental de Paul Riccoeur, (Riccoeur, 2004) las sociedades contemporáneas recuerdan hechos pasados y confeccionan relatos audiovisuales a partir de material de archivo y testimonios (testigos directos, citas de autoridad). En la década los productos audiovisuales combinan el archivo, el testimonio y otros elementos propios de las tecnologías informáticas que modifican las formas de construir memorias audiovisuales sobre la Guerra de Malvinas.

En esta Tesis, ubico el eje en el análisis de los cambios tecnológicos y la influencia de estrategias narrativas reservadas casi exclusivamente al terreno de la ficción en los documentales sobre la Guerra de 1982.

En el cruce entre la tecnología y los relatos sobre el material audiovisual bélico asumimos el riesgo de desafiar la conocida frase de Theodore Adorno sobre la poesía después de Auschwitz. Los sucesos traumáticos del pasado, fundamentalmente las guerras, vuelven como relatos que necesitan ser narrados desde distintos géneros, estilos y técnicas. Sólo se puede intentar crear imágenes donde no las hay, escuchar los relatos de quienes sobrevivieron, narrar en presente para tratar de entender la guerra.

Descriptores: Malvinas, documental, imágenes generadas por computadora, memoria, Historia.

Año: 2015.

Director: Gustavo Aprea. 


\section{WEBDOCUMENTÁRIO E AS FUNÇÕES PARA A INTERAÇÃO NO GÊNERO EMERGENTE: ANÁLISE DE FORT MCMONEY E BEAR 71}

\section{Fernanda Bernardes}

Dissertação de Mestrado.

E-mail: fernandacbernardes@gmail.com

Designação do Programa de Estudos: Programa de Pós-Graduação em Comunicação Social.

Instituição: Pontifícia Universidade Católica do Rio Grande do Sul PUCRS, Faculdade de Comunicação.

Resumo:

Webdocumentários são obras que tratam do mundo histórico, sendo desenvolvidas para distribuição e fruição na World Wide Web. O objetivo do trabalho é compreender que tipo de participação é proposta para os usuários nesse novo gênero, traçando uma análise qualitativa da interação em webdocumentários. Foram selecionados dois webdocumentários com formatos distintos: Fort McMoney e Bear 71. Ambos são examinados de acordo com os conceitos de modos de interação proposto por Gaudenzi (2013), os modos de interação de Nash (2012), e a interação mútua e reativa de Primo (2000, 2011). Após a análise, apresentamos uma proposta que identifica três usos da interação em webdocumentários: para reforçar o 
Webdocumentário e as funções ...

argumento do autor, para partilhar a função do autor e para reforçar/estabelecer o vínculo com o usuário.

Palavras-chave: webdocumentário, interação mútua, interação reativa, modos de interação, função da interação.

Ano: 2015.

Orientador: Roberto Tietzmann. 


\title{
A CONSTRUÇÃo Biográfica EM SANTIaGo
}

\author{
Tais Marcato
}

Dissertação de Mestrado.

E-mail: taismarcato@gmail.com

Designação do Programa de Estudos: Programa em Pós-graduação em Artes, Cultura e Linguagens.

Instituição: Universidade Federal de Juiz de Fora - UFJF, Instituto de Artes e Design.

Resumo:

No campo teórico da produção cinematográfica, a observação de construções biográficas ganha mais evidência com as constantes experiências da representação do $e u$ e do outro que o cinema estimula. Documentários biográficos e autobiográficos tornam-se práticas frequentes pós-retomada do Cinema Brasileiro. Nessa lógica, cresce a necessidade de criação de procedimentos que possibilitam a identificação de diferentes manifestações de relatar a (própria) vida no cinema documentário contemporâneo. Em sintonia com a proposta do espaço biográfico (Arfuch) e de categorias encontradas tanto na escrita biográfica literária (Vilas Boas) quanto na narrativa cinematográfica (Puccini), nossa pesquisa centrou-se em proceder à análise e à delimitação dos procedimentos de relatos biográficos e autobiográficos relacionados ao documentário Santiago (2007), filme de 
João Moreira Salles. Procurando debruçar-nos sobre as possibilidades da construção biográfica presentes no desenvolvimento da narrativa fílmica, distinguiremos cinco modalidades da abordagem biográfica que possibilitam uma melhor compreensão da feitura do relato em Santiago: (1) Santiago como personagem biografada do filme que o diretor tentou montar em 1992; (2) Santiago como biógrafo, uma vez que incorpora interpretações pessoais à escrita sobre as personagens da nobreza; (3) Santiago como escritor de uma escrita de caráter íntimo e confessional, que tem como centro a expressão de sua intimidade e que pode ser lida como um diário; (4) João Moreira Salles como diretor biógrafo, durante o momento da construção da trajetória de Santiago e (5) João Moreira Salles como personagem autobiografada, ao pontuar suas lembranças de infância através do relato autobiográfico em primeira pessoa.

Palavras-chave: Documentário Biográfico, Santiago, João Moreira Salles, Construção Biográfica.

Ano: 2015.

Orientador: Sérgio José Puccini Soares. 


\title{
AS PRIMEIRAS PRODUÇÕES DO DOCUMENTARISTA Jỗo Moreira SalleS
}

\author{
Caroline Maria Manabe
}

Dissertação de Mestrado.

E-mail: carolmanabe@gmail.com

Designação do Programa de Estudos: Programa de Pós-Graduação em Multimeios.

Instituição: Universidade Estadual de Campinas - UNICAMP.

Resumo:

Este trabalho aborda o início da carreira do documentarista João Moreira Salles. Investigamos como se deu sua entrada na produção televisiva, através de seu irmão Walter Salles, e como ocorre a transformação, tanto da noção de documentário como das temáticas abordadas pelo diretor. Nesta trajetória, dividimos as obras em dois conjuntos principais. O primeiro com as séries produzidas para a Rede Manchete, sendo elas Japão, China, América e o filme Blues; e o segundo com os documentários exibidos no canal a cabo GNT, Jorge Amado e a série Futebol. Ainda percorremos de maneira breve os vídeos experimentais e algumas reflexões feitas sobre o método de filmar presentes em Santiago. 
As primeiras produções ...

Palavras-chave: Documentário televisivo, João Moreira Salles, História do documentário.

Ano: 2015.

Orientador: Fernão Pessoa Ramos. 


\section{THE ACT OF KILLING, UMA AUTORIA PARTILHADA}

\section{Diana Rocha Svintiskas}

Dissertação de Mestrado.

E-mail: eaidiana@gmail.com

Designação do Programa de Estudos: Máster Universitario en Estudios de Cine y Audiovisual Contemporáneos.

Instituição: Universidat Pompeu Fabra - UPF.

Resumo:

Esta dissertação investiga as possíveis relações estéticas e temáticas entre o polêmico documentário de Joshua Oppenheimer The act of killing e dois dos seus produtores executivos, os conhecidos cineastas Werner Herzog e Errol Morris. Foram trabalhados temas-chave como: a escolha de personagens controversos, o uso da reencenação, o cinema verité, a recepção crítica e o uso da ironia para defender a hipótese de que a famosa dupla não possuiu um interesse aleatório no filme, que pelo contrário, se viu de alguma forma representada na direção do jovem sucessor Oppenheimer.

Palavras-chave: Documentário contemporâneo, não-ficção, cinema do real, Werner Herzog, Errol Morris, verité, ironia, estética, crítica, reencenação, reconstituição, dispositivo. 
The act of killing ...

Ano: 2013-2014.

Orientador: Jordi Balló Fantova. 


\title{
OS DOCUMENTÁRIOS DE GERALDO SARNO (1974-1987): SERTÃO, POESIA E RELIGIOSIDADE
}

\author{
Felipe Corrêa Bomfim
}

Dissertação de Mestrado.

E-mail: felipecorrea.bomfim@gmail.com

Designação do Programa de Estudos: Programa de Pós-Graduação em

Multimeios

Instituição: Universidade Estadual de Campinas - UNICAMP.

Resumo:

Esta pesquisa estuda a obra do cineasta Geraldo Sarno, considerando o conjunto de documentários realizados pelo diretor. $\mathrm{O}$ trabalho de pesquisa empírico - traduzido na organização do acervo do diretor, mediante a reunião dos dados sobre a produção dos documentários estudados - aliado às análises traçadas neste estudo, compreendem um breve investimento analítico, no intuito de apresentar e discutir o conjunto de documentários até então inéditos e que passam a ser considerados como conjunto na filmografia de Geraldo Sarno. Identifica-se a passagem para um novo ciclo em sua poética, evidenciado por meio do processo de revisão do próprio cineasta sobre sua maneira de documentar, iniciado na virada da década de 1970 e desenvolvido amplamente ao longo das décadas de 1970 e 1980. Este procedimento é dotado de momentos de radicalização formal e outras situações marcadas por investimentos mais ponderados, quanto aos 
parâmetros de registro utilizados pelo cineasta, condicionados às demandas de produção. Esta oscilação dificulta a compartimentação rígida de sua obra, e oferece a leitura de sua poética como processo singular e arbitrário, que extrapola metodologias de filmagem pré-estabelecidas para cada documentário. Assim, cabe ressaltar que essa passagem para um novo ciclo na filmografia do diretor é um processo sutil e gradual, a passos largos de uma mudança paradigmática.

Palavras-chave: Geraldo Sarno, documentário brasileiro, cinema e literatura, cinema e religião.

Ano: 2015.

Orientador: Gilberto Alexandre Sobrinho. 


\title{
DOCUMENTÁRIO E MEIO AMBIENTE NO BRASIL: UMA PROPOSTA DE LEITURA ECOLOGIZANTE
}

\author{
Janaína Welle
}

Dissertação de Mestrado.

E-mail: wellejanaina@gmail.com

Designação do Programa de Estudos: Programa de Pós-Graduação em Multimeios.

Instituição: Universidade Estadual de Campinas - UNICAMP.

Resumo:

Esta pesquisa tem como objetivo refletir sobre as representações fílmicas do meio ambiente e suas relações com os organismos que o constituem em suas diversas esferas. Inicialmente nos debruçamos sobre a categoria de cinema ambiental e apresentamos ao leitor a retrospectiva de um vasto leque de documentários brasileiros que, ao longo da história do cinema em nosso país, trazem em sua estrutura narrativa e estética, de maneira explícita ou tangencial, questões ambientais. Tendo em vista que o conceito de cinema ambiental é bastante impreciso e se rearranja de acordo com critérios e fronteiras estabelecidos por cada autor ou instituição e/ou com o lócus em que se dá a exibição do filme, apresentamos como metodologia de investigação dessas questões nossa proposta de leitura ecologizante dos filmes que pode ser aplicada, a princípio, na análise de qualquer obra 
audiovisual. Finalmente, empregamos a leitura ecologizante à análise de três documentários brasileiros: Aboio (2005), de Marília Rocha; Terra deu, terra come (2011), de Rodrigo Siqueira, e As hiper mulheres (2012), dirigido por Carlos Fausto, Leonardo Sette e Takumã Kuikuro. Para a leitura de cada um desses documentários buscamos jogar luz sobre aspectos representativos das questões ambientais que vão além da temática central de cada filme. Em Aboio privilegiamos as relações entre cinema e animal; em Terra deu, terra come os jogos e o feitiço presentes nas tradições e no cinema e, em As hiper mulheres, as relações entre cosmologia e ecologia na comunidade Kuikuro.

Palavras-chave: documentário (cinema), cinema ambiental, Marília Rocha, Rodrigo Siqueira, Carlos Fausto, Leonardo Sette, Takumã Kuikuro.

Ano: 2015.

Orientador: Marcius Freire. 


\title{
A REPRESENTAÇÃo DE INCLUSÃo SOCIAL E DIGITAL POR MEIO DA MÚSICA EM DOCUMENTÁRIOS BRASILEIROS
}

\author{
Pamela de Bortoli Machado
}

Dissertação de Mestrado.

E-mail:pam.dbmac@gmail.com

Designação do Programa de Estudos: Programa de Pós-Graduação em Multimeios.

Instituição: Universidade Estadual de Campinas - UNICAMP.

Resumo:

O vídeo documentário é elemento de mobilização e crítica social uma vez que contextualiza os fatos de um problema social, evidenciado pela valorização dos indivíduos que ilustram suas expectativas, dificuldades e ideais. Buscamos enfatizar nesta dissertação com a análise dos documentários Fala Tu (2003) e L.A.P. A. (2007) a ideia de que a música, no caso o rap, pode ser utilizada na inclusão social quando expressada de forma ideológica, pelo diálogo que representa na maior parte dos conflitos integrantes da vida na periferia. $\mathrm{E}$, ao estabelecer a música como prática de uma identidade cultural, a análise de Insurreição Rítmica (2008) explicita como a música promove a mudança social, ao retratar a transformação promovida por organizações sociais em bairros pobres de Salvador. Em paralelo à inclusão social, a questão da empregabilidade é mensurada a 
partir da inclusão no mercado da música digital, no uso das novas tecnologias disponíveis e que vêm transformando a prática do músico independente, ao substituir o consumismo do CD por arquivos de áudio intercambiáveis. Tal problemática foi explorada pelos documentários Música.BR e Internet (2009), We.Music (2010) e Profissão: Músico (2011), nos quais se pode compreender como os músicos dependentes de geração de renda por intermédio da música sobrevivem à transformação no mercado musical. A dissertação desenvolve-se a partir de teorias acerca das questões que envolvem esse conjunto de documentários, como conceitos de inclusão social e digital, identidade cultural e revolução digital no mercado musical juntamente com a análise dos mesmos. Assim, discute-se como se desenvolve a representatividade deste conjunto de documentários que explora as problemáticas relacionadas à inclusão social e digital fazendo uso da música e evidenciando o uso do audiovisual como fator de conscientização de realidades que expressam essas problemáticas.

Palavras-chave: documentário, inclusão social, inclusão digital, música digital, identidade cultural.

Ano: 2015.

Orientador: Fábio Nauras Akhras. 


\title{
O SOM NO DOCUMENTÁRIO: A TRILHA SONORA E SUAS TRANSFORMAÇÕES NOS PRINCIPAIS MOVIMENTOS E MOMENTOS DA TRADIÇÃO DOCUMENTÁRIA, DOS ANOS 1920 AOS 1960
}

\author{
Renan Paiva Chaves
}

Dissertação de Mestrado.

E-mail: renanpaivachaves@gmail.com

Designação do Programa de Estudos: Programa de Pós-Graduação em Multimeios.

Instituição: Universidade Estadual de Campinas - UNICAMP.

Resumo:

Nossa pesquisa dedica-se à trilha sonora do cinema documentário. Nossa abordagem privilegiou uma perspectiva panorâmica que percorre a produção documentária em momentos-chave de sua tradição desde os anos 1920 até os anos 1960. Perpassamos pelas produções dos anos 1920 e 1930 que começaram a solidificar o campo do cinema documental, pelas escolas britânica, norte-americana e canadense de documentário entre os anos 1930 e 1950 e pelo free cinema, cinema direto, cinema verdade e cinema do vivido nas décadas de 1950 e 1960. Nesse trilho, e na visita aos seus arredores, empreendemos nossos esforços em entender as principais 
O som no documentário ...

configurações sob as quais a trilha sonora do cinema documentário se estabeleceu e se transformou.

Palavras-chave: documentário, trilha sonora, som fílmico.

Ano: 2015.

Orientador: Claudiney Rodrigues Carrasco. 


\title{
SOKÚROV E A MONTAGEM EM VIDA HUMILDE (1997): IMAGEM E REPRESENTAÇÃO
}

\author{
Breno Morita Forastieri da Silva
}

Dissertação de Mestrado.

E-mail: brenomfs@gmail.com

Designação do Programa de Estudos: Programa de Pós-Graduação em Meios e Processos Audiovisuais.

Instituição: Universidade de São Paulo - USP.

\section{Resumo:}

Da confluência entre o conceito de texto artístico de Iuri Lotman e a teoria do cinema intelectual de Sergei Eisenstein, este trabalho oferece uma análise do filme Vida humilde (1997) de Aleksandr Sokúrov. De estudos de Eisenstein sobre a lógica composicional do pensamento por imagens, foi compilado um conjunto de ferramentas analíticas a fim de se investigar a imagem geral do filme. Por meio de tais ferramentas, é investigada a relação entre a construção plástica do filme e a percepção da imagem de uma vida humilde. Ainda alinhada à teoria da montagem eisensteiniana, essa imagem é proposta como resultante intelectual de outras três imagens: as da circularidade, da harmonia e da homologia. Desta maneira o filme é 
Sokúrov e a montagem ...

esquadrinhado de maneira a salientar os elementos formais que possibilitam sua decodificação como qualidades abstratas.

Palavras-chave: texto artístico, pensamento gráfico, cinema intelectual, montagem, Solidão, Smirenaia Jizn.

Ano: 2015 .

Orientador: Arlindo Machado. 